\title{
Evaluation of Elevated Tritium Levels in Groundwater Downgradient from the 618-11 Burial Ground Phase I Investigation
}

\author{
$\begin{array}{ll}\text { P. E. Dresel R. M. Smith } & \text { R. }\end{array}$ \\ B. A. Williams $\quad$ C. J. Thompson \\ J. C. Evans \\ Pacific Northwest National Laboratory
}

L. C. Hulstrom

CH2M Hill Hanford, Inc.

May 2000

Prepared for

the U.S. Department of Energy

under Contract DE-AC06-76RLO 1830

Pacific Northwest National Laboratory

Richland, Washington 99352 



\section{DISCLAIMER}

This report was prepared as an account of work sponsored by an agency of the United States Government. Neither the United States Government nor any agency thereof, nor any of their employees, make any warranty, express or implied, or assumes any legal liability or responsibility for the accuracy, completeness, or usefulness of any information, apparatus, product, or process disclosed, or represents that its use would not infringe privately owned rights. Reference herein to any specific commercial product, process, or service by trade name, trademark, manufacturer, or otherwise does not necessarily constitute or imply its endorsement, recommendation, or favoring by the United States Government or any agency thereof. The views and opinions of authors expressed herein do not necessarily state or reflect those of the United States Government or any agency thereof. 


\section{DISCLAIMER}

Portions of this document may be illegible in electronic image products. Images are produced from the best available original document. 


\section{Summary}

This report describes the results of the preliminary investigation of elevated tritium in groundwater discovered near the 618-11 burial ground, located in the eastern part of the Hanford Site. Tritium in one well downgradient of the burial ground was detected at levels up to $8,140,000 \mathrm{pCi} / \mathrm{L}$.

The 618-11 burial ground received a variety of radioactive waste from the 300 Area between 1962 and 1967 . The burial ground covers 3.5 hectare ( 8.6 acre) and contains trenches, large diameter caissons, and vertical pipe storage units. The burial ground was stabilized with a native sediment covering. The Energy Northwest reactor complex was constructed immediately east of the burial ground.

The Phase I investigation consisted of sampling existing monitoring wells in the vicinity of the 618-11 burial ground. The sampling included wells upgradient of the burial ground, downgradient wells, Energy Northwest water supply wells, and Energy Northwest monitoring wells. The samples were analyzed for a variety of radionuclides and chemicals including water quality parameters and potential contaminants. Sampling was conducted in February 2000.

The Phase I investigation confirmed the elevated tritium levels in a single well downgradient of the burial ground. Other wells contained tritium at lower levels similar to levels in the plume emanating from the 200 East Area. The well with the elevated tritium contained no other contaminants at levels that could be clearly tied to a source in the burial ground. Constituents detected at elevated levels in the sampling area include nitrate, uranium, technetium-99, and carbon tetrachloride. Levels of technetium-99 and carbon tetrachloride were below the drinking water standards. The nitrate and uranium does not appear to be related to the 618-11 burial ground, based on the distributions and chemical correlations. Insufficient information is available to define the source of technetium-99, but it is a known contaminant within the plume from the 200 East Area.

The distribution of tritium points strongly to a probable source within the $618-11$ burial ground. Other sources considered include the tritium plume from the 200 East Area and Energy Northwest operations. However, the tritium levels are too high to be explained by either of these sources. The distribution is inconsistent with the 200 East Area plume. Similarly, the high tritium is located upgradient of the Energy Northwest WNP-2 reactor, so known discharges from Energy Northwest are unlikely to be the source.

Potential tritium source materials and source locations within the 618-11 burial ground have not been identified. Possible source materials include fission products and activation products from nuclear operations. In particular, there is a possibility that the tritium is related to tritium production research carried out at the Hanford Site in the 1960s. Although that link has not been established, the hypothesis is consistent with what is known about the research and about burial ground operations.

The investigation did not define the extent of the elevated tritium levels in groundwater. The available data suggest the plume is narrow. Data on vertical extent of the contamination are sparse. No tritium was detected in the confined aquifer samples. 



\section{Contents}

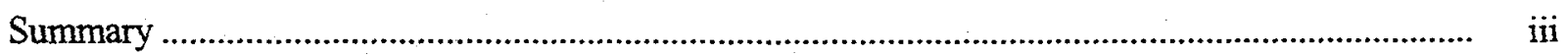

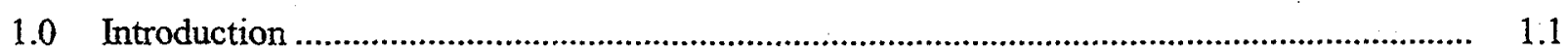

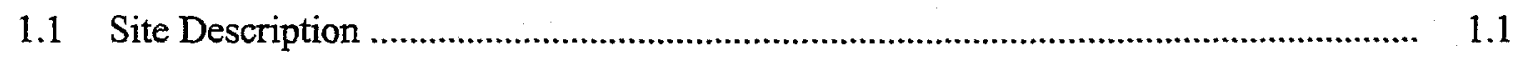

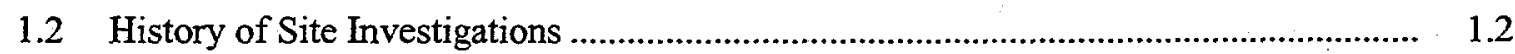

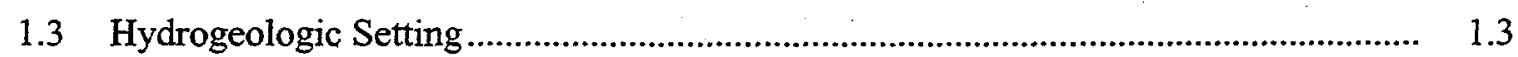

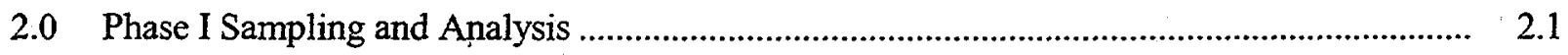

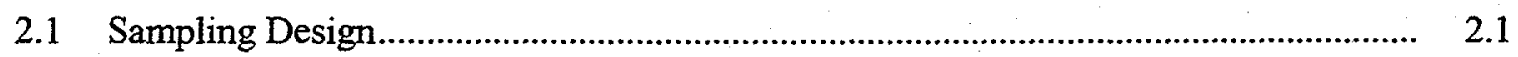

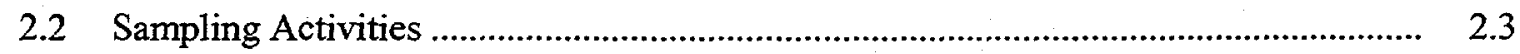

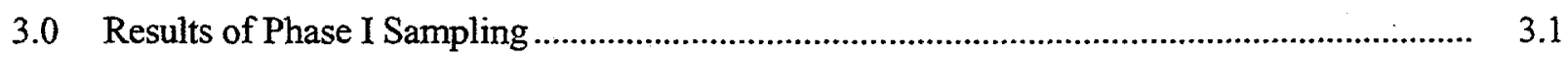

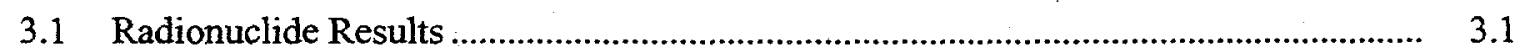

3.1.1 Tritium............................................................................................ 3.1

3.1.2 Uranium and Gross Alpha ...................................................................... 3.2

3.1.3 Gross Beta, Technetium-99, and Strontium-90 .......................................... 3.2

3.1.4 Other Radionuclides........................................................................ 3.3

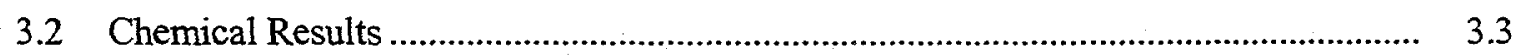

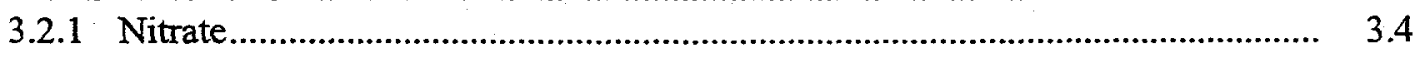

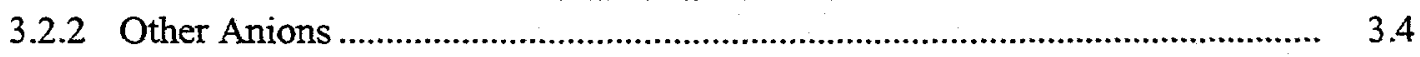

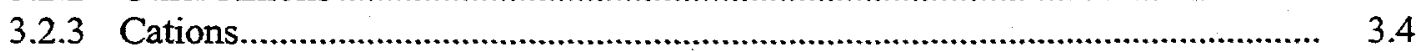

3.2.4 Major Ion Water Types .............................................................................. 3.5

3.2.5 Organic Constituents .......................................................................... 3.6

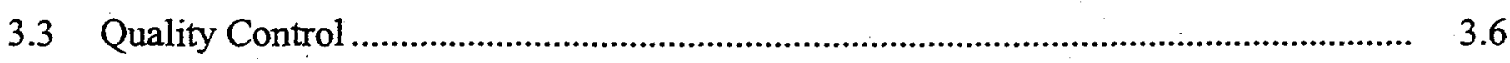

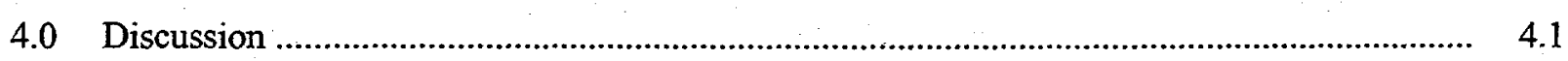

4.1 Relationship to the 200 East Area Tritium Plume ...............................................

4.1.1 Historical Plume Conditions .......................................................................... 4.1

4.1.2 Geological Constraints on the Tritium Plume Migration .................................. 4.3

4.1.3 Current Plume Conditions ............................................................................. 4.4

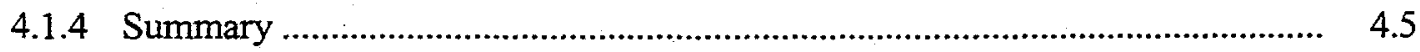

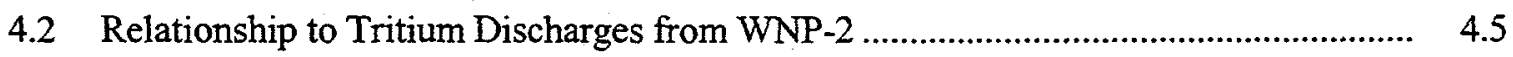

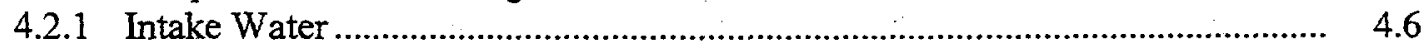

4.2.2 Wastewater from the Sanitary Waste Treatment Facility ................................. 4.6

4.2.3 Storm Drain Outfall.................................................................................. 4.7

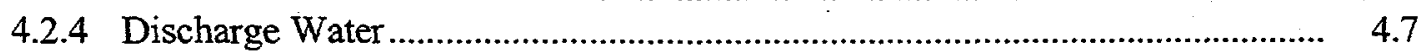


4.2.5 Groundwater

4.7

4.2.6 Summary

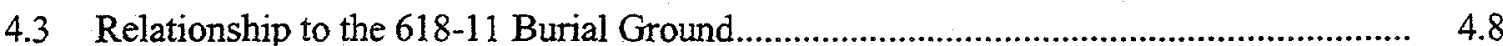

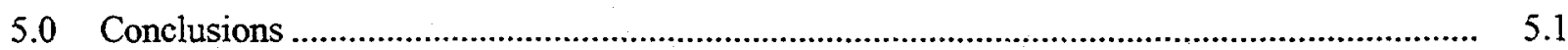

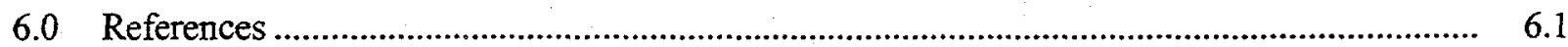

Appendix A - Sample and Analysis Instructions for Special Sampling of High Concentration

Tritium and Surrounding Wells Near the 618-11 Burial Ground, Rev. 1

Appendix B - Groundwater Sampling Reports for Phase I Evaluation of the 618-11 Burial Ground

Appendix C - Analytical Results for the Phase I Evaluation of the 618-11 Burial Ground

Appendix D - Quality Control Sample Definitions

D.1

\section{Tables}

2.1 Wells Sampled for the Phase I Sampling Event.

3.1 Comparison of Uranium Isotopic Concentrations to Gross Alpha and Total Uranium Concentrations

3.2 Field Quality Control Samples

\section{Figures}

1.1 Location of the 618-11 Burial Ground, Hanford Site, Washington

1.2 Tritium Concentrations at the Top of the Unconfined Aquifer, Hanford Site, Fiscal Year 1999

1.3 Generalized Hydrogeologic and Geologic Stratigraphy

1.4 Hydrologic Units Present at the Water Table, 1998

2.1 Groundwater Well Locations in the Vicinity of the 618-11 Burial Ground 
3.2 Calculated Uranium Concentrations for February 2000 Sampling Near the 618-11 Burial Ground.

3.3 Uranium Concentration Trend in Well 699-13-3A

3.4 Gross Alpha Concentration Trend in Well 699-13-3A

3.5 Gross Beta Concentration Trend in Well 699-13-3A

3.6 Nitrate Concentrations Expressed in $\mathrm{mg} / \mathrm{L}$ as $\mathrm{N}$ for February 2000 Sampling Near the 618-11 Burial Ground.

3.7 Piper Diagram for Major Ions in the Phase I Samples

3.8 Piper Diagram for Major Ions in the Phase I Samples Including Nitrate with the Chloride Component

3.9 Relationship Between the Percentage of Anion Milliequivalents in.Selected Wells Near the 618-11 Burial Ground....

4.1 Tritium Concentration Trends in Wells 699-13-1A and 699-13-1B

4.2 Well Construction and Lithology for Wells 699-13-1A and 699-13-1B

4.3 Tritium Plume as Reported in 1972

4.4 Tritium Plume as Reported in 1973

4.5 Tritium Plume as Reported in 1979.

4.6 Tritium Plume as Reported in 1980.

4.7 Tritium Plume Reported in 1980 Redrawn to Correct Incorrectly Contoured Points

4.8 Digital Terrain Map of the Hanford Site and Surrounding Areas.

4.9 Tritium Concentration Trends in Selected Wells Upgradient and Near the 618-11 Burial Ground.

4.10 Comparison of Tritium vs. Iodine- 129 for the 200 East Area Plume and Well 699-13-3A

4.11 Comparison of Tritium vs. Nitrate for the 200 East Area Plume and Well 699-13-3A 


\subsection{Introduction}

The 618-11 burial ground is located in the eastern part of the U.S. Department of Energy (DOE) Hanford Site (Figure 1.1). Groundwater monitoring well 699-13-3A was installed immediately downgradient of the 618-11 burial ground to determine if the burial ground had affected groundwater quality. A groundwater sample collected from this well in January 1999 contained $1,860,000 \mathrm{pCi} / \mathrm{L}$ of tritium.' A sample collected in January 2000 contained $8,140,000 \mathrm{pCi} / \mathrm{L}$ of tritium. After the January 2000 sampling, an investigation of the extent of tritium in this vicinity was initiated.

This report summarizes the results of Phase I of this investigation. Phase I consisted of sampling available wells in the vicinity of the burial ground for an extended group of constituents, interpretation of the sampling results, and an initial assessment of geologic, hydrologic, and historical data.

\subsection{Site Description}

The 618-11 burial ground received waste between March 1962 and December 1967 (Demiter and Greenhalgh 1997). The site consists of three trenches, two to five large-diameter caissons, and fifty vertical pipe storage units. The site covers an area of 3.5 hectare $(8.6 \mathrm{acre})$ and is located approximately $300 \mathrm{~m}(1,000 \mathrm{ft})$ west of Energy Northwest Plant 2 (WNP-2). The trenches are $274.3 \mathrm{~m}(900 \mathrm{ft})$ long by $15.2 \mathrm{~m}(50 \mathrm{ft})$ wide. The vertical pipe units are five 208-L (55-gal) drums welded together end-to-end and are approximately $4.6 \mathrm{~m}(15 \mathrm{ft})$ long by $55.9 \mathrm{~cm}$ ( $22 \mathrm{in}$.) in diameter. The caissons are $2.4-\mathrm{m}-(8-\mathrm{ft})$

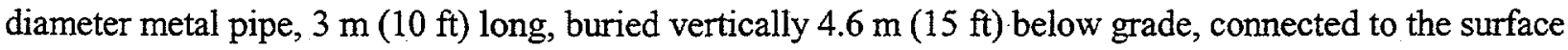
by offset $91.4-\mathrm{cm}$ - (36-in.) diameter pipe with a dome-type cap. All vertical pipe units and caissons were capped with concrete and covered with native sediment as they were filled.

Waste was sent to the 618-11 burial ground from the 324, 325 and 327 Building hot cells and the Plutonium Recycle Test Reactor in the 300 Area. Inventories of the waste do not specifically mention that tritium was disposed to the burial ground, though hydrogen gas (a possible misnomer) was identified.

Shortly after the site was closed, it was covered with $1.2 \mathrm{~m}(4 \mathrm{ft})$ of soil. In 1983, the surface of the site was stabilized with an additional $0.6 \mathrm{~m}(2 \mathrm{ft})$ of clean material and planted with wheatgrass. The

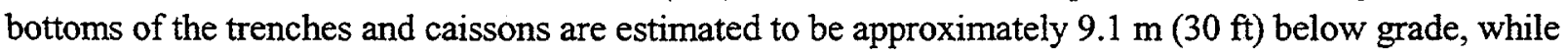
the bottoms of the vertical pipe units are estimated to be $6.4 \mathrm{~m}(21 \mathrm{ft})$ below grade. The site perimeter is fenced and marked with concrete markers. Plants in the area show no obvious signs of vegetative stress that would indicate radiological or chemical constituent uptake from either the waste site or the unplanned releases that have occurred at the site.

Groundwater contamination from the 200 East Area extends through the location of the $618-11$ burial ground. Contamination from the 200 East Area consists predominantly of tritium with associated nitrate and iodine-129. However, near the burial ground the iodine-129 is generally below detection limits. An

\footnotetext{
${ }^{1}$ In this report analytical results will be rounded to 3 significant digits.
} 
area of anomalously low tritium has been noted east of the burial ground when compared to the surrounding plume from the 200 East Area (Figure 1.2).

The Energy Northwest reactor complex was constructed east of the 618-11 burial ground. The WNP-2 reactor initially went critical in January 1984 (Washington Public Power Supply System 1985). Construction was not completed on two other power plants, WNP-1 and WNP-4. Some tritium is produced during reactor operations by ternary fission. Several instances of release of tritium and other radionuclides to the environment have been documented (Washington State Department of Health 1999). Release locations include the WNP-2 Sanitary Waste Treatment Facility and the storm drain outfall.

The relationship of the tritium in groundwater to these three potential sources, the 618-11 burial ground, the 200 East Area, and WNP-2, is discussed in Section 4 of this report.

\subsection{History of Site Investigations}

In 1978, Pacific Northwest Laboratory conducted both geophysical surveys and core drilling and sampling near the 618-11 burial ground (Phillips et al. 1980). According to Phillips et al. wells "were located to enable drilling beneath the structure where radiocontaminated leachate, if present, would be intercepted, rather than drilling into the structure." Two soil samples were collected from depths of 8.8 and $9.4 \mathrm{~m}$ ( 29 and $31 \mathrm{ft}$ ). Gross alpha, gross beta, and other natural occurring radionuclides were reported to be within background range. A small concentration of cesium-137 $(0.16 \mathrm{pCi} / \mathrm{g})$ was found at a depth of $8.8 \mathrm{~m}(29 \mathrm{ft})$ but was not judged to be a concern.

An Environmental Impact Statement (EIS) was issued in 1987. The EIS analyzed the impact of strategies for the final disposal of high-level, transuranic, and tank waste generated during national defense activities and stored at the Hanford Site (DOE 1987). The EIS also evaluated waste that was disposed at the Hanford Site prior to 1970 , before the transuranic category was established, that would otherwise be considered as transuranic if generated today. Because the 618-11 burial ground was used between 1962 and 1967 for disposal of laboratory waste (including remote-handled hot cell waste) from 300 Area operations, it was specifically included in the scope of the EIS under the classification of "pre1970 Buried Suspect Transuranic-Contaminated Solid Wastes."

Several disposal alternatives were studied in the EIS (DOE 1987). Based on the conclusions of that study, a preferred alternative for deferral of disposal decisions pending additional development and evaluation was selected for the single-shell tanks, transuranic-contaminated soil sites, and the pre-1970 buried suspect transuranic-contaminated solid waste sites. Prior to decisions on final disposition of these wastes, alternatives would be analyzed in subsequent environmental documentation, including a supplement to the EIS. These decisions were documented in a corresponding Record of Decision (ROD) (53 FR 12449) 
and implementation plan (DOE-RL 1988). The EIS and associated ROD included one exception to the preferred alternative, the 618-11 burial ground. A decision was made to proceed with removal and processing of waste from the 618-11 burial ground based on

- its location outside of the 200 Area plateau

- concerns over a potential for flooding

- a DOE desire to consolidate the pre-1970 buried transuranic-contaminated waste to the 200 Area plateau at a reasonable cost.

In 1992, the U.S Environmental Protection Agency (EPA) and Washington State Department of Ecology (Ecology) directed that an engineering evaluation/cost analysis be performed to consider Expedited Response Action (ERA) alternatives for the 618-11 burial ground. The evaluation analyzed options that included no action, increased monitoring, removal and monitored storage, and a

demonstration/feasibility study. The proximity of buried waste to the water table in the area and the potential for migration of contaminants were of concern based on the limited information known about waste inventory.

Increased monitoring was the selected option as documented in the ERA proposal (DOE-RL 1993). A removal action was eliminated as an immediate need based on the absence of data to identify a threat to human health and the environment and the lack of operating facilities to receive, process, and/or dispose of excavated high-activity transuranic material. To support the ERA recommendation, a new well (699-13-3A) was installed in 1995 to monitor groundwater adjacent to the burial ground. Groundwater samples from this well were analyzed for radioactive and hazardous chemical constituents of concern on an annual basis.

Tritium was not identified as a constituent of concern for the burial ground, so it was not included in the analyte list until January 1999. No follow-on action was taken regarding the $1,860,000 \mathrm{pCi} / \mathrm{L}$ result from the January sampling (reported in May 1999) until January of 2000 . The high tritium value from the January 1999 and January 2000 samples triggered an off normal event report, RL-PNNL-PNNLBOPER2000-0003, submitted on February 3, 2000.

\subsection{Hydrogeologic Setting}

The 618-11 burial ground and the Energy Northwest nuclear power plant complex are constructed on suprabasalt sediments of Miocene to Pleistocene age (Figure 1.3). The stratigraphic column includes in ascending order from oldest to most recent, the Columbia River Basalt Group, Ringold Formation, and Hanford formation and Pre-Missoula gravel. In addition, a thin, regionally discontinuous veneer of Holocene alluvium and eolian sediment overlies the principal geologic units. 
The information currently available to describe the hydrogeology of the area is regional in nature and does not provide the details necessary to delineate and accurately predict groundwater flow conditions near the WNP-2 plant and 618-11 burial ground. Lindsey (1995) describes the regional geology of the Hanford Site. The hydrogeologic description of the Hanford Site is provided in Hartman (2000).

The suprabasalt sediments are the hydrogeologically most significant units in terms of contaminant transport beneath the area because these units form the uppermost aquifer system. This aquifer system is the primary groundwater contaminant pathway to the Columbia River. The upper aquifer system consists of an upper unconfined aquifer and deeper confining to semi-confining aquifer conditions. The Elephant Mountain Member basalt forms the bottom of this uppermost aquifer system and is located at a depth greater than $150 \mathrm{~m}(500 \mathrm{ft})$ beneath the surface. Confined aquifer conditions exist beneath the Elephant Mountain Member basalt. The confined aquifer system is used for water supply at WNP-1 (two wells) and for emergency supply at WNP-2 (one well). Information obtained from well drilling records, and in recent water-level measurements, confirm that the basalt-confined aquifers have a higher water level (potentiometric surface) than the uppermost unconfined aquifer, resulting in upward flow if any leakage occurs between the two aquifers. This condition significantly reduces the possibility of a downward movement of tritium into the lower, deeper confined aquifer.

The Pliocene-age Ringold Formation, which overlays the Elephant Mountain Member basalt, is composed of a mix of variably cemented and consolidated gravel, sand, silt and clay. Overlying the Ringold Formation is the Hanford formation and pre-Missoula Gravel.

The Hanford formation units consist of mostly unconsolidated gravel, sand, and silt. Fluvial preMissoula (flood) gravel underlies the Hanford formation in some areas of the Hanford Site. The preMissoula gravel is difficult to distinguish from Hanford gravel and is commonly grouped together.

Hydraulic data have not been evaluated for this report. However, comparisons of aquifer testing data and well completion pumping results from similar lithologies west of the burial ground indicate that the Hanford formation is significantly higher in permeability (possibly by several orders of magnitude) than the underlying Ringold Formation sediment.

An accurate structure map of the Ringold Formation is key to understanding groundwater and tritium flow paths to the river because of the differences in permeability between the Ringold Formation and the Hanford formation sediment. The geologic unit at the water table varies from Hanford/pre-Missoula to Ringold Formation in the vicinity of the 618-11 burial ground because of structural features created on the top of the Ringold Formation by cataclysmic flooding, fluvial reworking, and erosion by the Columbia River. Areas where saturated Hanford formation sediments are thin or absent are expected to provide barriers to flow or to significantly decrease groundwater velocity.

In most of the area west and north of the 618-11 burial ground, the Ringold Formation sediments lie saturated beneath the present day water table. Most of the tritium (and associated contaminants) from the 200 East Area is presumed to be moving within the Hanford/Pre-Missoula sediments (Figure 1.4). Ringold Formation sediments are interpreted to be above the water table in the area east of the 618-11 burial ground. Limited data suggest that these Ringold Formation sediments may be exposed above the 
water table east of the burial ground to the river. The areal extent of this Ringold exposure is not accurately known but has been confirmed by outcrop evaluation along the river and in examination of excavations and drill cuttings during WNP-2 plant construction.

The water table surrounding the $618-11$ burial ground has been elevated over $4.6 \mathrm{~m}(15 \mathrm{ft})$ due to years of large volume artificial recharge to the aquifer in the 200 Areas located west of the site. Early water-level measurements are available from wells drilled in the $1950 \mathrm{~s}$. It is presumed that these old water-level measurements reflect a more regionally stable and natural condition that stabilized near the top of the Ringold Formation contact with the overlying Hanford/Pre-Missoula gravel and sand sequences. It is assumed this condition existed because the water table could not be sustained above this contact unless there was a significant flux in recharge, such as that which resulted from Hanford Site operations. 


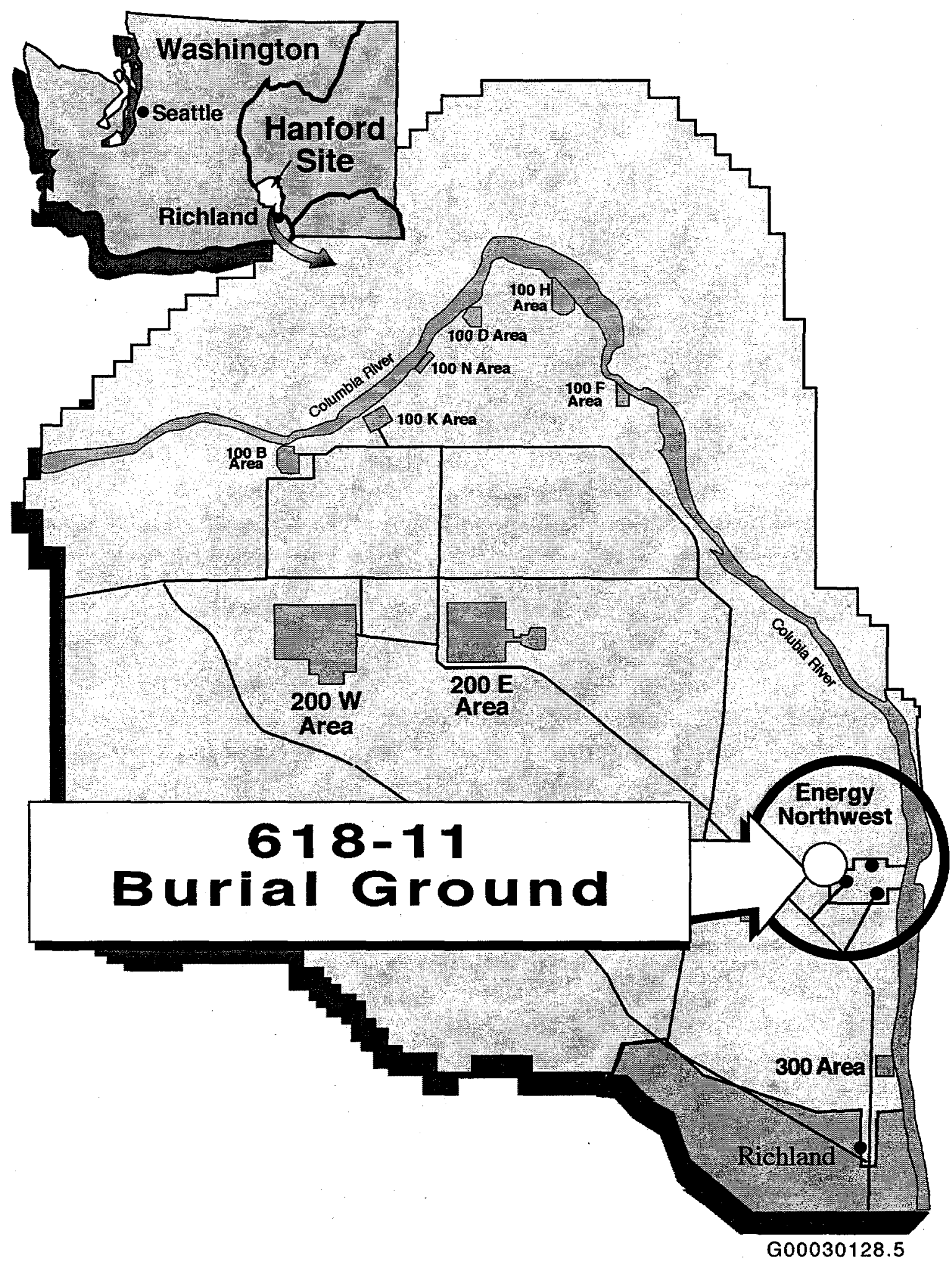

Figure 1.1. Location of the 618-11 Burial Ground, Hanford Site, Washington 


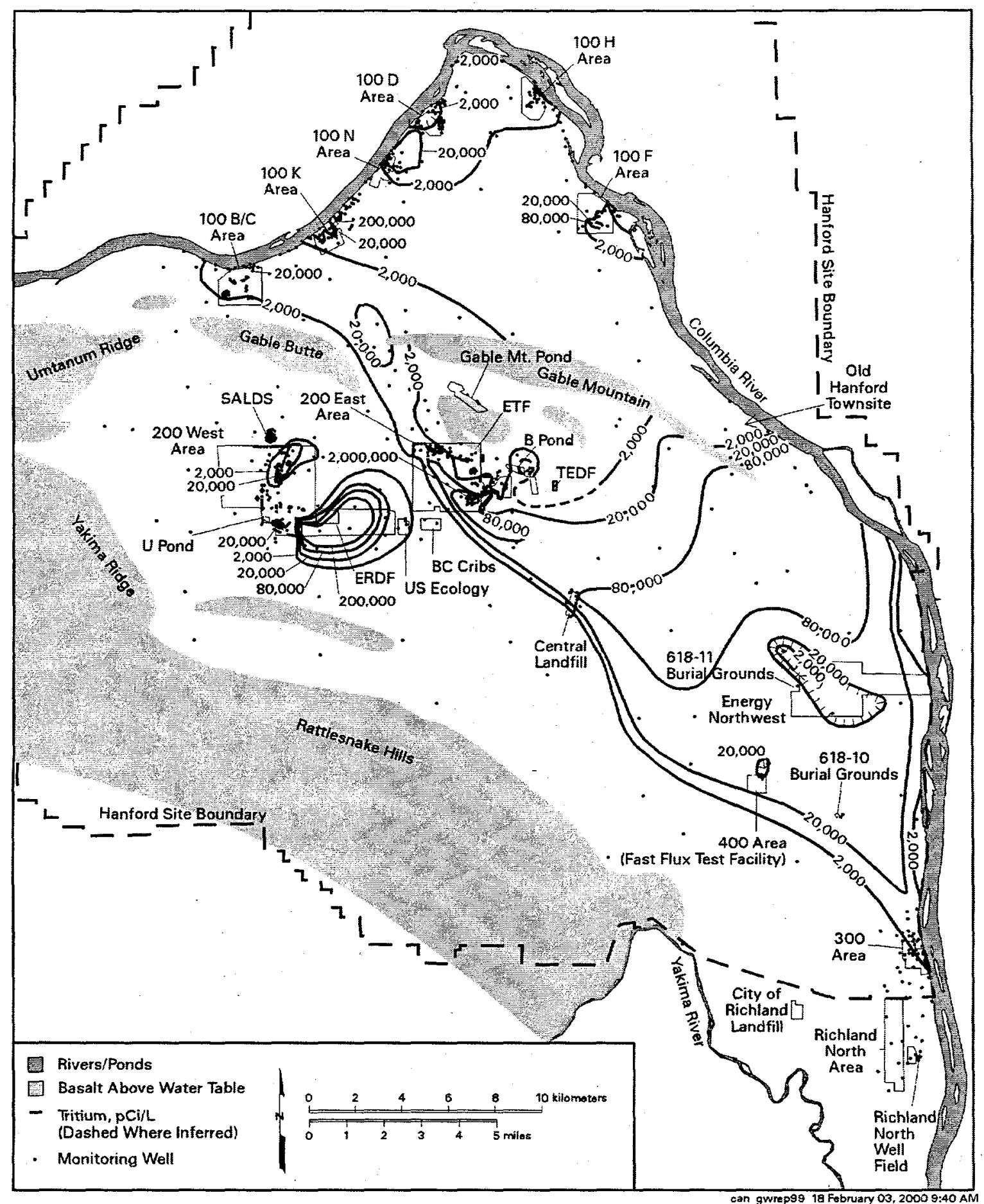

Figure 1.2. Tritium Concentrations at the Top of the Unconfined Aquifer, Hanford Site, Fiscal Year 1999 


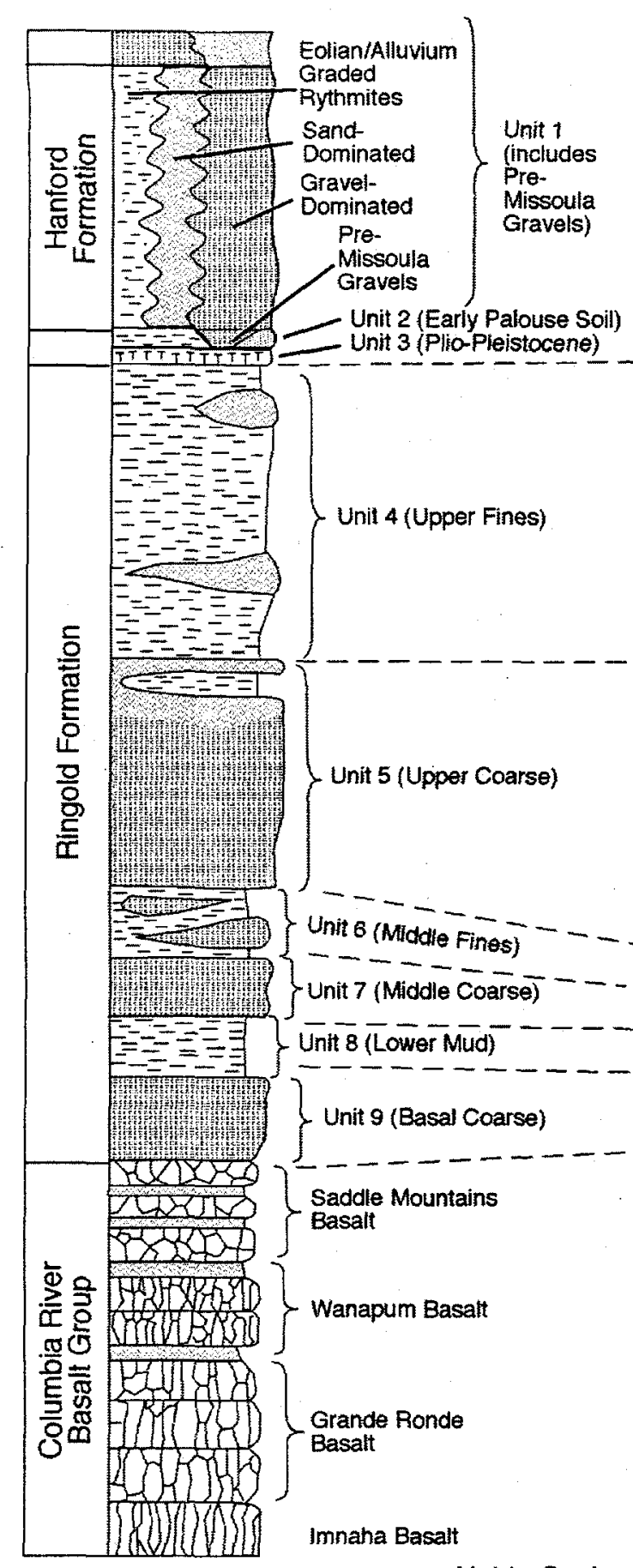

From PNL-8971

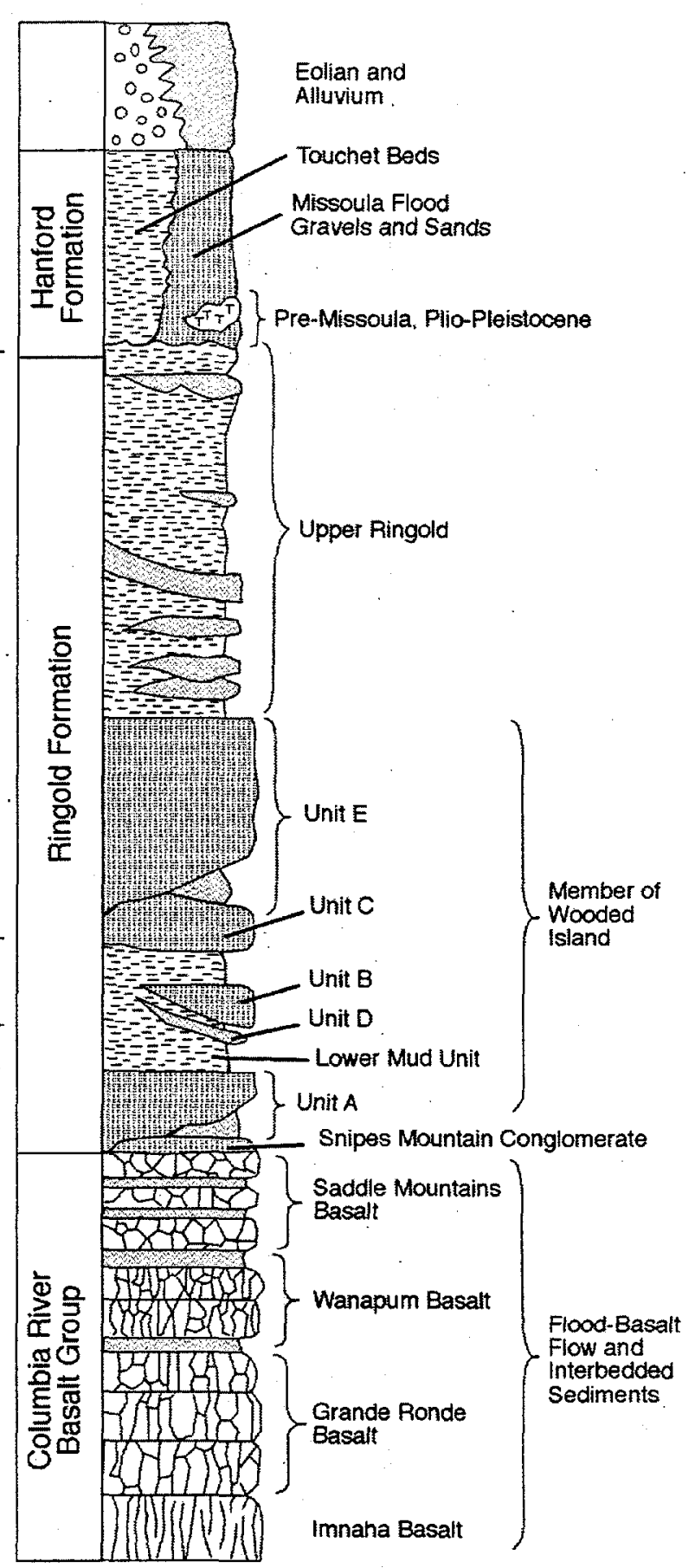

After BHI-00184

RG98120214.14

Figure 1.3. Generalized Hydrogeologic and Geologic Stratigraphy 


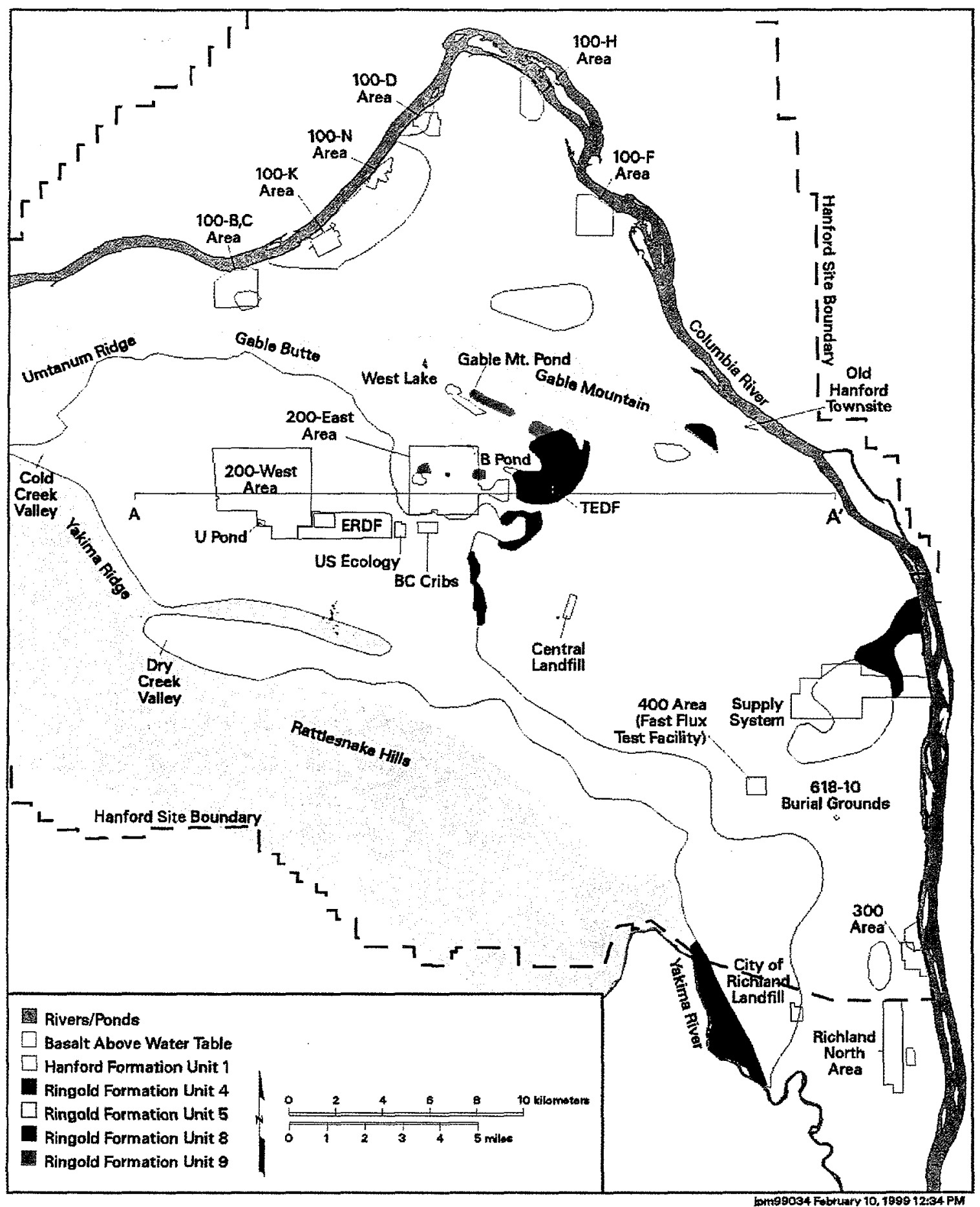

Figure 1.4. Hydrologic Units Present at the Water Table, 1998 


\subsection{Phase I Sampling and Analysis}

The Sample and Analysis Instructions for Special Sampling of High Concentration Tritium and Surrounding Wells Near the 618-11 Burial Ground, Revision 1, outlined the plan for this Phase I investigation (Appendix A). These instructions were based on a statement of data quality objectives that are included in the instructions.

The problem statement for the Data Quality Objectives is:

"In January 1999 a tritium level of $1,860,000 \mathrm{pCi} / \mathrm{L}$ was detected in well $699-13-3 \mathrm{~A}$, located near the 618-11 burial ground, just west of the Energy Northwest complex. This value was confirmed by reanalysis. A sample from January 2000 contained approximately $8,000,000 \mathrm{pCi} / \mathrm{L}$ of tritium. These levels are of concern because they are far above levels reported in the large tritium plume that extends from the 200 East Area through the area of the Energy Northwest complex.

The immediate task is to determine the extent of the anomalously high tritium concentrations and to provide data to distinguish the source."

\subsection{Sampling Design}

The Phase I investigation was designed to provide pertinent information as rapidly as was practicable. The investigation was restricted to sampling existing groundwater monitoring wells in the vicinity of the burial ground. Wells that needed significant remediation prior to sampling were excluded from the sampling. Phase I was restricted to a single round of sampling. The sampling concentrated on wells completed at the top of the unconfined aquifer, but some additional wells, including some confined aquifer wells, were included. Wells chosen for sampling are listed in Appendix A. Several of the wells could not be sampled as discussed in Section 2.2. The wells actually sampled are listed in Table 2.1 and are shown on Figure 2.1. The wells sampled include monitoring and water supply wells owned by Energy Northwest. These wells have not yet been assigned Hanford well names (i.e., "699" numbers), but unique well ID numbers have been assigned, corresponding to the Hanford well inventory. In this report, the well ID numbers and names used by Energy Northwest will be used to describe the wells. For example, Energy Northwest monitoring well MW-9 is associated with well ID C3079.

Radioactive analytes of interest include

- tritium

- strontium-90

- technetium-99

- iodine-129

- plutonium isotopes 
- gamma scan (reported radionuclides include beryllium-7, potassium-40, cobalt-60, ruthenium-106, antimony-125, cesium-134, cesium-137, europium-152, europium-154, and europium-155)

- gross alpha

- gross beta

- uranium (total and isotopic)

- plutonium isotopes (plutonium-238, plutonium-239/240).

Total activity screens were measured on a sample from well 699-13-3A where previous data indicated that the activity was near or above the Department of Transportation Shipping Limits for radionuclides and, thus, required special shipping papers. Total activity screens were also collected on wells where insufficient data were available to determine if the samples would need to be shipped as radioactive.

Chemical analytes of interest include

- alkalinity

- anions (including bromide, chloride, nitrate, and sulfate)

- filtered metals (including major cations such as calcium, magnesium, potassium, sodium, contaminants of interest such as chromium and other metals)

- semivolatile organic compounds (including tributyl phosphate and other compounds).

- volatile organic compounds (including carbon tetrachloride, trichloroethene, and other compounds).

Field parameters $\mathrm{pH}$, specific conductance, temperature, and turbidity were measured in all wells at the time of sampling.

The analytes for each well in the Phase I sampling are listed in the Sampling and Analysis Instructions (see Appendix A). The analyte list depended on the proximity to the burial ground, the monitored interval, and historical information from the wells. Only wells in the immediate vicinity of the 618-11 burial ground were sampled for volatile and semivolatile organic compounds. Plutonium isotopes, strontium-90, and total uranium were analyzed only in selected wells. Confined aquifer wells were sampled only for tritium.

Analysis of radiological constituents was performed by Quanterra Analytical Services, Richland Washington. A split sample from well 699-13-3A was sent to Thermo NUtech Laboratories, Richmond California, for tritium analysis. Chemical analyses were performed by Quanterra Analytical Services, St. Louis, Missouri. All analyses for well 699-13-3A were requested on a priority 7-day turn around time. Tritium analyses from other wells were requested on a 7-day turn around time and remaining analyses on a 14-day turn around time. In actuality, these turn around times were not met for all analyses as discussed in the following sections. Total activity screens were measured at the Waste Sampling and Characterization Facility laboratory on the Hanford Site and were reported in less than 24 hours. 
Additional radiological analyses were performed by Pacific Northwest National Laboratory. Screening sampling of strontium- 90 and technetium- 99 was performed using extraction with Empore ${ }^{\circledR}$ disks followed by gas proportional counting. In addition, technetium- 99 was measured using inductively coupled plasma/mass spectrometry (ICP/MS) because of disagreement between the different technetium-99 measurements and the gross beta measurements.

Several other groups collected split samples for independent analysis. These included Energy Northwest (tritium only), Washington State Department of Health, and Washington State Department of Ecology.

\subsection{Sampling Activities}

The sampling and analysis instructions were issued on Friday, February 4, 2000. Sampling began on Monday, February 7, 2000. The Phase I sampling was completed on February 15, 2000. Field records for the sampling were completed on Groundwater Sampling Report forms, which are included as Appendix B of this report.

The original sampling instructions listed 27 wells to be sampled, of which 22 wells actually were sampled. It was discovered that well 699-12-2A no longer exists. Well 699-14-E6T could not be sampled because of an obstruction. Wells 699-2-E14 and 699-15-E13 are confined aquifer wells that would require modification to collect representative samples. Therefore, they were removed from the Phase I sampling. Well 699-20-E12 was not sampled for several reasons. The annulus of the well was considered difficult or impossible to sample because of the presence of several piezometers. The uppermost piezometer had been removed, and, therefore, could not be sampled. The well was listed as requiring containment of purgewater, but the access road was not suitable for a purgewater truck. For these reasons, well 699-20-E12 was deleted from the Phase I sampling.

The results of the total activity screens for the sampling are listed in Appendix $\mathrm{C}$. The only samples that required shipping as radioactive material (greater than $2.0 \mathrm{nCi} / \mathrm{g}$ or $2,000,000 \mathrm{pCi} / \mathrm{L}$ ) were the samples from well 699-13-3A. The total activity screens also provide a useful comparison to laboratory results discussed in Section 3.

It is likely that decontamination water was left in the $90 \mathrm{~m} \mathrm{(300} \mathrm{ft)} \mathrm{pump} \mathrm{tubing} \mathrm{attached} \mathrm{to} \mathrm{the}$ portable pump during sampling of Energy Northwest well MW-7 (C3077). The specific conductance measured was low compared to that expected for groundwater samples. This well is located downgradient from a storm-water discharge that could have some impact on the specific conductance, but it is not felt that this would explain the unusual chemistry. For this reason, all data from sampling well MW-7 are considered suspect. Energy Northwest well MW-9 (C3079) is located upgradient of the storm-water discharge and closer to the 618-11 burial ground, so the data from MW-7 are not critical to the Phase I analysis. 
Table 2.1. Wells Sampled During the Phase I Sampling Event

\begin{tabular}{|c|c|c|c|c|c|c|c|}
\hline Well & Location & Pump Type & $\begin{array}{c}\text { Casing/ } \\
\text { Screen } \\
\text { Diameter } \\
\text { (in.) } \\
\end{array}$ & $\begin{array}{c}\text { Open } \\
\text { Interval } \\
\text { Top } \\
\text { (ft BGS) } \\
\end{array}$ & $\begin{array}{c}\text { Open } \\
\text { Interval } \\
\text { Bottom } \\
\text { (ft BGS) } \\
\end{array}$ & $\begin{array}{c}\text { Hydrogeologic } \\
\text { Interval }\end{array}$ & Comments \\
\hline $699-10-\mathrm{E} 12$ & Near River & Electric Submersible & 8 & 60 & 75.9 & Top unconfined & Perforated casing \\
\hline 699-12-4D & $\begin{array}{l}\text { At burial ground } \\
\text { (upgradient) }\end{array}$ & Electric Submersible & 8 & 65 & 145 & Top unconfined & Perforated casing \\
\hline $699-13-1 A$ & $\begin{array}{l}\text { Former WNP-2 } \\
\text { Supply Well }\end{array}$ & Portable Grundfos & 8 & 79 & 199.5 & Unconfined & Multiple screens \\
\hline $699-13-1 B$ & $\begin{array}{l}\text { Former WNP-2 } \\
\text { Supply Well }\end{array}$ & Portable Grundfos & 8 & 83 & 229.5 & Unconfined & Multiple screens \\
\hline $699-13-1 C$ & $\begin{array}{l}\text { WNP-2 Backup } \\
\text { Supply Well }\end{array}$ & Turbine & 6 & 506 & 695 & Confined & $\begin{array}{l}3 \text { Screens set in } \\
\text { open hole }\end{array}$ \\
\hline $699-13-3 A$ & $\begin{array}{l}\text { At burial ground } \\
\text { (downgradient) }\end{array}$ & Portable Grundfos & 4 & 55.94 & 76.28 & Top unconfined & \\
\hline $699-15-15 B$ & Upgradient & Electric Submersible & 6 & 141 & 154.7 & Top unconfined & \\
\hline $699-17-5$ & Upgradient & Electric Submersible & 8 & 45 & 62.5 & Top unconfined & Perforated casing \\
\hline $699-21-6$ & Upgradient & Electric Submersible & 6 & 43 & 66 & Top unconfined & $\begin{array}{l}\text { Screen inside } \\
\text { perforated casing }\end{array}$ \\
\hline $699-8-17$ & Upgradient & Electric Submersible & 8 & 109 & 139.3 & Top unconfined & $\begin{array}{l}\text { Screen inside } \\
\text { perforated casing }\end{array}$ \\
\hline 699-9-E2 & \begin{tabular}{|l} 
Energy \\
Northwest
\end{tabular} & Electric Submersible & 8 & 15 & 60 & Top unconfined & Perforated casing \\
\hline ENW-31 & $\begin{array}{l}\text { WNP-1 Supply } \\
\text { Well }\end{array}$ & Turbine & 12 & 247 & 341.5 & Confined & Multiple screens \\
\hline ENW-32 & $\begin{array}{l}\text { WNP-2 Supply } \\
\text { Well }\end{array}$ & Turbine & 12 & 244.25 & 366 & Confined & Multiple screens \\
\hline ENW-MW1 & \begin{tabular}{|l} 
Energy \\
Northwest
\end{tabular} & Portable Grundfos & 2 & 57.05 & 67.05 & Top unconfined & \\
\hline ENW-MW2 & $\begin{array}{l}\text { Energy } \\
\text { Northwest }\end{array}$ & Portable Grundfos & 2 & 55.00 & 65.00 & Top unconfined & \\
\hline ENW-MW3 & $\begin{array}{l}\text { Energy } \\
\text { Northwest }\end{array}$ & Portable Grundfos & 2 & 49.05 & 59.05 & Top unconfined & \\
\hline ENW-MW4 & \begin{tabular}{|l|} 
Energy \\
Northwest
\end{tabular} & Portable Grundfos & 2 & 63.50 & 73.50 & Top unconfined & . \\
\hline ENW-MW5 & \begin{tabular}{|l} 
Energy \\
Northwest
\end{tabular} & Portable Grundfos & 2 & 60.02 & 75.02 & Top unconfined & \\
\hline ENW-MW6 & $\begin{array}{l}\text { Energy } \\
\text { Northwest }\end{array}$ & Portable Grundfos & 2 & 36.37 & 46.37 & Top unconfined & \\
\hline ENW-MW7 & $\begin{array}{l}\text { Energy } \\
\text { Northwest }\end{array}$ & Portable Grundfos & 2 & 17.66 & 27.66 & Top unconfined & \\
\hline ENW-MW8 & \begin{tabular}{|l} 
Energy \\
Northwest
\end{tabular} & Portable Grundfos & 2 & 25.17 & 35.17 & Top unconfined & \\
\hline ENW-MW9 & \begin{tabular}{|l} 
Energy \\
Northwest
\end{tabular} & Portable Grundfos & 2 & 26.85 & 36.85 & Top unconfined & \\
\hline
\end{tabular}




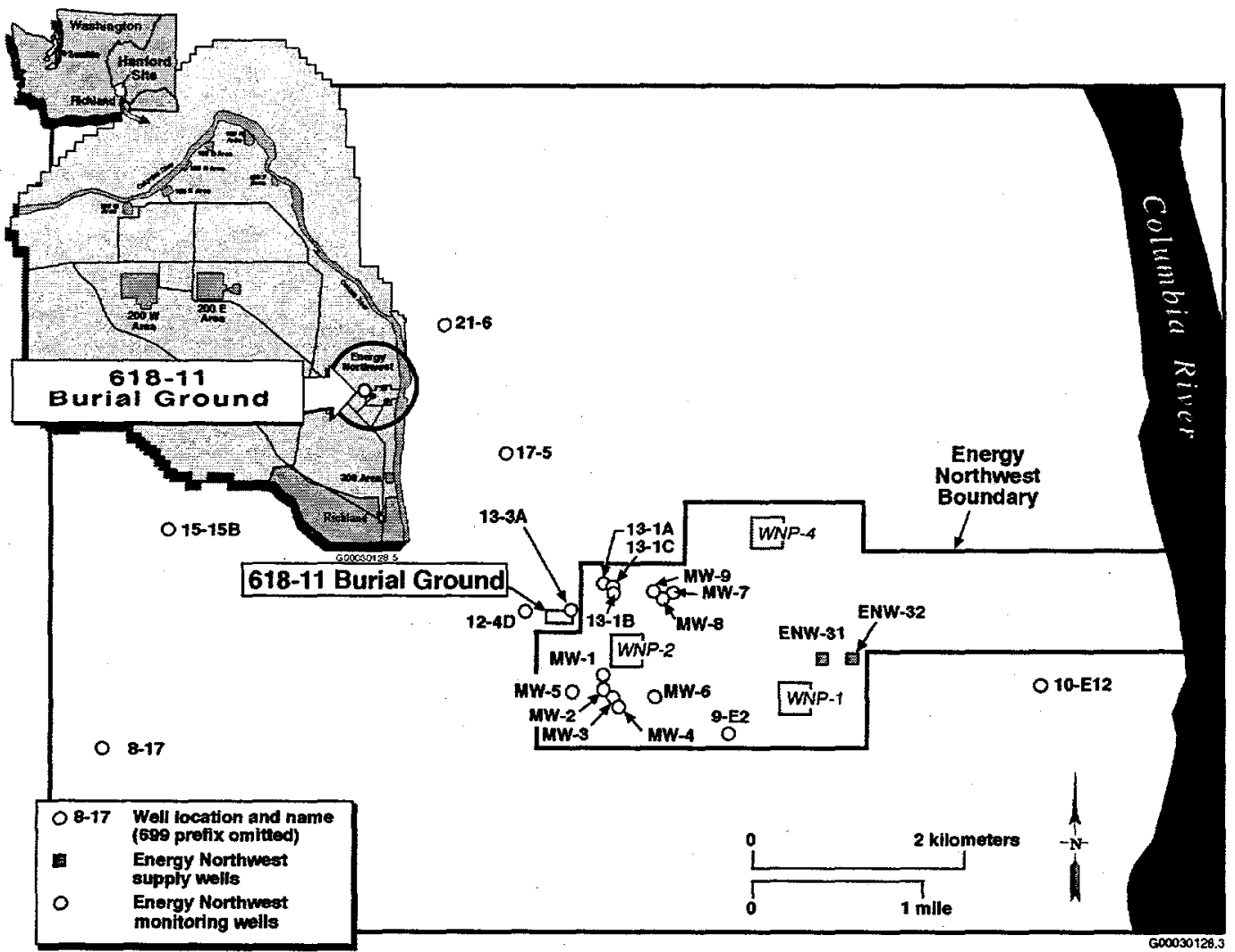

Figure 2.1. Groundwater Well Locations in the Vicinity of the 618-11 Burial Ground 


\subsection{Results of Phase I Sampling}

Analytical results for the Phase I sampling are tabulated in Appendix C. These results must be considered preliminary because not all formal data packages were received from the laboratory at the time this report was prepared. Well 699-13-3A continued to have elevated tritium compared to the surrounding 600 Area at 7,229,700 pCi/L (a replicate analysis indicated $6,894,100 \mathrm{pCi} / \mathrm{L}$ of tritium). Tritium levels in other wells are all less than $60,000 \mathrm{pCi} / \mathrm{L}$. This means that well $699-13-3 \mathrm{~A}$ remains the primary focus of the investigation. The results of radionuclide sampling will be summarized first. Then the results of the chemical constituent sampling will be described. Only the primary result will be discussed where replicate analyses are available unless there is a significant difference between replicates.

\subsection{Radionuclide Results}

\subsubsection{Tritium}

Tritium results are shown in Figure 3.1. As stated above, well 699-13-3A was the only well with extremely high tritium results $(7,230,000 \mathrm{pCi} / \mathrm{L})$. The maximum concentration detected in the other wells in this sampling event was $54,400 \mathrm{pCi} / \mathrm{L}$ in well $699-8-17$, which is located upgradient of the $618-11$ burial ground.

Well $699-12-4 \mathrm{D}$, located immediately upgradient of the burial ground, contained only $1,850 \mathrm{pCi} / \mathrm{L}$ of tritium. Well 699-12-4D is an older well, with perforated casing, that extends $28 \mathrm{~m}(92 \mathrm{ft})$ below the water table. Thus, the sample may be subject to some dilution by mixing in the borehole.

Other wells that are located upgradient or cross-gradient from the 618-11 burial ground include wells 699-8-17, 699-15-15B, 699-17-5, and 699-21-6. These wells are not believed to be effected by any potential release from the burial ground because of their location. Therefore, they provide information on the regional tritium plume. Tritium concentrations in these wells ranged from non-detect up to $54,400 \mathrm{pCi} / \mathrm{L}$. Although these data bound the regional plume concentrations, the rather large variation complicates detailed interpretation.

The nearest wells downgradient of well 699-13-3A are wells 699-13-1A, 699-13-1B, and 699-13-1C. Well 699-13-1A contained the highest tritium levels of the group, $23,300 \mathrm{pCi} / \mathrm{L}$, while tritium was barely detected in well $699-13-1 \mathrm{~B}$ at $300 \mathrm{pCi} / \mathrm{L}$. Tritium was not detected in well $699-13-3 \mathrm{C}$, which is completed in the uppermost basalt-confined aquifer. These wells were drilled as water supply wells and do not represent conditions at the top of the aquifer. Wells 699-13-1A and 699-13-1B have multiple open intervals, none across the water table. These wells were sampled with a portable pump. The pump was set in the middle of the uppermost screen. The great difference in tritium concentrations between wells 699-13-1A and 699-13-1B suggests that the samples came predominantly from different intervals.

Tritium concentrations in monitoring wells located near WNP-2 ranged up to $14,100 \mathrm{pCi} / \mathrm{L}$. These monitoring wells are roughly downgradient from the 618-11 burial ground. 
Wells currently designated ENW-31 (C3080) and ENW-32 (C3081) are water supply wells for WNP-1 that are completed in the uppermost basalt confined aquifer. Tritium was not detected in these wells.

Well $699-10-E 12$ is located approximately downgradient of the $618-11$ burial ground and roughly $1.5 \mathrm{~km}(0.9 \mathrm{mi})$ from the Columbia River. It contained $23,200 \mathrm{pCi} / \mathrm{L}$ of tritium, within the range of values for upgradient wells.

\subsubsection{Uranium and Gross Alpha}

The only radionuclides other than tritium detected in well 699-13-3A were uranium, technetium-99, gross alpha, and gross beta (see Appendix $\mathrm{C}$ ). The gross alpha measurements agree with the uranium isotopic measurements with the possible exception of Energy Northwest well MW-1 (C3071) where the total uranium concentration was over $5 \mathrm{pCi} / \mathrm{L}$ greater than the gross alpha concentration (Table 3.1). Thus, the uranium is the only significant alpha emitter in the groundwater. The uranium isotopic data can be compared to the total uranium measurements by converting the individual isotope activityconcentration to mass concentration using the specific activity of the isotopes. The sum of the isotopic mass is in agreement with the measured uranium concentrations where both analyses were performed.

The calculated uranium concentrations are shown in Figure 3.2. Uranium concentrations were greater than the proposed maximum contaminant level of $20 \mu \mathrm{g} / \mathrm{L}$ in monitoring wells Energy Northwest wells MW-2 (C3072), MW-3 (C3073), and MW-9 (C3079). The uranium concentration in well 699-13-3A was measured at $10.3 \mu \mathrm{g} / \mathrm{L}$ and calculated from the individual isotopes to be $10.7 \mu \mathrm{g} / \mathrm{L}$. This value is somewhat higher than the immediately upgradient well $699-12-4 \mathrm{D}$, where the calculated concentration is $5.7 \mu \mathrm{g} / \mathrm{L}$ but well within the range of data from surrounding wells. The uranium concentration in well 699-13-3A is comparable to previous results (Figure 3.3). The gross alpha measurements are also similar to previous results (Figure 3.4).

The cause of elevated uranium in groundwater in the study area is unclear. The concentrations are spatially variable and do not form distinct plumes. There is no obvious relationship to the $618-11$ burial ground or any other potential source.

The uranium concentrations in these samples are generally too low to develop an isotopic signature from the activity ratios. This is particularly true of the uranium-235, which was below the detection limit for several samples. It is possible to measure more precise isotopic ratios using other techniques.

\subsubsection{Gross Beta, Technetium-99, and Strontium-90}

Strontium- 89 and strontium- 90 were not detected in the total-beta radiostrontium analyses from any of the samples. Technetium-99 is a low energy beta emitter, so it is undercounted in the gross beta measurements. The energy of the technetium- 99 beta is only $0.294 \mathrm{MeV}$ compared to $0.546 \mathrm{MeV}$ for strontium-90 and $2.281 \mathrm{MeV}$ for yttrium-90, a short lived daughter of strontium-90. At the Hanford Site, a rule of thumb is that a gross beta measurement will be approximately one-third of the technetium-99 concentration where technetium-99 is the major beta-emitter present. 
Technetium-99 results reported by the primary analytical laboratory for well 699-13-3A are considered suspect because they do not agree with the gross beta measurements and the results do not agree with technetium-99 measurements reported using different methods by Pacific Northwest National Laboratory. The primary analytical laboratory reported $18,600 \mathrm{pCi} / \mathrm{L}$ of technetium- 99 with a duplicate value of $13,600 \mathrm{pCi} / \mathrm{L}$; compared to the gross beta measurement of $15 \mathrm{pCi} / \mathrm{L}$ with a duplicate value of $20.8 \mathrm{pCi} / \mathrm{L}$. The technetium -99 concentration of $54.5 \mathrm{pCi} / \mathrm{L}$ (by the Empore disk measurement at Pacific Northwest National Laboratory) is in agreement with the gross beta measurement. Additional technetium-99 measurements were made at Pacific Northwest National Laboratory using inductivelycoupled plasma/mass spectrometry because of the discrepancies between other analyses. The inductivelycoupled plasma/mass spectrometry results were $0.004 \mu \mathrm{g} / \mathrm{L}$ with a duplicate of $0.005 \mu \mathrm{g} / \mathrm{L}$ that correspond to $68 \mathrm{pCi} / \mathrm{L}$ and $85 \mathrm{pCi} / \mathrm{L}$ respectively. These results confirm the Empore disk measurements but are less precise because the results were near the detection limits (approximately $0.001 \mu \mathrm{g} / \mathrm{L}$ ). The inductively-coupled plasma/mass spectrometry analysis was performed on filtered samples rather than the standard unfiltered samples because there was insufficient unfiltered samples remaining for analysis. The primary analytical laboratory results are being investigated, and it appears that the tritium may have interfered with the measurement. The conclusion is that there are no major beta-emitting radionuclides that were not included in the analyte list.

Gross beta results from the February 2000 sampling of well 699-13-3A were considerably lower than results from the preceding sampling. Concentrations of gross beta had risen in this well, reaching $36.6 \mathrm{pCi} / \mathrm{L}$ in January 2000 . However, the February result was $15.0 \mathrm{pCi} / \mathrm{L}$ with a duplicate sample reported as $20.8 \mathrm{pCi} / \mathrm{L}$ (Figure 3.5). The reason for this decline is unclear, as is the reason for the previously increasing trend. It is possible that the pump was placed at a different depth in the February sample and resulted in changes in concentration. However, the drop in gross beta is proportionally greater than the drop in tritium concentration. Tritium is not detected in the gross beta measurement because the gross beta sample is first evaporated onto a planchet.

\subsubsection{Other Radionuclides}

No radionuclides were detected in the gamma-scan from any of the wells. Gamma-emitting radionuclides reported as non-detect include beryllium- 7 , potassium-40, cobalt- 60 , ruthenium-106, antimony-125, cesium-134, cesium-137, europium-152, europium-154, and europium-155. Other radionuclides would be reported if detected.

Iodine-129 was not detected in any of the samples. Even the wells upgradient of the 618-11 burial ground are outside the area of the detectable iodine- 129 plume from 200 East Area so this is not unexpected.

Plutonium isotopes were not detected in any of the samples.

\subsection{Chemical Results}

Anion, filtered metal, and alkalinity measurements were made at all wells sampled in February 2000 . Volatile organic compounds and semivolatile organic compounds were measured in wells $699-12-4 \mathrm{D}$, 
699-13-1A, 699-13-3A, and 699-10-E12. The charge balance calculated from the anion, major cations, and alkalinity was within $6 \%$ with the exception of Energy Northwest well MW-7 (C3077), which had a charge balance of $-13.55 \%$. As discussed in Section 2.2, the data from this well are suspect due to incomplete purging of decontamination rinse from the pump tubing.

\subsubsection{Nitrate}

The nitrate distribution in the vicinity of the 618-11 burial ground is shown in Figure 3.6. The highest nitrate concentration detected was $32.5 \mathrm{mg} / \mathrm{L}$ (as N) in Energy Northwest monitoring well MW-9 (C3079). The drinking water standard maximum contaminant level for nitrate is $10 \mathrm{mg} / \mathrm{L}$ as $\mathrm{N}$. The nitrate concentration in well 699-13-3A was also over twice the maximum contaminant level at $22.8 \mathrm{mg} / \mathrm{L}$ as N. Well 699-17-5, located north of the burial ground also contained nitrate at levels above the maximum contaminant level $(16.4 \mathrm{mg} / \mathrm{L}$ as $\mathrm{N})$. Thus the nitrate contamination is relatively widespread and does not correspond to the tritium contamination. Monitoring well 699-12-4D, located west (upgradient) of the $618-11$ burial ground contained $6.3 \mathrm{mg} / \mathrm{L}$ (as N) nitrate, a much lower concentration than well 699-13-3A.

\subsubsection{Other Anions}

Traces of nitrite were detected in wells $699-17-5(0.097 \mathrm{mg} / \mathrm{L}$ as $\mathrm{N})$ and $699-21-6(0.044 \mathrm{mg} / \mathrm{L}$ as $\mathrm{N})$. The presence of nitrite indicates slightly reducing conditions in these wells. The nitrite is less than the maximum contaminant level of $1 \mathrm{mg} / \mathrm{L}$ and appears unrelated to the high tritium concentration in well 699-13-3A. Nitrite was not detected in the other wells sampled.

Sulfate was detected at $259 \mathrm{mg} / \mathrm{L}$ in Energy Northwest monitoring well MW-9 (C3079), a level slightly above the $250 \mathrm{mg} / \mathrm{L}$ secondary maximum contaminant level. Sulfate varied greatly throughout the study area, ranging from $2 \mathrm{mg} / \mathrm{L}$ in uppermost basalt-confined aquifer well $699-13-1 \mathrm{C}$, to the $259 \mathrm{mg} / \mathrm{L}$ in Energy Northwest well MW-9 (C3079).

\subsubsection{Cations}

No metals were detected at levels above primary maximum contaminant levels. All metal analyses were performed on samples filtered through $0.45 \mu \mathrm{m}$ filters in the field. Aluminum was detected at an extremely high level of $1,060 \mu \mathrm{g} / \mathrm{L}$ in well $699-13-1 \mathrm{~A}$. It is not plausible that aluminum at this level is present in solution at the sample $\mathrm{pH}$ of 8.06 , so this result is considered suspect. This aluminum level is greater than the secondary maximum contaminant level.

Iron was detected in well 699-21-6 at $378 \mu \mathrm{g} / \mathrm{L}$, above the secondary maximum contaminant level of $300 \mu \mathrm{g} / \mathrm{L}$. Manganese in well 699-21-6 was also slightly above the $50 \mu \mathrm{g} / \mathrm{L}$ secondary maximum contaminant level at $50.1 \mu \mathrm{g} / \mathrm{L}$. The only other well with concentrations of manganese above the secondary maximum contaminant level was well $699-13-1 \mathrm{~B}$ with $94.2 \mu \mathrm{g} / \mathrm{L}$. The manganese concentration in well 
699-13-1A was slightly below the secondary maximum contaminant level at $49.2 \mu \mathrm{g} / \mathrm{L}$. The presence of iron and manganese may be related to slightly reducing conditions because the solubility is greater under reducing conditions.

\subsubsection{Major Ion Water Types}

The relationships between the major ions in groundwater are commonly used to distinguish waters of distinct geochemical types and to infer the history and evolution of groundwater chemistry. The Piper diagram is one method used to graph the relationships between cations and anions in groundwater (Piper 1944). The Piper diagram illustrates the relative proportion of cations and of anions (in milliequivalents per liter).

A Piper diagram for the samples analyzed in the Phase I investigation is shown in Figure 3.7. On this figure the black circles are samples from the top of the unconfined aquifer, except for well 699-13-3A, which is shown in red for emphasis. The samples from deeper in the unconfined aquifer (former water supply wells 699-13-1A and 699-13-1B) are shown in blue, and samples from the confined aquifer (former water supply well 699-13-1C and Energy Northwest water supply wells at WNP-1, ENW-31 (C3080) and ENW-32 (C3081) are shown in green.

The diagram shows a distinct difference among the three intervals, particularly with regard to the cations. The samples from the top of the unconfined aquifer are dominated by calcium with approximately equal proportions of sodium and magnesium. The confined aquifer samples are dominated by sodium with lesser amounts of calcium and magnesium. The samples from deeper in the unconfined aquifer are intermediate in composition between the top of the unconfined and the confined aquifer.

Nearly all the samples contain bicarbonate as the major anion (nitrate is not considered in the Piper diagram presented in Figure 3.7). Carbonate is insignificant at the $\mathrm{pH}$ of the samples. The confined aquifer, deeper unconfined aquifer, and some samples from the top of the unconfined aquifer contain over $80 \%$ bicarbonate. The samples from the top of the unconfined aquifer show considerable variation in the proportion of sulfate and bicarbonate present with only minor variation in the chloride. If nitrate is included in the Piper diagram by combining it with chloride, then the samples from the top of the unconfined aquifer scatter more with respect to anions (Figure 3.8). Well 699-13-3A has an elevated proportion of chloride plus nitrate relative to most samples.

Multivariate plots (also called spider diagrams or radar diagrams) provide an alternate way to compare groundwater chemistry between wells. An advantage of spider diagrams is that they can include as many individual ions as required. They can be plotted in absolute concentrations or as percents of the total. A disadvantage is that they can become quite complicated if many wells are included.

The spider diagram shown in Figure 3.9 illustrates several distinct ratios of anions in unconfined aquifer wells near the 618-11 burial ground. Wells 699-12-4D and Energy Northwest well MW-1 (C3071) are typical of most wells in the area, with high bicarbonate and low sulfate, nitrate, and chloride. Energy Northwest well MW-2 (C3072) is unique because it has somewhat elevated chloride. Energy Northwest well MW-9 (C3079) contains a distinctly high proportion of sulfate and nitrate, unlike any 
other wells sampled. The high sulfate raises questions regarding the relationship between elevated nitrate concentrations seen in well 699-13-3A and Energy Northwest well MW-9 (C3079). The ratio of the anions in well 699-13-3A is nearly identical to the ratio in well 699-17-7, located to the north suggesting a similar origin unrelated to the $618-11$ burial ground.

\subsubsection{Organic Constituents}

Organic constituents were measured in selected wells during the Phase I sampling and analysis. The samples measured for Appendix IX list volatile and semivolatile organic constituents are well 699-12-4D, located immediately upgradient of the burial ground, well 699-13-3A, immediately downgradient of the burial ground, well 699-13-1A, a former water supply well, and well 699-10-E12, located several kilometers downgradient of the burial ground (see Figure 2.1).

Methylene chloride was detected in both samples from well 699-13-3A at a concentration of 3 to $3.4 \mu \mathrm{g} / \mathrm{L}$. However, contamination was detected also in the laboratory blanks associated with these samples. A trace of methylene chloride, $0.68 \mu \mathrm{g} / \mathrm{L}$, was detected also in the sample from well 699-13-1A. The maximum contaminant level for methylene chloride (dichloromethane) is $5 \mu \mathrm{g} / \mathrm{L}$. Methylene chloride was detected in several field transfer and equipment blanks. Laboratory contamination is suspected because methylene chloride is a common laboratory contaminant.

Traces of carbon tetrachloride, $0.24 \mu \mathrm{g} / \mathrm{L}$, were detected in the duplicate samples from well 699-13-3A. Trichloroethene was detected in one of the two duplicates at a level of $0.32 \mu \mathrm{g} / \mathrm{L}$. Trichloroethene was also detected at a level of $0.21 \mu \mathrm{g} / \mathrm{L}$ in an equipment blank associated with this well.

Chlorobenzene was detected at $0.41 \mu \mathrm{g} / \mathrm{L}$ in well $699-12-4 \mathrm{D}$. This value is near the method detection limit. The MCL for chlorobenzene is $100 \mu \mathrm{g} / \mathrm{L}$.

The only semivolatile constituent identified in the samples was a detection of an estimated $1.4 \mu \mathrm{g} / \mathrm{L}$ of bis(2-ethylhexyl) phthalate in one of the duplicates from well 699-13-3A. The compound bis(2-ethylhexyl) phthalate is considered to be a common laboratory contaminant.

\subsection{Quality Control}

Quality control data for the 618-11 burial ground investigation includes the results from field blanks, field duplicates, split samples, and several types of laboratory-generated quality control samples. These latter samples include method blanks, laboratory control standards, matrix duplicates, matrix spikes, and matrix spike duplicates. Definitions of the different types of quality control samples are provided in Appendix D. This discussion focuses mainly on the field quality control results; however, a brief summary of the laboratory quality control data is provided near the end of this section.

Table 3.2 lists the number and types of field quality control samples that were collected for the Phase I investigation. Three types of field blanks were included to check for contamination resulting from field activities and/or bottle preparation. Two field duplicates were collected to provide a measure 
of the overall sampling and analysis precision. A split sample was also collected for additional confirmation of previous elevated tritium results from well 699-13-3A.

A total of 208 results were generated from the field blanks. Forty-nine results were above the detection limits, and 32 results were greater than the quality control limit for field blanks (generally 2 times the method detection limit for chemistry methods and 2 times the total propagated uncertainty for radiochemistry methods). Except for one potassium-40 result ( $133 \mathrm{pCi} / \mathrm{L} ; 2$ times the minimum detectable activity), no radionuclides were detected in any field blanks. The constituents with out-of-limit results were bromodichloromethane, calcium, chloride, chloroform, iron, sodium, and zinc. Most of the out-of-limit results were 10 to 20 times lower than the lowest concentrations measured in groundwater samples from the Phase I investigation. However, iron and zinc were detected in field blanks at levels similar to those in groundwater samples. Iron was found in 4 field blanks at concentrations ranging from $55.3 \mu \mathrm{g} / \mathrm{L}$ to $371 \mu \mathrm{g} / \mathrm{L}$. Zinc was detected in 6 field blanks; the results ranged from $6.7 \mu \mathrm{g} / \mathrm{L}$ to $26.1 \mu \mathrm{g} / \mathrm{L}$. Levels of iron and zinc up to $89.8 \mu \mathrm{g} / \mathrm{L}$ were also detected in laboratory method blanks. Bromodichloromethane and chloroform were measured in both equipment and full trip blanks at levels up to $23 \mu \mathrm{g} / \mathrm{L}$, but neither compound was detected in groundwater samples. Based on previous groundwater-monitoring-project data, the source of these trihalomethanes is suspected to be the reagent water used to prepare the field . blanks. Overall, the field blank results suggest that sample contamination was not significant for the Phase I investigation.

Field duplicate results are evaluated using the relative percent difference statistic, which is calculated for each pair of matching results. In general, field duplicates with at least one result greater than 5 times the method detection limit or minimum detectable activity must have a relative percent difference less than $20 \%$ to be considered acceptable. The two field duplicate samples for the Phase I investigation were analyzed for alkalinity, anions, metals, and several radionuclides to produce a total of 71 result pairs. Ninety-four percent of the field duplicate results were within quality control limits; thus, sampling and analysis precision was excellent overall. Four pairs of results had quantifiable results that exceeded the quality control limits. Iron had results of $71.7 \mu \mathrm{g} / \mathrm{L}$ and $262 \mu \mathrm{g} / \mathrm{L}$ for samples from Energy Northwest well MW-9 (C3079) ; the relative percent difference was 114\%. Two of the zinc results $(33 \mu \mathrm{g} / \mathrm{L}$ and $21.7 \mu \mathrm{g} / \mathrm{L}$ ) from well $699-13-3 \mathrm{~A}$ had a relative percent difference of $41 \%$. Both of these metals were detected in field and method blanks; thus, the poor precision may have resulted from sample contamination. The relative percent difference for gross beta and technetium-99 in samples from 699-13-3A was $32 \%(15.0 \mathrm{pCi} / \mathrm{L}$ and $20.8 \mathrm{pCi} / \mathrm{L})$ and $31 \%(13,600 \mathrm{pCi} / \mathrm{L}$ and $18,600 \mathrm{pCi} / \mathrm{L})$, respectively. The reason for the variability in these results is unknown, but it should be noted that the technetium-99 results appear to be unreasonably high based on the relatively low gross-beta concentrations. The technetium-99 matrix spike result for the $699-13-3 \mathrm{~A}$ sample was also very high (211\% recovery); thus, a matrix interference may have biased the results.

The split sample results for tritium in well $699-13-3 \mathrm{~A}$ were $7,230,000 \mathrm{pCi} / \mathrm{L}$ and $7,410,000 \mathrm{pCi} / \mathrm{L}$, indicating agreement between laboratories. These values, along with the field duplicate result of $6,890,000 \mathrm{pCi} / \mathrm{L}$, confirm the elevated result of $8,140,000 \mathrm{pCi} / \mathrm{L}$ measured at this well in January 2000. 
Most of the laboratory quality control results were within acceptance limits, indicating the analyses were generally in control, and the results are reliable. The following observations summarize the laboratory quality control results:

- Four constituents exceeded the quality control limits for method blanks: aluminum, chloride, iron, and zinc. Two method blanks had aluminum results $(63 \mu \mathrm{g} / \mathrm{L}$ and $89 \mu \mathrm{g} / \mathrm{L})$ that were greater than the levels measured in most of the groundwater samples taken during the Phase I investigation. As noted previously, iron and zinc were also detected at levels comparable to groundwater-sample concentrations.

- All laboratory-control-sample results were within acceptance limits.

- Four matrix duplicates with quantifiable results had a relative percent difference greater than $20 \%$. Three of the out-of-limit result pairs were for uranium-234. The largest relative percent difference for uranium-234 was $24.3 \%$; thus, the data was not significantly compromised. Gross alpha in laboratory duplicates from Energy Northwest well MW-8 (C3078) had results of 6.3 and $22 \mathrm{pCi} / \mathrm{L}$. The reason for the poor precision in these samples is unknown.

- Most matrix spike results were within acceptance limits; thus, sample-matrix effects did not appear to have a significant impact on data quality. Six matrix spike recoveries were high; the results were for chloride, fluoride, nitrite, technetium-99, and uranium. However, only the chloride and technetium99 recoveries were significantly out-of-limit (i.e., $>140 \%$ ). Both results were associated with samples from well $699-13-3 \mathrm{~A}$. The chloride recovery was $204 \%$, and the technetium- 99 recovery was $211 \%$. In both cases, the associated sample results may be biased high. 
Table 3.1. Comparison of Uranium Isotopic Concentrations to Gross Alpha and Total Uranium Concentrations

\begin{tabular}{|c|c|c|c|c|c|c|c|c|}
\hline Well & $\begin{array}{c}\text { Sample } \\
\text { Number }\end{array}$ & $\begin{array}{c}\mathrm{U}-234 \\
(\mathrm{pCi} / \mathrm{L})\end{array}$ & $\begin{array}{c}\mathrm{U}-235 \\
(\mathbf{p C i} / \mathbf{L})\end{array}$ & $\begin{array}{c}\mathrm{U}-238 \\
(\mathrm{pCi} / \mathrm{L})\end{array}$ & $\begin{array}{c}\text { Total } \\
\text { Uranium } \\
\text { (pCi/L) }\end{array}$ & $\begin{array}{c}\text { Gross Alpha } \\
(\mathbf{p C i} / \mathbf{L})\end{array}$ & $\begin{array}{c}\text { Calculated } \\
\text { Total Uranium } \\
(\mu \mathrm{g} / \mathrm{L})\end{array}$ & $\begin{array}{l}\text { Measured Total } \\
\text { Uranium }(\mu \mathrm{g} / \mathrm{L})\end{array}$ \\
\hline $699-10-\mathrm{E} 12$ & $\mathrm{~B} 0 \mathrm{XK02}$ & 2.37 & 0.09 & 1.43 & 3.90 & 3.71 & 4.30 & 5.15 \\
\hline $699-12-4 D$ & B0XJW0 & 1.80 & 0.02 & 1.91 & 3.74 & 3.44 & 5.70 & 5.87 \\
\hline $699-13-1 A$ & BOXJW9 & 2.77 & -0.01 & 1.29 & 4.05 & 4.16 & 3.83 & \\
\hline $699-13-3 A$ & BOXJT8 & 4.35 & 0.29 & 3.55 & 8.18 & 6.06 & 10.70 & 10.32 \\
\hline $699-15-15 B$ & B0XK20 & 3.39 & 0.12 & 2.28 & 5.79 & 4.22 & 6.84 & \\
\hline $699-17-5$ & B0XK15 & 1.36 & 0.11 & 0.99 & 2.46 & 2.48 & 2.98 & \\
\hline $699-21-6$ & $\mathrm{~B} 0 \times \mathrm{KK} 23$ & 1.56 & -0.01 & 0.96 & 2.51 & 2.08 & 2.85 & \\
\hline $699-8-17$ & $\mathrm{~B} 0 \mathrm{XK} 12$ & 1.53 & 0.04 & 1.32 & 2.89 & 3.83 & 3.95 & \\
\hline 699-9-E2 & B0XJY4 & 1.28 & 0.07 & 1.13 & 2.48 & 1.98 & 3.40 & \\
\hline C3071/ENW-MW1 & $\mathrm{B} 0 \mathrm{XKCl}$ & 5.93 & 0.34 & 5.09 & 11.36 & 5.23 & 15.31 & \\
\hline C3072/ENW-MW2 & $\mathrm{B} 0 \mathrm{XKC2}$ & 12.20 & 0.58 & 10.90 & 23.68 & 22.10 & 32.71 & \\
\hline C3073/ENW-MW3 & B0XKC3 & 7.67 & 0.79 & 7.96 & 16.42 & 18.40 & 24.06 & \\
\hline C3074/ENW-MW4 & B0XKC4 & 2.01 & 0.19 & 2.57 & 4.77 & 6.50 & 7.74 & \\
\hline C3075/ENW-MW5 & BOXKC5 & 1.45 & 0.02 & 0.93 & 2.39 & 3.51 & 2.77 & \\
\hline C3076/ENW-MW6 & B0XKC6 & 4.14 & 0.22 & 4.36 & 8.72 & 7.66 & 13.08 & \\
\hline C3078/ENW-MW8 & $\mathrm{B} 0 \mathrm{XKC} 8$ & 3.00 & 0.18 & 2.96 & 6.14 & 6.32 & 8.89 & \\
\hline C3079/ENW-MW9 & B0XKC9 & 12.60 & 0.52 & 12.30 & 25.42 & 22.10 & 36.85 & \\
\hline C3079/ENW-MW9 & B0XKD0 & 13.70 & 0.42 & 11.40 & 25.52 & 22.80 & 34.13 & \\
\hline C3080/ENW-31 & BOXKD1 & 1.05 & 0.18 & 0.25 & 1.48 & 1.19 & 0.82 & \\
\hline C3081/ENW-32 & B0XKD2 & 1.12 & 0.03 & 0.59 & 1.74 & 1.19 & 1.78 & \\
\hline
\end{tabular}

Table 3.2. Field Quality Control Samples

\begin{tabular}{|l|c|l|l||}
\hline \multicolumn{1}{|c|}{ Sample Type } & $\begin{array}{c}\text { Number of } \\
\text { Samples }\end{array}$ & \multicolumn{1}{|c||}{ Associated Wells } & \multicolumn{1}{c||}{ Comments } \\
\hline \hline Equipment Blanks & 4 & $699-13-3 \mathrm{~A}^{(\text {a) }}, 699-13-1 \mathrm{~B}$, ENW-MW5 & $\begin{array}{l}\text { Sampled with portable } \\
\text { Grundfos pump }\end{array}$ \\
\hline Full Trip Blanks & 2 & $699-13-3 \mathrm{~A}, 699-21-6$ & $\begin{array}{l}\text { Volatile organic } \\
\text { analysis only }\end{array}$ \\
\hline Field Transfer Blanks & 3 & $699-13-3 \mathrm{~A}, 699-13-1 \mathrm{~A}$, ENW-MW6 & \\
\hline Field Duplicates & 2 & $699-13-3 \mathrm{~A}$, ENW-MW9 & Tritium analysis only \\
\hline Split Samples & 1 & $699-13-3 \mathrm{~A}$ & \\
\hline $\begin{array}{l}\text { (a) Two equipment blanks were collected at 699-13-3A; the first was collected before the well was } \\
\text { sampled, and the second was collected after the well was sampled. }\end{array}$ \\
\hline
\end{tabular}




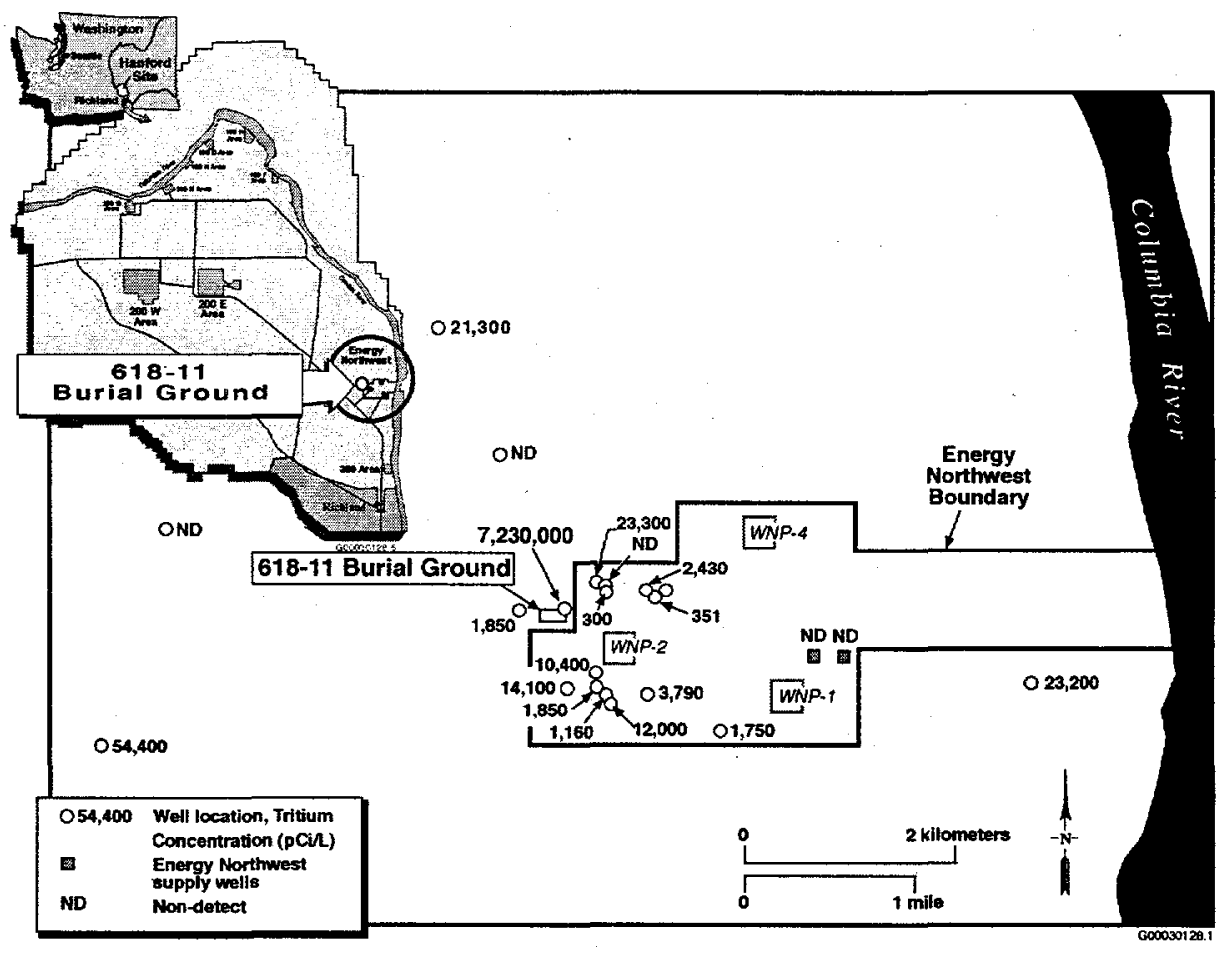

Figure 3.1. Tritium Concentrations for February 2000 Sampling Near the $618-11$ Burial Ground

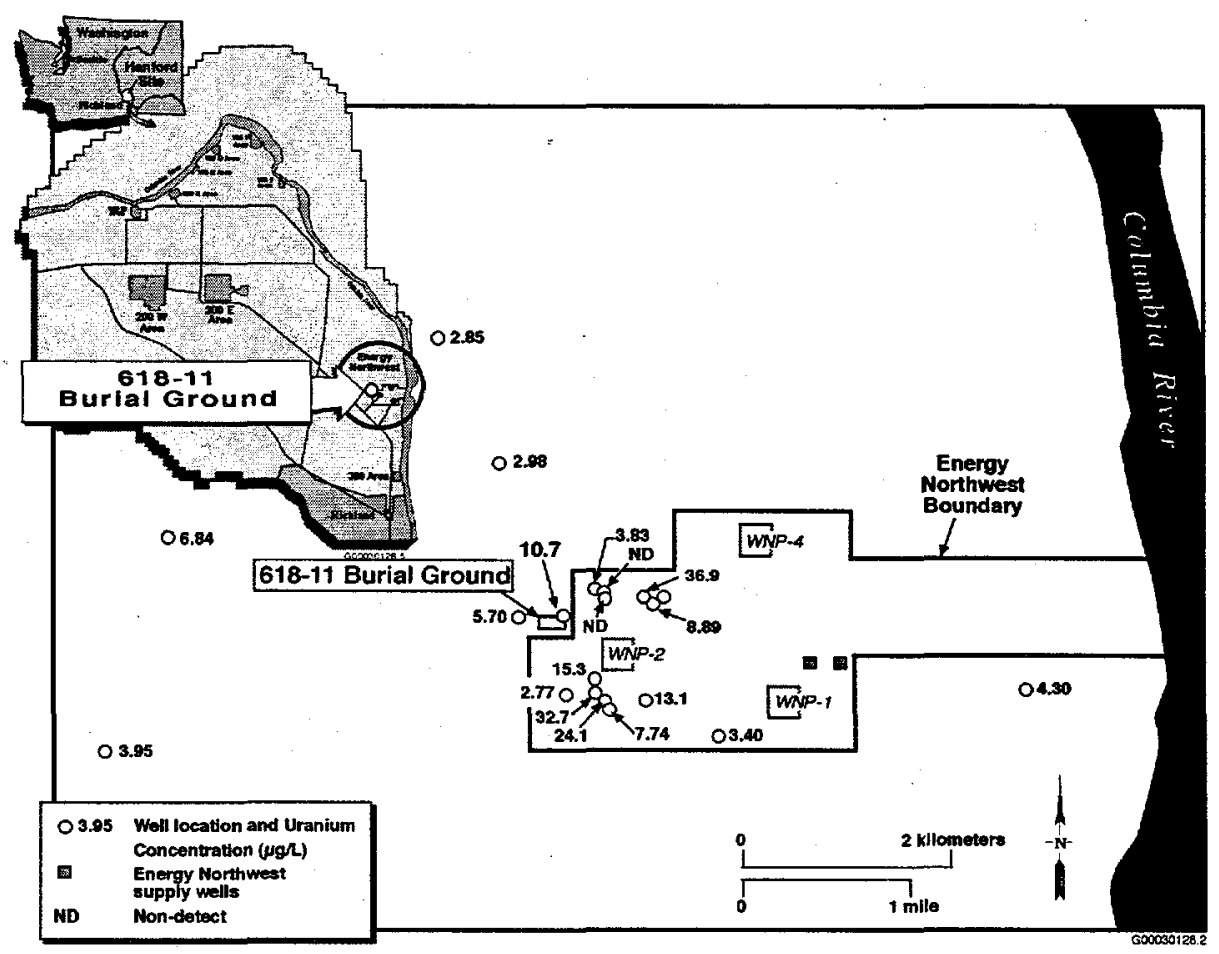

Figure 3.2. Calculated Uranium Concentrations for February 2000 Sampling Near the 618-11 Burial Ground 


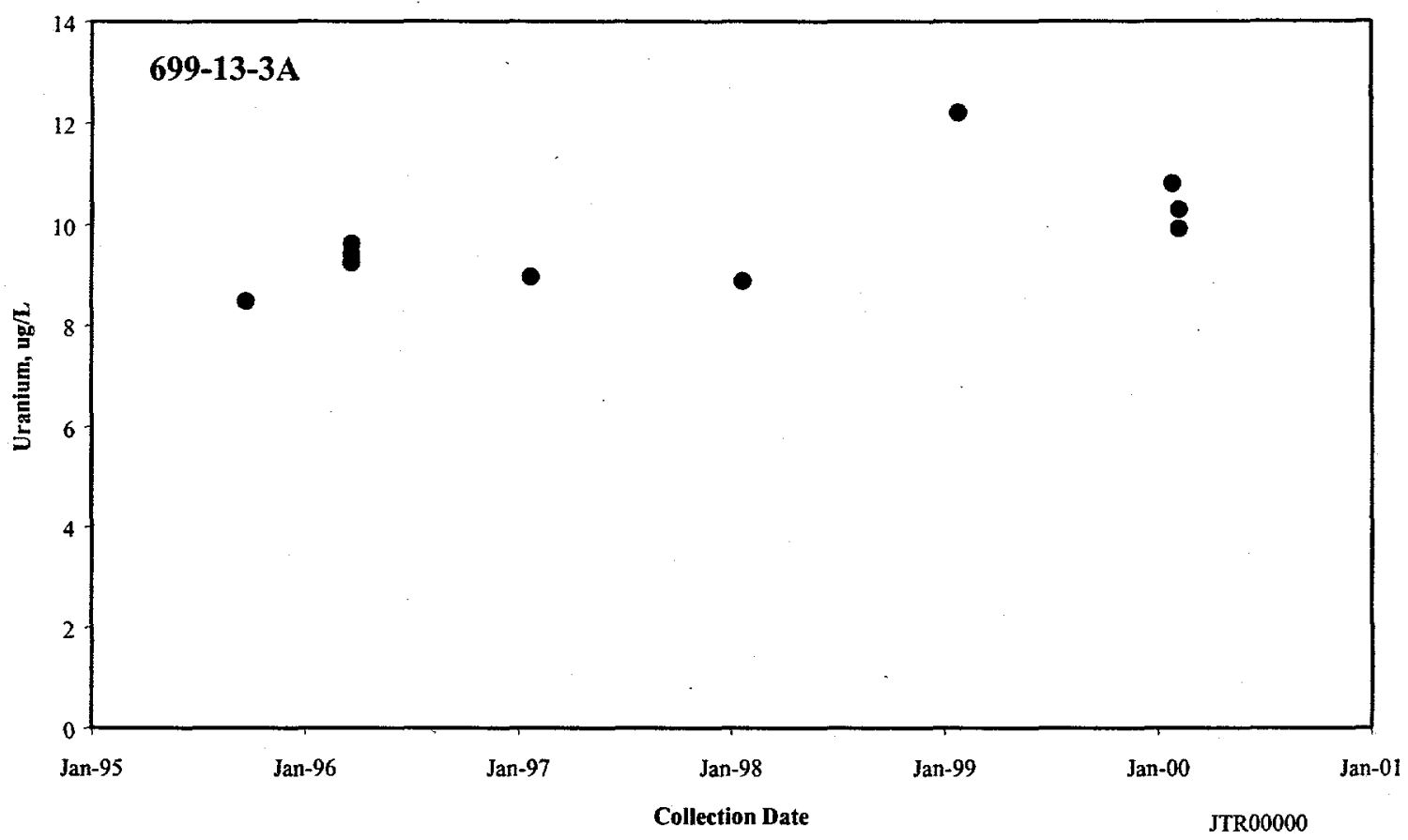

Figure 3.3. Uranium Concentration Trend in Well 699-13-3A

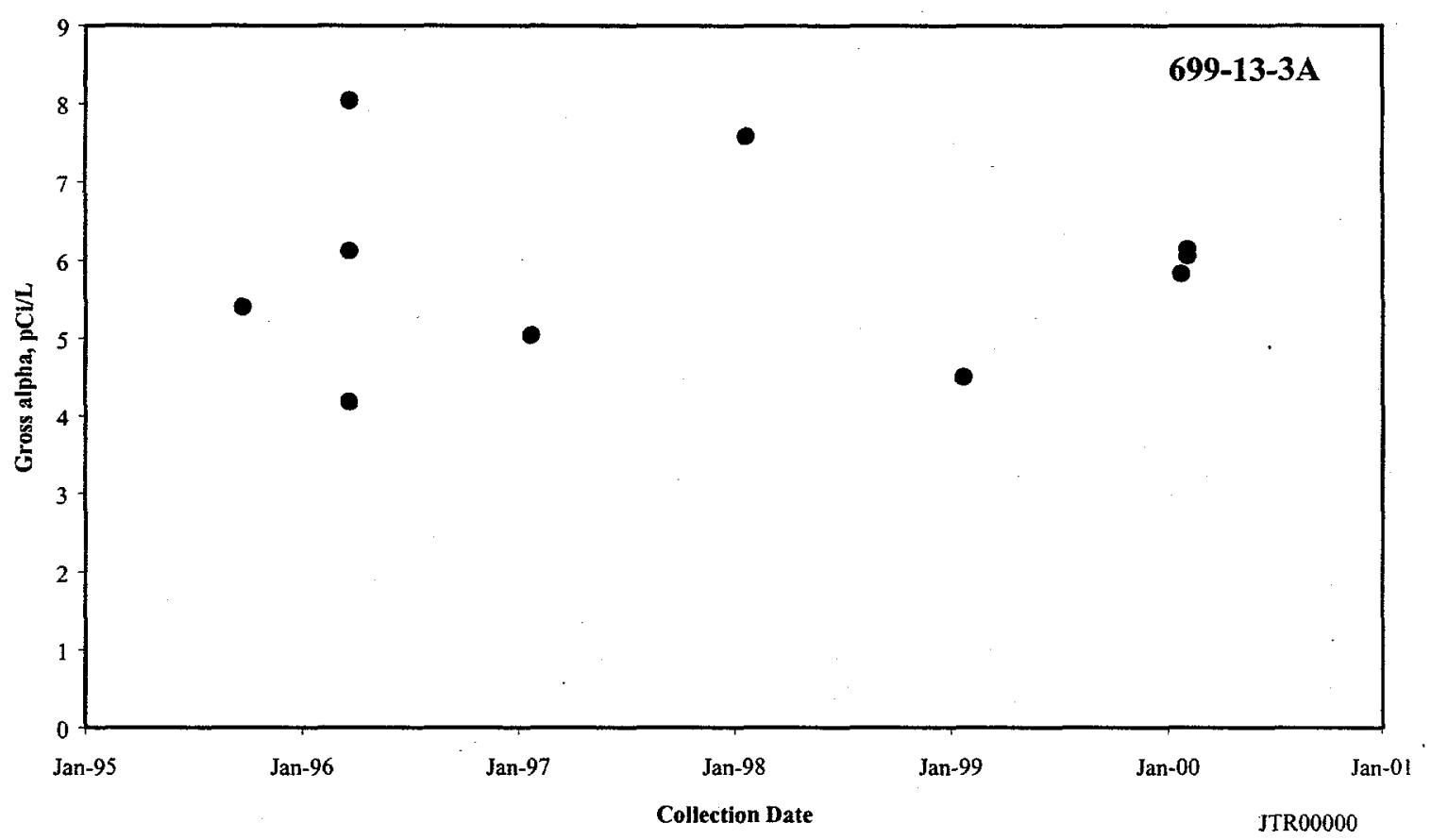

Figure 3.4. Gross Alpha Concentration Trend in Well 699-13-3A 


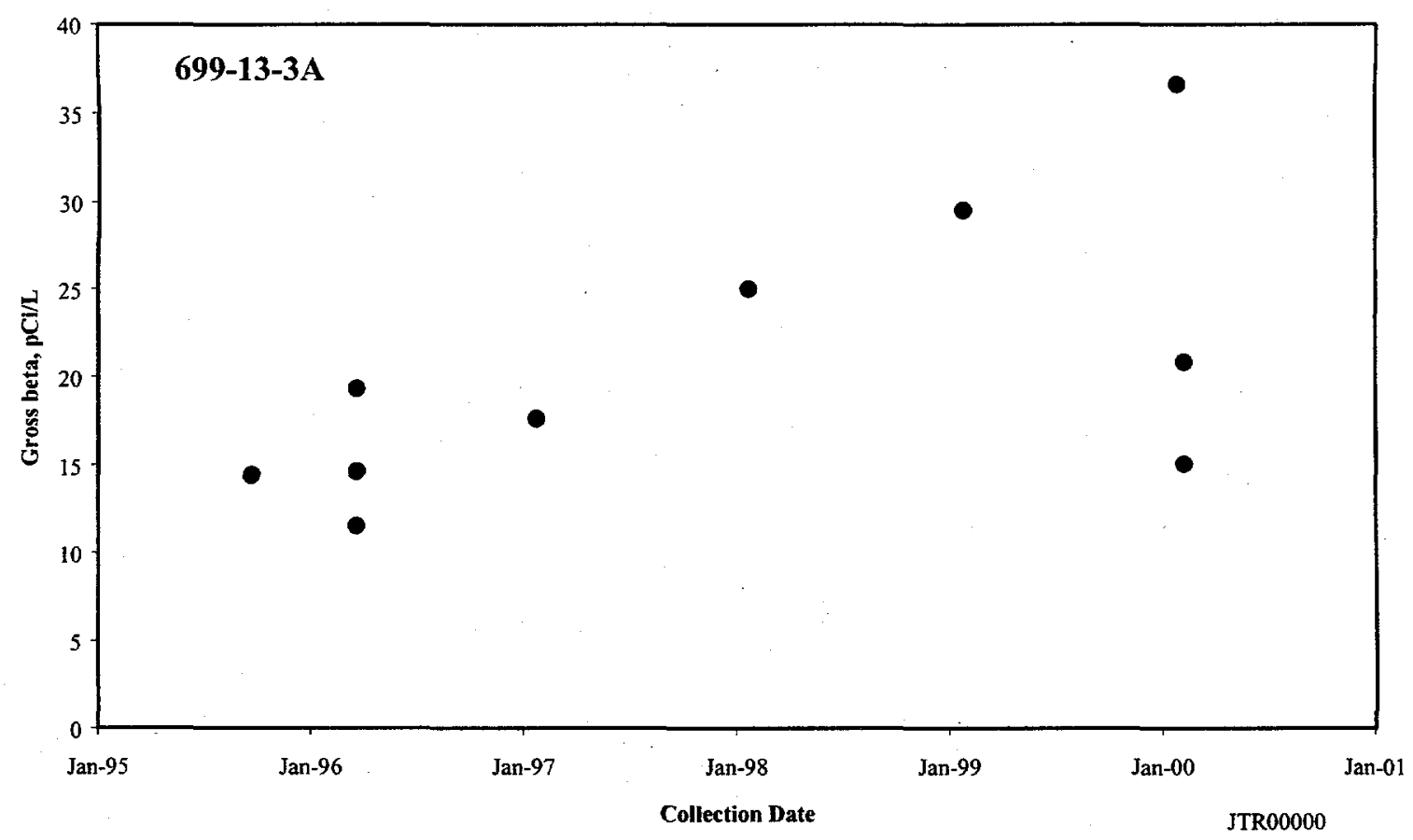

Figure 3.5. Gross Beta Concentration Trend in Well 699-13-3A

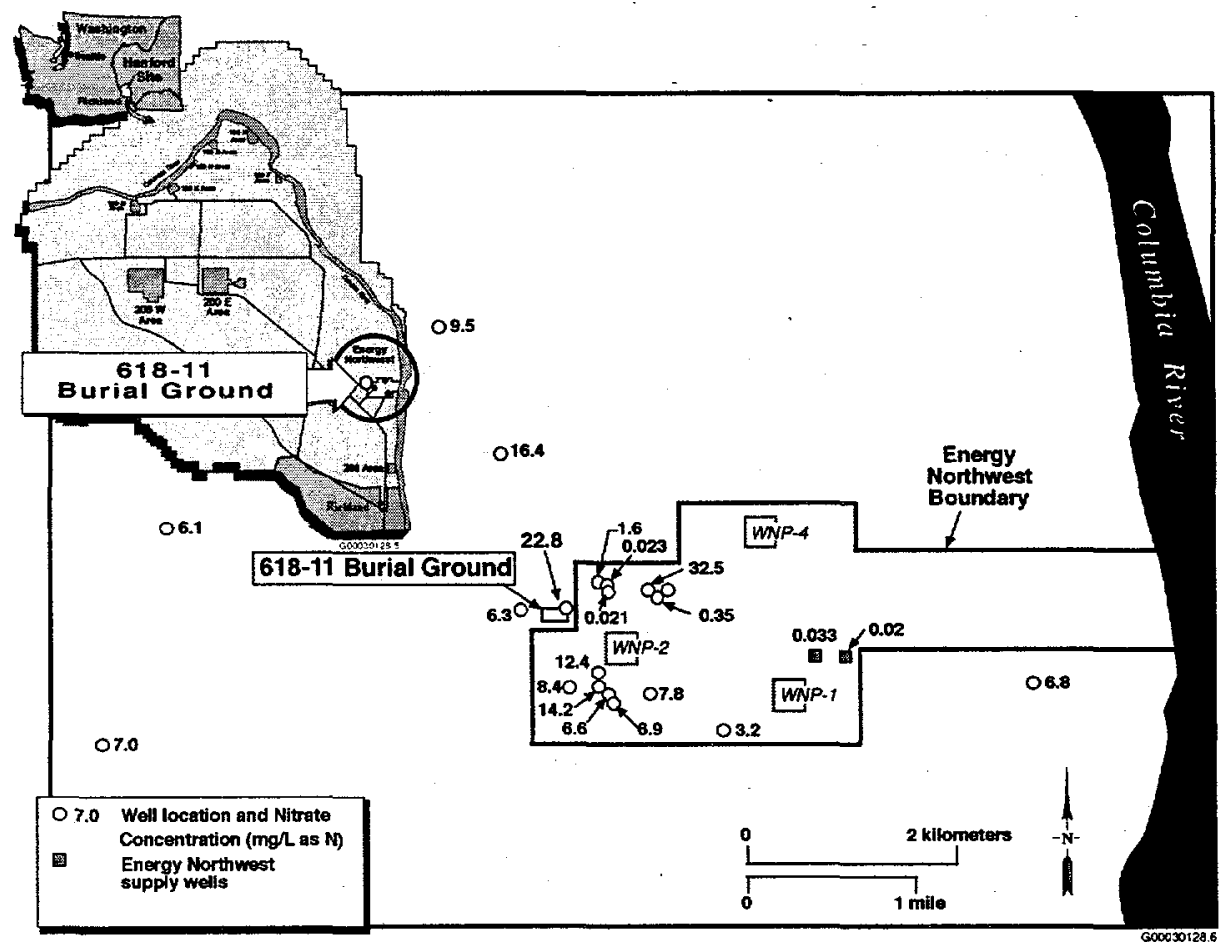

Figure 3.6. Nitrate Concentrations Expressed in $\mathrm{mg} / \mathrm{L}$ as $\mathrm{N}$ for February 2000 Sampling Near the 618-11 Burial Ground 
- Well 699-13-3A

- Water Table Well

- Deep Unconfined Well

- Confined Aquifer Well

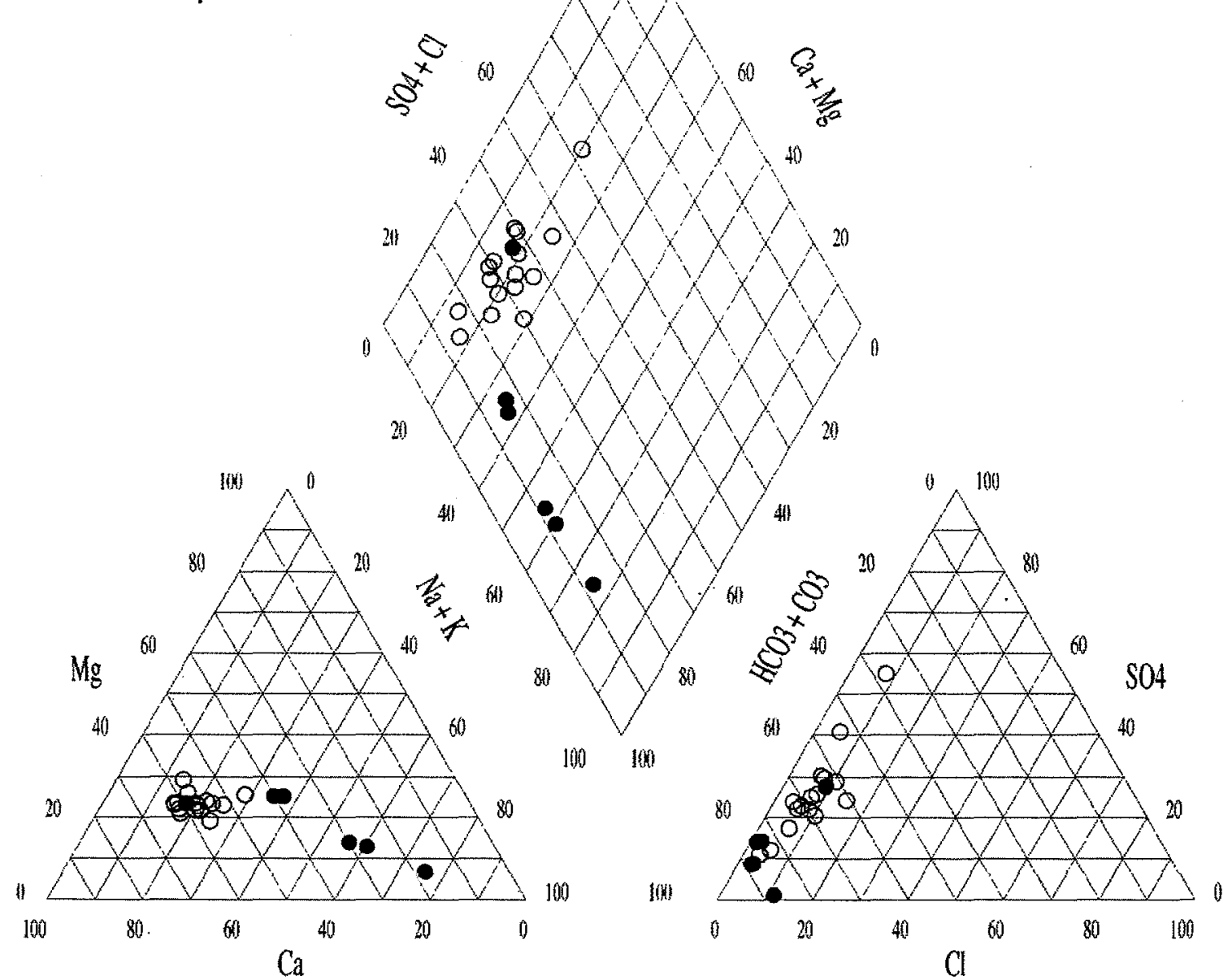

Figure 3.7. Piper Diagram for Major Ions in the Phase I Samples 
- Well 699-13-3A

O Water Table Well

- Deep Unconfined Well

- Confined Aquifer Well

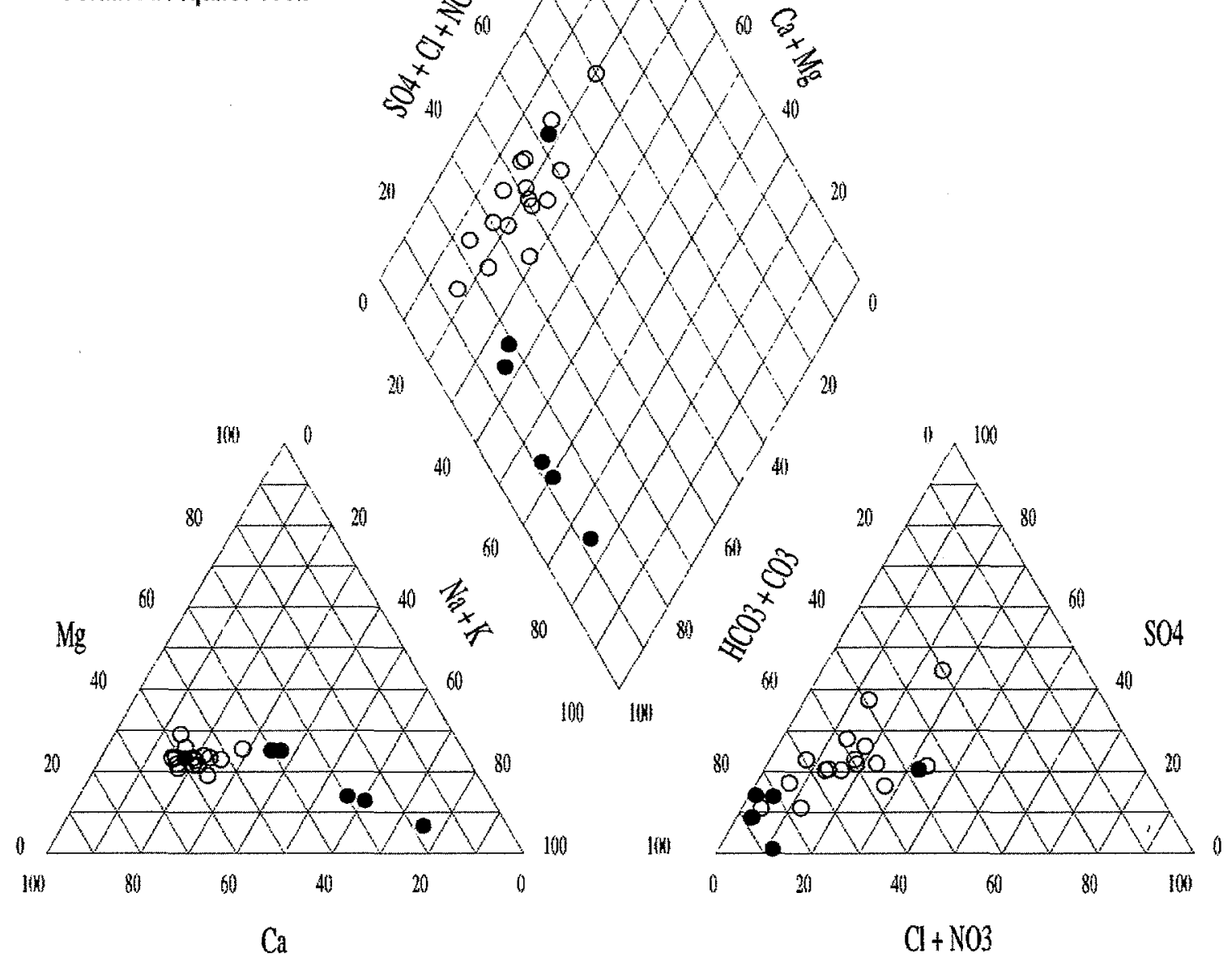

Figure 3.8. Piper Diagram for Major Ions in the Phase I Samples Including Nitrate with the Chloride Component 


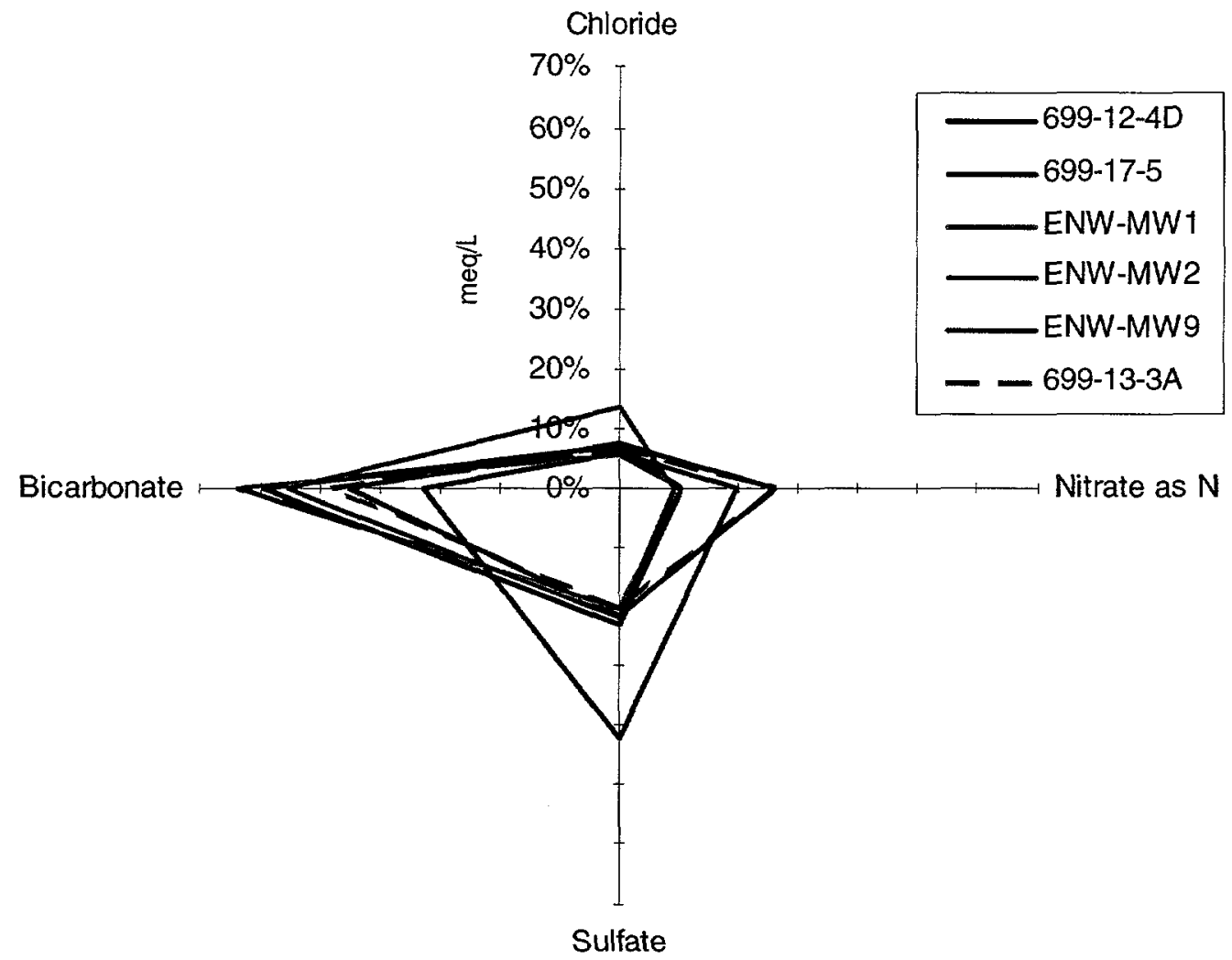

Figure 3.9. Relationship Between the Percentage of Anion Milliequivalents in Selected Wells Near the 618-11 Burial Ground 


\subsection{Discussion}

The most important result of the Phase I sampling is that the extremely elevated tritium levels remain restricted to only well 699-13-3A, immediately downgradient of the 618-11 burial ground. Well 699-12-4D, upgradient of the burial ground, contained $1,850 \mathrm{pCi} / \mathrm{L}$ of tritium. Any explanation of the tritium contamination must consider the much lower levels in surrounding wells. The explanation must also consider the lack of co-contaminants with the possible exception of nitrate and minor levels of technetium-99.

In the following sections the results will be discussed with respect to possible sources in the 200 East Area, Energy Northwest operations, and the 618-11 burial ground. A detailed discussion of the historical tritium concentrations in the plume emanating from the 200 East Area and in the vicinity of the 618-11 burial ground is included in order to evaluate the possibility of a source from the 200 East Area.

\subsection{Relationship to the 200 East Area Tritium Plume}

\subsubsection{Historical Plume Conditions}

The tritium plume from the 200 East Area has been mapped since the 1960s. Historical maps show the plume expanded into the vicinity of the 618-11 burial ground in approximately 1979 . However, this interpretation is heavily influenced by data from wells 699-13-1A and 699-13-1B that were drilled in 1973. Thus, concentrations in this area were not established earlier and no clear breakthrough curve was recorded. A reinterpretation of the historical data highlights some problems and unknowns regarding the details of the plume migration into this area.

Samples collected from wells 699-13-1A and 699-13-1B have historically contained elevated levels of tritium (Figure 4.1). In the first year it was sampled, 1973, tritium concentrations in well 699-13-1A averaged $121,000 \mathrm{pCi} / \mathrm{L}$ and rose to a maximum of $390,000 \mathrm{pCi} / \mathrm{L}$ in 1974 . In 1975 and 1976 , tritium concentrations dropped to a low of $8,800 \mathrm{pCi} / \mathrm{L}$, after which they began to rise in the last half of 1976 to another high of $200,000 \mathrm{pCi} / \mathrm{L}$ in 1977 . Beginning in 1978 , tritium concentrations fluctuated, ranging from 12,000 to $1,100,000 \mathrm{pCi} / \mathrm{L}$ in 1978 alone. These fluctuations occurred from 1978 through 1980 reaching a maximum value of $1,400,000 \mathrm{pCi} / \mathrm{L}$. The well was not sampled after June 1981 until February 2000. Tritium concentrations in well 699-13-1B are similar to those in well 699-13-1A, but the rise in tritium concentrations in 1974 and 1975 is absent in well 699-13-1B, and peak tritium concentrations in well 699-13-1B are only half the levels in well 699-13-1A.

Before the source of historical tritium in wells 699-13-1A and 699-13-1B is discussed, well con-

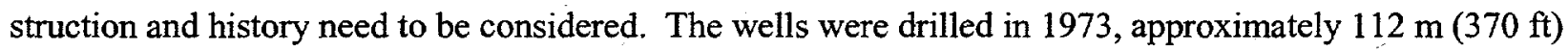
apart and approximately $425 \mathrm{~m}(1,400 \mathrm{ft})$ from the $618-11$ burial ground. Both wells were constructed to supply water for construction of facilities for Energy Northwest (formerly know as Washington Public Power Supply System). The wells are $20 \mathrm{~cm}$ ( $8 \mathrm{in}$.) in diameter, 72 and $75 \mathrm{~m}$ ( 235 and $245 \mathrm{ft}$ ) deep, respectively, with multiple screened sections and extending approximately $55 \mathrm{~m}(180 \mathrm{ft})$ below the water 
table. Well construction drawings of the wells are presented in Figure 4.2. Well 699-13-1A was constructed with three screen sections, the upper section $5 \mathrm{~m}$ (15 ft) long and the lower two each $3 \mathrm{~m}(10 \mathrm{ft})$ long. The top of the upper screen section was located approximately $6 \mathrm{~m}(20 \mathrm{ft})$ below the water table at the time it was drilled. Well 699-13-1B has four screen sections with the upper section $6 \mathrm{~m}(20 \mathrm{ft})$ long and lower three each $3 \mathrm{~m}$ (10 ft) long. The top of the upper screen was located approximately $8 \mathrm{~m}$ ( $25 \mathrm{ft}$ ) below the water table.

Details of the historical use of wells 699-13-1A and 699-13-1B for water supply are unknown. The location of the pump in the wells during their use and sampling, the volumes of water and rate at which it was withdrawn, and the continuity of withdrawals is also unknown. In addition, the effects of the pumping on the direction and velocity of groundwater flow in the area are unknown. It is likely that the wells were used on a demand basis that resulted in a variable pumping schedule. A fluctuating withdrawal schedule could be responsible for the fluctuating tritium concentrations in the two wells. If tritium concentrations are generally higher in the upper portion of the groundwater system and the pumps were set in the middle or lower screen sections, as might be expected for a water supply well, high tritium concentrations could have been drawn into the well from the upper part of the aquifer when the well was pumped at a high rate. As the pumping rate dropped, more of the water could have been produced from the lower screened sections where the pump was located and where tritium concentrations were low. This would explain the tritium levels that were high during the active reactor construction period and that dropped to low levels at the end of construction when withdrawals would likely have been reduced.

Reactor WPN-2 began operation in January 1984. It is probable that a major Columbia River water supply was developed in the early 1980s to support the need for WNP-2 reactor cooling water, eliminating the need for these two water supply wells. This may be the reason they were not sampled after mid-1981. Currently WNP-2 uses the Columbia River for its water supply. Whatever the source of tritium, historical tritium fluctuations in wells 699-13-1A and 699-13-1B could be explained by the variable pumping history of the two wells.

The tritium plume that extends southeast from 200 East Area has its source in early separations operations in 200 East Area. Historical interpretations of the growing Hanford sitewide tritium plume show a slow migration of the tritium plume to the east and southeast until approximately 1972 (Kipp 1973). Figure 4.3 shows the plume in 1972 consisting of a northern and a southern lobe with the highest concentrations in the northern lobe.

The slow eastern and southern migration of the southern lobe was believed to have continued until 1973 when the plume apparently reached well 699-13-1A, as shown in Figure 4.4 (Kipp 1975). It is unknown if tritium was present in this area prior to 1973 because well 699-13-1A was not drilled until 1973. Between 1973 and 1978, the depiction of the extent and distribution of the tritium plume changed little on this southern boundary. In reality, tritium levels were peaking at $390,000 \mathrm{pCi} / \mathrm{L}$ in well 699-13-1 A, but the annual average values were less than the $300 \mathrm{pCi} / \mathrm{mL}(300,000 \mathrm{pCi} / \mathrm{L})$ contour level. As a result, the plume maps do not indicate this rise until 1979 (Figure 4.5), at which time the average reached $905,000 \mathrm{pCi} / \mathrm{L}$ (Eddy and Wilbur 1980). The 1978 plume map should have indicated that well $699-13-1 \mathrm{~A}$ was greater than $300,000 \mathrm{pCi} / \mathrm{L}$ because the reported mean was $301,000 \mathrm{pCi} / \mathrm{L}$. This value would have been much higher $(460,000 \mathrm{pCi} / \mathrm{L})$ had a reported value of $1,100,000 \mathrm{pCi} / \mathrm{L}$ been included. 
The high data point resides in the HEIS database and in project records, but was not included in the evaluation. Regardless, the 1979 interpretation extended the $300,000 \mathrm{pCi} / \mathrm{L}$ tritium contour beyond well 699-13-1A.

Interpretations of tritium plume distributions differed between 1979 and 1980 in a very important and fundamental way. However, they were based on a common assumption. The common assumption was that there was a continuum of contamination between the well 699-20-20 area and the vicinity of the 61811 burial ground. Because there are no data in the intervening area, this assumption cannot be verified. The major difference is the flow path that connected the two areas. Because the investigators connect these two areas of high tritium concentration, it is reasonable to conclude that the authors had no indication that another source of tritium existed near wells 699-13-1A and 699-13-1B. The 1979 plume was based on the notion that contamination in the vicinity of well 699-13-1A migrated into the area through the southern lobe of the plume, south of well 699-15-15B and north of well 699-8-17. There are no intermediate control points along this narrow flow path to support this interpretation. The 1980 data were interpreted in Eddy and Wilbur (1981) to indicate that contamination was reaching the area through a narrow flow path from the northwest, east of well 699-15-15B and west of well 699-17-5, both of which had lower tritium concentrations (Figure 4.6). As in the 1979 interpretation, there are no intermediate wells along this flow path to support the interpretation.

The problem with the depiction of the 1980 plume is that three critical data points were incorrectly accounted for in the interpretation. Data for wells $699-20-20(583 \mathrm{pCi} / \mathrm{ml})$ and $699-15-26(250 \mathrm{pCi} / \mathrm{ml})$ were incorrectly included in regions of lower concentration and the mean tritium concentration for well $699-13-1 \mathrm{~A}$ was determined to be $297 \mathrm{pCi} / \mathrm{ml}(297,000 \mathrm{pCi} / \mathrm{L})$, slightly below the $300 \mathrm{pCi} / \mathrm{ml}$ contour. If these data are factored into the plume depictions, a significantly different plume geometry results (Figure 4.7). If this flow path is correct, wells upgradient of the 618-11 burial ground area should have contained tritium concentrations at least as high or higher than $1,100,000 \mathrm{pCi} / \mathrm{L}$. One well (699-26-15A) in this flow path and upgradient contained tritium as high as $1,600,000 \mathrm{pCi} / \mathrm{L}$ in 1970 and remained above $1,000,000 \mathrm{pCi} / \mathrm{L}$ until 1979. This indicates that a source of tritium existed at levels sufficient to explain high levels that appeared later in wells 699-13-1A and 699-13-1B.

\subsubsection{Geologic Constraints on the Tritium Plume Migration}

Geologic and well completion data must be used to help judge the merits of either interpretation. In 1979, data from wells 699-15-15B and 699-17-5 may have been used to infer an apparent barrier to southern migration of the plume. This interpretation is supported by the geology at these locations. Both wells are screened across the water table but the water table is near the Hanford formation/Ringold Formation contact. The wells recover slowly after removing water, indicating that the hydraulic conductivity is low, consistent with the Ringold Formation characteristics. The 1979 interpretation is consistent with an assumption that the low hydraulic conductivity region is continuous between wells 699-15-15B and 699-17-5, forming a hydrologic barrier to groundwater flow and contaminant migration. The 1980 interpretation may have assumed that the low conductivity regions are isolated to the vicinity of the wells and a higher conductivity zone exists between the two wells. The Ringold Formation has a shallow dip from east to west through the area and it outcrops along the eastern bank of the Columbia River east of the area. Recent interpretations as presented in Hartman (1999) show the Ringold 
Formation at the water table in an area east of the Energy Northwest reactors (see Figure 1.4). However, because the saturated part of the Hanford formation is thin and the dip of the contact is shallow, the zone of lower transmissivity may extend for a considerable distance to the west. As contaminants moved southeast out of the 200 East Area, via a flow path through highly transmissive sediments, they reached this lower transmissive Ringold sediment contact, which in effect diverted most of the flow, splitting it into two separate flow paths.

The Ringold Formation is not encountered at the water table in shallow wells located north of the Energy Northwest complex, apparently due to erosion associated with either catastrophic flooding and/or the ancestral Columbia River. The ancestral Columbia River migrated across this area, in a southeast to southerly direction and may have resulted in eroding or reworking the older Ringold Formation gravel, which is now-replaced and filled in with younger, more transmissive Hanford formation deposits. Some of these erosional events are illustrated as the topographic features that can be seen on the ground surface across the area (Figure 4.8). The top of the Ringold Formation was probably eroded to a lower elevation north of wells 699-15-15B and 699-178-5 by these erosional forces. Erosional features typical of braided stream environments are most likely the structural pattern developed on the Ringold surface. At present

no detailed evaluation has been completed to determine the nature and extent of the erosionally controlled flow paths. For example, if the river eroded into the Ringold sediment between well 699-15-15B and 699-17-5, a transmissive zone may exist, allowing the tritium plume to continue migrating toward the 618-11 burial ground. This scenario, however, is speculative.

The conceptual models are based on the information that well 699-17-5 is in an area of low transmissivity and, therefore, not a dynamic portion of the groundwater flow system. This explains why historical tritium concentrations in the well have been low. A major anomaly is that the well has consistently contained elevated levels of nitrate. The sitewide tritium and nitrate plumes had a common source and emanated from 200 East Area together with little chance that they would be separated by natural reactions in the groundwater system. Because tritium concentrations have been low in the well, the nitrate must be from a different source that contained no tritium. At the current time, there are no explanations for this observation.

\subsubsection{Current Plume Conditions}

The highest tritium concentrations detected in wells upgradient of the 618-11 burial ground were $1,600,000 \mathrm{pCi} / \mathrm{L}$ in 1969 in well 699-26-15A and 1,100,000 pCi/L in 1974 in well 699-27-8 (Figure 4.9). These levels are clearly lower than the recent values of $7,230,000$ to $8,140,000 \mathrm{pCi} / \mathrm{L}$ in well $699-13-3 \mathrm{~A}$. The discrepancy in concentration is even greater when you consider that approximately $2 \frac{1}{2}$ half-lives of decay have occurred in the intervening years.

The current distribution of tritium shown in the Phase I results (see Figure 3.1) is also inconsistent with a source from the 200 East Area. A plume from the 200 East Area would be expected to result in similar concentrations throughout the study area. However, the presence of considerably lower concentrations in wells other than well 699-13-3A indicates a local source. 
Further support for a local source for the tritium contamination comes from the relationship of tritium to co-contaminants. Iodine-129 was not detected in the samples from well 699-13-3A. Although the detectable iodine-129 plume does not extend as far as the tritium plume, the iodine- 129 is consistently detected within the area of the plume from 200 East Area when tritium concentrations are high (Figure 4.10). In contrast, the iodine-129 for the Phase I sampling of well 699-13-3A was extremely low compared to the 200 East Area plume. For the purpose of the figure the non-detect iodine-129 value for well $699-13-3 \mathrm{~A}$ was graphed at the minimum detectable activity value of $0.2 \mathrm{pCi} / \mathrm{L}$.

Nitrate in well 699-13-3A is also considerably lower than would be expected for at source from the 200 East Area (Figure 4.11). Although nitrate is higher in well 699-13-3A than in surrounding monitoring wells (see Figure 3.6), the nitrate levels do not approach the levels found in the highest tritium concentration samples from the 200 East Area. Thus, it is difficult to explain the chemistry by invoking a 200 East Area source.

\subsubsection{Summary}

The current high levels of tritium in well 699-13-3A are not consistent with the levels seen in surrounding wells and thus suggest a local source for the contamination. The tritium contamination level is higher than currently seen anywhere else in the plume from the 200 East Area. It is conceivable that elevated tritium levels seen in water supply wells in the late 1970 s are related to the 200 East Area tritium plume. However, the presence of low permeability sediments in the vicinity may inhibit transport of contamination from the 200 East Area. Further investigation of the geology would be needed to determine if erosional features provide a lower permeability pathway to the vicinity of the $618-11$ burial ground.

\subsection{Relationship to Tritium Discharges from WNP-2}

Energy Northwest operations use large volumes of water, some of which is disposed to the environment. Operation of WNP-2 uses primary and secondary cooling water loops. The primary loop is contained within the facility and the water has become highly radioactive. Because this loop contains valves and other structures that may leak, the atmosphere of the reactor containment building can become radioactive. The building contains an exhaust system that prevents the release of such contaminants. The secondary loop consists of 25 million liters (6.5 million gallons) of cooling water that is cycled at 2.3 million liters $(600,000$ gallons) per minute. The secondary cooling water passes through the cooling towers where approximately 49,000 liters (13,000 gallons) per minute is lost to the atmosphere as evaporate. Cooling tower blowdown is removed from the secondary system, at a rate of 5,700 liters (1,500 gallons) per minute and represents discharge water that is released directly to the Columbia River. The rest of the secondary cooling water is recovered and recycled. Secondary coolant makeup water represents the bulk of the intake water and is about 57,000 liters (15,000 gallons) per minute. 
Five types of water samples are collected as part of Energy Northwest's environmental monitoring program. The types of water samples collected include

- intake water from the Columbia River

- wastewater from the sanitary waste treatment facility (SWTF)

- storm drain outfall (released to a ditch and pond)

- discharge water that is released back into the Columbia River

- groundwater (three wells sampled).

The intake water represents "background" tritium concentrations for water used by Energy Northwest. The other four water types represent conditions of liquid streams affected by Energy Northwest operations as they are released back to the environment.

\subsubsection{Intake Water}

Tritium concentrations in intake water reflect levels present in precipitation and tritium that has entered the Columbia River from groundwater sources through the Hanford Reach of the river. Tritium is naturally formed in the upper atmosphere where highly energetic cosmic rays collide with nitrogen, resulting in the formation of tritium. The tritium atom is incorporated into a water molecule where it then falls to earth in precipitation. Davis and DeWiest (1966) reported that prior to major atmospheric testing of nuclear weapons beginning in 1952, tritium concentrations in rainfall were as high as $30 \mathrm{pCi} / \mathrm{L}$. Groundwater entering the Columbia River, just downstream of the Hanford Townsite, resulted in maximum tritium concentrations of $4,100 \mathrm{pCi} / \mathrm{L}$ in the river at 1998 in near shore locations with an average transect level of $730 \mathrm{pCi} / \mathrm{L}$ (Dirkes et al. 1999). Tritium concentrations at the 300 Area dropped to an average of $42 \mathrm{pCi} / \mathrm{L}$. Energy Northwest intake water averaged $120 \mathrm{pCi} / \mathrm{L}$ in 1998 (McDonald et al. 1999). Therefore, the Energy Northwest intake water has a low tritium concentration.

\subsubsection{Wastewater from the Sanitary Waste Treatment Facility}

This waste stream consists of sanitary wastewater from WNP-2 operations and from Fast Flux Test Facility sanitary wastewater. The average tritium concentration in this waste stream in 1998 was $3,723 \mathrm{pCi} / \mathrm{L}$ with a maximum sample concentration of $20,000 \mathrm{pCi} / \mathrm{L}$ (McDonald et al. 1999). In the previous 14 years of operation, this stream averaged $497 \mathrm{pCi} / \mathrm{L}$ with a maximum value of $6,700 \mathrm{pCi} / \mathrm{L}$. This increase is due to the addition in 1998 of sanitary wastewater from the Fast Flux Test Facility that contained an average tritium concentration of $8,008 \mathrm{pCi} / \mathrm{L}$ to the stream. Fast Flux Test Facility process water is pumped from one primary groundwater well and two backup wells if the primary well cannot be used. This water supply contains tritium at the levels found in the wastewater. This level rose to $20,000 \mathrm{pCi} / \mathrm{L}$ when the backup wells were used when the primary well was taken offline for pump maintenance. 


\subsubsection{Storm Drain Outfall}

The 1998 average tritium concentration in the storm drain outfall was $325 \mathrm{pCi} / \mathrm{L}$ with a high of $3,700 \mathrm{pCi} / \mathrm{L}$ (McDonald et al. 1999). In the previous 14 years, the average tritium concentration for this waste stream was $5,704 \mathrm{pCi} / \mathrm{L}$ with a high of $270,000 \mathrm{pCi} / \mathrm{L}$. The high levels were measured in 1992 when it was found that moisture in building exhaust ventilation condensed on surrounding buildings where it then entered the storm drains. This problem was corrected and levels dropped to current levels in the first half of 1993 (Washington Public Power Supply System 1996).

\subsubsection{Discharge Water}

Discharge water refers to all water discharged directly into the Columbia River; it is sampled before it is discharged to the river. This stream consists mainly of cooling tower blowdown. The 1998 average tritium concentration in the discharge water was $803 \mathrm{pCi} / \mathrm{L}$ with a high of $1,600 \mathrm{pCi} / \mathrm{L}$ (McDonald et al. 1999). In the previous 14 years, the average tritium concentration was $1,907 \mathrm{pCi} / \mathrm{L}$ with a high of $12,000 \mathrm{pCi} / \mathrm{L}$. This discharge is permitted with a National Pollutant Discharge Elimination System (NPDES) permit. The permit level has not been exceeded.

\subsubsection{Groundwater}

Energy Northwest samples three groundwater supply wells for their environmental surveillance program, well 699-13-1C, northeast of WNP-2, and wells designated ENW-31 (C3080) and ENW-32 (C3081) on the northeast side of WNP-1. These wells are all completed in the confined aquifer. Historically, the tritium concentrations in these wells have been near or below the detection limit of the analytical method. Reported tritium concentrations have ranged from less than detection to $324 \mathrm{pCi} / \mathrm{L}$ (McDonald et al. 1999). These numbers agree with values from the Phase I sampling where tritium was not detected at any of these locations.

From 1996 through 1998, Washington State Department of Health sampled five Energy Northwest monitoring wells for tritium. They also sampled the water supply wells discussed above. The Washington State Department of Health data for tritium are in general agreement with the Phase I sampling results reported here. The maximum concentration detected in the Washington State Department of Health data was $18,600 \mathrm{pCi} / \mathrm{L}$ in Energy Northwest monitoring well MW-5 (C3075).

\subsubsection{Summary}

In summary, Energy Northwest environmental monitoring data indicate that liquid waste streams generated by Energy Northwest operations, and DOE in the case of the 400 Area sanitary wastewater, contained average tritium concentrations at less than $6,000 \mathrm{pCi} / \mathrm{L}$ and a maximum of $270,000 \mathrm{pCi} / \mathrm{L}$. This information is corroborated by data from the Washington State Department of Health (1999). The highest tritium concentrations were related to a condition that was corrected shortly after it was detected. The result was that tritium concentrations dropped to previous low levels. These data indicate that Energy Northwest operations are not responsible for the high tritium concentrations in well 699-13-3A. 


\subsection{Relationship to the 618-11 Burial Ground}

The 200 East Area and Energy Northwest power plant are unlikely sources of the tritium at levels seen in well 699-13-3A. The 618-11 burial ground source is, however, consistent with the spatial distribution of tritium shown in Figure 3.1. Tritium levels in well 699-12-4D, located immediately upgradient from the burial ground, are considerably lower. The markedly lower tritium levels in other downgradient wells is consistent with a narrow plume that could be expected from a near-by source. A burial ground source would not be expected to be associated with large volumes of water, which is also consistent with a localized plume.

The presence of tritium bearing waste disposed to the 618-11 burial ground has not been established. A possible source is tritium present as a product of nuclear fission. Tritium is produced in nuclear reactors through several processes. Some tritium is produced through neutron capture on deuterium in the cooling water, but this is not expected to have a significant effect on other waste streams. In ternary fission, a fissionable atomic nucleus, such as uranium-235, is split into three nuclei. Ternary fission occurs much less frequently than binary fission. Tritium from reactor operations may also be produced through irradiation of trace impurities in the fuel, cladding materials or other reactor materials. Thus, some tritium can be expected to be present in materials that have been cycled through a nuclear reactor. Irradiated fuel and other radioactive materials were studied in the 300 Area and waste disposed to the 618-11 burial ground. The tritium content of the waste is generally not documented, and little is known about the potential tritium release to the environment from these waste forms. However, significant tritium contamination has not been identified with other radioactive solid-waste burial grounds. A possible exception is the $118-\mathrm{F}-1$ burial ground where tritium concentrations up to $180,000 \mathrm{pCi} / \mathrm{L}$ have been detected in a downgradient well.

A potentially larger source of tritium is from tritium production carried out at the Hanford Site. Although most of the U.S. government tritium production occurred at the Savannah River Site, significant tritium production and production research occurred at the Hanford Site during two time periods. The first time period was approximately 1949 to 1952 when tritium was produced by irradiation of lithium containing targets and processed in the $100 \mathrm{~B}$ Area. This campaign was called the $\mathrm{P}-10$ project.

The second time period for recorded tritium production at the Hanford Site was a mid-1960s project know as the Hanford Coproduct Program. Information associated with that work was declassified in the early 1970s. In its early stages, which began in 1963, the project was intended to provide comprehensive engineering data on the optimal characteristics of lithium based irradiation targets to be used for tritium production in parallel with plutonium and electrical energy production at the Hanford $\mathrm{N}$ Reactor. This work is documented in numerous unclassified reports. A good summary of the activities performed can be found in Johnson et al. 1976.

Initial irradiation for the Hanford Coproduct Program was performed in one of the K Reactors using aluminum-lithium rods similar to those used in the P-10 Project. All subsequent irradiation was performed at $\mathrm{N}$ Reactor during 1965 to 1967 , culminating with a full-scale test involving more than 1,500 lithium aluminate target columns containing on the order of 17 tons of lithium aluminate. Tritium production associated with that test was calculated to be on the order of 70 million curies of tritium per 
year. Following irradiation, the entire target load was shipped to Savannah River for extraction, so it is unlikely that the production run itself was responsible for significant tritium releases at the Hanford Site. However, research activities involving smaller but still significant quantities of tritium production are almost certain to have generated some major waste products. All research activities, including tritium extraction performed in support of the Coproduct Program, were performed in the Hanford 300 Area through 1967.

The fate of any waste generated by the Coproduct Program research activities, including the extracted tritium itself, remains unknown. However, because the work was performed during the time period for which the 618-11 burial ground was used as the primary site for disposal of waste from 300 Area operations, it is quite possible that some, if not all, of the Coproduct Program research waste was routed to that location. The limited records associated with the 618-11 burial ground do, in fact, list aluminum-lithium as having possibly been disposed to the burial ground. While lithium aluminate and other related materials are not specifically enumerated separately, it is unlikely that the minor difference in terminology is significant. For lack of additional details, it would be prudent to assume that the term is used as a generic reference to tritium production target materials. It is, however, unclear whether the aluminum-lithium material, if present, was actually irradiated and what amount of tritium could have remained in the material after study. Hydrogen gas is also included on the same list. Because it seems unlikely that actual high pressure cylinders of hydrogen would be placed in a burial ground intended for low-level radioactive waste, it is possible that this is an oblique reference to gaseous tritium waste associated with the target extractions. Tritium is a very labile material with the ability to eventually diffuse through most materials and reactively exchange with normal hydrogen in water and some organics. Unless specifically packaged for long-term storage, it is quite likely that tritium containing materials disposed to a landfill would pose an eventual potential for groundwater contamination.

The potential rate of release of tritium from the waste and the travel time through the vadose zone have not been established. There is no record of disposal of liquids to the 618-11 burial ground. Thus, tritium transport would probably have occurred under natural recharge conditions or with recharge enhanced by some anthropogenic process. Water was applied over the burial ground when the wheatgrass cover was established in 1983 (Demiter and Greenhalgh 1997). This could have enhanced recharge and contaminant transport in the vadose zone. However, enhanced recharge in 1983 would not explain the elevated tritium levels seen in the late 1970s in well 699-13-1A.

It is fairly well established that the downward migration of the leading edge of the tritium bomb-pulse through the vadose zone is faster than the bulk water velocity. This is attributed to exchange between the aqueous and vapor phases in the soil and vapor phase transport (Phillips et al. 1988). The implications of the vapor transport effect on travel time to the water table for tritium at the 618-11 burial ground has not been quantified.

The relatively shallow depth to groundwater and the lack of deep rooted vegetation, such as sagebrush, on the burial ground suggest that there has most likely been sufficient time for tritium transport to the water table. The exact timing of any transport and the mass flux cannot be ascertained with any certainty at this point. It is unclear, for instance, if vadose transport would have been sufficiently rapid to allow the high levels of tritium to arrive in well 699-13-1A in the 1970s. 

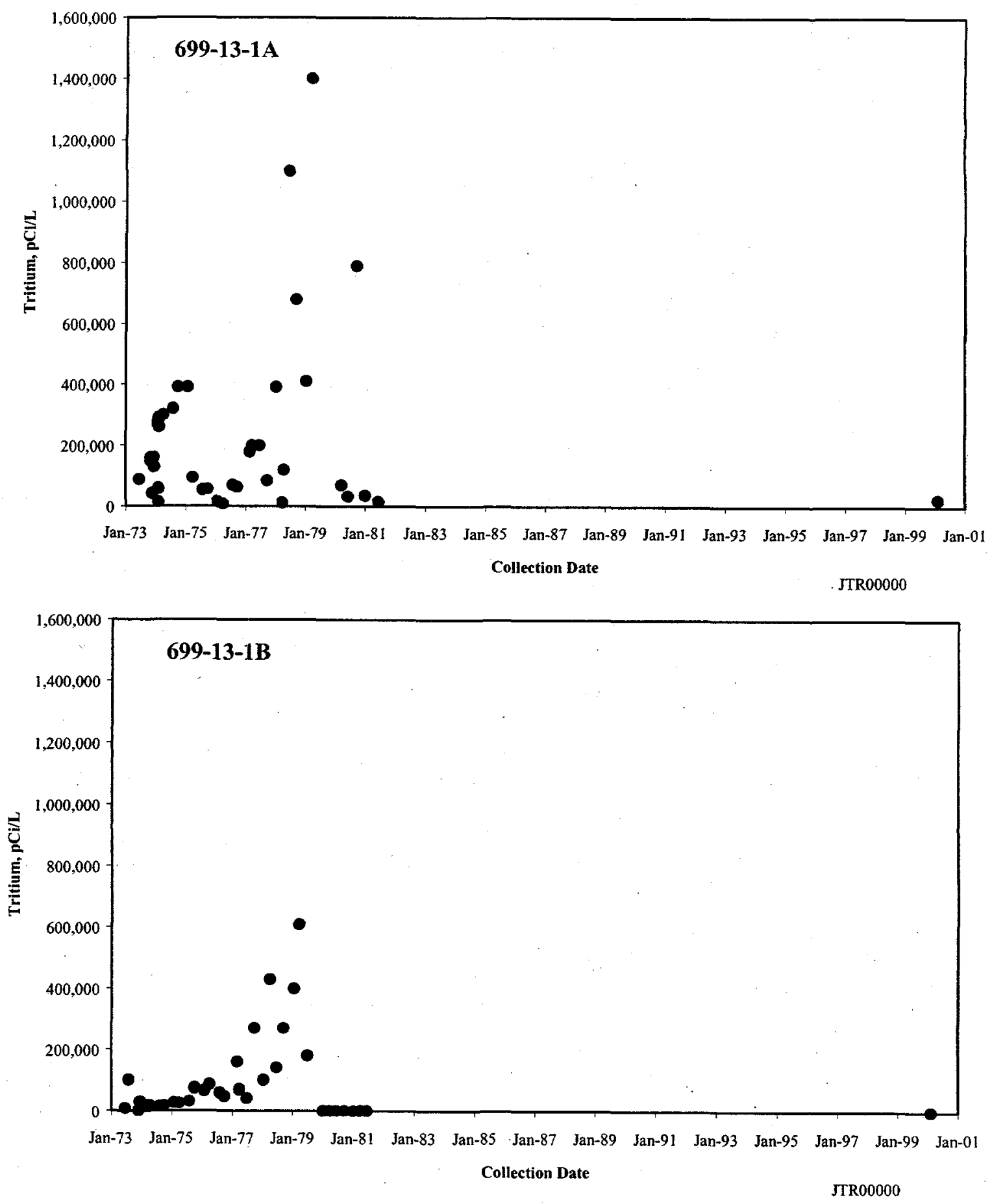

Figure 4.1. Tritium Concentration Trends in Wells 699-13-1A and 699-13-1B 


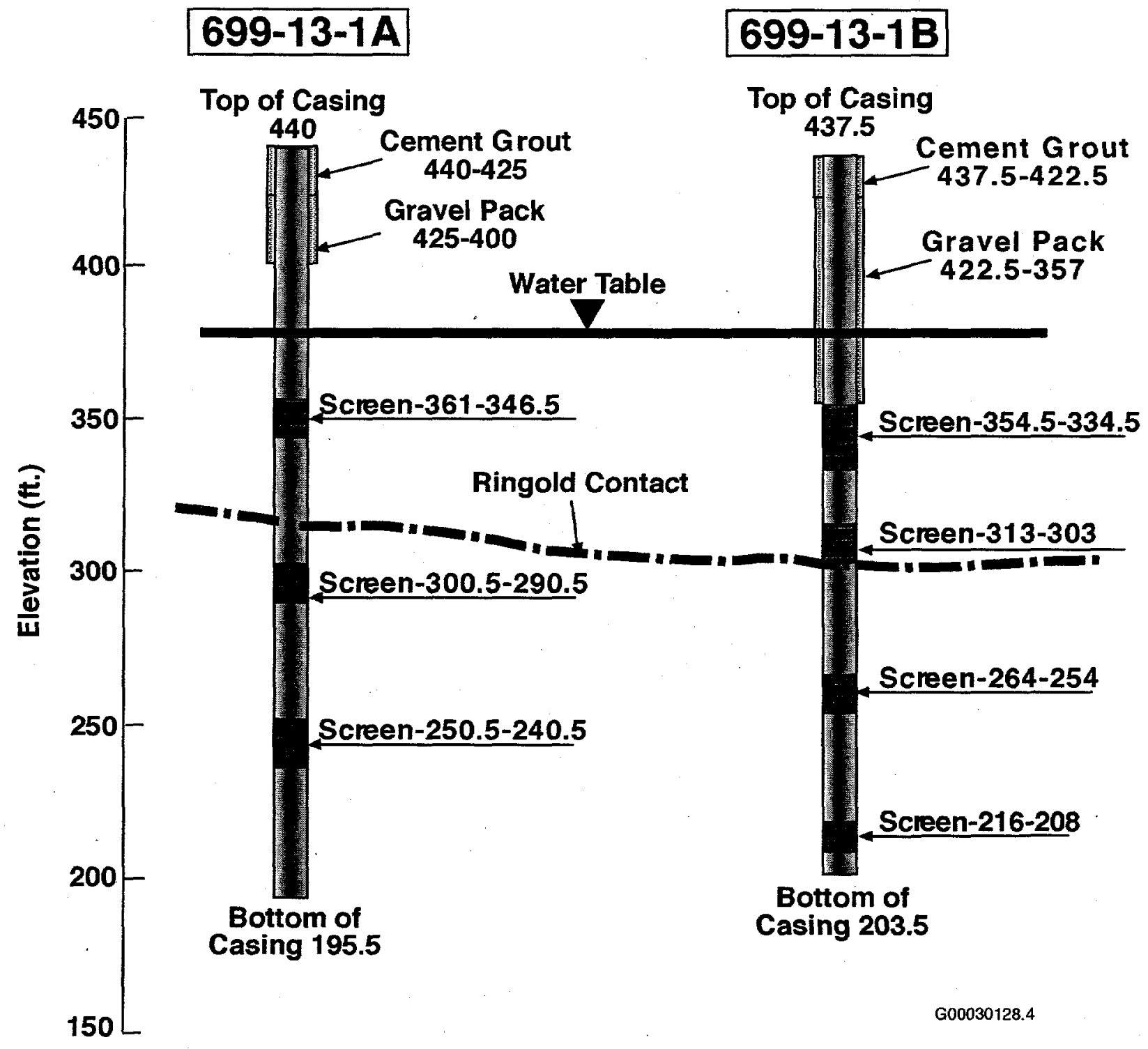

Figure 4.2. Well Construction and Lithology for Wells 699-13-1A and 699-13-1B 


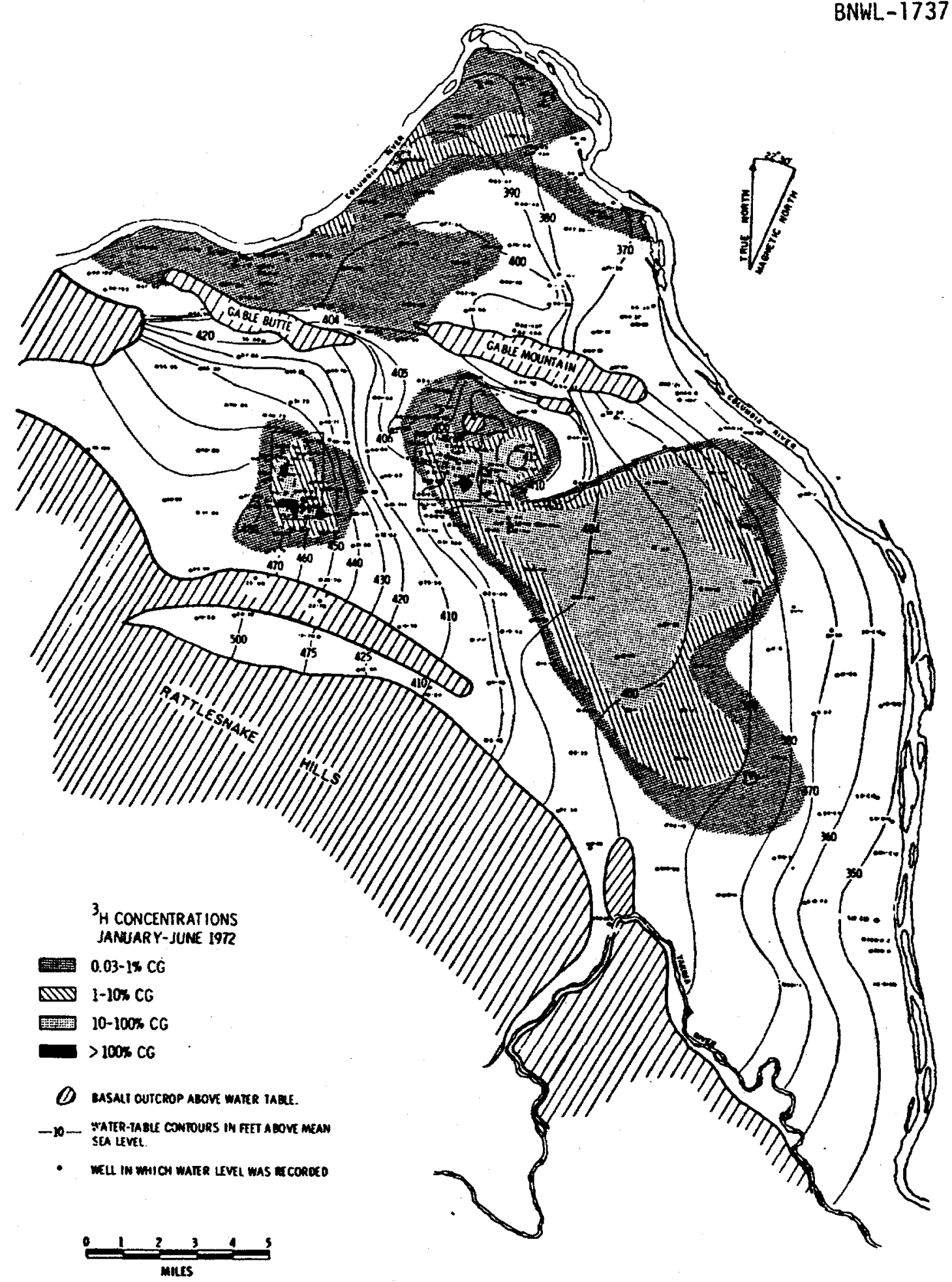

Figure 4.3. Tritium Plume as Reported in 1972 (Kipp 1973). CG for tritium equals $3,000,000 \mathrm{pCi} / \mathrm{L}$. 


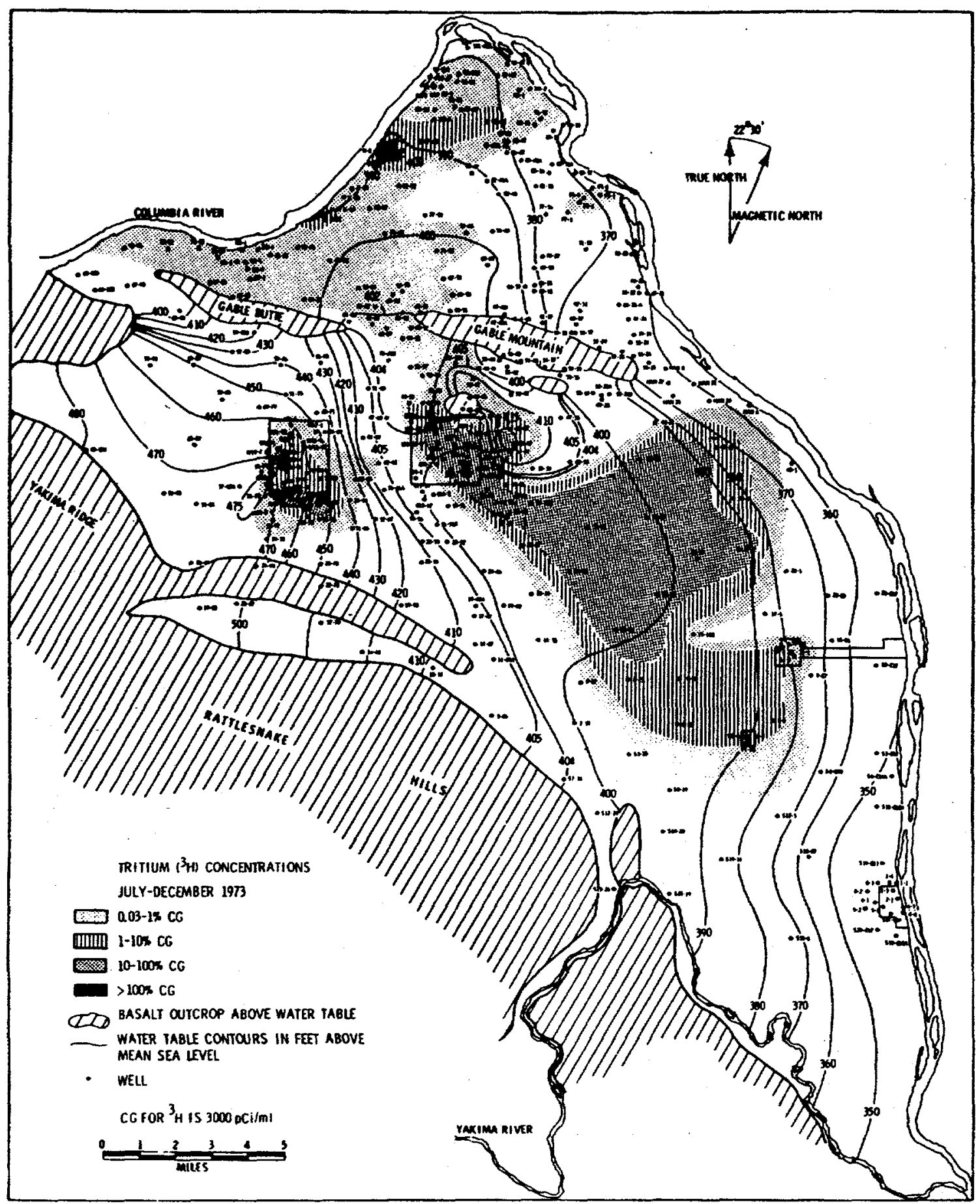

Figure 4.4. Tritium Plume as Reported in 1973 (Kipp 1975). CG for tritium equals 3,000,000 pCi/L. 


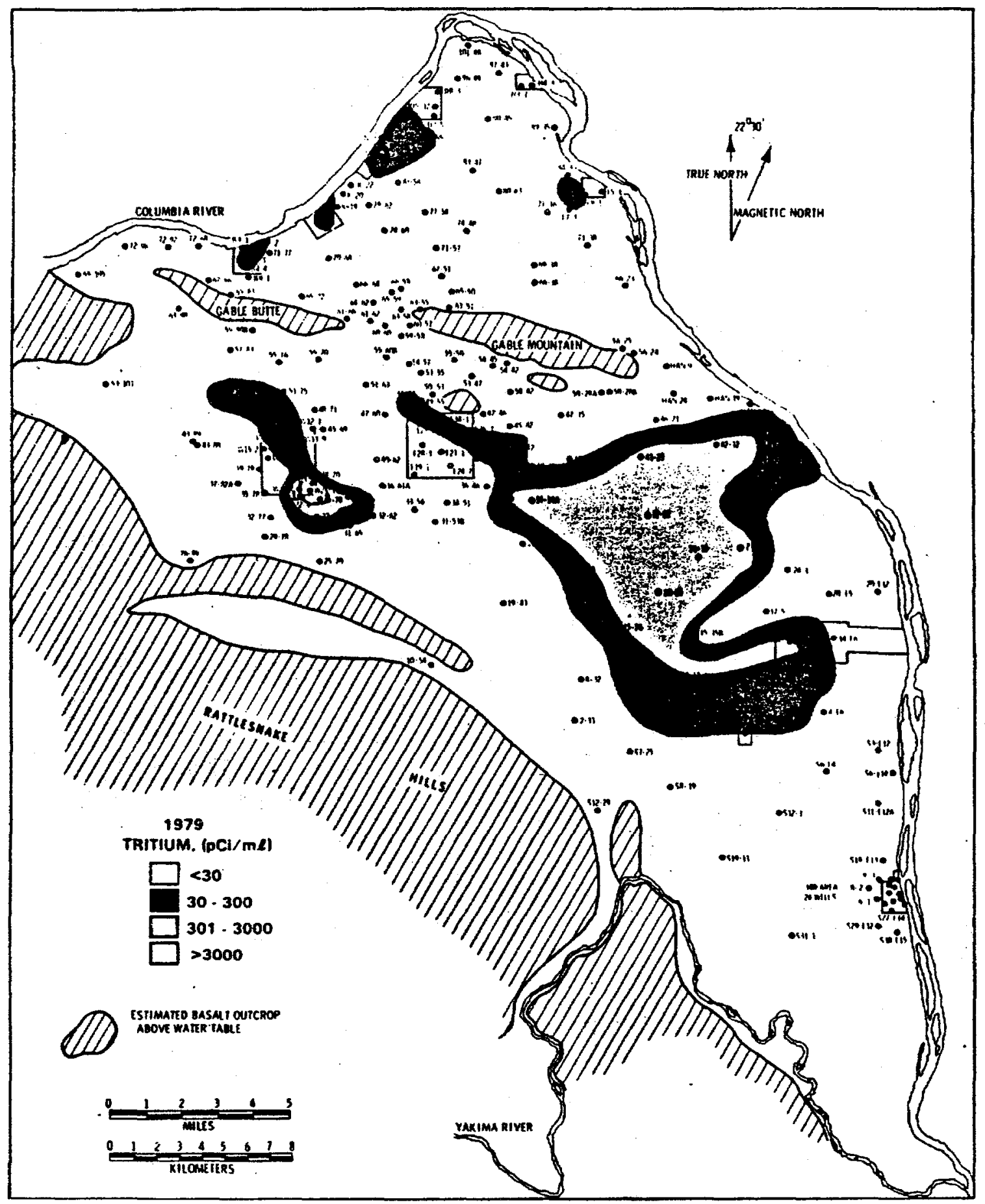

Figure 4.5. Tritium Plume as Reported in 1979 (Eddy and Wilbur 1980) 


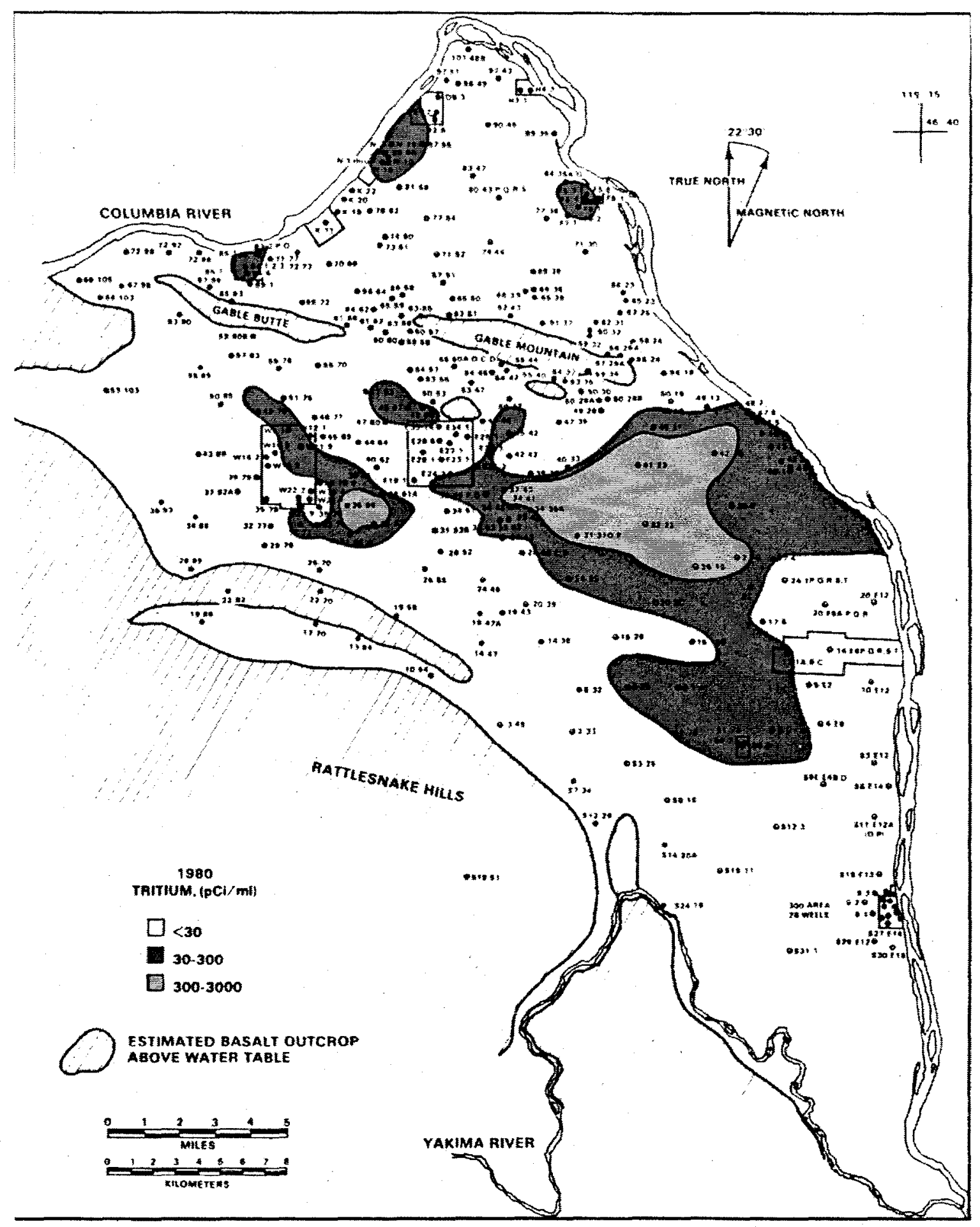

Figure 4.6. Tritium Plume as Reported in 1980 (Eddy and Wilbur 1981) 


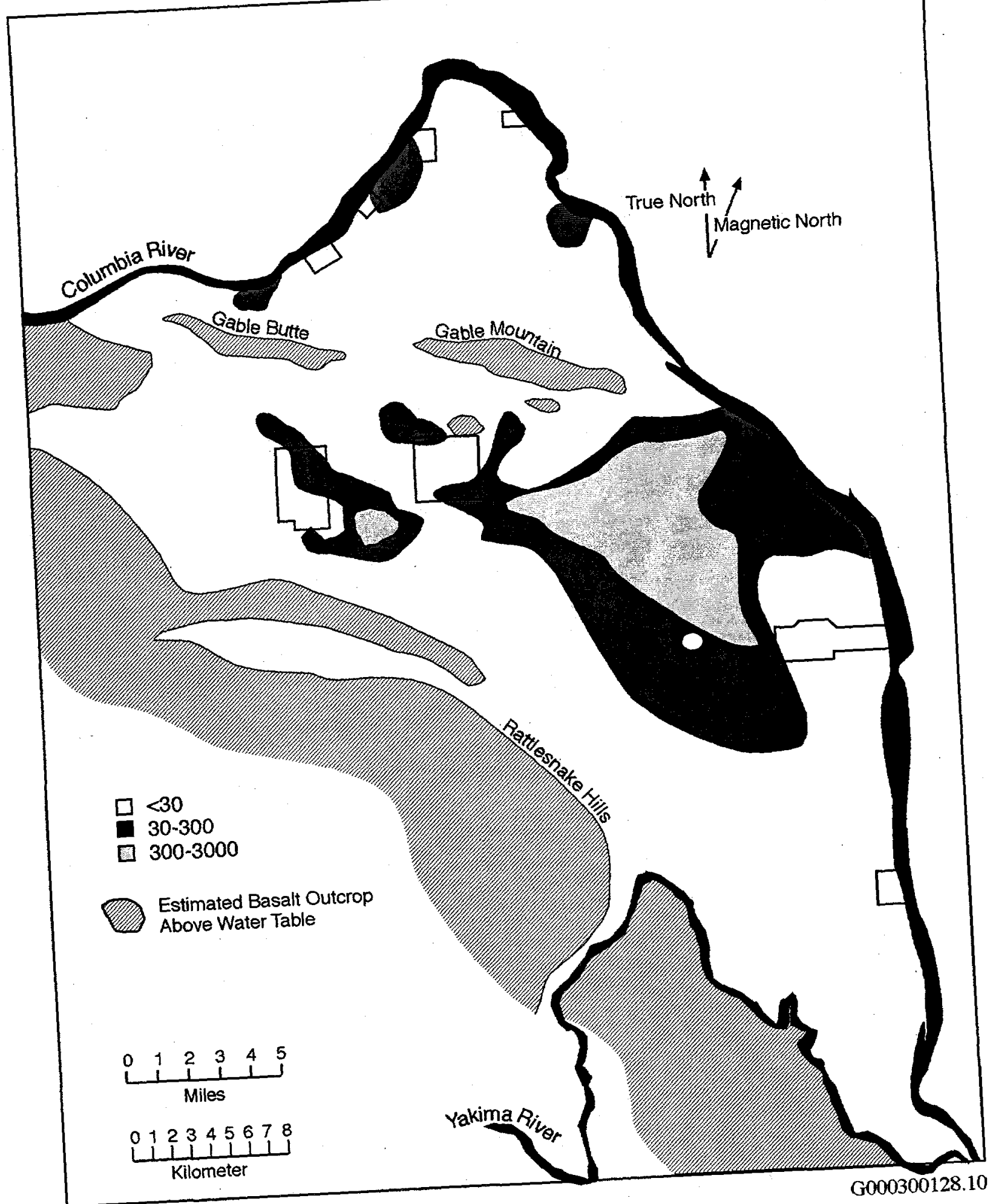

Figure 4.7. Tritium Plume Reported in 1980 Redrawn to Correct Incorrectly Contoured Points 


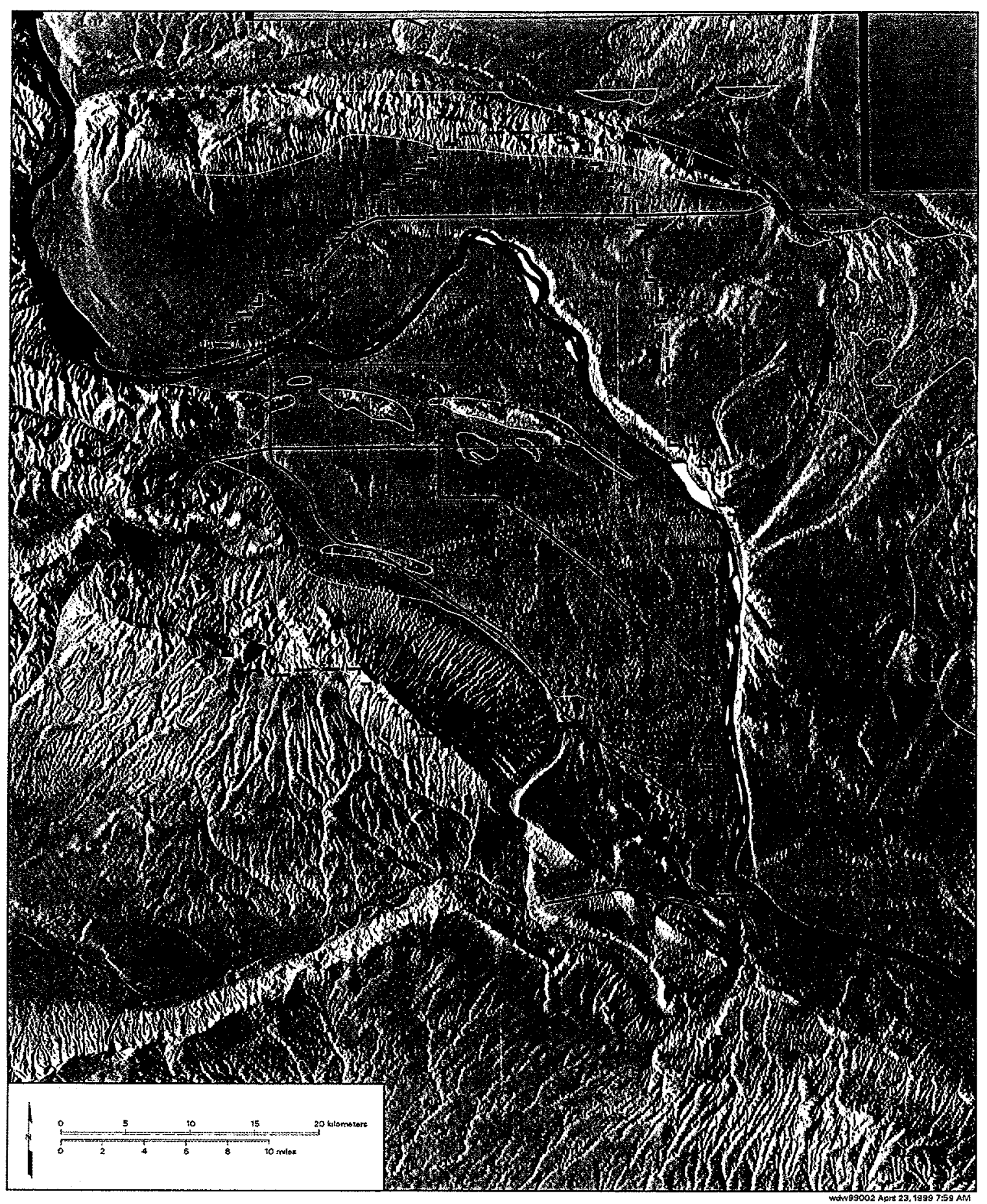

Figure 4.8. Digital Terrain Map of the Hanford Site and Surrounding Areas 


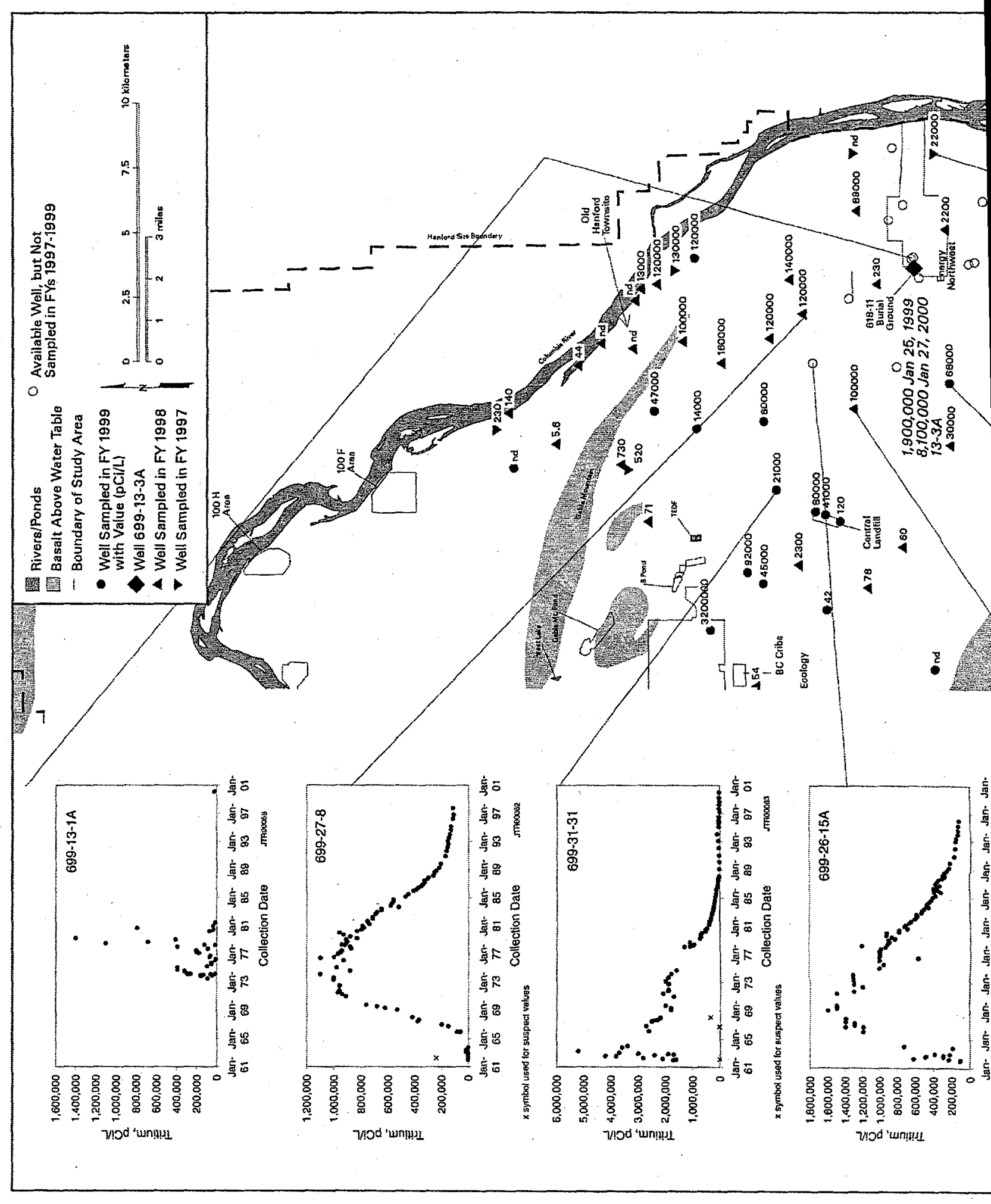




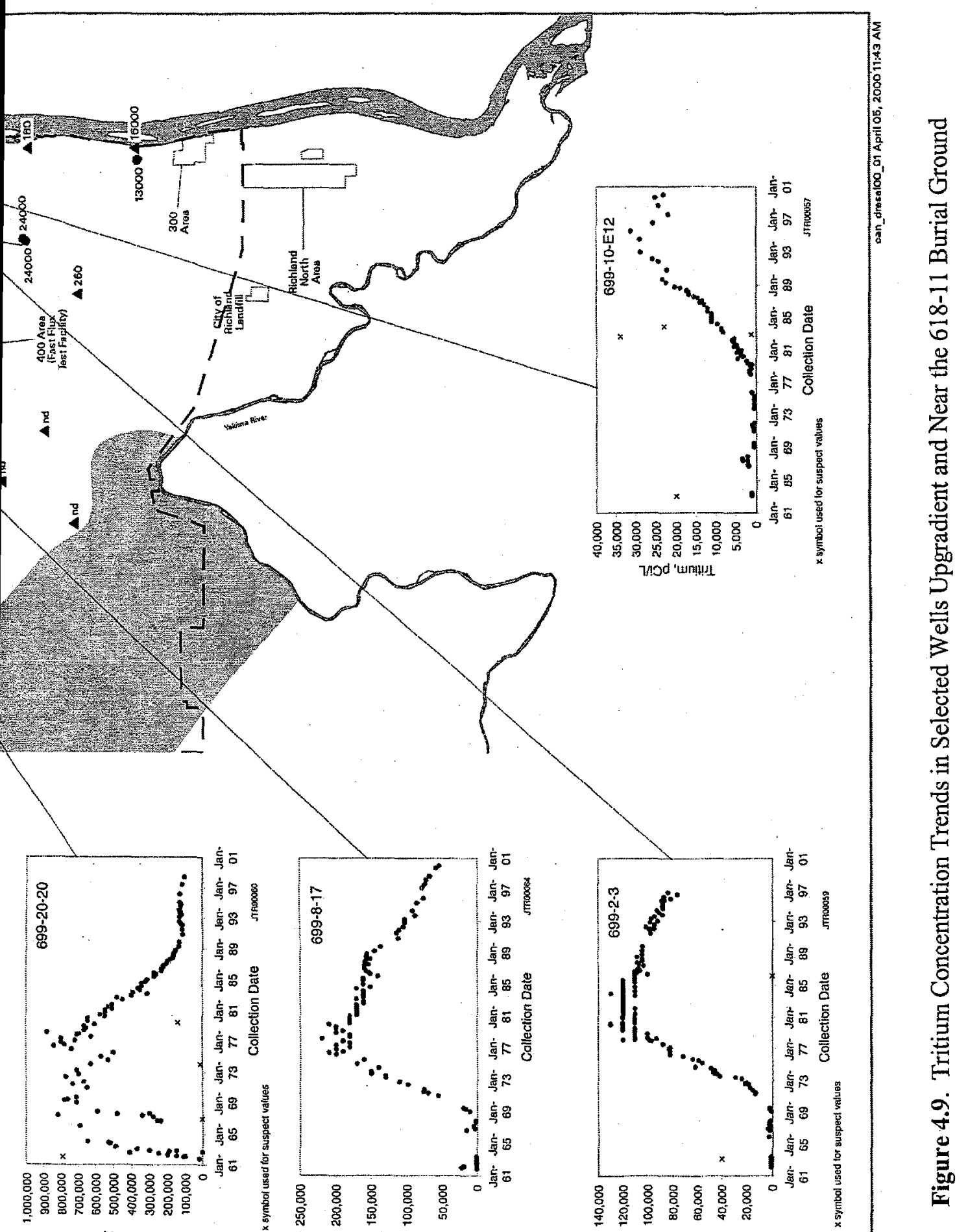




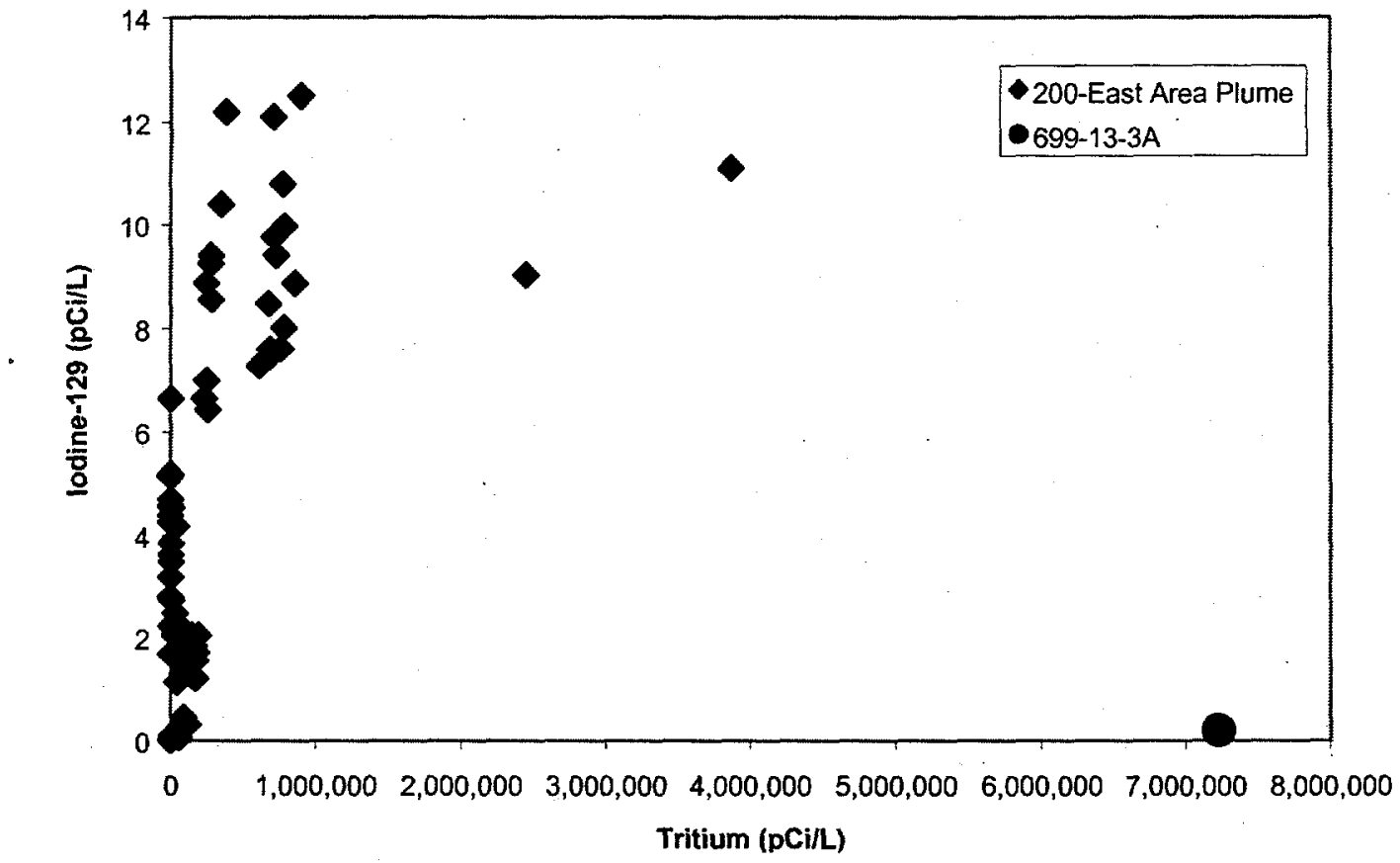

Figure 4.10. Comparison of Tritium vs. Iodine-129 for the 200 East Area Plume and Well 699-13-3A

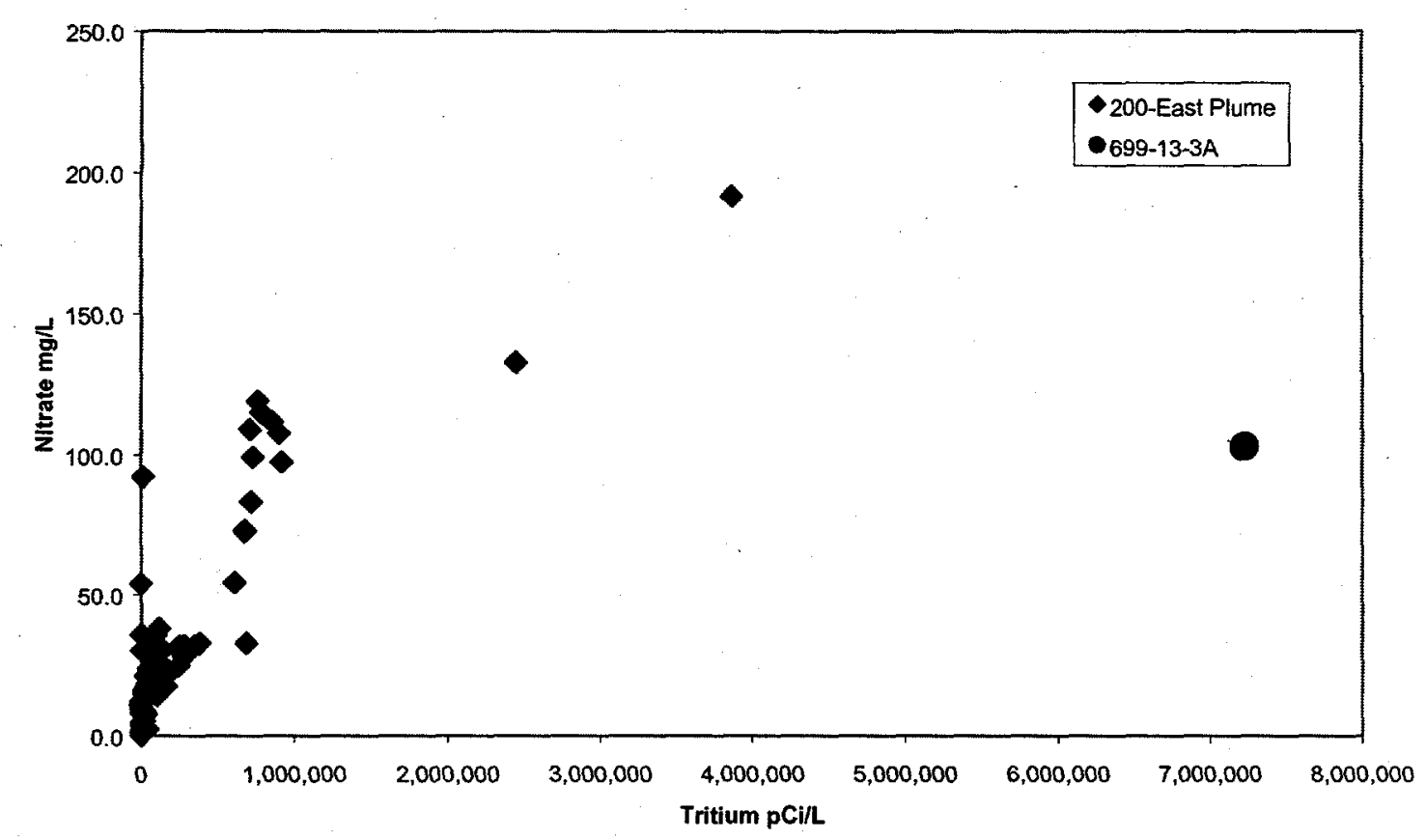

Figure 4.11. Comparison of Tritium vs. Nitrate for the 200 East Area Plume and Well 699-13-3A 


\subsection{Conclusions}

The lack of high tritium concentrations upgradient from the 618-11 burial ground suggests that the burial ground is the source of the tritium. A local source is also suggested by the lack of correlation with downgradient wells. Currently the plume at concentration levels greater than seen in the regional tritium plume from the 200 East Area has only been identified in well 699-13-3A. This indicates a fairly narrow plume that cannot be tracked by the current well coverage. The levels of contamination do not appear explainable by either a source in the 200 East Area or from Energy Northwest activities. Iodine-129 and nitrate concentrations are low compared to the tritium concentration in well 699-13-3A producing a signature distinctly different from the 200 East Area plume. The lack of co-contaminants, with the possible exception of nitrate and minor amounts of technetium-99, suggests that the specific source either does not contain co-contaminants or that the tritium is migrating significantly faster than other contaminants. The identification of the burial ground as the probable source of tritium is consistent with circumstantial evidence of the history of tritium production research at the Hanford Site and the possible disposal of materials that may have been used in that research. However, it is possible that other transuranic materials known to have been disposed to the burial ground may have contained tritium impurities.

The source of the tritium at concentrations greater than $1,000,000 \mathrm{pCi} / \mathrm{L}$ seen in this vicinity in the late 1970 s is still not unequivocally defined. However, the timing and magnitude of the arrival of tritium in water supply wells 699-13-1A and 699-13-1B are approximately what would be expected if the source of the tritium was in the 200 East Area. The presence of low-permeability sediments and historically low tritium concentrations in wells upgradient from the 618-11 burial ground, indicate geologic constraints on the transport of tritium into this area. A local source for the tritium seen in the 1970 s must be considered a possibility since the current concentrations in well 699-13-3A indicate a source of tritium at the 618-11 burial ground. However, further assessment would be needed to determine if the possible release rate of tritium from the waste and travel time through the vadose zone and groundwater are rapid enough to account for the arrival of tritium in wells 699-13-1A and 699-13-1B in the late 1970s - approximately 15 years after the burial ground was used.

Gross beta measured in well 699-13-3A, located immediately downgradient of the 618-11 burial ground, was increasing slowly prior to the Phase I sampling. Gross beta measurements for the Phase I sample were somewhat lower. The gross beta content appears to be attributable to technetium- 99 that is present in the regional plume from the 200 East Area. Thus, no causal relationship to the burial ground has been established.

No co-contaminants have been clearly associated with the tritium plume. Nitrate is present in this area at concentrations that are elevated compared to the regional tritium plume from the 200 East Area. The extent of the nitrate and the proportions of major anions in different wells indicate that the nitrate source probably is not the 618-11 burial ground. The region of elevated nitrate extends for considerable distance north of the burial ground. The source of the nitrate has not been determined. 
A low level of carbon tetrachloride and trichloroethene in groundwater may also have a source in the 618-11 burial ground, but further monitoring is needed to rule out contamination issues and to establish a trend. The only semivolatile organic constituent detected, bis(2-ethylhexyl) phthalate is likely attributable to laboratory contamination.

Uranium was detected at levels above the proposed maximum contaminant level of $20 \mu \mathrm{g} / \mathrm{L}$ in several wells, but the distribution does not indicate a source in the 618-11 burial ground. Further monitoring would be needed to establish a source and to understand the variations in natural uranium concentrations that may result from lithologic variation in the area.

The wells sampled in this phase of the investigation place only rough boundaries on the extent of tritium contamination. The downgradient and lateral extent will be addressed in follow-on work. The Phase I investigation did not assess the vertical extent of contamination and that will also be addressed in subsequent work. The Phase I investigation was not designed to address specific sources within the burial ground. A strategy for investigating whether the tritium contamination can be tied to specific parts of the: burial ground is being developed. 


\subsection{References}

53 FR 12449. 1988. "Disposal of Hanford Defense High-Level, Transuranic, and Tank Waste, Hanford Site, Richland, Washington; Record of Decision (ROD)," Federal Register, Vol. 53, No. 72, pp. 12449.

BHI-00184. See Lindsey, K. A.. 1995.

Davis, S. N., and R.J.M. DeWiest. 1966. Hydrogeology. John Wiley \& Sons, Inc. New York, New York.

Demiter, J. A., and W. O. Greenhalgh. 1997. Characterization of the 618-11 Solid Waste Burial Ground, Disposed Wastes, and Description of the Waste Generating Facilitates. HNF-EP-0649, Waste Management Federal Services, Inc., Richland, Washington.

Dirkes, R. L., R. W. Hanf, and T. M. Poston (eds). 1999. Hanford Site Environmental Report for Calendar Year 1998. PNNL-12088, Pacific Northwest National Laboratory, Richland, Washington.

DOE. 1987. Final Environmental Impact Statement, Disposal of Hanford Defense High-Level, Transuranic, and Tank Wastes. DOE/EIS-0113, U.S. Department of Energy, Washington, D.C.

DOE-RL. 1988. Implementation Plan for the Record of Decision for Disposal of Hanford Defense HighLevel, Transuranic, and Tank Wastes. DOE/RL-88-13, U.S. Department of Energy, Richland Operations Office, Richland, Washington.

DOE-RL. 1993. 618-11 Burial Ground Expedited Response Action Proposal. DOE/RL-93-49, U.S. Department of Energy, Richland Operations Office, Richland, Washington.

Eddy, P. A., and J. S. Wilbur. 1980. Radiological Status of the Ground Water Beneath the Hanford Project January - December 1979. PNL-3346, Pacific Northwest Laboratory, Richland, Washington.

Eddy, P. A., and J. S. Wilbur. 1981. Radiological Status of the Ground Water Beneath the Hanford Site January - December 1980. PNL-3768, Pacific Northwest Laboratory, Richland, Washington.

Hartman, M. J. (ed.). 1999. Hanford Site Groundwater Monitoring for Fiscal Year 1998. PNNL-12086, Pacific Northwest National Laboratory, Richland, Washington.

Hartman, M. J. (ed.). 2000. Hanford Site Groundwater Monitoring: Setting, Sources and Methods. PNNL-13080, Pacific Northwest National Laboratory, Richland, Washington.

Johnson, A. B., T. J. Kabele, and W. E. Gurwell. 1976. Tritium Production from Ceramic Targets: A Summary of the Hanford Coproduct Program. BNWL-2097, Battelle-Northwest Laboratories, Richland, Washington. 
Kipp, K. L., Jr. 1973. Radiological Status of the Groundwater Beneath the Hanford Reservation January - June 1973. PNL-1737, Pacific Northwest Laboratory, Richland, Washington.

Kipp, K. L., Jr. 1975. Radiological Status of the Groundwater Beneath the Hanford Reservation January - December 1973. PNL-1860, Pacific Northwest Laboratory, Richland, Washington.

Lindsey, K. A. 1995. Miocene- to Pliocene-Aged Suprabasalt Sediments of the Hanford Site, SouthCentral Washington. BHI-00184, Bechtel Hanford, Inc., Richland, Washington.

McDonald, J. E., L. S. Schleder, and C. A. Mendola. 1999. Nuclear Plant 2, 1998 Annual Radiological Environmental Operating Report, January 1 to December 31, 1998. Washington Public Power Supply System, Richland, Washington.

Phillips, F. M., J. L. Mattick, T. A. Duval, D. Elmore, and P. W. Kubik. 1988. "Chlorine 36 and tritium from nuclear weapons fallout as tracers for long-term liquid and vapor movement in desert soils." Water Resource Research Vol. 24, pp. 1877-1891.

Phillips, S. J., L. L. Ames, R. E. Fitzner, G. W. Gee, G. A. Sandness, and C. S. Simmons. 1980. Characterization of the Hanford 300 Area Burial Grounds, Final Report, Decontamination and Decommissioning. PNL-2557, Pacific Northwest Laboratory, Richland, Washington.

Piper, A. M. 1944. "A graphic procedure in the geochemical interpretation of water-analysis." American Geophysical Union Trans. Vol. 25, pp. 914-923.

PNL-8971. See Thorne, P. D. et al. 1993.

Thorne, P. D., M. A. Chamness, F. A. Spane, Jr., V. R. Vermeul, and W. D. Webber. 1993. ThreeDimensional Conceptual Model for the Hanford Site Unconfined Aquifer System, FY 93 Status Report. PNL-8971, Pacific Northwest Laboratory, Richland, Washington.

Washington Public Power Supply System. 1985. Preoperational Environmental Radiological Monitoring Program WNP-2. Washington Public Power Supply System, Richland, Washington.

Washington Public Power Supply System. 1996. Nuclear Plant 2, 1995 Annual Report, January 1 to December 31, 1995, Radiological Environmental Monitoring Program. Washington Public Power Supply System, Richland, Washington.

Washington State Department of Health. 1999. Environmental Radiation Program 1992-1994 Annual Report. Washington State Department of Health, Division of Radiation Protection. WDOH/320-021, Washington State Department of Health, Olympia, Washington. 


\section{Appendix A}

Sample and Analysis Instructions for Special Sampling of High Concentration Tritium and Surrounding Wells Near the 618-11 Burial Ground

Revision 1 
Sample and Analysis Instructions

For Special Sampling of High Concentration Tritium and Surrounding Wells Near the 618-11 Burial Ground

\section{Revision 1}

April 17, 2000

Revision 1 updates the attachments to the plan and includes minor editorial corrections.

Prepared by:

P. Evan Dresel

Date

Hanford Groundwater Project

Jane V. Borghese

Date

Groundwater Vadose Integration Project

Approval:

Stuart P. Luttrell

Groundwater Monitoring Task Lead

Hanford Groundwater Project

James G. Bush

Date

Group Leader

Field Hydrology and Geochemistry Group

Pacific Northwest National Laboratory 


\section{Introduction}

In January, 1999 a tritium level of 1,860,000 pCi/L was detected in well 699-13-3A, located near the 618-11 burial ground, just west of the Energy Northwest complex. This value was confirmed by reanalysis. A sample from January 2000 contained approximately $8,000,000 \mathrm{pCi} / \mathrm{L}$ of tritium. These levels are of concern because they are far above levels reported in the large tritium plume that extends from the 200 East Area through the area.

The immediate task is to determine the extent of the anomalously high tritium concentrations and to provide data to distinguish the source. Three potential sources are to be investigated:

- A large scale tritium plume extends from the 200 East Area through this vicinity. Other contaminants in this tritium plume include iodine-129, nitrate, and low levels of technetium- 99 . Cobalt- 60 has been detected in this plume in the past, but levels are currently near or below the detection limit. The sampling will include a broad range of radionuclides, and nitrate to look for signatures indicative of a 200 Area source.

- Some tritium is released from reactor operations at Energy Northwest. Some of the tritium is discharged to ground with storm water run off or through other systems. This tritium is not expected to contain the other contaminants found in the large plume but full research of the concentrations and distribution of the tritium from Energy Northwest has not been performed. The sampling will provide information on spatial distribution and levels to compare to what may be possible from this source.

- The 618-11 burial grounds received a variety of transuranic and other radioactive waste from the 300 Area. The waste may have included tritium and organic compounds. The sampling will include a wide range of radionuclides to look for materials which may indicate a source in the burial ground and to support the definition of possible exposure scenarios.

Sampling will be restricted to existing wells that do not require rehabilitation activities prior to sampling. Wells with no dedicated pump will be sampled with a portable pump, bailer, or air-lift. The sampling will concentrate on wells completed at the top of the unconfined aquifer, but selected deeper wells will be screened for tritium. Wells downgradient and upgradient from the burial ground will be included.

This plan is the initial effort of what is expected to be a more complete evaluation of the contaminant distribution around the 618-11 burial round. Additional plans will control these activities. This plan will be considered a supplement to the Integrated Monitoring Plan for the Hanford Groundwater Monitoring Project (September 1999, PNNL-1 1989, Rev. 1). This plan was developed according to the attached data quality objectives Process documentation (Attachment 1). 


\section{Task Organization}

These instructions were developed by the Hanford Groundwater Project at Pacific Northwest National Laboratory and the Environmental Restoration Contract Groundwater Vadose Integration Project. Coordination and scheduling of the sampling activity is performed by the Hanford Groundwater Project Sampling and Analysis Task.

Environmental Restoration Contractor Field Support Group will provide support services. Sampling services will be provided by Waste Management Technical Services under contract to Pacific Northwest National Laboratory.

\section{Analytes of Interest}

The constituents for which sampling will be conducted and a brief rationale for their selection follows, not all constituents will be analyzed in all wells.

Tritium - This is the target constituent and has been detected at high levels. The concentrations in the surrounding area typically range between less than 1,000 to 80,000 $\mathrm{pCi} / \mathrm{L}$.

Iodine-129 - This is a co-contaminant in the 200 East Area tritium plume but typically is found at less than $1 \mathrm{pCi} / \mathrm{L}$ in the surrounding area.

Gross alpha - This is a general screen for alpha emitting radionuclides. It may also provide a quality control check on the measurement of specific alpha emitters such as uranium included in the analyte list.

Gross beta - This is a general screen for beta emitting radionuclides. It may also provide a quality control check on the measurement of specific beta emitters such as strontium-90 and technetium-99.

Gamma scan - This provides data on the potential presence of cobalt- 60 and other gamma emitters. This will help to characterize sources and will provide assurance that other fission products are not being transported in groundwater.

Strontium-90 - This is indicative of reactor operations in some situations but is not expected from the 200 Area plumes.

Technetium-99 - Minor amounts of technetium-99 are found in the plume from the 200 East Area and will help define sources.

Uranium isotopes - The measurement of concentrations of the different uranium isotopes may help define sources of contamination because the different sources may have different isotopic ratios. For example, depeleted uranium has been found in the vicinity of the 618-10 burial ground, which received similar waste to the 618-11 burial ground. 
Plutonium isotopes - Plutonium generally has a low mobility in Hanford groundwater. However, since the disposal at the burial ground included transuranic waste, plutonium will be included in the analyte list for selected near-by wells.

Anions - These constituents provide nitrate and general water quality data. Nitrate is known to occur in the plume from the 200 East Area.

Filtered metals - These constituents provide general water quality data, a screen for trace hazardous metals (e.g. chromium) and quality control on analysis through calculation of charge balance.

Alkalinity - Analysis for alkalinity provides general water quality data and quality control on analysis through calculation of charge balance.

Volatile Organic Compounds - These constituents may be present in the burial ground. Samples from wells in the immediate vicinity of the burial ground will be analyzed for these constituents.

SemiVolatile Organic Compounds - These constituents may be present in the burial ground. Samples from wells in the immediate vicinity of the burial ground will be analyzed for these constituents.

Samples will be analyzed for the above constituents under the Hanford Site Analytical Contract. See Attachment 2 for the Sample Analytical Form. Detection limits are specified in the contract for the primary analytical laboratory.

Field measurements will be performed for parameters, $\mathrm{pH}$, specific conductance, temperature, dissolved oxygen, and turbidity.

Wells will be purged and sampled per documented procedures implemented by Waste Management Technical Services (WMNW-CM-004. 1998. Operational Environmental Monitoring. Waste Management Federal Services, Northwest Operations, Inc., Richland, Washington).

\section{Target Wells}

The wells to be sampled are included in Table 1, which also lists the analytes to be included with each well. Wells in Table 1 are grouped according to similar location and purpose. The grouping is for information only. As-built diagrams or other well construction information are available for many of the wells to be sampled and are attached as Attachment 3 to these instructions. The well locations are shown in Figures 1 and 2. 


\section{Schedule}

The monitoring defined in this plan is for a one-time sampling event. Future monitoring will be based on the results of this sampling. In addition, well 699-13-3A will be sampled monthly for selected constituents until further notice.

\section{Quality Control Samples}

Quality control samples will be generated to evaluate aspects of the sampling and analysis process that may impact the reliability of groundwater data. For example, field blanks are collected and analyzed to assess the potential for sample contamination and false detection of constituents. Similarly, field duplicates and split samples provide measures of sampling and analysis precision and data comparability. Additional quality control samples such as method blanks, laboratory control samples, and matrix spikes are also prepared and analyzed by analytical laboratories to help to ensure that laboratory measurements are accurate and reliable.

For the 618-11 burial ground sampling event, field quality control samples shall include two full-trip blanks, two field duplicates, one split sample, and several field transfer and equipment blanks. In general, the field quality control samples shall be analyzed for all constituents monitored at the associated well. The split sample will be analyzed for tritium only and the field transfer blank is applicable only to volatile organic compounds. The split sample and one of the field duplicates shall be collected from well 699-13-3A to provide additional confirmation of previous elevated tritium measurements. At least two equipment blanks shall be collected for each type of nondedicated sampling equipment (e.g. portable pump, bailer, Kabis sampler) that is used for groundwater sampling to help ensure that groundwater samples are not contaminated from sampling equipment. One equipment blank shall be collected before sampling well 699-13-3A which will be sampled with a portable pump. A second equipment blank will be collected after the sampling of well 699-13-3A to ensure there is no transfer of contamination to sample collection at other wells. One additional portable pump equipment blank will be collected where the portable pump is used on other weils. One field transfer blank will be collected on each day where wells are sampled for volatile organic compounds. The field transfer blanks are used to check for sample contamination caused by conditions at the sampling site (e.g. exhaust fumes from vehicles).

Cosampling of wells by Washington State Department of Health, Washington State Department of Ecology, and Energy Northwest will be performed as requested.

\section{Health and Safety}

Subcontractors will follow their established health and safety procedures for groundwater sampling activities. Although higher than usual levels of tritium have been found in this area, the levels do not require additional actions to reduce exposure or additional monitoring of the work site. 
Data Quality Objectives for initial follow-up sampling for high tritium levels detected near the 618-11 burial ground

\section{1) Problem Statement}

In January 1999 a tritium level of $1,860,000 \mathrm{pCi} / \mathrm{L}$ was detected in well $699-13-3 \mathrm{~A}$ located near the 618-11 burial ground, just west of the Energy Northwest complex. This value was confirmed by reanalysis. A sample from January 2000 contained approximately $8,000,000 \mathrm{pCi} / \mathrm{L}$ of tritium. These levels are of concern because they are far above levels reported in the large tritium plume that extends from the 200 East Area through the eastern part of the Hanford Site.

The immediate task is to determine the extent of the anomalously high tritium concentrations and to provide data to distinguish the source.

2) Specify the Decision

Does the high level tritium extend beyond the known well and are co-contaminants present which point to one of three possible sources for the contamination:

- the PUREX plume

- the 616-11 burial ground

- the Energy Northwest reactor operations

3) Identify the Inputs to the Decision

Inputs include analytical results from samples collected in groundwater wells and results of field parameters measured in groundwater wells. Also water level measurements will be taken in wells.

4) Boundaries

The spatial and temporal boundaries on this initial investigation are as follows:

- Existing monitoring wells

- Downgradient from the burial ground to the river

- Nearby upgradient wells

- Wells which can be sampled immediately

- Emphasis in unconfined aquifer with possible screening in confined aquifer and lower unconfined.

\section{5) Decision Rule}

If the high-level tritium plume extends to other wells sampled, then use this information in defining locations for further monitoring and for evaluating transport rates. If the 
chemical signatures indicate a source in the burial ground, then use this information to plan further evaluation of the site. If the signatures indicate a source at Energy Northwest, inform that company. If the signatures indicate a 200 Area source, then investigate the transport mechanism and sources that would lead to this occurrence and implications for site decisions.

Screening samples in deeper aquifers will be for tritium only.

\section{6) Specify Tolerable Limits on Decision Errors}

All analytical results will be performed by standard methods and procedures in order to provide defensible data. No statistical evaluation of well sampling location is required. The data are not immediately expected to be evaluated using a statistical approach.

7) Optimize the Design

The design is developed in the sampling and analysis plan. 

Attachment 2

Sample Authorization Form 

PNNL

SAMPLING AUTHORIZATION FORM

SAF Number: Y00-001

Rev: $\underline{0}$

Program Type SURV

Project Type Characterization

Task ID
Project ID PRIFEBOO

Operable Unit N/A

Round Number $\underline{0}$

SAF Title SITEWIDE SURVEILLANCE PRIORITY GW, FEBRUARY 2000

\begin{tabular}{l} 
Task Manager STEWART. DL \\
Charge Codes- \\
Anaytical Serrices \\
Project Coordinator STEWART. DL \\
\hline Estimated Start Date 02/01/00 \\
SampleArea Hanford Site \\
Sampling Organizations \\
WMFS. WW Operations \\
Laboratory/Turnaround/Data Deliverable \\
Primary: 300 Analytical Services/15 Days/Single Sheet Summary \\
Primary: Field Analysis Activities/ Field/Field \\
Primary: Quanterra Incorporated/7 Days/Single Sheet Summary \\
Primary: Quanterra St. Louis/7 Days/Single Sheet Summary \\
Primary: TMA/RECRA/7 Days/Single Sheet Summary \\
Primary: Waste Sampling \& Characterization/24 Hours/Single Sheet Summary
\end{tabular}

SAF Comment

PRIORITY TURNAROUND 7 DAYS FAX/45 DAYS SUMMARY AND 15 DAY FAX/45 DAYS

SUMM. SEE COC FOR SPECIFIC TURNAROUND TIMES.

TOTAL ACTTVITY EXEMPTION DOES NOT APPLY FOR ALL SAMPLES

REPORT TRI-BUTYL PHOSPHATE W/SEMI-VOA 8270

Submit invoices \& deliverables to DL STEWART, PNNL. BATCH ALL SAMPLES SUBMITTED

UNDER THIS SAF INTO ONE SDG, NOT TO EXCEED PRIORITY TURNAROUND TIME.

COC Comments

PRIORITY TURNAROUND 7 DAYS FAX/45 DAYS SUMMARY AND 15 DAY FAX/45 DAYS

SUMM. SEE COC FOR SPECIFIC TURNAROUND TIMES.

Date $02 / 05 / 00$

BHAEED:002 (12S4)

SAFStatus: Final

2/4/00 10:30:00 PM 


\section{PNNL}

\section{SAMPLING AUTHORIZATION FORM}

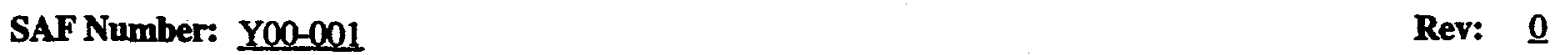

TOTAL ACTIVITY EXEMPTION DOES NOT APPLY FOR ALL SAMPLES

REPORT TRI-BUTYL PHOSPHATE W/SEMI-VOA 8270

Submit invoices \& deliverables to DL STEWART, PNNL. BATCH ALL SAMPLES SUBMTTED

UNDER THIS SAF INTO ONE SDG, NOT TO EXCEED PRIORITY TURNAROUND TIME. 
PNNL

Laboratory: 300 Analutical Services

\begin{tabular}{|c|c|c|c|c|c|}
\hline Paremeter / Analysis & Roteronce Mothod & Contuiner / Volume & VolReq & Preservation & $\begin{array}{l}\text { Holding } \\
\text { Times }\end{array}$ \\
\hline $\begin{array}{l}\text { Technotium-99 } \\
\text { Tectunetium-99 }\end{array}$ & TCOS_SEP_LSC & P $4000 \mathrm{~mL}$ & Minimum & $\mathrm{HCl}$ to $\mathrm{pH}<2$ & 6 Months \\
\hline
\end{tabular}

Field Sampling Requirements

Laboratory Analysis

Matrix: Water

Key to Container Types

$$
\begin{array}{ll}
G=\text { Glass } & a G=\text { Amber Glass } \\
G_{s}=\text { Glass w/ septum cap } & a G s=\text { Amber Glass w/ septum cap } \\
G^{*}=\text { Glass w/septum cap- } & a_{s}^{*}=\text { Amber Glass w/septum cap- } \\
\text { no bead space in container } & \text { no bead space in container } \\
P=\text { Plastic (Polyethylene) } &
\end{array}
$$

FSR Comment:

SAF Number: Y00-001

Rev. 0

Page 1

SAF Status: Final

2/4/00 10:30:00 PM 
PNNL

Field Sampling Requirements

Laboratory Analysis

Laboratory: Field Analysis Activitios

Matrix: Water

\begin{tabular}{|c|c|c|c|c|}
\hline Parameter I Analyale & Conteniner / Volume & VolReq & Proservation & $\begin{array}{l}\text { Holding } \\
\text { Times }\end{array}$ \\
\hline $\begin{array}{l}\text { DISSOLVED OXYGEN } \\
\text { Dissolved Oxygen }\end{array}$ & 360.1_OXYGEN_FD & None & None & ASAP \\
\hline $\begin{array}{l}\text { CONDuctivitry } \\
\text { Conductivity }\end{array}$ & 120.1_CONDUCT_FLD & None & None & None \\
\hline $\begin{array}{r}\text { TEMPERATURE } \\
\text { Temperature }\end{array}$ & 170.1_TEMP_FLD & None & & \\
\hline $\begin{array}{l}\text { TURBIDITY } \\
\text { Tubicity }\end{array}$ & 180.1_TURBIDITY_FLD & None & & \\
\hline $\begin{array}{l}\text { PH ANALYSIS } \\
\text { pH Moasurement }\end{array}$ & PH_ELECT_FD & None & None & None \\
\hline
\end{tabular}

Key to Container Types

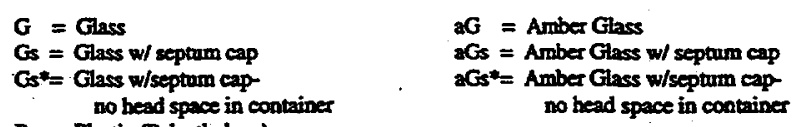

FSR Comment:

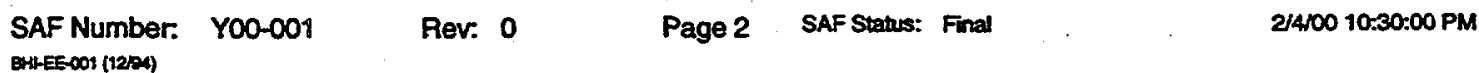


PNNL

Field Sampling Requirements

Laboratory Analysis

Laboratory: Quanterra incorporated

Matrix: Water

\begin{tabular}{|c|c|c|c|c|c|}
\hline Parameter / Analysis & Relerence Method & container / Volume & VolReq & Preservation & $\begin{array}{l}\text { Holding } \\
\text { Times }\end{array}$ \\
\hline $\begin{array}{l}\text { 906.0_HB_LSC: Tritium (1) } \\
\text { Tritium }\end{array}$ & 906.0_H3_LSC & $P 1000 \mathrm{~mL}$ & Full CC & None & 6 Months \\
\hline $\begin{array}{l}\text { 9310_AlPHABETA_GPC: Apha + } \\
\text { Gross alpha, Gross bata }\end{array}$ & 9310_ALPHABETA_GPC & $P 1000 \mathrm{~mL}$ & Full ac & HNOS to pH 2 & 6 Months \\
\hline $\begin{array}{l}\text { Activity Scan } \\
\text { No CAS }\end{array}$ & ACTIVITY_SCAN & $P 20 \mathrm{ml}$ & Minimum & None & 6 Months \\
\hline \multicolumn{6}{|c|}{ Antimony-125, Berylium-7, Cesium-134, Cesium-137, Cobalt-60, Europium-154, Europium-155, Potassium-40, Ruthenium-106 } \\
\hline $\begin{array}{l}\text { 1129_SEP_LEPS_GS: } 1-129(1) \\
\text { lodine-129 }\end{array}$ & 1129_SEP_LEPS_GS & GP $4000 \mathrm{~mL}$ & Full Qc & None & 6 Months \\
\hline $\begin{array}{l}\text { PUISO_PLATE_AEA: PU-238 + 22 } \\
\text { Plutonium-238, Plutonium-239/2 }\end{array}$ & $\begin{array}{l}\text { PUISO_PLATE_AEA } \\
40\end{array}$ & $\mathrm{G} / \mathrm{P} 1000 \mathrm{~mL}$ & Full $\mathbf{C}$ & HNOS to pH 2 & 6 Months \\
\hline $\begin{array}{l}\text { SRTOT_SEP_PRECIP_GPC: Tote S } \\
\text { Total beta rediostrontium }\end{array}$ & FTTOT_SEP_PRECIP_GPC & C GP $3 \times 1000 \mathrm{~mL}$ & Full $\mathrm{CC}$ & HNOB to pH 2 & 6 Months \\
\hline $\begin{array}{l}\text { TC99_ETVDSK_LSC: TC-99 (1) } \\
\text { Technetium-99 }\end{array}$ & TCS9_ETVDSK_LSC & $P 500 \mathrm{~mL}$ & Full QC & $\mathrm{HCl}$ to $\mathrm{pH}<2$ & 6 Months \\
\hline $\begin{array}{l}\text { UISO_PLATE_AEA: List-1 (3) } \\
\text { Uranium-234, Uranium-235, Uran }\end{array}$ & $\begin{array}{l}\text { UISO_PLATE_AEA } \\
\text { nitm-238 }\end{array}$ & GP $1000 \mathrm{~mL}$ & Full $Q C$ & HNOB to pH 2 & 6 Months \\
\hline $\begin{array}{l}\text { UTOT_KPA: Uranium (1) } \\
\text { Uranium }\end{array}$ & UTOT_KPA & GP $500 \mathrm{~mL}$ & Fult CC & HNOB to pH 2 & 6 Months \\
\hline
\end{tabular}

Key to Container Types
$\mathbf{G}=$ Glass
$\mathrm{Gs}=$ Glass w/ septum cap
$\mathbf{G s}^{*}=$ Glass w/septum cap
no head space in container
P = Plastic (Polycthylene)

$a G=$ Amber Glass

$a G s=$ Amber Glass $w /$ septum cap

$\mathrm{aCs}^{*}=$ Amber Glass w/septum cap-

no head space in container

FSR Comment:

SAF Number: Y00-001 Rev: 0 Page 3 SAF Status: Final 2/4/00 10:30:00 PM
at-1-EE-001 (12/24) 


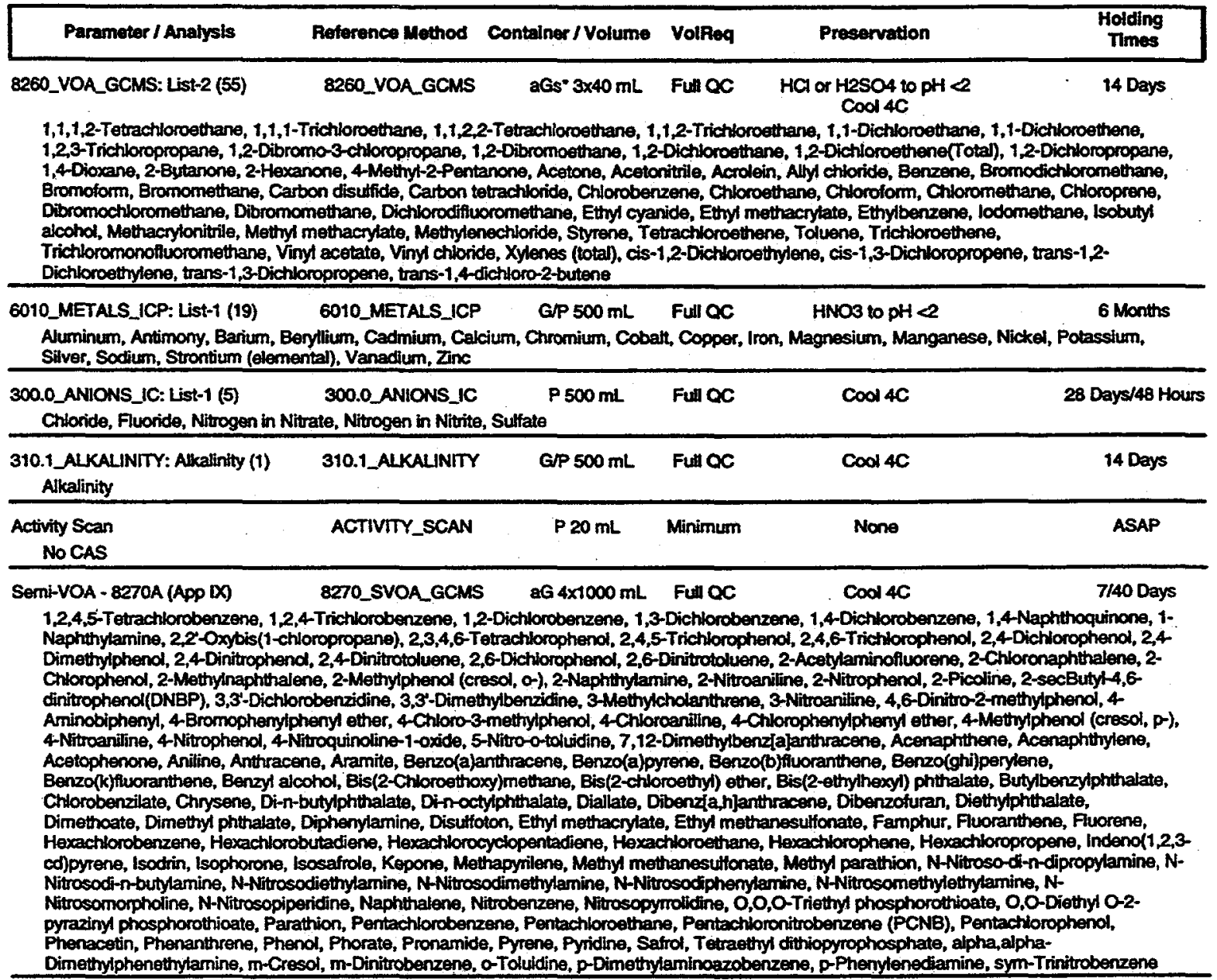

\section{Key to Container Types}

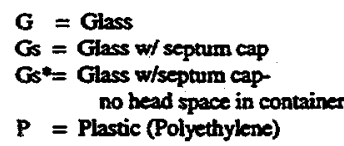

FSR Comment:

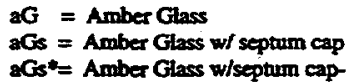

SAF Number: Yo0-001 Rev: $0 \quad$ Page 4 SAF Status: Final 2/4/00 10:30:00 PM
gatt-EE-01 (129)


PNNL

Laboratory: Quanterrast_Louis

Semi-VOA - 8270A (App IX Add-C 8270_SVOAGGMS Tributyl phosphate
Field Sampling Requirements

Laboratory Analysis

Matrix: Water

aG $0 \times 1000 \mathrm{~mL}$ Full $\mathrm{OC}$

$\mathrm{CoOl} 4 \mathrm{C}$

$7 / 40$ Days
Key to Container Types

$$
\begin{aligned}
& \mathbf{G}=\text { Glass } \\
& \mathbf{G}=\text { Glass w/ septum cap } \\
& \mathbf{G} s^{*}=\text { Glass w/septum cap- } \\
& \mathbf{P}=\text { no head space in container } \\
& \mathbf{P}=\text { Plastic (Polyethylene) }
\end{aligned}
$$

$\mathrm{aG}=$ Amber Glass

$\mathbf{a G s}=$ Amber Glass w/ septum cap

$\mathrm{aGs}^{*}=$ Amber Glass w/septum cap-

no bead space in containe

FSR Comment:

SAF Number: Y00-001

Rev: 0

Page 5

SAF Status: Final

2/4/00 10:30:00 PM EA-EE-001 (1200) 
PNNL

Field Sampling Requirements

Laboratory Analysis

Laboratory: IMARECRA

Matrix: Water

\begin{tabular}{|c|c|c|c|c|c|}
\hline Parameter / Analyals & Aoference Method & Contalner / Volume & Volfeg & Preservation & $\begin{array}{l}\text { Holding } \\
\text { Tlmes }\end{array}$ \\
\hline $\begin{array}{l}\text { Activity Scan } \\
\text { No CAS }\end{array}$ & ACTIVITY_SCAN & $P 20 \mathrm{~mL}$ & Minimum & None & 6 Months \\
\hline $\begin{array}{c}\text { Tritium - HB } \\
\text { Tritium }\end{array}$ & TRITIUM_DIST_LSC & $P 250 \mathrm{~mL}$ & Fun $\propto$ & None & 6 Months \\
\hline
\end{tabular}

Key to Container Types

$$
\begin{aligned}
& \mathbf{G}=\text { Glass } \\
& G_{s}=\text { Glass w/ septum cap } \\
& G^{*}=\text { Glass w/septum cap- } \\
& \text { no head space in container } \\
& P=\text { Plastic (Polyethylene) }
\end{aligned}
$$

FSR Comment:

SAF Number: Y00-001 Rev: $0 \quad$ Page 6 SAF Status: Final
EHeE-001 (12/4)


PNNL

Field Sampling Requirements

Laboratory Analysis

Laboratory: Waste Sampling \& Characterization

Matrix: Water

\begin{tabular}{lccccc}
\hline Parameter / Anabsis & Reference Method Contalner/Volume VolReq & Preservation \\
$\begin{array}{l}\text { Activity Scan } \\
\text { No CAS }\end{array}$ & ACTiVTY_SCAN & P $20 \mathrm{~mL}$ & Minimum & None \\
\hline
\end{tabular}

Key to Container Types
$\mathbf{G}=$ Glass
Gs = Glass w/ septum cap
$\mathrm{Cs}^{*}=$ Glass w/septum cap-
no bead space in containct
P = Plastic (Potyethyienc)

$\mathbf{a G}=$ Amber Glass

aGs = Amber Glass w/ septum cap

$2 G^{*}=$ Amber Glass w/septum cap-

FSR Comment:

SAF Number: Y00-001

Rev. 0

Page 7

SAF Status: Final

2/4/00 10:30:00 PM 



\section{Attachment 3}

\section{Well Construction Information}

No Well Information Available for Well 699-12-2A 



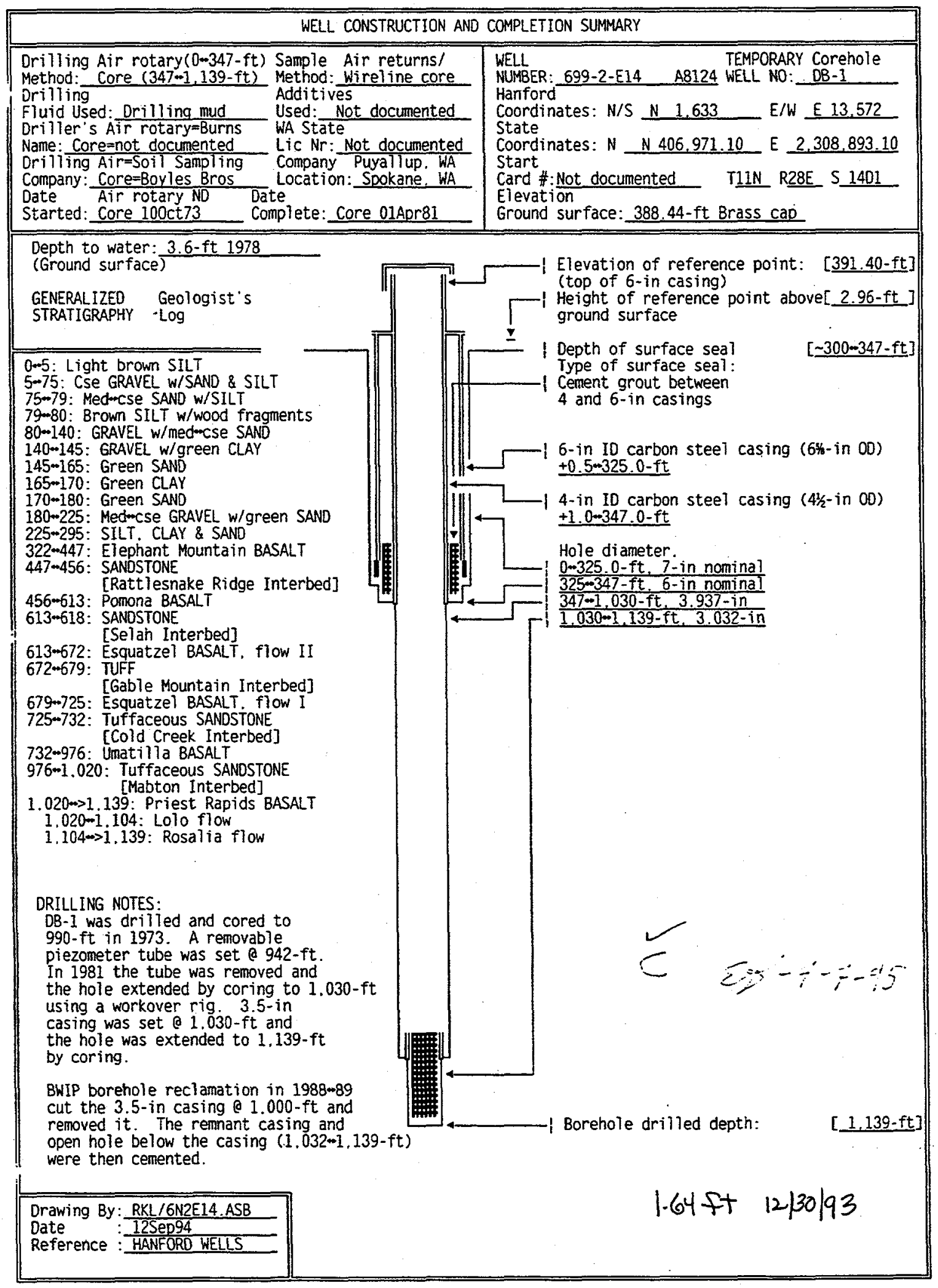


SUMMARY OF CONSTRUCTION DATA AND FIELD OBSERVATIONS

RESOURCE PROTECTION WELL - 699-2-E14

WELL OESIGNATION

ICRA FACILITY

EERCLA UNIT

HANFORD COORDINATES

LAMBERT COORDINATES

DATE DRILLED

DEPTH DRILLED (GS)

MEASURED DEPTH (GS)

DEPTH TO WATER (GS):

CASING DIAMETER

ELEV TOP CASING

ELEV GROUND SURFACE : PERFORATED INTERVALL SCREENED INTERVAL COMMENTS

AVAILABLE LOGS

TV SCAN COMMENTS

DATE EVALUATED

EVAL RECOMMENDATION:

LISTED USE

CURRENT USER

PUMP TYPE

MAINTENANCE
699-2-E14

Not applicable

Not applicable

$\mathrm{N} 1.633 \mathrm{E}$

Dec73/Extended Apr81

990.0-ft/Extended 1.139-ft

Not documented

3.6-ft. 1978

$6-i n$, carbon steel, $+0.5+325 \cdot 0-\mathrm{ft}$

4-in. carbon steel, +1.0-347.0-ft

$3.5-$ in carbon steel. $1.000-1.030-\mathrm{ft}$

$391.40-\mathrm{ft} .\left(6-\mathrm{in}^{2}\right.$ [15Jan74-Not documented]

388.44-ft. Brass cap [Aug85-Not documented

Not applicable

Not applicable - open $347 \% 1,030-\mathrm{ft}$

FIELD INSPECTION.

OTHER:

Geologist

Not applicable

Not applicable

Not applicable

Waste management/BWIP geohydrologic investigation

PNL sitewide $w / 1$ monitoring.

None documented 


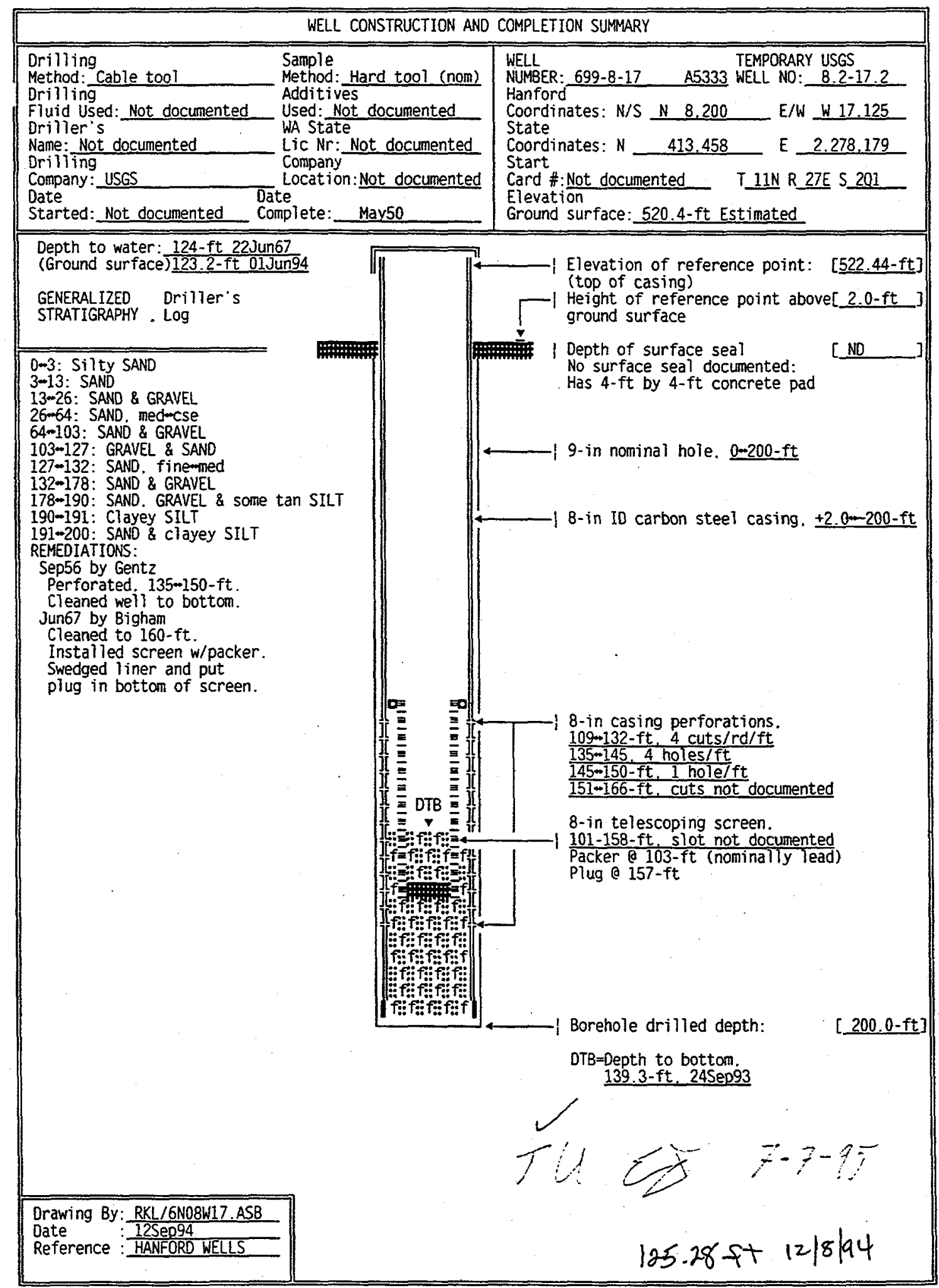




\section{SUMMARY OF CONSTRUCTION DATA AND FIELD OBSERVATIONS RESOURCE PROTECTION WELL - 699-8-17}

WELL DESIGNATION
CCRA FACILITY
ERRCLA UNIT
HANFORD COORDINATES
LAMBERT COORDINATES
DATE DRILLED
DEPTH DRILLED (GS)
MEASURED DEPTH (GS)
DEPTH TO WATER (GS)
CASING DIAMETER
ELEV TOP CASING
ELEV GROUND SURFACE
PERFORATED INTERVAL
SCREENED INTERVAL
COMMENTS

AVAILABLE LOGS TV SCAN COMMENTS DATE EVALUATED

EVAL RECOMMENDATION : LISTED USE CURRENT USER

PUMP TYPE MAINTENANCE
699-8-17

Not applicable

Not applicable

$\mathrm{N} \quad 8.200 \mathrm{~W} \quad 17.125$ [HANFORD WELLS]

$N$ 413.458 E 2.278.179 [HANCONV]

May50

200.0-ft

139.3-ft. 24Sep93

124.0-ft: 22Jun67

123.2-ft. 01Jun94

8-in. carbon steel. $+2.0-200-\mathrm{ft}$ (nominal)

$522.44-\mathrm{ft}$. [HANFORD WELLS]

520.4-ft. Estimated

$109+166-\mathrm{ft}$

101-158-ft [HANFORD WELLS]

FIELD INSPECTION. 24Sep93.

8 -in carbon steel casing. Capped and locked

Has 4-ft by 4-ft pad. no posts or permanent identification. Not in radiation zone.

OTHER:

Driller

Not applicable

Not applicable

Not applicable

Sitewide annual water level measurement. 01May91\%01Jun94:

WHC ES\&M W/I monitoring.

PNL sitewide sampling and characterization

Electric submersible 


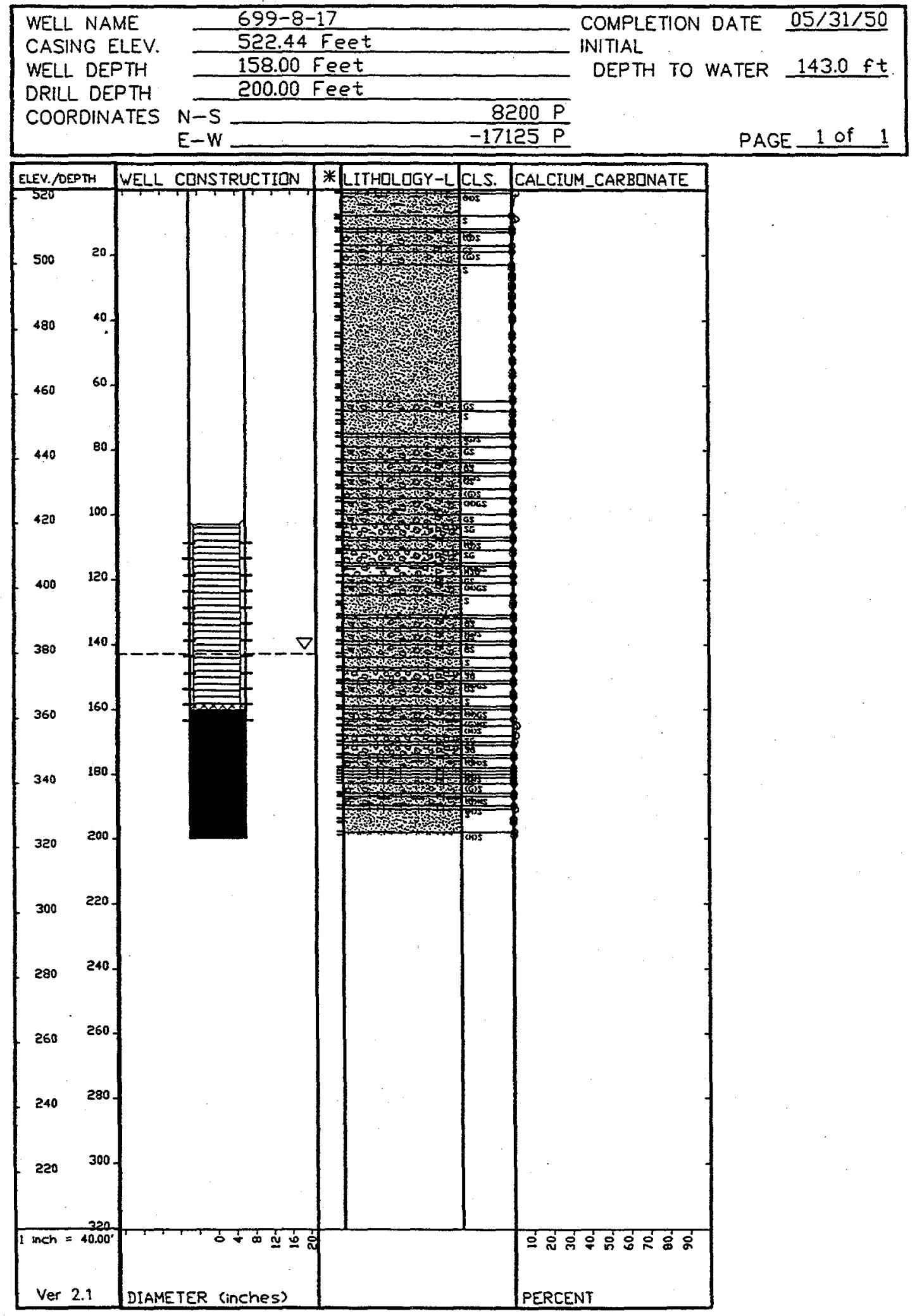




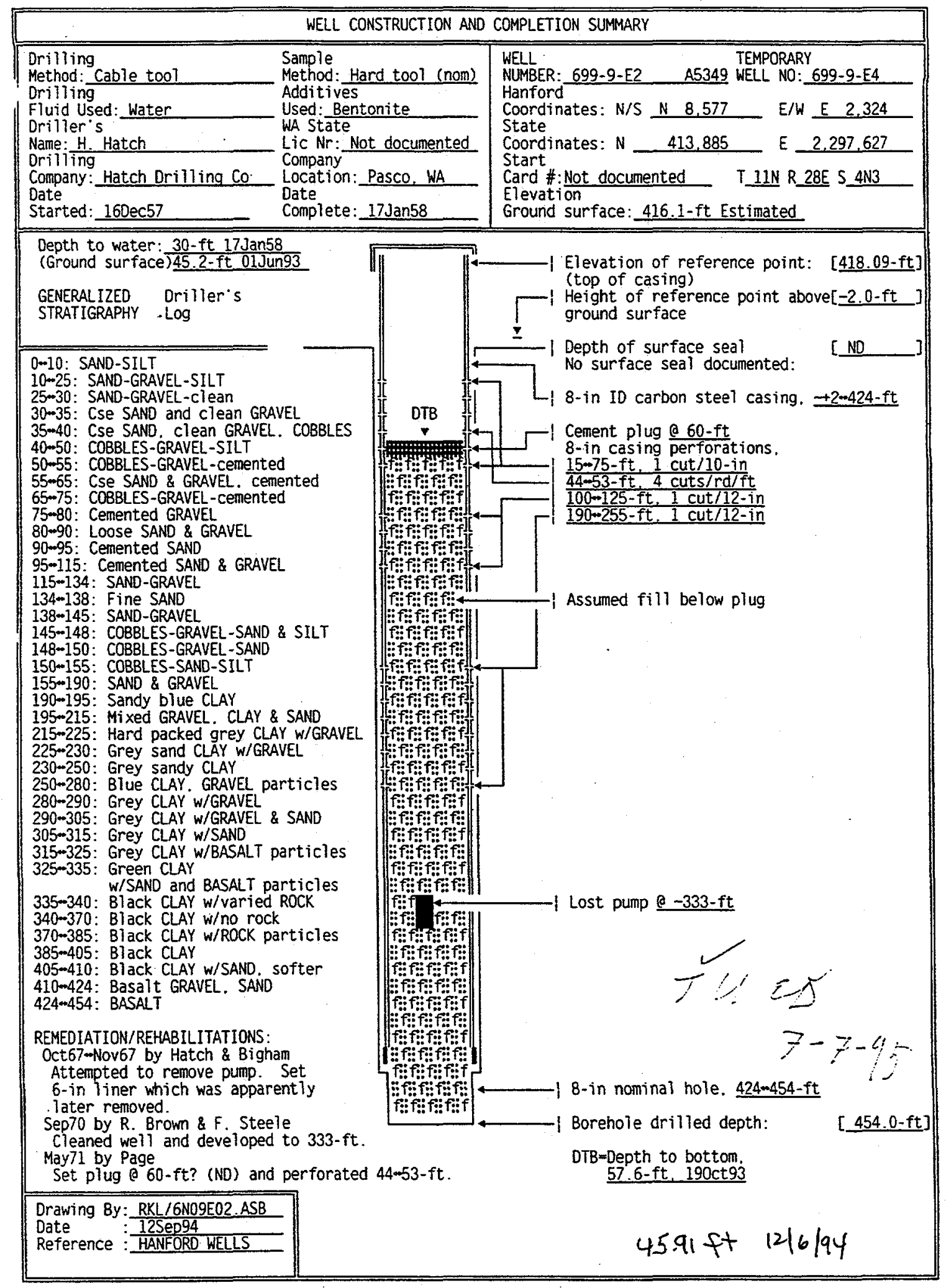


SUMMARY OF CONSTRUCTION DATA AND FIELD OBSERVATIONS RESOURCE PROTECTION WELL - 699-9-E2

WELL DESIGNATION
?ERCLA UNIT
RCRA FACILITY
HANFORD COORDINATES
LAMBERT COORDINATES
DATE DRILLED
DEPTH ORILLED (GS)
MEASURED OEPTH (GS)
OEPTH TO WATER (GS)
CASING DIAMETER
ELEV TOP CASING
ELEV GROUND SURFACE
PERFORATED INTERVAL
SCREENED INTERVAL*
COMMENTS

AVAILABLE LOGS

TV SCAN COMMENTS

DATE EVALUATED

EVAL RECOMMENDATION

LISTED USE

CURRENT USER

PUMP TYPE

MAINTENANCE
699-9-E2

Not applicable

Not applicable

$\mathrm{N} 8.577 \mathrm{E} \quad 2.324$ [HANFORD WELLS]

$N 413.885$ E 2.297.627 [HANCONV]

Jan58

454-ft

57.6-ft, 190 ctg3

$30-\mathrm{ft}, 17 \mathrm{Jan} 58$

45.2-ft, 01 Jun93

$8-i n$. +0.6- $424-f t$

418.09-ft. [HANFORD WELLS]

416.1-ft. Estimated

15-255-ft

Not applicable

FIELD INSPECTION. 190ct92.

8-in carbon steel casing. Capped and locked

No pad. posts or permanent identification.

Not in radiation zone.

OTHER:

Driller

Not applicable

Not applicable

Not applicable

Sitewide semiannual water level measurement. 11Jun91-01Jun93. WHC ES\&M w/I monitoring.

PNL $W / 7$ monitoring

Electric submersible 


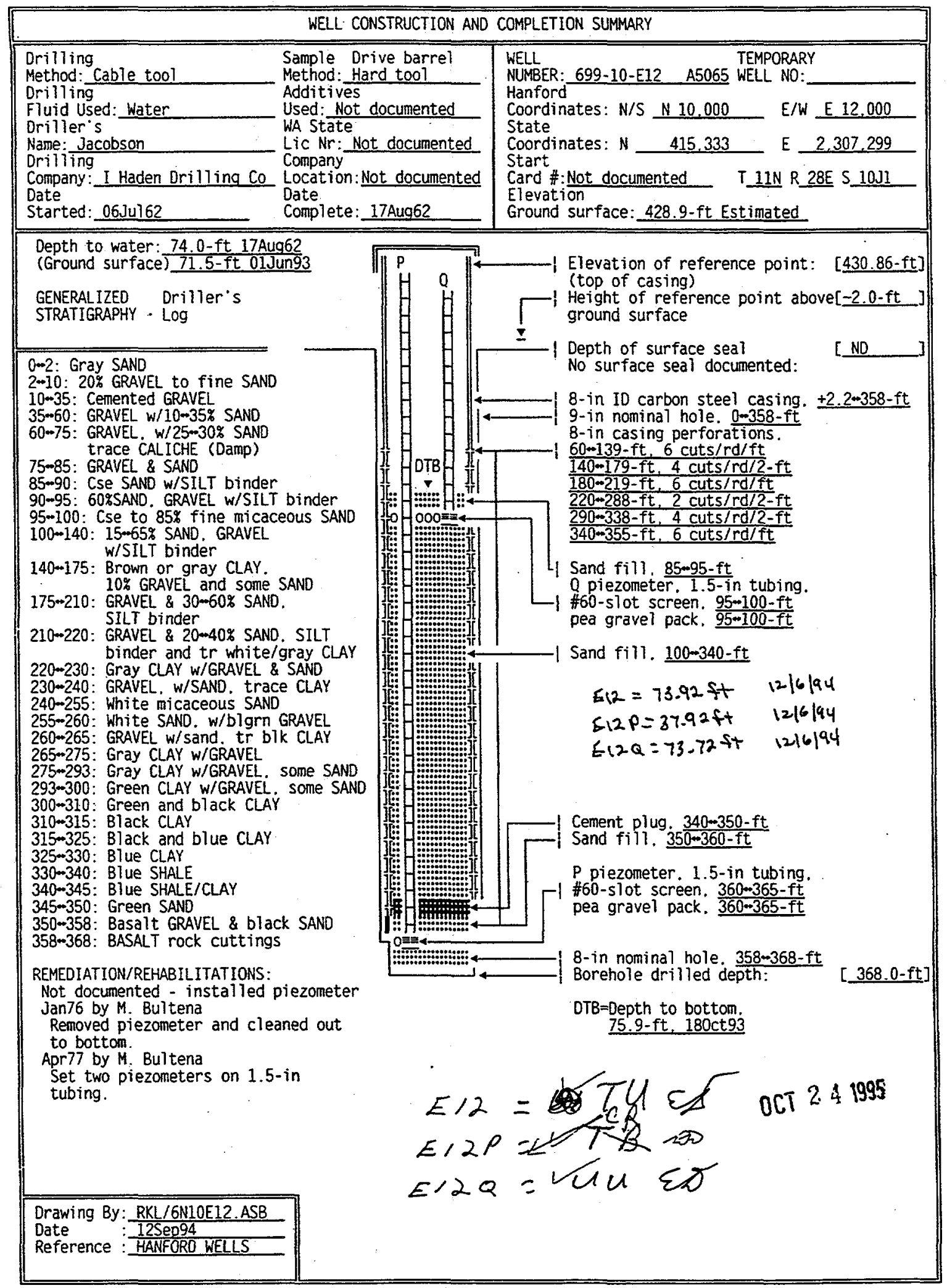




\section{SUMMARY OF CONSTRUCTION DATA AND FIELD OBSERVATIONS}

RESOURCE PROTECTION WELL - 699-10-E12

WELL DESIGNATION
CERCLA UNIT
RCRA FACILITY
HANFORD COORDINATES
LAMBERT COORDINATES
DATE DRILLED
OEPTH DRILLED (GS)
MEASURED DEPTH (GS)
DEPTH TO WATER (GS)
CASING DIAMETER
ELEV TOP CASING
ELEV GROUND SURFACE
PERFORATED INTERVAL
SCREENED INTERVAL
COMMENTS

AVAILABLE LOGS TV SCAN COMMENTS OATE EVALUATED

EVAL RECOMMENDATION LISTED USE CURRENT USER

PUMP TYPE MAINTENANCE
699-10-E12

Not applicable

Not applicable

$N \quad 10.000$ E 12,000 [HANFORD WELLS]

N 415.333 E 2.307.299 [HANCONV]

Aug62

$368-\mathrm{ft}$

75.9-ft. 180 ct93

74.0t. 17Aug62

71.5-ft. 01 Jun93

$8-i n+2.2-358-\mathrm{ft}$

430.86- $\mathrm{ft}$. [HANFORD WELLS]

428.9-ft. Estimated

$60-355-\mathrm{ft}$

Q piezometer. 95-100-ft. \#60-slot.

$P$ piezometer, 360-365-ft. \#60-slot

FIELD INSPECTION. 180ct93.

8 -in carbon steel casing. Capped and locked

No pad. posts or permanent identification.

Not in radiation zone.

OTHER:

Driller

Not applicable

Not applicable

Not applicable

Sitewide semiannual water level measurement. 01May91-01Jun93.

WHC ES\&M $w / 1$ monitoring.

PNL sampling, $w / 7$ monitoring and characterization

Electric submersible 


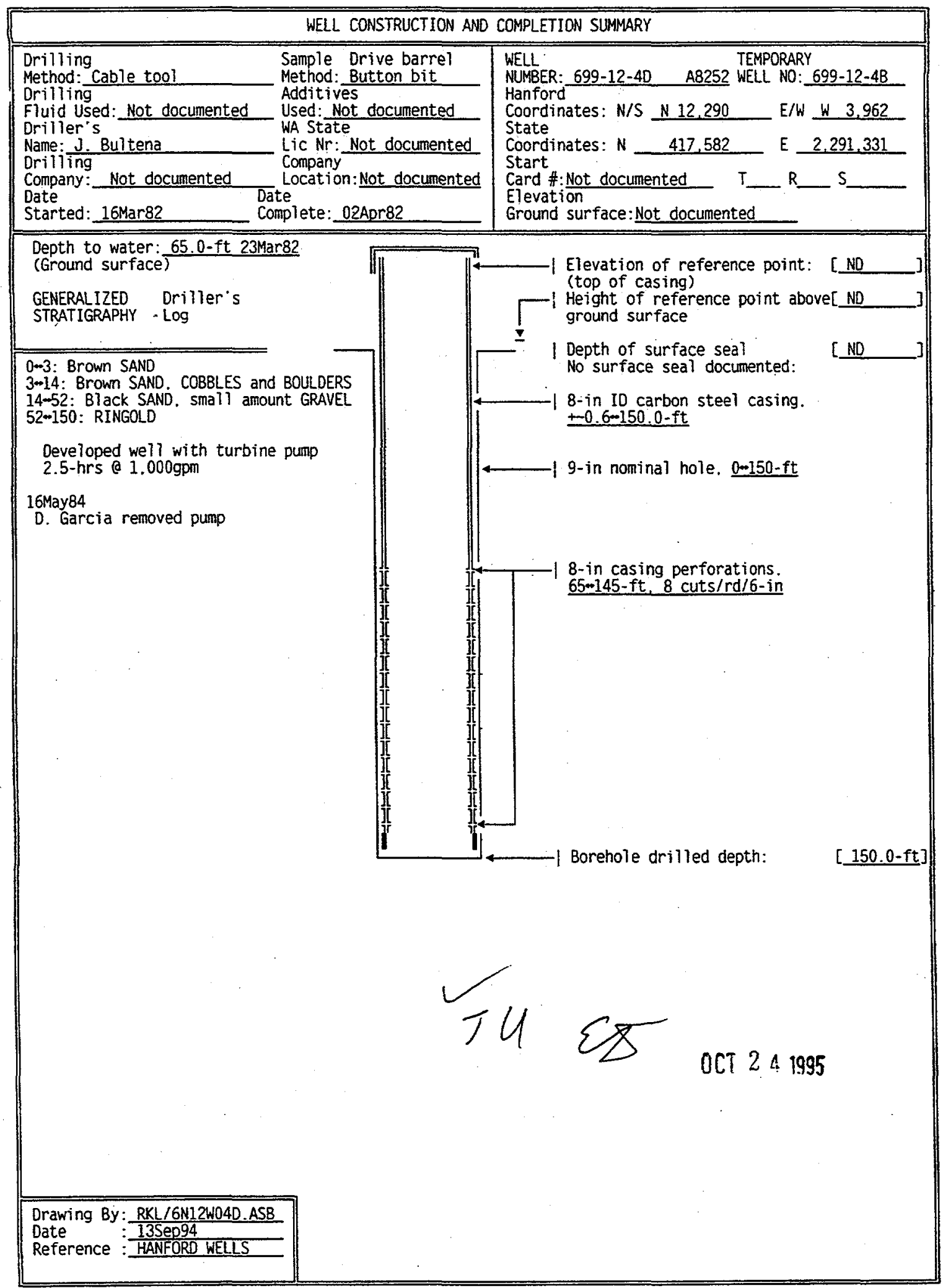


SUMMARY OF CONSTRUCTION DATA AND FIELD OBSERVATIONS

RESOURCE PROTECTION WELL - 699-12-40

WELL DESIGNATION
RCRA FACILITY
CERCLA UNIT
HANFORD COORDINATES
LAMBERT COORDINATES
DATE DRILLED
DEPTH DRILLED (GS)
MEASURED DEPTH (GS)
DEPTH TO WATER (GS)
CASING DIAMETER
ELEV TOP OF CASING
ELEV GROUND SURFACE
PERFORATED INTERVAL
SCREENED INTERVAL
COMMENTS
AVAILABLE LOGS
TV SCAN COMMENTS
DATE EVALUATED
EVAL RECOMMENDATION
LISTED USE
CURRENT USER
PUMP TYPE
MAINTENANCE
REMEDIATIONS

$699-12-40$

Not applicable

Not applicable

$\mathrm{N} 12.290 \mathrm{~W} \quad 3.962$ [HANFORD WELLS]

N 417.582 E 2.291.331 [HANCONV]

Apr82

150 - ft

Not documented

65.0-ft. 23Mar82

8 -in. carbon steel. $+\infty .6-150.0-\mathrm{ft}$

Not documented

Not documented

65-145-ft

Not applicable

FIELD INSPECTION,

OTHER:

Driller

Not applicable

Not applicable

Not applicable

Drilled as 618-11 Burial Ground cleanup water supply well

PNL sitewide rehabilitation

Electric submersible 
Well * 699-13-1A (WNP-2 Well \#1)

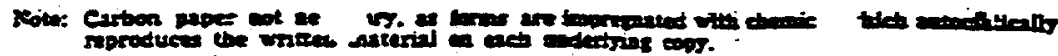

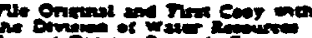

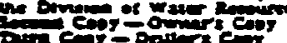

WATER WET REPORT

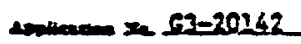
crear or wastmoros

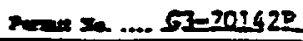

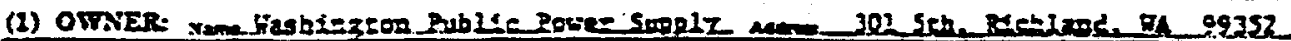

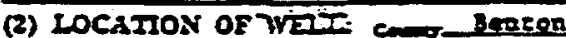

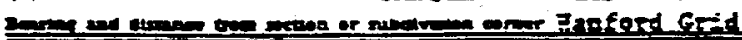

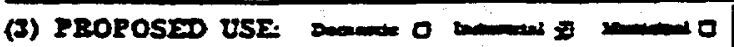

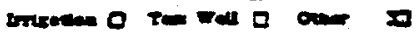

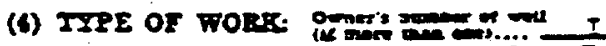

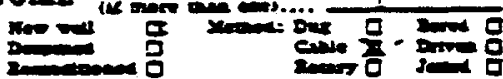
(5) DDronstoNs:

(6) CONSIRUCHON DEIATS:

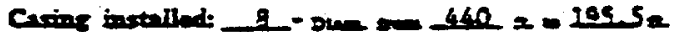

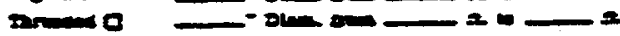
wane $=-\operatorname{arn}=2=2$

Pexperations Yo 0 yo $Q$

300 - 200

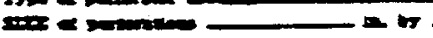

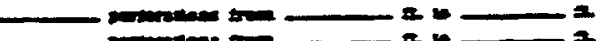

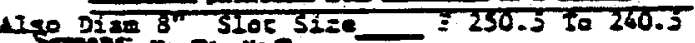

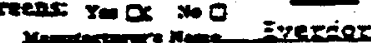

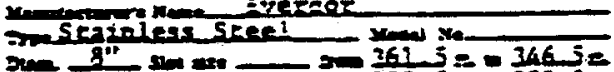

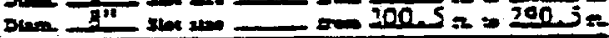

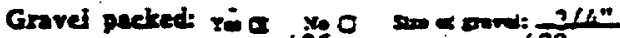
com and $\sin 4250-400$

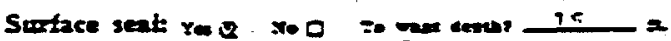

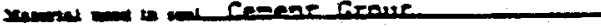

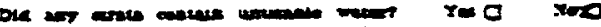

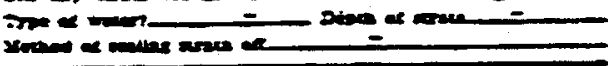

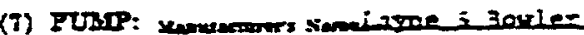

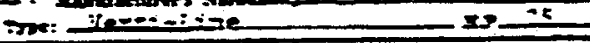

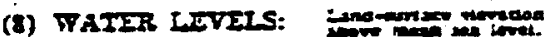

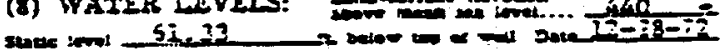

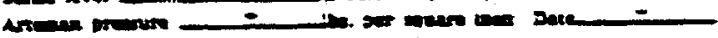

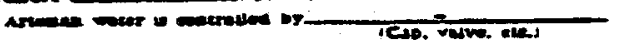

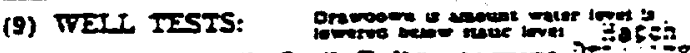

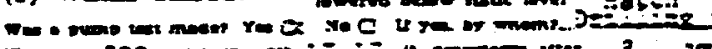

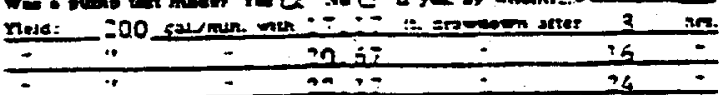

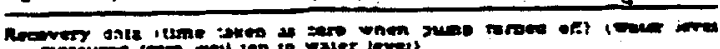

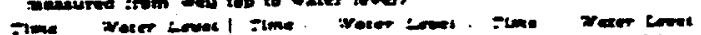

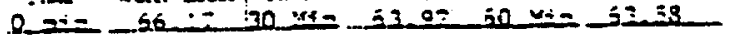
$10 "$ "

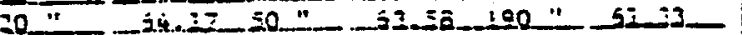
setr of ient $12-28-.2$

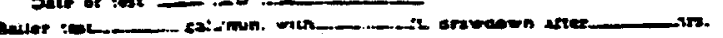

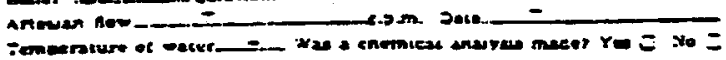

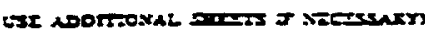

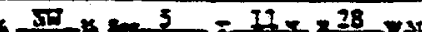
E. 1.340 .25 (10) meL 200:

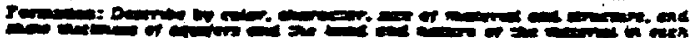

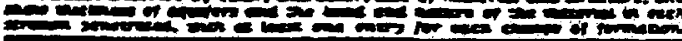

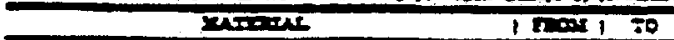

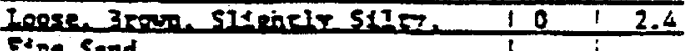
Esne sind $\frac{1}{1} \frac{i}{1}$

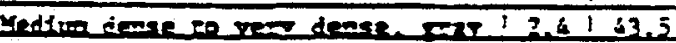

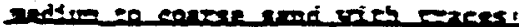

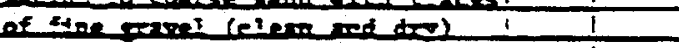

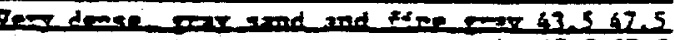
$+47.567 .5$

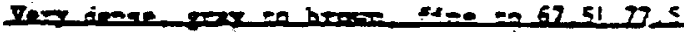

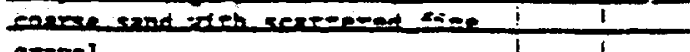

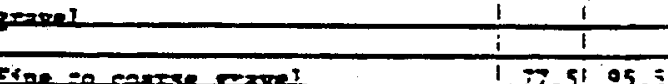

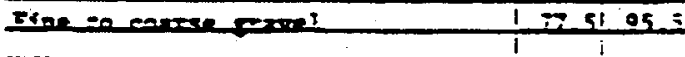

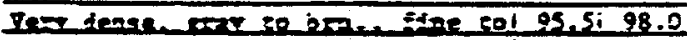

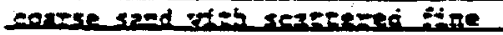
- 201

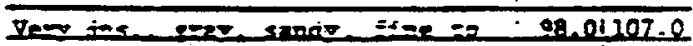
are zarel i 1

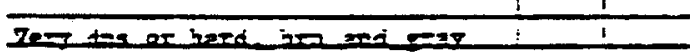

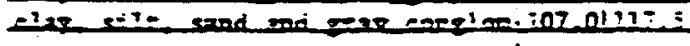

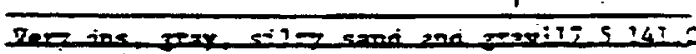

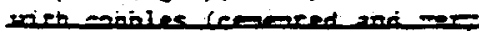
$-\infty \operatorname{los}^{-1}$

Sne :

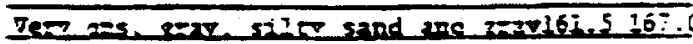

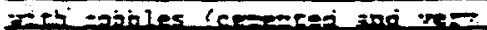
exme-1

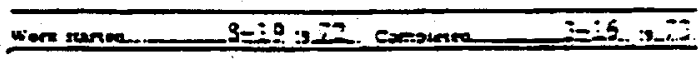
VELL DRRIERS SI2IDLET:

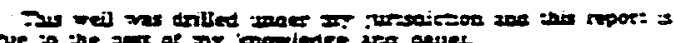

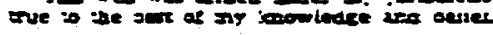

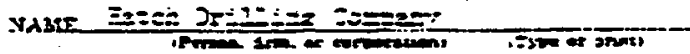

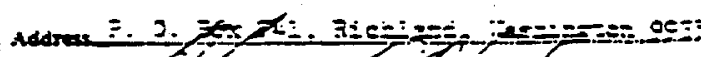
!Sienel

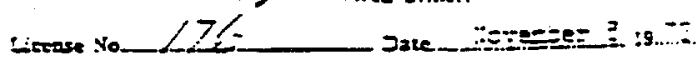


Well * 699-13-1B (WNP-2 Well *2)

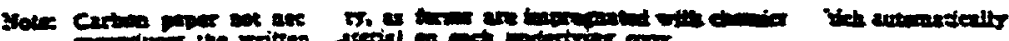

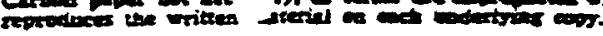

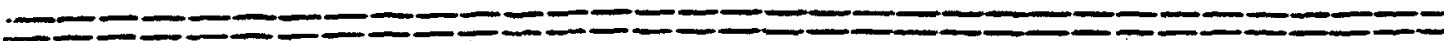

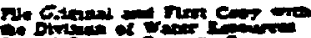

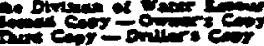

WATER WET RAPORT

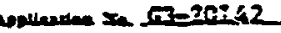

STATE OF WASTENGTON

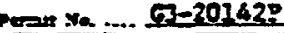

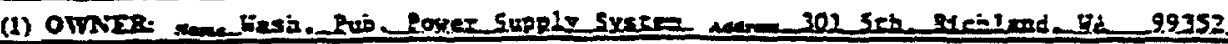

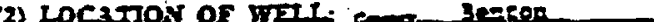

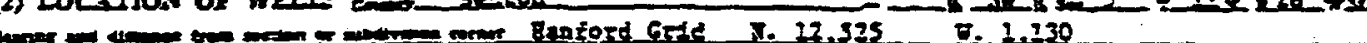

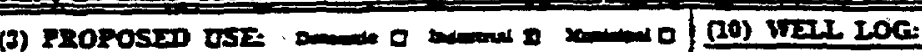

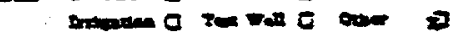

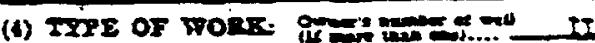

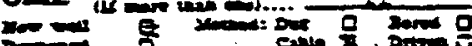
2010

(5) Dnmorsions

$\operatorname{man}-\frac{1}{2}$

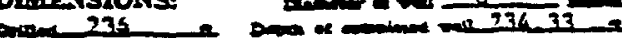

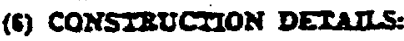

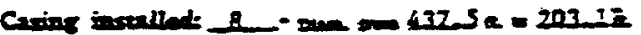

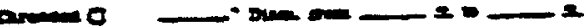

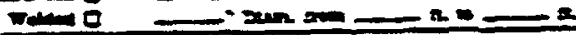

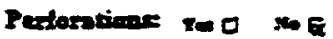

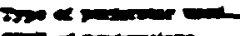

$m<\infty=0$

(1)

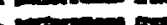

$\div=$

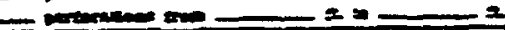

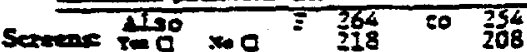

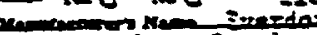
Sritiless SFef?

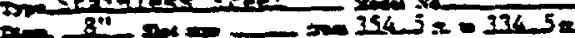

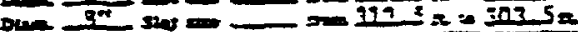

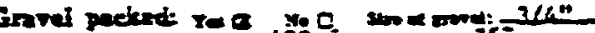

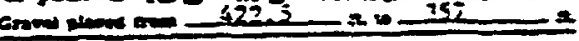

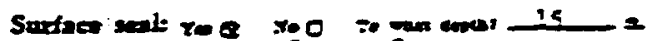

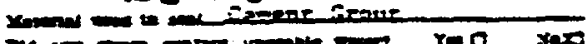

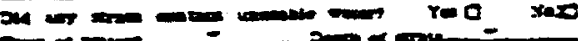

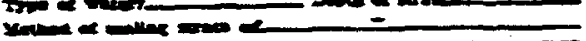

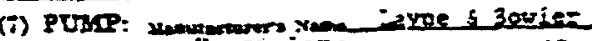
Tov: Te=-

80

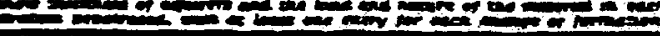

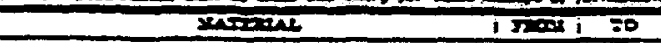

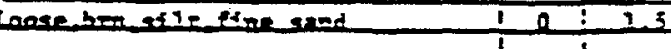

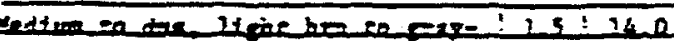

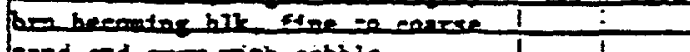

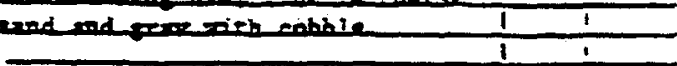

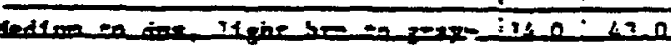

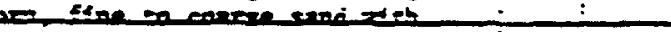

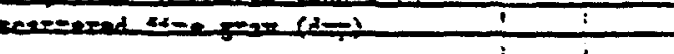

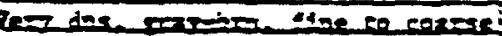

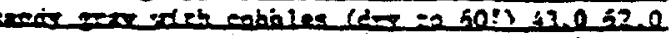

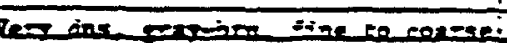

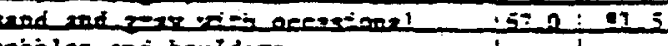
erinles snethouiders

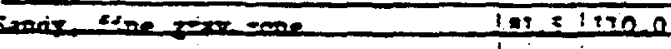

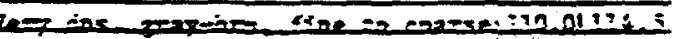

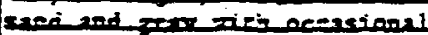

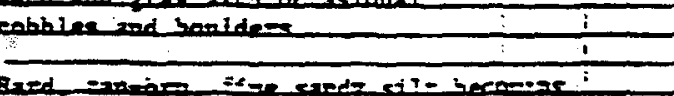

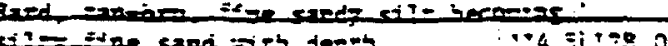

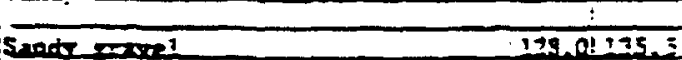

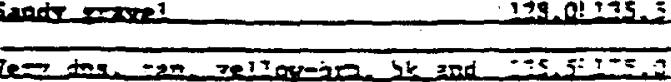

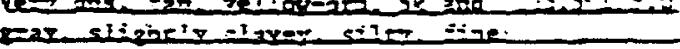

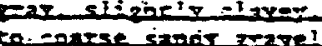

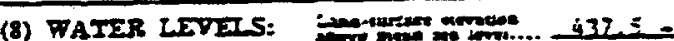

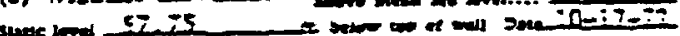

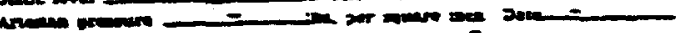

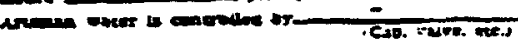

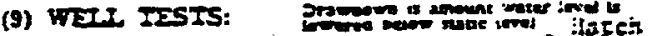

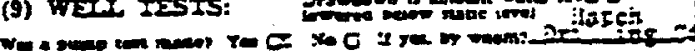

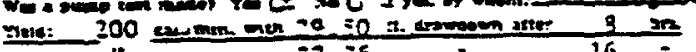

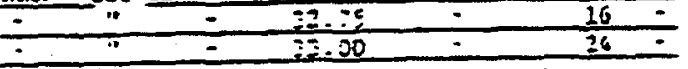

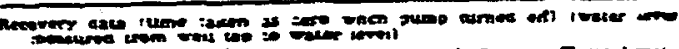

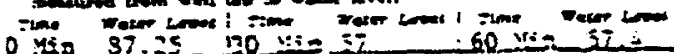

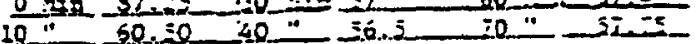

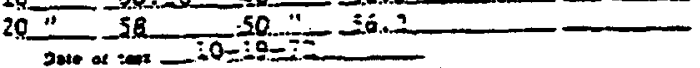

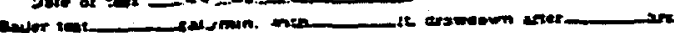
Arweren sur.

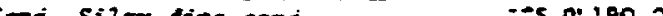

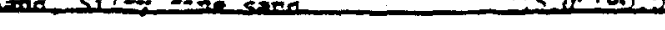

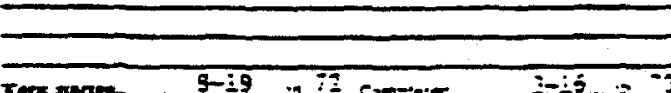

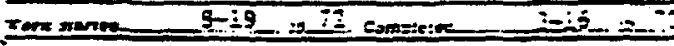
WeI DRTrEBS STAIEREI:

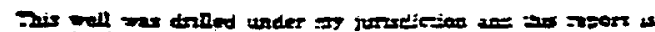

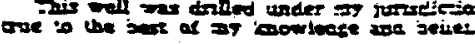

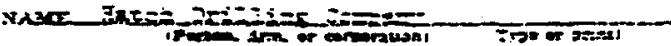

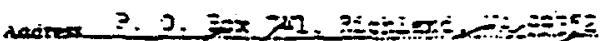
simen 1 (2)

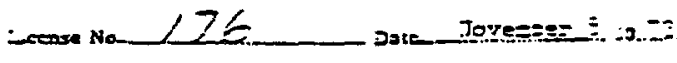

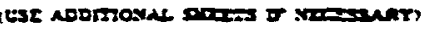
후으. 


\section{WF' L COMPLETION REF רRT}

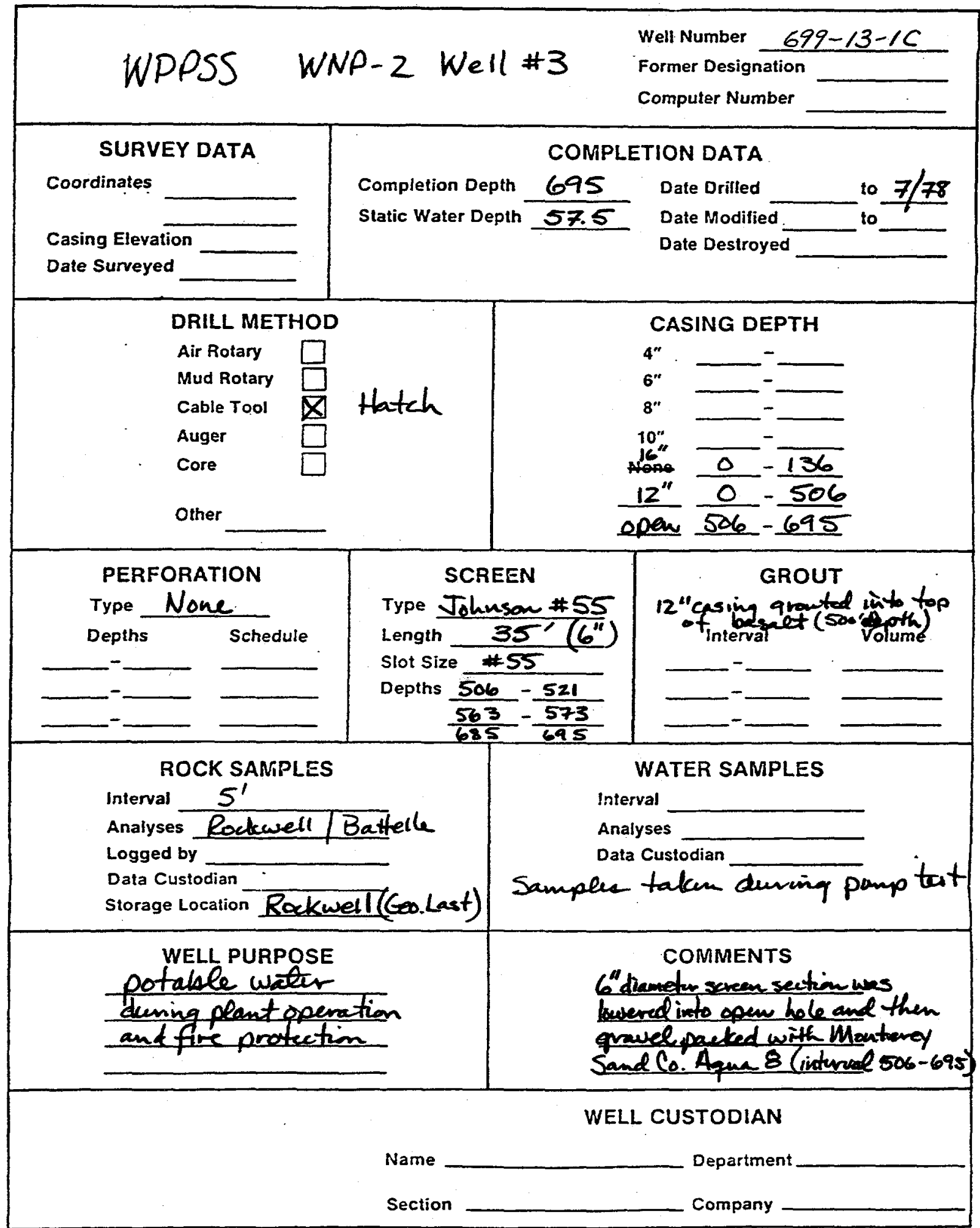




\section{PUMP TEST COMPLETION REPORT}

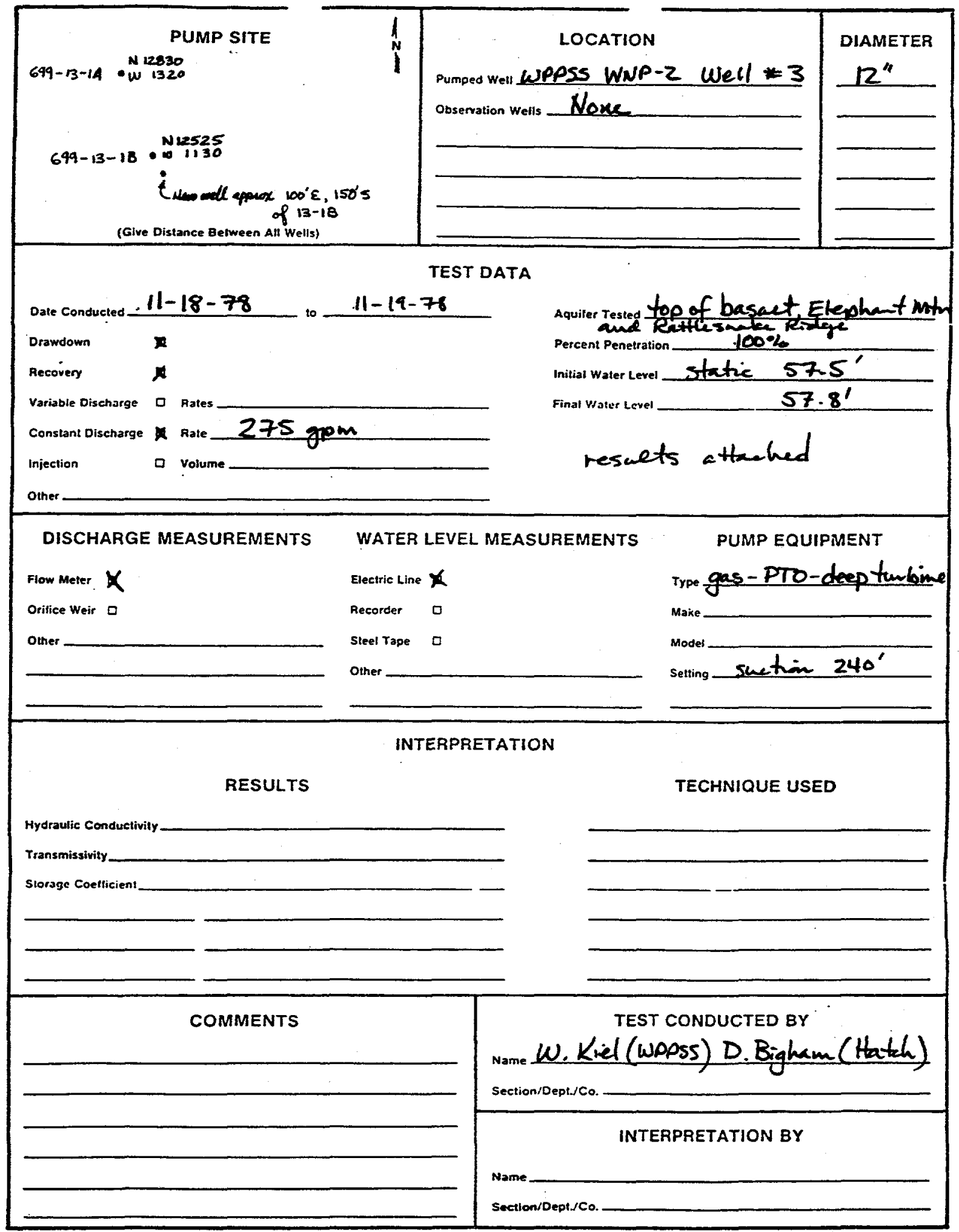


wiv- $<w_{H}->$

DATE 11-18-iv

STick UP $2.0^{\prime}$ to m.P.

START TIME 8:30 am

StATIC $57.5^{\prime}$
35 feet of \#55 slot Johnison

well screen (6" diametur)

gravel packed in a 12" open

hole with Moritercy Sand Company

Aqua 8.

PAGE 1 of 2

avallable Drawdown 182.5

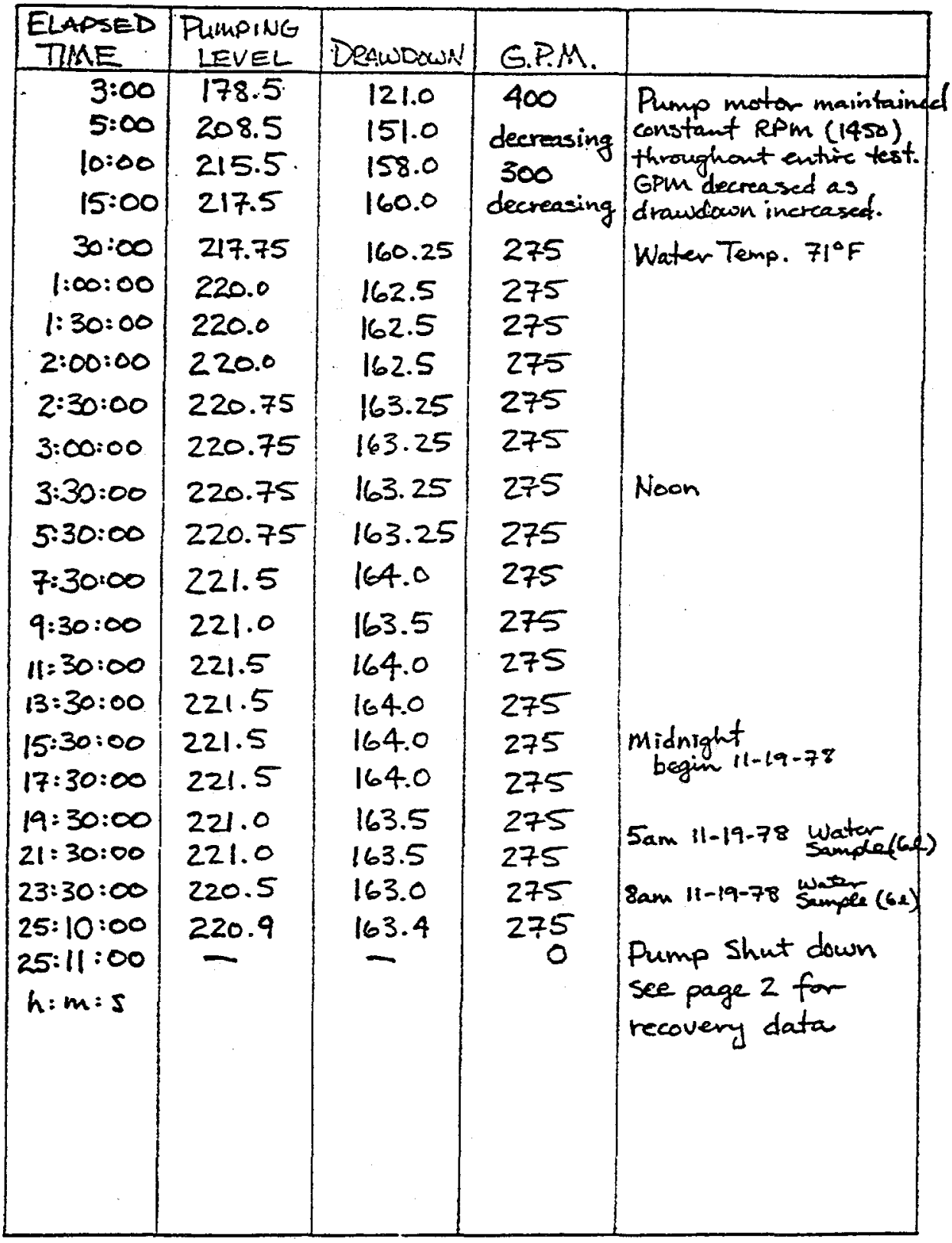




$$
\text { WNP-2 Well } 23
$$

DATE $11-19-78$

Sick UP $2.0^{\prime}$ to m.p.

\section{RECOVERY}

START TIME -

STATIC $57.5^{\prime}$

PAGE 2 of 2

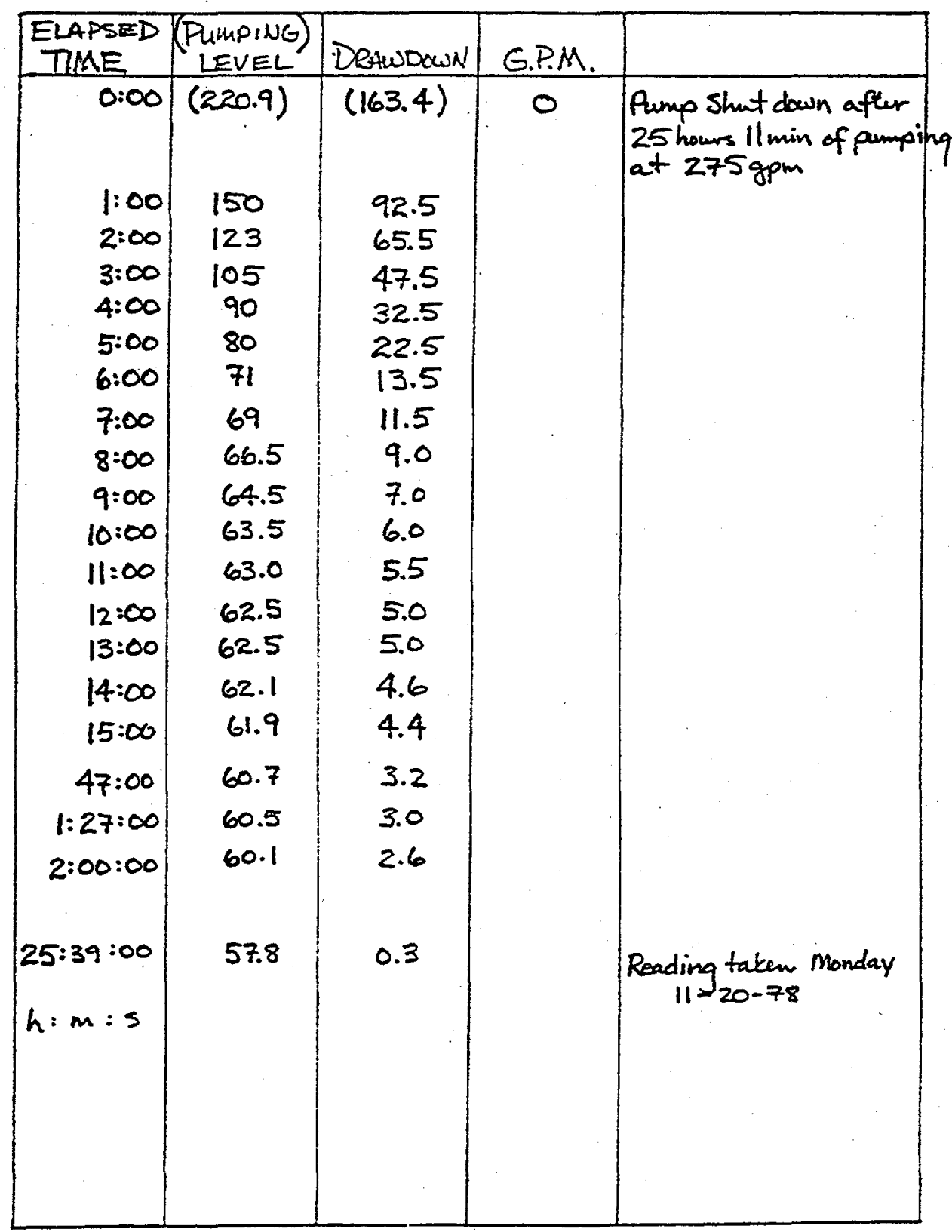




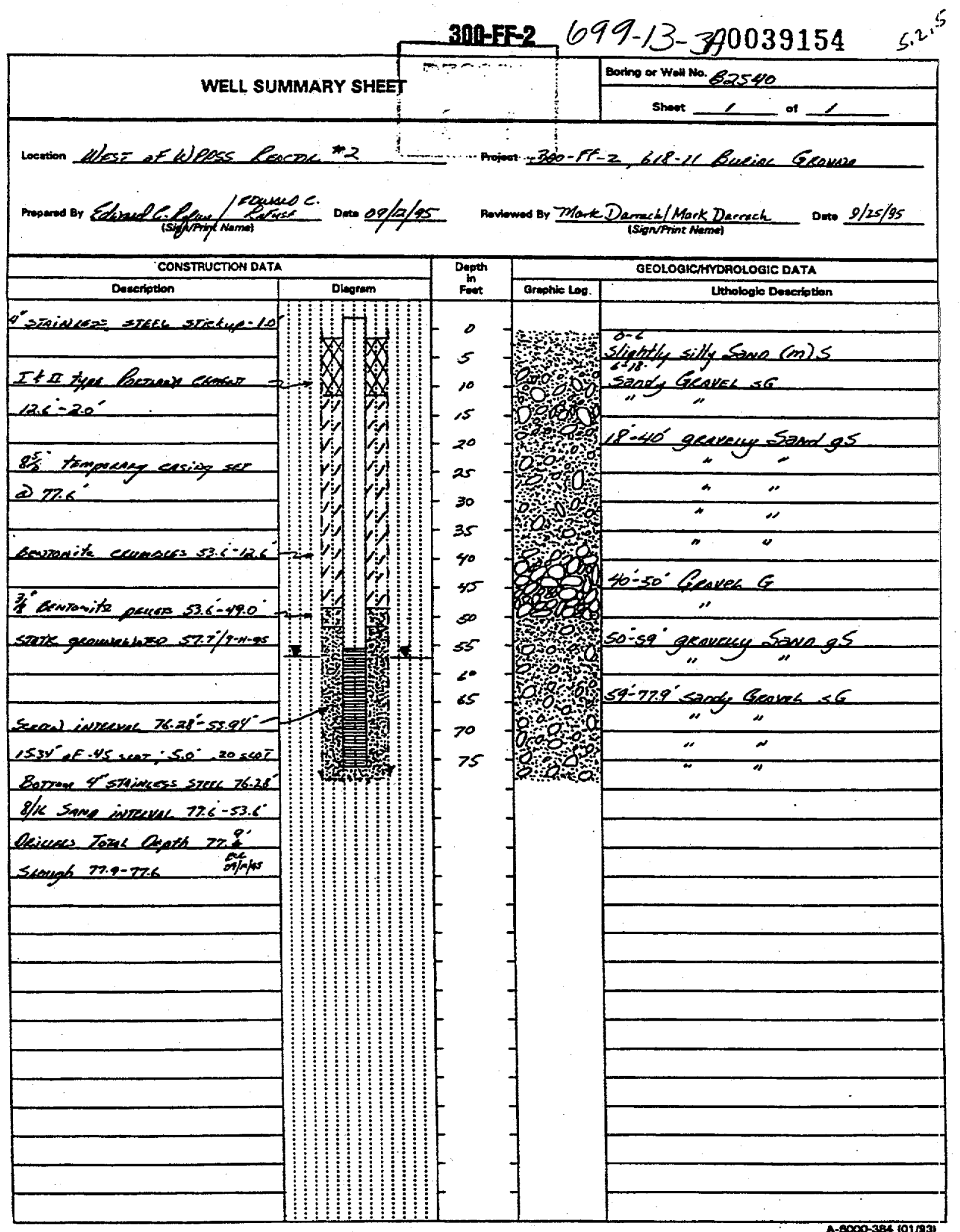




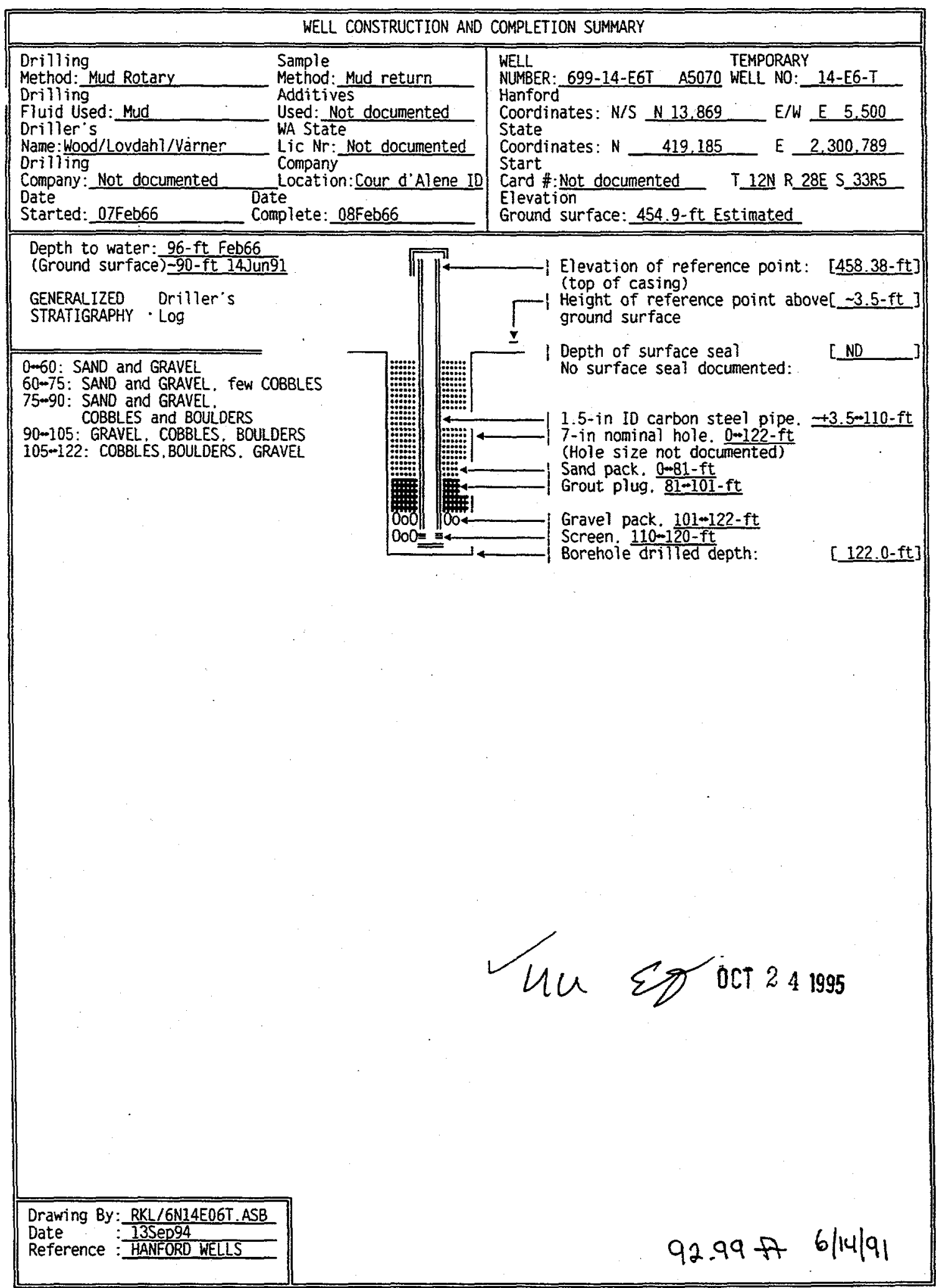


SUMMARY OF CONSTRUCTION DATA AND FIELD OBSERVATIONS

RESOURCE PROTECTION WELL - 699-14-E6T

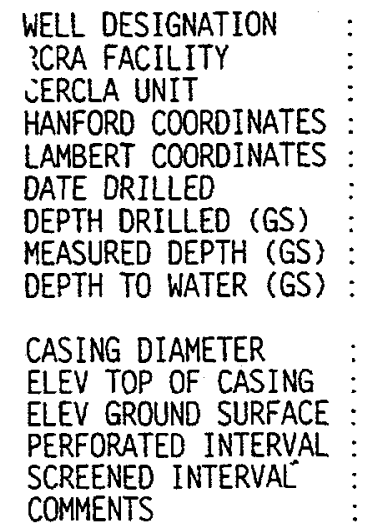

AVAILABLE LOGS

TV SCAN COMMENTS

DATE EVALUATED

EVAL RECOMMENDATION

LISTED USE

CURRENT USER

PUMP TYPE

MAINTENANCE
699-14-E6T

Not applicable

Not applicable

N $13.869 \mathrm{E}$

5.500 [HANFORD WELLS]

N 419.185 E 2.300.789 [HANCONV]

Feb66

390.0-ft

Not documented

96-ft. Feb66.

-90 -ft. 14Jung1

$1 \frac{1}{2}$-in. carbon steel, (nominal) $+3.5-110.0-\mathrm{ft}$

458.38- $\mathrm{ft}$, [HANFORO WELLS]

454.9-ft. Estimated

Not applicable

$110-120-\mathrm{ft}$

FIELD INSPECTION. 190ct93.

1.5-in galvanized steel casing. Casing is bent. Not capped or locked No pad. posts or permanent identification.

Not in radiation zone.

OTHER: Apparentiy has broken casing as noted

Driller

in water level measurements after $14 \mathrm{Jun} 91$

Not applicable

Not applicable

Not applicable

Sitewide semiannual water level measurement, 01May91-14Jun91

WHC ES\&M W/I monitoring.

None documented 


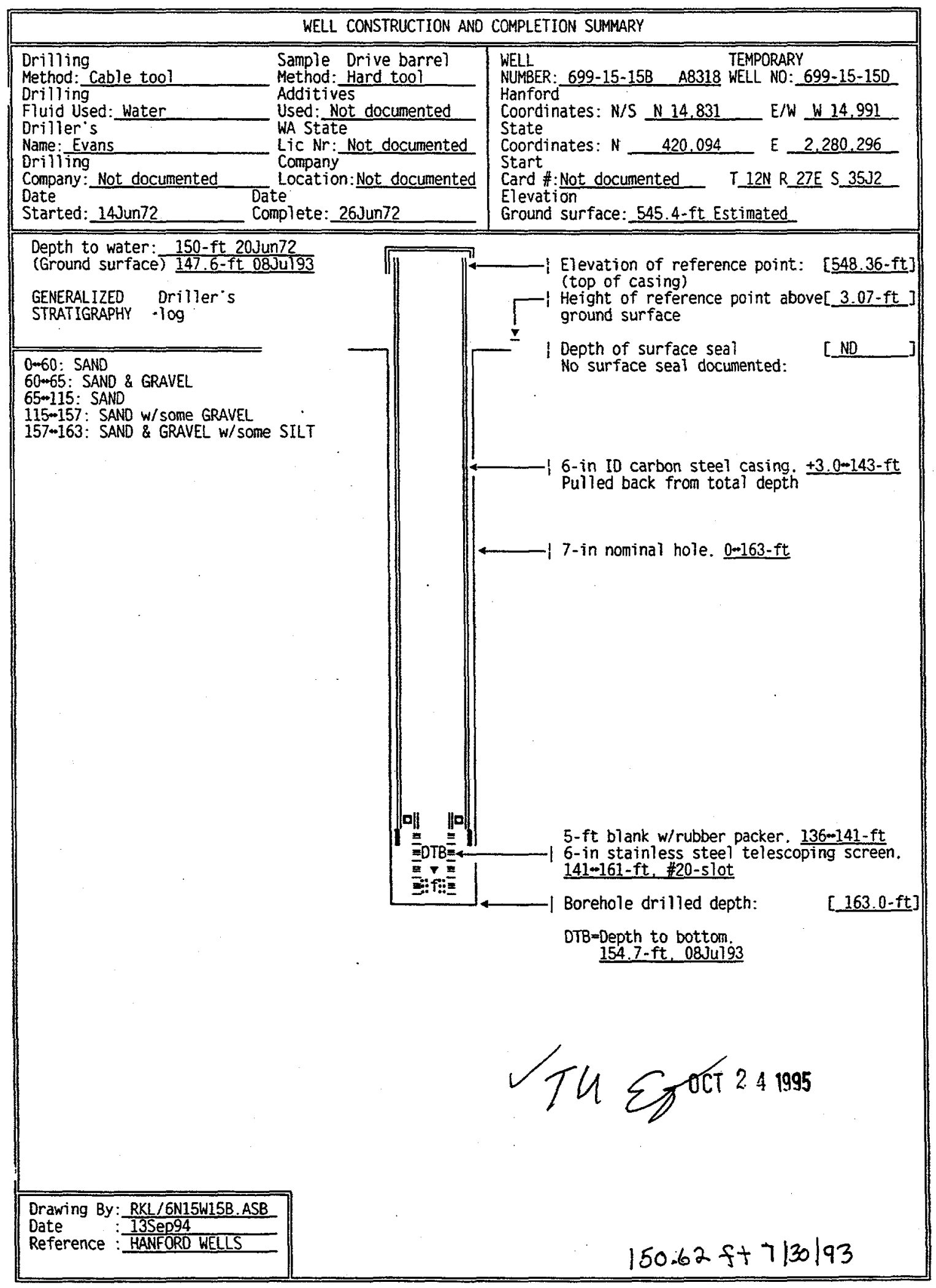


SUMMARY OF CONSTRUCTION DATA AND FIELD OBSERVATIONS RESOURCE PROTECTION WELL - 699-15-15B

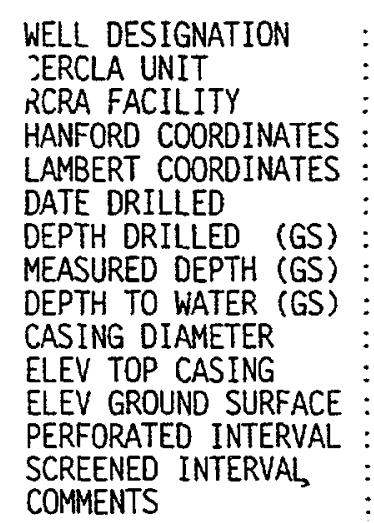

AVAILABLE LOGS

TV SCAN COMMENTS

DATE EVALUATED

EVAL RECOMMENDATION

LISTED USE

CURRENT USER

PUMP TYPE

MAINTENANCE
699-15-15B

Not applicable

Not applicable

$\mathrm{N} 14.831 \mathrm{~W} 14.991$ [HANFORD WELLS]

$N$ 420.094 E 2.280.296 [HANCONV]

Jun72

163.0-ft

Not documented

150.0-ft. 20Jun72

6 -in ID carbon steel, $+3.0-143.0-\mathrm{ft}$

548.36- $\mathrm{ft}$. [HANFORD WELLS]

545.4-ft. Estimated

Not applicable

141-161-ft. \#20-slat

FIELD INSPECTION, 08Ju193.

6 -in carbon steel casing. Capped and locked

No pad. posts or permanent identification.

Not in radiation zone.

OTHER:

Dritler

Not applicable

Not applicable

Not applicable

None documented

PNL sitewide characterization

None documented 


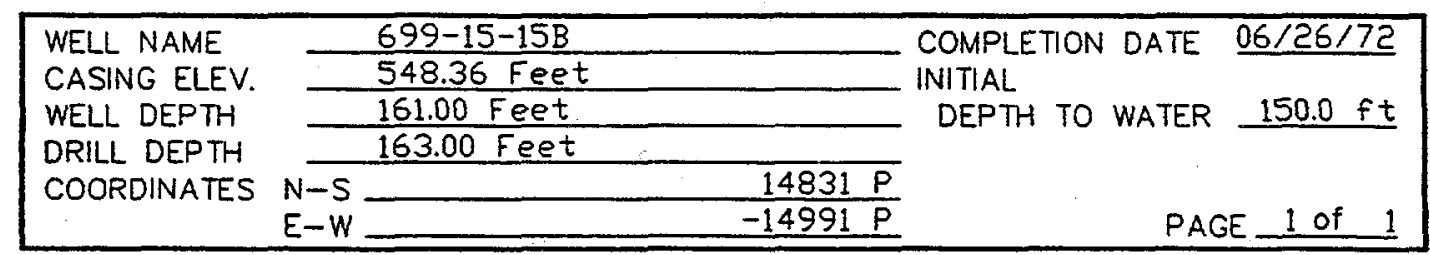

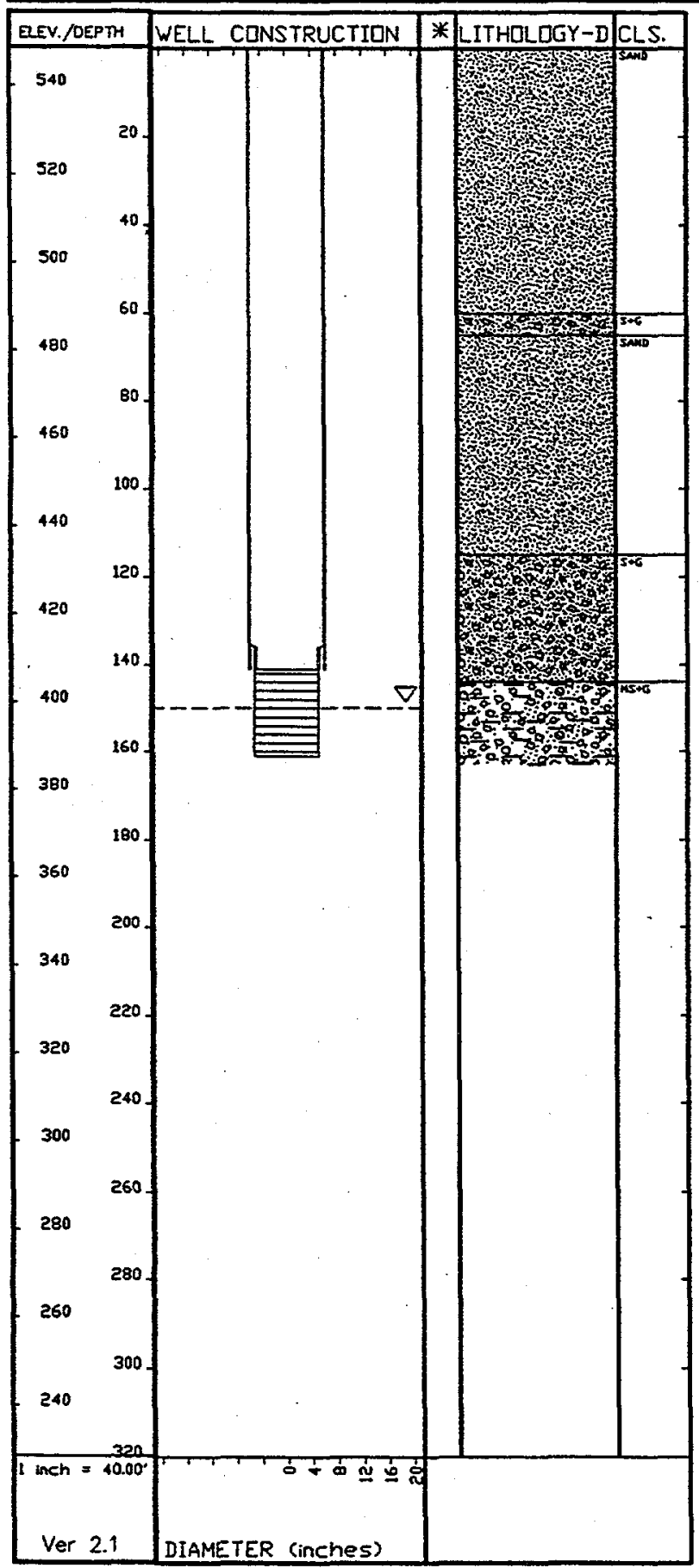




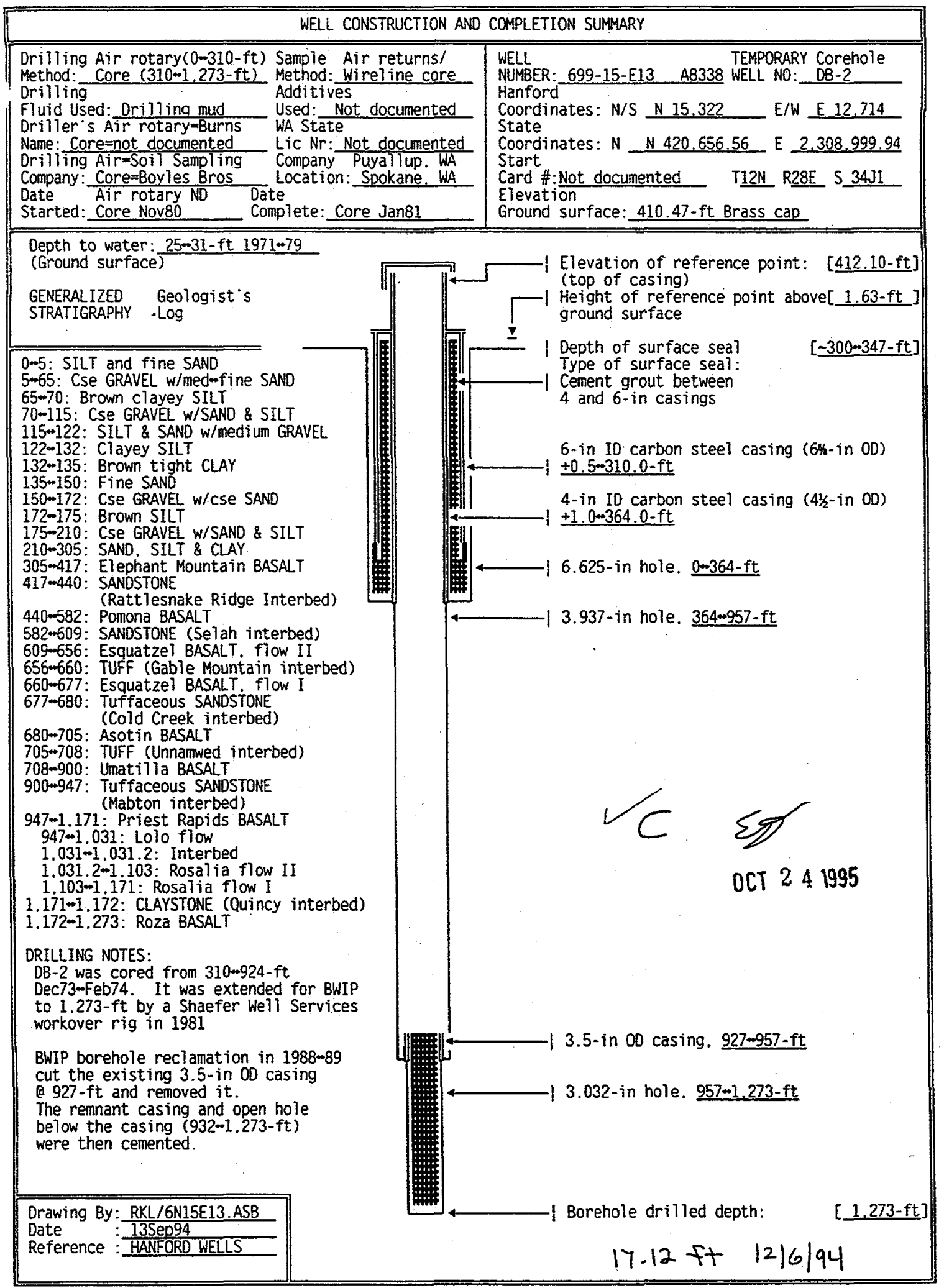


SUMMARY OF CONSTRUCTION DATA AND FIELD OBSERVATIONS RESOURCE PROTECTION WELL - 699-15-E13

WELL DESIGNATION
TCRA FACILITY
JERCLA UNIT
HANFORO COORDINATES
LAMBERT COORDINATES
DATE DRILLED
DEPTH DRILLED (GS)
MEASURED DEPTH (GS)
OEPTH TO WATER (GS)
CASING DIAMETER

ELEV TOP CASING
ELEV GROUND SURFACE
PERFORATED INTERVAL
SCREENED INTERVAL
COMMENTS
AVAILABLE LOGS
TV SCAN COMMENTS
DATE EVALUATED
EVAL RECOMMENDATION
LISTED USE
CURRENT USER
PUMP TYPE
MAINTENANCE

$699-15-\mathrm{E} 13$

Not applicable

Not applicable

N. 15.322. E 12.714 [Aug85-P1ant]

$N \quad 420.656 .56$ E 2.308.999.94 [Aug85-NAD27]

Feb74/Extended 1981

924.0-ft/Extended 1.273-ft

Not documented

$25-31-\mathrm{ft}, 1971-79$

$6-$ in. carbon steel. $+0.5+310.0-\mathrm{ft}$

4-in. carbon steel, $+1.0+364.0-\mathrm{ft}$

3.5-in. carbon steel, 927-957-ft

412.10-ft. [HANFORD WELLS]

410.47-ft. Brass cap [Aug85-Not documented

Not applicable

Not applicable

FIELD INSPECTION.

OTHER:

Geologist

Not applicable

Not applicable

Not applicable

Waste management/BWIP geohydrologic investigation

PNL sitewide $W / 7$ monitoring.

None documented 


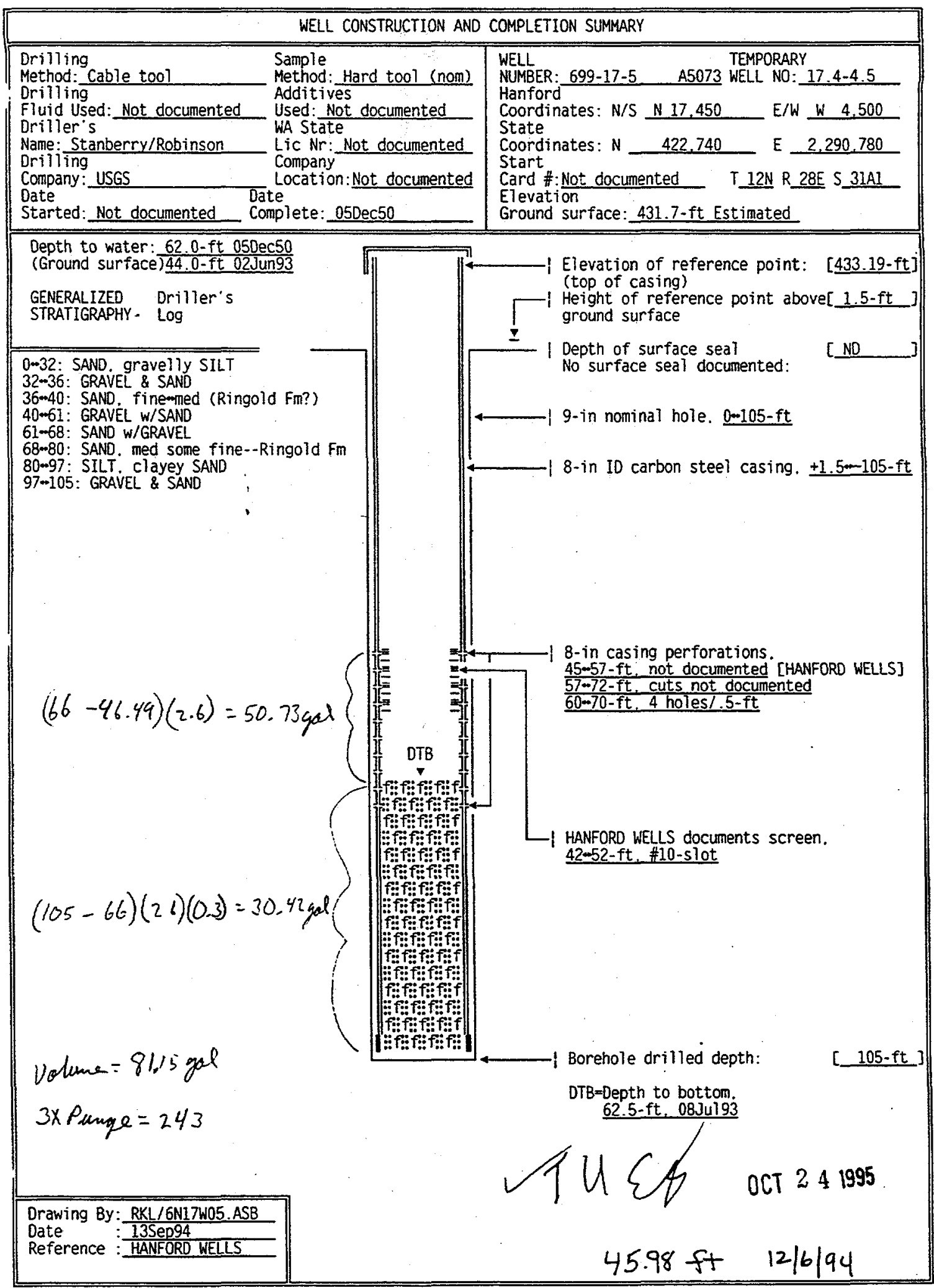


SUMMARY OF CONSTRUCTION DATA AND FIELD OBSERVATIONS RESOURCE PROTECTION WELL - 699-17-5

WELL DESIGNATION
ICRA FACILITY
¿ERCLA UNIT
HANFORD COORDINATES
LAMBERT COORDINATES
DATE DRILLED
DEPTH DRILLED (GS)
MEASURED DEPTH (GS)
DEPTH TO WATER (GS)
CASING DIAMETER
ELEV TOP CASING
ELEV GROUND SURFACE
PERFORATED INTERVAL
SCREENED INTERVAL
COMMENTS

AVAILABLE LOGS

TV SCAN COMMENTS

DATE EVALUATED

EVAL RECOMMENDATION

LISTED USE

CURRENT USER

PUMP TYPE

MAINTENANCE
699-17-5

Not applicable

Not applicable

$\mathrm{N} 17.450 \mathrm{~W}$

N 422.740

4.500

Dec50

105.0-ft

62.5-ft. 08Ju193

$62.0-\mathrm{ft}$. 05Dec50.

44.0-ft. 02Jun93

8-in, carbon steel, +1.5*105-ft (nominal)

433.19- $\mathrm{ft}$. [HANFORD WELLS]

$431.7-\mathrm{ft}$. Estimated

$45-70-\mathrm{ft}$

42-52-ft [HANFORD WELLS]

FIELD INSPECTION, 08JU193.

8-in carbon steel casing. Capped and locked

No pad. posts or permanent identification.

Not in radiation zone.

OTHER:

Driller

Not applicable

Not applicable

Not applicable

Sitewide annual water level measurement. 01May91-02Jun93:

WHC ES\&M $W / 7$ monitoring.

PNL sitewide sampling and $w / 1$ monitoring

Electric submersible 


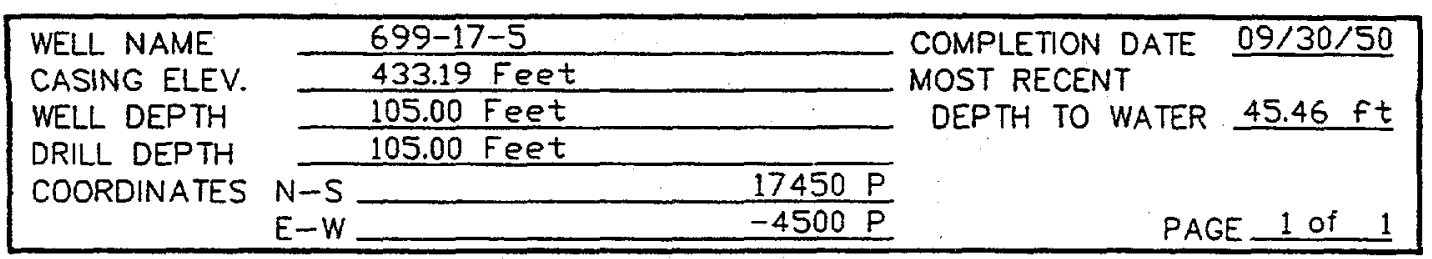

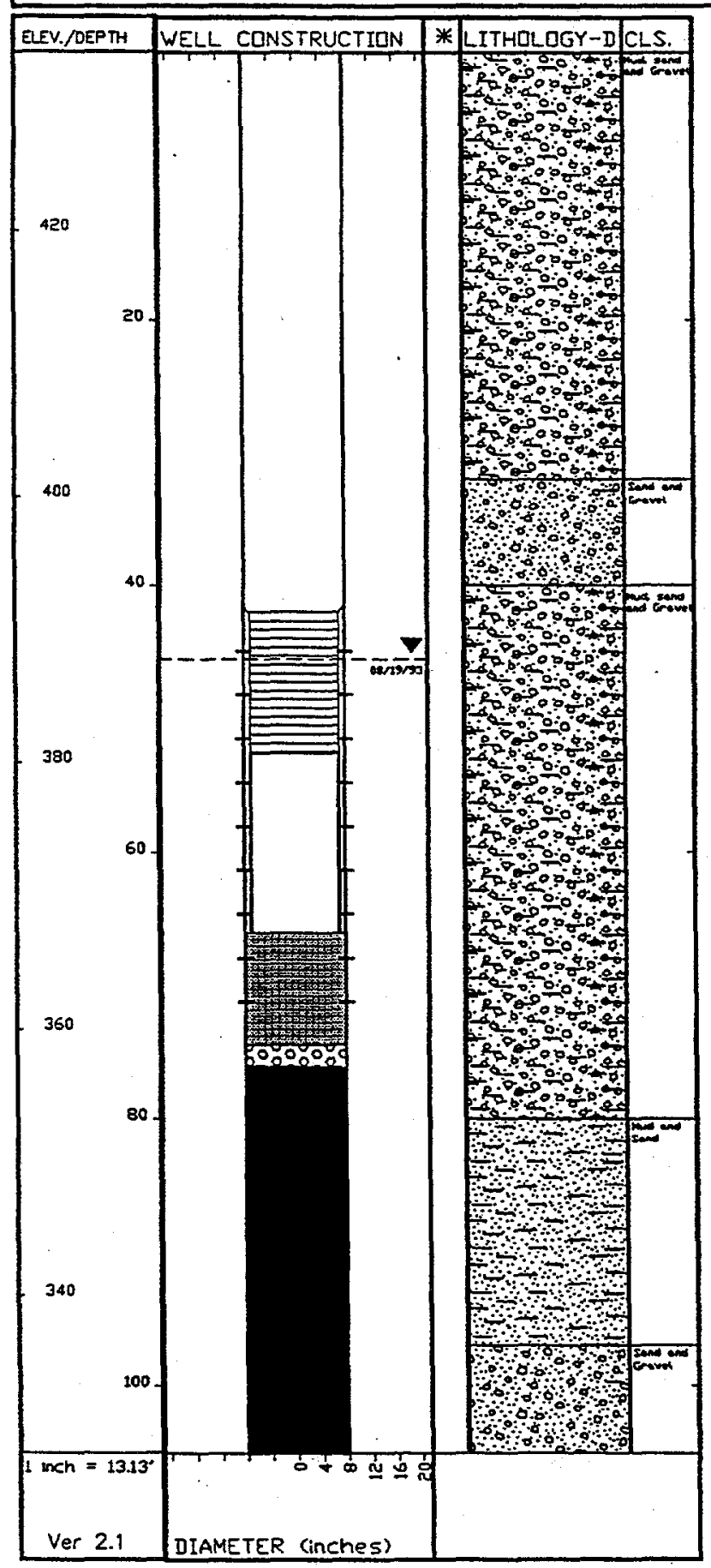




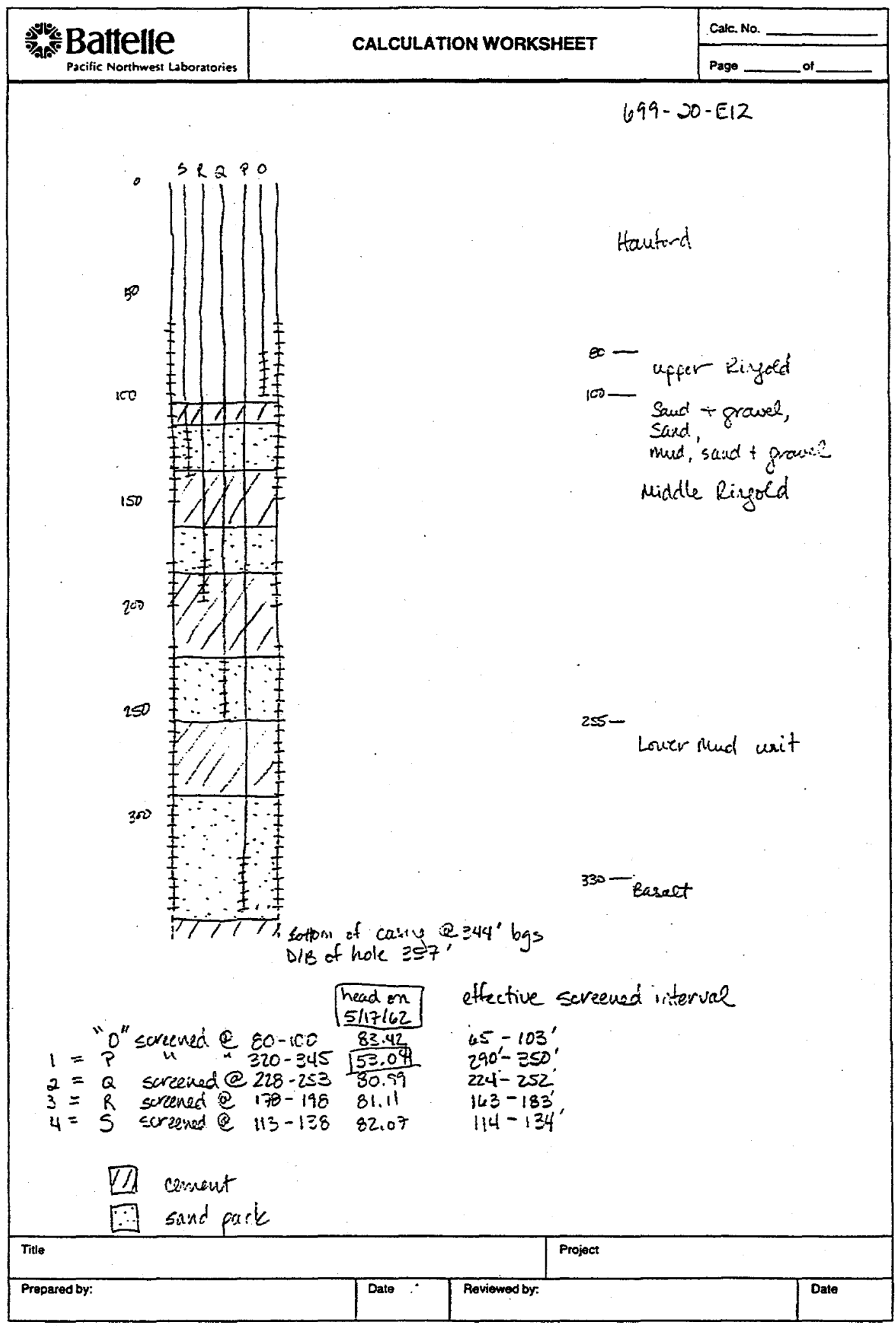




\section{SUMMARY OF CONSTRUCTION DATA AND FIELD OBSERVATIONS RESOURCE PROTECTION WELL - 699-20-E12}

WELL OESIGNATION
CERCLA UNIT
RCRA FACILITY
HANFORD COORDINATES
LAMBERT COORDINATES
DATE DRILLED
DEPTH DRILLED (GS)
MEASURED DEPTH (GS)
DEPTH TO WATER (GS)

CASING DIAMETER ELEV TOP CASING ELEV GROUND SURFACE PERFORATED INTERVAL SCREENED INTERVAL COMMENTS

AVAILABLE LOGS

TV SCAN COMMENTS

DATE EVALUATED

EVAL RECOMMENDATION

LISTED USE CURRENT USER

PUMP TYPE MAINTENANCE
699-20-E12

Not applicable

Not applicable

$\mathrm{N} 20.304 \mathrm{E} \quad 12.017$ [HANFORD WELLS]

$N$ 425.637 E 2.307.290 [HANCONV]

Nov61

357-ft

Not documented

86.0-ft. 02Nov61

0 piezometer - $77.5-\mathrm{ft}$. 06Jung4.

$P$ piezometer - Not documented.

0 piezometer - $77.9-\mathrm{ft}$. 06Jun94.

R piezometer - 77.9-ft. 06Jun94.

$S$ piezometer - 77.7-ft. 06Jun94.

8-in. $+2.0=344-\mathrm{ft}$ :

$437.25-\mathrm{ft}$. [HANFORD WELLS]

435.2-ft Estimated

$65-150$ and $220 * 344-\mathrm{ft}$

Not documented

FIELD INSPECTION. 160ct93.

8-in carbon steel casing. Capped and locked. No pad, posts or permanent identification.

Contains five 1.5-in PVC piezometers:

$$
\begin{aligned}
& 0=+2.3+100-\mathrm{ft} \\
& P=+2.5=345-\mathrm{ft} \\
& \mathrm{Q}=+2.5=-253-\mathrm{ft} \\
& \mathrm{R}=+2.5 \cos 198-\mathrm{ft} \\
& S=+2.5=138-\mathrm{ft}
\end{aligned}
$$

Driller

Not applicable

Not applicable

Not applicable

Sitewide annual $w / 1$ measurement, 01May91-06Jun94

WHC ES\&M $w / 1$ monitoring.

PNL sitewide sampling and $w / /$ monitoring

None documented 


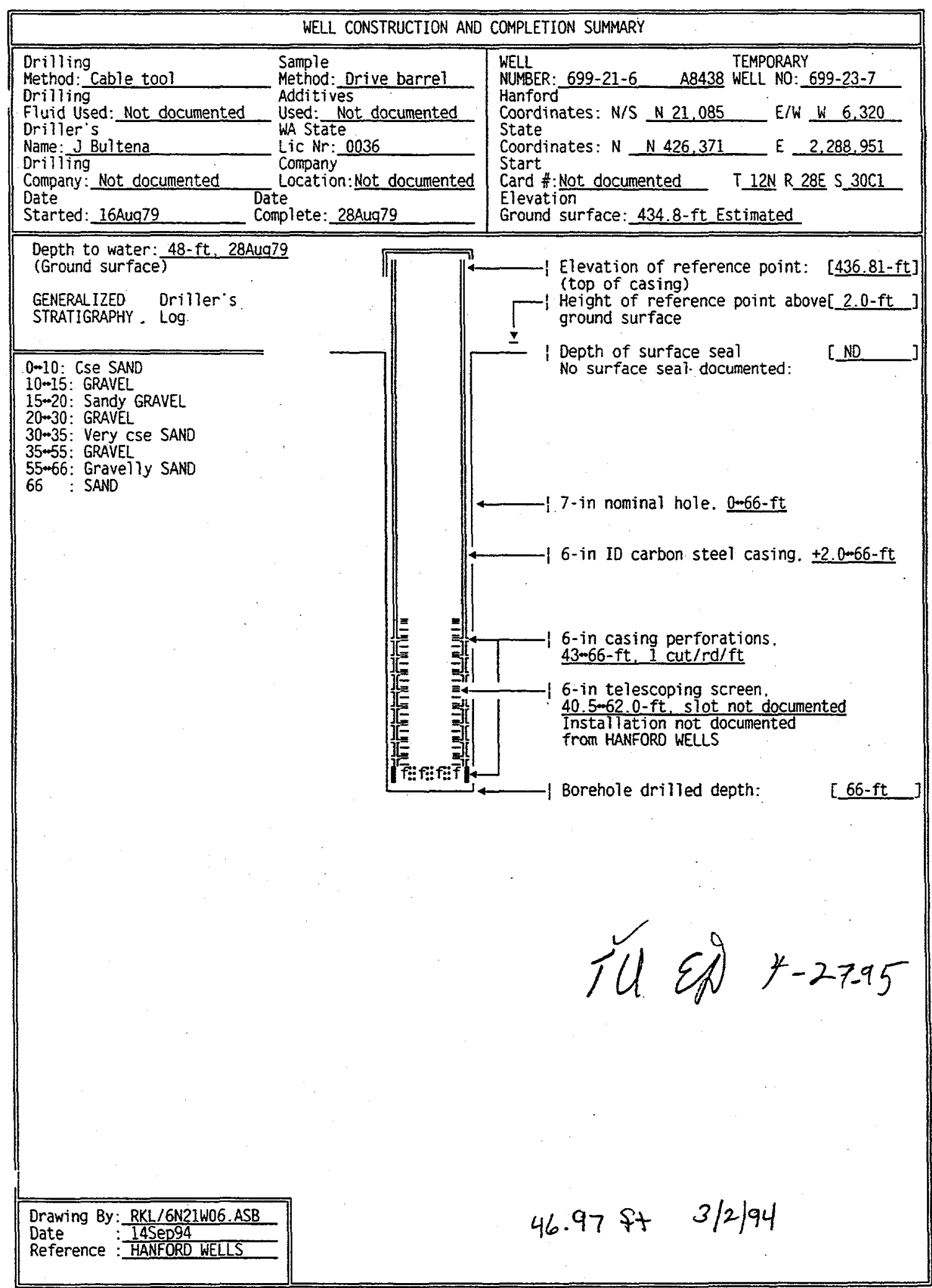


SUMMARY OF CONSTRUCTION DATA AND FIELD OBSERVATIONS RESOURCE PROTECTION WELL - 699-21-6

WELL DESIGNATION
PCRA FACILITY
EERCLA UNIT
HANFORO COORDINATES
LAMBERT COORDINATES
OATE ORILLED
DEPTH DRILLED (GS)
MEASURED DEPTH (GS)
DEPTH TO WATER (GS)
CASING DIAMETER
ELEV TOP CASING
ELEV GROUND SURFACE :
PERFORATED INTERVAL :
SCREENED INTERVAL
COMMENTS
AVAILABLE LOGS
DATE EVALUATED
EVAL RECOMMENDATION $:$
LISTED USE
CURRENT USER
PUMP TYPE

699-21-6

Not applicable

Not applicable

N $21.085 \mathrm{~W}$

Aug79

$66-\mathrm{ft}$

Not documented

48-ft. 28Aug79

6-in. carbon steel, +2.0॰66-ft

$436.81-\mathrm{ft}$. [HANFORD WELLS]

434.8-ft. Estimated

$43-66-\mathrm{ft}$

40.5-62.0-ft [HANFORD WELLS]

FIELD INSPECTION.

OTHER:

Driller

None

Not applicable

None documented

None documented

Electric submersible 
MONITORING WELL INSTALLATION LOG

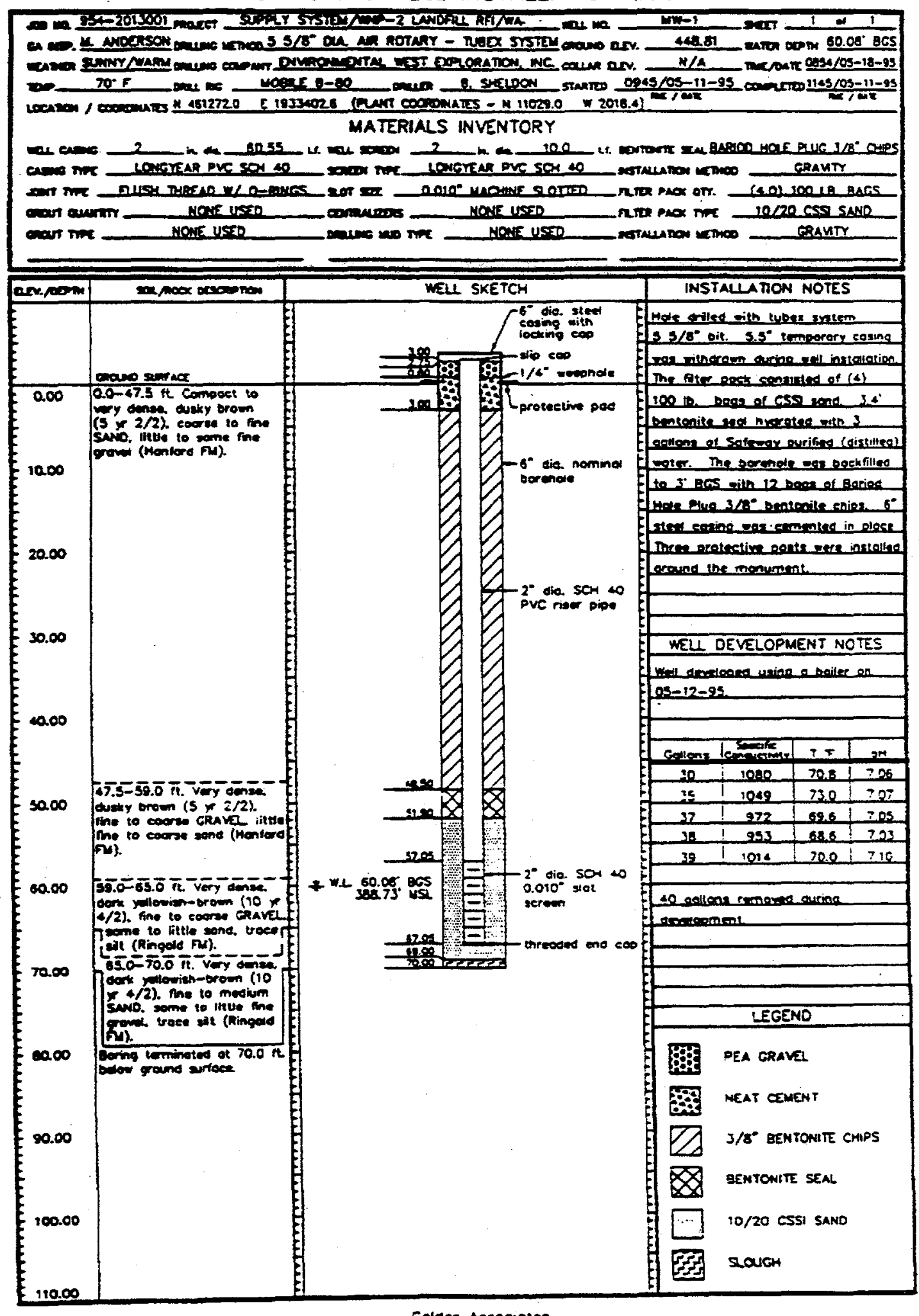

Goider Associates 
MONITORING WELL INSTALLATION LOG

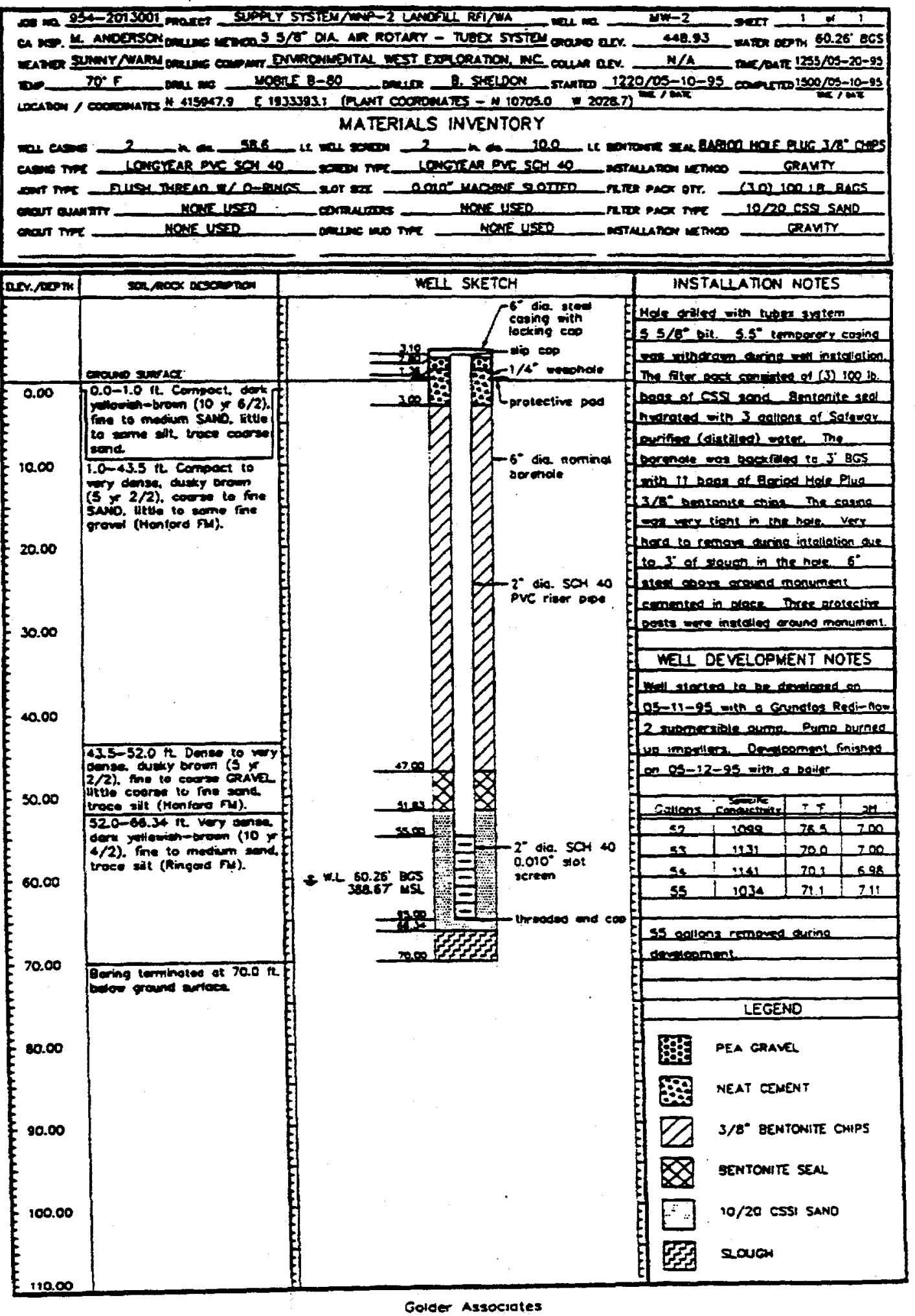


MONITORING WELL INSTALLATION LOG

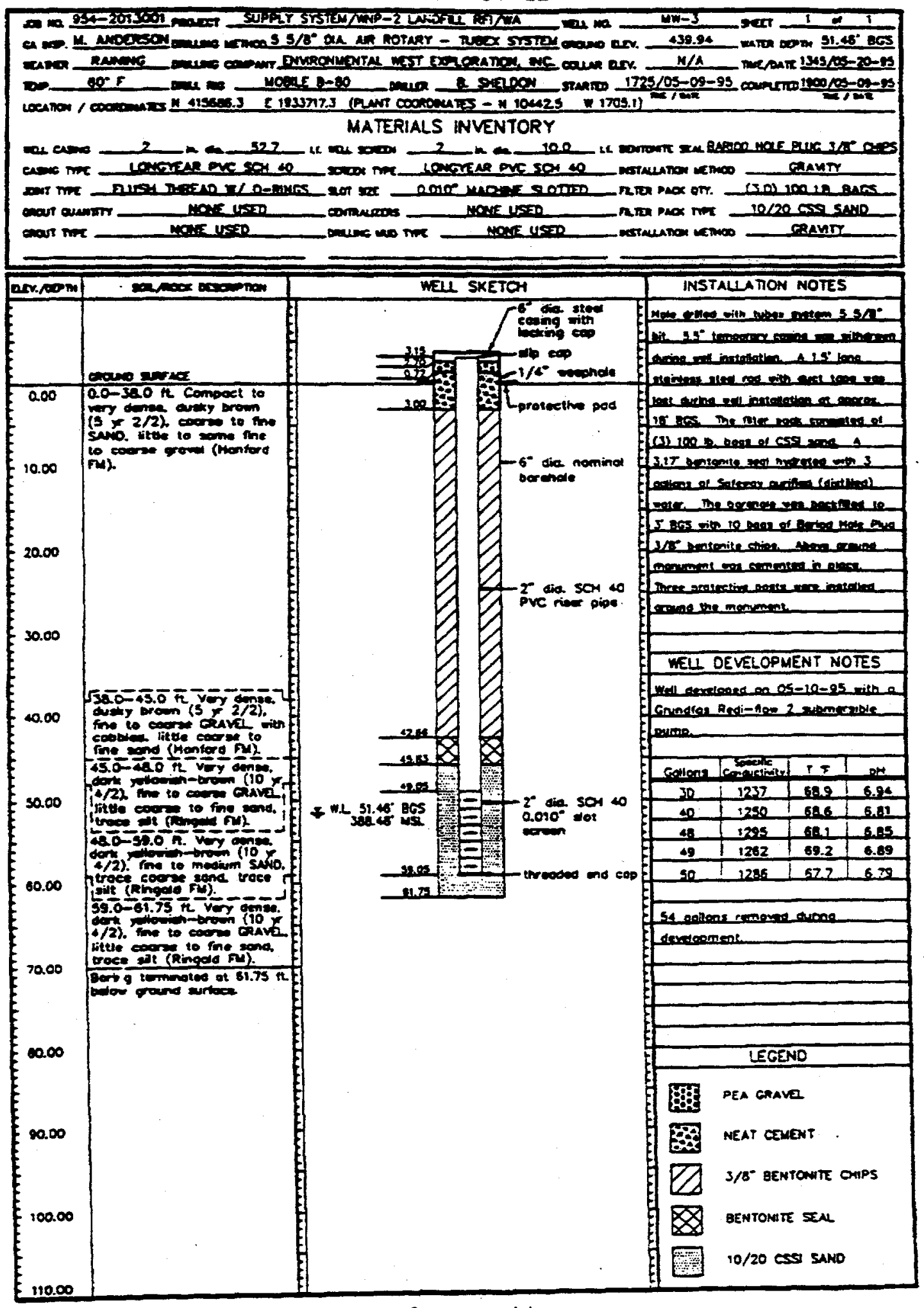

Golce Associotes 
MONITORING WELL INSTALLATION LOG

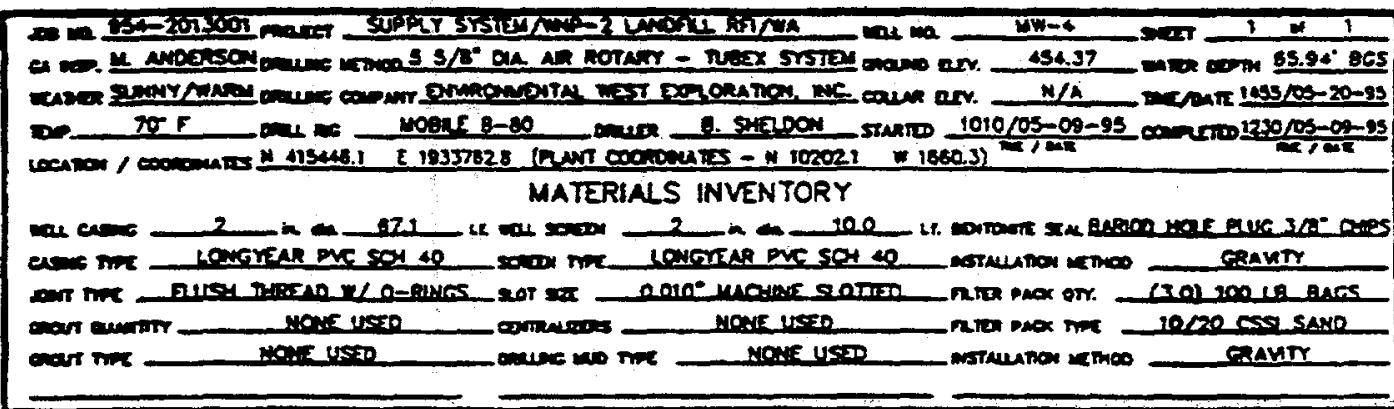

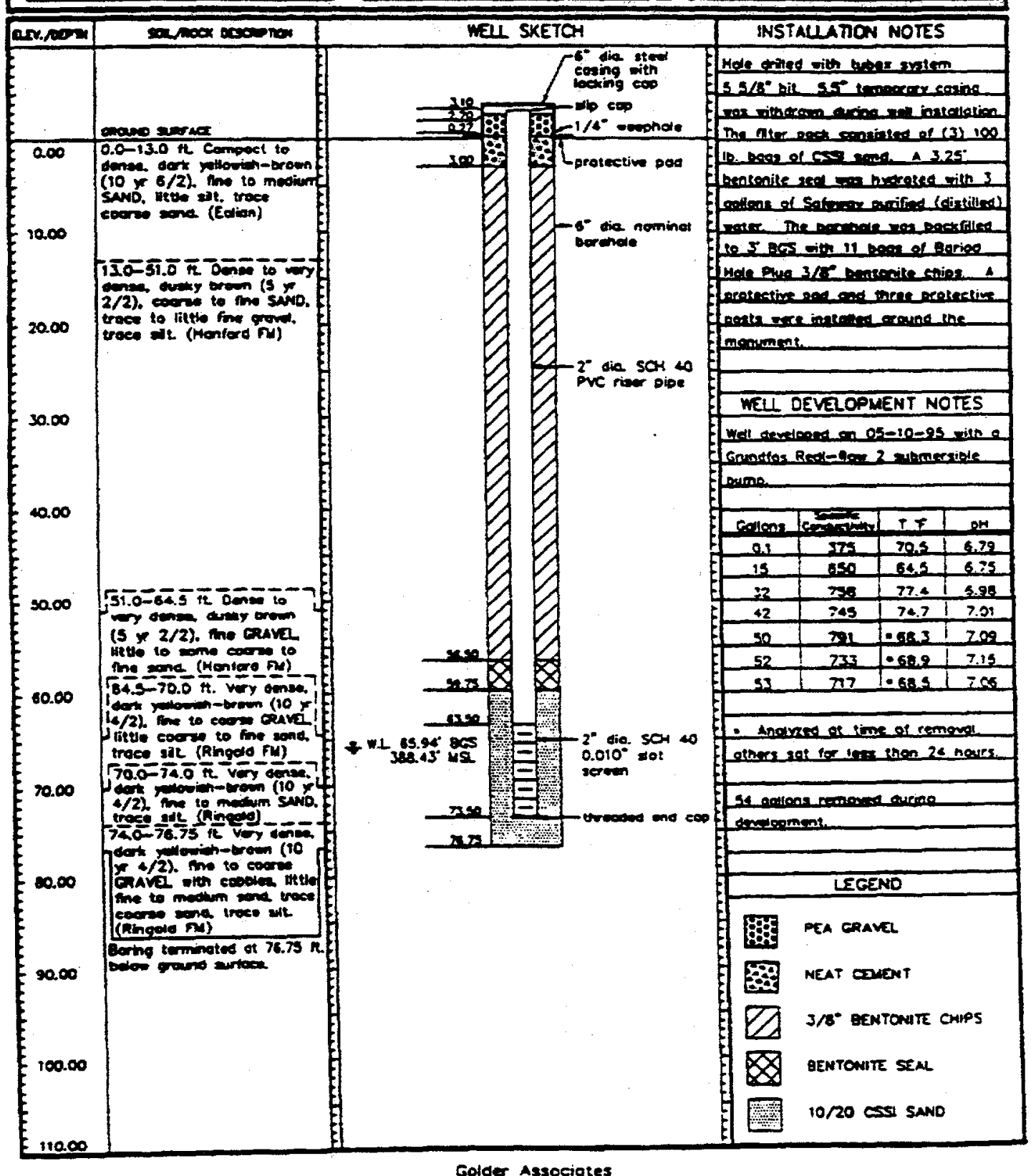

Colder Associotes 
MONITORING WELL INSTALLATION LOG

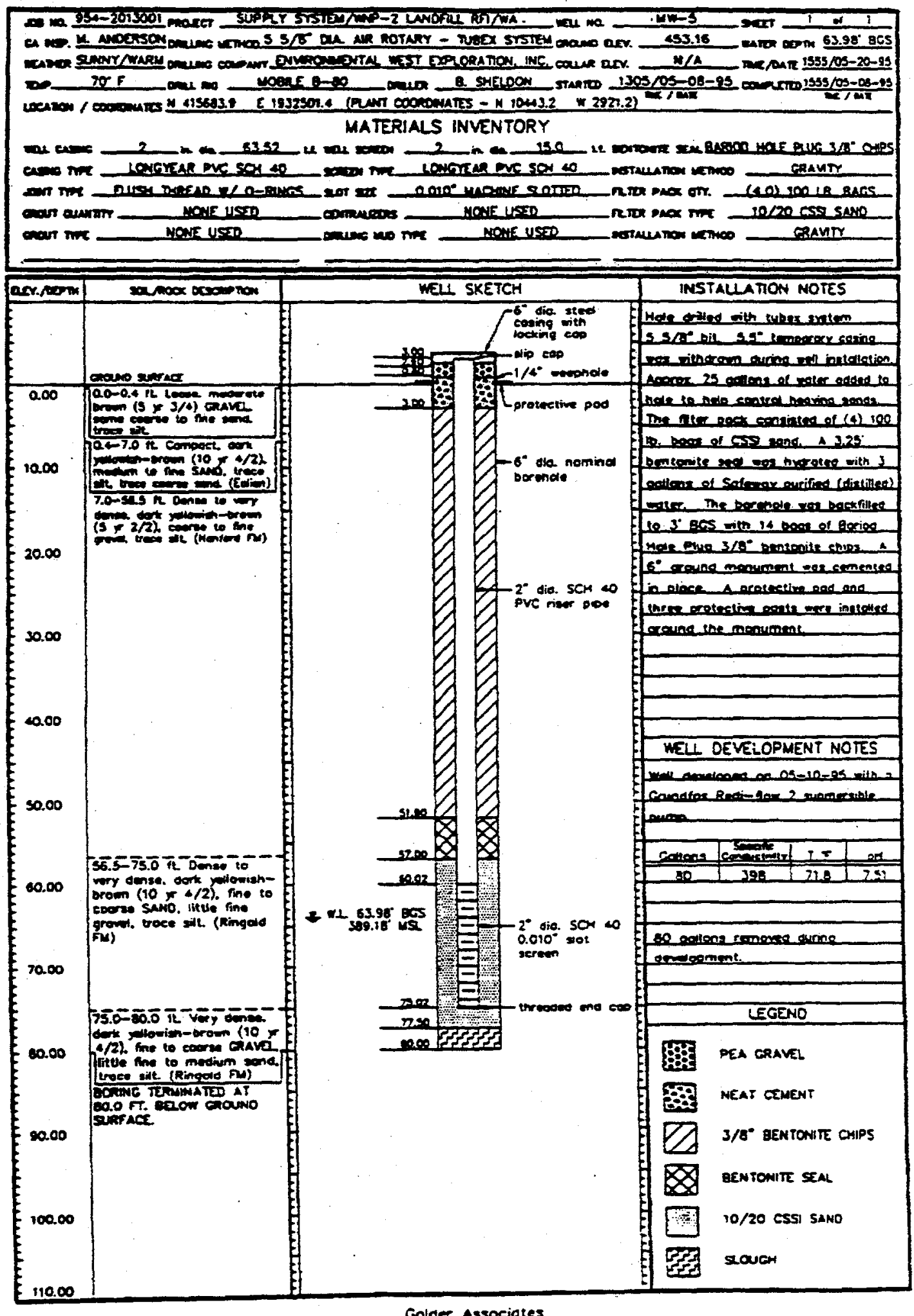

Golder Associates 
MONITORING WELL INSTALLATION LOG

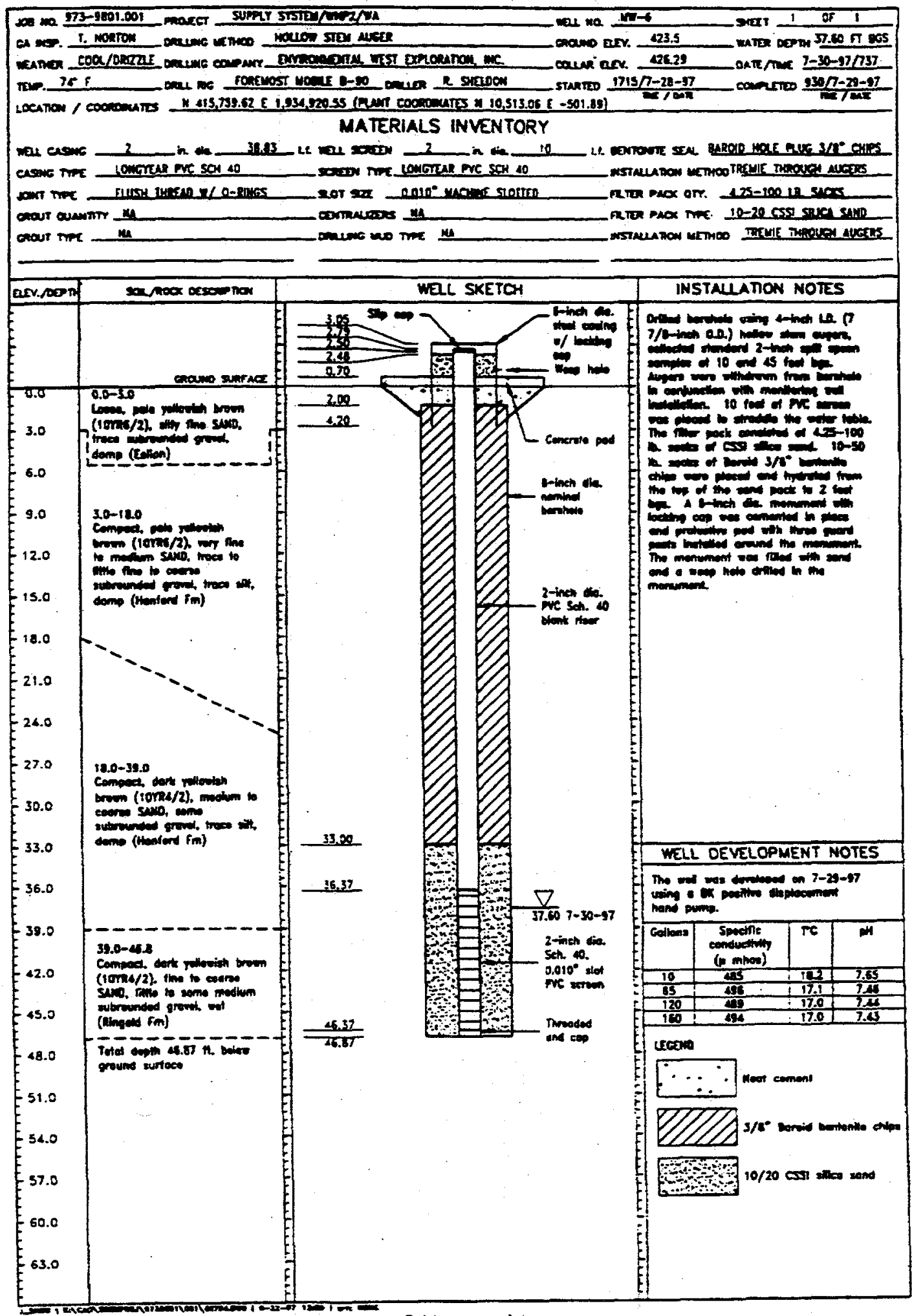


MONITORING WEUL INSTALLATION LOG

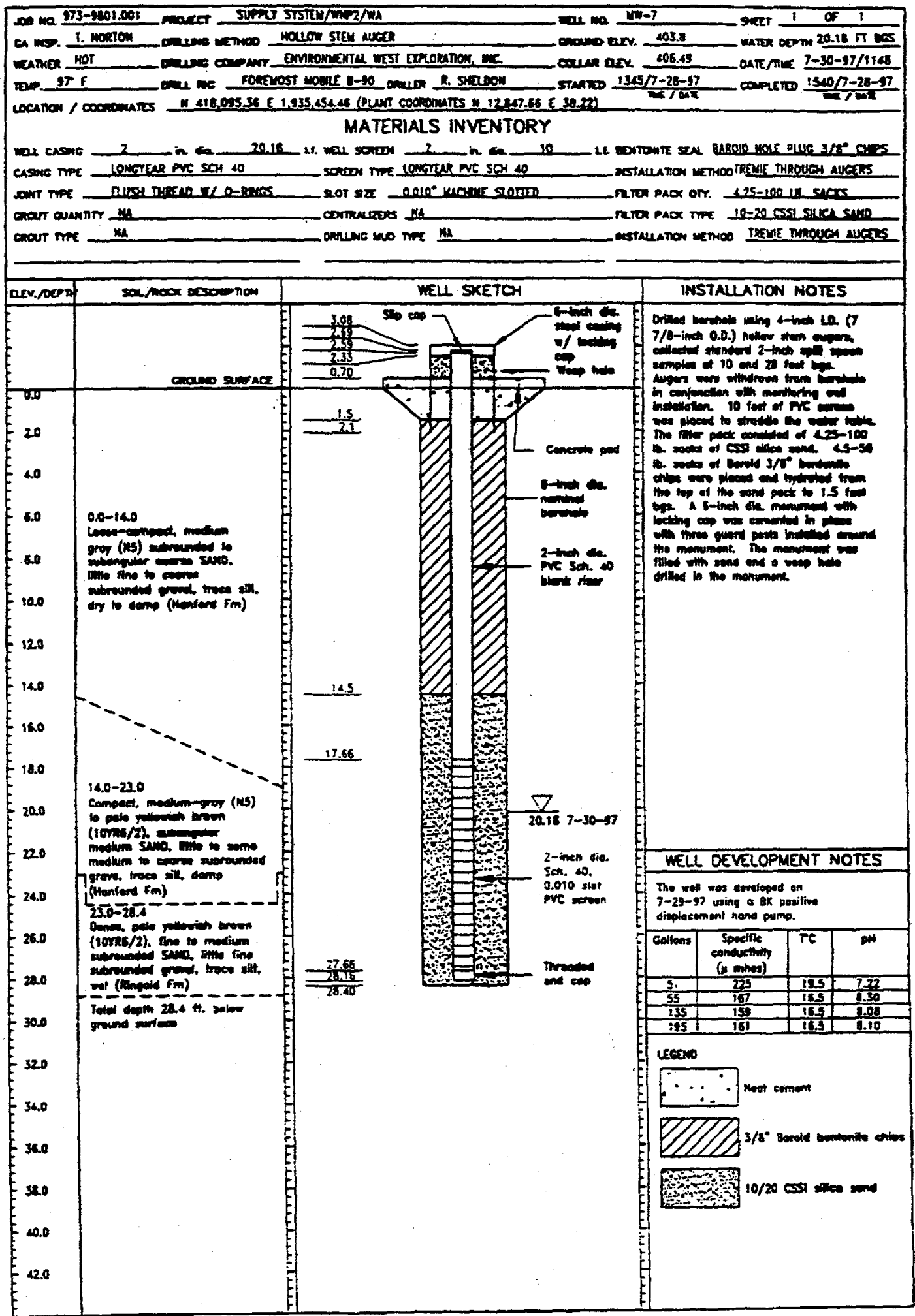

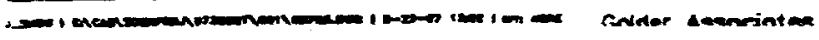


MONITORING WELL INSTALLATION LOG

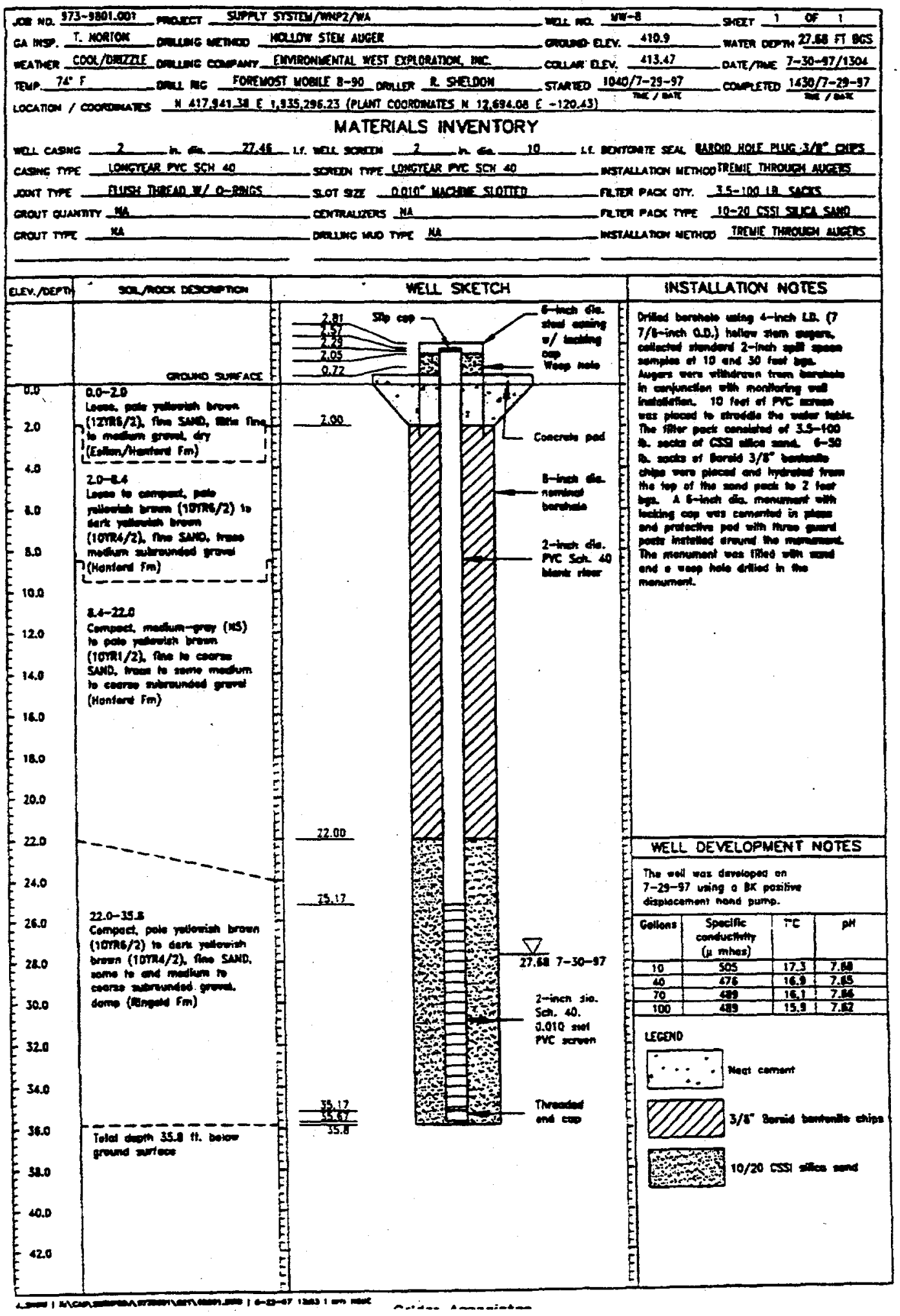


MONITORING WELL INSTALLATION LOG

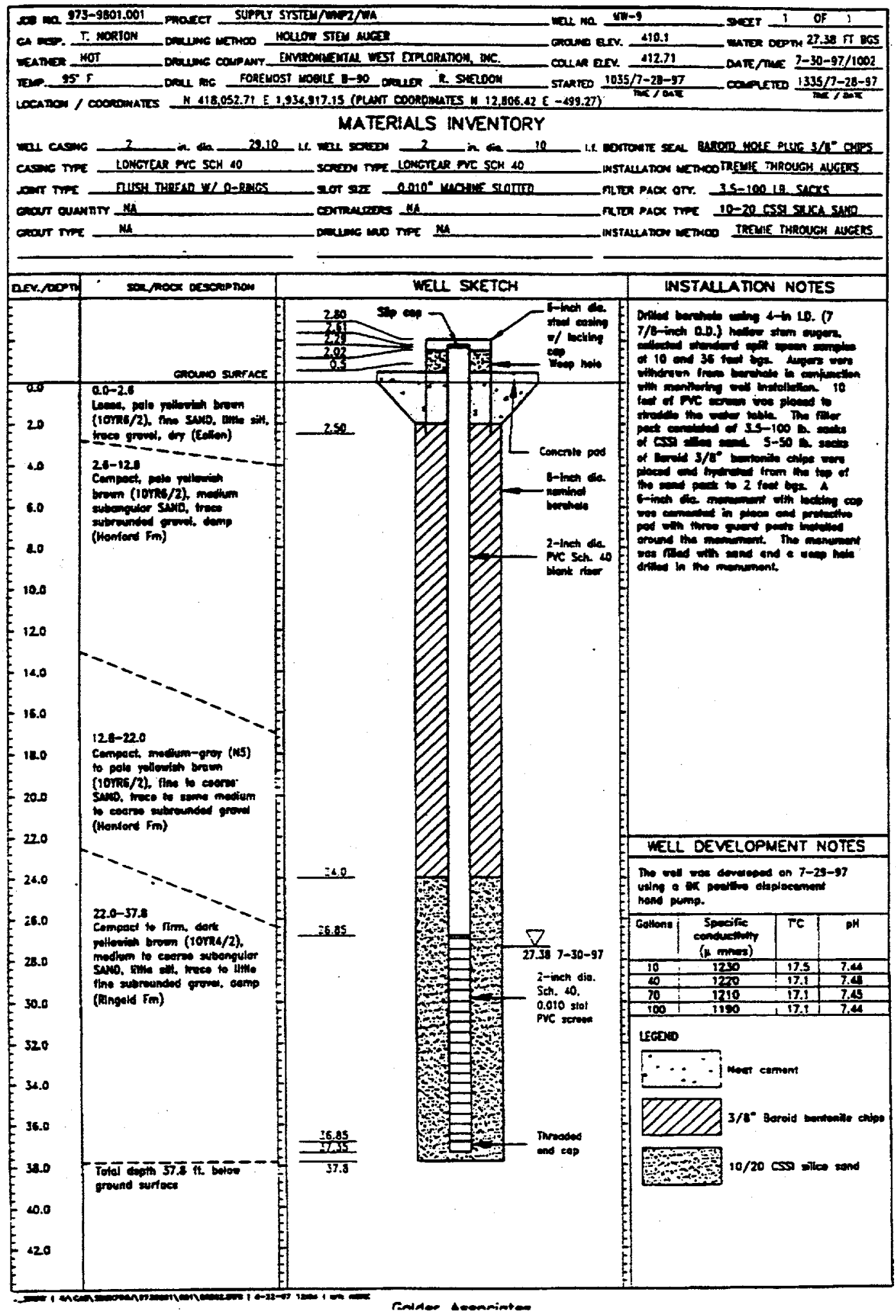


Mr. J. E. Woolsey, WNP 1/4 Site Manager Washington Public Power Supply System 3000 George Washington Way

Richland, Washington 99352

Dear Mr. Woolsey:

WPPSS Nuclear Project No. $1 \& 4$ Well \#1 \& \#2 Boring Logs

Attached are copies of Well it 1 \& $\$ 2$ Boring Logs. These are being transmitted to you for your information.

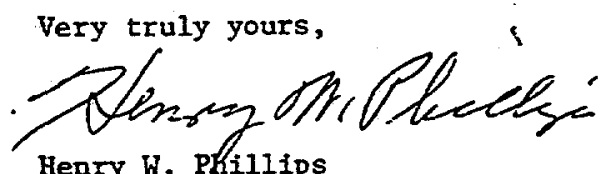

Henry W. Phillips

Resident Construction Manager

BWP : JCG : jc

in triplicate

ce: JE Hoolsey, WPPSS

JP Thomas, WPPSS

EC Nagle, UE\&C

JR Schmieder, UE\&C

\begin{tabular}{|c|c|}
\hline \multicolumn{2}{|c|}{ ROUTIIS H P 1 \& 4} \\
\hline & INFO \\
\hline atsulather & $C s$ \\
\hline THOHAS, I, P. & \\
\hline ORGAN C. B. & \\
\hline DAVIS. J. R. & \\
\hline TRAPP, O. E. & \\
\hline HOSLER, : & \\
\hline 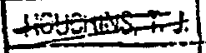 & \\
\hline PROJ. ENG. [D) & \\
\hline PROS.CCin nits & $=6$ \\
\hline $\begin{array}{l}\text { seinititi. } \\
\text { COMinol }\end{array}$ & $a \hat{0}$ \\
\hline McLoO, B.K. K. & \\
\hline FILES I \& 4 & \\
\hline WOYSEY. J.E. & \\
\hline
\end{tabular}


HANFORD 1 \& 4 Well No. 1

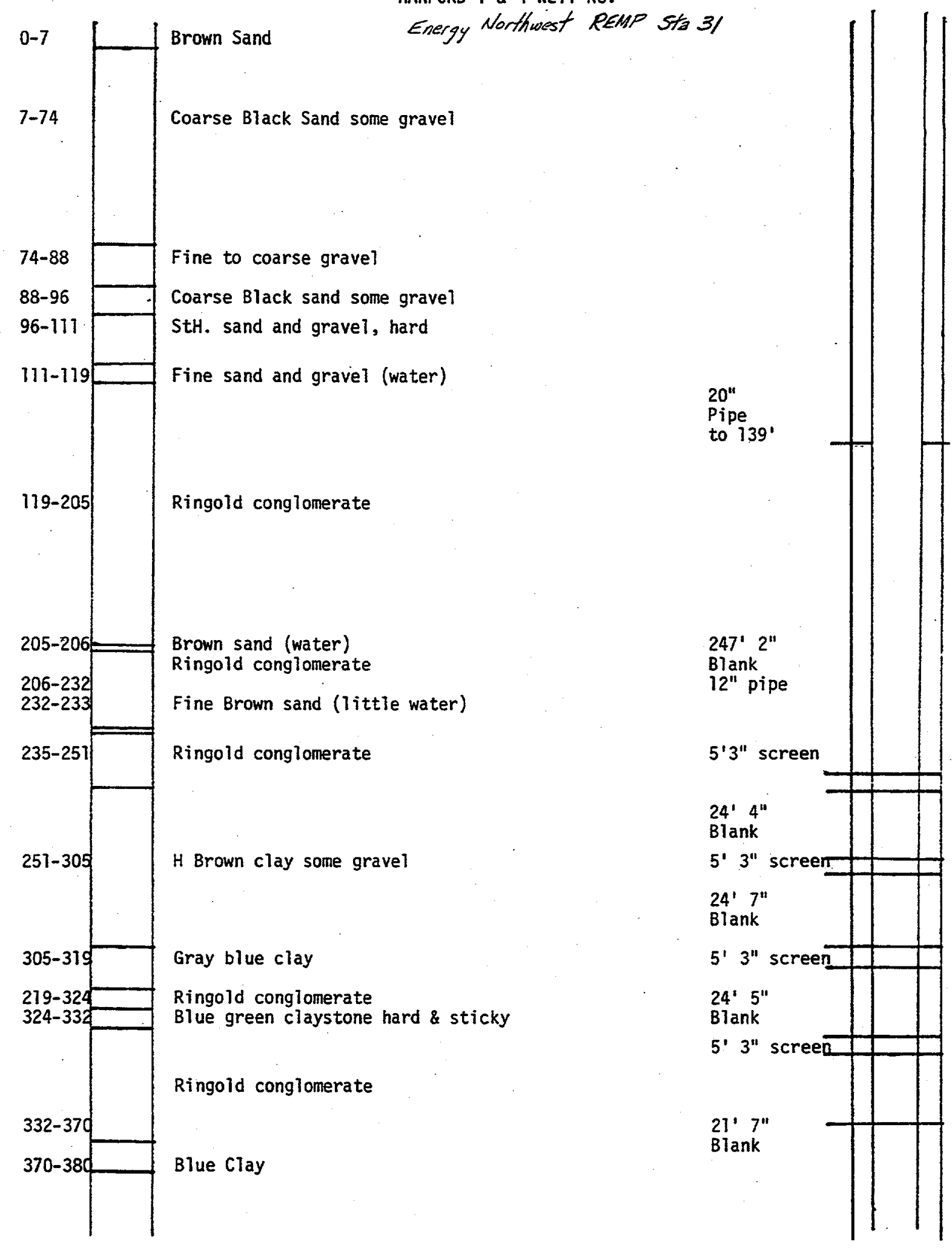




\begin{tabular}{|c|c|}
\hline $380-420$ & Dark Brown \\
\hline $400-438$ & Blue clay \\
\hline 438-457 & Broken Basalt and Blue Clay \\
\hline 457-465 & Black sand and broken basalt (water) \\
\hline
\end{tabular}

$119^{\prime} 7^{\prime \prime}$
$10^{\prime \prime}$ pipe
Bottom
$10^{\prime}$ torch
cut ||




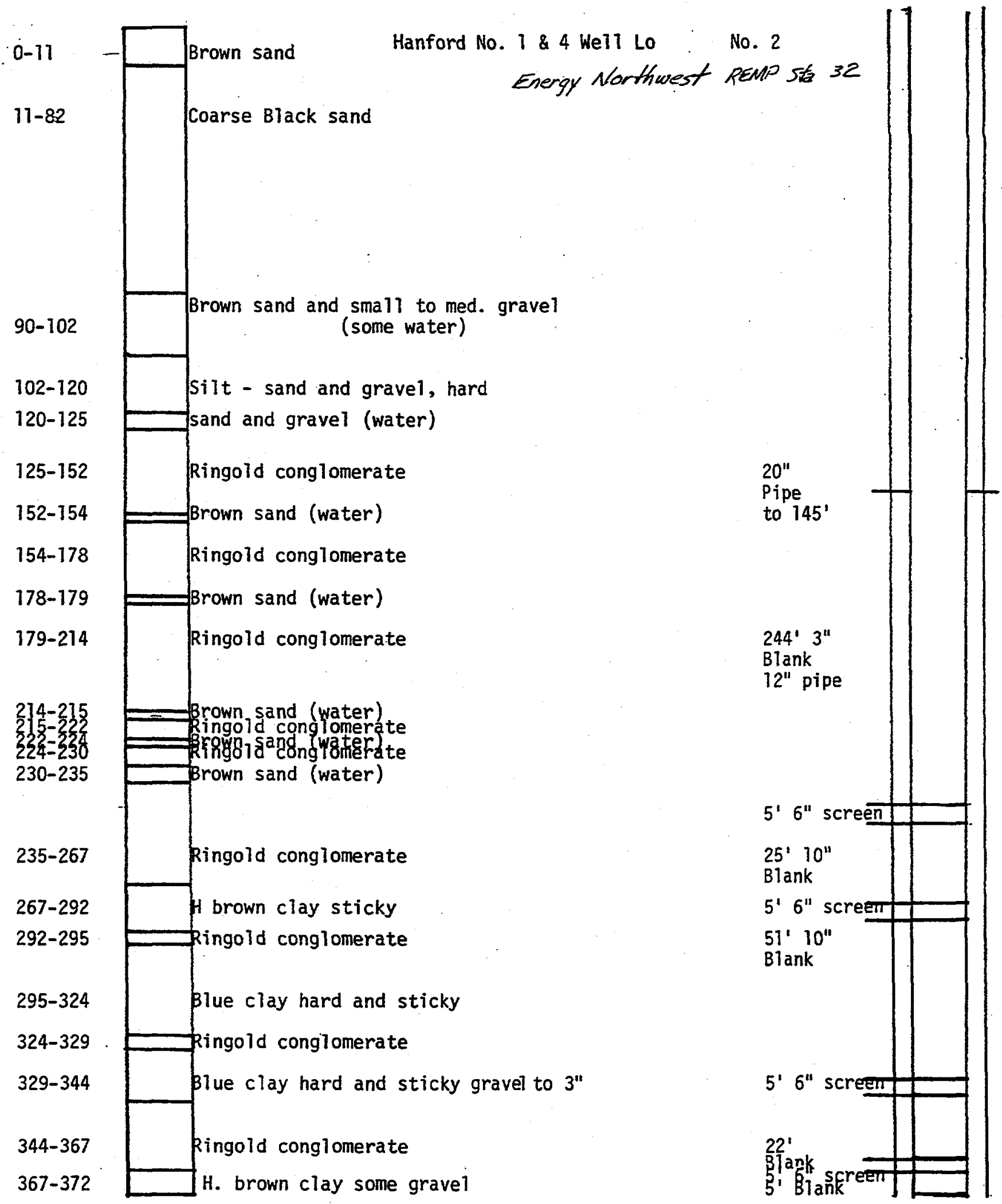




\section{Appendix B}

\section{Groundwater Sampling Reports for Phase I Evaluation of the 618-11 Burial Ground}




\begin{tabular}{|c|c|c|c|c|c|c|c|}
\hline \multicolumn{6}{|l|}{ Project: SURV $/ 600 \mathrm{DOH}$} & पैË 082000 & Page 1 of 3 \\
\hline \multirow{2}{*}{$\begin{array}{l}\text { Sampling FY Quarter: FEB/2000 } \\
\text { Well Number: 699-10-E12 }\end{array}$} & & OC Type: & & $A$ & & \multirow{4}{*}{\multicolumn{2}{|c|}{$42 / 6=7$ pupastios }} \\
\hline & & A\#: 506 & & & & & \\
\hline \multicolumn{2}{|l|}{ Total Purge Volume (gal): } & Purge Flow & Zate (gal/mi & (n): & 8 & & \\
\hline $\begin{array}{l}\text { Pump Type: } \\
\text { Electric }\end{array}$ & Time on: & $\mid \begin{array}{l}\text { Water: } \\
|24|\end{array}$ & $\begin{array}{l}\text { Purge: } \\
1248\end{array}$ & Samp: & 1318 & & \\
\hline
\end{tabular}

\begin{tabular}{|c|c|c|}
\hline & & SAMPLES COLLECTED \\
\hline BOXJV8 & 300 Analytical Services & $\operatorname{coc}$ No.: Y00-001-99 \\
\hline $\begin{array}{c}1342020 \text { 1;4000mL;P } \\
\text { BoxjW7 }\end{array}$ & $\begin{array}{l}\text { Technebium-99 (HCl bo pH <2) } \\
\text { Quanterra Incorporated }\end{array}$ & COC No.: YOO-001-101 \\
\hline $\begin{array}{c}7235040 \text { 1;1000mL:P } \\
\text { 1:20mL:P } \\
\text { BoxjY8 (Filtered) }\end{array}$ & $\begin{array}{l}\text { 906.0_H3_LSC: Tritium (1) (None) } \\
\text { Activity Scan (None) } \\
\text { Quanterra St. Louis }\end{array}$ & COCNO.: Y00-001-5 \\
\hline $8010 \quad 1 ; 500 \mathrm{~mL} ; \mathrm{G} / \mathrm{P}$ & 0 & 2) \\
\hline
\end{tabular}

Total No. Bottles: 25

Containment Code:

$-730$

Collector

K. YOUNG

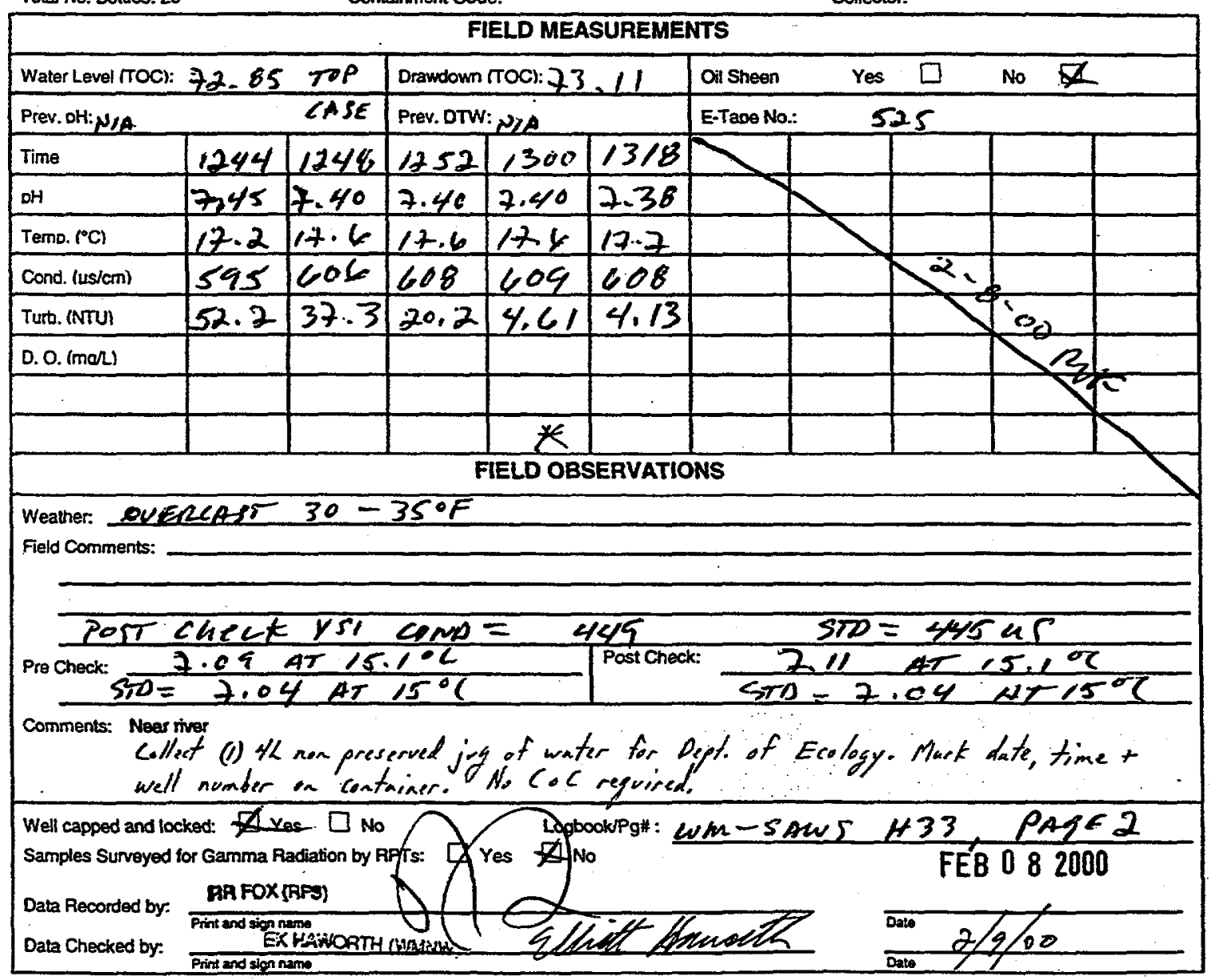


NO DUMP

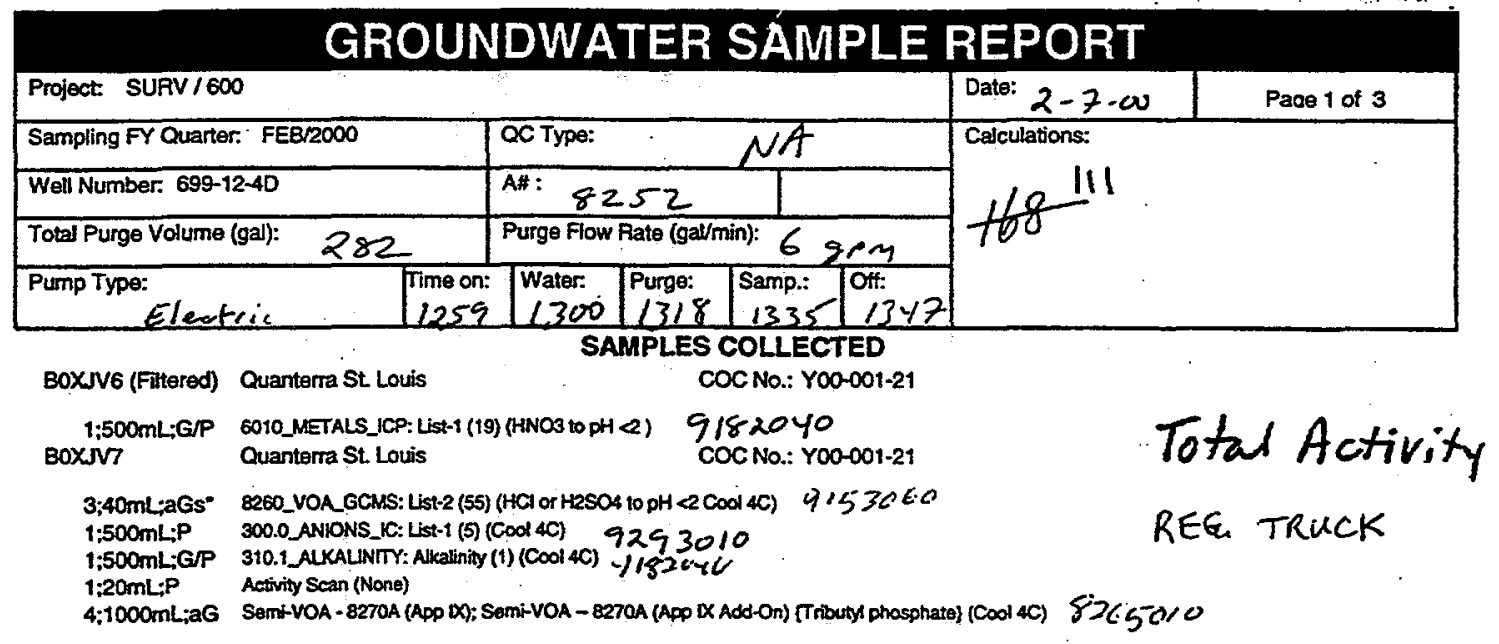

R.T SICKLE

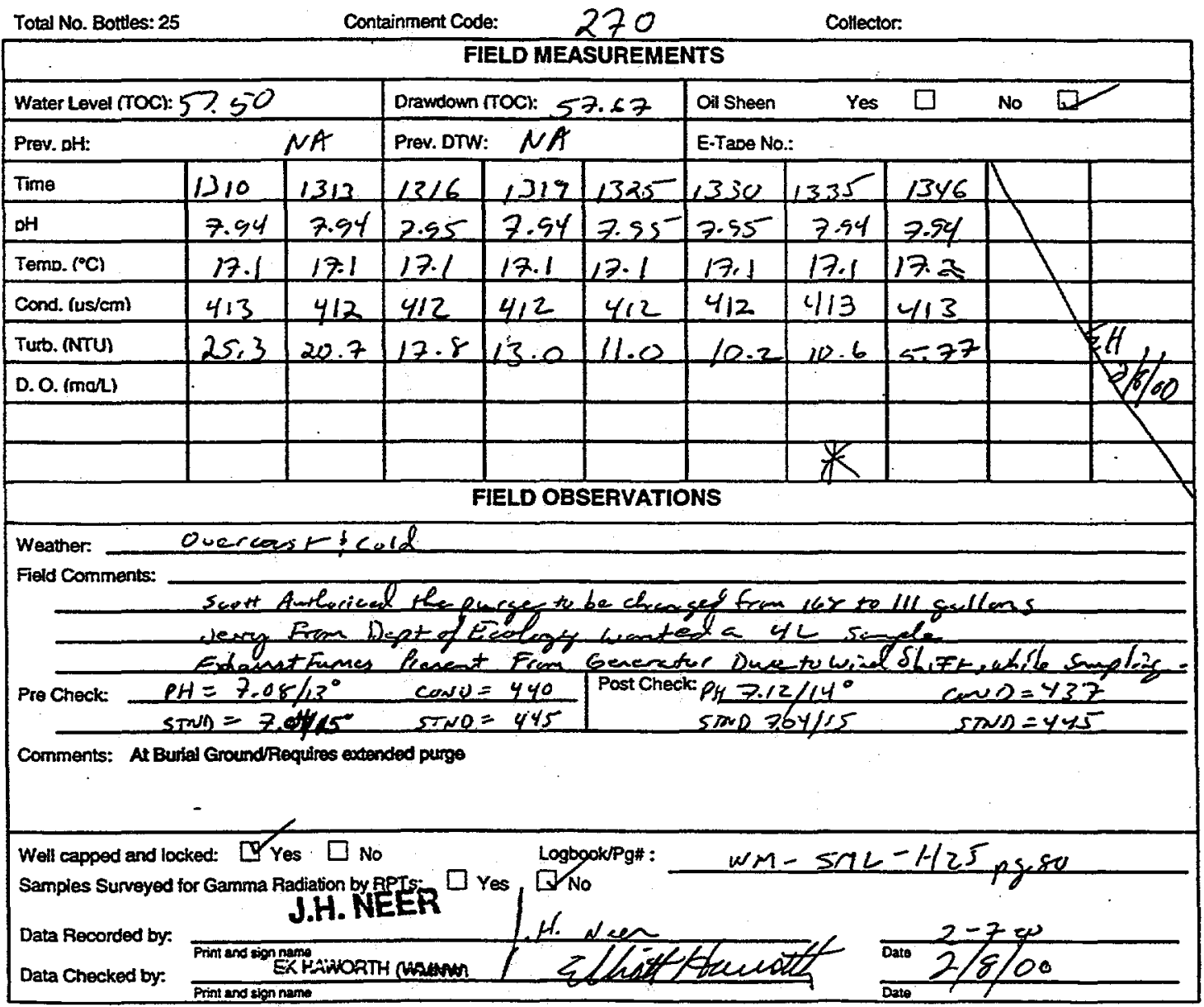




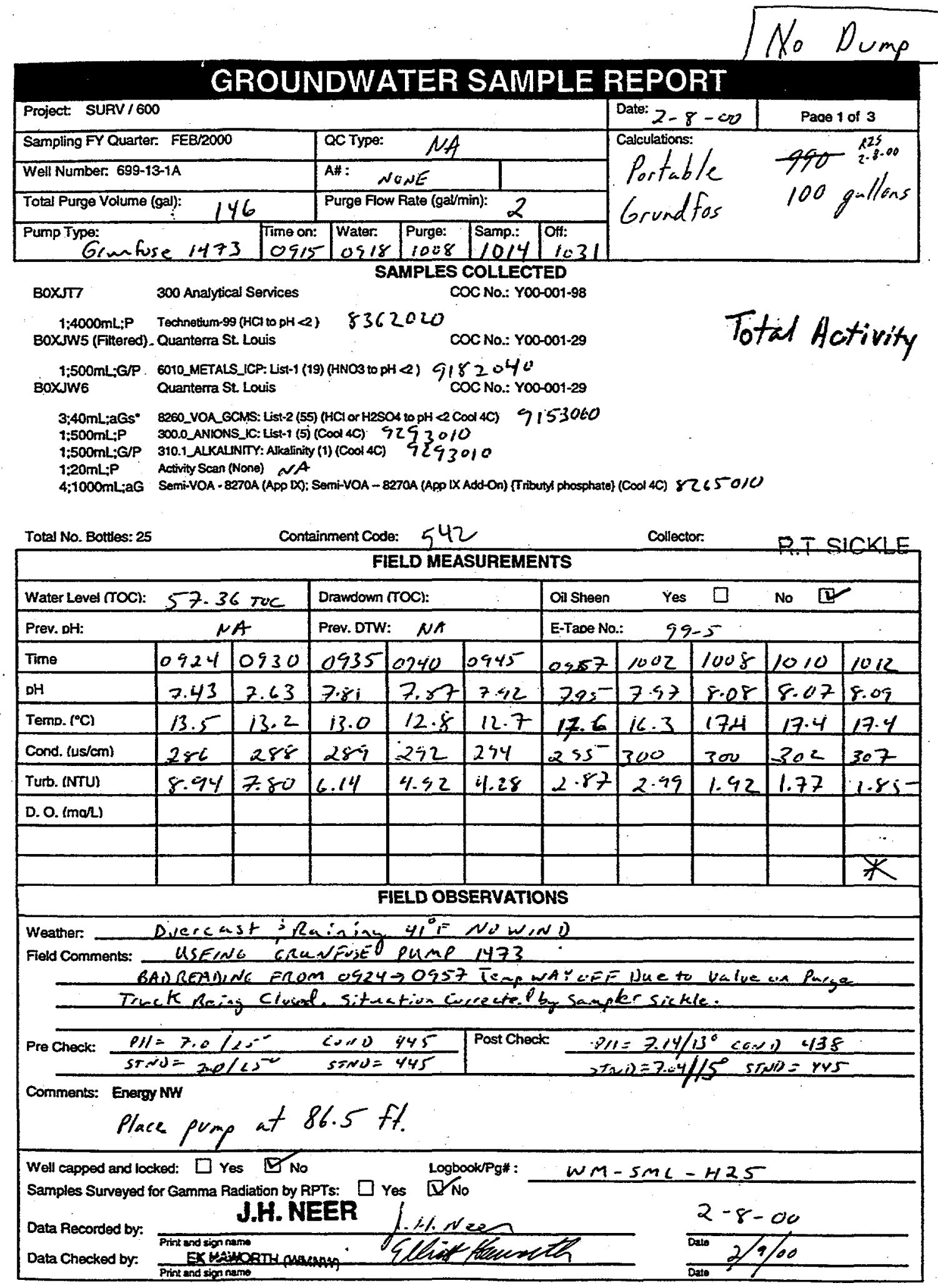




\section{GROUNDWATER SAMPLE REPORT}

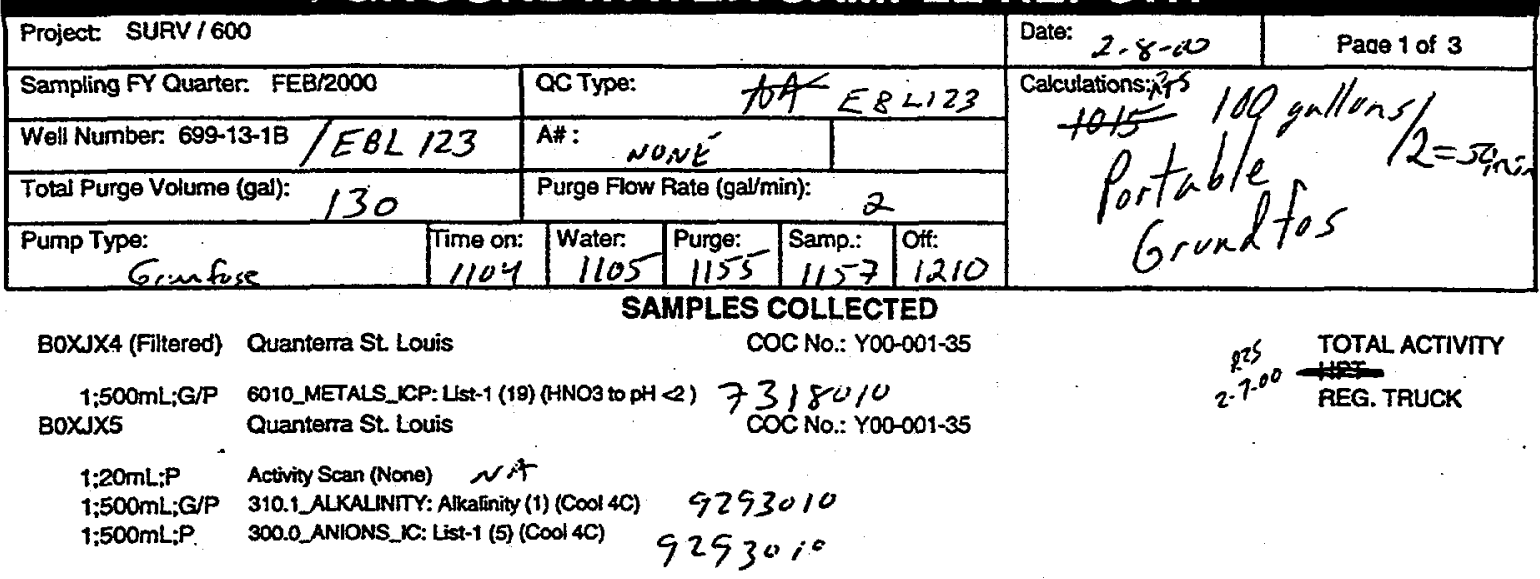

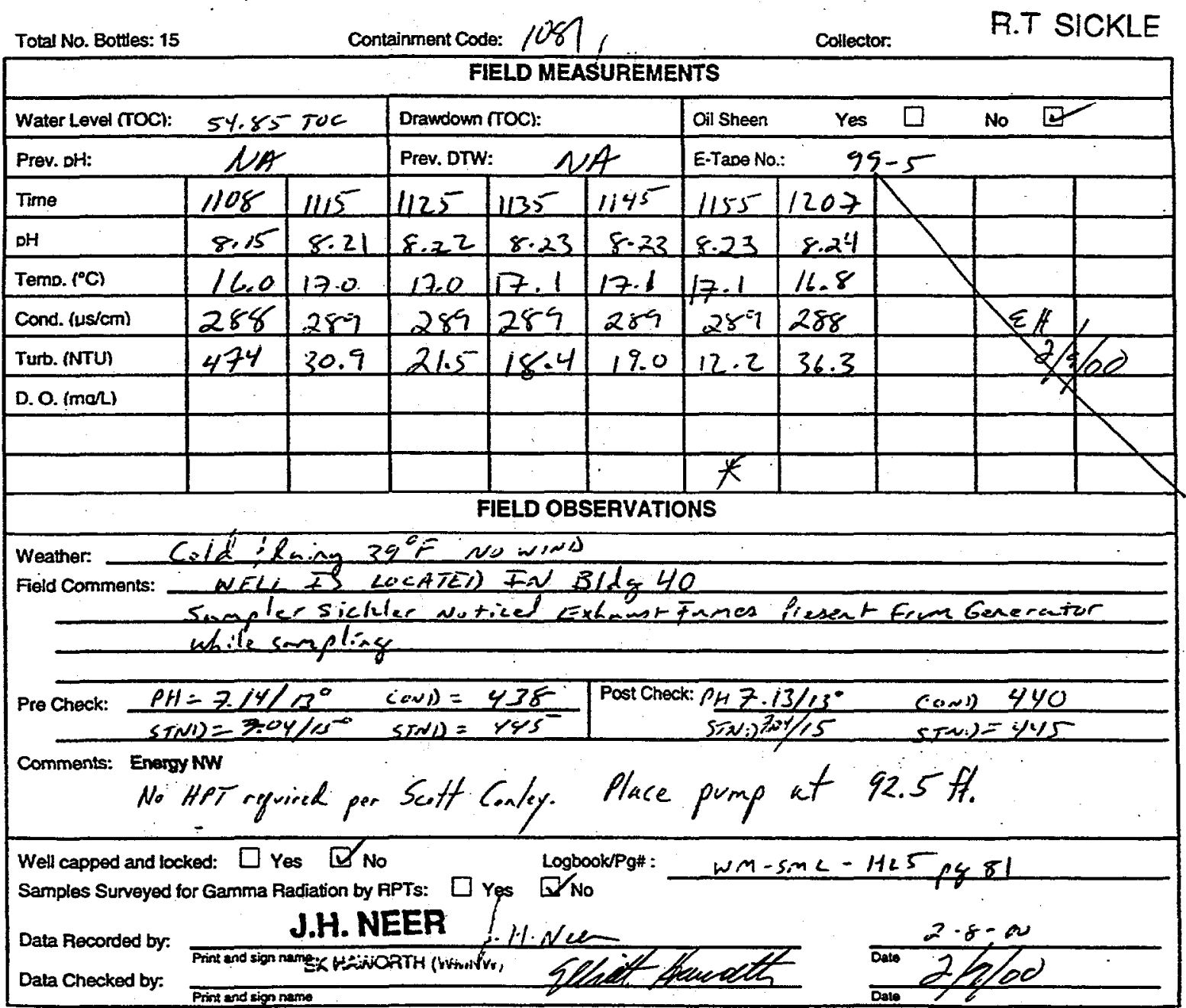




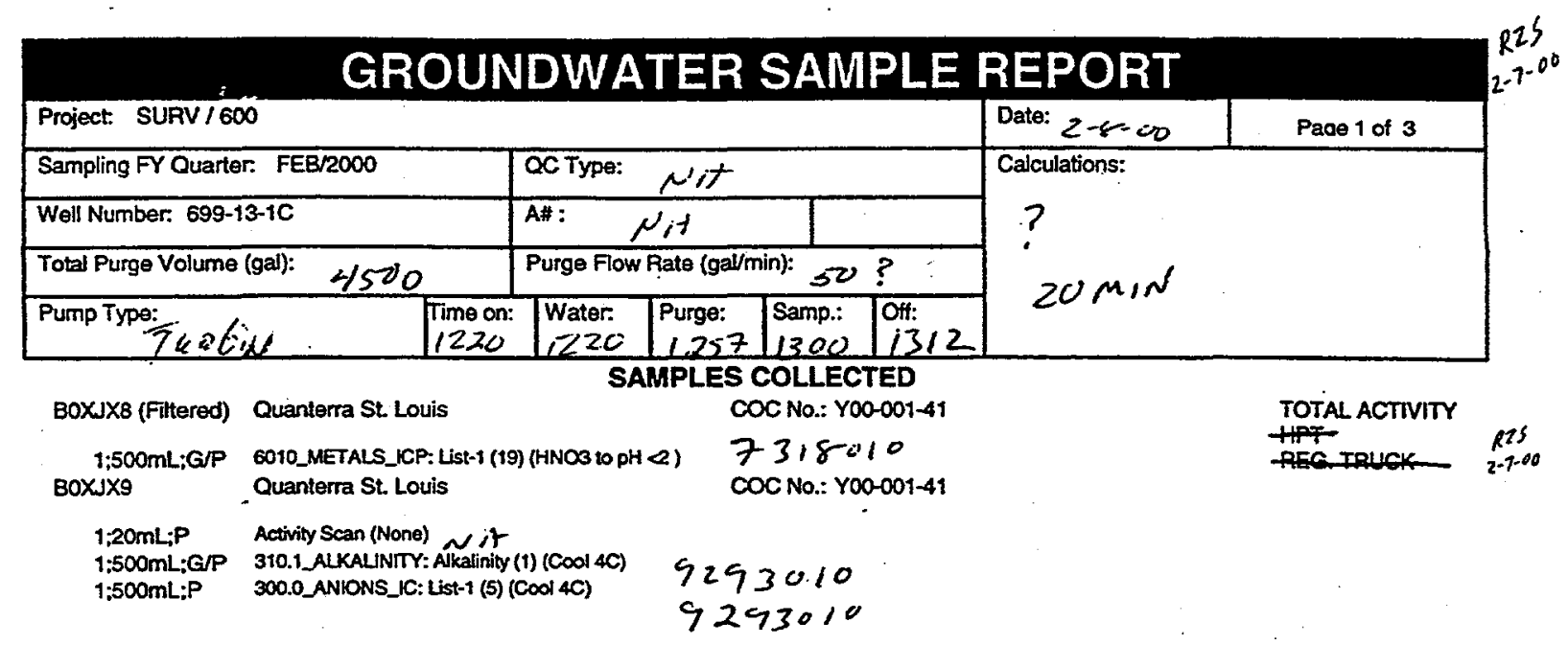

Total No. Bottles: 15

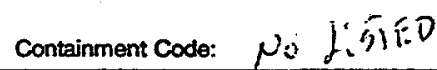

R.T SICKLE

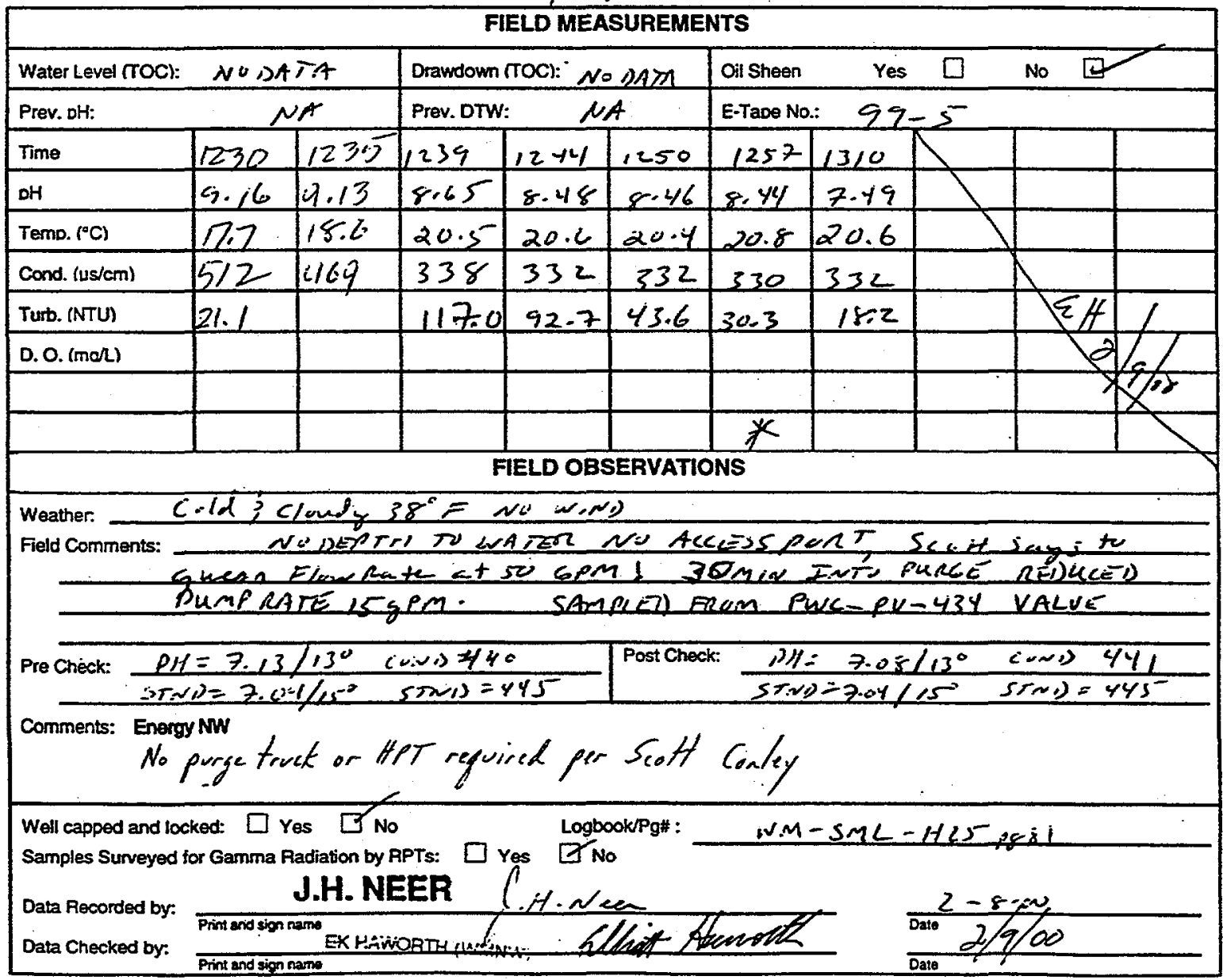


NIA DIIMP-

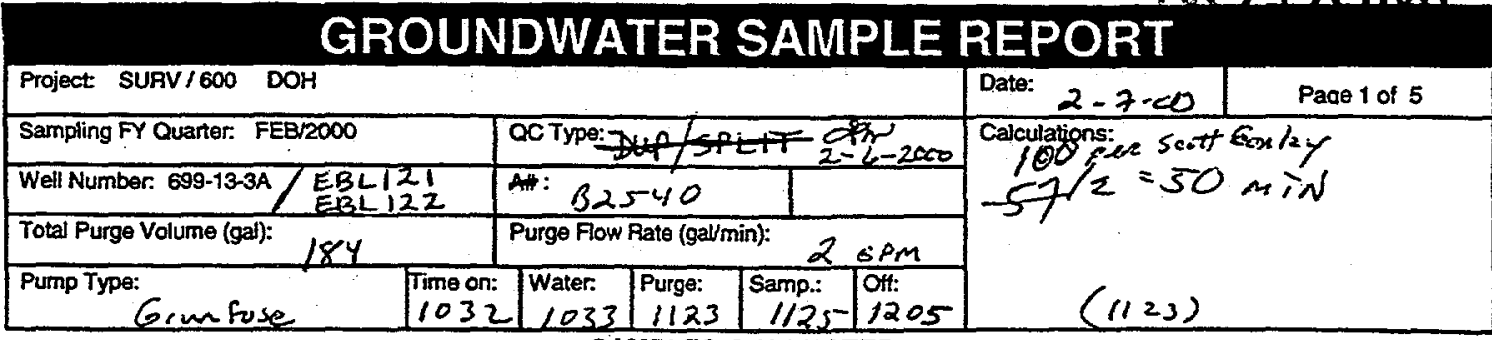

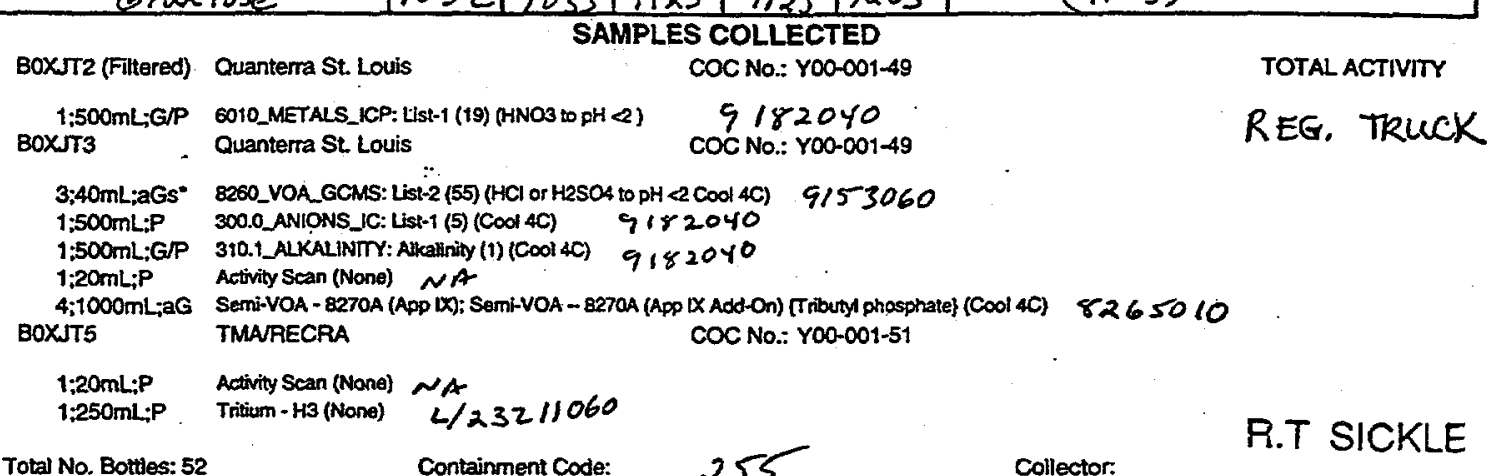

\begin{tabular}{|c|c|c|c|c|c|c|c|c|c|c|}
\hline \multirow{2}{*}{\multicolumn{11}{|c|}{$\begin{array}{rlr}\text { Total No. Bottles: } 52 & \text { Containment Code: } & 255 \\
& \text { FIELD MEASUREMENTS }\end{array}$}} \\
\hline & & & & & & & & & & \\
\hline \multirow{2}{*}{\multicolumn{3}{|c|}{$\begin{array}{lc}\text { Water Level (TOC): } & 61.36 \text { TOC } \\
\text { Prev. DH: } & N A \\
\end{array}$}} & \multicolumn{3}{|c|}{ Drawdown (TOC): no aATft } & Oil Sheen & Yes & $\square$ & \multicolumn{2}{|c|}{ No $\square$} \\
\hline & & & \multicolumn{3}{|c|}{ Prev. DTW: $\quad H / A$} & \multicolumn{5}{|c|}{ E-Tape No.: $\quad 99-5$} \\
\hline & 1038 & 2045 & $\cos 0$ & 1055 & 1100 & 1105 & 1110 & 1115 & 1120 & 1123 \\
\hline $\mathrm{pH}$ & 7.45 & 7.65 & 7.67 & 269 & 7.6 .8 & 7.69 & 7.70 & 7.70 & 7.69 & 7.70 \\
\hline Temo. $\left.1^{\circ} \mathrm{C}\right)$ & 16.6 & 16.8 & 16.9 & $17 \cdot 0$ & 17.0 & 17.0 & 16.9 & 17.0 & 17.0 & 17.1 \\
\hline Cond. (us/cm) & 602 & 629 & 633 & 610 & 621 & 621 & 680 & 625 & 617 & 624 \\
\hline Turb. (NTU) & 9.22 & 2.15 & 8.02 & 16.8 & 15.0 & 8.94 & 8.71 & 8.17 & 5.46 & 5.19 \\
\hline \multicolumn{11}{|l|}{ D. O. (ma/) } \\
\hline & & & & & & & & & & \\
\hline & & & & & & & & & & 米 \\
\hline \multicolumn{11}{|c|}{ FIELD OBSERVATIONS } \\
\hline \multicolumn{11}{|c|}{ 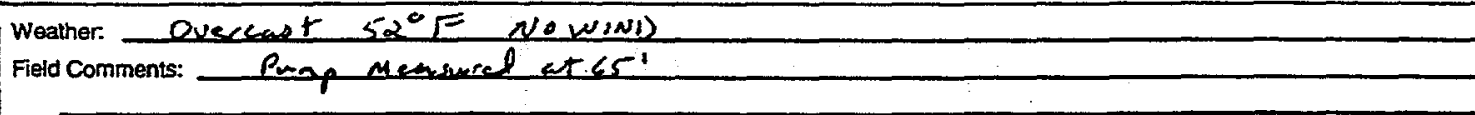 } \\
\hline \multicolumn{3}{|c|}{ Pre Check: $\frac{P H=7.0 / 25^{\circ}}{S N_{N}}=7.012^{50}$} & $\frac{\cos (1)}{\sin (0)=}$ & $\begin{array}{ll}4+5 \\
y+5\end{array}$ & Post Check: & \multicolumn{3}{|c|}{ 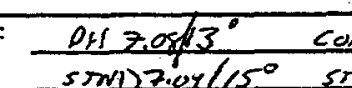 } & 10440 & \\
\hline \multicolumn{11}{|c|}{ Comments: At Burlal Ground (OC WITH THIS WEUL: DUP/SPUT/EBL 121/EBL122/ FTB3e2) } \\
\hline \multicolumn{11}{|c|}{$\begin{array}{l}\text { Well capped and locked: } \square \text { Yes } \square \text { No } \\
\text { Samples Surveyed for Gamma Radiation by RPTs: } \square \text { Ye } \\
\text { Data Recorded by: } \frac{\text { J.H. NEER }}{\text { Print exd soon name }}\end{array}$} \\
\hline Data Checked by. & 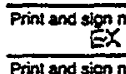 & Pistrith & costasen & & & & & & & \\
\hline
\end{tabular}




\section{GROUNDWATER SAMPLE REPORT}

Project: SURV/600

\begin{tabular}{|c|c|c|c|c|c|}
\hline Sampling FY Quarter: FEB/2000 & & QC Туре: & & $N A$ & \\
\hline Well Number: 699-15-15B & & A\#: & 318 & & \\
\hline Total Purge Volume (gal): & & Purge Flow & Rate $(\mathrm{ga} / \mathrm{m}$ & (in): & 7 \\
\hline $\begin{array}{l}\text { Pump Type: } \\
\qquad E(E)+R / L\end{array}$ & Time on: & Water: 6.959 & $\begin{array}{l}\text { Purge: } \\
1008\end{array}$ & $\begin{array}{l}\text { Samp:: } \\
10 / 3\end{array}$ & $\begin{array}{l}\text { Off: } \\
1022\end{array}$ \\
\hline
\end{tabular}

Calculations:

$$
\begin{aligned}
& 6 / 17=8.71 \\
& 9 \text { MIN. PURQE }
\end{aligned}
$$

BOXK18 (Filtered) Quanterra St Lovis COC No: Y00-001-57

$3 / 8010$ 1:500mL;G/P 6010_METALS_ICP: List-1 (19) (HNO3 to pH \& ) BoxK19

Quanterra St. Lovis

COC No.: Y00-001-57

R $^{\text {IS }}$ TOTAL ACTIVITY

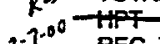
$2-1.00$ REG. TRUCK

1;20mL;P Activity Sean (None)

A:500mL:G/P 310.1_ALKALINTY: Alkalinity (1) (COO) 4C)

OS5030 Y;500mL;P 300.0_ANIONS_1C:List-1 (5) (COO 4C)

Total No. Bottles: 13

Containment Code:

Nove

Collector:

FIELD MEASUREMENTS

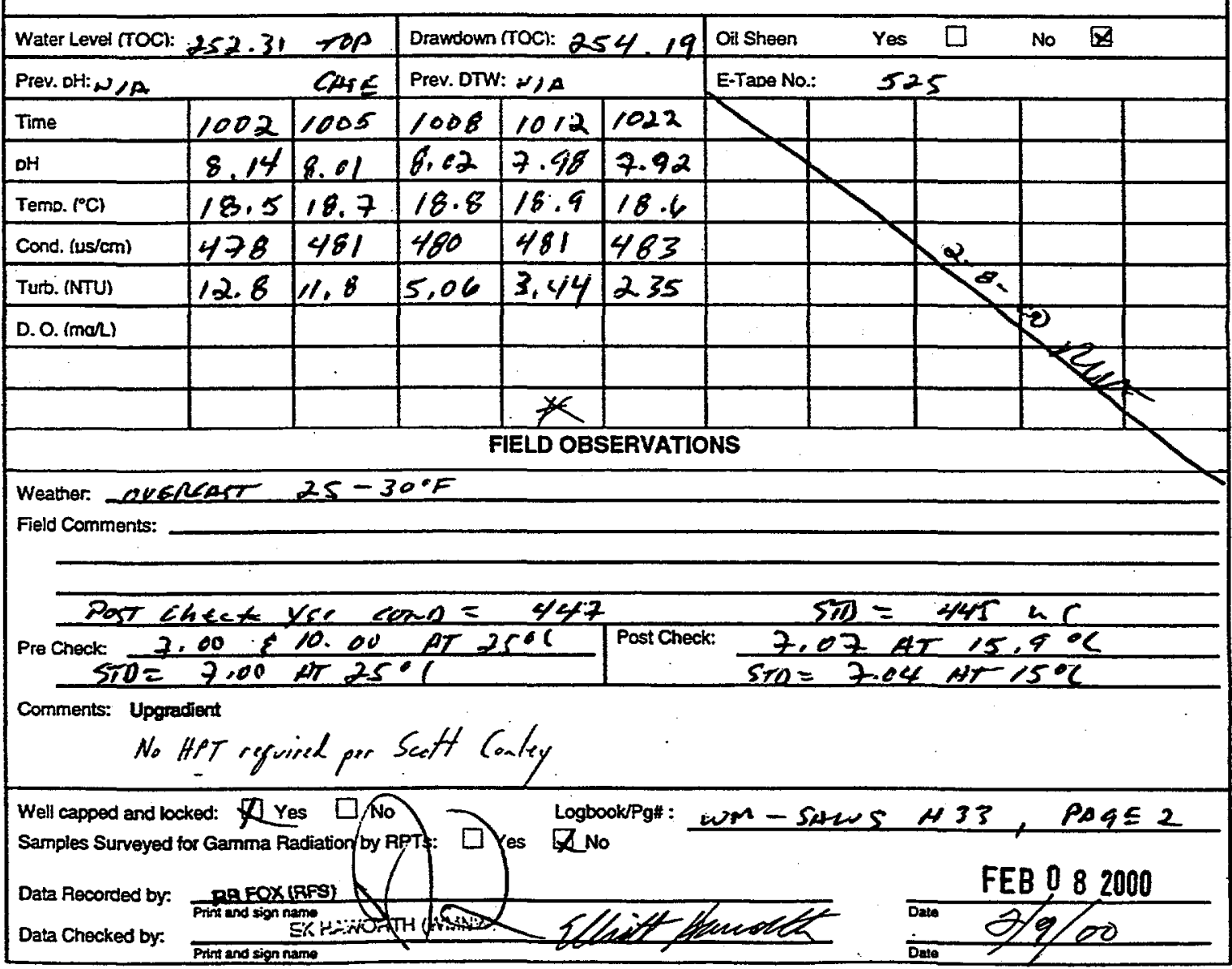

B.7 


\begin{tabular}{|c|c|c|c|c|c|}
\hline \multicolumn{6}{|c|}{ GROUNDWATER SAMPLE REPORT } \\
\hline Project: SURV $/ 600$ DOH & & & & DateB 072000 & Paoe 1 of 3 \\
\hline Sampling Fr Quaster: FEB/2000 & & OC Type: & & Calculations: & \\
\hline Well Number: $699-17-5$ & & A\#: & & 296 & $=14.64$ \\
\hline Total Purge Volume (gal): $A+P P_{30}^{2 O}$ & & Purge Fow & Rate (gal/min): & Lee & $15 \mathrm{mon}$ \\
\hline $\begin{array}{l}\text { Pump Type: } \\
\text { EIEC } \rightarrow R / K\end{array}$ & $\begin{array}{l}\text { Time on: } \\
1051\end{array}$ & $\begin{array}{l}\text { Water } \\
105 \mid\end{array}$ & 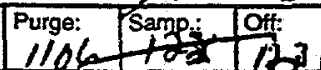 & Comments & pungE \\
\hline
\end{tabular}

BOXK13 (Filtered) Quanterra St. Louis

$7 / 8010$ 1;500mL;G/P. 6010_METALS_ICP:List-1 (19) (HNO3 $10 \mathrm{pH}$ \&) B0XK14

1;20mL;P

1:500mL:G/P $310010<1: 500 \mathrm{~mL} ; P$
Quanterra St. Louis

Activity Scan (None)

310.1 ALKAUNTT: Alkalinity (1) (COOl 4C) 300.0_ANIONS_LC: List-1 (5) (COOt 4C)
SAMPLES COLLECTED \&R. FoY $2.7-00$

$\operatorname{COC}$ No.: YOO-001-63

$\operatorname{coc}$ No.: Yo0-001-63
Total Activity

REG. TRUCK

Pump oro 2 No trme 12, wateil to Sunface 121 Flow RATE $=15$. Gallons per minutE SHMPIE collector WEll 1223

Total No. Botties: 13

Containment Code: 1052 Pump off 1231

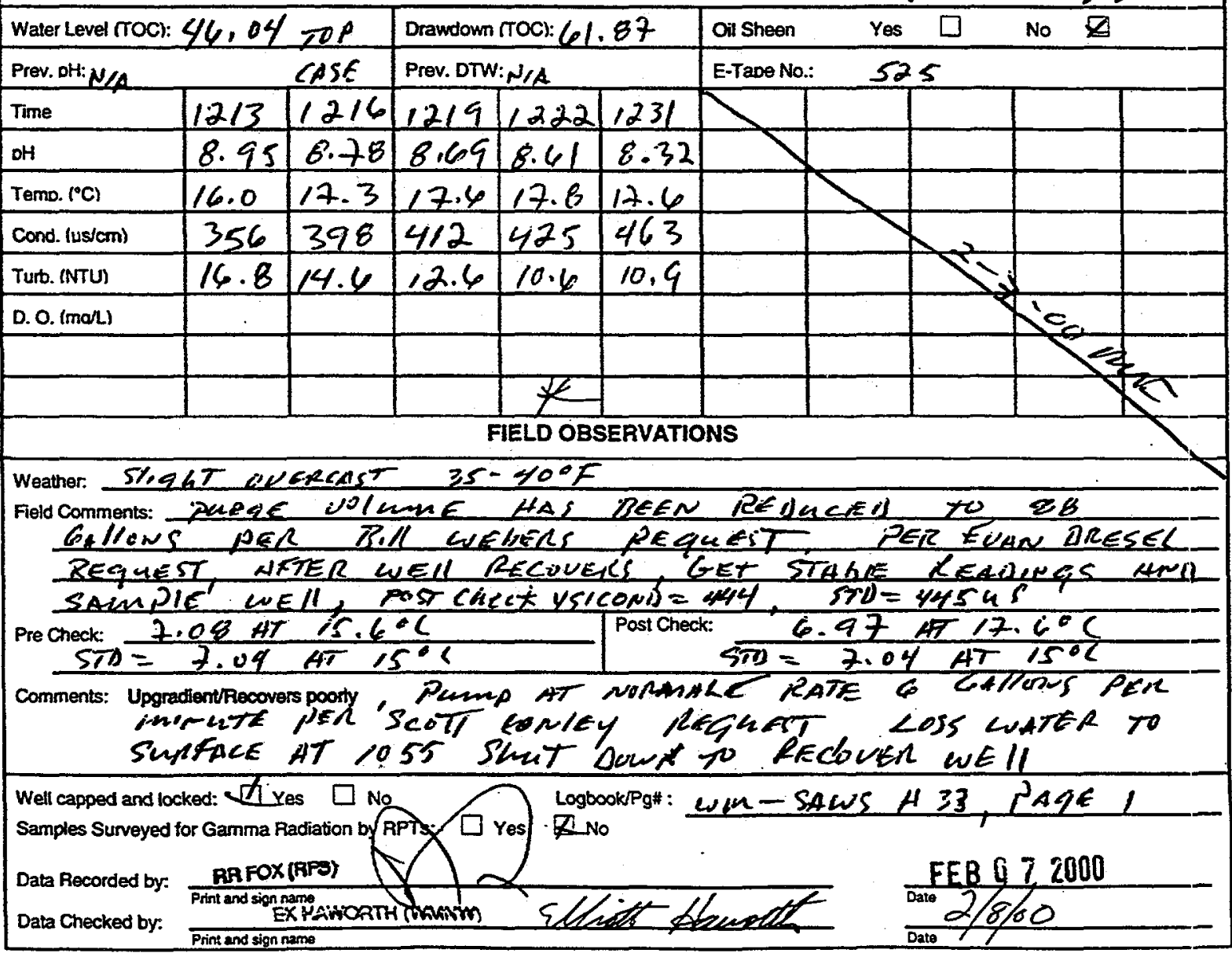




\section{GROUNDWATER SAMPLE REPORT}

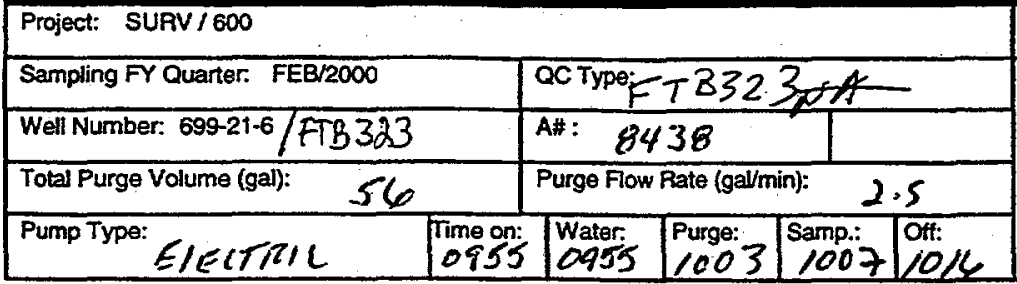

Date:

FER 1720 Paos 1 of 3

Calculations:

$20 / 2 \cdot 5=8$ inin PQRRGE SAMPLES COLLECTED

B0XK21 (Filtered) Quanterra St. Louis COC No.: Y00-001-73

$1 / 826410$ 1:500mL:G/P G010_METALS_ICP: List-1 (19) (HNO3 to PH $\angle 2$ )

BOXK22 Quanterta St. Louis

$\operatorname{COCN}$ No.: Y00-001-73

1;20mL:P Activity Scan (None)

1;500mL;G/P 310.1_ALKALINTY: Alkatining (1) (Cool 4C)

.318010 (1;500mL;P 300.0_ANIONS_K: List-1 (5) (CoO 4C)
Total Activity

REGi TRUCK

Total No. Botties: 13

Containment Code: $\quad 464$

collector. Ka. YOUNG

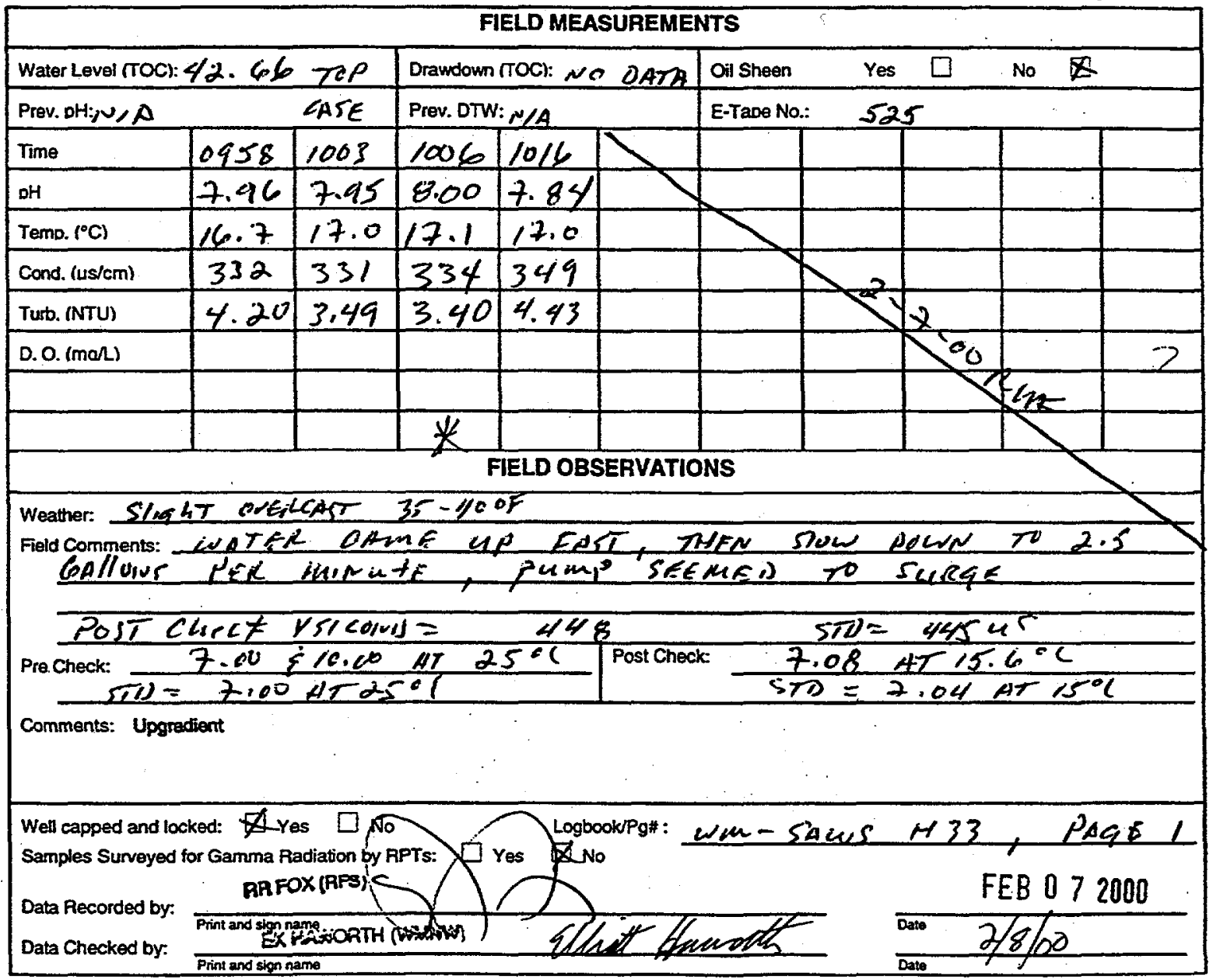

B.9 


\section{GROUNDWATER SAMPLE REPORT}

Project: SURV/600

D位E $B \cup 8$ 2000

Paoe 1 of 2

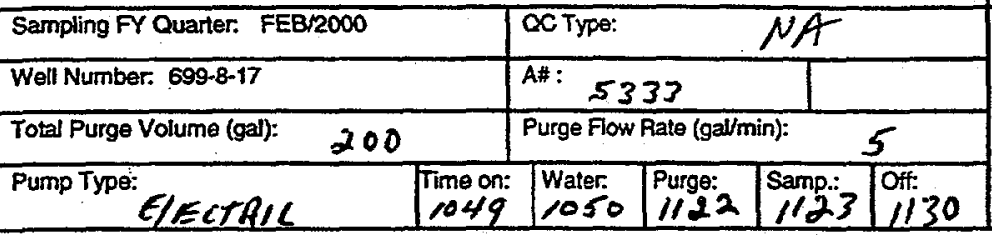

Calculations: $160 / 5=32$

purge

B0XK10 (Filtered) Quanterra St. Louis

SAMPLES COLLECTED

$1 / 820 \%$ 1:500mL:G/P 6010_METALS_ICP: List-1 (19) (HNO3 to pH \&)

BoXK11 Quanterra St Louis

$\operatorname{coc}$ No: Y00-00t-77

1;20mL;P Activity Sean (None)

1500mL:G/P 310.1_ALKALINTY: Alkatinity (1) (Cool 4C)

055030 1:500mL:P 300.0_ANIONS_1C: Listt 1 (5) (CoOl 4C)

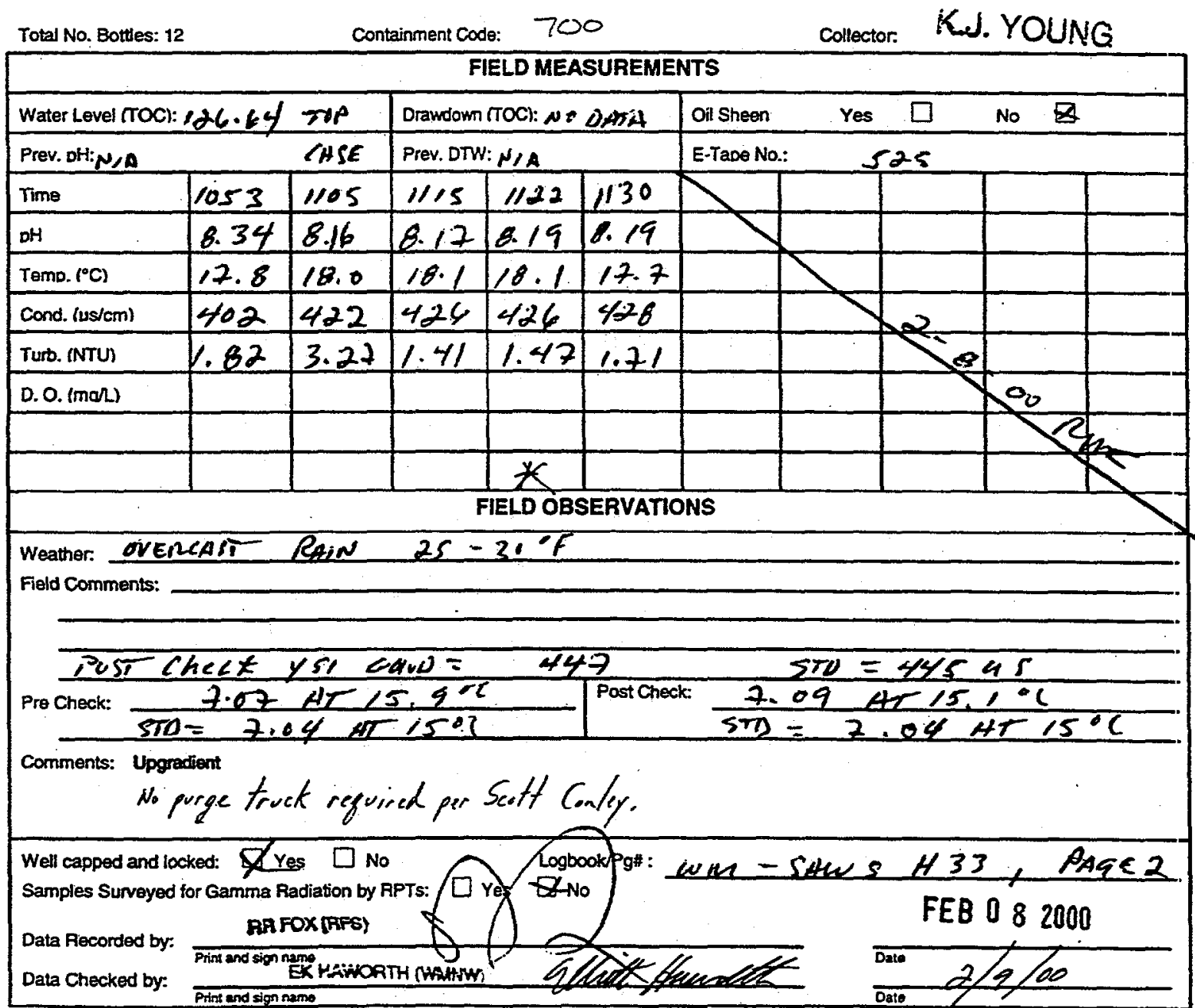

B. 10 


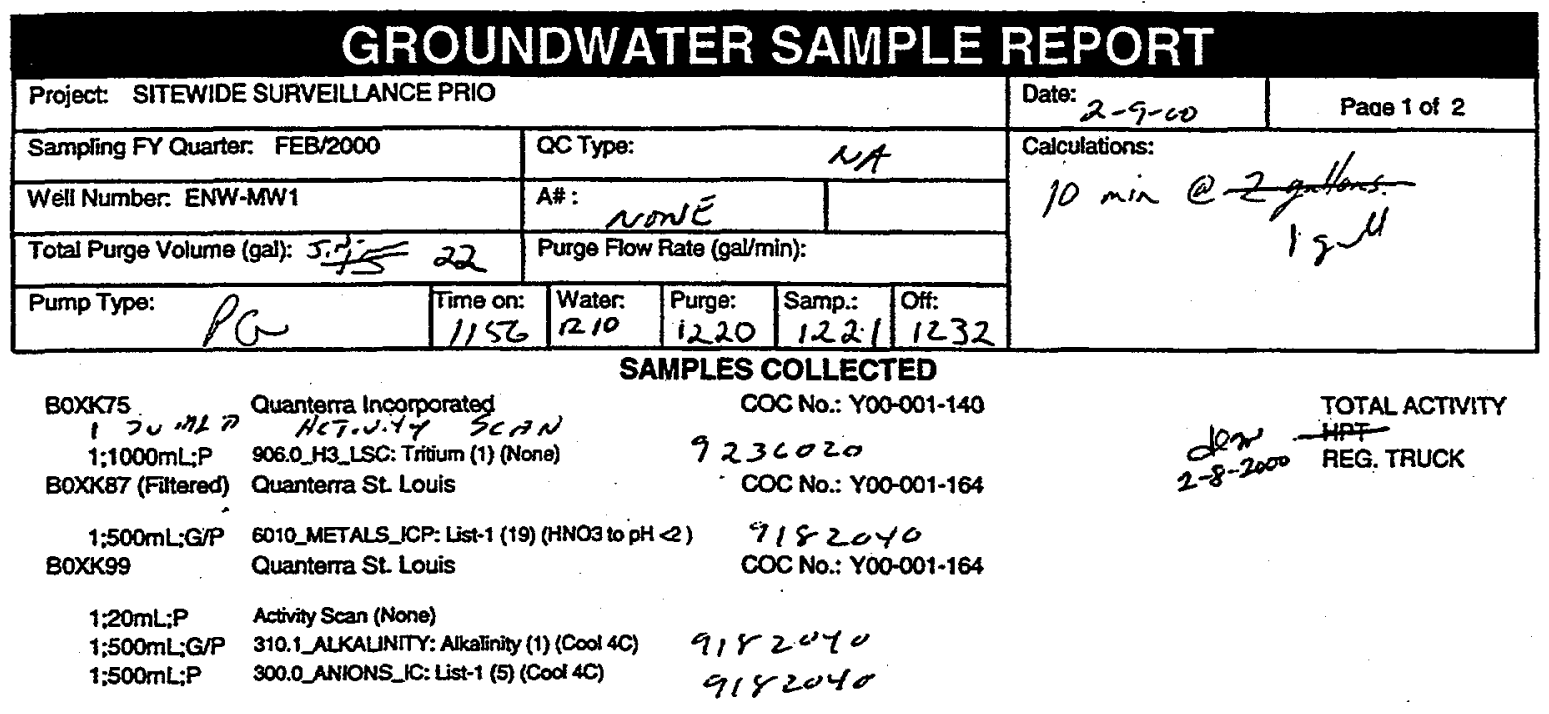

Total No. Bottles: T2

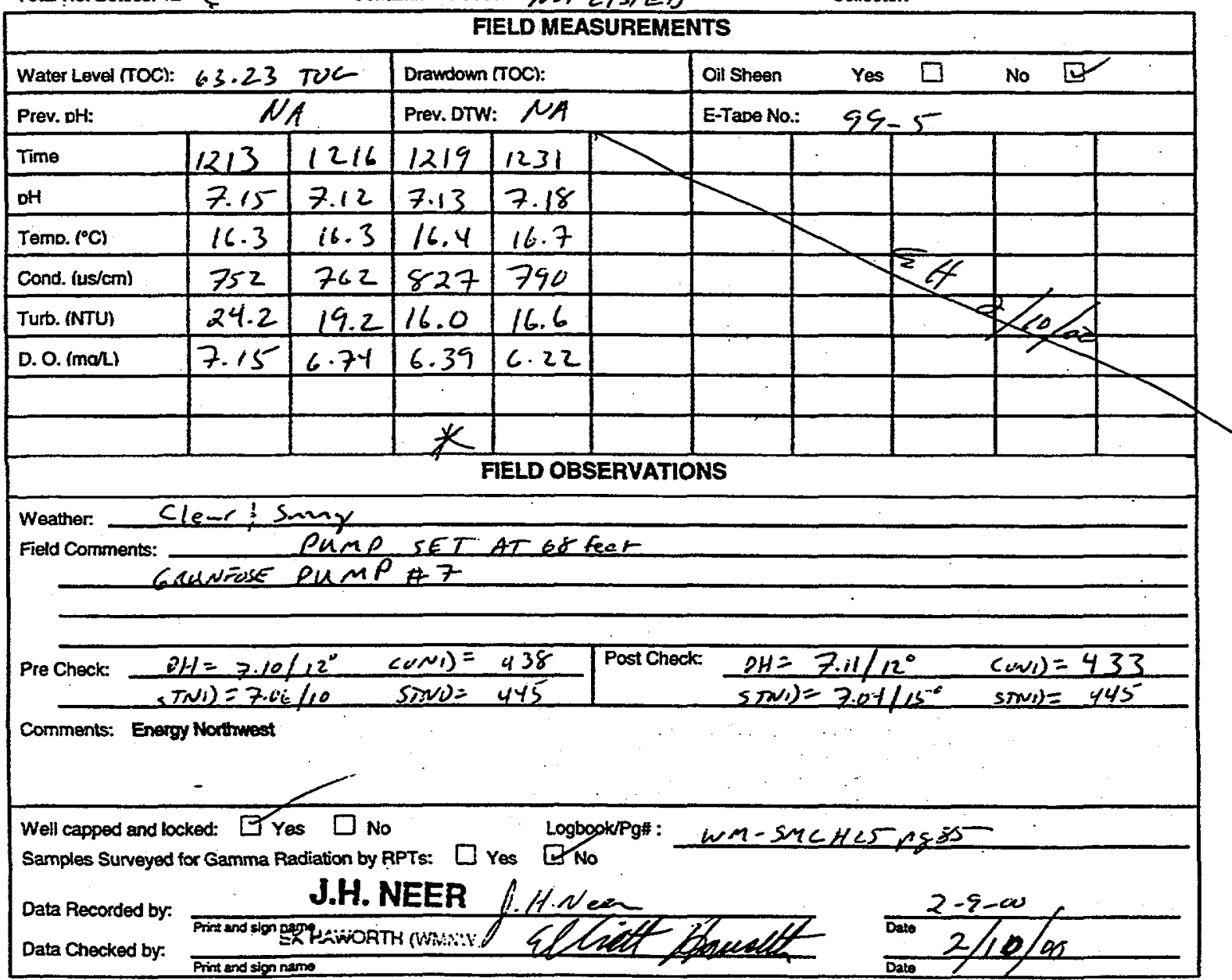




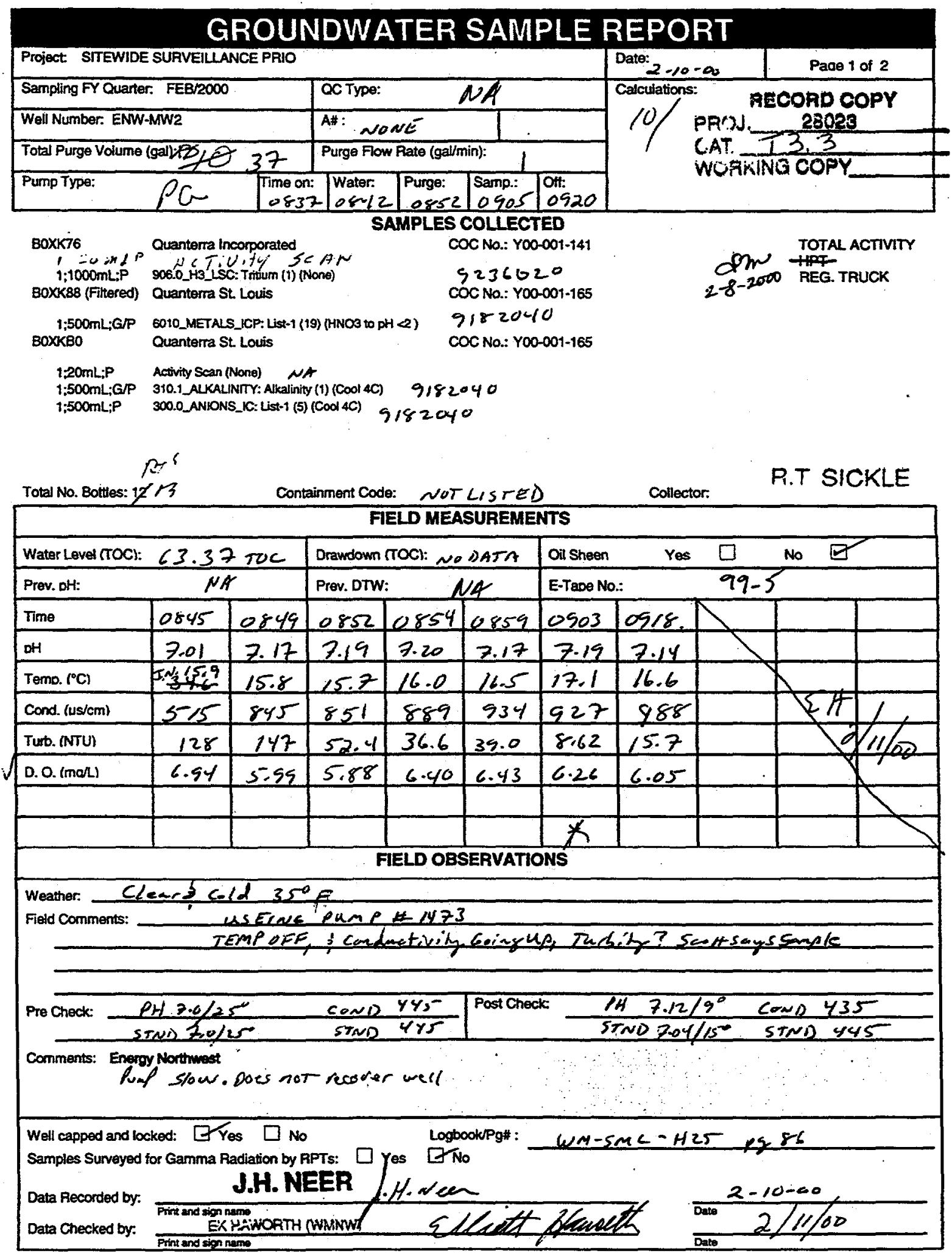

B. 12 


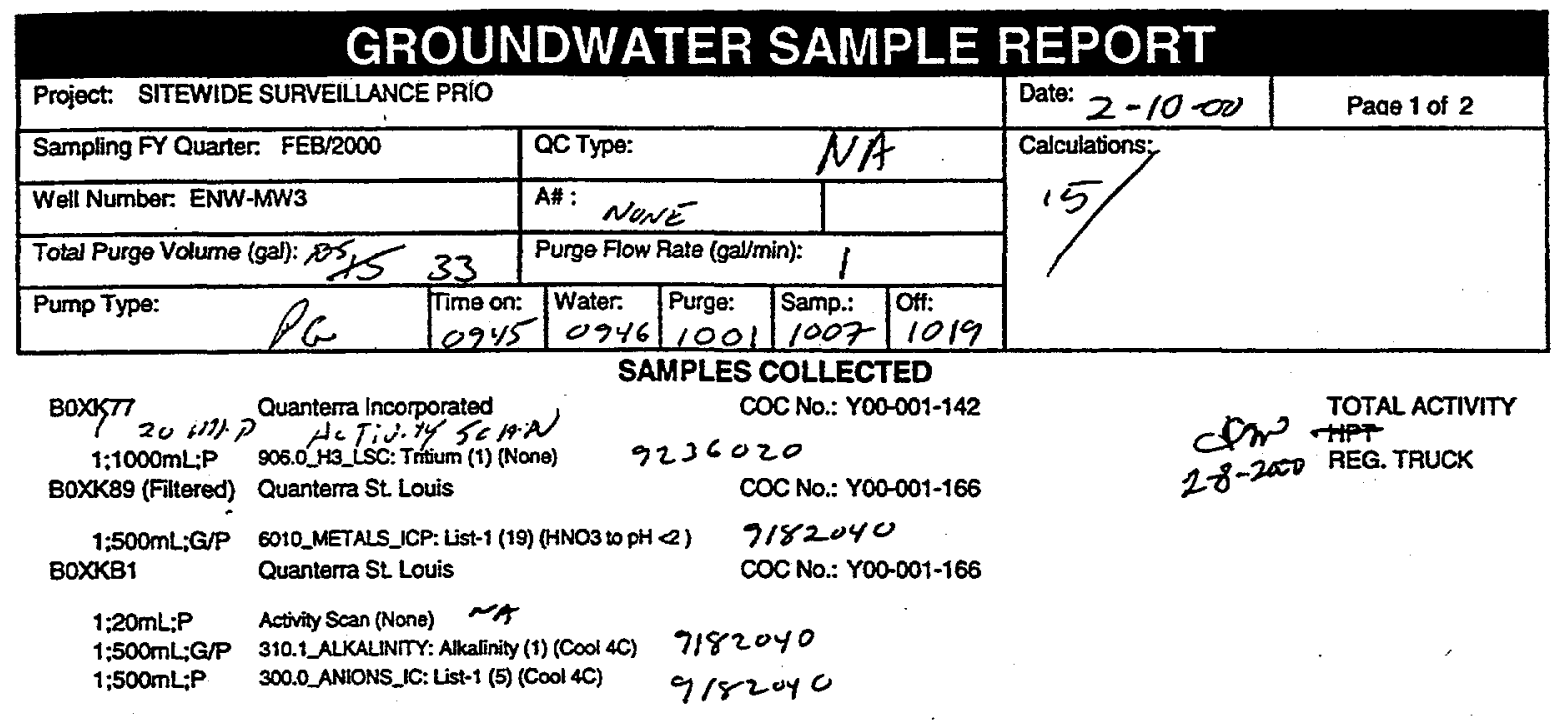

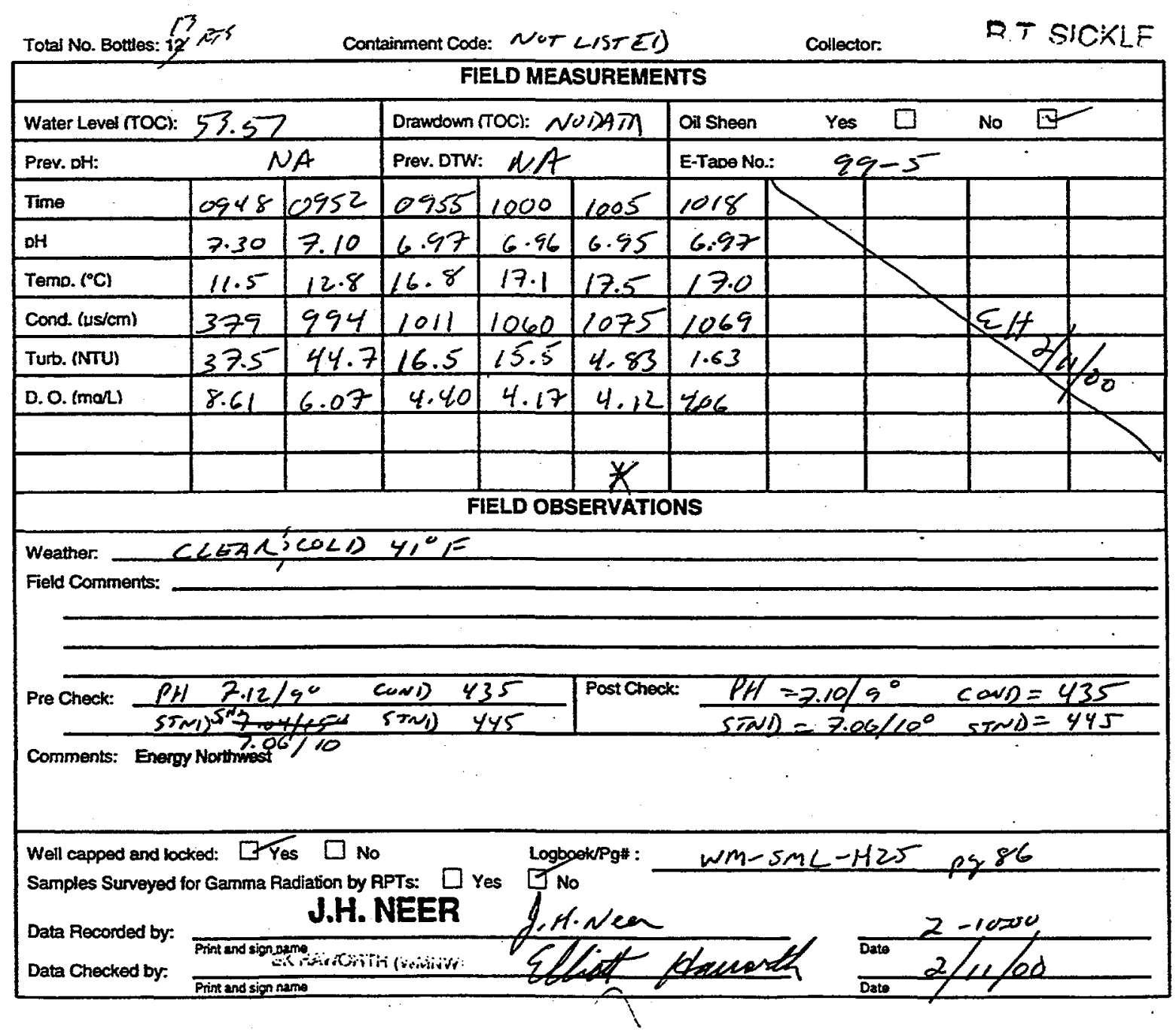

B. 13 


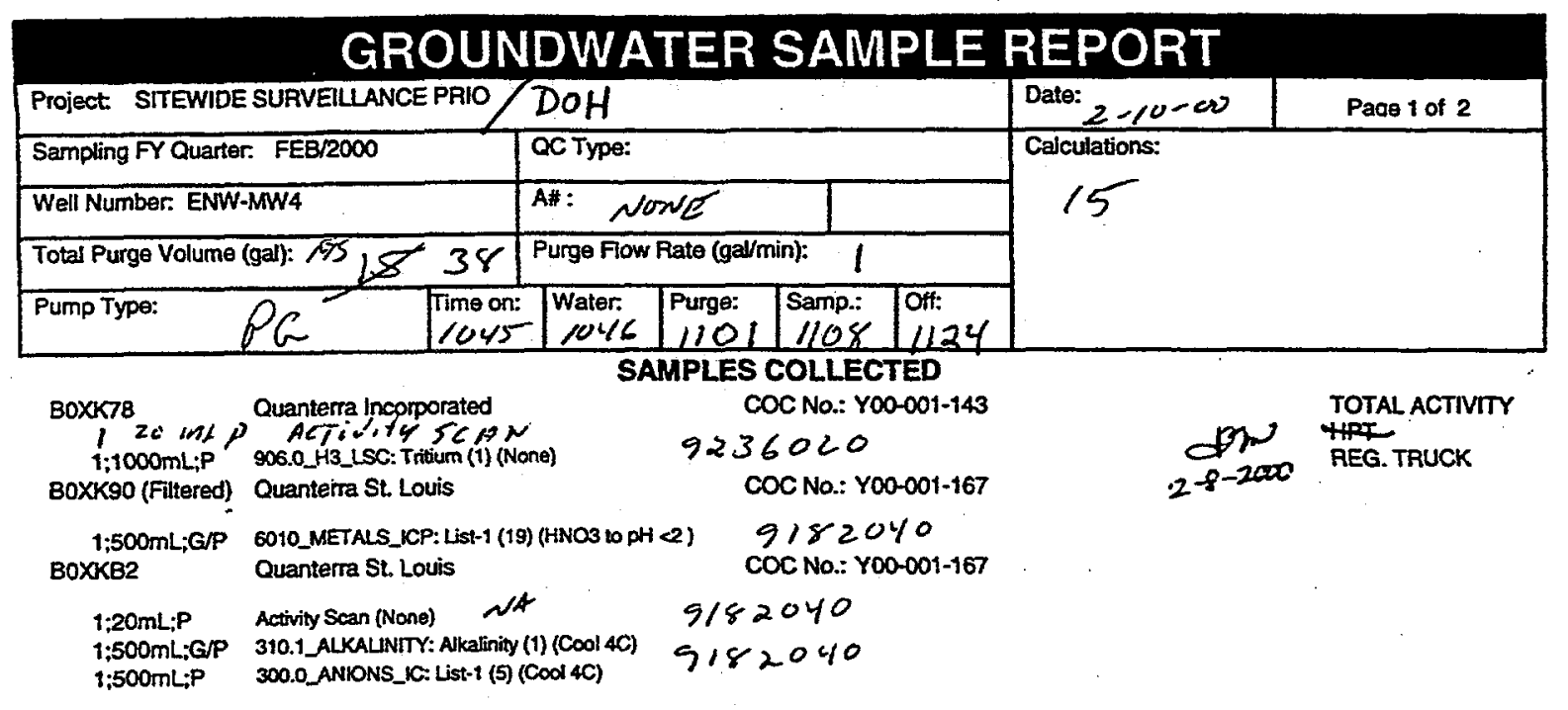

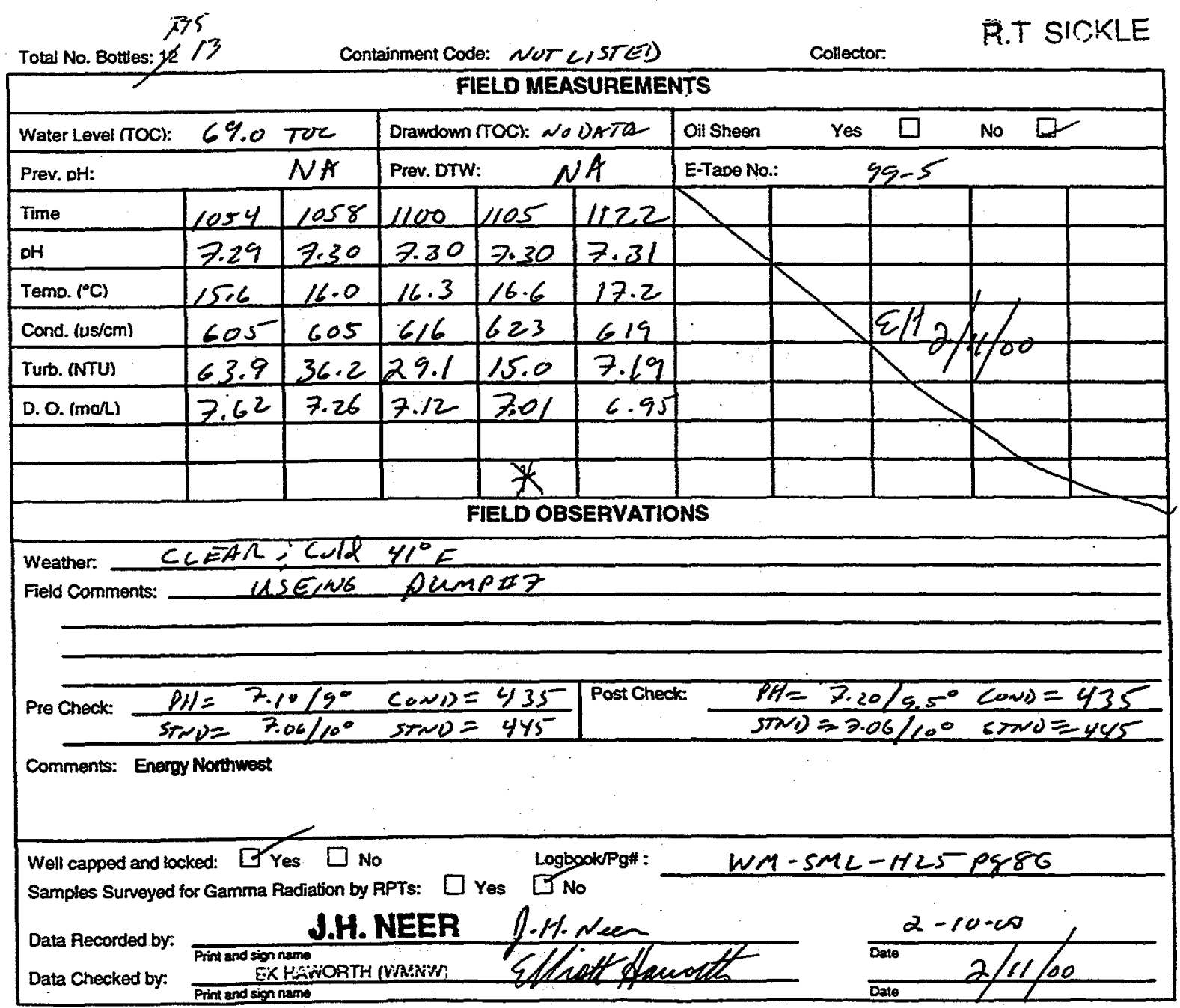




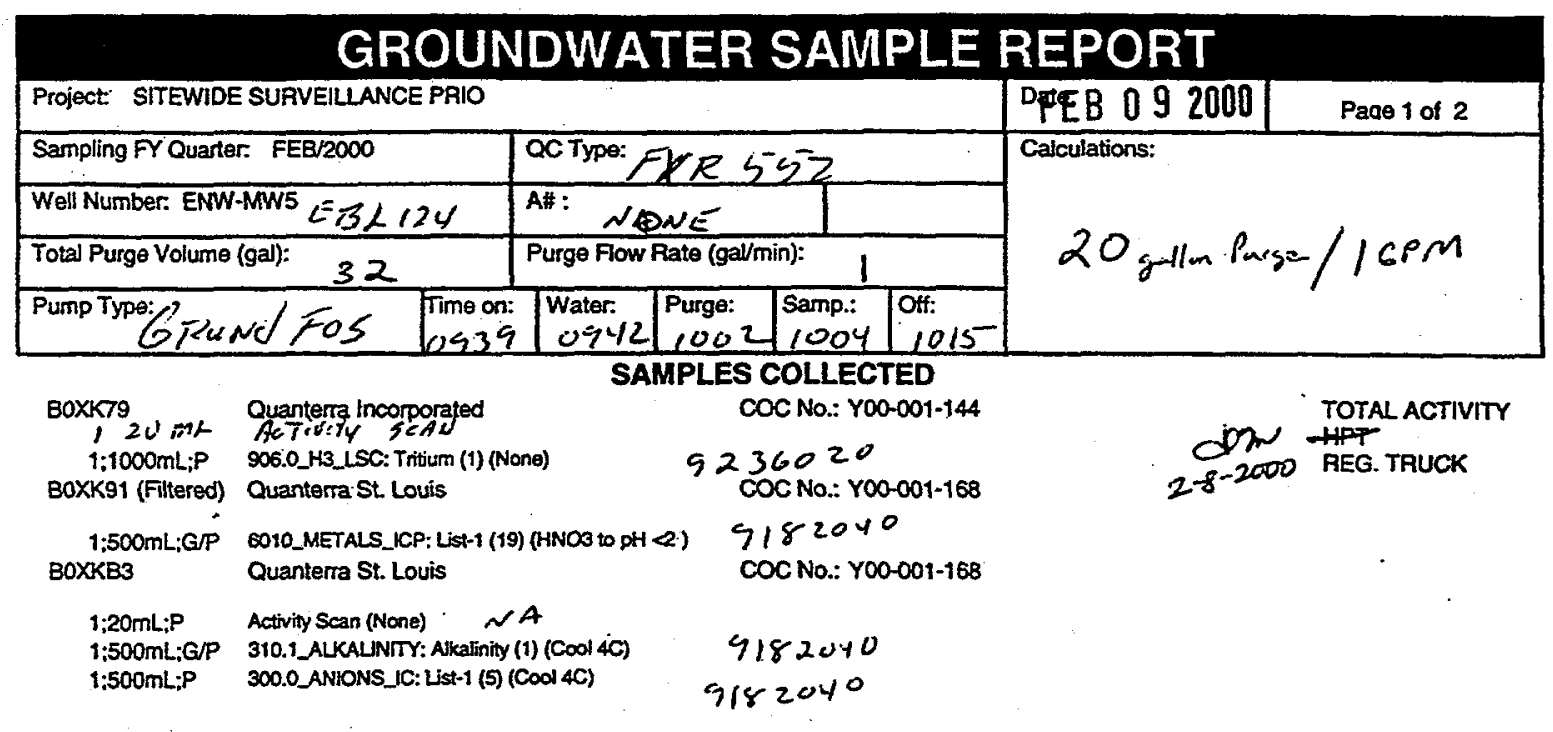

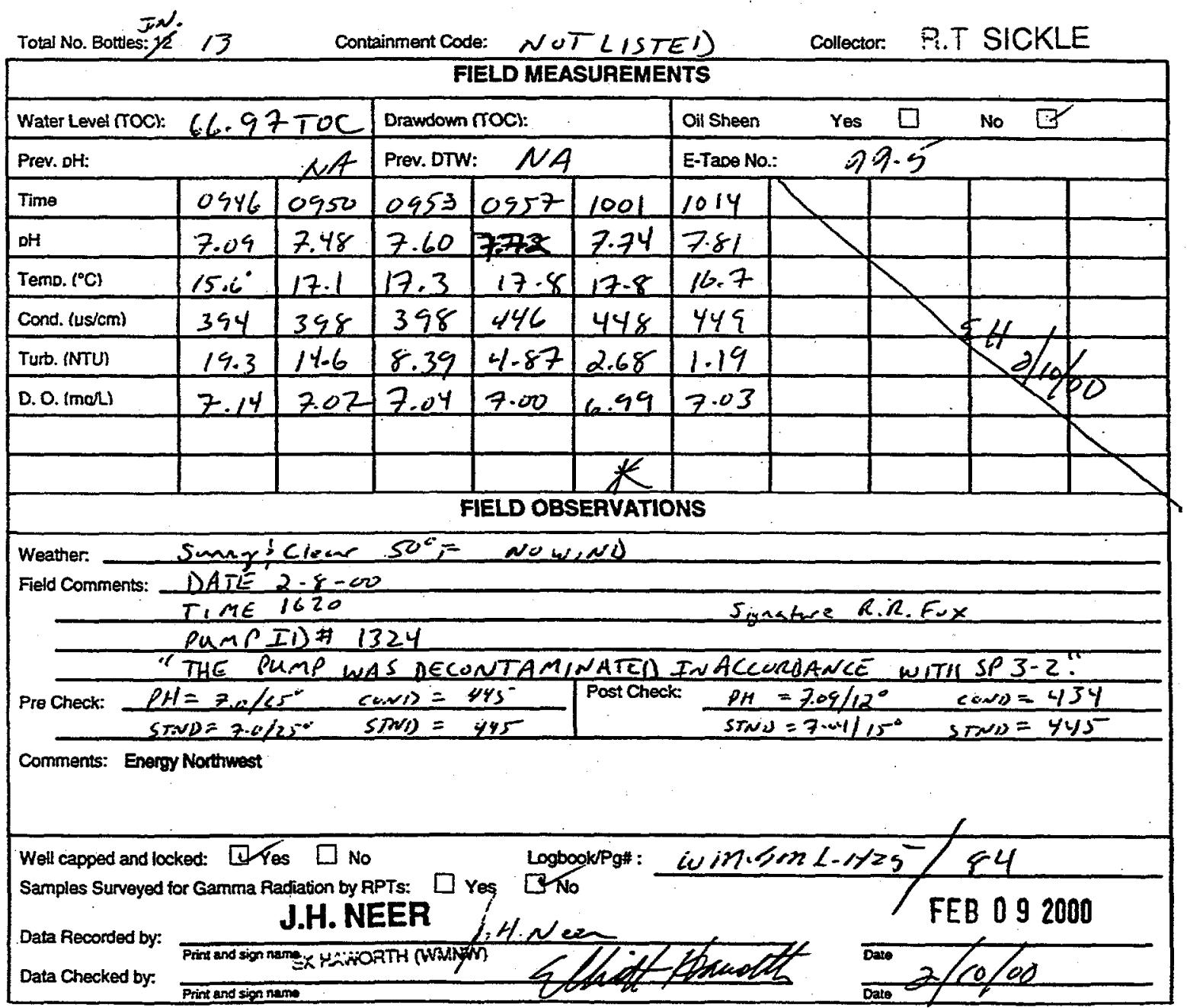

B. 15 


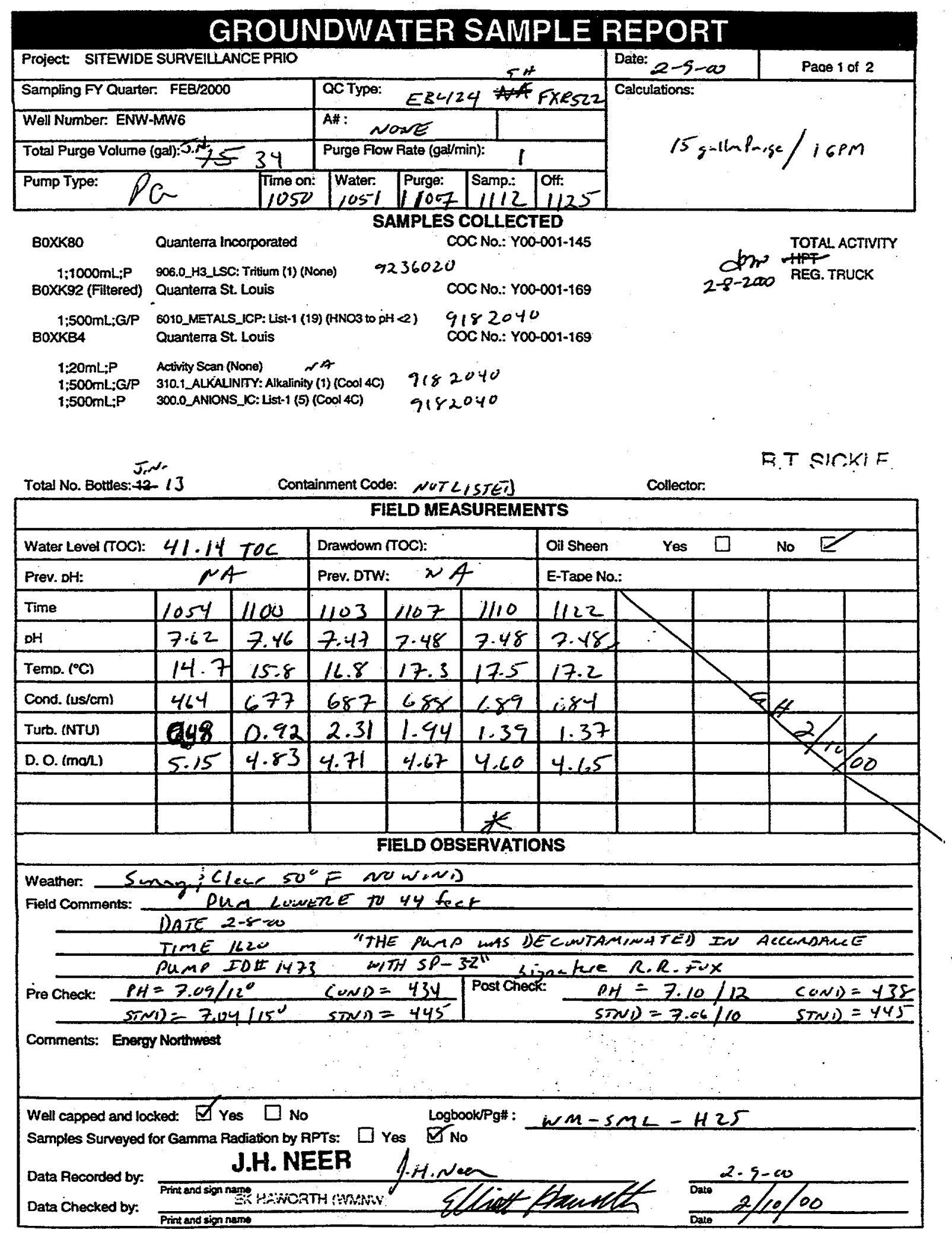









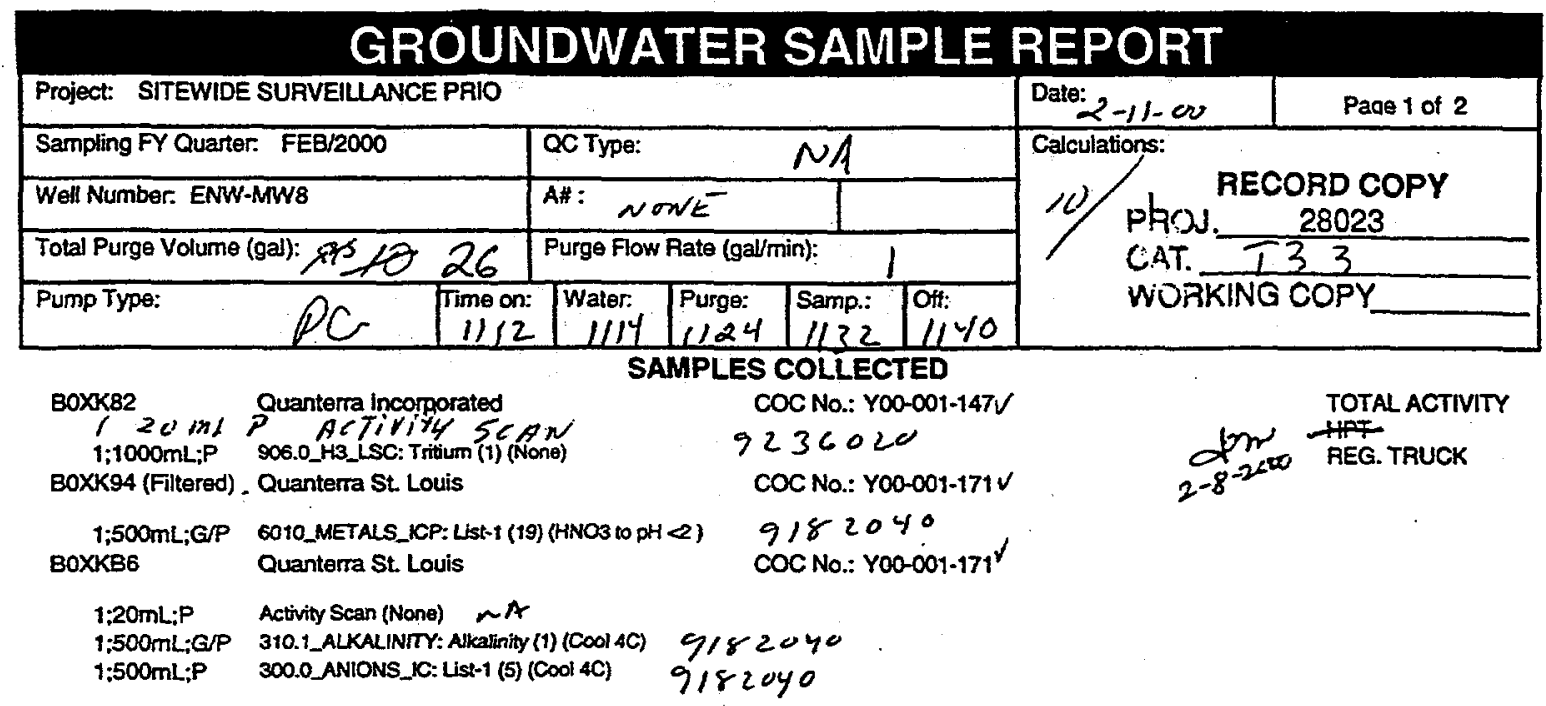

Total No. Bottles: 12

Containment Code: NOT LISTED

R.T SICKLE

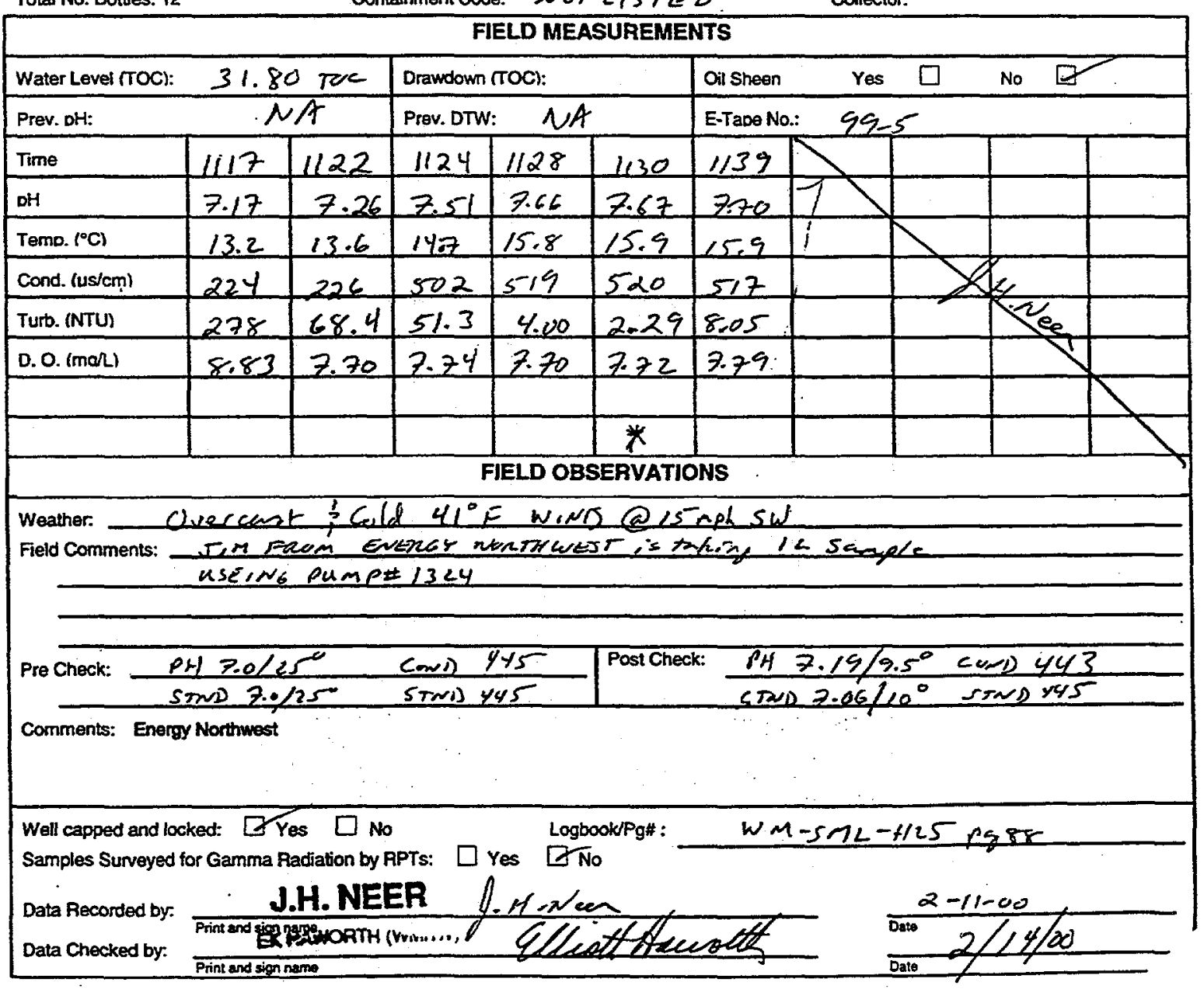




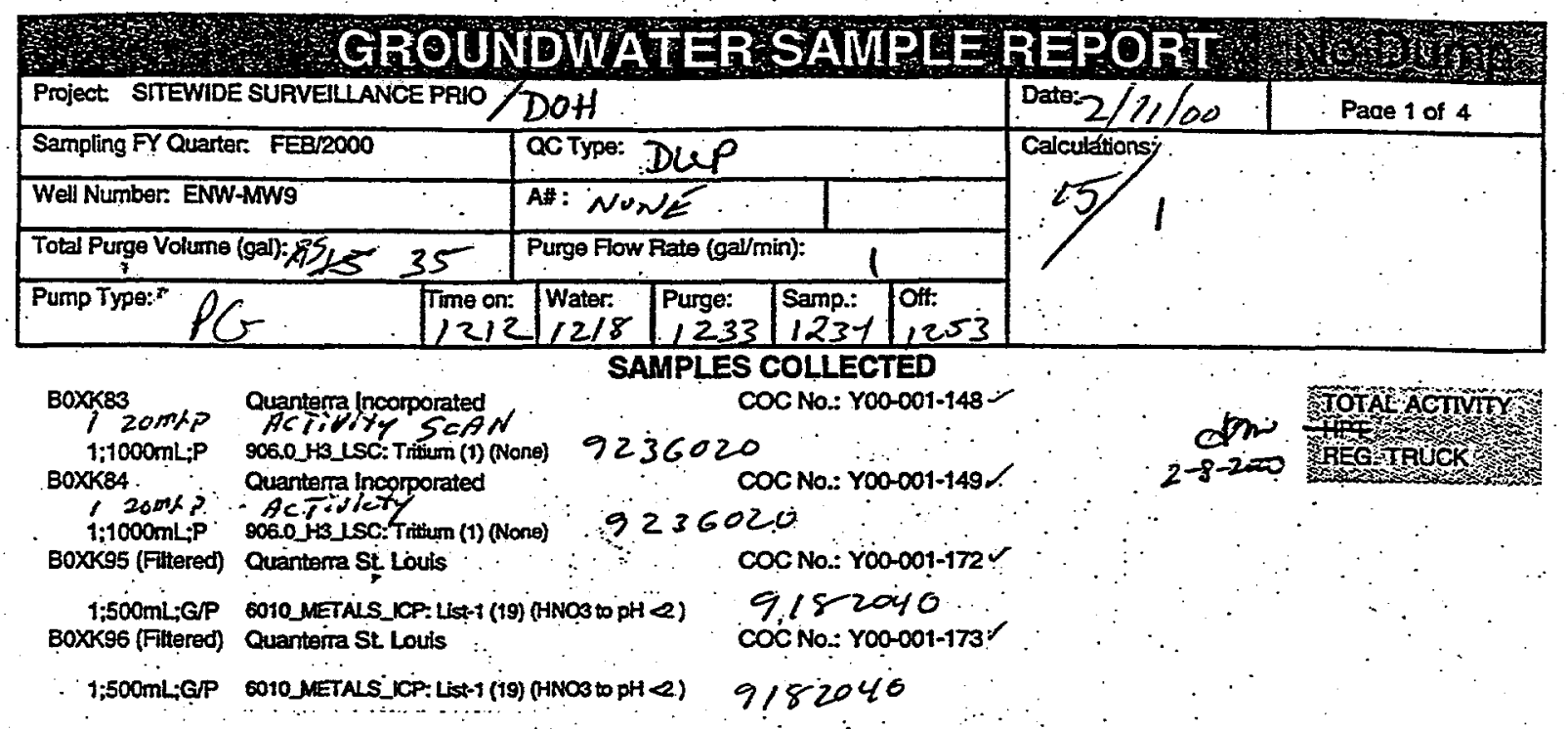

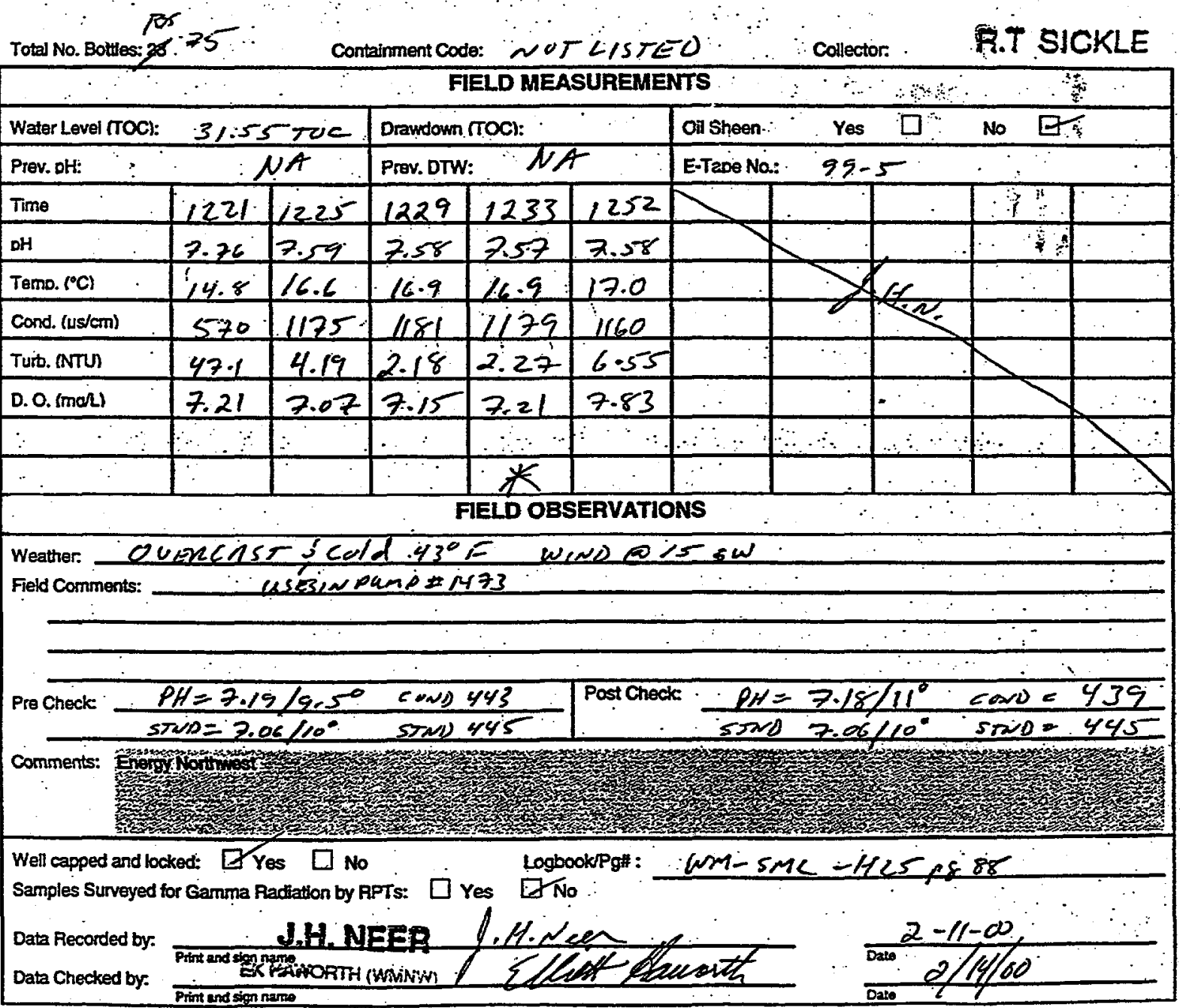




\begin{tabular}{|c|c|c|c|c|c|}
\hline \multicolumn{4}{|c|}{ Project: STTEWIDE SURVEILLANCE PRIO $/ \mathrm{DOH}$} & DAEB 082000 & Paqe 1 of 2 \\
\hline \multicolumn{2}{|c|}{ Sampling FY Quarter: FEB/2000 } & QC Typ: $-\sigma$ & & \multirow{4}{*}{\multicolumn{2}{|c|}{ Calculations: }} \\
\hline \multicolumn{2}{|c|}{ Well Number ENW-31 $(M W 31)$} & A\#: $\quad-6$ & & & \\
\hline \multicolumn{2}{|c|}{ Total Purge Volume (gal): } & \multicolumn{2}{|c|}{ Purge Flow Rate (gal/min): } & & \\
\hline \multicolumn{2}{|c|}{ Pump Type: } & \begin{tabular}{|l|l|l|} 
Water & Purge: \\
\end{tabular} & 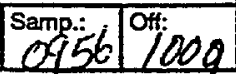 & & \\
\hline \multicolumn{6}{|c|}{ SAMPLES COLLECTED } \\
\hline \multirow{2}{*}{$\begin{array}{l}\text { BoXK85 } \\
\quad \begin{array}{l}1 ; 1000 \mathrm{~mL}: P \\
80 \times K 97 \text { (Filtered) }\end{array}\end{array}$} & Quanterra Incorporated & \multicolumn{2}{|c|}{ COCNo.: YOO-001-150 } & \multirow{2}{*}{\multicolumn{2}{|c|}{$\begin{array}{l}\text { FOTALACTMT } \\
\text { HFF } \\
\text { HEG. THEK }\end{array}$}} \\
\hline & \multicolumn{3}{|c|}{ S06.0_H3_LSC: Tritium (1) (None) 9236020} & & \\
\hline 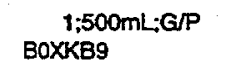 & \multicolumn{3}{|c|}{$\begin{array}{l}\text { 6010_METALS_ICP: LSt-1 (19) (HNOS to pH 2) } 73180 / 0 \\
\text { Quanterra St. Louis } \\
\text { COC No. Y00-001-174 }\end{array}$} & & \\
\hline $\begin{array}{l}1: 20 \mathrm{~mL} ; P \\
1: 500 \mathrm{~mL}: G / P \\
1: 500 \mathrm{~mL} ; P\end{array}$ & \multicolumn{3}{|c|}{$\begin{array}{l}\text { Activity Scan (None) } \\
\text { 310.1_ALKALINTY: Alkalinity (1) (Cool 4C) } 9182040 \\
\text { 300.0_ANIONS_KC: List-1 (5) (Cool 4C) }\end{array}$} & & \\
\hline
\end{tabular}

Total No. Bottles: 11

Containment Code:

collect th. JONES

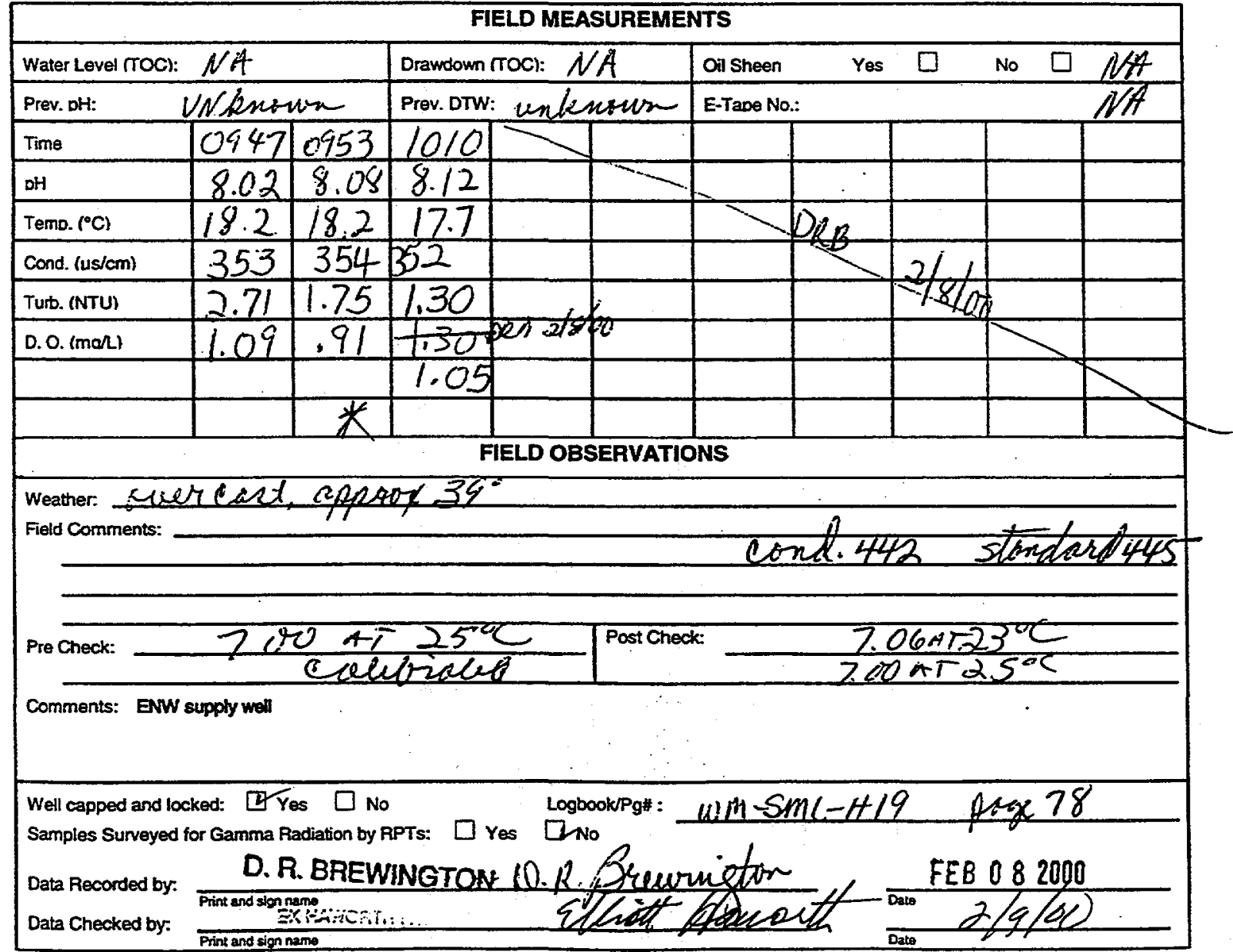




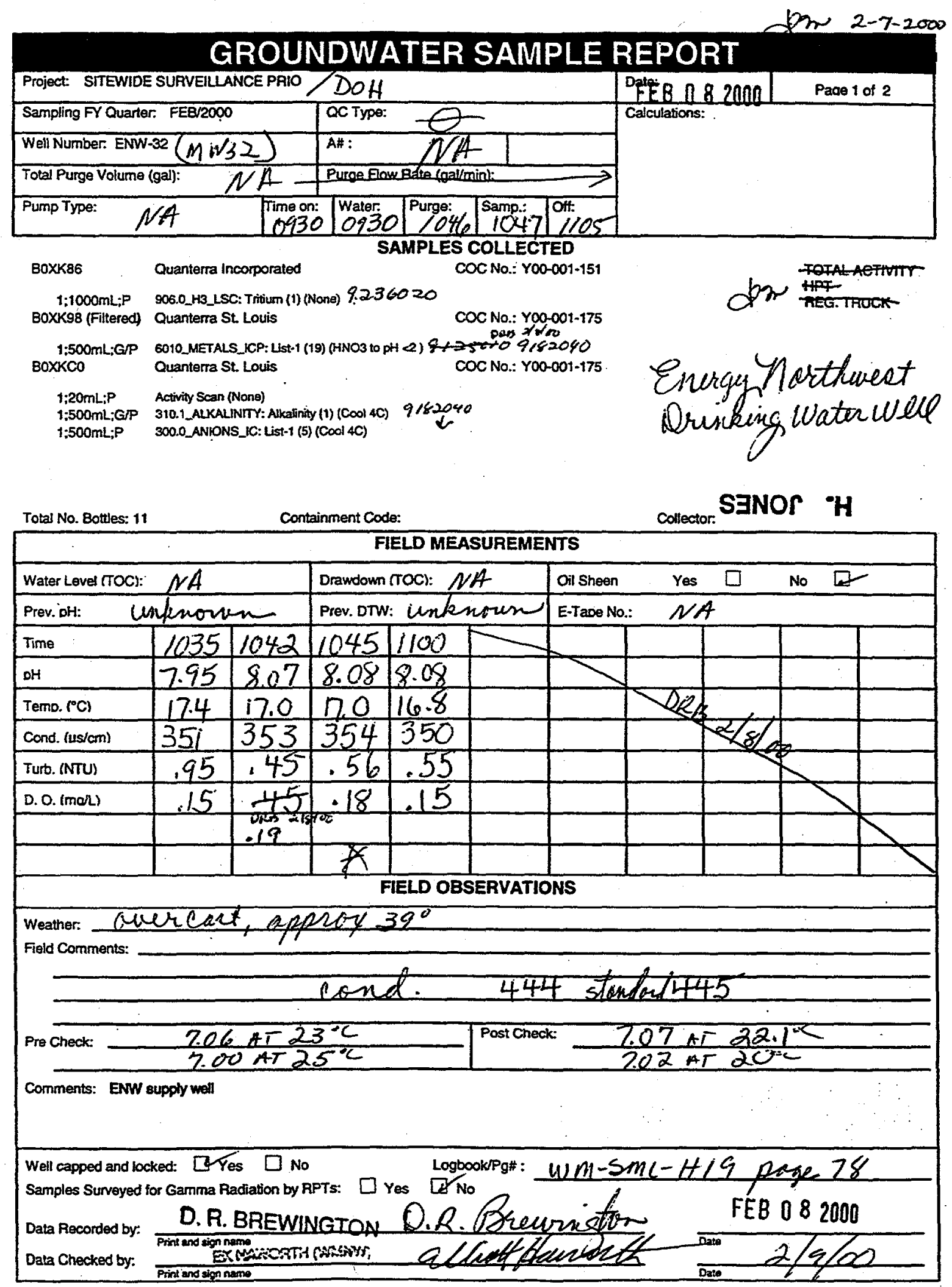




\section{Appendix C}

\section{Analytical Results for Phase I Evaluation of the}

618-11 Burial Ground 
Table C.1. Tritium Results for 618-11 Burial Ground Investigation, February 2000

\begin{tabular}{|c|c|c|c|c|c|c|c|}
\hline Constituent & Sample Number & Well Name & Sample Date & $\begin{array}{c}\text { Value } \\
\text { Reported }\end{array}$ & Units & $\begin{array}{c}\text { Lab } \\
\text { Qualifier }^{(a)}\end{array}$ & MDA \\
\hline Tritium & BOXJW7 & 699-10-E12 & $02 / 08 / 2000$ & $2.32 \mathrm{E}+04$ & $\mathrm{pCi} / \mathrm{L}$ & & $2.73 E+02$ \\
\hline Tritium & BOXK00 & 699-12-4D & $02 / 07 / 2000$ & $1.85 \mathrm{E}+03$ & $\mathrm{pCi} / \mathrm{L}$ & & $2.71 E+02$ \\
\hline Tritium & BOXK01 & $699-13-1 \mathrm{~A}$ & $02 / 08 / 2000$ & $2.33 \mathrm{E}+04$ & $\mathrm{pCi} / \mathrm{L}$ & & $2.57 \mathrm{E}+02$ \\
\hline Tritium $^{\text {(b) }}$ & BOXK01 DUP & 699-13-1 A DUP & $02 / 08 / 2000$ & $2.40 \mathrm{E}+04$ & $\mathrm{pCi} / \mathrm{L}$ & & $2.57 \mathrm{E}+02$ \\
\hline Tritium & BOXK29 & $699-13-1 B$ & $02 / 08 / 2000$ & $3.00 \mathrm{E}+02$ & $\mathrm{pCi} / \mathrm{L}$ & $\mathrm{J}$ & $2.58 \mathrm{E}+02$ \\
\hline Tritium & BOXK30 & $699-13-1 \mathrm{C}$ & $02 / 08 / 2000$ & $1.10 \mathrm{E}+02$ & $\mathrm{pCi} / \mathrm{L}$ & $\mathrm{U}$ & $2.55 \mathrm{E}+02$ \\
\hline Tritium & $\mathrm{B} 0 \mathrm{XK} 47$ & 699-13-3A & $02 / 07 / 2000$ & $7.23 \mathrm{E}+06$ & $\mathrm{pCi} / \mathrm{L}$ & & $4.87 E+02$ \\
\hline Tritium & $\mathrm{B} 0 \mathrm{XK} 48$ & $699-13-3 \mathrm{~A}$ & $02 / 07 / 2000$ & $6.89 \mathrm{E}+06$ & $\mathrm{pCi} / \mathrm{L}$ & & $4.73 E+02$ \\
\hline Tritium & BOXK49 & $699-15-15 B$ & $02 / 08 / 2000$ & $7.00 \mathrm{E}+01$ & $\mathrm{pCi} / \mathrm{L}$ & $\mathrm{U}$ & $2.57 \mathrm{E}+02$ \\
\hline Tritium & BOXK55 & $699-17-5$ & $02 / 07 / 2000$ & $8.15 \mathrm{E}+01$ & $\mathrm{pCi} / \mathrm{L}$ & $\mathrm{U}$ & $2.73 E+02$ \\
\hline Tritium & BOXK57 & $699-21-6$ & $02 / 07 / 2000$ & $2.13 \mathrm{E}+04$ & $\mathrm{pCi} / \mathrm{L}$ & & $2.73 E+02$ \\
\hline Tritium & BOXK58 & $699-8-17$ & $02 / 08 / 2000$ & $5.44 \mathrm{E}+04$ & $\mathrm{pCi} / \mathrm{L}$ & & $2.73 \mathrm{E}+02$ \\
\hline Tritium & BOXK59 & 699-9-E2 & $02 / 10 / 2000$ & $1.75 \mathrm{E}+03$ & $\mathrm{pCi} / \mathrm{L}$ & & $2.80 \mathrm{E}+02$ \\
\hline Tritium $^{\text {(b) }}$ & BOXK59 DUP & 699-9-E2 DUP & $02 / 10 / 2000$ & $1.67 \mathrm{E}+03$ & $\mathrm{pCi} / \mathrm{L}$ & & $2.82 \mathrm{E}+02$ \\
\hline Tritium & BOXK75 & C3071/ENW-MW1 & $02 / 09 / 2000$ & $1.04 \mathrm{E}+04$ & $\mathrm{pCi} / \mathrm{L}$ & & $2.72 E+02$ \\
\hline Tritium $^{(\mathrm{b})}$ & BOXK75 DUP & C3071/ENW-MW1 DUP & $02 / 09 / 2000$ & $1.00 \mathrm{E}+04$ & $\mathrm{pCi} / \mathrm{L}$ & & $2.72 \mathrm{E}+02$ \\
\hline Tritium & BOXK 76 & C3072/ENW-MW2 & $02 / 10 / 2000$ & $1.85 \mathrm{E}+03$ & $\mathrm{pCi} / \mathrm{L}$ & & $2.79 \mathrm{E}+02$ \\
\hline Tritium & BOXK77 & C3073/ENW-MW3 & $02 / 10 / 2000$ & $1.16 \mathrm{E}+03$ & $\mathrm{pCi} / \mathrm{L}$ & & $2.82 \mathrm{E}+02$ \\
\hline Tritium & BOXK78 & C3074/ENW-MW4 & $02 / 10 / 2000$ & $1.20 \mathrm{E}+04$ & $\mathrm{pCi} / \mathrm{L}$ & & $2.79 \mathrm{E}+02$ \\
\hline Tritium & BOXK79 & C3075/ENW-MW5 & $02 / 09 / 2000$ & $1.41 \mathrm{E}+04$ & $\mathrm{pCi} / \mathrm{L}$ & & $2.72 \mathrm{E}+02$ \\
\hline Tritium & BOXK80 & C3076/ENW-MW6 & $02 / 09 / 2000$ & $3.79 E+03$ & $\mathrm{pCi} / \mathrm{L}$ & & $2.73 \mathrm{E}+02$ \\
\hline Tritium & B0XK81 & C3077/ENW-MW7 & $02 / 15 / 2000$ & $5.10 \mathrm{E}+01$ & $\mathrm{pCi} / \mathrm{L}$ & $\mathrm{U}$ & $2.69 \mathrm{E}+02$ \\
\hline Tritium $^{(\mathrm{b})}$ & B0XK81 DUP & C3077/ENW-MW7 DUP & $02 / 15 / 2000$ & $6.48 \mathrm{E}+01$ & $\mathrm{pCi} / \mathrm{L}$ & $\mathrm{U}$ & $2.73 \mathrm{E}+02$ \\
\hline Tritium & B0XK82 & C3078/ENW-MW8 & $02 / 11 / 2000$ & $3.51 \mathrm{E}+02$ & $\mathrm{pCi} / \mathrm{L}$ & $\mathrm{J}$ & $3.09 E+02$ \\
\hline Tritium $^{(b)}$ & B0XK82 DUP & C3078/ENW-MW8 DUP & $02 / 11 / 2000$ & $5.02 \mathrm{E}+02$ & $\mathrm{pCi} / \mathrm{L}$ & & $3.04 E+02$ \\
\hline Tritium & B0XK83 & C3079/ENW-MW9 & $02 / 11 / 2000$ & $2.43 \mathrm{E}+03$ & $\mathrm{pCi} / \mathrm{L}$ & & $3.01 E+02$ \\
\hline Tritium & B0XK84 & C3079/ENW-MW9 & $02 / 11 / 2000$ & $2.84 \mathrm{E}+03$ & $\mathrm{pCi} / \mathrm{L}$ & & $3.03 E+02$ \\
\hline Tritium & BOXK85 & ENW-31 & $02 / 08 / 2000$ & $-3.98 \mathrm{E}+01$ & $\mathrm{pCi} / \mathrm{L}$ & $\mathrm{U}$ & $2.74 \mathrm{E}+02$ \\
\hline Tritium & BOXK86 & ENW-32 & $02 / 08 / 2000$ & $-3.51 \mathrm{E}+01$ & $\mathrm{pCi} / \mathrm{L}$ & $\mathrm{U}$ & $2.72 \mathrm{E}+02$ \\
\hline \multicolumn{8}{|c|}{ Quality Control Samples } \\
\hline Tritium $^{(c)}$ & BOXK60 & EBL 121/699-13-3A & $02 / 07 / 2000$ & $9.93 \mathrm{E}+01$ & $\mathrm{pCi} / \mathrm{L}$ & $\mathrm{U}$ & $2.72 \mathrm{E}+02$ \\
\hline Tritium $^{(b, c)}$ & BOXK60 DUP & EBL 121/699-13-3A DUP & $02 / 07 / 2000$ & $1.76 \mathrm{E}+02$ & $\mathrm{pCi} / \mathrm{L}$ & $\mathrm{U}$ & $2.72 \mathrm{E}+02$ \\
\hline Tritium $^{(\mathrm{d})}$ & BOXK61 & EBL 122/699-13-3A & $02 / 07 / 2000$ & $1.79 \mathrm{E}+02$ & $\mathrm{pCi} / \mathrm{L}$ & $\mathrm{U}$ & $2.74 \mathrm{E} \div 02$ \\
\hline Tritium & BOXK62 & EBL123/699-13-1B & $02 / 08 / 2000$ & $8.45 \mathrm{E}+01$ & $\mathrm{pCi} / \mathrm{L}$ & $\mathrm{U}$ & $2.73 \mathrm{E}+02$ \\
\hline Tritium & BOXK63 & EBL124/C3075/ENW-MW5 & $02 / 09 / 2000$ & $2.31 \mathrm{E}+02$ & $\mathrm{pCi} / \mathrm{L}$ & $\mathrm{U}$ & $2.56 \mathrm{E}+02$ \\
\hline Tritium & BOXK66 & FTB 322/699-13-3A & $02 / 07 / 2000$ & $7.04 \mathrm{E}+01$ & $\mathrm{pCi} / \mathrm{L}$ & $\mathrm{U}$ & $2.72 \mathrm{E}+02$ \\
\hline Tritium & BOXK67 & FTB $323 / 699-21-6$ & $02 / 07 / 2000$ & $1.30 \mathrm{E}+02$ & $\mathrm{pCi} / \mathrm{L}$ & $\mathrm{U}$ & $2.73 \mathrm{E}+02$ \\
\hline $\begin{array}{ll}\text { (a) } & \mathrm{U}=\mathrm{Res} \\
& \mathrm{J}=\text { Esti } \\
\text { (b) } & \text { Lab dup } \\
\text { (c) Before } \\
\text { (d) After sa }\end{array}$ & $\begin{array}{l}\text { sult is less than the } \\
\text { imated result (J qual } \\
\text { plicate. } \\
\text { sampling. } \\
\text { ampling. }\end{array}$ & $\begin{array}{l}\text { minimum detectable activity } \\
\text { alifier has not been assigned to }\end{array}$ & $\begin{array}{l}\text { (MDA). } \\
\text { all preliminary }\end{array}$ & & & & \\
\hline
\end{tabular}


Table C.2. Tritium Results for 618-11 Burial Ground Investigation, Thermo NUtech Laboratory, February 2000

\begin{tabular}{|c|c|c|c|c|c|c|c|}
\hline Constituent & Sample Number & Well Name & Sample Date & Value Reported & Units & Lab Qualifier & MDA \\
\hline Tritium & B0XJT5 & $699-13-3 A$ & $02 / 07 / 2000$ & $7.41 \mathrm{E}+06$ & $\mathrm{pCi} / \mathrm{L}$ & & 2200 \\
\hline Tritium $^{(a)}$ & B0XJT5 DUP & 699-13-3A DUP & $02 / 07 / 2000$ & $7.55 \mathrm{E}+06$ & $\mathrm{pCi} / \mathrm{L}$ & & 2200 \\
\hline
\end{tabular}


Table C.3. Radionuclide Results for 618-11 Burial Ground Investigation, February 2000

\begin{tabular}{|c|c|c|c|c|c|c|c|c|}
\hline Constituent & $\begin{array}{c}\text { Sample } \\
\text { Number }\end{array}$ & Well Name & $\begin{array}{c}\text { Sample } \\
\text { Date }\end{array}$ & $\begin{array}{c}\text { Value } \\
\text { Reported }\end{array}$ & Units & $\begin{array}{c}\text { Lab } \\
\text { Qualifier }\end{array}$ & $\begin{array}{c}\text { Reporting } \\
\text { Limit }\end{array}$ & MDA \\
\hline Antimony-125 & $\mathrm{B} 0 \times \mathrm{KK} 02$ & $699-10-\mathrm{E} 12$ & $02 / 08 / 2000$ & $-9.51 E+00$ & $\mathrm{pCi} / \mathrm{L}$ & U & $1.83 E+01$ & $1.83 \mathrm{E}+01$ \\
\hline Beryllium-7 & B0XK02 & 699-10-E12 & $02 / 08 / 2000$ & $-2.02 E+01$ & $\mathrm{pCi} / \mathrm{L}$ & $\mathrm{U}$ & $5.44 \mathrm{E}+01$ & $5.44 \mathrm{E}+01$ \\
\hline Cesium-134 & B0XK02 & 699-10-E12 & $02 / 08 / 2000$ & $-2.97 E+00$ & $\mathrm{pCi} / \mathrm{L}$ & $\mathrm{U}$ & $7.35 \mathrm{E}+00$ & $7.35 \mathrm{E}+00$ \\
\hline Cesium-137 & B0XK02 & 699-10-E12 & $02 / 08 / 2000$ & $3.97 \mathrm{E}-01$ & $\mathrm{pCi} / \mathrm{L}$ & $\mathrm{U}$ & $9.09 \mathrm{E}+00$ & $9.09 \mathrm{E}+00$ \\
\hline Cobalt- 60 & $\mathrm{~B} 0 \mathrm{XK} 02$ & 699-10-E12 & $02 / 08 / 2000$ & $-1.01 \mathrm{E}+00$ & $\mathrm{pCi} / \mathrm{L}$ & $\mathrm{U}$ & $8.87 \mathrm{E}+00$ & $8.87 \mathrm{E}+00$ \\
\hline Europium-152 & $\mathrm{B} 0 \mathrm{XK02}$ & 699-10-E12 & $02 / 08 / 2000$ & $-2.55 \mathrm{E}+00$ & $\mathrm{pCi} / \mathrm{L}$ & $\mathrm{U}$ & $2.11 \mathrm{E}+01$ & $2.11 \mathrm{E}+01$ \\
\hline Europium-154 & B0XK02 & 699-10-E12 & $02 / 08 / 2000$ & $2.11 \mathrm{E}+00$ & $\mathrm{pCi} / \mathrm{L}$ & $U$ & $2.33 \mathrm{E}+01$ & $2.33 \mathrm{E}+01$ \\
\hline Europium-155 & $\mathrm{B} 0 \mathrm{XK} 02$ & 699-10-E12 & $02 / 08 / 2000$ & $4.97 \mathrm{E}+00$ & $\mathrm{pCi} / \mathrm{L}$ & $\mathrm{U}$ & $1.72 \mathrm{E}+01$ & $1.72 \mathrm{E}+01$ \\
\hline Gross alpha & $\mathrm{B} 0 \mathrm{XK} 02$ & 699-10-E12 & $02 / 08 / 2000$ & $3.71 \mathrm{E}+00$ & $\mathrm{pCi} / \mathrm{L}$ & & $1.79 \mathrm{E}+00$ & $1.79 \mathrm{E}+00$ \\
\hline Gross beta & B0XK02 & 699-10-E12 & $02 / 08 / 2000$ & $1.09 \mathrm{E}+01$ & $\mathrm{pCi} / \mathrm{L}$ & & $2.99 \mathrm{E}+00$ & $2.99 \mathrm{E}+00$ \\
\hline Iodine- 129 & $\mathrm{~B} 0 \mathrm{XK02}$ & 699-10-E12 & $02 / 08 / 2000$ & $1.78 \mathrm{E}-02$ & $\mathrm{pCi} / \mathrm{L}$ & $\mathrm{U}$ & $2.69 \mathrm{E}-01$ & $2.69 \mathrm{E}-01$ \\
\hline Plutonium-238 & B0XK02 & 699-10-E12 & $02 / 08 / 2000$ & $-2.75 \mathrm{E}-02$ & $\mathrm{pCi} / \mathrm{L}$ & $\mathrm{U}$ & $3.04 \mathrm{E}-01$ & 3.04E-01 \\
\hline Plutonium-239/240 & B0XK02 & 699-10-E12 & $02 / 08 / 2000$ & $-3.93 E-03$ & $\mathrm{pCi} / \mathrm{L}$ & $\mathrm{U}$ & $1.98 \mathrm{E}-01$ & $1.98 \mathrm{E}-01$ \\
\hline Potassium-40 & $\mathrm{B} 0 \mathrm{XK02}$ & 699-10-E12 & $02 / 08 / 2000$ & $-5.01 \mathrm{E}+01$ & $\mathrm{pCi} / \mathrm{L}$ & $\mathrm{U}$ & $1.96 \mathrm{E}+02$ & $1.96 \mathrm{E}+02$ \\
\hline Ruthenium-106 & $\mathrm{B} 0 \mathrm{XK02}$ & 699-10-E12 & $02 / 08 / 2000$ & $-1.46 \mathrm{E}+01$ & $\mathrm{pCi} / \mathrm{L}$ & $\mathrm{U}$ & $6.72 \mathrm{E}+01$ & $6.72 \mathrm{E}+01$ \\
\hline Technetium-99 & $\mathrm{B} 0 \mathrm{XK02}$ & 699-10-E12 & $02 / 08 / 2000$ & $8.55 \mathrm{E}+01$ & $\mathrm{pCi} / \mathrm{L}$ & & $1.23 \mathrm{E}+01$ & $1.23 \mathrm{E}+01$ \\
\hline $\begin{array}{l}\text { Total beta } \\
\text { radiostrontium }\end{array}$ & $\mathrm{B} 0 \mathrm{XK02}$ & 699-10-E12 & $02 / 08 / 2000$ & $-8.58 \mathrm{E}-02$ & $\mathrm{pCi} / \mathrm{L}$ & $\mathrm{U}$ & $8.11 \mathrm{E}-01$ & $8.11 \mathrm{E}-01$ \\
\hline Uranium & $\mathrm{B} 0 \mathrm{XK} 02$ & 699-10-E12 & $02 / 08 / 2000$ & $5.15 \mathrm{E}+00$ & $\mathrm{ug} / \mathrm{L}$ & & 7.29E-02 & $7.29 \mathrm{E}-02$ \\
\hline Uranium-234 & $\mathrm{B0XK02}$ & 699-10-E12 & $02 / 08 / 2000$ & $2.37 \mathrm{E}+00$ & $\mathrm{pCi} / \mathrm{L}$ & & $3.61 \mathrm{E}-01$ & $3.61 E-01$ \\
\hline Uranium-235 & $\mathrm{B} 0 \mathrm{XK02}$ & $699-10-\mathrm{E} 12$ & $02 / 08 / 2000$ & $9.23 \mathrm{E}-02$ & $\mathrm{pCi} / \mathrm{L}$ & $\mathrm{U}$ & $2.62 \mathrm{E}-01$ & $2.62 \mathrm{E}-01$ \\
\hline Uranium-238 & B0XK02 & 699-10-E12 & $02 / 08 / 2000$ & $1.43 \mathrm{E}+00$ & $\mathrm{pCi} / \mathrm{L}$ & & $3.49 \mathrm{E}-01$ & $3.49 \mathrm{E}-01$ \\
\hline Uranium-234 $4^{(\mathrm{b})}$ & $\begin{array}{l}\text { B0XK02 } \\
\text { DUP }\end{array}$ & 699-10-E12 DUP & $02 / 08 / 2000$ & $1.88 \mathrm{E}+00$ & $\mathrm{pCi} / \mathrm{L}$ & & & $1.24 \mathrm{E}+00$ \\
\hline Uranium-235 & $\begin{array}{l}\text { BOXK02 } \\
\text { DUP }\end{array}$ & 699-10-E12 DUP & $02 / 08 / 2000$ & $1.31 \mathrm{E}-01$ & $\mathrm{pCi} / \mathrm{L}$ & $\mathrm{U}$ & & $1.24 \mathrm{E}+00$ \\
\hline Uranium-238 & $\begin{array}{l}\text { BOXK02 } \\
\text { DUP }\end{array}$ & 699-10-E12 DUP & $02 / 08 / 2000$ & $1.04 \mathrm{E}+00$ & $\mathrm{pCi} / \mathrm{L}$ & $\mathrm{U}$ & & $1.09 \mathrm{E}+00$ \\
\hline Antimony-125 & BoXJW0 & 699-12-4D & $02 / 07 / 2000$ & $-5.16 \mathrm{E}+00$ & $\mathrm{pCi} / \mathrm{L}$ & $\mathrm{U}$ & & $1.94 \mathrm{E}+01$ \\
\hline Beryllium-7 & BOXJW0 & 699-12-4D & $02 / 07 / 2000$ & $-9.76 \mathrm{E}+00$ & $\mathrm{pCi} / \mathrm{L}$ & $\mathrm{U}$ & & $6.89 \mathrm{E}+01$ \\
\hline Cesium-134 & B0XJW0 & 699-12-4D & $02 / 07 / 2000$ & $-4.53 E+00$ & $\mathrm{pCi} / \mathrm{L}$ & $U$ & & $5.77 \mathrm{E}+00$ \\
\hline Cesium-137 & BoXJW0 & $699-12-4 \mathrm{D}$ & $02 / 07 / 2000$ & $3.09 \mathrm{E}+00$ & $\mathrm{pCi} / \mathrm{L}$ & $\mathrm{U}$ & & $9.67 \mathrm{E}+00$ \\
\hline Cobalt- 60 & BoXJw0 & 699-12-4D & $02 / 07 / 2000$ & $-1.41 E+00$ & $\mathrm{pCi} / \mathrm{L}$ & $\mathrm{U}$ & & $7.81 \mathrm{E}+00$ \\
\hline Europium-152 & B0XJw0 & $699-12-4 \mathrm{D}$ & $02 / 07 / 2000$ & $-4.75 E+00$ & $\mathrm{pCi} / \mathrm{L}$ & U & & $2.23 \mathrm{E}+01$ \\
\hline Europium-154 & B0XJw0 & 699-12-4D & $02 / 07 / 2000$ & $-8.12 E+00$ & $\mathrm{pCi} / \mathrm{L}$ & $\mathrm{U}$ & & $2.10 \mathrm{E}+01$ \\
\hline Europium-155 & BOXJWO & 699-12-4D & $02 / 07 / 2000$ & $2.67 \mathrm{E}+00$ & $\mathrm{pCi} / \mathrm{L}$ & $\mathrm{U}$ & & $1.51 \mathrm{E}+01$ \\
\hline Gross alpha & BOXJW0 & 699-12-4D & $02 / 07 / 2000$ & $3.44 \mathrm{E}+00$ & $\mathrm{pCi} / \mathrm{L}$ & & & $1.80 \mathrm{E}+00$ \\
\hline Gross beta & BoXJW0 & 699-12-4D & $02 / 07 / 2000$ & $7.63 \mathrm{E}+00$ & $\mathrm{pCi} / \mathrm{L}$ & & & $2.81 \mathrm{E}+00$ \\
\hline Iodine-129 & B0XJW0 & $699-12-4 D$ & $02 / 07 / 2000$ & $-1.88 \mathrm{E}-02$ & $\mathrm{pCi} / \mathrm{L}$ & $\mathrm{U}$ & & $2.93 \mathrm{E}-01$ \\
\hline Plutonium-238 & B0XJw0 & 699-12-4D & $02 / 07 / 2000$ & $-3.55 \mathrm{E}-03$ & $\mathrm{pCi} / \mathrm{L}$ & $\mathrm{U}$ & & $1.78 \mathrm{E}-01$ \\
\hline Plutonium-239/240 & BOXJW0 & 699-12-4D & $02 / 07 / 2000$ & $0.00 \mathrm{E}+00$ & $\mathrm{pCi} / \mathrm{L}$ & $\mathrm{U}$ & & $1.20 \mathrm{E}-01$ \\
\hline
\end{tabular}


Table C.3. (contd)

\begin{tabular}{|c|c|c|c|c|c|c|c|c|}
\hline Constituent & $\begin{array}{c}\text { Sample } \\
\text { Number }\end{array}$ & Well Name & $\begin{array}{c}\text { Sample } \\
\text { Date }\end{array}$ & $\begin{array}{c}\text { Value } \\
\text { Reported }\end{array}$ & Units & $\begin{array}{c}\text { Lab } \\
\text { Qualifier }\end{array}$ & \begin{tabular}{|c} 
Reporting \\
Limit
\end{tabular} & MDA \\
\hline Potassium-40 & B0XJWO & 699-12-4D & $02 / 07 / 2000$ & $6.15 \mathrm{E}+01$ & $\mathrm{pCi} / \mathrm{L}$ & $\mathrm{U}$ & & $1.05 \mathrm{E}+02$ \\
\hline Ruthenium-106 & BOXJW0 & 699-12-4D & $02 / 07 / 2000$ & $-1.11 \mathrm{E}+01$ & $\mathrm{pCi} / \mathrm{L}$ & $\mathrm{U}$ & & $6.97 \mathrm{E}+(01$ \\
\hline Strontium- $89 / 90$ & BOXJW0 & 699-12-4D & $02 / 07 / 2000$ & $-1.20 \mathrm{E}-01$ & $\mathrm{pCi} / \mathrm{L}$ & $\mathrm{U}$ & & $6.06 \mathrm{E}-01$ \\
\hline Technetium- 99 & B0XJW0 & 699-12-4D & $02 / 07 / 2000$ & $5.17 \mathrm{E}+00$ & $\mathrm{pCi} / \mathrm{L}$ & $\mathrm{U}$ & & $1.23 \mathrm{E}+01$ \\
\hline Uranium & BOXJW0 & 699-12-4D & $02 / 07 / 2000$ & $5.87 \mathrm{E}+00$ & $\mathrm{ug} / \mathrm{L}$ & & & $7.29 \mathrm{E}-02$ \\
\hline Uranium-234 & BOXJWO & 699-12-4D & $02 / 07 / 2000$ & $1.80 \mathrm{E}+00$ & $\mathrm{pCi} / \mathrm{L}$ & & & 3.53E-01 \\
\hline Uranium-235 & BOXJW0 & $699-12-4 \mathrm{D}$ & $02 / 07 / 2000$ & $2.35 \mathrm{E}-02$ & $\mathrm{pCi} / \mathrm{L}$ & $U$ & & $2.68 \mathrm{E}-01$ \\
\hline Uranium-238 & B0XJW0 & 699-12-4D & $02 / 07 / 2000$ & $1.91 \mathrm{E}+00$ & $\mathrm{pCi} / \mathrm{L}$ & & & $3.01 \mathrm{E}-01$ \\
\hline Uranium $^{(b)}$ & $\begin{array}{l}\text { B0XJW0 } \\
\text { DUP }\end{array}$ & 699-12-4D DUP & $02 / 07 / 2000$ & $5.70 \mathrm{E}+00$ & $\mathrm{ug} / \mathrm{L}$ & & & $7.29 \mathrm{E}-\mathrm{C} 2$ \\
\hline Antimony-125 & B0XJW9 & 699-13-1A & $02 / 08 / 2000$ & $-9.44 E+00$ & $\mathrm{pCi} / \mathrm{L}$ & $\mathrm{U}$ & $2.12 \mathrm{E}+01$ & $2.12 \mathrm{E}+101$ \\
\hline Beryllium-7 & B0XJW9 & $699-13-1 A$ & $02 / 08 / 2000$ & $7.57 \mathrm{E}+00$ & $\mathrm{pCi} / \mathrm{L}$ & $\mathrm{U}$ & $7.52 \mathrm{E} \div 01$ & $7.52 \mathrm{E}+01$ \\
\hline Cesium-134 & B0XJW9 & 699-13-1A & $02 / 08 / 2000$ & $-4.72 E+00$ & $\mathrm{pCi} / \mathrm{L}$ & $\mathrm{U}$ & $8.59 \mathrm{E}+00$ & $8.59 \mathrm{E}+00$ \\
\hline Cesium-137 & B0XJW9 & 699-13-1A & $02 / 08 / 2000$ & $-2.66 \mathrm{E}+00$ & $\mathrm{pCi} / \mathrm{L}$ & $\mathrm{U}$ & $7.86 \mathrm{E}+00$ & $7.86 \mathrm{E} \div 00$ \\
\hline Cobalt-60 & B0XJW9 & $699-13-1 \mathrm{~A}$ & $02 / 08 / 2000$ & $1.08 \mathrm{E}+00$ & $\mathrm{pCi} / \mathrm{L}$ & $\mathrm{U}$ & $1.06 \mathrm{E}+01$ & $1.06 \mathrm{E}+01$ \\
\hline Europium-152 & B0XJw9 & $699-13-1 \mathrm{~A}$ & $02 / 08 / 2000$ & $6.04 \mathrm{E}+00$ & $\mathrm{pCi} / \mathrm{L}$ & $\mathrm{U}$ & $2.47 E+01$ & $2.47 \mathrm{E}+01$ \\
\hline Europium-154 & B0XJW9 & 699-13-1A & $02 / 08 / 2000$ & $-1.45 E+01$ & $\mathrm{pCi} / \mathrm{L}$ & $\mathrm{U}$ & $2.41 E+01$ & $2.41 \mathrm{E}+01$ \\
\hline Europium-155 & B0XJW9 & 699-13-1A & $02 / 08 / 2000$ & $1.28 \mathrm{E}+01$ & $\mathrm{pCi} / \mathrm{L}$ & $\mathrm{U}$ & $2.19 E+01$ & $2.19 \mathrm{E}+01$ \\
\hline Gross alpha & B0XJW9 & $699-13-1 \mathrm{~A}$ & $02 / 08 / 2000$ & $4.16 \mathrm{E}+00$ & $\mathrm{pCi} / \mathrm{L}$ & & $1.93 \mathrm{E}+00$ & $1.93 \mathrm{E}+00$ \\
\hline Gross beta & B0XJw9 & $699-13-1 A$ & $02 / 08 / 2000$ & $9.61 \mathrm{E}+00$ & $\mathrm{pCil}$ & & $2.99 \mathrm{E}+00$ & $2.99 \mathrm{E}+00$ \\
\hline lodine-129 & B0XJW9 & $699-13-1 \mathrm{~A}$ & $02 / 08 / 2000$ & $1.29 \mathrm{E}-01$ & $\mathrm{pCi} / \mathrm{L}$ & $\mathrm{U}$ & 2.52E-01 & $2.52 \mathrm{E}-01$ \\
\hline Plutonium-238 & B0XJW9 & $699-13-1 \mathrm{~A}$ & $02 / 08 / 2000$ & $0.00 \mathrm{E}+00$ & $\mathrm{pCi} / \mathrm{L}$ & $\mathrm{U}$ & $9.84 \mathrm{E}-02$ & $9.84 \mathrm{E}-102$ \\
\hline Plutonium-239/240 & BoXJW9 & $699-13-1 A$ & $02 / 08 / 2000$ & $0.00 \mathrm{E}+00$ & $\mathrm{pCi} / \mathrm{L}$ & $\mathrm{U}$ & $9.84 \mathrm{E}-02$ & $9.84 \mathrm{E}-02$ \\
\hline Potassium-40 & BoXJW9 & $699-13-1 \mathrm{~A}$ & $02 / 08 / 2000$ & $-1.06 \mathrm{E}+02$ & $\mathrm{pCi} / \mathrm{L}$ & $\mathrm{U}$ & $2.06 E+02$ & $2.06 \mathrm{E}+02$ \\
\hline Ruthenium-106 & B0XJW9 & 699-13-1A & $02 / 08 / 2000$ & $6.06 \mathrm{E}+00$ & $\mathrm{pCi} / \mathrm{L}$ & $\mathrm{U}$ & $7.94 E+01$ & $7.94 \mathrm{E}+01$ \\
\hline Technetium-99 & B०XJW9 & 699-13-1A & $02 / 08 / 2000$ & $3.01 \mathrm{E}+01$ & $\mathrm{pCi} / \mathrm{L}$ & & $1.22 \mathrm{E}+01$ & $1.22 \mathrm{E}+01$ \\
\hline $\begin{array}{l}\text { Total beta } \\
\text { radiostrontium }\end{array}$ & B0XJW9 & $699-13-1 A$ & $02 / 08 / 2000$ & $2.02 \mathrm{E}-01$ & $\mathrm{pCi} / \mathrm{L}$ & $\mathrm{U}$ & $6.93 \mathrm{E}-01$ & $6.93 \mathrm{E}-101$ \\
\hline Uranium-234 & B0XJW9 & 699-13-1A & $02 / 08 / 2000$ & $2.77 \mathrm{E}+00$ & $\mathrm{pCi} / \mathrm{L}$ & & $2.46 \mathrm{E}-01$ & $2.46 \mathrm{E}-01$ \\
\hline Uranium-235 & B0XJW9 & 699-13-1A & $02 / 08 / 2000$ & $-1.04 \mathrm{E}-02$ & $\mathrm{pCi} / \mathrm{L}$ & $\mathrm{U}$ & $2.17 \mathrm{E}-01$ & 2.17E-01 \\
\hline Uranium-238 & B0XJW9 & $699-13-1 \mathrm{~A}$ & $02 / 08 / 2000$ & $1.29 \mathrm{E}+00$ & $\mathrm{pCi} / \mathrm{L}$ & & 2.32E-01 & $2.32 \mathrm{E}-01$ \\
\hline Gross alpha ${ }^{(b)}$ & $\begin{array}{l}\text { B0XJW9 } \\
\text { DUP }\end{array}$ & 699-13-1A DUP & $02 / 08 / 2000$ & $4.29 E+00$ & $\mathrm{pCi} / \mathrm{L}$ & & & $2.06 \mathrm{E}+00$ \\
\hline Plutonium-238 & $\begin{array}{l}\text { B0XJW9 } \\
\text { DUP }\end{array}$ & 699-13-1A DUP & $02 / 08 / 2000$ & $0.00 \mathrm{E}+00$ & $\mathrm{pCi} / \mathrm{L}$ & U & & $9.52 \mathrm{E}-02$ \\
\hline Plutonium-239/240 (b) & $\begin{array}{l}\text { B0XJW9 } \\
\text { DUP }\end{array}$ & 699-13-1A DUP & $02 / 08 / 2000$ & $0.00 \mathrm{E}+00$ & $\mathrm{pCi} / \mathrm{L}$ & $\mathrm{U}$ & & $9.52 \mathrm{E}-02$ \\
\hline Antimony-125 & B0XJX6 & 699-13-1B & $02 / 08 / 2000$ & $3.58 \mathrm{E}+00$ & $\mathrm{pCi} / \mathrm{L}$ & $\mathrm{U}$ & $2.10 \mathrm{E}+01$ & $2.10 \mathrm{E}+-01$ \\
\hline Beryllium-7 & B0XJX6 & $699-13-1 B$ & $02 / 08 / 2000$ & $2.42 \mathrm{E}+01$ & $\mathrm{pCi} / \mathrm{L}$ & $\mathrm{U}$ & $6.19 \mathrm{E}+01$ & $6.19 \mathrm{E}+01$ \\
\hline Cesium-134 & B0XJX6 & $699-13-1 \mathrm{~B}$ & $02 / 08 / 2000$ & $-4.64 \mathrm{E}+00$ & $\mathrm{pCi} / \mathrm{L}$ & $\mathrm{U}$ & $6.92 \mathrm{E}+00$ & $6.92 \mathrm{E}+00$ \\
\hline Cesium-137 & B0XJX6 & 699-13-1B & $02 / 08 / 2000$ & $1.03 \mathrm{E}+00$ & $\mathrm{pCi} / \mathrm{L}$ & U & $8.19 E+00$ & $8.19 \mathrm{E}-00$ \\
\hline
\end{tabular}


Table C.3. (contd)

\begin{tabular}{|c|c|c|c|c|c|c|c|c|}
\hline Constituent & $\begin{array}{c}\text { Sample } \\
\text { Number }\end{array}$ & Well Name & $\begin{array}{c}\text { Sample } \\
\text { Date }\end{array}$ & $\begin{array}{c}\text { Value } \\
\text { Reported }\end{array}$ & Units & $\begin{array}{c}\text { Lab } \\
\text { Qualifier }^{(a)}\end{array}$ & $\begin{array}{c}\text { Reporting } \\
\text { Limit }\end{array}$ & MDA \\
\hline Cobalt -60 & B0XJX6 & $699-13-1 \mathrm{~B}$ & $02 / 08 / 2000$ & $3.49 \mathrm{E}-01$ & $\mathrm{pCi} / \mathrm{L}$ & U & $9.82 \mathrm{E}+00$ & $9.82 \mathrm{E}+00$ \\
\hline Europium-152 & B0XJX6 & $699-13-1 B$ & $02 / 08 / 2000$ & $-2.28 \mathrm{E}+00$ & $\mathrm{pCi} / \mathrm{L}$ & $\mathrm{U}$ & $2.00 \mathrm{E}+01$ & $2.00 \mathrm{E}+01$ \\
\hline Europium-154 & B0XJX6 & 699-13-1B & $02 / 08 / 2000$ & $8.71 E+00$ & $\mathrm{pCi} / \mathrm{L}$ & $\mathrm{U}$ & $2.96 \mathrm{E}+01$ & $2.96 \mathrm{E}+01$ \\
\hline Europium-155 & B0XJX6 & 699-13-1B & $02 / 08 / 2000$ & $-9.32 E+00$ & $\mathrm{pCi} / \mathrm{L}$ & U & $1.65 E+01$ & $1.65 \mathrm{E}+01$ \\
\hline Gross alpha & B0XJX6. & $699-13-1 B$ & $02 / 08 / 2000$ & $2.24 \mathrm{E}+00$ & $\mathrm{pCi} / \mathrm{L}$ & $\mathrm{J}$ & $1.69 \mathrm{E}+00$ & $1.69 \mathrm{E}+00$ \\
\hline Gross beta & B0XJX6 & 699-13-1B & $02 / 08 / 2000$ & $6.52 \mathrm{E}+00$ & $\mathrm{pCi} / \mathrm{L}$ & & $2.96 \mathrm{E}+00$ & $2.96 \mathrm{E}+00$ \\
\hline Iodine- 129 & B0XJX6 & 699-13-1B & $02 / 08 / 2000$ & $-3.53 \mathrm{E}-02$ & $\mathrm{pCi} / \mathrm{L}$ & $\mathrm{U}$ & $2.98 \mathrm{E}-01$ & $2.98 \mathrm{E}-01$ \\
\hline Potassium-40 & B0XJX6 & 699-13-1B & $02 / 08 / 2000$ & $-6.82 \mathrm{E}+01$ & $\mathrm{pCi} / \mathrm{L}$ & $\mathrm{U}$ & $1.28 \mathrm{E}+02$ & $1.28 \mathrm{E}+02$ \\
\hline Ruthenium- 106 & B0XJX6 & 699-13-1B & $02 / 08 / 2000$ & $-1.15 \mathrm{E}+01$ & $\mathrm{pCi} / \mathrm{L}$ & $\mathrm{U}$ & $7.05 \mathrm{E}+01$ & $7.05 \mathrm{E}+01$ \\
\hline Technetium-99 & B0XJX6 & 699-13-1B & $02 / 08 / 2000$ & $1.58 \mathrm{E}+00$ & $\mathrm{pCi} / \mathrm{L}$ & $\mathrm{U}$ & $1.22 \mathrm{E}+01$ & $1.22 \mathrm{E}+01$ \\
\hline $\begin{array}{l}\text { Total beta } \\
\text { radiostrontium }\end{array}$ & B0XJX6 & $699-13-1 B$ & $02 / 08 / 2000$ & $-4.72 E-02$ & $\mathrm{pCi} / \mathrm{L}$ & $\overline{\mathrm{U}}$ & $7.05 \mathrm{E}-01$ & $7.05 \mathrm{E}-01$ \\
\hline Antimony-125 & BOXJY0 & 699-13-1C & $02 / 08 / 2000$ & $-2.00 \mathrm{E}-01$ & $\mathrm{pCi} / \mathrm{L}$ & $\mathrm{U}$ & $1.87 \mathrm{E}+01$ & $1.87 \mathrm{E}+01$ \\
\hline Beryllium-7 & BOXJY0 & $699-13-1 \mathrm{C}$ & $02 / 08 / 2000$ & $2.05 \mathrm{E}+01$ & $\mathrm{pCi} / \mathrm{L}$ & $\mathrm{U}$ & $6.62 E+01$ & $6.62 \mathrm{E}+01$ \\
\hline Cesium-134 & BOXJY0 & $699-13-1 C$ & $02 / 08 / 2000$ & $-3.37 E+00$ & $\mathrm{pCi} / \mathrm{L}$ & $\mathrm{U}$ & $8.45 \mathrm{E}+00$ & $8.45 \mathrm{E}+00$ \\
\hline Cesium-137 & BOXJY0 & $699-13-1 C$ & $02 / 08 / 2000$ & $-1.26 \mathrm{E}+00$ & $\mathrm{pCi} / \mathrm{L}$ & $\mathrm{U}$ & $8.61 \mathrm{E}+00$ & $8.61 \mathrm{E}+00$ \\
\hline Cobalt-60 & BOXJY0 & 699-13-1C & $02 / 08 / 2000$ & $2.19 \mathrm{E}+00$ & $\mathrm{pCi} / \mathrm{L}$ & $\mathrm{U}$ & $1.15 \mathrm{E}+01$ & $1.15 \mathrm{E}+01$ \\
\hline Europium-152 & BOXJY0 & $699-13-1 \mathrm{C}$ & $02 / 08 / 2000$ & $2.20 \mathrm{E}+00$ & $\mathrm{pCi} / \mathrm{L}$ & $\mathrm{U}$ & $2.21 \mathrm{E}+01$ & $2.21 \mathrm{E}+01$ \\
\hline Europium-154 & BOXJY0 & 699-13-1C & $02 / 08 / 2000$ & $-2.03 E+00$ & $\mathrm{pCi} / \mathrm{L}$ & $\mathrm{U}$ & $3.11 \mathrm{E}+01$ & $3.11 \mathrm{E}+01$ \\
\hline Europium- 155 & BOXJY0 & 699-13-1C & $02 / 08 / 2000$ & $3.43 E+00$ & $\mathrm{pCi} / \mathrm{L}$ & $\mathrm{U}$ & $1.71 \mathrm{E}+01$ & $1.71 \mathrm{E}+01$ \\
\hline Gross alpha & BOXJY0 & 699-13-1C & $02 / 08 / 2000$ & $5.59 \mathrm{E}-01$ & $\mathrm{pCi} / \mathrm{L}$ & $\mathrm{U}$ & $1.88 \mathrm{E}+00$ & $1.88 \mathrm{E}+00$ \\
\hline Gross beta & $\mathrm{B} 0 \mathrm{XJY0}$ & 699-13-1C & $02 / 08 / 2000$ & $7.32 \mathrm{E}+00$ & $\mathrm{pCi} / \mathrm{L}$ & & $3.02 \mathrm{E}+00$ & $3.02 \mathrm{E}+00$ \\
\hline Iodine-129 & B0XJY0 & $699-13-1 C$ & $02 / 08 / 2000$ & $1.18 \mathrm{E}-01$ & $\mathrm{pCi} / \mathrm{L}$ & $\mathrm{U}$ & $2.88 \mathrm{E}-01$ & $2.88 \mathrm{E}-01$ \\
\hline Potassium-40 & BOXJY0 & 699-13-1C & $02 / 08 / 2000$ & $-2.12 \mathrm{E}+01$ & $\mathrm{pCi} / \mathrm{L}$ & $\bar{U}$ & $2.04 \mathrm{E}+02$ & $2.04 \mathrm{E}+02$ \\
\hline Ruthenium-106 & BOXJY0 & $699-13-1 \mathrm{C}$ & $02 / 08 / 2000$ & $-1.29 E+00$ & $\mathrm{pCi} / \mathrm{L}$ & $\mathrm{U}$ & $7.28 \mathrm{E}+01$ & $7.28 \mathrm{E}+01$ \\
\hline Technetium-99 & BOXJY0 & 699-13-1C & $02 / 08 / 2000$ & $-5.68 \mathrm{E}+00$ & $\mathrm{pCi} / \mathrm{L}$ & $\mathrm{U}$ & $1.23 \mathrm{E}+01$ & $1.23 E+01$ \\
\hline $\begin{array}{l}\text { Total beta } \\
\text { radiostrontium }\end{array}$ & BOXJY0 & $699-13-1 C$ & $02 / 08 / 2000$ & 2.84E-01 & $\mathrm{pCi} / \mathrm{L}$ & $\mathrm{U}$ & 7.37E-01 & $7.37 \mathrm{E}-01$ \\
\hline Antimony-125 & BOXJYO DUP & 699-13-1C DUP & $02 / 08 / 2000$ & $-9.30 \mathrm{E}+00$ & $\mathrm{pCi} / \mathrm{L}$ & $\mathrm{U}$ & & $2.09 \mathrm{E}+01$ \\
\hline Beryllium- $7^{(b)}$ & BOXJY0 DUP & 699-13-1C DUP & $02 / 08 / 2000$ & $5.08 \mathrm{E}+00$ & $\mathrm{pCi} / \mathrm{L}$ & $\mathrm{U}$ & & $7.46 \mathrm{E}+01$ \\
\hline Cesium-134 ${ }^{(b)}$ & BOXJYO DUP & 699-13-1C DUP & $02 / 08 / 2000$ & $-3.24 \mathrm{E}+00$ & $\mathrm{pCi} / \mathrm{L}$ & $\mathrm{U}$ & & $7.76 \mathrm{E}+00$ \\
\hline Cesium-137 $7^{(b)}$ & B0XJY0 DUP & 699-13-1C DUP & $02 / 08 / 2000$ & $2.52 \mathrm{E}+00$ & $\mathrm{pCi} / \mathrm{L}$ & $\mathrm{U}$ & & $9.02 \mathrm{E}+00$ \\
\hline Cobalt- $60^{(\mathrm{b})}$ & BOXJY0 DUP & 699-13-1C DUP & $02 / 08 / 2000$ & $-1.08 \mathrm{E}+00$ & $\mathrm{pCi} / \mathrm{L}$ & $\mathrm{U}$ & & $8.29 \mathrm{E}+00$ \\
\hline Europium- $152^{(\mathrm{b})}$ & BOXJY0 DUP & 699-13-1C DUP & $02 / 08 / 2000$ & $-3.08 \mathrm{E}+00$ & $\mathrm{pCi} / \mathrm{L}$ & $\mathrm{U}$ & & $2.12 E+01$ \\
\hline Europium-154 & BOXJYO DUP & 699-13-1C DUP & $02 / 08 / 2000$ & $7.67 \mathrm{E}+00$ & $\mathrm{pCi} / \mathrm{L}$ & $\mathrm{U}$ & & $2.99 E+01$ \\
\hline Europium- $155^{(\mathrm{b})}$ & BOXJYO DUP & 699-13-1C DUP & $02 / 08 / 2000$ & $3.05 \mathrm{E}-01$ & $\mathrm{pCi} / \mathrm{L}$ & $\mathrm{U}$ & & $1.57 \mathrm{E}+01$ \\
\hline Potassium- $40^{\text {(b) }}$ & BOXJYO DUP & 699-13-1C DUP & $02 / 08 / 2000$ & $3.54 \mathrm{E}+00$ & $\mathrm{pCi} / \mathrm{L}$ & $\mathrm{U}$ & & $2.53 \mathrm{E}+02$ \\
\hline Ruthenium-106 ${ }^{(b)}$ & BOXJYO DUP & 699-13-1C DUP & $02 / 08 / 2000$ & $2.78 \mathrm{E}+00$ & $\mathrm{pCi} / \mathrm{L}$ & $\mathrm{U}$ & & $7.58 \mathrm{E}+01$ \\
\hline Antimony-125 & BOXJT8 & $699-13-3 A$ & $02 / 07 / 2000$ & $-7.46 \mathrm{E}+00$ & $\mathrm{pCi} / \mathrm{L}$ & $\mathrm{U}$ & & $1.49 \mathrm{E}+01$ \\
\hline Antimony-125 & BOXJT9 & 699-13-3A & $02 / 07 / 2000$ & $-6.24 \mathrm{E}+00$ & $\mathrm{pCi} / \mathrm{L}$ & $\mathrm{U}$ & & $2.11 \mathrm{E}+01$ \\
\hline Beryllium-7 & BOXJT8 & 699-13-3A & $02 / 07 / 2000$ & $-1.21 \mathrm{E}+01$ & $\mathrm{pCi} / \mathrm{L}$ & $\mathrm{U}$ & & $5.27 \mathrm{E}+01$ \\
\hline
\end{tabular}


Table C.3. (contd)

\begin{tabular}{|c|c|c|c|c|c|c|c|c|}
\hline Constituent & $\begin{array}{l}\text { Sample } \\
\text { Number }\end{array}$ & Well Name & $\begin{array}{c}\text { Sample } \\
\text { Date }\end{array}$ & $\begin{array}{c}\text { Value } \\
\text { Reported }\end{array}$ & Units & $\begin{array}{c}\text { Lab } \\
\text { Qualifier }^{(\mathbf{a})}\end{array}$ & $\begin{array}{c}\text { Reporting } \\
\text { Limit }\end{array}$ & MDA \\
\hline Beryllium-7 & BOXJT9 & $699-13-3 A$ & $02 / 07 / 2000$ & $-3.24 E+00$ & $\mathrm{pCi} / \mathrm{L}$ & $\mathrm{U}$ & & $6.41 \mathrm{E}+01$ \\
\hline Cesium-134 & BOXJT8 & $699-13-3 A$ & $02 / 07 / 2000$ & 7.69E-02 & $\mathrm{pCi} / \mathrm{L}$ & $\mathbf{U}$ & & $7.12 \mathrm{E}+00$ \\
\hline Cesium-134 & BOXJT9 & $699-13-3 \mathrm{~A}$ & $02 / 07 / 2000$ & $2.54 \mathrm{E}-01$ & $\mathrm{pCi} / \mathrm{L}$ & $\mathrm{U}$ & & $8.54 \mathrm{E}+00$ \\
\hline Cesium-137 & BOXJT8 & 699-13-3A & $02 / 07 / 2000$ & $-1.47 \mathrm{E}+00$ & $\mathrm{pCi} / \mathrm{L}$ & $\mathrm{U}$ & & $7.49 \mathrm{E}+00$ \\
\hline Cesium-137 & BOXJT9 & 699-13-3A & $02 / 07 / 2000$ & $-3.27 E+00$ & $\mathrm{pCi} / \mathrm{L}$ & $\mathrm{U}$ & & $8.21 \mathrm{E}+00$ \\
\hline Cobalt- 60 & BOXJT8 & $699-13-3 \mathrm{~A}$ & $02 / 07 / 2000$ & $1.54 \mathrm{E}+00$ & $\mathrm{pCi} / \mathrm{L}$ & $\mathrm{U}$ & & $8.89 \mathrm{E}+00$ \\
\hline Cobalt- 60 & BOXJT9 & $699-13-3 A$ & $02 / 07 / 2000 \mid \subseteq$ & $9.89 \mathrm{E}-01$ & $|\mathrm{pCi} / \mathrm{L}|$ & $\mathrm{U}$ & & $8.75 E+00$ \\
\hline Europium-152 & BOXJT8 & $699-13-3 A$ & $02 / 07 / 2000$ & $1.20 \mathrm{E} \div 01$ & $\mathrm{pCi} / \mathrm{L}$ & U & & $1.76 \mathrm{E}+01$ \\
\hline Europium-152 & BOXJT9 & $699-13-3 A$ & $02 / 07 / 2000$ & $1.05 \mathrm{E}+01$ & $\mathrm{pCi} / \mathrm{L}$ & $\mathrm{U}$ & & $2.47 \mathrm{E}+01$ \\
\hline Europium-154 & BOXJT8 & 699-13-3A & $02 / 07 / 2000$ & $-4.40 \mathrm{E}+00$ & $\mathrm{pCi} / \mathrm{L}$ & $\mathrm{U}$ & & 2.17E-01 \\
\hline Europium-154 & BOXJT9 & 699-13-3A & $02 / 07 / 2000$ & $4.22 \mathrm{E}+00$ & $\mathrm{pCi} / \mathrm{L}$ & $\mathrm{U}$ & & $2.59 \mathrm{E}+01$ \\
\hline Europium- 155 & BOXJT8 & 699-13-3A & $02 / 07 / 2000$ & $-4.66 \mathrm{E}+00$ & $\mathrm{pCi} / \mathrm{L}$ & $\mathrm{U}$ & & $1.31 \mathrm{E}+01$ \\
\hline Europium-155 & BOXJT9 & 699-13-3A & $02 / 07 / 2000$ & $-1.33 E+00$ & $\mathrm{pCi} / \mathrm{L}$ & $\mathrm{U}$ & & $1.46 \mathrm{E}+01$ \\
\hline Gross alpha & BOXJT8 & $699-13-3 \mathrm{~A}$ & $02 / 07 / 2000$ & $6.06 \mathrm{E}+00$ & $\mathrm{pCi} / \mathrm{L}$ & & & $1.78 \mathrm{E} \div 00$ \\
\hline Gross alpha & BOXJT9 & $699-13-3 \mathrm{~A}$ & $02 / 07 / 2000$ & $6.15 \mathrm{E}+00$ & $\mathrm{pCi} / \mathrm{L}$ & & & $2.28 \mathrm{E}-00$ \\
\hline Gross beta & BOXJT8 & 699-13-3A & $02 / 07 / 2000$ & $1.50 \mathrm{E}+01$ & $\mathrm{pCi} / \mathrm{L}$ & & & $3.00 \mathrm{E} \div 00$ \\
\hline Gross beta & BOXJT9 & $699-13-3 A$ & $02 / 07 / 2000$ & $2.08 \mathrm{E}+01$ & $\mathrm{pCi} / \mathrm{L}$ & & & $2.96 \mathrm{E}-00$ \\
\hline Iodine-129 & BOXJT8 & $699-13-3 \mathrm{~A}$ & $02 / 07 / 2000$ & $-1.13 \mathrm{E}-01$ & $\mathrm{pCi} / \mathrm{L}$ & $\mathrm{U}$ & & $2.37 \mathrm{E}-01$ \\
\hline Iodine-129 & BOXJT9 & 699-13-3A & $02 / 07 / 2000$ & $2.31 \mathrm{E}-01$ & $\mathrm{pCi} / \mathrm{L}$ & $\mathrm{U}$ & & $3.40 \mathrm{E}-01$ \\
\hline Plutonium-238 & BOXJT8 & 699-13-3A & $02 / 07 / 2000$ & $0.00 \mathrm{E}+00$ & $\mathrm{pCi} / \mathrm{L}$ & U & & $1.02 \mathrm{E}-01$ \\
\hline Plutonium-238 & BOXJT9 & 699-13-3A & $02 / 07 / 2000$ & $3.51 \mathrm{E}-02$ & $\mathrm{pCi} / \mathrm{L}$ & $\mathrm{U}$ & & $9.52 \mathrm{E}-02$ \\
\hline Plutonium-239/240 & BOXJT8 & $699-13-3 A$ & $02 / 07 / 2000$ & $0.00 \mathrm{E}+00$ & $\mathrm{pCi} / \mathrm{L}$ & $\mathrm{U}$ & & $1.02 \mathrm{E}-01$ \\
\hline Plutonium-239/240 & BOXJT9 & $699-13-3 A$ & $02 / 07 / 2000$ & $0.00 \mathrm{E}+00$ & $\mathrm{pCi} / \mathrm{L}$ & U & & $9.52 \mathrm{E}-02$ \\
\hline Potassium-40 & BOXJT8 & 699-13-3A & $02 / 07 / 2000 \mid$ & $-3.28 \mathrm{E}+01$ & $\mathrm{pCi} / \mathrm{L}$ & $\mathrm{U}$ & & $2.51 \mathrm{E}+02$ \\
\hline Potassium-40 & BOXJT9 & 699-13-3A & $02 / 07 / 2000$ & $1.56 \mathrm{E}+00$ & $\mathrm{pCi} / \mathrm{L}$ & $\mathrm{U}$ & & $7.26 \mathrm{E}-01$ \\
\hline Ruthenium-106 & BOXJT8 & 699-13-3A & $02 / 07 / 2000$ & $2.72 \mathrm{E}+01$ & $\mathrm{pCi} / \mathrm{L}$ & $\mathrm{U}$ & & $7.45 \mathrm{E}+01$ \\
\hline Ruthenium-106 & BOXJT9 & 699-13-3A & $02 / 07 / 2000$ & $2.41 \mathrm{E}+01$ & $\mathrm{pCi} / \mathrm{L}$ & $\mathrm{U}$ & & $8.56 \mathrm{E}+01$ \\
\hline Strontium- $89 / 90$ & BOXJT8 & $699-13-3 \mathrm{~A}$ & $02 / 07 / 2000$ & $-3.15 E-02$ & $\mathrm{pCi} / \mathrm{L}$ & $\mathrm{U}$ & & $8.69 \mathrm{E}-01$ \\
\hline Technetium-99 & BOXJT8 & $699-13-3 \mathrm{~A}$ & $02 / 07 / 2000$ & $1.86 \mathrm{E}+04$ & $\mathrm{pCi} / \mathrm{L}$ & & & $2.88 \mathrm{E}+01$ \\
\hline Technetium-99 & BOXJT9 & $699-13-3 \mathrm{~A}$ & $02 / 07 / 2000$ & $1.36 \mathrm{E}+04$ & $\mathrm{pCi} / \mathrm{L}$ & & & $2.88 \mathrm{E}+01$ \\
\hline Uranium & BOXJT8 & 699-13-3A & $02 / 07 / 2000$ & $1.03 \mathrm{E}+01$ & $\mathrm{ug} / \mathrm{L}$ & & & $7.29 \mathrm{E}-02$ \\
\hline Uranium & BOXJT9 & 699-13-3A & $02 / 07 / 2000$ & $9.91 \mathrm{E}+00$ & $\mathrm{ug} / \mathrm{L}$ & & & $7.29 \mathrm{E}-02$ \\
\hline Uranium-234 & BOXJT8 & $699-13-3 \mathrm{~A}$ & $02 / 07 / 2000$ & $4.35 \mathrm{E}+00$ & $\mathrm{pCi} / \mathrm{L}$ & & & $2.40 \mathrm{E}-01$ \\
\hline Uranium-234 & BOXJT9 & 699-13-3A & $02 / 07 / 2000$ & $3.80 \mathrm{E}+00$ & $\mathrm{pCi} / \mathrm{L}$ & & & $2.49 \mathrm{E}-01$ \\
\hline Uranium-235 & BOXJT8 & 699-13-3A & $02 / 07 / 2000$ & $2.86 \mathrm{E}-01$ & $\mathrm{pCi} / \mathrm{L}$ & & & $2.11 \mathrm{E}-01$ \\
\hline Uranium-235 & BOXJT9 & 699-13-3A & $02 / 07 / 2000$ & $8.26 \mathrm{E}-02$ & $\mathrm{pCi} / \mathrm{L}$ & U & & 3.23E-01 \\
\hline Uranium-238 & BOXJT8 & 699-13-3A & $02 / 07 / 2000$ & $3.55 \mathrm{E}+00$ & $\mathrm{pCi} / \mathrm{L}$ & & & $1.94 \mathrm{E}-01$ \\
\hline Uranium-238 & BOXJT9 & 699-13-3A & $02 / 07 / 2000$ & $3.62 \mathrm{E}+00$ & $\mathrm{pCi} / \mathrm{L}$ & & & 3.23E-01 \\
\hline Antimony-125(b) & BOXJT8DUP & 699-13-3A DUP & $02 / 07 / 2000$ & $-1.93 E+00$ & $\mathrm{pCi} / \mathrm{L}$ & $\mathrm{U}$ & & $1.89 \mathrm{E}+01$ \\
\hline Beryllium- $7^{(\mathrm{b})}$ & BOXJT8DUP & 699-13-3A DUP & $02 / 07 / 2000$ & $-2.33 \mathrm{E}+01$ & $\mathrm{pCi} / \mathrm{L}$ & $\mathrm{U}$ & & $5.50 \mathrm{E}+01$ \\
\hline
\end{tabular}


Table C.3. (contd)

\begin{tabular}{|c|c|c|c|c|c|c|c|c|}
\hline Constituent & $\begin{array}{c}\text { Sample } \\
\text { Number }\end{array}$ & Well Name & $\begin{array}{c}\text { Sample } \\
\text { Date }\end{array}$ & $\begin{array}{c}\text { Value } \\
\text { Reported }\end{array}$ & Units & $\begin{array}{c}\text { Lab } \\
\text { Qualifier }\end{array}$ & $\begin{array}{c}\text { Reporting } \\
\text { Limit }\end{array}$ & MDA \\
\hline Cesium-134 ${ }^{(b)}$ & BOXJT8DUP & 699-13-3A DUP & $02 / 07 / 2000$ & $-1.32 E+00$ & $\mathrm{pCi} / \mathrm{L}$ & $\mathrm{U}$ & & $8.10 \mathrm{E}+00$ \\
\hline Cesium-137(b) & BOXJT8DUP & 699-13-3A DUP & $02 / 07 / 2000$ & $-1.23 E+00$ & $\mathrm{pCi} / \mathrm{L}$ & $\mathrm{U}$ & & $7.14 \mathrm{E}+00$ \\
\hline Cobalt- $60^{(b)}$ & BOXJT8DUP & 699-13-3A DUP & $02 / 07 / 2000$ & $8.54 \mathrm{E}-01$ & $\mathrm{pCi} / \mathrm{L}$ & $\mathrm{U}$ & & $9.82 \mathrm{E}+00$ \\
\hline Europium-152 $2^{(\mathrm{b})}$ & BOXJT8DUP & 699-13-3A DUP & $02 / 07 / 2000$ & $5.57 \mathrm{E}+00$ & $\mathrm{pCi} / \mathrm{L}$ & $\mathrm{U}$ & & $2.17 \mathrm{E}+01$ \\
\hline Europium- $154^{(\mathrm{b})}$ & BOXJT8DUP & 699-13-3A DUP & $02 / 07 / 2000$ & $-8.96 \mathrm{E}+00$ & $\mathrm{pCi} / \mathrm{L}$ & $\mathrm{U}$ & & $2.26 \mathrm{E}+01$ \\
\hline Europium- $155^{(b)}$ & BOXJT8DUP & 699-13-3A DUP & $02 / 07 / 2000$ & $-7.34 \mathrm{E}-01$ & $\mathrm{pCi} / \mathrm{L}$ & $\mathrm{U}$ & & $1.88 \mathrm{E}+01$ \\
\hline Iodine- $129^{(\mathrm{b})}$ & BOXJT8DUP & 699-13-3A DUP & $02 / 07 / 2000$ & $1.12 \mathrm{E}-01$ & $\mathrm{pCi} / \mathrm{L}$ & $\mathrm{U}$ & & $3.53 \mathrm{E}-01$ \\
\hline Potassium- $40^{(\mathrm{b})}$ & BOXJT8DUP & 699-13-3A DUP & $02 / 07 / 2000$ & $1.88 \mathrm{E}+01$ & $\mathrm{pCi} / \mathrm{L}$ & $\mathrm{U}$ & & $1.53 \mathrm{E}+02$ \\
\hline Ruthenium-106 ${ }^{(\mathrm{b})}$ & BOXJT8DUP & 699-13-3A DUP & $02 / 07 / 2000$ & $-1.90 \mathrm{E}+01$ & $\mathrm{pCi} / \mathrm{L}$ & $\mathrm{U}$ & & $6.17 E+01$ \\
\hline Technetium-99(b) & \begin{tabular}{|l} 
BOXJT9 \\
DUP
\end{tabular} & 699-13-3A DUP & $02 / 07 / 2000$ & $1.50 \mathrm{E}+04$ & $\mathrm{pCi} / \mathrm{L}$ & & & $2.88 \mathrm{E}+01$ \\
\hline Antimony-125 & B0XK20 & 699-15-15B & $02 / 08 / 2000$ & $-1.84 \mathrm{E}+00$ & $\mathrm{pCi} / \mathrm{L}$ & $\mathrm{U}$ & $1.85 \mathrm{E}+01$ & $1.85 \mathrm{E}+01$ \\
\hline Beryllium-7 & B0XK20 & 699-15-15B & $02 / 08 / 2000$ & $-3.90 \mathrm{E}+00$ & $\mathrm{pCi} / \mathrm{L}$ & $\mathrm{U}$ & $6.33 E+01$ & $6.33 E+01$ \\
\hline Cesium-134 & B0XK20 & 699-15-15B & $02 / 08 / 2000$ & $-2.23 \mathrm{E}+00$ & $\mathrm{pCi} / \mathrm{L}$ & $\mathrm{U}$ & $7.39 \mathrm{E}+00$ & $7.39 \mathrm{E}+00$ \\
\hline Cesium-137 & $\mathrm{B} 0 \mathrm{XK} 20$ & 699-15-15B & $02 / 08 / 2000$ & $-3.50 \mathrm{E}-01$ & $\mathrm{pCi} / \mathrm{L}$ & $\mathrm{U}$ & $7.61 \mathrm{E}+00$ & $7.61 E+00$ \\
\hline Cobalt- 60 & B0XK20 & 699-15-15B & $02 / 08 / 2000$ & 4.77E-01 & $\mathrm{pCi} / \mathrm{L}$ & $\mathrm{U}$ & $7.00 \mathrm{E}+00$ & $7.00 \mathrm{E}+00$ \\
\hline Europium-152 & B0XK20 & 699-15-15B & $02 / 08 / 2000$ & $-5.69 \mathrm{E} \div 00$ & $\mathrm{pCi} / \mathrm{L}$ & $\mathrm{U}$ & $1.78 \mathrm{E}+01$ & $1.78 \mathrm{E}+01$ \\
\hline Europium-154 & B0XK20 & 699-15-15B & $02 / 08 / 2000$ & $1.44 \mathrm{E}+01$ & $\mathrm{pCi} / \mathrm{L}$ & $\mathrm{U}$ & $2.91 E+01$ & $2.91 \mathrm{E}+01$ \\
\hline Europium-155 & B0XK20 & 699-15-15B & $02 / 08 / 2000$ & $-1.09 \mathrm{E}+00$ & $\mathrm{pCi} / \mathrm{L}$ & $\mathrm{U}$ & $1.47 \mathrm{E}+01$ & $1.47 \mathrm{E}+01$ \\
\hline Gross alpha & $\mathrm{B} 0 \mathrm{XK} 20$ & 699-15-15B & $02 / 08 / 2000$ & $4.22 \mathrm{E}+00$ & $\mathrm{pCi} / \mathrm{L}$ & & $2.23 \mathrm{E}+00$ & $2.23 \mathrm{E}+00$ \\
\hline Gross beta & B0XK20 & 699-15-15B & $02 / 08 / 2000$ & $8.56 \mathrm{E}+00$ & $\mathrm{pCi} / \mathrm{L}$ & & $3.00 \mathrm{E}+00$ & $3.00 \mathrm{E}+00$ \\
\hline Iodine-129 & $\mathrm{B} 0 \mathrm{XK} 20$ & 699-15-15B & $02 / 08 / 2000$ & $-1.27 \mathrm{E}-02$ & $\mathrm{pCi} / \mathrm{L}$ & $\mathrm{U}$ & 2.89E-01 & $2.89 \mathrm{E}-01$ \\
\hline Potassium -40 & B0XK20 & 699-15-15B & $02 / 08 / 2000$ & $-8.84 \mathrm{E}+01$ & $\mathrm{pCi} / \mathrm{L}$ & $\mathrm{U}$ & $2.30 \mathrm{E}+02$ & $2.30 \mathrm{E}+02$ \\
\hline Ruthenium-106 & B0XK20 & 699-15-15B & $02 / 08 / 2000$ & $1.78 \mathrm{E}+01$ & $\mathrm{pCi} / \mathrm{L}$ & $\mathrm{U}$ & $7.32 \mathrm{E}+01$ & $7.32 \mathrm{E}+01$ \\
\hline Technetium-99 & $\mathrm{B} 0 \mathrm{XK} 20$ & 699-15-15B & $02 / 08 / 2000$ & $-4.61 \mathrm{E}+00$ & $\mathrm{pCi} / \mathrm{L}$ & $\mathrm{U}$ & $1.22 \mathrm{E}+01$ & $1.22 \mathrm{E}+01$ \\
\hline Uranium-234 & $\mathrm{B} 0 \mathrm{XK} 20$ & 699-15-15B & $02 / 08 / 2000$ & $3.39 \mathrm{E}+00$ & $\mathrm{pCi} / \mathrm{L}$ & & $4.05 \mathrm{E}-01$ & $4.05 \mathrm{E}-01$ \\
\hline Uranium-235 & B0XK20 & 699-15-15B & $02 / 08 / 2000$ & $1.20 \mathrm{E}-01$ & $\mathrm{pCi} / \mathrm{L}$ & $\mathrm{U}$ & $3.27 \mathrm{E}-01$ & $3.27 \mathrm{E}-01$ \\
\hline Uranium-238 & B0XK20 & 699-15-15B & $02 / 08 / 2000$ & $2.28 \mathrm{E}+00$ & $\mathrm{pCi} / \mathrm{L}$ & & $3.88 \mathrm{E}-01$ & $3.88 \mathrm{E}-01$ \\
\hline Iodine-129(b) & $\begin{array}{l}\text { B0XK20 } \\
\text { DUP }\end{array}$ & 699-15-15B DUP & $02 / 08 / 2000$ & $-5.04 \mathrm{E}-02$ & $\mathrm{pCi} / \mathrm{L}$ & $\mathrm{U}$ & & $2.21 \mathrm{E}-01$ \\
\hline Uranium-234 (b) & $\begin{array}{l}\text { B0XK20 } \\
\text { DUP }\end{array}$ & 699-15-15B DUP & $02 / 08 / 2000$ & $3.03 E+00$ & $\mathrm{pCi} / \mathrm{L}$ & & & $2.74 \mathrm{E}-01$ \\
\hline Uranium-235 ${ }^{(\mathrm{b})}$ & $\begin{array}{l}\text { B0XK20 } \\
\text { DUP }\end{array}$ & 699-15-15B DUP & $02 / 08 / 2000$ & $3.51 \mathrm{E}-02$ & $\mathrm{pCi} / \mathrm{L}$ & $\mathrm{U}$ & & $2.31 \mathrm{E}-01$ \\
\hline Uranium-238 & $\begin{array}{l}\text { BOXK20 } \\
\text { DUP }\end{array}$ & 699-15-15B DUP & $02 / 08 / 2000$ & $2.55 \mathrm{E}+00$ & $\mathrm{pCi} / \mathrm{L}$ & & & $3.18 \mathrm{E}-01$ \\
\hline Antimony-125 & B0XK15 & $699-17-5$ & $02 / 07 / 2000$ & $-1.05 \mathrm{E}-01$ & $\mathrm{pCi} / \mathrm{L}$ & $\mathrm{U}$ & $1.85 \mathrm{E}+01$ & $1.85 \mathrm{E}+01$ \\
\hline Beryllium-7 & B0XK15 & $699-17-5$ & $02 / 07 / 2000$ & $2.83 E+01$ & $\mathrm{pCi} / \mathrm{L}$ & $\mathrm{U}$ & $6.40 \mathrm{E}+01$ & $6.40 \mathrm{E}+01$ \\
\hline Cesium-134 & B0XK15 & 699-17-5 & $02 / 07 / 2000$ & $-5.37 E+00$ & $\mathrm{pCi} / \mathrm{L}$ & $\mathrm{U}$ & $6.30 \mathrm{E}+00$ & $6.30 \mathrm{E}+00$ \\
\hline Cesium-137 & B0XK15 & $699-17-5$ & $02 / 07 / 2000$ & $3.19 \mathrm{E}+00$ & $\mathrm{pCi} / \mathrm{L}$ & $\mathrm{U}$ & $8.55 \mathrm{E}+00$ & $8.55 \mathrm{E}+00$ \\
\hline Cobalt- 60 & B0XK15 & $699-17-5$ & $02 / 07 / 2000$ & $-8.42 \mathrm{E}-01$ & $\mathrm{pCi} / \mathrm{L}$ & $\mathrm{U}$ & $8.28 \mathrm{E}+00$ & $8.28 \mathrm{E}+00$ \\
\hline
\end{tabular}


Table C.3. (contd)

\begin{tabular}{|c|c|c|c|c|c|c|c|c|}
\hline Constituent & $\begin{array}{c}\text { Sample } \\
\text { Number } \\
\end{array}$ & Well Name & $\begin{array}{c}\text { Sample } \\
\text { Date }\end{array}$ & $\begin{array}{c}\begin{array}{c}\text { Value } \\
\text { Reported }\end{array} \\
\end{array}$ & Units & $\begin{array}{c}\text { Lab } \\
\text { Qualifier }{ }^{(\mathrm{a})}\end{array}$ & $\begin{array}{c}\text { Reporting } \\
\text { Limit }\end{array}$ & MDA \\
\hline Europium-152 & $\mathrm{B} 0 \mathrm{XK} 15$ & $699-17-5$ & $02 / 07 / 2000$ & $6.42 \mathrm{E}+00$ & $\mathrm{pCi} / \mathrm{L}$ & $\mathrm{U}$ & $2.09 \mathrm{E}+01$ & $2.09 \mathrm{E}+01$ \\
\hline Europium-154 & B0XK15 & $699-17-5$ & $02 / 07 / 2000$ & $1.37 \mathrm{E}+00$ & $\mathrm{pCi} / \mathrm{L}$ & $\mathrm{U}$ & $2.16 \mathrm{E}+01$ & $2.16 \mathrm{E}+01$ \\
\hline Europium-155 & B0XK15 & 699-17-5 & $02 / 07 / 2000$ & $-8.78 \mathrm{E}-01$ & $\mathrm{pCi} / \mathrm{L}$ & $\mathrm{U}$ & $1.51 \mathrm{E}+01$ & $1.51 \mathrm{E}+01$ \\
\hline Gross alpha & B0XK15 & $699-17-5$ & $02 / 07 / 2000$ & $2.48 \mathrm{E}+00$ & $\mathrm{pCi} / \mathrm{L}$ & $\mathrm{J}$ & $2.04 \mathrm{E}+00$ & $2.04 \mathrm{E}+00$ \\
\hline Gross beta & B0XK15 & $699-17-5$ & $02 / 07 / 2000$ & $7.92 \mathrm{E}+00$ & $\mathrm{pCi} / \mathrm{L}$ & & $2.82 \mathrm{E}+00$ & $2.82 \mathrm{E}+00$ \\
\hline Iodine-129 & B0XK15 & $699-17-5$ & $02 / 07 / 2000$ & $-7.25 \mathrm{E}-02$ & $\mathrm{pCi} / \mathrm{L}$ & $\mathrm{U}$ & $2.08 \mathrm{E}-01$ & $2.08 \mathrm{E}-01$ \\
\hline Potassium-40 & B0XK15 & 699-17-5 & $02 / 07 / 2000$ & $4.77 \mathrm{E}+01$ & $\mathrm{pCi} / \mathrm{L}$ & $\mathrm{U}$ & $4.85 \mathrm{E}+01$ & $4.85 \mathrm{E}+01$ \\
\hline Ruthenium-106 & B0XK15 & $699-17-5$ & $02 / 07 / 2000$ & $-1.48 \mathrm{E}+01$ & $\mathrm{pCi} / \mathrm{L}$ & $\mathrm{U}$ & $6.52 \mathrm{E}+01$ & $6.52 E+01$ \\
\hline Technetium-99 & B0XK15 & $699-17-5$ & $02 / 07 / 2000$ & $2.18 \mathrm{E}+00$ & $\mathrm{pCi} / \mathrm{L}$ & $\mathrm{U}$ & $1.23 \mathrm{E}+01$ & $1.23 \mathrm{E}+01$ \\
\hline Uranium-234 & B0XK15 & $699-17-5$ & $02 / 07 / 2000$ & $1.36 \mathrm{E}+00$ & $\mathrm{pCi} / \mathrm{L}$ & & $4.08 \mathrm{E}-01$ & $4.08 \mathrm{E}-101$ \\
\hline Uranium-235 & B0XK15 & $699-17-5$ & $02 / 07 / 2000$ & 1.12E-01 & $\mathrm{pCi} / \mathrm{L}$ & $\mathrm{U}$ & 3.17E-01 & 3.17E-()1 \\
\hline Uranium-238 & B0XK15 & $699-17-5$ & $02 / 07 / 2000$ & $9.85 \mathrm{E}-01$ & $\mathrm{pCi} / \mathrm{L}$ & $J$ & 3.77E-01 & $3.77 \mathrm{E}-101$ \\
\hline Antimony-125 & \begin{tabular}{|l|} 
B0XK15 \\
DUP
\end{tabular} & 699-17-5 DUP & $02 / 07 / 2000$ & $4.57 \mathrm{E}+00$ & $\mathrm{pCi} / \mathrm{L}$ & $\mathrm{U}$ & & $1.92 E+01$ \\
\hline Beryllium-7 $7^{(b)}$ & \begin{tabular}{|l} 
B0XK15 \\
DUP
\end{tabular} & 699-17-5 DUP & $02 / 07 / 2000$ & $-1.52 \mathrm{E}+01$ & $\mathrm{pCi} / \mathrm{L}$ & $\mathrm{U}$ & & $6.35 E+01$ \\
\hline Cesium-134 & \begin{tabular}{|l|} 
B0XK15 \\
DUP \\
\end{tabular} & 699-17-5 DUP & $02 / 07 / 2000$ & $1.43 E+00$ & $\mathrm{pCi} / \mathrm{L}$ & $\mathbf{U}$ & & $8.07 E+00$ \\
\hline Cesium-137(b) & \begin{tabular}{|l} 
B0XK15 \\
DUP
\end{tabular} & 699-17-5 DUP & $02 / 07 / 2000$ & $1.94 \mathrm{E}+00$ & $\mathrm{pCi} / \mathrm{L}$ & $\mathbf{U}$ & & $8.31 \mathrm{E}+00$ \\
\hline Cobalt- $60^{(\mathrm{b})}$ & \begin{tabular}{|l|} 
B0XK15 \\
DUP
\end{tabular} & 699-17-5 DUP & $02 / 07 / 2000$ & $-2.24 E+00$ & $\mathrm{pCi} / \mathrm{L}$ & $\mathrm{U}$ & & $7.84 \mathrm{E}+00$ \\
\hline Europium- $152^{(\text {b) }}$ & \begin{tabular}{|l|} 
B0XK15 \\
DUP
\end{tabular} & 699-17-5 DUP & $02 / 07 / 2000$ & $-2.01 E+00$ & $\mathrm{pCi} / \mathrm{L}$ & $\mathrm{U}$ & & $1.76 E+01$ \\
\hline Europium- $154^{(b)}$ & $\begin{array}{l}\text { B0XK15 } \\
\text { DUP }\end{array}$ & 699-17-5 DUP & $02 / 07 / 2000$ & $2.98 \mathrm{E}+00$ & $\mathrm{pCi} / \mathrm{L}$ & $\mathrm{U}$ & & $2.52 \mathrm{E}+.01$ \\
\hline Europium- $155^{(\mathrm{b})}$ & $\begin{array}{l}\text { B0XK15 } \\
\text { DUP }\end{array}$ & 699-17-5 DUP & $02 / 07 / 2000$ & $3.05 \mathrm{E}+00$ & $\mathrm{pCi} / \mathrm{L}$ & $\mathrm{U}$ & & $1.35 \mathrm{E}+01$ \\
\hline Potassium-40 & \begin{tabular}{|l|} 
B0XK15 \\
DUP \\
\end{tabular} & 699-17-5 DUP & $02 / 07 / 2000$ & $3.15 E+01$ & $\mathrm{pCi} / \mathrm{L}$ & $\mathrm{U}$ & & $7.00 \mathrm{E}+01$ \\
\hline Ruthenium-106 $6^{(\mathrm{b})}$ & \begin{tabular}{|l|} 
BOXK15 \\
DUP
\end{tabular} & 699-17-5 DUP & $02 / 07 / 2000$ & $-1.13 E+01$ & $\mathrm{pCi} / \mathrm{L}$ & $\mathrm{U}$ & & $6.59 E+01$ \\
\hline Antimony-125 & B0XK23 & $699-21-6$ & $02 / 07 / 2000$ & $-1.69 \mathrm{E}+01$ & $\mathrm{pCi} / \mathrm{L}$ & $\mathrm{U}$ & $2.02 \mathrm{E}+01$ & $2.02 E+01$ \\
\hline Beryllium-7 & B0XK23 & $699-21-6$ & $02 / 07 / 2000$ & $1.30 \mathrm{E}+01$ & $\mathrm{pCi} / \mathrm{L}$ & $\mathrm{U}$ & $7.62 \mathrm{E}+01$ & $7.62 \mathrm{E}+01$ \\
\hline Cesium-134 & B0XK23 & $699-21-6$ & $02 / 07 / 2000$ & $-4.93 \mathrm{E}+00$ & $\mathrm{pCi} / \mathrm{L}$ & $\mathrm{U}$ & $8.80 \mathrm{E}+00$ & $8.80 \mathrm{E}+00$ \\
\hline Cesium-137 & B0XK23 & $699-21-6$ & $02 / 07 / 2000$ & $-1.44 \mathrm{E}+00$ & $\mathrm{pCi} / \mathrm{L}$ & $\mathrm{U}$ & $8.53 \mathrm{E}+00$ & $8.53 \mathrm{E}-00$ \\
\hline Cobalt- 60 & $\mathrm{~B} 0 \mathrm{XK} 23$ & $699-21-6$ & $02 / 07 / 2000$ & $2.63 \mathrm{E}+00$ & $\mathrm{pCi} / \mathrm{L}$ & U & $1.09 \mathrm{E}+01$ & $1.09 \mathrm{E}-01$ \\
\hline Europium-152 & B0XK23 & 699-21-6 & $02 / 07 / 2000$ & $2.93 \mathrm{E}+00$ & $\mathrm{pCi} / \mathrm{L}$ & $\mathrm{U}$ & $2.30 \mathrm{E}+01$ & $2.30 \mathrm{E}-01$ \\
\hline Europium-154 & $\mathrm{B} 0 \mathrm{XK} 23$ & $699-21-6$ & $02 / 07 / 2000$ & $8.80 \mathrm{E}+00$ & $\mathrm{pCi} / \mathrm{L}$ & $\mathrm{U}$ & $3.18 \mathrm{E}+01$ & $3.18 \mathrm{E}-01$ \\
\hline Europium-155 & $\mathrm{B} 0 \mathrm{XK} 23$ & 699-21-6 & $02 / 07 / 2000$ & $2.92 \mathrm{E}+00$ & $\mathrm{pCi} / \mathrm{L}$ & $\mathrm{U}$ & $2.13 E+01$ & $2.13 \mathrm{E}-01$ \\
\hline Gross alpha & B0XK23 & 699-21-6 & $02 / 07 / 2000$ & $2.08 \mathrm{E}+00$ & $\mathrm{pCi} / \mathrm{L}$ & $\mathrm{J}$ & $1.77 \mathrm{E}+00$ & $1.77 \mathrm{E}-00$ \\
\hline Gross beta & B0XK23 & $699-21-6$ & $02 / 07 / 2000$ & $9.52 \mathrm{E}+00$ & $\mathrm{pCi} / \mathrm{L}$ & & $2.72 \mathrm{E}+00$ & $2.72 \mathrm{E}-00$ \\
\hline Iodine-129 & $\mathrm{B} 0 \mathrm{XK} 23$ & 699-21-6 & $02 / 07 / 2000$ & $7.73 \mathrm{E}-02$ & $\mathrm{pCi} / \mathrm{L}$ & $\mathrm{U}$ & $3.33 \mathrm{E}-01$ & $3.33 \mathrm{E}-01$ \\
\hline
\end{tabular}


Table C.3. (contd)

\begin{tabular}{|c|c|c|c|c|c|c|c|c|}
\hline Constituent & $\begin{array}{c}\text { Sample } \\
\text { Number }\end{array}$ & Well Name & $\begin{array}{c}\text { Sample } \\
\text { Date }\end{array}$ & $\begin{array}{c}\text { Value } \\
\text { Reported }\end{array}$ & Units & $\begin{array}{c}\text { Lab } \\
\text { Qualifier }\end{array}$ & $\begin{array}{c}\text { Reporting } \\
\text { Limit }\end{array}$ & MDA \\
\hline Potassium-40 & B0XK23 & $699-21-6$ & $02 / 07 / 2000$ & $-2.29 \mathrm{E}+01$ & $\mathrm{pCi} / \mathrm{L}$ & $\mathrm{U}$ & $2.24 \mathrm{E}+02$ & $2.24 \mathrm{E}+02$ \\
\hline Ruthenium-106 & B0XK23 & 699-21-6 & $02 / 07 / 2000$ & $-1.79 \mathrm{E}+01$ & $\mathrm{pCi} / \mathrm{L}$ & $\mathrm{U}$ & $7.15 \mathrm{E}+01$ & $7.15 E+01$ \\
\hline Technetium-99 & B0XK23 & $699-21-6$ & $02 / 07 / 2000$ & $5.18 \mathrm{E}+01$ & $\mathrm{pCi} / \mathrm{L}$ & & $1.23 E+01$ & $1.23 \mathrm{E}+01$ \\
\hline Uranium-234 & B0XK23 & 699-21-6 & $02 / 07 / 2000$ & $1.56 \mathrm{E}+00$ & $\mathrm{pCi} / \mathrm{L}$ & & $2.62 \mathrm{E}-01$ & 2.62E-01 \\
\hline Uranium-235 & B0XK23 & $699-21-6$ & $02 / 07 / 2000$ & $-1.11 \mathrm{E}-02$ & $\mathrm{pCi} / \mathrm{L}$ & $\mathrm{U}$ & $2.31 \mathrm{E}-01$ & $2.31 \mathrm{E}-01$ \\
\hline Uranium-238 & B0XK23 & 699-21-6 & $02 / 07 / 2000$ & $9.58 \mathrm{E}-01$ & $\mathrm{pCi} / \mathrm{L}$ & $\mathrm{J}$ & $2.47 \mathrm{E}-01$ & $2.47 E-01$ \\
\hline Antimony- 125 & B0XK12 & $699-8-17$ & $02 / 08 / 2000$ & $2.65 \mathrm{E}+00$ & $\mathrm{pCi} / \mathrm{L}$ & $\mathrm{U}$ & $2.26 \mathrm{E}+01$ & $2.26 \mathrm{E}+01$ \\
\hline Beryllium-7 & B0XK12 & $699-8-17$ & $02 / 08 / 2000$ & $-1.26 \mathrm{E}+01$ & $\mathrm{pCi} / \mathrm{L}$ & $\mathrm{U}$ & $5.62 \mathrm{E}+01$ & $5.62 \mathrm{E}+01$ \\
\hline Cesium-134 & B0XK12 & $699-8-17$ & $02 / 08 / 2000$ & $-6.01 E+00$ & $\mathrm{pCi} / \mathrm{L}$ & $\mathrm{U}$ & $6.60 \mathrm{E}+00$ & $6.60 \mathrm{E}+00$ \\
\hline Cesium-137 & B0XK12 & 699-8-17 & $102 / 08 / 2000$ & $3.55 \mathrm{E}+00$ & $\mathrm{pCi} / \mathrm{L}$ & $\mathrm{U}$ & $9.57 E+00$ & $9.57 \mathrm{E}+00$ \\
\hline Cobalt- 60 & $\mathrm{~B} 0 \mathrm{XK} 12$ & 699-8-17 & $02 / 08 / 2000$ & $7.01 \mathrm{E}-01$ & $\mathrm{pCi} / \mathrm{L}$ & $\mathrm{U}$ & $7.81 \mathrm{E}+00$ & $7.81 \mathrm{E}+00$ \\
\hline Europium-152 & B0XK12 & $699-8-17$ & $02 / 08 / 2000$ & $1.46 \mathrm{E}+01$ & $\mathrm{pCi} / \mathrm{L}$ & U & $2.45 \mathrm{E}+01$ & $2.45 \mathrm{E}+01$ \\
\hline Europium-154 & B0XK12 & 699-8-17 & $02 / 08 / 2000$ & $3.71 \mathrm{E}+00$ & $\mathrm{pCi} / \mathrm{L}$ & $\mathrm{U}$ & $2.68 \mathrm{E}+01$ & $2.68 \mathrm{E}+01$ \\
\hline Europium-155 & B0XK12 & 699-8-17 & $02 / 08 / 2000$ & $3.74 \mathrm{E}+00$ & $\mathrm{pCi} / \mathrm{L}$ & $\mathrm{U}$ & $1.59 \mathrm{E}+01$ & $1.59 \mathrm{E}+01$ \\
\hline Gross alpha & B0XK12 & $699-8-17$ & $02 / 08 / 2000$ & $3.83 E+00$ & $\mathrm{pCi} / \mathrm{L}$ & & $1.53 \mathrm{E}+00$ & $1.53 \mathrm{E}+00$ \\
\hline Gross beta & B0XK12 & 699-8-17 & $02 / 08 / 2000$ & $2.18 \mathrm{E}+01$ & $\mathrm{pCi} / \mathrm{L}$ & & $2.80 \mathrm{E}+00$ & $2.80 \mathrm{E}+00$ \\
\hline Iodine-129 & B0XK12 & 699-8-17 & $02 / 08 / 2000$ & $1.72 \mathrm{E}-01$ & $\mathrm{pCi} / \mathrm{L}$ & $\mathrm{U}$ & $2.96 \mathrm{E}-01$ & $2.96 \mathrm{E}-01$ \\
\hline Potassium -40 & $\mathrm{~B} 0 \mathrm{XK} 12$ & $699-8-17$ & $02 / 08 / 2000$ & $2.12 E+01$ & $\mathrm{pCi} / \mathrm{L}$ & $\mathrm{U}$ & $2.53 \mathrm{E}+02$ & $2.53 \mathrm{E}+02$ \\
\hline Ruthenium-106 & B0XK12 & $699-8-17$ & $02 / 08 / 2000$ & $-2.20 \mathrm{E}+01$ & $\mathrm{pCi} / \mathrm{L}$ & $\underline{U}$ & $6.98 \mathrm{E}+01$ & $6.98 \mathrm{E}+01$ \\
\hline Technetium-99 & B0XK12 & $699-8-17$ & $102 / 08 / 2000$ & $1.56 \mathrm{E}+02$ & $\mathrm{pCi} / \mathrm{L}$ & & $1.23 \mathrm{E}+01$ & $1.23 \mathrm{E}+01$ \\
\hline Uranium-234 & B0XK12 & $699-8-17$ & $02 / 08 / 2000$ & $1.53 E+00$ & $\mathrm{pCi} / \mathrm{L}$ & & $2.56 \mathrm{E}-01$ & $2.56 \mathrm{E}-01$ \\
\hline Uranium-235 & B0XK12 & $699-8-17$ & $02 / 08 / 2000$ & $4.32 \mathrm{E}-02$ & $\mathrm{pCi} / \mathrm{L}$ & $\mathrm{U}$ & $2.35 \mathrm{E}-01$ & $2.35 \mathrm{E}-01$ \\
\hline Uranium-238 & B0XK12 & $699-8-17$ & $02 / 08 / 2000$ & $1.32 \mathrm{E}+00$ & $\mathrm{pCi} / \mathrm{L}$ & & $2.74 \mathrm{E}-01$ & $2.74 \mathrm{E}-01$ \\
\hline Antimony-125 & B0XJY4 & 699-9-E2 & $02 / 10 / 2000$ & $2.38 \mathrm{E}+00$ & $\mathrm{pCi} / \mathrm{L}$ & $\mathrm{U}$ & $2.08 \mathrm{E}+01$ & $2.08 \mathrm{E}+01$ \\
\hline Beryllium-7 & В0XJY4 & 699-9-E2 & $02 / 10 / 2000$ & $-1.40 \mathrm{E}+00$ & $\mathrm{pCi} / \mathrm{L}$ & $\mathrm{U}$ & $6.60 \mathrm{E}+01$ & $6.60 \mathrm{E}+01$ \\
\hline Cesium-134 & $\mathrm{B} 0 \mathrm{XJY} 4$ & 699-9-E2 & $02 / 10 / 2000$ & $-3.58 \mathrm{E}+00$ & $\mathrm{pCi} / \mathrm{L}$ & $\mathrm{U}$ & $7.24 \mathrm{E}+00$ & $7.24 \mathrm{E}+00$ \\
\hline Cesium-137 & B0XJY4 & 699-9-E2 & $02 / 10 / 2000$ & $-2.92 \mathrm{E}+00$ & $\mathrm{pCi} / \mathrm{L}$ & $\mathrm{U}$ & $6.93 E+00$ & $6.93 \mathrm{E}+00$ \\
\hline Cobalt- 60 & B0XJY4 & 699-9-E2 & $02 / 10 / 2000$ & $2.31 E+00$ & $\mathrm{pCi} / \mathrm{L}$ & $\mathrm{U}$ & $1.00 \mathrm{E}+01$ & $1.00 \mathrm{E}+01$ \\
\hline Europium-152 & B0XJY4 & 699-9-E2 & $02 / 10 / 2000$ & $4.51 \mathrm{E}+00$ & $\mathrm{pCi} / \mathrm{L}$ & $\mathrm{U}$ & $2.25 \mathrm{E}+01$ & $2.25 \mathrm{E}+01$ \\
\hline Europium-154 & B0XJY4 & 699-9-E2 & $02 / 10 / 2000$ & $2.82 \mathrm{E}+00$ & $\mathrm{pCi} / \mathrm{L}$ & $\mathrm{U}$ & $3.20 \mathrm{E}+01$ & $3.20 \mathrm{E}+01$ \\
\hline Europium-155 & B0XJY4 & 699-9-E2 & $02 / 10 / 2000$ & $-2.13 E+00$ & $\mathrm{pCi} / \mathrm{L}$ & $\mathrm{U}$ & $1.88 \mathrm{E}+01$ & $1.88 \mathrm{E}+01$ \\
\hline Gross alpha & B0XJY4 & 699-9-E2 & $02 / 10 / 2000$ & $1.98 \mathrm{E}+00$ & $\mathrm{pCi} / \mathrm{L}$ & $\mathrm{J}$ & $1.32 \mathrm{E}+00$ & $1.32 \mathrm{E}+00$ \\
\hline Gross beta & B0XJY4 & 699-9-E2 & $02 / 10 / 2000$ & $7.35 E+00$ & $\mathrm{pCi} / \mathrm{L}$ & & $3.11 E+00$ & $3.11 \mathrm{E}+00$ \\
\hline Iodine-129 & B0XJY4 & 699-9-E2 & $02 / 10 / 2000$ & $1.83 \mathrm{E}-01$ & $\mathrm{pCi} / \mathrm{L}$ & $\mathrm{U}$ & $3.52 \mathrm{E}-01$ & $3.52 \mathrm{E}-01$ \\
\hline Potassium-40 & B0XJY4 & 699-9-E2 & $02 / 10 / 2000$ & $-3.63 E+01$ & $\mathrm{pCi} / \mathrm{L}$ & $\mathrm{U}$ & $1.44 \mathrm{E}+02$ & $1.44 \mathrm{E}+02$ \\
\hline Ruthenium-106 & B0XJY4 & 699-9-E2 & $02 / 10 / 2000$ & $-1.07 E+01$ & $\mathrm{pCi} / \mathrm{L}$ & U & $6.23 E+01$ & $6.23 \mathrm{E}+01$ \\
\hline Technetium-99 & BOXJY4 & 699-9-E2 & $02 / 10 / 2000$ & $-3.32 E+00$ & $\mathrm{pCi} / \mathrm{L}$ & $\mathrm{U}$ & $1.25 E+01$ & $1.25 \mathrm{E}+01$ \\
\hline $\begin{array}{l}\text { Total beta } \\
\text { radiostrontium }\end{array}$ & B0XJY4 & 699-9-E2 & $02 / 10 / 2000$ & $-5.44 \mathrm{E}-02$ & $\mathrm{pCi} / \mathrm{L}$ & $\mathrm{U}$ & $6.42 \mathrm{E}-01$ & $6.42 \mathrm{E}-01$ \\
\hline Uranium-234 & B0XJY4 & 699-9-E2 & $02 / 10 / 2000$ & $1.28 \mathrm{E}+00$ & $\mathrm{pCi} / \mathrm{L}$ & & $3.96 \mathrm{E}-01$ & $3.96 \mathrm{E}-01$ \\
\hline
\end{tabular}


Table C.3. (contd)

\begin{tabular}{|c|c|c|c|c|c|c|c|c|}
\hline Constituent & $\begin{array}{l}\text { Sample } \\
\text { Number }\end{array}$ & Well Name & $\begin{array}{c}\text { Sample } \\
\text { Date }\end{array}$ & $\begin{array}{c}\text { Value } \\
\text { Reported }\end{array}$ & Units & $\begin{array}{c}\text { Lab } \\
\text { Qualifier } \\
\end{array}$ & $\begin{array}{c}\text { Reporting } \\
\text { Limit }\end{array}$ & MDA \\
\hline Uranium-235 & B0XJY4 & 699-9-E2 & $02 / 10 / 2000$ & $7.15 \mathrm{E}-02$ & $\mathrm{pCi} / \mathrm{L}$ & $\mathrm{U}$ & $3.07 \mathrm{E}-01$ & $3.07 \mathrm{E}-(01$ \\
\hline Uranium-238 & B0XJY4 & 699-9-E2 & $02 / 10 / 2000$ & $1.13 E+00$ & $\mathrm{pCi} / \mathrm{L}$ & & 3.88E-01 & $3.88 \mathrm{E}-(01$ \\
\hline Antimony-125 ${ }^{(\mathrm{b})}$ & B0XJY4 DUP & 699-9-E2 DUP & $02 / 10 / 2000$ & $6.22 \mathrm{E}-01$ & $\mathrm{pCi} / \mathrm{L}$ & $\mathrm{U}$ & & $2.24 \mathrm{E}+01$ \\
\hline Beryllium- $7^{(b)}$ & B0XNY4 DUP & 699-9-E2 DUP & $02 / 10 / 2000$ & $1.72 \mathrm{E}+01$ & $\mathrm{pCi} / \mathrm{L}$ & $\mathrm{U}$ & & $8.90 \mathrm{E}+01$ \\
\hline Cesium-134(b) & B0XJY4 DUP & 699-9-E2 DUP & $02 / 10 / 2000$ & $-5.94 \mathrm{E}+00$ & $\mathrm{pCi} / \mathrm{L}$ & $\mathrm{U}$ & & $8.72 \mathrm{E}+00$ \\
\hline Cesium-137(b) & B0XJY4 DUP & 699-9-E2 DUP & $02 / 10 / 2000$ & $1.63 \mathrm{E}+00$ & $\mathrm{pCi} / \mathrm{L}$ & $\mathrm{U}$ & & $9.54 \mathrm{E}+00$ \\
\hline Cobalt- $60^{(\mathrm{b})}$ & B0XJY4 DUP & 699-9-E2 DUP & $02 / 10 / 2000$ & $-1.84 E+00$ & $\mathrm{pCi} / \mathrm{L}$ & $\mathrm{U}$ & & $9.25 \mathrm{E}+00$ \\
\hline Europium- $152^{\text {(b) }}$ & B0XJY4 DUP & 699-9-E2 DUP & $02 / 10 / 2000$ & $7.70 \mathrm{E}+00$ & $\mathrm{pCi} / \mathrm{L}$ & $\mathrm{U}$ & & $2.39 \mathrm{E}+01$ \\
\hline Europium-154 ${ }^{(\mathrm{b})}$ & BOXJY4 DUP & 699-9-E2 DUP & $02 / 10 / 2000$ & $4.22 \mathrm{E}+00$ & $\mathrm{pCi} / \mathrm{L}$ & $\mathrm{U}$ & & $2.81 \mathrm{E}+01$ \\
\hline Europium-155 ${ }^{\text {(b) }}$ & B0XJY4 DUP & 699-9-E2 DUP & $02 / 10 / 2000$ & $-9.94 \mathrm{E}-01$ & $\mathrm{pCi} / \mathrm{L}$ & $\mathrm{U}$ & & $1.99 \mathrm{E}+01$ \\
\hline Potassium- $40^{\text {(b) }}$ & B0XJY4 DUP & 699-9-E2 DUP & $02 / 10 / 2000$ & $-2.14 \mathrm{E}+01$ & $\mathrm{pCi} / \mathrm{L}$ & $\mathrm{U}$ & & $2.28 E+02$ \\
\hline Ruthenium-106 $6^{(b)}$ & B0XJY4 DUP & 699-9-E2 DUP & $02 / 10 / 2000$ & $7.23 \mathrm{E}+00$ & $\mathrm{pCi} / \mathrm{L}$ & $\mathrm{U}$ & & $8.75 E+01$ \\
\hline Technetium-99 $9^{(\text {b) }}$ & B0XJY4 DUP & 699-9-E2 DUP & $02 / 10 / 2000$ & $2.66 \mathrm{E}+00$ & $\mathrm{pCi} / \mathrm{L}$ & $\mathrm{U}$ & & $1.25 \mathrm{E}+01$ \\
\hline $\begin{array}{l}\text { Total beta } \\
\text { radiostrontium } \\
\text { (b) }\end{array}$ & BOXJY4 DUP & 699-9-E2 DUP & $02 / 10 / 2000$ & $-5.14 \mathrm{E}-02$ & $\mathrm{pCi} / \mathrm{L}$ & $\mathrm{U}$ & & $7.41 \mathrm{E}-01$ \\
\hline Antimony-125 & $\mathrm{BOXKCl}$ & C3071/ENW-MW1 & $02 / 09 / 2000$ & $-3.60 \mathrm{E}+00$ & $\mathrm{pCi} / \mathrm{L}$ & $U$ & $2.00 \mathrm{E}+01$ & $2.00 E+01$ \\
\hline Beryllium-7 & BOXKCl & C3071/ENW-MW1 & $02 / 09 / 2000$ & $6.28 \mathrm{E}+00$ & $\mathrm{pCi} / \mathrm{L}$ & $\mathrm{U}$ & $8.34 \mathrm{E}+01$ & $8.34 \mathrm{E}+01$ \\
\hline Cesium-134 & $\mathrm{B} 0 \mathrm{XKCl}$ & C3071/ENW-MW1 & $02 / 09 / 2000$ & $2.48 \mathrm{E}+00$ & $\mathrm{pCi} / \mathrm{L}$ & $\mathrm{U}$ & $8.47 \mathrm{E}+00$ & $8.47 \mathrm{E}+00$ \\
\hline Cesium-137 & $\mathrm{B} 0 \mathrm{XKCl}$ & C3071/ENW-MW1 & $02 / 09 / 2000$ & 3.44E-01 & $\mathrm{pCi} / \mathrm{L}$ & $\mathrm{U}$ & $8.06 \mathrm{E}+00$ & $8.06 \mathrm{E}-00$ \\
\hline Cobalt -60 & $\mathrm{~B} 0 \mathrm{XKCl}$ & C3071/ENW-MW1 & $02 / 09 / 2000$ & $5.09 \mathrm{E}+00$ & $\mathrm{pCi} / \mathrm{L}$ & $\mathrm{U}$ & $1.24 \mathrm{E}+01$ & $1.24 \mathrm{E}-01$ \\
\hline Europium-152 & $\mathrm{B} 0 \mathrm{XKCl}$ & C3071/ENW-MW1 & $02 / 09 / 2000$ & $5.08 \mathrm{E}-01$ & $\mathrm{pCi} / \mathrm{L}$ & $\mathrm{U}$ & $2.19 \mathrm{E}+01$ & $2.19 \mathrm{E}-01$ \\
\hline Europium-154 & B0XKCl & C3071/ENW-MW1 & $02 / 09 / 2000$ & $1.23 E+01$ & $\mathrm{pCi} / \mathrm{L}$ & $\mathrm{U}$ & $3.14 \mathrm{E}+01$ & $3.14 \mathrm{E}+0 \mathrm{i}$ \\
\hline Europium-155 & $\mathrm{BOXKCl}$ & C3071/ENW-MW1 & $02 / 09 / 2000$ & $2.20 \mathrm{E}-01$ & $\mathrm{pCi} / \mathrm{L}$ & $\mathrm{U}$ & $1.61 \mathrm{E}+01$ & $1.61 \mathrm{E}+01$ \\
\hline Gross alpha & $\mathrm{B} 0 \mathrm{XKCl}$ & C3071/ENW-MW1 & $02 / 09 / 2000$ & $5.23 \mathrm{E}+00$ & $\mathrm{pCi} / \mathrm{L}$ & & $3.23 \mathrm{E}+00$ & $3.23 E+00$ \\
\hline Gross beta & $\mathrm{B} 0 \mathrm{XKC1}$ & C3071/ENW-MW1 & $02 / 09 / 2000$ & $3.07 \mathrm{E}+01$ & $\mathrm{pCi} / \mathrm{L}$ & & $3.39 \mathrm{E}+00$ & $3.39 \mathrm{E}+00$ \\
\hline Iodine- 129 & $\mathrm{~B} 0 \mathrm{XKCl}$ & C3071/ENW-MW1 & $02 / 09 / 2000$ & $5.62 \mathrm{E}-02$ & $\mathrm{pCi} / \mathrm{L}$ & $\mathrm{U}$ & $2.68 \mathrm{E}-01$ & $2.68 \mathrm{E}-01$ \\
\hline Potassium-40 & $\mathrm{B} 0 \mathrm{XKCl}$ & C3071/ENW-MW1 & $02 / 09 / 2000$ & $2.08 \mathrm{E}+01$ & $\mathrm{pCi} / \mathrm{L}$ & $\mathrm{U}$ & $9.38 E+01$ & $9.38 \mathrm{E}+01$ \\
\hline Ruthenium-106 & B0XKC1 & C3071/ENW-MW1 & $02 / 09 / 2000$ & $1.88 \mathrm{E}+01$ & $\mathrm{pCi} / \mathrm{L}$ & $\mathrm{U}$ & $7.90 \mathrm{E}+01$ & $7.90 \mathrm{E}+01$ \\
\hline Technetium-99 & $\mathrm{B} 0 \mathrm{XKCl}$ & C3071/ENW-MW1 & $02 / 09 / 2000$ & $8.84 \mathrm{E}+01$ & $\mathrm{pCi} / \mathrm{L}$ & & $1.26 \mathrm{E}+01$ & $1.26 \mathrm{E}+01$ \\
\hline Uranium-234 & $\mathrm{B} 0 \mathrm{XKC1}$ & C3071/ENW-MW1 & $02 / 09 / 2000$ & $5.93 \mathrm{E} \div 00$ & $\mathrm{pCi} / \mathrm{L}$ & & 4.68E-01 & $4.68 \mathrm{E}-01$ \\
\hline Uranium-235 & $\mathrm{B} 0 \mathrm{XKC1}$ & C3071/ENW-MW1 & $02 / 09 / 2000$ & $3.38 \mathrm{E}-01$ & $\mathrm{pCi} / \mathrm{L}$ & $\mathrm{U}$ & $3.63 \mathrm{E}-01$ & $3.63 \mathrm{E}-01$ \\
\hline Uranium-238 & $\mathrm{B} 0 \mathrm{XKC1}$ & C3071/ENW-MW1 & $02 / 09 / 2000$ & $5.09 \mathrm{E}+00$ & $\mathrm{pCi} / \mathrm{L}$ & & $4.33 \mathrm{E}-01$ & $4.33 \mathrm{E}-01$ \\
\hline Antimony-125 $5^{(\mathrm{b})}$ & $\begin{array}{l}\text { B0XKC1 } \\
\text { DUP }\end{array}$ & $\begin{array}{l}\text { C3071/ENW-MW1 } \\
\text { DUP }\end{array}$ & $02 / 09 / 2000$ & $2.24 \mathrm{E}+00$ & $\mathrm{pCi} / \mathrm{L}$ & $\mathrm{U}$ & & $2.36 \mathrm{E}+01$ \\
\hline Beryllium- $7^{(b)}$ & $\begin{array}{l}\text { B0XKC1 } \\
\text { DUP }\end{array}$ & $\begin{array}{l}\text { C3071/ENW-MW1 } \\
\text { DUP }\end{array}$ & $02 / 09 / 2000$ & $-1.72 E+01$ & $\mathrm{pCi} / \mathrm{L}$ & $U$ & & $7.28 \mathrm{E}+01$ \\
\hline Cesium-134 ${ }^{(\mathrm{b})}$ & \begin{tabular}{|l|} 
BOXKCl \\
DUP \\
\end{tabular} & $\begin{array}{l}\text { C3071/ENW-MW1 } \\
\text { DUP }\end{array}$ & $02 / 09 / 2000$ & $-6.55 E+00$ & $\mathrm{pCi} / \mathrm{L}$ & U & & $8.11 E+00$ \\
\hline Cesium-137(b) & \begin{tabular}{|l|} 
B0XKC1 \\
DUP
\end{tabular} & $\begin{array}{l}\text { C3071/ENW-MW1 } \\
\text { DUP }\end{array}$ & $02 / 09 / 2000$ & $1.01 E+00$ & $\mathrm{pCi} / \mathrm{L}$ & U & & $9.54 \mathrm{E}+00$ \\
\hline Cobalt- $60^{(b)}$ & $\begin{array}{l}\text { B0XKCl } \\
\text { DUP }\end{array}$ & $\begin{array}{l}\text { C3071/ENW-MW1 } \\
\text { DUP }\end{array}$ & $02 / 09 / 2000$ & $5.22 \mathrm{E}+00$ & $\mathrm{pCi} / \mathrm{L}$ & $\mathrm{U}$ & & $1.15 \mathrm{E}+01$ \\
\hline
\end{tabular}


Table C.3. (contd)

\begin{tabular}{|c|c|c|c|c|c|c|c|c|}
\hline Constituent & $\begin{array}{c}\text { Sample } \\
\text { Number }\end{array}$ & Well Name & $\begin{array}{c}\text { Sample } \\
\text { Date }\end{array}$ & $\begin{array}{c}\text { Value } \\
\text { Reported }\end{array}$ & Units & $\begin{array}{c}\text { Lab } \\
\text { Qualifier }^{(a)}\end{array}$ & $\begin{array}{c}\text { Reporting } \\
\text { Limit }\end{array}$ & MDA \\
\hline Europium-1 $52^{(\mathrm{b})}$ & $\begin{array}{l}\text { BOXKCl } \\
\text { DUP }\end{array}$ & $\begin{array}{l}\text { C3071/ENW-MW1 } \\
\text { DUP }\end{array}$ & $02 / 09 / 2000$ & $-5.36 E+00$ & $\mathrm{pCi} / \mathrm{L}$ & $\mathrm{U}$ & & $2.18 \mathrm{E}+01$ \\
\hline Europium-154 ${ }^{(\mathrm{b})}$ & $\begin{array}{l}\text { B0XKCl } \\
\text { DUP }\end{array}$ & $\begin{array}{l}\text { C3071/ENW-MW1 } \\
\text { DUP }\end{array}$ & $02 / 09 / 2000$ & $1.20 \mathrm{E}+01$ & $\mathrm{pCi} / \mathrm{L}$ & $\mathrm{U}$ & & $3.39 \mathrm{E}+01$ \\
\hline Europium-155(b) & $\begin{array}{l}\text { BOXKCl } \\
\text { DUP }\end{array}$ & $\begin{array}{l}\text { C3071/ENW-MW1 } \\
\text { DUP }\end{array}$ & $02 / 09 / 2000$ & $-2.45 E+00$ & $\mathrm{pCi} / \mathrm{L}$ & $\mathrm{U}$ & & $2.04 \mathrm{E}+01$ \\
\hline Gross alpha $^{(b)}$ & $\begin{array}{l}\text { BOXKC1 } \\
\text { DUP }\end{array}$ & $\begin{array}{l}\text { C3071/ENW-MW1 } \\
\text { DUP }\end{array}$ & $02 / 09 / 2000$ & $7.26 \mathrm{E}+00$ & $\mathrm{pCi} / \mathrm{L}$ & & & $2.86 \mathrm{E}+00$ \\
\hline Potassium- $40^{(b)}$ & $\begin{array}{l}\text { BOXKC1 } \\
\text { DUP }\end{array}$ & $\begin{array}{l}\text { C3071/ENW-MW1 } \\
\text { DUP }\end{array}$ & $02 / 09 / 2000$ & $-5.15 E+01$ & $\mathrm{pCi} / \mathrm{L}$ & $\mathrm{U}$ & & $2.20 \mathrm{E}+02$ \\
\hline Ruthenium-106 $6^{(\mathrm{b})}$ & $\begin{array}{l}\text { BOXKCl } \\
\text { DUP }\end{array}$ & $\begin{array}{l}\text { C3071/ENW-MW1 } \\
\text { DUP }\end{array}$ & $02 / 09 / 2000$ & $2.59 \mathrm{E}+01$ & $\mathrm{pCi} / \mathrm{L}$ & $\mathrm{U}$ & & $8.74 E+01$ \\
\hline Technetium- $99^{(b)}$ & $\begin{array}{l}\text { B0XKCl } \\
\text { DuP }\end{array}$ & $\begin{array}{l}\text { C3071/ENW-MW1 } \\
\text { DUP }\end{array}$ & $02 / 09 / 2000$ & $8.82 E+01$ & $\mathrm{pCi} / \mathrm{L}$ & & & $1.27 \mathrm{E}+01$ \\
\hline Antimony-125 & $\mathrm{B} 0 \mathrm{XKC2}$ & C3072/ENW-MW2 & $02 / 10 / 2000$ & $-2.39 E+00$ & $\mathrm{pCi} / \mathrm{L}$ & $\mathrm{U}$ & $2.05 \mathrm{E}+01$ & $2.05 \mathrm{E}+01$ \\
\hline Beryllium-7 & $\mathrm{B} 0 \times \mathrm{KKC} 2$ & C3072/ENW-MW2 & $02 / 10 / 2000$ & $2.17 \mathrm{E}+01$ & $\mathrm{pCi} / \mathrm{L}$ & $\mathrm{U}$ & $8.33 \mathrm{E}+01$ & $8.33 \mathrm{E}+01$ \\
\hline Cesium-134 & $\mathrm{B} 0 \mathrm{XKC} 2$ & C3072/ENW-MW2 & $02 / 10 / 2000$ & $-2.68 E+00$ & $\mathrm{pCi} / \mathrm{L}$ & $\mathrm{U}$ & $7.80 \mathrm{E}+00$ & $7.80 \mathrm{E}+00$ \\
\hline Cesium-137 & $\mathrm{B} 0 \mathrm{XKC2}$ & C3072/ENW-MW2 & $02 / 10 / 2000$ & $3.09 \mathrm{E}+00$ & $\mathrm{pCi} / \mathrm{L}$ & $\mathrm{U}$ & $8.90 \mathrm{E}+00$ & $8.90 \mathrm{E}+00$ \\
\hline Cobalt- 60 & B0XKC2 & C3072/ENW-MW2 & $02 / 10 / 2000$ & $-3.01 E+00$ & $\mathrm{pCi} / \mathrm{L}$ & $\mathrm{U}$ & $9.21 \mathrm{E} \div 00$ & $9.21 \mathrm{E}+00$ \\
\hline Europium-152 & $\mathrm{B} 0 \mathrm{XKC2}$ & C3072/ENW-MW2 & $02 / 10 / 2000$ & $3.31 \mathrm{E}+00$ & $\mathrm{pCi} / \mathrm{L}$ & $\mathrm{U}$ & $2.34 \mathrm{E}+01$ & $2.34 \mathrm{E}+01$ \\
\hline Europium-154 & B0XKC2 & C3072/ENW-MW2 & $02 / 10 / 2000$ & $-1.71 E+00$ & $\mathrm{pCi} / \mathrm{L}$ & $\mathrm{U}$ & $2.63 E+01$ & $2.63 \mathrm{E}+01$ \\
\hline Europium-155 & BOXKC2 & C3072/ENW-MW2 & $02 / 10 / 2000$ & $-1.29 \mathrm{E}+00$ & $\mathrm{pCi} / \mathrm{L}$ & $\mathrm{U}$ & $1.52 \mathrm{E}+01$ & $1.52 \mathrm{E}+01$ \\
\hline Gross alpha & $\mathrm{B} 0 \mathrm{XKC2}$ & C3072/ENW-MW2 & $02 / 10 / 2000$ & $2.21 \mathrm{E}+01$ & $\mathrm{pCi} / \mathrm{L}$ & & $3.16 \mathrm{E}+00$ & $3.16 \mathrm{E}+00$ \\
\hline Gross beta & $\mathrm{B} 0 \mathrm{XKC2}$ & C3072/ENW-MW2 & $02 / 10 / 2000$ & $2.29 E+01$ & $\mathrm{pCi} / \mathrm{L}$ & & 4.47E+00 & $4.47 \mathrm{E}+00$ \\
\hline Iodine-129 & $\mathrm{B} 0 \mathrm{XKC2}$ & C3072/ENW-MW2 & $02 / 10 / 2000$ & $-6.29 \mathrm{E}-02$ & $\mathrm{pCi} / \mathrm{L}$ & $\mathrm{U}$ & $2.41 E-01$ & 2.41E-01 \\
\hline Potassium-40 & B0XKC2 & C3072/ENW-MW2 & $02 / 10 / 2000$ & $1.10 \mathrm{E}+01$ & $\mathrm{pCi} / \mathrm{L}$ & $\mathrm{U}$ & $8.86 \mathrm{E}+01$ & $8.86 \mathrm{E}+01$ \\
\hline Ruthenium-106 & $\mathrm{BOXKC2}$ & C3072/ENW-MW2 & $02 / 10 / 2000$ & $-1.12 \mathrm{E}+01$ & $\mathrm{pCi} / \mathrm{L}$ & $\mathrm{U}$ & $7.43 \mathrm{E}+01$ & $7.43 E+01$ \\
\hline Technetium-99 & B0XKC2 & C3072/ENW-MW2 & $02 / 10 / 2000$ & $9.96 \mathrm{E}+00$ & $\mathrm{pCi} / \mathrm{L}$ & $\mathrm{U}$ & $1.25 \mathrm{E}+01$ & $1.25 \mathrm{E}+01$ \\
\hline Uranium-234 & $\mathrm{B} 0 \mathrm{XKC2}$ & C3072/ENW-MW2 & $02 / 10 / 2000$ & $1.22 E+01$ & $\mathrm{pCi} / \mathrm{L}$ & & 2.17E-01 & 2.17E-01 \\
\hline Uranium-235 & $\mathrm{B} 0 \mathrm{XKC} 2$ & C3072/ENW-MW2 & $02 / 10 / 2000$ & $5.80 \mathrm{E}-01$ & $\mathrm{pCi} / \mathrm{L}$ & $\mathrm{J}$ & $2.79 \mathrm{E}-01$ & $2.79 \mathrm{E}-01$ \\
\hline Uranium-238 & $\mathrm{B} 0 \mathrm{XKC} 2$ & C3072/ENW-MW2 & $02 / 10 / 2000$ & $1.09 E+01$ & $\mathrm{pCi} / \mathrm{L}$ & & $3.24 \mathrm{E}-01$ & $3.24 \mathrm{E}-01$ \\
\hline Gross alpha $^{(b)}$ & \begin{tabular}{|l} 
BOXKC2 \\
DUP
\end{tabular} & $\begin{array}{l}\text { C3072/ENW-MW2 } \\
\text { DUP }\end{array}$ & $02 / 10 / 2000$ & $2.59 \mathrm{E}+01$ & $\mathrm{pCi} / \mathrm{L}$ & & & $2.83 \mathrm{E}+00$ \\
\hline Iodine-129(b) & $\begin{array}{l}\text { BOXKC2 } \\
\text { DUP }\end{array}$ & $\begin{array}{l}\text { C3072/ENW-MW2 } \\
\text { DUP }\end{array}$ & $02 / 10 / 2000$ & $1.66 \mathrm{E}-02$ & $\mathrm{pCi} / \mathrm{L}$ & $\mathrm{U}$ & & $3.36 \mathrm{E}-01$ \\
\hline Antimony-125 & B0XKC3 & C3073/ENW-MW3 & $02 / 10 / 2000$ & $5.63 \mathrm{E}+00$ & $\mathrm{pCi} / \mathrm{L}$ & $\mathrm{U}$ & $1.84 \mathrm{E}+01$ & $1.84 \mathrm{E}+01$ \\
\hline Beryllium-7 & B0XKC3 & C3073/ENW-MW3 & $02 / 10 / 2000$ & $2.96 \mathrm{E}+01$ & $\mathrm{pCi} / \mathrm{L}$ & $\mathrm{U}$ & $6.79 \mathrm{E}+01$ & $6.79 \mathrm{E}+01$ \\
\hline Cesium-134 & $\mathrm{B} 0 \times \mathrm{XKC} 3$ & C3073/ENW-MW3 & $02 / 10 / 2000$ & $-1.30 \mathrm{E}+00$ & $\mathrm{pCi} / \mathrm{L}$ & $\mathrm{U}$ & $6.76 \mathrm{E}+00$ & $6.76 \mathrm{E}+00$ \\
\hline Cesium-137 & $\mathrm{B} 0 \mathrm{XKC} 3$ & C3073/ENW-MW3 & $02 / 10 / 2000$ & $2.14 \mathrm{E}+00$ & $\mathrm{pCi} / \mathrm{L}$ & $\mathrm{U}$ & $8.49 \mathrm{E}+00$ & $8.49 \mathrm{E}+00$ \\
\hline Cobalt- 60 & B0XKC3 & C3073/ENW-MW3 & $02 / 10 / 2000$ & $1.15 E+00$ & $\mathrm{pCi} / \mathrm{L}$ & $\mathrm{U}$ & $7.67 \mathrm{E}+00$ & $7.67 \mathrm{E}+00$ \\
\hline Europium-152 & $\mathrm{B} 0 \mathrm{XKC} 3$ & C3073/ENW-MW3 & $02 / 10 / 2000$ & $3.01 E+00$ & $\mathrm{pCi} / \mathrm{L}$ & $\mathrm{U}$ & $1.81 \mathrm{E}+01$ & $1.81 \mathrm{E}+01$ \\
\hline Europium-154 & $\mathrm{B} 0 \mathrm{XKC3}$ & C3073/ENW-MW3 & $02 / 10 / 2000$ & $6.78 \mathrm{E}+00$ & $\mathrm{pCi} / \mathrm{L}$ & $\mathrm{U}$ & $2.49 \mathrm{E}+01$ & $2.49 \mathrm{E}+01$ \\
\hline
\end{tabular}


Table C.3. (contd)

\begin{tabular}{|c|c|c|c|c|c|c|c|c|}
\hline Constituent & $\begin{array}{c}\text { Sample } \\
\text { Number }\end{array}$ & Well Name & $\begin{array}{c}\text { Sample } \\
\text { Date }\end{array}$ & $\begin{array}{c}\text { Value } \\
\text { Reported }\end{array}$ & Units & $\begin{array}{c}\text { Lab } \\
\text { Qualifier }\end{array}$ & $\begin{array}{c}\text { Reporting } \\
\text { Limit }\end{array}$ & MDA \\
\hline Europium-155 & $\mathrm{B} 0 \mathrm{XKC} 3$ & C3073/ENW-MW3 . & $02 / 10 / 2000$ & $-3.16 \mathrm{E}-01$ & $\mathrm{pCi} / \mathrm{L}$ & $\mathrm{U}$ & $1.38 \mathrm{E}+01$ & $1.38 \mathrm{E}+01$ \\
\hline Gross alpha & $\mathrm{B} 0 \mathrm{XKC} 3$ & C3073/ENW-MW3 & $02 / 10 / 2000$ & $1.84 \mathrm{E}+01$ & $\mathrm{pCi} / \mathrm{L}$ & & $2.56 \mathrm{E}+00$ & $2.56 \mathrm{E}+00$ \\
\hline Gross beta & $\mathrm{B} 0 \mathrm{XKC} 3$ & C3073/ENW-MW3 & $02 / 10 / 2000$ & $1.44 \mathrm{E}+01$ & $\mathrm{pCi} / \mathrm{L}$ & & $3.94 \mathrm{E}+00$ & $3.94 \mathrm{E}+00$ \\
\hline Iodine-129 & B0XKC3 & C3073/ENW-MW3 & $02 / 10 / 2000$ & $8.33 \mathrm{E}-03$ & $\mathrm{pCi} / \mathrm{L}$ & $\mathrm{U}$ & $2.09 \mathrm{E}-01$ & $2.09 \mathrm{E}-01$ \\
\hline Potassium-40 & B0XKC3 & C3073/ENW-MW3 & $02 / 10 / 2000$ & $-6.32 E+01$ & $\mathrm{pCi} / \mathrm{L}$ & $\mathrm{U}$ & $2.22 \mathrm{E}+02$ & $2.22 E+02$ \\
\hline Ruthenium-106 & B0XKC3 & C3073/ENW-MW3 & $02 / 10 / 2000$ & $-7.06 \mathrm{E}-01$ & $\mathrm{pCi} / \mathrm{L}$ & $\mathrm{U}$ & $6.84 \mathrm{E}+01$ & $6.84 \mathrm{E}+01$ \\
\hline Technetium-99 & B0XKC3 & C3073/ENW-MW3 & $02 / 10 / 2000$ & $3.82 \mathrm{E}+00$ & $\mathrm{pCi} / \mathrm{L}$ & $\mathrm{U}$ & $1.25 \mathrm{E}+01$ & $1.25 E+01$ \\
\hline Uranium-234 & B0XKC3 & C3073/ENW-MW3 & $02 / 10 / 2000$ & $7.67 E+00$ & $\mathrm{pCi} / \mathrm{L}$ & & $5.05 \mathrm{E}-01$ & $5.05 \mathrm{E}-01$ \\
\hline Uranium-235 & B0XKC3 & C3073/ENW-MW3 & $02 / 10 / 2000$ & $7.94 \mathrm{E}-01$ & $\mathrm{pCi} / \mathrm{L}$ & $\mathrm{J}$ & $4.63 \mathrm{E}-01$ & 4.63E-01 \\
\hline Uranium-238 & B0XKC3 & C3073/ENW-MW3 & $02 / 10 / 2000$ & $7.96 \mathrm{E}+00$ & $\mathrm{pCi} / \mathrm{L}$ & & $5.72 \mathrm{E}-01$ & $5.72 \mathrm{E}-01$ \\
\hline Gross beta ${ }^{(b)}$ & $\begin{array}{l}\text { BOXKC3 } \\
\text { DUP }\end{array}$ & $\begin{array}{l}\text { C3073/ENW-MW3 } \\
\text { DUP }\end{array}$ & $02 / 10 / 2000$ & $1.57 \mathrm{E}+01$ & $\mathrm{pCi} / \mathrm{L}$ & & & $3.83 \mathrm{E}+00$ \\
\hline Antimony-125 & BOXKC4 & C3074/ENW-MW4 & $02 / 10 / 2000$ & $-9.66 \mathrm{E}+00$ & $\mathrm{pCi} / \mathrm{L}$ & $\mathrm{U}$ & $1.53 \mathrm{E}+01$ & $1.53 \mathrm{E}+01$ \\
\hline Beryllium-7 & BOXKC4 & C3074/ENW-MW4 & $02 / 10 / 2000$ & $2.00 \mathrm{E}+01$ & $\mathrm{pCi} / \mathrm{L}$ & $\mathrm{U}$ & $7.40 \mathrm{E}+01$ & $7.40 \mathrm{E}+01$ \\
\hline Cesium-134 & BOXKC4 & C3074/ENW-MW4 & $02 / 10 / 2000$ & $-1.44 \mathrm{E}+00$ & $\mathrm{pCi} / \mathrm{L}$ & $\mathrm{U}$ & $6.56 \mathrm{E}+00$ & $6.56 \mathrm{E}+-00$ \\
\hline Cesium-137 & $\mathrm{B} 0 \mathrm{XKCA}$ & C3074/ENW-MW4 & $02 / 10 / 2000$ & $1.59 \mathrm{E}+00$ & $\mathrm{pCi} / \mathrm{L}$ & $\mathrm{U}$ & $7.53 \mathrm{E}+00$ & $7.53 \mathrm{E}-00$ \\
\hline Cobalt- 60 & $\mathrm{~B} 0 \times \mathrm{XKC}$ & C3074/ENW-MW4 & $02 / 10 / 2000$ & $-1.24 E+00$ & $\mathrm{pCi} / \mathrm{L}$ & $\mathrm{U}$ & $8.99 \mathrm{E}+00$ & $8.99 \mathrm{E}-00$ \\
\hline Europium-152 & B0XKC4 & C3074/ENW-MW4 & $02 / 10 / 2000$ & $1.32 \mathrm{E}+01$ & $\mathrm{pCi} / \mathrm{L}$ & $\mathrm{U}$ & $2.38 \mathrm{E}+01$ & $2.38 \mathrm{E}-01$ \\
\hline Europium-154 & $\mathrm{B} 0 \mathrm{XKC4}$ & C3074/ENW-MW4 & $02 / 10 / 2000$ & $-2.61 E+00$ & $\mathrm{pCi} / \mathrm{L}$ & $\mathrm{U}$ & $2.34 \mathrm{E}+01^{\circ}$ & $2.34 \mathrm{E}-01$ \\
\hline Europium-155 & BOXKC4 & C3074/ENW-MW4 & $02 / 10 / 2000$ & $1.97 \mathrm{E}+00$ & $\mathrm{pCi} / \mathrm{L}$ & $\mathrm{U}$ & $1.47 \mathrm{E}+01$ & $1.47 \mathrm{E}-01$ \\
\hline Gross alpha & BOXKC4 & C3074/ENW-MW4 & $02 / 10 / 2000$ & $6.50 \mathrm{E}+00$ & $\mathrm{pCi} / \mathrm{L}$ & & $1.37 \mathrm{E}+00$ & $1.37 \mathrm{E}-00$ \\
\hline Gross beta & $\mathrm{B} 0 \mathrm{XKC4}$ & C3074/ENW-MW4 & $02 / 10 / 2000$ & $1.40 \mathrm{E}+01$ & $\mathrm{pCi} / \mathrm{L}$ & & $3.20 \mathrm{E}+00$ & $3.20 \mathrm{E}-00$ \\
\hline Iodine-129 & $\mathrm{B} 0 \mathrm{XKC4}$ & C3074/ENW-MW4 & $|02 / 10 / 2000|$ & $-6.91 \mathrm{E}-02$ & $\mathrm{pCi} / \mathrm{L}$ & $U$ & $2.59 \mathrm{E}-01$ & $2.59 \mathrm{E}-01$ \\
\hline Potassium-40 & $\mathrm{B} 0 \mathrm{XKC4}$ & C3074/ENW-MW4 & $02 / 10 / 2000$ & $2.74 \mathrm{E}+01$ & $\mathrm{pCi} / \mathrm{L}$ & $\mathrm{U}$ & $1.87 \mathrm{E}+02$ & $1.87 \mathrm{E}-02$ \\
\hline Ruthenium-106 & $\mathrm{B} 0 \mathrm{XKCA}$ & C3074/ENW-MW4 & $02 / 10 / 2000$ & 7.40E-01 & $\mathrm{pCi} / \mathrm{L}$ & $\mathrm{U}$ & $7.35 E+01$ & $7.35 \mathrm{E}+01$ \\
\hline Technetium-99 & B0XKC4 & C3074/ENW-MW4 & $02 / 10 / 2000$ & $2.81 E+01$ & $\mathrm{pCi} / \mathrm{L}$ & & $1.25 \mathrm{E}+01$ & $1.25 \mathrm{E}+01$ \\
\hline Uranium-234 & B0XKC4 & C3074/ENW-MW4 & $02 / 10 / 2000$ & $2.01 E+00$ & $\mathrm{pCi} / \mathrm{L}$ & & 7.31E-01 & 7.31E-01 \\
\hline Uranium-235 & B0XKC4 & C3074/ENW-MW4 & $02 / 10 / 2000$ & $1.93 \mathrm{E}-01$ & $\mathrm{pCi} / \mathrm{L}$ & $\mathrm{U}$ & $5.47 \mathrm{E}-01$ & 5.47E-01 \\
\hline Uranium-238 & B0XKC4 & C3074/ENW-MW4 & $02 / 10 / 2000$ & $2.57 E+00$ & $\mathrm{pCi} / \mathrm{L}$ & & $6.79 \mathrm{E}-01$ & $6.79 \mathrm{E}-01$ \\
\hline Uranium-234 & $\begin{array}{l}\text { B0XKC4 } \\
\text { DUP }\end{array}$ & $\begin{array}{l}\text { C3074/ENW-MW4 } \\
\text { DUP }\end{array}$ & $02 / 10 / 2000$ & $1.98 \mathrm{E}+00$ & $\mathrm{pCi} / \mathrm{L}$ & & & $6.94 \mathrm{E}-01$ \\
\hline Uranium-235 ${ }^{(\mathbf{b})}$ & $\begin{array}{l}\text { B0XKC4 } \\
\text { DUP }\end{array}$ & $\begin{array}{l}\text { C3074/ENW-MW4 } \\
\text { DUP }\end{array}$ & $02 / 10 / 2000$ & $2.19 \mathrm{E}-01$ & $\mathrm{pCi} / \mathrm{L}$ & U & & $5.16 \mathrm{E}-01$ \\
\hline Uranium-238 ${ }^{(\mathbf{b})}$. & $\begin{array}{l}\text { BOXKC4 } \\
\text { DUP }\end{array}$ & $\begin{array}{l}\text { C3074/ENW-MW4 } \\
\text { DUP }\end{array}$ & $02 / 10 / 2000$ & $2.44 E+00$ & $\mathrm{pCi} / \mathrm{L}$ & & & $6.33 E-01$ \\
\hline Antimony-125 & $\mathrm{BOXKC5}$ & C3075/ENW-MW5 & $02 / 09 / 2000$ & $-9.89 \mathrm{E}-01$ & $\mathrm{pCi} / \mathrm{L}$ & $\mathrm{U}$ & $1.81 \mathrm{E}+01$ & $1.81 E+01$ \\
\hline Beryllium-7 & B0XKC5 & C3075/ENW-MW5 & $02 / 09 / 2000$ & $1.12 \mathrm{E}+01$ & $\mathrm{pCi} / \mathrm{L}$ & $\mathbf{U}$ & $7.61 \mathrm{E}+01$ & $7.61 \mathrm{E}+01$ \\
\hline Cesium-134 & B0XKC5 & C3075/ENW-MW5 & $02 / 09 / 2000$ & $-5.96 \mathrm{E}+00$ & $\mathrm{pCi} / \mathrm{L}$ & $\mathrm{U}$ & $5.84 \mathrm{E}+00$ & $5.84 \mathrm{E}+00$ \\
\hline Cesium-137 & B0XKC5 & C3075/ENW-MW5 & $02 / 09 / 2000$ & $-3.31 \mathrm{E}+00$ & $\mathrm{pCi} / \mathrm{L}$ & $\mathrm{U}$ & $6.16 \mathrm{E}+00$ & $6.16 \mathrm{E}+00$ \\
\hline Cobalt-60 & B0XKC5 & C3075/ENW-MW5 & $02 / 09 / 2000$ & $5.77 \mathrm{E}-01$ & $\mathrm{pCi} / \mathrm{L}$ & $\mathrm{U}$ & $8.45 \mathrm{E}+00$ & $8.45 \mathrm{E}+00$ \\
\hline Europium-152 & B0XKC5 & C3075/ENW-MW5 & $02 / 09 / 2000$ & $4.32 \mathrm{E}+00$ & $\mathrm{pCi} / \mathrm{L}$ & $\mathrm{U}$ & $1.99 \mathrm{E}+01$ & $1.99 \mathrm{E}+01$ \\
\hline
\end{tabular}


Table C.3. (contd)

\begin{tabular}{|c|c|c|c|c|c|c|c|c|}
\hline Constituent & $\begin{array}{c}\text { Sample } \\
\text { Number }\end{array}$ & Well Name & $\begin{array}{c}\text { Sample } \\
\text { Date }\end{array}$ & $\begin{array}{c}\text { Value } \\
\text { Reported }\end{array}$ & Units & $\begin{array}{c}\text { Lab } \\
\text { Qualifier }^{(\mathbf{2})}\end{array}$ & $\begin{array}{c}\text { Reporting } \\
\text { Limit }\end{array}$ & MDA \\
\hline Europium-154 & BOXKC5 & C3075/ENW-MW5 & $02 / 09 / 2000$ & $-7.33 \mathrm{E}-01$ & $\mathrm{pCi} / \mathrm{L}$ & $\mathrm{U}$ & $2.37 \mathrm{E}+01$ & $2.37 E+01$ \\
\hline Europium-155 & $\mathrm{B} 0 \mathrm{XKC5}$ & C3075/ENW-MW5 & $02 / 09 / 2000$ & $3.68 \mathrm{E}+00$ & $\mathrm{pCi} / \mathrm{L}$ & $\mathrm{U}$ & $1.52 \mathrm{E}+01$ & $1.52 \mathrm{E}+01$ \\
\hline Gross alpha & BOXKC5 & C3075/ENW-MW5 & $02 / 09 / 2000$ & $3.51 \mathrm{E}+00$ & $\mathrm{pCi} / \mathrm{L}$ & & $1.85 E+00$ & $1.85 \mathrm{E}+00$ \\
\hline Gross beta & $\mathrm{B} 0 \mathrm{XKC5}$ & C3075/ENW-MW5 & $02 / 09 / 2000$ & $1.13 \mathrm{E}+01$ & $\mathrm{pCi} / \mathrm{L}$ & & $3.15 \mathrm{E}+00$ & $3.15 \mathrm{E}+00$ \\
\hline Iodine-129 & BOXKC5 & C3075/ENW-MW5 & $02 / 09 / 2000$ & $7.26 \mathrm{E}-02$ & $\mathrm{pCi} / \mathrm{L}$ & $\mathrm{U}$ & $3.20 \mathrm{E}-01$ & $3.20 \mathrm{E}-01$ \\
\hline Potassium- 40 & B0XKC5 & C3075/ENW-MW5 & $02 / 09 / 2000$ & $1.42 \mathrm{E}+01$ & $\mathrm{pCi} / \mathrm{L}$ & $\mathrm{U}$ & $1.82 \mathrm{E}+02$ & $1.82 \mathrm{E} \div 02$ \\
\hline Ruthenium-106 & $\mathrm{B} 0 \mathrm{XKC5}$ & C3075/ENW-MW5 & $02 / 09 / 2000$ & $3.18 \mathrm{E}+00$ & $\mathrm{pCi} / \mathrm{L}$ & $\mathrm{U}$ & $7.17 \mathrm{E}+01$ & $7.17 \mathrm{E}+01$ \\
\hline Technetium-99 & BOXKC5 & C3075/ENW-MW5 & $02 / 09 / 2000$ & $2.87 \mathrm{E}+01$ & $\mathrm{pCi} / \mathrm{L}$ & & $1.26 \mathrm{E}+01$ & $1.26 \mathrm{E}+01$ \\
\hline Uranium-234 & BOXKC5 & C3075/ENW-MW5 & $02 / 09 / 2000$ & $1.45 \mathrm{E}+00$ & $\mathrm{pCi} / \mathrm{L}$ & & $3.61 \mathrm{E}-01$ & $3.61 \mathrm{E}-01$ \\
\hline Uranium-235 & B0XKC5 & C3075/ENW-MW5 & $02 / 09 / 2000$ & $1.60 \mathrm{E}-02$ & $\mathrm{pCi} / \mathrm{L}$ & $\mathrm{U}$ & $2.86 \mathrm{E}-01$ & $2.86 \mathrm{E}-01$ \\
\hline Uranium-238 & B0XKC5 & C3075/ENW-MW5 & $02 / 09 / 2000$ & $9.28 \mathrm{E}-01$ & $\mathrm{pCi} / \mathrm{L}$ & $J$ & 3.39E-01 & $3.39 \mathrm{E}-01$ \\
\hline Gross beta ${ }^{(b)}$ & $\begin{array}{l}\text { BOXKC5 } \\
\text { DUP }\end{array}$ & $\begin{array}{l}\text { C3075/ENW-MW5 } \\
\text { DUP }\end{array}$ & $02 / 09 / 2000$ & $1.08 \mathrm{E}+01$ & $\mathrm{pCi} / \mathrm{L}$ & . & & $3.16 \mathrm{E}+00$ \\
\hline Iodine-129(b) & $\begin{array}{l}\text { B0XKC5 } \\
\text { DUP }\end{array}$ & $\begin{array}{l}\text { C3075/ENW-MW5 } \\
\text { DUP }\end{array}$ & $02 / 09 / 2000$ & $6.23 \mathrm{E}-02$ & $\mathrm{pCi} / \mathrm{L}$ & $\mathrm{U}$ & & $2.95 \mathrm{E}-01$ \\
\hline Antimony. 125 & B0XKC6 & C3076/ENW-MW6 & $02 / 09 / 2000$ & $2.52 \mathrm{E}+00$ & $\mathrm{pCi} / \mathrm{L}$ & $\mathrm{U}$ & $2.42 \mathrm{E}+01$ & $2.42 \mathrm{E}+01$ \\
\hline Beryllium-7 & B0XKC6 & C3076/ENW-MW6 & $02 / 09 / 2000$ & $-3.46 \mathrm{E}+01$ & $\mathrm{pCi} / \mathrm{L}$ & $\mathrm{U}$ & $6.77 \mathrm{E}+01$ & $6.77 \mathrm{E}+01$ \\
\hline Cesium-134 & B0XKC6 & C3076/ENW-MW6 & $02 / 09 / 2000$ & $-1.48 \mathrm{E}+00$ & $\mathrm{pCi} / \mathrm{L}$ & $\mathrm{U}$ & $8.88 \mathrm{E}+00$ & $8.88 \mathrm{E}+00$ \\
\hline Cesium-137 & B0XKC6 & C3076/ENW-MW6 & $02 / 09 / 2000$ & $2.91 \mathrm{E}+00$ & $\mathrm{pCi} / \mathrm{L}$ & $\mathrm{U}$ & $9.79 \mathrm{E}+00$ & $9.79 \mathrm{E}+00$ \\
\hline Cobalt- 60 & B0XKC6 & C3076/ENW-MW6 & $02 / 09 / 2000$ & $-2.24 \mathrm{E}+00$ & $\mathrm{pCi} / \mathrm{L}$ & $\mathrm{U}$ & $9.99 \mathrm{E}+00$ & $9.99 \mathrm{E}+00$ \\
\hline Europium-152 & B0XKC6 & C3076/ENW-MW6 & $02 / 09 / 2000$ & $5.04 \mathrm{E}+00$ & $\mathrm{pCi} / \mathrm{L}$ & $\mathrm{U}$ & $2.34 \mathrm{E}+01$ & $2.34 \mathrm{E}+01$ \\
\hline Europium-154 & B0XKC6 & C3076/ENW-MW6 & $02 / 09 / 2000$ & $-5.49 \mathrm{E}-01$ & $\mathrm{pCi} / \mathrm{L}$ & $\mathrm{U}$ & $3.03 \mathrm{E}+01$ & $3.03 \mathrm{E}+01$ \\
\hline Europium-155 & B0XKC6 & C3076/ENW-MW6 & $02 / 09 / 2000$ & $-1.26 \mathrm{E}+00$ & $\mathrm{pCi} / \mathrm{L}$ & $\mathrm{U}$ & $2.02 \mathrm{E}+01$ & $2.02 \mathrm{E}+01$ \\
\hline Gross alpha & B0XKC6 & C3076/ENW-MW6 & $02 / 09 / 2000$ & $7.66 \mathrm{E}+00$ & $\mathrm{pCi} / \mathrm{L}$ & & $2.49 \mathrm{E}+00$ & $2.49 \mathrm{E}+00$ \\
\hline Gross beta & $\mathrm{B} 0 \mathrm{XKC6}$ & C3076/ENW-MW6 & $02 / 09 / 2000$ & $1.26 \mathrm{E}+01$ & $\mathrm{pCi} / \mathrm{L}$ & & $3.17 \mathrm{E}+00$ & $3.17 \mathrm{E}+00$ \\
\hline Iodine-129 & B0XKC6 & C3076/ENW-MW6 & $02 / 09 / 2000$ & $7.98 \mathrm{E}-02$ & $\mathrm{pCi} / \mathrm{L}$ & $\mathrm{U}$ & $3.43 \mathrm{E}-01$ & $3.43 \mathrm{E}-01$ \\
\hline Potassium-40 & B0XKC6 & C3076/ENW-MW6 & $02 / 09 / 2000$ & $2.74 \mathrm{E}+01$ & $\mathrm{pCi} / \mathrm{L}$ & $\mathrm{U}$ & $2.39 \mathrm{E}+02$ & $2.39 \mathrm{E}+02$ \\
\hline Ruthenium-106 & B0XKC6 & C3076/ENW-MW6 & $02 / 09 / 2000$ & $-4.86 \mathrm{E}+01$ & $\mathrm{pCi} / \mathrm{L}$ & $\mathrm{U}$ & $7.68 \mathrm{E}+01$ & $7.68 \mathrm{E}+01$ \\
\hline Technetium-99 & B0XKC6 & C3076/ENW-MW6 & $02 / 09 / 2000$ & $7.13 E+00$ & $\mathrm{pCi} / \mathrm{L}$ & $\mathrm{U}$ & $1.26 \mathrm{E}+01$ & $1.26 \mathrm{E}+01$ \\
\hline Uranium-234 & B0XKC6 & C3076/ENW-MW6 & $02 / 09 / 2000$ & $4.14 \mathrm{E}+00$ & $\mathrm{pCi} / \mathrm{L}$ & & $2.23 \mathrm{E}-01$ & $2.23 \mathrm{E}-01$ \\
\hline Uranium-235 & B0XKC6 & C3076/ENW-MW6 & $02 / 09 / 2000$ & $2.16 \mathrm{E}-01$ & $\mathrm{pCi} / \mathrm{L}$ & $\mathrm{J}$ & 2.04E-01 & $2.04 \mathrm{E}-01$ \\
\hline Uranium-238 & B0XKC6 & C3076/ENW-MW6 & $02 / 09 / 2000$ & $4.36 \mathrm{E}+00$ & $\mathrm{pCi} / \mathrm{L}$ & & $2.38 \mathrm{E}-01$ & $2.38 \mathrm{E}-01$ \\
\hline Uranium-234 ${ }^{(\mathrm{b})}$ & $\begin{array}{l}\text { B0XKC6 } \\
\text { DUP }\end{array}$ & $\begin{array}{l}\text { C3076/ENW-MW6 } \\
\text { DUP }\end{array}$ & $02 / 09 / 2000$ & $5.18 \mathrm{E}+00$ & $\mathrm{pCi} / \mathrm{L}$ & & & $2.29 \mathrm{E}-01$ \\
\hline Uranium-235 ${ }^{(\mathrm{b})}$ & $\begin{array}{l}\text { B0XKC6 } \\
\text { DUP }\end{array}$ & $\begin{array}{l}\text { C3076/ENW-MW6 } \\
\text { DUP }\end{array}$ & $02 / 09 / 2000$ & $1.12 \mathrm{E}-01$ & $\mathrm{pCi} / \mathrm{L}$ & $\mathrm{U}$ & & $2.84 \mathrm{E}-01$ \\
\hline Uranium- $238^{(\mathrm{b})}$ & $\begin{array}{l}\text { B0XKC6 } \\
\text { DUP }\end{array}$ & $\begin{array}{l}\text { C3076/ENW-MW6 } \\
\text { DUP }\end{array}$ & $02 / 09 / 2000$ & $4.92 \mathrm{E}+00$ & $\mathrm{pCi} / \mathrm{L}$ & & & $3.25 \mathrm{E}-01$ \\
\hline Antimony-125 & B0XKC7 & C3077/ENW-MW7 & $02 / 15 / 2000$ & $-8.47 \mathrm{E}+00$ & $\mathrm{pCi} / \mathrm{L}$ & $\mathrm{U}$ & & $1.54 \mathrm{E}+01$ \\
\hline Beryllium-7 & B0XKC7 & C3077/ENW-MW7 & $02 / 15 / 2000$ & $-1.27 \mathrm{E}+00$ & $\mathrm{pCi} / \mathrm{L}$ & $\mathrm{U}$ & & $5.69 \mathrm{E}+01$ \\
\hline Cesium-134 & B0XKC7 & C3077/ENW-MW7 & $02 / 15 / 2000$ & $1.52 \mathrm{E}+00$ & $\mathrm{pCi} / \mathrm{L}$ & $U$ & & $7.91 \mathrm{E}+00$ \\
\hline
\end{tabular}


Table C.3. (contd)

\begin{tabular}{|c|c|c|c|c|c|c|c|c|}
\hline Constituent & $\begin{array}{l}\text { Sample } \\
\text { Number }\end{array}$ & Well Name & $\begin{array}{c}\text { Sample } \\
\text { Date }\end{array}$ & $\begin{array}{c}\text { Value } \\
\text { Reported }\end{array}$ & Units & $\begin{array}{c}\text { Lab } \\
\text { Qualifier }\end{array}$ & $\begin{array}{c}\text { Reporting } \\
\text { Limit }\end{array}$ & MDA \\
\hline Cesium-137 & B0XKC7 & C3077/ENW-MW7 & $02 / 15 / 2000$ & $1.34 \mathrm{E}+00$ & $\mathrm{pCi} / \mathrm{L}$ & $\mathrm{U}$ & & $7.69 E+00$ \\
\hline Cobalt- 60 & B0XKC7 & C3077/ENW-MW7 & $02 / 15 / 2000$ & $6.67 \mathrm{E} \div 00$ & $\mathrm{pCi} / \mathrm{L}$ & $\mathrm{U}$ & & $1.20 \mathrm{E}+01$ \\
\hline Europium-152 & B0XKC7 & C3077/ENW-MW7 & $02 / 15 / 2000$ & $8.88 \mathrm{E}+00$ & $\mathrm{pCi} / \mathrm{L}$ & $\mathrm{U}$ & & $2.18 \mathrm{E}+01$ \\
\hline Europium-154 & B0XKC7 & C3077/ENW-MW7 & $02 / 15 / 2000$ & $4.43 \mathrm{E}+00$ & $\mathrm{pCi} / \mathrm{L}$ & $\mathrm{U}$ & & $2.66 \mathrm{E}+01$ \\
\hline Europium-155 & B0XKC7 & C3077/ENW-MW7 & $02 / 15 / 2000$ & $8.04 \mathrm{E}+00$ & $\mathrm{pCi} / \mathrm{L}$ & $\mathrm{U}$ & & $1.73 \mathrm{E}+01$ \\
\hline Gross alpha & B0XKC7 & C3077/ENW-MW7 & $02 / 15 / 2000$ & $3.01 \mathrm{E}+01$ & $\mathrm{pCi} / \mathrm{L}$ & & & $4.14 \mathrm{E}+00$ \\
\hline Gross beta & B0XKC7 & C3077/ENW-MW7 & $02 / 15 / 2000$ & $4.25 \mathrm{E}+01$ & $\mathrm{pCi} / \mathrm{L}$ & & & $5.09 \mathrm{E}+00$ \\
\hline Iodine-129 & B0XKC7 & C3077/ENW-MW7 & $02 / 15 / 2000$ & $3.61 \mathrm{E}-02$ & $\mathrm{pCi} / \mathrm{L}$ & $\mathrm{U}$ & & $3.03 \mathrm{E}-01$ \\
\hline Potassium-40 & B0XKC7 & C3077/ENW-MW7 & $02 / 15 / 2000$ & $-2.03 E+01$ & $\mathrm{pCi} / \mathrm{L}$ & $\mathrm{U}$ & & $1.98 \mathrm{E}+02$ \\
\hline Ruthenium- 106 & B0XKC7 & C3077/ENW-MW7 & $02 / 15 / 2000$ & $9.93 E+00$ & $\mathrm{pCi} / \mathrm{L}$ & $\mathrm{U}$ & & $6.76 \mathrm{E}+01$ \\
\hline Technetium-99 & B0XKC7 & C3077/ENW-MW7 & $02 / 15 / 2000$ & $-2.01 E-01$ & $\mathrm{pCi} / \mathrm{L}$ & $\mathrm{U}$ & & $1.21 E+01$ \\
\hline Uranium-234 & BOXKC7 & C3077/ENW-MW7 & $02 / 15 / 2000$ & $1.18 E+00$ & $\mathrm{pCi} / \mathrm{L}$ & & & $2.29 \mathrm{E}-01$ \\
\hline Uranium-235 & B0XKC7 & C3077/ENW-MW7 & $02 / 15 / 2000$ & $8.45 \mathrm{E}-02$ & $\mathrm{pCi} / \mathrm{L}$ & $\mathbf{U}$ & & $2.10 \mathrm{E}-01$ \\
\hline Uranium-238 & $\mathrm{B} 0 \times \mathrm{XKC} 7$ & C3077/ENW-MW7 & $02 / 15 / 2000$ & $1.32 \mathrm{E}+00$ & $\mathrm{pCi} / \mathrm{L}$ & & & $2.45 \mathrm{E}-01$ \\
\hline Antimony-125 & $\begin{array}{l}\text { B0XKC7 } \\
\text { DUP }\end{array}$ & $\begin{array}{l}\text { C3077/ENW-MW7 } \\
\text { DUP }\end{array}$ & $02 / 15 / 2000$ & $-1.10 \mathrm{E}+00$ & $\mathrm{pCi} / \mathrm{L}$ & $\mathrm{U}$ & & $2.26 \mathrm{E}+01$ \\
\hline Beryllium- $7^{(b)}$ & $\begin{array}{l}\text { B0XKC7 } \\
\text { DUP }\end{array}$ & $\begin{array}{l}\text { C3077/ENW-MW7 } \\
\text { DUP }\end{array}$ & $02 / 15 / 2000$ & $-2.72 E+01$ & $\mathrm{pCi} / \mathrm{L}$ & $\mathrm{U}$ & & $7.14 \mathrm{E}+01$ \\
\hline Cesium-134(b) & $\begin{array}{l}\text { B0XKC7 } \\
\text { DUP }\end{array}$ & $\begin{array}{l}\text { C3077/ENW-MW7 } \\
\text { DUP }\end{array}$ & $02 / 15 / 2000$ & $-7.55 \mathrm{E}+00$ & $\mathrm{pCi} / \mathrm{L}$ & $\mathrm{U}$ & & $7.74 \mathrm{E}+00$ \\
\hline Cesium-137(b) & $\begin{array}{l}\text { B0XKC7 } \\
\text { DUP }\end{array}$ & $\begin{array}{l}\text { C3077/ENW-MW7 } \\
\text { DUP }\end{array}$ & $02 / 15 / 2000$ & $2.74 \mathrm{E}+00$ & $\mathrm{pCi} / \mathrm{L}$ & $\mathrm{U}$ & & $9.13 \mathrm{E}+00$ \\
\hline Cobalt- $60^{(\mathrm{b})}$ & $\begin{array}{l}\text { B0XKC7 } \\
\text { DUP }\end{array}$ & $\begin{array}{l}\text { C3077/ENW-MW7 } \\
\text { DUP }\end{array}$ & $02 / 15 / 2000$ & $-3.69 \mathrm{E}-01$ & $\mathrm{pCi} / \mathrm{L}$ & $\mathrm{U}$ & & $8.88 \mathrm{E}+00$ \\
\hline Europium-152(b) & $\begin{array}{l}\text { B0XKC7 } \\
\text { DUP }\end{array}$ & $\begin{array}{l}\text { C3077/ENW-MW7 } \\
\text { DUP }\end{array}$ & $02 / 15 / 2000$ & $-7.75 E+00$ & $\mathrm{pCi} / \mathrm{L}$ & $\mathrm{U}$ & & $2.16 \mathrm{E}+01$ \\
\hline Europium-154 & $\begin{array}{l}\text { B0XKC7 } \\
\text { DUP }\end{array}$ & $\begin{array}{l}\text { C3077/ENW-MW7 } \\
\text { DUP }\end{array}$ & $02 / 15 / 2000$ & $-3.63 E+00$ & $\mathrm{pCi} / \mathrm{L}$ & $\mathrm{U}$ & & $2.58 \mathrm{E}+01$ \\
\hline Europium-155 & $\begin{array}{l}\text { B0XKC7 } \\
\text { DUP }\end{array}$ & $\begin{array}{l}\text { C3077/ENW-MW7 } \\
\text { DUP }\end{array}$ & $02 / 15 / 2000$ & $-5.70 \mathrm{E}+00$ & $\mathrm{pCi} / \mathrm{L}$ & $\mathrm{U}$ & & $1.89 \mathrm{E}+01$ \\
\hline Gross alpha $^{(\mathrm{b})}$ & $\begin{array}{l}\text { B0XKC7 } \\
\text { DUP }\end{array}$ & $\begin{array}{l}\text { C3077/ENW-MW7 } \\
\text { DUP }\end{array}$ & $02 / 15 / 2000$ & $3.50 \mathrm{E}+01$ & $\mathrm{pCi} / \mathrm{L}$ & & & $2.15 \mathrm{E}+00$ \\
\hline Gross beta $^{(b)}$ & $\begin{array}{l}\text { B0XKC7 } \\
\text { DUP }\end{array}$ & $\begin{array}{l}\text { C3077/ENW-MW7 } \\
\text { DUP }\end{array}$ & $02 / 15 / 2000$ & $4.43 E+01$ & $\mathrm{pCi} / \mathrm{L}$ & & & $5.14 E+00$ \\
\hline Iodine-129(b) & $\begin{array}{l}\text { B0XKC7 } \\
\text { DUP }\end{array}$ & $\begin{array}{l}\text { C3077/ENW-MW7 } \\
\text { DUP }\end{array}$ & $02 / 15 / 2000$ & $-6.19 \mathrm{E}-02$ & $\mathrm{pCi} / \mathrm{L}$ & $\mathrm{U}$ & & $2.74 \mathrm{E}-01$ \\
\hline Potassium- $40^{(b)}$ & \begin{tabular}{|l} 
B0XKC7 \\
DUP
\end{tabular} & $\begin{array}{l}\text { C3077/ENW-MW7 } \\
\text { DUP } \\
\end{array}$ & $02 / 15 / 2000$ & $-5.16 \mathrm{E}+01$ & $\mathrm{pCi} / \mathrm{L}$ & $\mathrm{U}$ & & $2.20 E+02$ \\
\hline Ruthenium- $106^{\text {(b) }}$ & $\begin{array}{l}\text { B0XKC7 } \\
\text { DUP }\end{array}$ & $\begin{array}{l}\text { C3077/ENW-MW7 } \\
\text { DUP }\end{array}$ & $02 / 15 / 2000$ & $1.94 \mathrm{E}+01$ & $\mathrm{pCi} / \mathrm{L}$ & $U$ & & $8.71 E+01$ \\
\hline Technetium-99 ${ }^{(b)}$ & $\begin{array}{l}\text { BOXKC7 } \\
\text { DUP }\end{array}$ & $\begin{array}{l}\text { C3077/ENW-MW7 } \\
\text { DUP }\end{array}$ & $02 / 15 / 2000$ & $7.20 \mathrm{E}+00$ & $\mathrm{pCi} / \mathrm{L}$ & $\mathrm{U}$ & & $1.21 \mathrm{E}+01$ \\
\hline Uranium-234 ${ }^{(\mathrm{b})}$ & $\begin{array}{l}\text { B0XKC7 } \\
\text { DUP }\end{array}$ & $\begin{array}{l}\text { C3077/ENW-MW7 } \\
\text { DUP }\end{array}$ & $02 / 15 / 2000$ & $1.24 \mathrm{E}+00$ & $\mathrm{pCi} / \mathrm{L}$ & & & $3.33 \mathrm{E}-01$ \\
\hline
\end{tabular}


Table C.3. (contd)

\begin{tabular}{|c|c|c|c|c|c|c|c|c|}
\hline Constituent & $\begin{array}{c}\text { Sample } \\
\text { Number }\end{array}$ & Well Name & $\begin{array}{c}\text { Sample } \\
\text { Date }\end{array}$ & $\begin{array}{c}\text { Value } \\
\text { Reported }\end{array}$ & Units & $\begin{array}{c}\text { Lab } \\
\text { Qualifier }^{(\mathbf{a})}\end{array}$ & $\begin{array}{c}\text { Reporting } \\
\text { Limit }\end{array}$ & MDA \\
\hline Uranium-235 $5^{(b)}$ & $\begin{array}{l}\text { B0XKC7 } \\
\text { DUP }\end{array}$ & $\begin{array}{l}\text { C3077/ENW-MW7 } \\
\text { DUP }\end{array}$ & $02 / 15 / 2000$ & $7.69 \mathrm{E}-02$ & $\mathrm{pCi} / \mathrm{L}$ & $\mathrm{U}$ & & $2.44 \mathrm{E}-01$ \\
\hline Uranium-238 ${ }^{(b)}$ & \begin{tabular}{|l|} 
B0XKC7 \\
DUP
\end{tabular} & $\begin{array}{l}\text { C3077/ENW-MW7 } \\
\text { DuP }\end{array}$ & $02 / 15 / 2000$ & $9.74 \mathrm{E}-01$ & $\mathrm{pCi} / \mathrm{L}$ & $\mathrm{J}$ & & $3.05 \mathrm{E}-01$ \\
\hline Antimony-125 & B0XKC8 & C3078/ENW-MW8 & $02 / 11 / 2000$ & $-2.90 \mathrm{E}+00$ & $\mathrm{pCi} / \mathrm{L}$ & $\mathrm{U}$ & & $2.10 \mathrm{E}+01$ \\
\hline Beryllium-7 & B0XKC8 & C3078/ENW-MW8 & $02 / 11 / 2000$ & $-1.92 \mathrm{E}+01$ & $\mathrm{pCi} / \mathrm{L}$ & $\mathrm{U}$ & & $6.36 \mathrm{E}+01$ \\
\hline Cesium-134 & BOXKC 8 & C3078/ENW-MW8 & $02 / 11 / 2000$ & $-5.66 \mathrm{E}-01$ & $\mathrm{pCi} / \mathrm{L}$ & $\mathrm{U}$ & & $7.59 \mathrm{E}+00$ \\
\hline Cesium-137 & B0XKC8 & C3078/ENW-MW8. & $02 / 11 / 2000$ & $8.34 \mathrm{E}-02$ & $\mathrm{pCi} / \mathrm{L}$ & $\mathrm{U}$ & & $9.01 \mathrm{E}+00$ \\
\hline Cobalt- 60 & $\mathrm{BOXKC8}$ & C3078/ENW-MW8 & $02 / 11 / 2000$ & $2.26 \mathrm{E}+00$ & $\mathrm{pCi} / \mathrm{L}$ & $\mathrm{U}$ & & $9.21 E+00$ \\
\hline Europium-152 & B0XKC8 & C3078/ENW-MW8 & $02 / 11 / 2000$ & $-3.48 \mathrm{E}+00$ & $\mathrm{pCi} / \mathrm{L}$ & $\mathrm{U}$ & & $2.16 \mathrm{E}+01$ \\
\hline Europium-154 & BOXKC8 & C3078/ENW-MW8 & $02 / 11 / 2000$ & $4.68 \mathrm{E}+00$ & $\mathrm{pCi} / \mathrm{L}$ & $\mathrm{U}$ & & $2.36 \mathrm{E}+01$ \\
\hline Europium-155 & $\mathrm{BOXKC8}$ & C3078/ENW-MW8 & $02 / 11 / 2000$ & $-9.85 E-01$ & $\mathrm{pCi} / \mathrm{L}$ & $\mathrm{U}$ & & $1.70 \mathrm{E}+01$ \\
\hline Gross alpha & B0XKC8 & C3078/ENW-MW8 & $02 / 11 / 2000$ & $6.32 \mathrm{E}+00$ & $\mathrm{pCi} / \mathrm{L}$ & & & $1.41 \mathrm{E}+00$ \\
\hline Gross beta & B0XKC8 & C3078/ENW-MW8 & $02 / 11 / 2000$ & $8.12 \mathrm{E}+00$ & $\mathrm{pCi} / \mathrm{L}$ & & & $3.13 E+00$ \\
\hline Iodine-129 & B0XKC8 & C3078/ENW-MW8 & $02 / 11 / 2000$ & $-6.64 \mathrm{E}-03$ & $\mathrm{pCi} / \mathrm{L}$ & $\mathrm{U}$ & & $2.43 \mathrm{E}-01$ \\
\hline Potassium- 40 & B0XKC8 & C3078/ENW-MW8 & $02 / 11 / 2000$ & $-3.72 E+01$ & $\mathrm{pCi} / \mathrm{L}$ & $\mathrm{U}$ & & $2.51 E+02$ \\
\hline Ruthenium-106 & BOXKC8 & C3078/ENW-MW8 & $02 / 11 / 2000$ & $1.79 \mathrm{E}+01$ & $\mathrm{pCi} / \mathrm{L}$ & $\mathrm{U}$ & & $7.89 \mathrm{E}+01$ \\
\hline Technetium-99 & B0XKC8 & C3078/ENW-MW8 & $02 / 11 / 2000$ & $-6.56 \mathrm{E}-01$ & $\mathrm{pCi} / \mathrm{L}$ & U & & $1.26 \mathrm{E}+01$ \\
\hline Uranium-234 & $\mathrm{B} 0 \mathrm{XKC} 8$ & C3078/ENW-MW8 & $02 / 11 / 2000$ & $3.00 \mathrm{E}+00$ & $\mathrm{pCi} / \mathrm{L}$ & & & $2.64 \mathrm{E}-01$ \\
\hline Uranium-235 & $\mathrm{B} 0 \mathrm{XKC} 8$ & C3078/ENW-MW8 & $02 / 11 / 2000$ & $1.82 \mathrm{E}-01$ & $\mathrm{pCi} / \mathrm{L}$ & $\mathrm{U}$ & & $3.27 \mathrm{E}-01$ \\
\hline Uranium-238 & B0XKC 8 & C3078/ENW-MW8 & $02 / 11 / 2000$ & $2.96 \mathrm{E}+00$ & $\mathrm{pCi} / \mathrm{L}$ & & & $3.94 \mathrm{E}-01$ \\
\hline Antimony-125 $5^{(\mathrm{b})}$ & $\begin{array}{l}\text { B0XKC8 } \\
\text { DUP }\end{array}$ & $\begin{array}{l}\text { C3078/ENW-MW8 } \\
\text { DUP }\end{array}$ & $02 / 11 / 2000$ & $1.89 \mathrm{E}+00$ & $\mathrm{pCi} / \mathrm{L}$ & $\mathrm{U}$ & & $2.38 \mathrm{E}+01$ \\
\hline Beryllium-7 $7^{(b)}$ & \begin{tabular}{|l} 
B0XKC8 \\
DUP \\
\end{tabular} & $\begin{array}{l}\text { C3078/ENW-MW8 } \\
\text { DUP }\end{array}$ & $02 / 11 / 2000$ & $3.89 \mathrm{E}+00$ & $\mathrm{pCi} / \mathrm{L}$ & $\mathbf{U}$ & & $8.30 \mathrm{E}+01$ \\
\hline Cesium-134(b) & \begin{tabular}{|l} 
B0XKC8 \\
DUP
\end{tabular} & $\begin{array}{l}\text { C3078/ENW-MW8 } \\
\text { DUP }\end{array}$ & $02 / 11 / 2000$ & $-4.49 E+00$ & $\mathrm{pCi} / \mathrm{L}$ & U & & $8.32 \mathrm{E}+00$ \\
\hline Cesium-137(b) & $\begin{array}{l}\text { B0XKC8 } \\
\text { DUP } \\
\end{array}$ & $\begin{array}{l}\text { C3078/ENW-MW8 } \\
\text { DUP }\end{array}$ & $02 / 11 / 2000$ & $-1.63 E+00$ & $\mathrm{pCi} / \mathrm{L}$ & $\mathrm{U}$ & & $9.52 \mathrm{E}+00$ \\
\hline Cobalt $-60^{(b)}$ & \begin{tabular}{|l} 
B0XKC8 \\
DUP \\
\end{tabular} & $\begin{array}{l}\text { C3078/ENW-MW8 } \\
\text { DUP }\end{array}$ & $02 / 11 / 2000$ & $-4.75 E+00$ & $\mathrm{pCi} / \mathrm{L}$ & $\mathrm{U}$ & & $9.02 \mathrm{E}+00$ \\
\hline Europium-152(b) & $\begin{array}{l}\text { BOXKC8 } \\
\text { DUP }\end{array}$ & $\begin{array}{l}\text { C3078/ENW-MW8 } \\
\text { DUP } \\
\end{array}$ & $02 / 11 / 2000$ & $-4.10 E+00$ & $\mathrm{pCi} / \mathrm{L}$ & $U$ & & $2.25 \mathrm{E}+01$ \\
\hline Europium-154 ${ }^{(\mathrm{b})}$ & \begin{tabular}{|l} 
B0XKC8 \\
DUP
\end{tabular} & $\begin{array}{l}\text { C3078/ENW-MW8 } \\
\text { DUP }\end{array}$ & $02 / 11 / 2000$ & $6.88 \mathrm{E}+00$ & $\mathrm{pCi} / \mathrm{L}$ & $\mathrm{U}$ & & $2.97 \mathrm{E}+01$ \\
\hline Europium- $155^{(\mathrm{b})}$ & \begin{tabular}{|l} 
B0XKC8 \\
DUP
\end{tabular} & $\begin{array}{l}\text { C3078/ENW-MW8 } \\
\text { DUP }\end{array}$ & $02 / 11 / 2000$ & $5.93 E+00$ & $\mathrm{pCi} / \mathrm{L}$ & $\mathrm{U}$ & & $2.06 \mathrm{E}+01$ \\
\hline Gross alpha $^{(b)}$ & \begin{tabular}{|l} 
B0XKC8 \\
DUP
\end{tabular} & $\begin{array}{l}\text { C3078/ENW-MW8 } \\
\text { DUP }\end{array}$ & $02 / 11 / 2000$ & $2.20 \mathrm{E}+01$ & $\mathrm{pCi} / \mathrm{L}$ & & & $3.15 \mathrm{E}+00$ \\
\hline Gross beta $^{(\mathrm{b})}$ & $\begin{array}{l}\text { B0XKC } 8 \\
\text { DUP }\end{array}$ & $\begin{array}{l}\text { C3078/ENW-MW8 } \\
\text { DUP }\end{array}$ & $02 / 11 / 2000$ & $1.30 \mathrm{E}+01$ & $\mathrm{pCi} / \mathrm{L}$ & & & $4.04 \mathrm{E}+00$ \\
\hline Iodine- $129^{(\mathrm{b})}$ & \begin{tabular}{|l} 
BOXKC8 \\
DUP
\end{tabular} & $\begin{array}{l}\text { C3078/ENW-MW8 } \\
\text { DUP }\end{array}$ & $02 / 11 / 2000$ & $1.42 \mathrm{E}-01$ & $\mathrm{pCi} / \mathrm{L}$ & $\mathrm{U}$ & & $2.53 \mathrm{E}-01$ \\
\hline
\end{tabular}


Table C.3. (contd)

\begin{tabular}{|c|c|c|c|c|c|c|c|c|}
\hline Constituent & $\begin{array}{c}\text { Sample } \\
\text { Number } \\
\end{array}$ & Well Name & $\begin{array}{c}\text { Sample } \\
\text { Date }\end{array}$ & $\begin{array}{c}\text { Value } \\
\text { Reported } \\
\end{array}$ & Units & $\begin{array}{c}\text { Lab } \\
\text { Qualifier }^{(2)}\end{array}$ & $\begin{array}{c}\text { Reporting } \\
\text { Limit }\end{array}$ & MDA \\
\hline Potassium $-40^{(b)}$ & $\begin{array}{l}\text { B0XKC8 } \\
\text { DUP }\end{array}$ & $\begin{array}{l}\text { C3078/ENW-MW8 } \\
\text { DUP }\end{array}$ & $02 / 11 / 2000 \mid 1$ & $1.95 \mathrm{E}+00$ & $\mathrm{pCi} / \mathrm{L}$ & $\mathrm{U}$ & & $2.28 \mathrm{E} \div 02$ \\
\hline Ruthenium-106 $6^{(\mathrm{b})}$ & $\begin{array}{l}\text { B0XKC8 } \\
\text { DUP } \\
\end{array}$ & $\begin{array}{l}\text { C3078/ENW-MW8 } \\
\text { DUP }\end{array}$ & $02 / 11 / 2000 \mid 9$ & $9.11 \mathrm{E}+00$ & $\mathrm{pCi} / \mathrm{L}$ & $\mathrm{U}$ & & $8.17 \mathrm{E}+01$ \\
\hline Technetium- $99^{(b)}$ & \begin{tabular}{|l} 
B0XKC8 \\
DUP
\end{tabular} & $\begin{array}{l}\text { C3078/ENW-MW8 } \\
\text { DUP }\end{array}$ & $02 / 11 / 2000 \mid-$ & $-1.40 \mathrm{E}+00$ & $\mathrm{pCi} / \mathrm{L}$ & $\mathrm{U}$ & & $1.26 \mathrm{E}+01$ \\
\hline Uranium-234 ${ }^{(b)}$ & \begin{tabular}{|l} 
B0XKC8 \\
DUP
\end{tabular} & $\begin{array}{l}\text { C3078/ENW-MW8 } \\
\text { DUP }\end{array}$ & $|02 / 11 / 2000|^{2}$ & $2.35 \mathrm{E} \div 00$ & $\mathrm{pCi} / \mathrm{L} \mid$ & & & $3.84 \mathrm{E}-01$ \\
\hline Uranium-235 $5^{(\mathfrak{b})}$ & $\begin{array}{l}\text { B0XKC8 } \\
\text { DUP }\end{array}$ & $\begin{array}{l}\text { C3078/ENW-MW8 } \\
\text { DUP }\end{array}$ & $02 / 11 / 2000 \mid 2$ & $2.15 \mathrm{E}-01$ & $\mathrm{pCi} / \mathrm{L}$ & $\mathrm{U}$ & & $3.37 \mathrm{E}-01$ \\
\hline Uranium-238 & \begin{tabular}{|l|} 
BOXKC8 \\
DUP \\
\end{tabular} & $\begin{array}{l}\text { C3078/ENW-MW8 } \\
\text { DUP }\end{array}$ & $02 / 11 / 20002$ & $2.97 \mathrm{E}+00$ & $\mathrm{pCi} / \mathrm{L}$ & & & $3.19 \mathrm{E}-01$ \\
\hline Antimony-125 & $\mathrm{B} 0 \times \mathrm{KC} 9$ & C3079/ENW-MW9 & $02 / 11 / 2000$ & $2.56 \mathrm{E}+00$ & $\mathrm{pCi} / \mathrm{L}$ & $\mathrm{U}$ & & $2.19 \mathrm{E}+01$ \\
\hline Antimony- $125^{(\mathrm{c})}$ & BOXKD0 & C3079/ENW-MW9 & $02 / 11 / 2000$ & $-6.06 \mathrm{E}+00$ & $\mathrm{pCi} / \mathrm{L}$ & $\mathrm{U}$ & & $1.68 \mathrm{E}+01$ \\
\hline Beryllium-7 & $\mathrm{B} 0 \mathrm{XKC9}$ & C3079/ENW-MW9 & $02 / 11 / 2000$ & $-1.40 \mathrm{E}+01$ & $\mathrm{pCi} / \mathrm{L}$ & $\mathrm{U}$ & & $7.54 \mathrm{E}+01$ \\
\hline Beryllium-7 ${ }^{(c)}$ & B0XKD0 & C3079/ENW-MW9 & $02 / 11 / 2000$ & $-9.20 \mathrm{E}+00$ & $\mathrm{pCi} / \mathrm{L}$ & $\mathrm{U}$ & & $7.13 \mathrm{E}+01$ \\
\hline Cesium-134 & BOXKC9 & C3079/ENW-MW9 & $02 / 11 / 2000$ & $-2.61 \mathrm{E}-01$ & $\mathrm{pCi} / \mathrm{L}$ & U & & $7.60 \mathrm{E}+00$ \\
\hline Cesium-134 ${ }^{(\mathrm{c})}$ & BOXKDO & C3079/ENW-MW9 & $02 / 11 / 2000$ & $-2.39 \mathrm{E}+00$ & $\mathrm{pCi} / \mathrm{L}$ & $\mathrm{U}$ & & $7.19 \mathrm{E}+00$ \\
\hline Cesium-137 & BOXKC9 & C3079/ENW-MW9 & $02 / 11 / 2000$ & $3.30 \mathrm{E}+00$ & $\mathrm{pCi} / \mathrm{L}$ & $\mathrm{U}$ & & $9.66 \mathrm{E}+00$ \\
\hline Cesium-137(c) & B0XKD0 & C3079/ENW-MW9 & $02 / 11 / 2000$ & $-1.74 E+00$ & $\mathrm{pCi} / \mathrm{L}$ & $U$ & & $6.44 \mathrm{E}+00$ \\
\hline Cobalt-60 & B0XKC9 & C3079/ENW-MW9 & $02 / 11 / 2000$ & $-2.09 E+00$ & $\mathrm{pCi} / \mathrm{L}$ & $\mathrm{U}$ & & $9.21 E+00$ \\
\hline Cobalt- $60^{(c)}$ & B0XKD0 & C3079/ENW-MW9 & $02 / 11 / 2000$ & $2.06 \mathrm{E}+00$ & $\mathrm{pCi} / \mathrm{L}$ & $\mathrm{U}$ & & $8.67 \mathrm{E}+00$ \\
\hline Europium-152 & B0XKC9 & C3079/ENW-MW9 & $02 / 11 / 2000$ & $-3.62 E+00$ & $\mathrm{pCi} / \mathrm{L}$ & $\mathrm{U}$ & & $2.23 \mathrm{E}+01$ \\
\hline Europium-152 $2^{(\mathrm{c})}$ & B0XKD0 & C3079/ENW-MW9 & $02 / 11 / 2000$ & $-7.83 E+00$ & $\mathrm{pCi} / \mathrm{L}$ & U & & $1.75 E+001$ \\
\hline Europium-154 & B0XKC9 & C3079/ENW-MW9 & $02 / 11 / 2000$ & $-2.56 \mathrm{E}+00$ & $\mathrm{pCi} / \mathrm{L}$ & $\mathrm{U}$ & & $2.36 \mathrm{E}+01$ \\
\hline Europium- $154^{(\mathrm{c})}$ & BOXKD0 & C3079/ENW-MW9 & $02 / 11 / 2000$ & $3.99 \mathrm{E}+00$ & $\mathrm{pCi} / \mathrm{L}$ & $\mathrm{U}$ & & $2.86 E+01$ \\
\hline Europium-155 & B0XKC9 & C3079/ENW-MW9 & $02 / 11 / 2000$ & $2.78 \mathrm{E}+00$ & $\mathrm{pCi} / \mathrm{L}$ & $\mathrm{U}$ & & $1.66 \mathrm{E}+01$ \\
\hline Europium-155 & BOXKD0 & C3079/ENW-MW9 & $02 / 11 / 2000$ & $4.52 \mathrm{E}+00$ & $\mathrm{pCi} / \mathrm{L}$ & $\underline{U}$ & & $1.37 \mathrm{E}-01$ \\
\hline Gross alpha & B0XKC9 & C3079/ENW-MW9 & $02 / 11 / 2000$ & $2.21 \mathrm{E}+01$ & $\mathrm{pCi} / \mathrm{L}$ & & & $3.22 \mathrm{E}-00$ \\
\hline Gross alpha $^{(c)}$ & B0XKD0 & C3079/ENW-MW9 & $02 / 11 / 2000$ & $2.28 \mathrm{E}+01$ & $\mathrm{pCi} / \mathrm{L}$ & & & $3.15 \mathrm{E}-00$ \\
\hline Gross beta & B0XKC9 & C3079/ENW-MW9 & $02 / 11 / 2000$ & $1.61 \mathrm{E}+01$ & $\mathrm{pCi} / \mathrm{L}$ & & & $4.03 \mathrm{E}-00$ \\
\hline Gross beta ${ }^{(c)}$ & B0XKD0 & C3079/ENW-MW9 & $02 / 11 / 2000$ & $1.59 \mathrm{E}+01$ & $\mathrm{pCi} / \mathrm{L}$ & & & $4.10 \mathrm{E}-00$ \\
\hline Iodine-129 & B0XKC9 & C3079/ENW-MW9 & $02 / 11 / 2000$ & $3.48 \mathrm{E}-02$ & $\mathrm{pCi} / \mathrm{L}$ & U & & 3.65E-01 \\
\hline Iodine-129(c) & BOXKD0 & C3079/ENW-MW9 & $02 / 11 / 2000$ & $3.41 \mathrm{E}-02$ & $\mathrm{pCi} / \mathrm{L}$ & $U$ & & $3.09 \mathrm{E}-01$ \\
\hline Potassium-40 & BOXKC9 & C3079/ENW-MW9 & $02 / 11 / 2000$ & $-6.76 E+01$ & $\mathrm{pCi} / \mathrm{L}$ & U & & $2.40 \mathrm{E}+02$ \\
\hline Potassium-40 & B0XKD0 & C3079/ENW-MW9 & $02 / 11 / 2000$ & $6.17 \mathrm{E}+01$ & $\mathrm{pCi} / \mathrm{L}$ & $\mathrm{U}$ & & $8.26 \mathrm{E}+01$ \\
\hline Ruthenium-106 & B0XKC9 & C3079/ENW-MW9 & $02 / 11 / 2000$ & $4.09 \mathrm{E}+01$ & $\mathrm{pCi} / \mathrm{L}$ & $\mathrm{U}$ & & $8.94 \mathrm{E}-01$ \\
\hline Ruthenium-106 $6^{(\mathrm{c})}$ & BOXKD0 & C3079/ENW-MW9 & $02 / 11 / 2000$ & $1.04 \mathrm{E}+01$ & $\mathrm{pCi} / \mathrm{L}$ & $\mathrm{U}$ & & $7.13 \mathrm{E}-01$ \\
\hline Technetium-99 & B0XKC9 & C3079/ENW-MW9 & $02 / 11 / 2000$ & $4.73 E+00$ & $\mathrm{pCi} / \mathrm{L}$ & $\mathrm{U}$ & & $1.26 \mathrm{E}+01$ \\
\hline Technetium-99 ${ }^{\text {(c) }}$ & BOXKDO & C3079/ENW-MW9 & $02 / 11 / 2000$ & $5.66 \mathrm{E}-01$ & $\mathrm{pCi} / \mathrm{L}$ & $\mathrm{U}$ & & $1.26 \mathrm{E}+01$ \\
\hline Uranium-234 & B0XKC9 & C3079/ENW-MW9 & $02 / 11 / 2000$ & $1.26 \mathrm{E}+01$ & $\mathrm{pCi} / \mathrm{L}$ & & & 3.37E- 01 \\
\hline Uranium-234 & BOXKDO & C3079/ENW-MW9 & $02 / 11 / 2000$ & $1.37 \mathrm{E}+01$ & $\mathrm{pCi} / \mathrm{L}$ & & & $3.97 \mathrm{E}-01$ \\
\hline
\end{tabular}


Table C.3. (contd)

\begin{tabular}{|c|c|c|c|c|c|c|c|c|}
\hline Constituent & $\begin{array}{c}\text { Sample } \\
\text { Number } \\
\end{array}$ & Well Name & $\begin{array}{c}\text { Sample } \\
\text { Date }\end{array}$ & $\begin{array}{c}\text { Value } \\
\text { Reported }\end{array}$ & Units & $\begin{array}{c}\text { Lab } \\
\text { Qualifier }^{(a)}\end{array}$ & $\begin{array}{c}\text { Reporting } \\
\text { Limit }\end{array}$ & MDA \\
\hline Uranium-235 & B0XKC9 & C3079/ENW-MW9 & $02 / 11 / 2000$ & $5.24 \mathrm{E}-01$ & $\mathrm{pCi} / \mathrm{L}$ & & & $2.62 \mathrm{E}-01$ \\
\hline Uranium-235 ${ }^{(\mathrm{c})}$ & B0XKD0 & C3079/ENW-MW9 & $02 / 11 / 2000$ & $4.24 \mathrm{E}-01$ & $\mathrm{pCi} / \mathrm{L}$ & & & $2.95 \mathrm{E}-01$ \\
\hline Uranium-238 & BOXKC9 & C3079/ENW-MW9 & $02 / 11 / 2000$ & $1.23 \mathrm{E}+01$ & $\mathrm{pCi} / \mathrm{L}$ & & & $3.04 \mathrm{E}-01$ \\
\hline Uranium-238 $8^{(\mathrm{c})}$ & B0XKD0 & C3079/ENW-MW9 & $02 / 11 / 2000$ & $1.14 \mathrm{E}+01$ & $\mathrm{pCi} / \mathrm{L}$ & & & $3.71 \mathrm{E}-01$ \\
\hline Gross alpha $^{(b)}$ & $\begin{array}{l}\text { BOXKC9 } \\
\text { DUP }\end{array}$ & $\begin{array}{l}\text { C3079/ENW-MW9 } \\
\text { DUP }\end{array}$ & $02 / 11 / 2000$ & $2.20 \mathrm{E}+01$ & $\mathrm{pCi} / \mathrm{L}$ & & & $3.15 \mathrm{E}+00$ \\
\hline Gross beta $^{(b)}$ & $\begin{array}{l}\text { BOXKDO } \\
\text { DUP }\end{array}$ & $\begin{array}{l}\text { C3079/ENW-MW9 } \\
\text { DUP }\end{array}$ & $02 / 11 / 2000$ & $1.30 \mathrm{E}+01$ & $\mathrm{pCi} / \mathrm{L}$ & & & $4.04 \mathrm{E}+00$ \\
\hline Iodine- $129^{(\mathrm{b})}$ & $\begin{array}{l}\text { B0XKC9 } \\
\text { DUP }\end{array}$ & $\begin{array}{l}\text { C3079/ENW-MW9 } \\
\text { DUP }\end{array}$ & $02 / 11 / 2000$ & $1.42 \mathrm{E}-01$ & $\mathrm{pCi} / \mathrm{L}$ & U & & $2.53 \mathrm{E}-01$ \\
\hline Antimony-125 & B0XKDI & ENW-31 & $02 / 08 / 2000$ & $-4.50 \mathrm{E}+00$ & $\mathrm{pCi} / \mathrm{L}$ & $U$ & $1.83 \mathrm{E}+01$ & $1.83 \mathrm{E}+01$ \\
\hline Beryilium-7 & B0XKD1 & ENW-31 & $02 / 08 / 2000$ & $1.61 \mathrm{E}+01$ & $\mathrm{pCi} / \mathrm{L}$ & $\mathrm{U}$ & $6.50 \mathrm{E}+01$ & $6.50 \mathrm{E}+01$ \\
\hline Cesium-134 & B0XKD1 & ENW-31 & $02 / 08 / 2000$ & $-5.11 \mathrm{E}-01$ & $\mathrm{pCi} / \mathrm{L}$ & $\mathrm{U}$ & $7.79 \mathrm{E}+00$ & $7.79 \mathrm{E}+00$ \\
\hline Cesium-137 & B0XKD1 & ENW-31 & $02 / 08 / 2000$ & $2.28 \mathrm{E}+00$ & $\mathrm{pCi} / \mathrm{L}$ & $\mathrm{U}$ & $7.97 \mathrm{E}+00$ & $7.97 \mathrm{E}+00$ \\
\hline Cobalt-60 & B0XKDI & ENW-31 & $02 / 08 / 2000$ & $-3.41 E+00$ & $\mathrm{pCi} / \mathrm{L}$ & $\mathrm{U}$ & $6.87 \mathrm{E}+00$ & $6.87 \mathrm{E}+00$ \\
\hline Europium-152 & B0XKD1 & ENW-31 & $02 / 08 / 2000$ & 8.88E-01 & $\mathrm{pCi} / \mathrm{L}$ & U & $2.00 \mathrm{E}+01$ & $2.00 \mathrm{E}+01$ \\
\hline Europium-154 & B0XKD1 & ENW-31 & $02 / 08 / 2000$ & $-8.76 E+00$ & $\mathrm{pCi} / \mathrm{L}$ & $\mathrm{U}$ & $2.51 \mathrm{E}+01$ & $2.51 \mathrm{E}+01$ \\
\hline Europium-155 & B0XKD1 & ENW-31 & $02 / 08 / 2000$ & $1.06 \mathrm{E}+00$ & $\mathrm{pCi} / \mathrm{L}$ & $\mathrm{U}$ & $1.46 \mathrm{E}+01$ & $1.46 \mathrm{E}+01$ \\
\hline Gross alpha & BOXKDI & ENW-31 & $02 / 08 / 2000$ & $1.19 \mathrm{E}+00$ & $\mathrm{pCi} / \mathrm{L}$ & $\mathrm{U}$ & $1.97 \mathrm{E}+00$ & $1.97 \mathrm{E}+00$ \\
\hline Gross beta & B0XKD1 & ENW-31 & $02 / 08 / 2000$ & $6.57 \mathrm{E}+00$ & $\mathrm{pCi} / \mathrm{L}$ & & $2.86 \mathrm{E}+00$ & $2.86 \mathrm{E}+00$ \\
\hline Iodine-129 & B0XKD1 & ENW-31 & $02 / 08 / 2000$ & $-2.14 \mathrm{E}-02$ & $\mathrm{pCi} / \mathrm{L}$ & $\mathrm{U}$ & $3.15 \mathrm{E}-01$ & $3.15 \mathrm{E}-01$ \\
\hline Potassium-40 & B0XKD1 & ENW-31 & $02 / 08 / 2000$ & $-1.69 E+01$ & $\mathrm{pCi} / \mathrm{L}$ & $U$ & $2.50 \mathrm{E} \div 02$ & $2.50 \mathrm{E}+02$ \\
\hline Ruthenium-106 & B0XKD1 & ENW-31 & $02 / 08 / 2000$ & $-3.53 E+00$ & $\mathrm{pCi} / \mathrm{L}$ & $\mathrm{U}$ & $6.41 \mathrm{E}+01$ & $6.41 \mathrm{E}+01$ \\
\hline Technetium-99 & B0XKD1 & ENW-31 & $02 / 08 / 2000$ & $-1.53 E+00$ & $\mathrm{pCi} / \mathrm{L}$ & $\mathrm{U}$ & $1.23 E+01$ & $1.23 E+01$ \\
\hline Uranium-234 & B0XKD1 & ENW-31 & $02 / 08 / 2000$ & $1.05 E+00$ & $\mathrm{pCi} / \mathrm{L}$ & & $2.77 \mathrm{E}-01$ & $2.77 \mathrm{E}-01$ \\
\hline Uranium-235 & BoXKD1 & ENW-31 & $02 / 08 / 2000$ & $1.79 \mathrm{E}-01$ & $\mathrm{pCi} / \mathrm{L}$ & $\mathrm{U}$ & $2.13 \mathrm{E}-01$ & $2.13 \mathrm{E}-01$ \\
\hline Uranium-238 & B0XKDI & ENW-31 & $02 / 08 / 2000$ & $2.46 \mathrm{E}-01$ & $\mathrm{pCi} / \mathrm{L}$ & $\mathrm{U}$ & $3.10 \mathrm{E}-01$ & $3.10 \mathrm{E}-01$ \\
\hline Antimony-125 & B0XKD2 & ENW-32 & $02 / 08 / 2000$ & $5.17 \mathrm{E}+00$ & $\mathrm{pCi} / \mathrm{L}$ & $\mathrm{U}$ & $1.80 \mathrm{E}+01$ & $1.80 \mathrm{E}+01$ \\
\hline Beryllium-7 & B0XKD2 & ENW-32 & $02 / 08 / 2000$ & $-1.41 \mathrm{E}+01$ & $\mathrm{pCi} / \mathrm{L}$ & $\mathrm{U}$ & $5.96 \mathrm{E}+01$ & $5.96 \mathrm{E}+01$ \\
\hline Cesium-134 & B0XKD2 & ENW-32 & $02 / 08 / 2000$ & $7.41 \mathrm{E}-01$ & $\mathrm{pCi} / \mathrm{L}$ & $\mathrm{U}$ & $8.61 \mathrm{E}+00$ & $8.61 E+00$ \\
\hline Cesium-137 & B0XKD2 & ENW-32 & $02 / 08 / 2000$ & $-2.35 E+00$ & $\mathrm{pCi} / \mathrm{L}$ & $\mathrm{U}$ & $7.49 \mathrm{E}+00$ & $7.49 \mathrm{E}+00$ \\
\hline Cobalt- 60 & B0XKD2 & ENW-32 & $02 / 08 / 2000$ & $-1.08 \mathrm{E}+00$ & $\mathrm{pCi} / \mathrm{L}$ & U & $8.81 \mathrm{E}+00$ & $8.81 \mathrm{E}+00$ \\
\hline Europium-152 & B0XKD2 & ENW-32 & $02 / 08 / 2000$ & $-6.21 E+00$ & $\mathrm{pCi} / \mathrm{L}$ & $\mathrm{U}$ & $1.83 \mathrm{E}+01$ & $1.83 \mathrm{E}+01$ \\
\hline Europium-154 & $\mathrm{B} 0 \mathrm{XKD} 2$ & ENW-32 & $02 / 08 / 2000$ & $-5.71 \mathrm{E}-01$ & $\mathrm{pCi} / \mathrm{L}$ & $\mathrm{U}$ & $2.29 E+01$ & $2.29 \mathrm{E}+01$ \\
\hline Europium-155 & B0XKD2 & ENW-32 & $02 / 08 / 2000$ & $6.65 \mathrm{E}-01$ & $\mathrm{pCi} / \mathrm{L}$ & $U$ & $1.74 \mathrm{E}+01$ & $1.74 \mathrm{E}+01$ \\
\hline Gross alpha & B0XKD2 & ENW-32 & $02 / 08 / 2000$ & $2.16 E+00$ & $\mathrm{pCi} / \mathrm{L}$ & $J$ & $1.95 \mathrm{E}+00$ & $1.95 \mathrm{E}+00$ \\
\hline Gross beta & $\mathrm{B} 0 \mathrm{XKD} 2$ & ENW-32 & $02 / 08 / 2000$ & $8.35 \mathrm{E}+00$ & $\mathrm{pCi} / \mathrm{L}$ & & $2.87 \mathrm{E}+00$ & $2.87 \mathrm{E}+00$ \\
\hline Iodine-129 & B0XKD2 & ENW-32 & $02 / 08 / 2000$ & $5.78 \mathrm{E}-02$ & $\mathrm{pCi} / \mathrm{L}$ & $\mathrm{U}$ & $2.43 \mathrm{E}-01$ & $2.43 \mathrm{E}-01$ \\
\hline Potassium-40 & B0XKD2 & ENW-32 & $02 / 08 / 2000$ & $-5.63 \mathrm{E}+01$ & $\mathrm{pCi} / \mathrm{L}$ & $U$ & $1.17 E+02$ & $1.17 \mathrm{E}+02$ \\
\hline Ruthenium-106 & B0XKD2 & ENW-32 & $02 / 08 / 2000$ & $-2.26 \mathrm{E}+01$ & $\mathrm{pCi} / \mathrm{L}$ & $\mathrm{U}$ & $6.45 E+01$ & $6.45 \mathrm{E}+01$ \\
\hline Technetium-99 & B0XKD2 & ENW-32 & $02 / 08 / 2000$ & $2.96 \mathrm{E}+00$ & $\mathrm{pCi} / \mathrm{L}$ & $\mathrm{U}$ & $1.23 \mathrm{E}+01$ & $1.23 E+01$ \\
\hline
\end{tabular}


Table C.3. (contd)

\begin{tabular}{|c|c|c|c|c|c|c|c|c|}
\hline Constituent & $\begin{array}{l}\text { Sample } \\
\text { Number } \\
\end{array}$ & Well Name & $\begin{array}{c}\text { Sample } \\
\text { Date }\end{array}$ & $\begin{array}{c}\text { Value } \\
\text { Reported }\end{array}$ & Units & $\begin{array}{c}\text { Lab } \\
\text { Qualifier }\end{array}$ & $\begin{array}{c}\begin{array}{c}\text { Reporting } \\
\text { Limit }\end{array} \\
\end{array}$ & MDA \\
\hline Uranium-234 & B0XKD2 & ENW-32 & $02 / 08 / 2000$ & $1.12 \mathrm{E}+00$ & $\mathrm{pCi} / \mathrm{L}$ & & $4.09 \mathrm{E}-01$ & 4.09E-101 \\
\hline Uranium-235 & B0XKD2 & ENW-32 & $02 / 08 / 2000$ & $2.79 \mathrm{E}-02$ & $\mathrm{pCi} / \mathrm{L}$ & $\mathrm{U}$ & $3.18 \mathrm{E}-01$ & $3.18 \mathrm{E}-101$ \\
\hline Uranium-238 & B0XKD2 & ENW-32 & $|02 / 08 / 2000|$ & $5.92 \mathrm{E}-01$ & $\mathrm{pCi} / \mathrm{L}$ & $\mathbf{J}$ & $3.90 \mathrm{E}-01$ & $3.90 \mathrm{E}-101$ \\
\hline \multicolumn{9}{|c|}{ Quality Control Samples } \\
\hline Antimony-125 ${ }^{(\mathrm{d})}$ & B0XK43 & EBL 121/699-13-3A & $02 / 07 / 2000$ & $2.28 \mathrm{E}+00$ & $\mathrm{pCi} / \mathrm{L}$ & $\mathrm{U}$ & & $2.13 E+01$ \\
\hline Beryllium- $7^{(\mathrm{d})}$ & B0XK43 & EBL 121/699-13-3A & $02 / 07 / 2000$ & $-4.67 \mathrm{E}+00$ & $\mathrm{pCi} / \mathrm{L}$ & $\mathrm{U}$ & & $6.51 \mathrm{E} \div 01$ \\
\hline Cesium-134 $4^{(\mathrm{d})}$ & B0XK43 & EBL 121/699-13-3A & $02 / 07 / 2000$ & $-1.16 \mathrm{E}+00$ & $\mathrm{pCi} / \mathrm{L}$ & $\mathrm{U}$ & & $8.09 \mathrm{E}+00$ \\
\hline Cesium-137 $7^{(d)}$ & B0XK43 & EBL 121/699-13-3A & $02 / 07 / 2000$ & $5.71 \mathrm{E}-01$ & $\mathrm{pCi} / \mathrm{L}$ & $\mathrm{U}$ & & $9.00 \mathrm{E}+00$ \\
\hline Cobalt-60 $0^{(\mathrm{d})}$ & B0XK43 & EBL 121/699-13-3A & $02 / 07 / 2000$ & $-2.80 E+00$ & $\mathrm{pCi} / \mathrm{L}$ & $\mathrm{U}$ & & $6.36 \mathrm{E}+00$ \\
\hline Europium-152 $2^{\text {(d) }}$ & B0XK43 & EBL 121/699-13-3A & $02 / 07 / 2000$ & $1.49 \mathrm{E}+01$ & $\mathrm{pCi} / \mathrm{L}$ & $\mathrm{U}$ & & $2.27 \mathrm{E}+01$ \\
\hline Europium-154 & B0XK43 & EBL 121/699-13-3A & $02 / 07 / 2000$ & $-4.48 \mathrm{E}+00$ & $\mathrm{pCi} / \mathrm{L}$ & $\mathrm{U}$ & & $2.33 E+01$ \\
\hline Europium- $155^{(\mathrm{d})}$ & B0XK43 & EBL 121/699-13-3A & $02 / 07 / 2000$ & $-1.02 E+01$ & $\mathrm{pCi} / \mathrm{L}$ & $U$ & & $1.46 \mathrm{E}+01$ \\
\hline Gross alpha $a^{(\mathrm{d})}$ & B0XK43 & EBL 121/699-13-3A & $02 / 07 / 2000$ & 4.17E-01 & $\mathrm{pCi} / \mathrm{L}$ & $\mathrm{U}$ & & $6.82 \mathrm{E}-01$ \\
\hline Gross beta ${ }^{(\mathrm{d})}$ & B0XK43 & EBL 121/699-13-3A & $02 / 07 / 2000$ & $0.00 \mathrm{E}+00$ & $\mathrm{pCi} / \mathrm{L}$ & $\mathrm{U}$ & & $2.71 E+00$ \\
\hline Iodine-129(d) & B0XK43 & EBL 121/699-13-3A & $02 / 07 / 2000$ & $-2.19 \mathrm{E}-02$ & $\mathrm{pCi} / \mathrm{L}$ & $\mathrm{U}$ & & $2.35 \mathrm{E}-01$ \\
\hline Plutonium- $238^{(\mathrm{d})}$ & B0XK43 & EBL 121/699-13-3A & $02 / 07 / 2000$ & $-2.99 \mathrm{E}-03$ & $\mathrm{pCi} / \mathrm{L}$ & $\mathrm{U}$ & & $1.51 \mathrm{E}-01$ \\
\hline Plutonium-239/240 (d) & B0XK43 & EBL 121/699-13-3A & $02 / 07 / 2000$ & $2.99 \mathrm{E}-03$ & $\mathrm{pCi} / \mathrm{L}$ & $\mathrm{U}$ & & $1.50 \mathrm{E}-01$ \\
\hline Potassium- $40^{\text {(d) }}$ & $\mathrm{B} 0 \mathrm{XK} 43$ & EBL 121/699-13-3A & $02 / 07 / 2000$ & $2.50 \mathrm{E}+01$ & $\mathrm{pCi} / \mathrm{L}$ & $\mathrm{U}$ & & $2.19 \mathrm{E}+02$ \\
\hline Ruthenium-106 ${ }^{(\mathrm{d})}$ & B0XK43 & EBL 121/699-13-3A & $02 / 07 / 2000$ & $1.79 E+01$ & $\mathrm{pCi} / \mathrm{L}$ & $\bar{U}$ & & $7.61 E+01$ \\
\hline Strontium- $89 / 90^{(d)}$ & B0XK43 & EBL 121/699-13-3A & $02 / 07 / 2000$ & $-9.09 \mathrm{E}-03$ & $\mathrm{pCi} / \mathrm{L}$ & $\mathrm{U}$ & & $6.79 \mathrm{E}-01$ \\
\hline Technetium- $99^{(\mathrm{d})}$ & B0XK43 & EBL 121/699-13-3A & $02 / 07 / 2000$ & $-3.33 E+00$ & $\mathrm{pCi} / \mathrm{L}$ & $\mathbf{U}$ & & $1.22 \mathrm{E}-01$ \\
\hline Uranium $^{(\mathrm{d})}$ & B0XK43 & EBL 121/699-13-3A & $02 / 07 / 2000$ & $4.36 \mathrm{E}-03$ & $\mathrm{ug} / \mathrm{L}$ & $\mathrm{U}$ & & $7.29 \mathrm{E}-02$ \\
\hline Uranium-234 ${ }^{(\mathrm{d})}$ & B0XK43 & EBL 121/699-13-3A & $02 / 07 / 2000$ & $3.96 \mathrm{E}-02$ & $\mathrm{pCi} / \mathrm{L}$ & $\mathrm{U}$ & & $2.15 \mathrm{E}-01$ \\
\hline Uranium-235 (d) & B0XK43 & EBL 121/699-13-3A & $02 / 07 / 2000$ & $7.16 \mathrm{E}-02$ & $\mathrm{pCi} / \mathrm{L}$ & $\mathrm{U}$ & & $2.80 \mathrm{E}-01$ \\
\hline Uranium-238 & B0XK43 & EBL 121/699-13-3A & $02 / 07 / 2000$ & $-4.15 \mathrm{E}-02$ & $\mathrm{pCi} / \mathrm{L}$ & $\mathrm{U}$ & & $3.33 \mathrm{E}-01$ \\
\hline Strontium-89/90 & \begin{tabular}{|l} 
B0XK43 \\
DUP
\end{tabular} & $\begin{array}{l}\text { EBL 121/699-13-3A } \\
\text { DUP }\end{array}$ & $02 / 07 / 2000$ & $1.84 \mathrm{E}-01$ & $\mathrm{pCi} / \mathrm{L}$ & $\mathrm{U}$ & & $6.41 \mathrm{E}-01$ \\
\hline Antimony-125(e) & B0XK46 & EBL 122/699-13-3A & $02 / 07 / 2000$ & $2.05 E+00$ & $\mathrm{pCi} / \mathrm{L}$ & $\underline{U}$ & & $2.20 \mathrm{E}-01$ \\
\hline Beryllium- $7^{(e)}$ & B0XK46 & EBL 122/699-13-3A & $02 / 07 / 2000$ & $1.22 \mathrm{E}+01$ & $\mathrm{pCi} / \mathrm{L}$ & $\mathrm{U}$ & & $7.79 \mathrm{E}+01$ \\
\hline Cesium-134(e) & B0XK46 & EBL 122/699-13-3A & $02 / 07 / 2000$ & $-8.49 \mathrm{E}+00$ & $\mathrm{pCi} / \mathrm{L}$ & $\mathrm{U}$ & & $8.09 \mathrm{E}+00$ \\
\hline Cesium-137(e) & B0XK46 & EBL 122/699-13-3A & $02 / 07 / 2000$ & $-4.64 \mathrm{E}+00$ & $\mathrm{pCi} / \mathrm{L}$ & $\mathrm{U}$ & & $8.49 \mathrm{E}+00$ \\
\hline Cobalt-60 & B0XK46 & EBL 122/699-13-3A & $02 / 07 / 2000$ & $-5.49 \mathrm{E}+00$ & $\mathrm{pCi} / \mathrm{L}$ & $\mathrm{U}$ & & $6.68 \mathrm{E}+00$ \\
\hline Europium-152 ${ }^{(\mathrm{c})}$ & B0XK46 & EBL 122/699-13-3A & $02 / 07 / 2000$ & $1.02 \mathrm{E}+01$ & $\mathrm{pCi} / \mathrm{L}$ & $\mathrm{U}$ & & $2.39 \mathrm{E}+01$ \\
\hline Europium-154 ${ }^{(\mathrm{e})}$ & B0XK46 & EBL 122/699-13-3A & $02 / 07 / 2000$ & $2.89 \mathrm{E}+00$ & $\mathrm{pCi} / \mathrm{L}$ & $\mathrm{U}$ & & $2.92 \mathrm{E}+01$ \\
\hline Europium-155 ${ }^{(e)}$ & B0XK46 & EBL 122/699-13-3A & $02 / 07 / 2000$ & $-8.77 \mathrm{E}-01$ & $\mathrm{pCi} / \mathrm{L}$ & $\mathrm{U}$ & & $1.89 \mathrm{E}+01$ \\
\hline Gross alpha ${ }^{(e)}$ & B0XK46 & EBL 122/699-13-3A & $02 / 07 / 2000$ & $1.02 \mathrm{E}-02$ & $\mathrm{pCi} / \mathrm{L}$ & $\mathrm{U}$ & & 9.34E-01 \\
\hline Gross beta ${ }^{(e)}$ & B0XK46 & EBL 122/699-13-3A & $02 / 07 / 2000$ & $7.25 \mathrm{E}-01$ & $\mathrm{pCi} / \mathrm{L}$ & $\mathrm{U}$ & & $2.67 \mathrm{E}+00$ \\
\hline lodine-129 $9^{(e)}$ & B0XK46 & EBL 122/699-13-3A & $02 / 07 / 2000$ & $9.97 \mathrm{E}-02$ & $\mathrm{pCi} / \mathrm{L}$ & $\mathrm{U}$ & & $3.10 \mathrm{E}-01$ \\
\hline Plutonium-238 $8^{(\mathrm{e})}$ & B0XK46 & EBL 122/699-13-3A & $02 / 07 / 2000$ & $-2.79 \mathrm{E}-03$ & $\mathrm{pCi} / \mathrm{L}$ & $\mathrm{U}$ & & $1.40 \mathrm{E}-01$ \\
\hline Plutonium-239/240 & B0XK46 & EBL $122 / 699-13-3 A$ & $02 / 07 / 2000$ & $0.00 \mathrm{E}+00$ & $\mathrm{pCi} / \mathrm{L}$ & $\mathrm{U}$ & & $9.43 \mathrm{E}-02$ \\
\hline
\end{tabular}


Table C.3. (contd)

\begin{tabular}{|c|c|c|c|c|c|c|c|c|}
\hline Constituent & $\begin{array}{l}\text { Sample } \\
\text { Number }\end{array}$ & Well Name & $\begin{array}{c}\text { Sample } \\
\text { Date }\end{array}$ & $\begin{array}{c}\text { Value } \\
\text { Reported }\end{array}$ & Units & $\begin{array}{c}\text { Lab } \\
\text { Qualifier }^{(a)}\end{array}$ & $\begin{array}{c}\text { Reporting } \\
\text { Limit }\end{array}$ & MDA \\
\hline Potassium-40 & B0XK46 & EBL $122 / 699-13-3 \mathrm{~A}$ & $02 / 07 / 2000$ & $-4.41 \mathrm{E}+01$ & $\mathrm{pCi} / \mathrm{L}$ & $\mathrm{U}$ & & $2.30 \mathrm{E}+02$ \\
\hline Ruthenium-106 $6^{(\mathrm{e})}$ & B0XK46 & EBL 122/699-13-3A & $02 / 07 / 2000$ & $2.87 \mathrm{E}+01$ & $\mathrm{pCi} / \mathrm{L}$ & $\mathrm{U}$ & & $9.08 E+01$ \\
\hline Strontium- $89 / 90^{(\mathrm{e})}$ & B0XK46 & EBL $122 / 699-13-3 \mathrm{~A}$ & $02 / 07 / 2000$ & $-2.00 \mathrm{E}-01$ & $\mathrm{pCi} / \mathrm{L}$ & $\mathrm{U}$ & & $6.51 \mathrm{E}-01$ \\
\hline Technetium-99(e) & B0XK46 & EBL $122 / 699-13-3 \mathrm{~A}$ & $02 / 07 / 2000$ & $-3.90 \mathrm{E}+00$ & $\mathrm{pCi} / \mathrm{L}$ & $\mathrm{U}$ & & $1.22 \mathrm{E}+01$ \\
\hline Uranium $^{(e)}$ & B0XK46 & EBL 122/699-13-3A & $02 / 07 / 2000$ & $6.05 \mathrm{E}-03$ & $\mathrm{ug} / \mathrm{L}$ & $\mathrm{U}$ & & $7.29 \mathrm{E}-02$ \\
\hline Uranium-234(e) & B0XK46 & EBL 122/699-13-3A & $02 / 07 / 2000$ & $2.66 \mathrm{E}-02$ & $\mathrm{pCi} / \mathrm{L}$ & $\mathrm{U}$ & & $2.51 \mathrm{E}-01$ \\
\hline Uranium-235 & B0XK46 & EBL $122 / 699-13-3 A$ & $02 / 07 / 2000$ & $3.37 \mathrm{E}-02$ & $\mathrm{pCi} / \mathrm{L}$ & $\mathrm{U}$ & & $2.22 \mathrm{E}-01$ \\
\hline Uranium-238 & B0XK46 & EBL 122/699-13-3A & $02 / 07 / 2000$ & $-1.42 \mathrm{E}-02$ & $\mathrm{pCi} / \mathrm{L}$ & $\bar{U}$ & & $2.37 \mathrm{E}-01$ \\
\hline Gross beta $^{(\text {b) }}$ & $\begin{array}{l}\text { BOXK46 } \\
\text { DUP }\end{array}$ & $\begin{array}{l}\text { EBL 122/699-13-3A } \\
\text { DUP }\end{array}$ & $02 / 07 / 2000$ & $2.58 \mathrm{E}-01$ & $\mathrm{pCi} / \mathrm{L}$ & $\mathrm{U}$ & & $2.71 \mathrm{E}+00$ \\
\hline Technetium-99(b) & $\begin{array}{l}\text { B0XK46 } \\
\text { DUP }\end{array}$ & $\begin{array}{l}\text { EBL 122/699-13-3A } \\
\text { DUP }\end{array}$ & $02 / 07 / 2000$ & $4.46 \mathrm{E}+00$ & $\mathrm{pCi} / \mathrm{L}$ & $U$ & & $1.23 \mathrm{E}+01$ \\
\hline Antimony-125 & B0XK32. & EBL 123/699-13-1B & $02 / 08 / 2000$ & $-1.72 \mathrm{E}+00$ & $\mathrm{pCi} / \mathrm{L}$ & $\mathrm{U}$ & & $1.84 \mathrm{E}+01$ \\
\hline Beryllium-7 & B0XK32 & EBL 123/699-13-1B & $02 / 08 / 2000$ & $-4.00 \mathrm{E}+00$ & $\mathrm{pCi} / \mathrm{L}$ & $\mathrm{U}$ & & $6.21 \mathrm{E}+01$ \\
\hline Cesium-134 & B0XK32 & EBL 123/699-13-1B & $02 / 08 / 2000$ & $-2.25 \mathrm{E}+00$ & $\mathrm{pCi} / \mathrm{L}$ & $\mathrm{U}$ & & $6.65 \mathrm{E}+00$ \\
\hline Cesium-137 & $\mathrm{B} 0 \mathrm{XK} 32$ & EBL 123/699-13-1B & $02 / 08 / 2000$ & $1.91 \mathrm{E}+00$ & $\mathrm{pCi} / \mathrm{L}$ & $\mathrm{U}$ & & $9.48 \mathrm{E}+00$ \\
\hline Cobalt-60 & B0XK32 & EBL 123/699-13-1B & $02 / 08 / 2000$ & $-1.90 E+00$ & $\mathrm{pCi} / \mathrm{L}$ & $\mathrm{U}$ & & $8.09 \mathrm{E}+00$ \\
\hline Europium-152 & B0XK32 & EBL 123/699-13-1B & $02 / 08 / 2000$ & $5.18 \mathrm{E}+00$ & $\mathrm{pCi} / \mathrm{L}$ & $\mathrm{U}$ & & $1.84 \mathrm{E}+01$ \\
\hline Europium-154 & $\mathrm{B} 0 \times \mathrm{KK} 32$ & EBL $123 / 699-13-1 \mathrm{~B}$ & $02 / 08 / 2000$ & $-5.30 \mathrm{E}+00$ & $\mathrm{pCi} / \mathrm{L}$ & $\mathrm{U}$ & & $2.15 \mathrm{E}+01$ \\
\hline Europium-155 & B0XK32 & EBL 123/699-13-1B & $02 / 08 / 2000$ & $3.29 \mathrm{E}+00$ & $\mathrm{pCi} / \mathrm{L}$ & $\mathrm{U}$ & & $1.77 \mathrm{E}+01$ \\
\hline Gross alpha & B0XK32 & EBL 123/699-13-1B & $02 / 08 / 2000$ & $2.33 \mathrm{E}-01$ & $\mathrm{pCi} / \mathrm{L}$ & $\mathrm{U}$ & & $8.90 \mathrm{E}-01$ \\
\hline Gross beta & $\mathrm{B} 0 \times \mathrm{XK} 32$ & EBL 123/699-13-1B & $02 / 08 / 2000$ & $3.34 \mathrm{E}-01$ & $\mathrm{pCi} / \mathrm{L}$ & $\mathrm{U}$ & & $2.64 \mathrm{E}+00$ \\
\hline Iodine- 129 & B0XK32 & EBL $123 / 699-13-1 B$ & $02 / 08 / 2000$ & $5.29 \mathrm{E}-02$ & $\mathrm{pCi} / \mathrm{L}$ & $\mathrm{U}$ & & $3.23 \mathrm{E}-01$ \\
\hline Plutonium-238 & B0XK32 & EBL 123/699-13-1B & $02 / 08 / 2000$ & $-7.04 \mathrm{E}-03$ & $\mathrm{pCi} / \mathrm{L}$ & $\mathrm{U}$ & & $2.01 \mathrm{E}-01$ \\
\hline Plutonium-239/240 & B0XK32 & EBL 123/699-13-1B & $02 / 08 / 2000$ & $-7.04 \mathrm{E}-03$ & $\mathrm{pCi} / \mathrm{L}$ & $\mathrm{U}$ & & $2.01 \mathrm{E}-01$ \\
\hline Potassium-40 & $\mathrm{B} 0 \mathrm{XK} 32$ & EBL 123/699-13-1B & $02 / 08 / 2000$ & $-1.16 \mathrm{E}+00$ & $\mathrm{pCi} / \mathrm{L}$ & $\mathrm{U}$ & & $1.32 \mathrm{E}+02$ \\
\hline Ruthenium-106 & B0XK32 & EBL 123/699-13-1B & $02 / 08 / 2000$ & $-1.13 \mathrm{E}+01$ & $\mathrm{pCi} / \mathrm{L}$ & $\mathrm{U}$ & & $5.79 \mathrm{E}+01$ \\
\hline Strontium-89/90 & B0XK32 & EBL 123/699-13-1B & $02 / 08 / 2000$ & $1.01 \mathrm{E}-01$ & $\mathrm{pCi} / \mathrm{L}$ & $\mathrm{U}$ & & $6.83 \mathrm{E}-01$ \\
\hline Technetium-99 & B0XK32 & EBL 123/699-13-1B & $02 / 08 / 2000$ & $-8.21 \mathrm{E}+00$ & $\mathrm{pCi} / \mathrm{L}$ & $\mathrm{U}$ & & $1.23 \mathrm{E}+01$ \\
\hline Uranium & B0XK32 & EBL 123/699-13-1B & $02 / 08 / 2000$ & $1.54 \mathrm{E}-02$ & $\mathrm{ug} / \mathrm{L}$ & $\mathrm{U}$ & & $7.29 \mathrm{E}-02$ \\
\hline Uranium-234 & B0XK32 & EBL 123/699-13-1B & $02 / 08 / 2000$ & $8.06 \mathrm{E}-02$ & $\mathrm{pCi} / \mathrm{L}$ & $\mathrm{U}$ & & $2.28 \mathrm{E}-01$ \\
\hline Uranium-235 & B0XK32 & EBL 123/699-13-1B & $02 / 08 / 2000$ & $-2.56 \mathrm{E}-02$ & $\mathrm{pCi} / \mathrm{L}$ & $\mathrm{U}$ & & $2.83 \mathrm{E}-01$ \\
\hline Uranium-238 & $\mathrm{B} 0 \times \mathrm{XK} 32$ & EBL 123/699-13-1B & $02 / 08 / 2000$ & $4.39 \mathrm{E}-02$ & $\mathrm{pCi} / \mathrm{L}$ & $\mathrm{U}$ & & $3.41 \mathrm{E}-01$ \\
\hline Plutonium-238 & $\begin{array}{l}\text { BOXK32 } \\
\text { DUP }\end{array}$ & $\begin{array}{l}\text { EBL } 123 / 699-13-1 B \\
\text { DUP }\end{array}$ & $02 / 08 / 2000$ & $-7.14 \mathrm{E}-03$ & $\mathrm{pCi} / \mathrm{L}$ & $\mathrm{U}$ & & $2.04 \mathrm{E}-01$ \\
\hline Plutonium-239/240 & $\begin{array}{l}\text { B0XK32 } \\
\text { DUP }\end{array}$ & $\begin{array}{l}\text { EBL } 123 / 699-13-1 \mathrm{~B} \\
\text { DUP }\end{array}$ & $02 / 08 / 2000$ & $4.45 \mathrm{E}-02$ & $\mathrm{pCi} / \mathrm{L}$ & $U$ & & $1.21 \mathrm{E}-01$ \\
\hline Antimony-125 & B0XJW1 & EBL 124/ENW-MW5 & $02 / 09 / 2000$ & $-1.07 E+00$ & $\mathrm{pCi} / \mathrm{L}$ & $\mathrm{U}$ & $2.12 \mathrm{E}+01$ & $2.12 \mathrm{E}+01$ \\
\hline Beryllium-7 & B0XJW1 & EBL 124/ENW-MW5 & $02 / 09 / 2000$ & $-1.61 \mathrm{E}+01$ & $\mathrm{pCi} / \mathrm{L}$ & $\mathrm{U}$ & $5.56 \mathrm{E}+01$ & $5.56 \mathrm{E}+01$ \\
\hline Cesium-134 & B0XJW1 & EBL 124/ENW-MW5 & $02 / 09 / 2000$ & $-3.50 \mathrm{E}+00$ & $\mathrm{pCi} / \mathrm{L}$ & $\bar{U}$ & $7.07 \mathrm{E}+00$ & $7.07 \mathrm{E}+00$ \\
\hline Cesium-137 & B0XJW1 & EBL 124/ENW-MW5 & $02 / 09 / 2000$ & $2.57 \mathrm{E}+00$ & $\mathrm{pCi} / \mathrm{L}$ & $\mathrm{U}$ & $8.70 \mathrm{E} \div 00$ & $8.70 \mathrm{E}+00$ \\
\hline
\end{tabular}


Table C.3. (contd)

\begin{tabular}{|c|c|c|c|c|c|c|c|c|}
\hline Constituent & $\begin{array}{c}\text { Sample } \\
\text { Number } \\
\end{array}$ & Well Name & $\begin{array}{c}\text { Sample } \\
\text { Date } \\
\end{array}$ & $\begin{array}{c}\text { Value } \\
\text { Reported } \\
\end{array}$ & Units & $\begin{array}{c}\text { Lab } \\
\text { Qualifier }^{(\mathrm{a})}\end{array}$ & $\begin{array}{c}\text { Reporting } \\
\text { Limit }\end{array}$ & MDA \\
\hline Cobalt-60 & B0XJW1 & EBL 124/ENW-MW5 & $02 / 09 / 2000$ & $-3.62 \mathrm{E}+00$ & $\mathrm{pCi} / \mathrm{L}$ & $\mathrm{U}$ & $7.18 \mathrm{E}+00$ & $7.18 \mathrm{E}+20$ \\
\hline Europium-152 & B0XJW1 & EBL 124/ENW-MW5 & $02 / 09 / 2000$ & $-9.53 E+00$ & $\mathrm{pCi} / \mathrm{L}$ & $\mathrm{U}$ & $1.64 E+01$ & $1.64 \mathrm{E}+01$ \\
\hline Europium-154 & B0XJW1 & EBL 124/ENW-MW5 & $|02 / 09 / 2000|$ & $-2.37 E+00$ & $\mathrm{pCi} / \mathrm{L}$ & $\mathrm{U}$ & $1.85 \mathrm{E}+01$ & $1.85 \mathrm{E}+01$ \\
\hline Europium-155 & B0XJW1 & EBL 124/ENW-MW5 & $02 / 09 / 2000$ & $7.00 \mathrm{E}+00$ & $\mathrm{pCi} / \mathrm{L}$ & $\mathrm{U}$ & $1.59 \mathrm{E}+01$ & $1.59 \mathrm{E}+01$ \\
\hline Gross alpha & B0XJW1 & EBL 124/ENW-MW5 & $02 / 09 / 2000$ & $-8.97 \mathrm{E}-02$ & $\mathrm{pCi} / \mathrm{L}$ & $\mathrm{U}$ & $9.09 \mathrm{E}-01$ & $9.09 \mathrm{E}-(1)$ \\
\hline Gross beta & B0XJW1 & EBL 124/ENW-MW5 & $02 / 09 / 2000$ & 8.27E-01 & $\mathrm{pCi} / \mathrm{L}$ & $\mathrm{U}$ & $2.67 \mathrm{E}+00$ & $2.67 \mathrm{E}+00$ \\
\hline lodine-129 & B0XJW1 & EBL 124/ENW-MW5 & $02 / 09 / 2000$ & $7.08 \mathrm{E}-02$ & $\mathrm{pCi} / \mathrm{L}$ & $\mathrm{U}$ & $3.53 \mathrm{E}-01$ & $3.53 \mathrm{E}-01$ \\
\hline Plutonium-238 & B0XJW1 & EBL 124/ENW-MW5 & $02 / 09 / 2000$ & $0.00 \mathrm{E}+00$ & $\mathrm{pCi} / \mathrm{L}$ & $\mathrm{U}$ & $9.26 \mathrm{E}-02$ & $9.26 \mathrm{E}-(12$ \\
\hline Plutonium-239/240 & B0XJW1 & EBL 124/ENW-MW5 & $02 / 09 / 2000$ & $0.00 \mathrm{E}+00$ & $\mathrm{pCi} / \mathrm{L}$ & $\mathrm{U}$ & $9.26 \mathrm{E}-02$ & $9.26 \mathrm{E}-(1) 2$ \\
\hline Potassium-40 & B0XJW1 & EBL 124/ENW-MW5 & $02 / 09 / 2000$ & $1.16 \mathrm{E}+01$ & $\mathrm{pCi} / \mathrm{L}$ & $\mathrm{U}$ & $1.85 \mathrm{E}+02$ & $1.85 \mathrm{E} \div 02$ \\
\hline Ruthenium-106 & B0XJW1 & EBL 124/ENW-MW5 & $02 / 09 / 2000$ & $5.43 \mathrm{E}+00$ & $\mathrm{pCi} / \mathrm{L}$ & $\mathrm{U}$ & $6.18 \mathrm{E}+01$ & $6.18 \mathrm{E}+01$ \\
\hline Technetium-99 & B0XJW1 & EBL 124/ENW-MW5 & $02 / 09 / 2000$ & $2.90 \mathrm{E}+00$ & $\mathrm{pCi} / \mathrm{L}$ & $U$ & $1.22 \mathrm{E}+01$ & $1.22 E+01$ \\
\hline $\begin{array}{l}\text { Total beta } \\
\text { radiostrontium }\end{array}$ & B0XJW1 & EBL 124/ENW-MW5 & $02 / 09 / 2000$ & $2.93 \mathrm{E}-01$ & $\mathrm{pCi} / \mathrm{L}$ & $\mathrm{U}$ & $7.57 \mathrm{E}-01$ & $7.57 \mathrm{E}-01$ \\
\hline Uranium & B0XJW1 & EBL 124/ENW-MW5 & $02 / 09 / 2000$ & 2.72E-03 & $\mathrm{ug} / \mathrm{L}$ & $\mathrm{U}$ & $7.29 \mathrm{E}-02$ & $7.29 \mathrm{E}-102$ \\
\hline Uranium-234 & B0XJW1 & EBL 124/ENW-MW5 & $02 / 09 / 2000$ & $3.04 \mathrm{E}-02$ & $\mathrm{pCi} / \mathrm{L}$ & $\mathrm{U}$ & $3.86 \mathrm{E}-01$ & $3.86 \mathrm{E}-01$ \\
\hline Uranium-235 & B0XJW1 & EBL 124/ENW-MW5 & $02 / 09 / 2000$ & $-3.04 \mathrm{E}-02$ & $\mathrm{pCi} / \mathrm{L}$ & $\mathrm{U}$ & $3.05 \mathrm{E}-01$ & $3.05 \mathrm{E}-01$ \\
\hline Uranium-238 & B0XJW1 & EBL 124/ENW-MW5 & $02 / 09 / 2000$ & $8.92 \mathrm{E}-02$ & $\mathrm{pCi} / \mathrm{L}$ & $\mathrm{U}$ & $3.62 \mathrm{E}-01$ & $3.62 \mathrm{E}-01$ \\
\hline Gross beta $^{(\mathrm{b})}$ & $\begin{array}{l}\text { B0XJW1 } \\
\text { DUP }\end{array}$ & $\begin{array}{l}\text { EBL 124/ENW-MWS } \\
\text { DUP }\end{array}$ & $02 / 09 / 2000$ & $5.01 \mathrm{E}-01$ & $\mathrm{pCi} / \mathrm{L}$ & $\mathrm{U}$ & & $2.67 \mathrm{E}+00$ \\
\hline Technetium- $99^{(\mathrm{b})}$ & \begin{tabular}{|l|} 
B0XJW1 \\
DUP
\end{tabular} & $\begin{array}{l}\text { EBL 124/ENW-MW5 } \\
\text { DUP }\end{array}$ & $02 / 09 / 2000$ & $1.51 E+00$ & $\mathrm{pCi} / \mathrm{L}$ & $\mathrm{U}$ & & $1.22 \mathrm{E}+01$ \\
\hline $\begin{array}{l}\text { Total beta } \\
\text { radiostrontium }^{(\mathrm{b})}\end{array}$ & $\begin{array}{l}\text { B0XJW1 } \\
\text { DUP }\end{array}$ & $\begin{array}{l}\text { EBL 124/ENW-MW5 } \\
\text { DUP }\end{array}$ & $02 / 09 / 2000$ & $2.43 E-01$ & $\mathrm{pCi} / \mathrm{L}$ & $\mathrm{U}$ & & $7.37 \mathrm{E}-01$ \\
\hline Uranium $^{(\mathbf{b})}$ & \begin{tabular}{|l|} 
B0XJW1 \\
DUP
\end{tabular} & $\begin{array}{l}\text { EBL 124/ENW-MW5 } \\
\text { DUP }\end{array}$ & $02 / 09 / 2000$ & $1.03 \mathrm{E}-02$ & $\mathrm{ug} / \mathrm{L}$ & $\mathrm{U}$ & & 7.29E-02 \\
\hline Antimony-125 & B0XJV5 & FTB 322/699-13-3A & $02 / 07 / 2000$ & $1.61 \mathrm{E}+00$ & $\mathrm{pCi} / \mathrm{L}$ & $\mathrm{U}$ & & $1.89 \mathrm{E}+01$ \\
\hline Beryllium-7 & B0XJV5 & FTB 322/699-13-3A & $02 / 07 / 2000$ & $-2.34 \mathrm{E}+01$ & $\mathrm{pCi} / \mathrm{L}$ & $\mathrm{U}$ & & $5.79 \mathrm{E}+01$ \\
\hline Cesium-134. & BoxJv5 & FTB $322 / 699-13-3 \mathrm{~A}$ & $02 / 07 / 2000$ & $-2.14 \mathrm{E}+00$ & $\mathrm{pCi} / \mathrm{L}$ & $\mathrm{U}$ & & $6.93 \mathrm{E}+00$ \\
\hline Cesium-137 & BoxJv5 & FTB 322/699-13-3A & $02 / 07 / 2000$ & $2.37 \mathrm{E}+00$ & $\mathrm{pCi} / \mathrm{L}$ & U & & $7.95 \mathrm{E}+-00$ \\
\hline Cobalt- 60 & B0XJv5 & FTB 322/699-13-3A & $02 / 07 / 2000$ & $3.08 \mathrm{E}+00$ & $\mathrm{pCi} / \mathrm{L}$ & $\mathrm{U}$ & & $1.04 \mathrm{E}-01$ \\
\hline Europium-152 & B0XJV5 & FTB 322/699-13-3A & $02 / 07 / 2000$ & $5.97 \mathrm{E}-01$ & $\mathrm{pCi} / \mathrm{L}$ & $\mathrm{U}$ & & $1.97 \mathrm{E}-01$ \\
\hline Europium-154 & B0XJV5 & FTB 322/699-13-3A & $02 / 07 / 2000$ & $2.84 \mathrm{E}+00$ & $\mathrm{pCi} / \mathrm{L}$ & $\mathrm{U}$ & & $2.22 \mathrm{E}-01$ \\
\hline Europium-155 & B0XJV5 & FTB 322/699-13-3A & $02 / 07 / 2000$ & $-1.83 \mathrm{E}-01$ & $\mathrm{pCi} / \mathrm{L}$ & $\mathrm{U}$ & & $1.50 \mathrm{E}-01$ \\
\hline Gross alpha & B0XJV5 & FTB 322/699-13-3A & $02 / 07 / 2000$ & 2.14E-01 & $\mathrm{pCi} / \mathrm{L}$ & $\mathrm{U}$ & & $9.28 \mathrm{E}-01$ \\
\hline Gross beta & B0XJV5 & FTB 322/699-13-3A & $02 / 07 / 2000$ & $7.76 \mathrm{E}-01$ & $\mathrm{pCi} / \mathrm{L}$ & $\mathrm{U}$ & & $2.67 \mathrm{E}-00$ \\
\hline Iodine-129 & B0XJV5 & FTB 322/699-13-3A & $02 / 07 / 2000$ & $1.43 \mathrm{E}-01$ & $\mathrm{pCi} / \mathrm{L}$ & $\mathrm{U}$ & & $3.46 \mathrm{E}-01$ \\
\hline Plutonium-238 & B0XJV5 & FTB 322/699-13-3A & $02 / 07 / 2000$ & $0.00 \mathrm{E}+00$ & $\mathrm{pCi} / \mathrm{L}$ & $\mathrm{U}$ & & $9.30 \mathrm{E}-02$ \\
\hline Plutonium-239/240 & B0XJV5 & FTB 322/699-13-3A & $02 / 07 / 2000$ & $-2.75 \mathrm{E}-03$ & $\mathrm{pCi} / \mathrm{L}$ & $\mathrm{U}$ & & $1.38 \mathrm{E}-01$ \\
\hline Potassium-40 & B0XJV5 & FTB 322/699-13-3A & $02 / 07 / 2000$ & $-1.08 E+01$ & $\mathrm{pCi} / \mathrm{L}$ & $\mathrm{U}$ & & $1.65 \mathrm{E}+02$ \\
\hline Ruthenium-106 & B0XJV5 & FTB 322/699-13-3A & $02 / 07 / 2000$ & $7.21 \mathrm{E}+00$ & $\mathrm{pCi} / \mathrm{L}$ & $\mathrm{U}$ & & $7.43 \mathrm{E}+01$ \\
\hline
\end{tabular}


Table C.3. (contd)

\begin{tabular}{|c|c|c|c|c|c|c|c|c|}
\hline Constituent & $\begin{array}{l}\text { Sample } \\
\text { Number }\end{array}$ & Well Name & $\begin{array}{c}\text { Sample } \\
\text { Date }\end{array}$ & $\begin{array}{c}\text { Value } \\
\text { Reported }\end{array}$ & Units & $\begin{array}{c}\text { Lab } \\
\text { Qualifier }^{(2)}\end{array}$ & $\begin{array}{c}\text { Reporting } \\
\text { Limit }\end{array}$ & MDA \\
\hline Strontium- $89 / 90$ & B0XJV5 & FTB 322/699-13-3A & $02 / 07 / 2000$ & $2.20 \mathrm{E}-01$ & $\mathrm{pCi} / \mathrm{L}$ & $\mathrm{U}$ & & $6.17 \mathrm{E}-01$ \\
\hline Technetium-99 & B0XJv5 & FTB 322/699-13-3A & $02 / 07 / 2000$ & $-2.51 \mathrm{E}+00$ & $\mathrm{pCi} / \mathrm{L}$ & $\mathrm{U}$ & & $1.22 \mathrm{E}+01$ \\
\hline Uranium & B0XJV5 & FTB 322/699-13-3A & $02 / 07 / 2000$ & $1.18 \mathrm{E}-03$ & $\mathrm{ug} / \mathrm{L}$ & $\mathrm{U}$ & & $7.29 \mathrm{E}-02$ \\
\hline Uranium-234 & B0XJV5 & FTB 322/699-13-3A & $02 / 07 / 2000$ & $1.12 \mathrm{E}-01$ & $\mathrm{pCi} / \mathrm{L}$ & $\mathrm{U}$ & & $2.64 \mathrm{E}-01$ \\
\hline Uranium-235 & B0XJV5 & FTB 322/699-13-3A & $02 / 07 / 2000$ & $1.16 \mathrm{E}-01$ & $\mathrm{pCi} / \mathrm{L}$ & $\mathrm{U}$ & & $2.52 \mathrm{E}-01$ \\
\hline Uranium-238 & B0XNV5 & FTB 322/699-13-3A & $02 / 07 / 2000$ & $1.19 \mathrm{E}-01$ & $\mathrm{pCi} / \mathrm{L}$ & $\mathrm{U}$ & & $2.38 \mathrm{E}-01$ \\
\hline Gross alpha $^{(b)}$ & B0XJV5 DUP & $\begin{array}{l}\text { FTB 322/699-13-3A } \\
\text { DUP }\end{array}$ & 36563 & $2.33 \mathrm{E}-01$ & $\mathrm{pCi} / \mathrm{L}$ & $\mathrm{U}$ & & $8.34 \mathrm{E}-01$ \\
\hline Antimony-125 & B0XK24 & FTB 323/699-21-6 & $02 / 07 / 2000$ & $-1.06 \mathrm{E}+01$ & $\mathrm{pCi} / \mathrm{L}$ & $\mathrm{U}$ & $1.76 \mathrm{E}+01$ & $1.76 \mathrm{E}+01$ \\
\hline Beryllium-7 & $\mathrm{B} 0 \mathrm{XK} 24$ & FTB 323/699-21-6 & $02 / 07 / 2000$ & $-1.52 \mathrm{E}+01$ & $\mathrm{pCi} / \mathrm{L}$ & $\mathrm{U}$ & $5.70 \mathrm{E}+01$ & $5.70 \mathrm{E}+01$ \\
\hline Cesium-134 & B0XK24 & FTB 323/699-21-6 & $02 / 07 / 2000$ & $8.49 \mathrm{E}-01$ & $\mathrm{pCi} / \mathrm{L}$ & $\mathrm{U}$ & $8.44 \mathrm{E}+00$ & $8.44 \mathrm{E}+00$ \\
\hline Cesium-137 & B0XK24 & FTB 323/699-21-6 & $02 / 07 / 2000$ & $-1.84 \mathrm{E}+00$ & $\mathrm{pCi} / \mathrm{L}$ & $\mathrm{U}$ & $8.17 \mathrm{E}+00$ & $8.17 \mathrm{E}+00$ \\
\hline Cobalt-60 & B0XK24 & FTB 323/699-21-6 & $02 / 07 / 2000$ & $1.73 \mathrm{E}-01$ & $\mathrm{pCi} / \mathrm{L}$ & $\mathrm{U}$ & $7.81 E+00$ & $7.81 \mathrm{E}+00$ \\
\hline Europium-1 52 & B0XK24 & FTB 323/699-21-6 & $02 / 07 / 2000$ & $4.80 \mathrm{E}+00$ & $\mathrm{pCi} / \mathrm{L}$ & $\mathrm{U}$ & $2.32 \mathrm{E}+01$ & $2.32 \mathrm{E}+01$ \\
\hline Europium-154 & B0XK24 & FTB 323/699-21-6 & $02 / 07 / 2000$ & $-8.12 E+00$ & $\mathrm{pCi} / \mathrm{L}$ & $\mathrm{U}$ & $2.10 \mathrm{E}+01$ & $2.10 \mathrm{E}+01$ \\
\hline Europium-155 & B0XK24 & FTB 323/699-21-6 & $02 / 07 / 2000$ & $1.21 E+01$ & $\mathrm{pCi} / \mathrm{L}$ & $\mathrm{U}$ & $1.79 \mathrm{E}+01$ & $1.79 \mathrm{E}+01$ \\
\hline Gross alpha & $\mathrm{B} 0 \mathrm{XK} 24$ & FTB $323 / 699-21-6$ & $02 / 07 / 2000$ & $3.12 \mathrm{E}-01$ & $\mathrm{pCi} / \mathrm{L}$ & $U$ & $9.16 \mathrm{E}-01$ & $9.16 \mathrm{E}-01$ \\
\hline Gross beta & B0XK24 & FTB 323/699-21-6 & $02 / 07 / 2000$ & $1.13 \mathrm{E}+00$ & $\mathrm{pCi} / \mathrm{L}$ & $\mathrm{U}$ & $2.52 \mathrm{E}+00$ & $2.52 \mathrm{E}+00$ \\
\hline Iodine-129 & $\mathrm{B} 0 \times \mathrm{XK} 24$ & FTB 323/699-21-6 & $02 / 07 / 2000$ & $-1.83 \mathrm{E}-02$ & $\mathrm{pCi} / \mathrm{L}$ & $\mathrm{U}$ & $3.18 \mathrm{E}-01$ & $3.18 \mathrm{E}-01$ \\
\hline Potassium-40 & $\mathrm{B} 0 \times \mathrm{XK} 24$ & FTB 323/699-21-6 & $02 / 07 / 2000$ & $1.33 \mathrm{E}+02$ & $\mathrm{pCi} / \mathrm{L}$ & & $6.69 \mathrm{E}+01$ & $6.69 \mathrm{E}+01$ \\
\hline Ruthenium-106 & B0XK24 & FTB 323/699-21-6 & $02 / 07 / 2000$ & $-1.03 \mathrm{E}+01$ & $\mathrm{pCi} / \mathrm{L}$ & $\mathrm{U}$ & $7.68 \mathrm{E}+01$ & $7.68 \mathrm{E}+01$ \\
\hline Technetium-99 & $\mathrm{B} 0 \mathrm{XK} 24$ & FTB 323/699-21-6 & $02 / 07 / 2000$ & $-4.05 \mathrm{E}-01$ & $\mathrm{pCi} / \mathrm{L}$ & $\mathrm{U}$ & $1.23 \mathrm{E}+01$ & $1.23 \mathrm{E}+01$ \\
\hline Uranium-234 & B0XK24 & FTB 323/699-21-6 & $02 / 07 / 2000$ & $-1.06 \mathrm{E}-02$ & $\mathrm{pCi} / \mathrm{L}$ & $\mathrm{U}$ & $2.21 \mathrm{E}-01$ & $2.21 \mathrm{E}-01$ \\
\hline Uranium-235 & B0XK24 & FTB 323/699-21-6 & $02 / 07 / 2000$ & $-1.06 \mathrm{E}-02$ & $\mathrm{pCi} / \mathrm{L}$ & $\mathrm{U}$ & $2.21 \mathrm{E}-01$ & $2.21 \mathrm{E}-01$ \\
\hline Uranium-238 & $\mathrm{B} 0 \times \mathrm{XK24}$ & FTB 323/699-21-6 & $02 / 07 / 2000$ & $2.66 \mathrm{E}-02$ & $\mathrm{pCi} / \mathrm{L}$ & $\mathrm{U}$ & $2.50 \mathrm{E}-01$ & $2.50 \mathrm{E}-01$ \\
\hline Iodine-129(b) & $\begin{array}{l}\text { B0XK24 } \\
\text { DUP }\end{array}$ & $\begin{array}{l}\text { FTB 323/699-21-6 } \\
\text { DUP }\end{array}$ & $02 / 07 / 2000$ & $1.27 \mathrm{E}-01$ & $\mathrm{pCi} / \mathrm{L}$ & $\mathrm{U}$ & & $2.79 \mathrm{E}-01$ \\
\hline \multicolumn{9}{|c|}{$\begin{array}{l}\text { (a) } \mathrm{U}=\text { Value reported is less than the MDA. } \\
\text { (b) Lab duplicate. } \\
\text { (c) Field duplicate. } \\
\text { (d) Before sampling. } \\
\text { (e) After sampling. } \\
\text { EBL = Equipment blank; FTB = Full trip blank; MDA = Minimum detectable activity. }\end{array}$} \\
\hline
\end{tabular}


Table C.4. Radionuclide Results for 618-11 Burial Ground Investigation, 325 Radiochemical Processing Group, February 2000

\begin{tabular}{|c|c|c|c|c|c|c|c|}
\hline Constituent & $\begin{array}{l}\text { Sample } \\
\text { Number }\end{array}$ & Well Name & $\begin{array}{l}\text { Sample } \\
\text { Date }\end{array}$ & $\begin{array}{c}\text { Value } \\
\text { Reported }\end{array}$ & Units & $\begin{array}{c}\text { Lab } \\
\text { Qualifier }\end{array}$ & Comments \\
\hline $\begin{array}{l}\text { Tc-99 Rad } \\
\text { Disks }\end{array}$ & B0XJT6 & $699-13-3 A$ & $02 / 07 / 2000$ & $5.45 \mathrm{E} \div 01$ & $\mathrm{pCi} / \mathrm{L}$ & & Measured Activities \\
\hline $\begin{array}{l}\text { Tc-99 Rad } \\
\text { Disks }\end{array}$ & $\begin{array}{l}\text { B0XJT6 } \\
\text { DUP }\end{array}$ & $\begin{array}{l}\text { 699-13-3A } \\
\text { DUP }\end{array}$ & $02 / 07 / 2000$ & $5.77 \mathrm{E}+01$ & $\mathrm{pCi} / \mathrm{L}$ & & Measured Activities/Lab Duplicate \\
\hline \begin{tabular}{|l} 
Sr-90 Rad \\
Disks
\end{tabular} & B0XJT6 & $699-13-3 \mathrm{~A}$ & $02 / 07 / 2000$ & $<2$ & $\mathrm{pCi} / \mathrm{L}$ & & Measured Activities/Corrected ${ }^{(a)}$ \\
\hline $\begin{array}{l}\text { Sr-90 Rad } \\
\text { Disks }\end{array}$ & $\begin{array}{l}\text { B0XJT6 } \\
\text { DUP }\end{array}$ & $\begin{array}{l}699-13-3 A \\
\text { DUP }\end{array}$ & $02 / 07 / 2000$ & $<2$ & $\mathrm{pCi} / \mathrm{L}$ & & $\begin{array}{l}\text { Measured Activities/ } \\
\text { Corrected }{ }^{(2)} / \text { Lab Duplicate }\end{array}$ \\
\hline
\end{tabular}


Table C.5. Anion and Alkalinity Results for 618-11 Burial Ground Investigation, February 2000

\begin{tabular}{|c|c|c|c|c|c|c|c|c|c|}
\hline Constituent & $\begin{array}{l}\text { Sample } \\
\text { Number }\end{array}$ & Well Name & Sample Date & $\begin{array}{c}\text { Value } \\
\text { Reported }\end{array}$ & Units & $\begin{array}{c}\text { Lab } \\
\text { Qualifier }\end{array}$ & \begin{tabular}{|c|} 
Dilution \\
Factor
\end{tabular} & $\begin{array}{c}\text { Reporting } \\
\text { Limit }\end{array}$ & MDL \\
\hline Chloride & B0XJY9 & 699-10-E12 & $02 / 08 / 2000$ & 11.2 & $\mathrm{mg} / \mathrm{L}$ & & 10 & 2 & 0.35 \\
\hline Fluoride & B0XJY9 & 699-10-E12 & $02 / 08 / 2000$ & 0.26 & $\mathrm{mg} / \mathrm{L}$ & & 1 & 0.1 & 0.01 \\
\hline Nitrate as $\mathrm{N}$ & B0XJY9 & 699-10-E12 & $02 / 08 / 2000$ & 6.8 & $\mathrm{mg} / \mathrm{L}$ & & 10 & 0.2 & 0.11 \\
\hline Nitrite as $\mathrm{N}$ & B0XJY9 & 699-10-E12 & $02 / 08 / 2000$ & ND & $\mathrm{mg} / \mathrm{L}$ & $\mathrm{U}$. & 1 & 0.02 & 0.0074 \\
\hline Sulfate & B0XJY9 & 699-10-E12 & $02 / 08 / 2000$ & 35.4 & $\mathrm{mg} / \mathrm{L}$ & & 10 & 5 & 1.1 \\
\hline Total Alkalinity & B0XJY9 & 699-10-E12 & $02 / 08 / 2000$ & 252 & $\mathrm{mg} / \mathrm{L}$ & & 1 & 5 & 2.2 \\
\hline Chloride & B0XJV7 & 699-12-4D & $02 / 07 / 2000$ & 11 & $\mathrm{mg} / \mathrm{L}$ & & 10 & 2 & 0.35 \\
\hline Fluoride & B0XJV7 & 699-12-4D & $02 / 07 / 2000$ & 0.31 & $\mathrm{mg} / \mathrm{L}$ & & 1 & 0.1 & 0.01 \\
\hline Nitrate as $\mathrm{N}$ & B0XJV7 & 699-12-4D & $02 / 07 / 2000$ & 6.3 & $\mathrm{mg} / \mathrm{L}$ & & 10 & 0.2 & 0.11 \\
\hline Nitrite as N & B0XJV7 & 699-12-4D & $02 / 07 / 2000$ & ND & $\mathrm{mg} / \mathrm{L}$ & $\mathrm{U}$ & 1 & 0.02 & 0.0074 \\
\hline Sulfate & B0XJV7 & 699-12-4D & $02 / 07 / 2000$ & 47.7 & $\mathrm{mg} / \mathrm{L}$ & & 10 & 5 & 1.1 \\
\hline Total Alkalinity & B0XJV7 & 699-12-4D & $02 / 07 / 2000$ & 128 & $\mathrm{mg} / \mathrm{L}$ & & 1 & 5 & 2.2 \\
\hline Chloride & B0XJW6 & 699-13-1A & $02 / 08 / 2000$ & 2.8 & $\mathrm{mg} / \mathrm{L}$ & & 1 & 0.2 & 0.035 \\
\hline Fluoride & B0XJW6 & 699-13-1A & $02 / 08 / 2000$ & 0.36 & $\mathrm{mg} / \mathrm{L}$ & & 1 & 0.1 & 0.01 \\
\hline Nitrate as N & B0XJW6 & 699-13-1A & $02 / 08 / 2000$ & 1.6 & $\mathrm{mg} / \mathrm{L}$ & & 2 & 0.04 & 0.021 \\
\hline Nitrite as $\mathrm{N}$ & B0XJW6 & 699-13-1A & $02 / 08 / 2000$ & ND & $\mathrm{mg} / \mathrm{L}$ & $\mathrm{U}$ & 1 & 0.02 & 0.0074 \\
\hline Sulfate & B0XJW6 & 699-13-1A & $02 / 08 / 2000$ & 25.1 & $\mathrm{mg} / \mathrm{L}$ & & 2 & 1 & 0.22 \\
\hline Total Alkalinity & B0XJW6 & $699-13-1 \mathrm{~A}$ & $02 / 08 / 2000$ & 152 & $\mathrm{mg} / \mathrm{L}$ & & 1 & 5 & 2.2 \\
\hline Chloride & $\mathrm{B} 0 \mathrm{XJX5}$ & 699-13-1B & $02 / 08 / 2000$ & 1.4 & $\mathrm{mg} / \mathrm{L}$ & & 1 & 0.2 & 0.035 \\
\hline Fluoride & B0XJX5 & 699-13-1B & $02 / 08 / 2000$ & 0.36 & $\mathrm{mg} / \mathrm{L}$ & & 1 & 0.1 & 0.01 \\
\hline Nitrate as N & B0XJX5 & 699-13-1B & $02 / 08 / 2000$ & 0.021 & $\mathrm{mg} / \mathrm{L}$ & & 1 & 0.02 & 0.011 \\
\hline Nitrite as N & B0XJX5 & 699-13-1B & $02 / 08 / 2000$ & $\mathrm{ND}$ & $\mathrm{mg} / \mathrm{L}$ & $\mathbf{U}$ & 1 & 0.02 & 0.0074 \\
\hline Sulfate & B0XJX5 & 699-13-1B & $02 / 08 / 2000$ & 20.6 & $\mathrm{mg} / \mathrm{L}$ & & 2 & 1 & 0.22 \\
\hline Total Alkalinity & B0XJX5 & 699-13-1B & $02 / 08 / 2000$ & 128 & $\mathrm{mg} / \mathrm{L}$ & & 1 & 5 & 2.2 \\
\hline \begin{tabular}{|l|} 
Chloride \\
\end{tabular} & B0XJX9 & 699-13-1C & $02 / 08 / 2000$ & 14.4 & $\mathrm{mg} / \mathrm{L}$ & & 5 & 1 & 0.17 \\
\hline Fluoride & B0XJX9 & 699-13-1C & $02 / 08 / 2000$ & 2.3 & $\mathrm{mg} / \mathrm{L}$ & & 1 & 0.1 & 0.01 \\
\hline Nitrate as $\mathrm{N}$ & B0XJX9 & 699-13-1C & $02 / 08 / 2000$ & 0.023 & $\mathrm{mg} / \mathrm{L}$ & & 1 & 0.02 & 0.011 \\
\hline Nitrite as $\mathrm{N}$ & B0XJX9 & 699-13-1C & $02 / 08 / 2000$ & $\mathrm{ND}$ & $\mathrm{mg} / \mathrm{L}$ & $\mathrm{U}$ & 1 & 0.02 & 0.0074 \\
\hline Sulfate & B0XJX9 & 699-13-1C & $02 / 08 / 2000$ & 2 & $\mathrm{mg} / \mathrm{L}$ & & 1 & 0.5 & 0.11 \\
\hline Total Alkalinity & B0XJX9 & 699-13-1C & $02 / 08 / 2000$ & 158 & $\mathrm{mg} / \mathrm{L}$ & & 1 & 5 & 2.2 \\
\hline Chloride & BOXJT3 & $699-13-3 \mathrm{~A}$ & $02 / 07 / 2000$ & 14.9 & $\mathrm{mg} / \mathrm{L}$ & & 5 & 1 & 0.17 \\
\hline Chloride ${ }^{(\mathrm{b})}$ & BOXJV1 & 699-13-3A & $02 / 07 / 2000$ & 14.8 & $\mathrm{mg} / \mathrm{L}$ & & 5 & 1 & 0.17 \\
\hline Fluoride & BOXJT3 & 699-13-3A & $02 / 07 / 2000$ & 0.26 & $\mathrm{mg} / \mathrm{L}$ & & 1 & 0.1 & 0.01 \\
\hline Fluoride $^{(b)}$ & BOXJV1 & 699-13-3A & $02 / 07 / 2000$ & 0.26 & $\mathrm{mg} / \mathrm{L}$ & & 1 & 0.1 & 0.01 \\
\hline Nitrate as $\mathbf{N}$ & BOXJT3 & 699-13-3A & $02 / 07 / 2000$ & 22.8 & $\mathrm{mg} / \mathrm{L}$ & & 50 & 1 & 0.53 \\
\hline Nitrate as $\mathrm{N}^{(\mathrm{b})}$ & BOXJV1 & 699-13-3A & $02 / 07 / 2000$ & 23.3 & $\mathrm{mg} / \mathrm{L}$ & & 50 & 1 & 0.53 \\
\hline Nitrite as $\mathrm{N}$ & BOXJT3 & $699-13-3 \mathrm{~A}$ & $02 / 07 / 2000$ & ND & $\mathrm{mg} / \mathrm{L}$ & $\mathrm{U}$ & 1 & 0.02 & 0.0074 \\
\hline Nitrite as $\mathrm{N}^{(\mathrm{b})}$ & BOXJV1 & 699-13-3A & $02 / 07 / 2000$ & ND & $\mathrm{mg} / \mathrm{L}$ & $\mathrm{U}$ & 1 & 0.02 & 0.0074 \\
\hline Sulfate & BOXJT3 & $699-13-3 A$ & $02 / 07 / 2000$ & 62.4 & $\mathrm{mg} / \mathrm{L}$ & & 5 & 2.5 & 0.54 \\
\hline Sulfate ${ }^{(b)}$ & BOXJV1 & $699-13-3 A$ & $02 / 07 / 2000$ & 62.7 & $\mathrm{mg} / \mathrm{L}$ & & 5 & 2.5 & 0.54 \\
\hline Total Alkalinity & BOXJT3 & $699-13-3 \mathrm{~A}$ & $02 / 07 / 2000$ & 150 & $\mathrm{mg} / \mathrm{L}$ & & 1 & 5 & 2.2 \\
\hline Total Alkalinity ${ }^{(b)}$ & BOXJV1 & $699-13-3 A$ & $02 / 07 / 2000$ & 152 & $\mathrm{mg} / \mathrm{L}$ & & 1 & 5 & 2.2 \\
\hline Chloride ${ }^{(e)}$ & \begin{tabular}{|l} 
BOXJT3 \\
DUP
\end{tabular} & 699-13-3A DUP & $02 / 07 / 2000$ & 14.8 & $\mathrm{mg} / \mathrm{L}$ & & 5 & 1 & 0.17 \\
\hline Fluoride $^{(c)}$ & \begin{tabular}{|l} 
BOXJT3 \\
DUP
\end{tabular} & 699-13-3A DUP & $02 / 07 / 2000$ & 0.27 & $\mathrm{mg} / \mathrm{L}$ & & 1 & 0.1 & 0.01 \\
\hline
\end{tabular}


Table C.5. (contd)

\begin{tabular}{|c|c|c|c|c|c|c|c|c|c|}
\hline Constituent & $\begin{array}{c}\text { Sample } \\
\text { Number } \\
\end{array}$ & Well Name & Sample Date & \begin{tabular}{|c|} 
Value \\
Reported
\end{tabular} & Units & \begin{tabular}{|c|} 
Lab \\
Qualifier \\
\end{tabular} & $\begin{array}{c}\text { Dilution } \\
\text { Factor }\end{array}$ & $\begin{array}{c}\text { Reporting } \\
\text { Limit } \\
\end{array}$ & MDL. \\
\hline Nitrate as $\mathrm{N}^{(\mathrm{c})}$ & $\begin{array}{l}\text { BOXJT3 } \\
\text { DUP }\end{array}$ & 699-13-3A DUP & $02 / 07 / 2000$ & 22.5 & $\mathrm{mg} / \mathrm{L}$ & & 50 & 1 & 0.53 \\
\hline Nitrite as $\mathrm{N}^{(\mathrm{c})}$ & \begin{tabular}{|l} 
BOXJT3 \\
DUP
\end{tabular} & 699-13-3A DUP & $02 / 07 / 2000$ & ND & $\mathrm{mg} / \mathrm{L}$ & $\mathrm{U}$ & 1 & 0.02 & $0.007 \overline{4}$ \\
\hline Sulfate ${ }^{(c)}$ & \begin{tabular}{|l} 
BOXJT3 \\
DUP
\end{tabular} & 699-13-3A DUP & $02 / 07 / 2000$ & 62.2 & $\mathrm{mg} / \mathrm{L}$ & & 5 & 2.5 & 0.54 \\
\hline Total Alkalinity ${ }^{(c)}$ & $\begin{array}{l}\text { BOXJT3 } \\
\text { DUP }\end{array}$ & 699-13-3A DUP & $02 / 07 / 2000$ & 146 & $\mathrm{mg} / \mathrm{L}$ & & 1 & 5 & 2.2 \\
\hline Chloride & B0XK19 & 699-15-15B & $02 / 08 / 2000$ & 8.6 & $\mathrm{mg} / \mathrm{L}$ & & 10 & 2 & 0.35 \\
\hline Fluoride & B0XK19 & $699-15-15 B$ & $02 / 08 / 2000$ & 0.34 & $\mathrm{mg} / \mathrm{L}$ & & 1 & 0.1 & 0.01 \\
\hline Nitrate as N & B0XK19 & $699-15-15 B$ & $02 / 08 / 2000$ & 6.1 & $\mathrm{mg} / \mathrm{L}$ & & 10 & 0.2 & 0.11 \\
\hline Nitrite as N & $\overline{B 0 X K 19}$ & 699-15-15B & $02 / 08 / 2000$ & ND & $\mathrm{mg} / \mathrm{L}$ & $\mathrm{U}$ & 1 & 0.02 & 0.0074 \\
\hline Sulfate & B0XK19 & 699-15-15B & $02 / 08 / 2000$ & 90.6 & $\mathrm{mg} / \mathrm{L}$ & & 10 & 5 & 1.1 \\
\hline Total Alkalinity & B0XK19 & $699-15-15 B$ & $02 / 08 / 2000$ & 124 & $\mathrm{mg} / \mathrm{L}$ & & 1 & 5 & $\overline{2.2}$ \\
\hline Chloride & B0XK14 & $699-17-5$ & $02 / 07 / 2000$ & 12.4 & $\mathrm{mg} / \mathrm{L}$ & & 5 & 1 & 0.17 \\
\hline Fluoride & $\overline{B 0 \times K 14}$ & 699-17-5 & $02 / 07 / 2000$ & 0.26 & $\mathrm{mg} / \mathrm{L}$ & & 1 & 0.1 & 0.01 \\
\hline Nitrate as N & B0XK14 & $699-17-5$ & $02 / 07 / 2000$ & 16.4 & $\mathrm{mg} / \mathrm{L}$ & & 50 & 1 & 0.53 \\
\hline Nitrite as N & B0XK14 & $699-17-5$ & $02 / 07 / 2000$ & 0.097 & $\mathrm{mg} / \mathrm{L}$ & & 1 & 0.02 & 0.0074 \\
\hline Sulfate & B0XK14 & $699-17-5$ & $02 / 07 / 2000$ & 46.5 & $\mathrm{mg} / \mathrm{L}$ & & 5 & 2.5 & 0.54 \\
\hline Total Alkalinity & B0XK14 & $699-17-5$ & $02 / 07 / 2000$ & 102 & $\mathrm{mg} / \mathrm{L}$ & & 1 & 5 & 2.2 \\
\hline Chloride & B0XK22 & $699-21-6$ & $02 / 07 / 2000$ & 10.7 & $\mathrm{mg} / \mathrm{L}$ & & 5 & 1 & 0.17 \\
\hline Fluoride & B0XK22 & 699-21-6 & $02 / 07 / 2000$ & 0.19 & $\mathrm{mg} / \mathrm{L}$ & & 1 & 0.1 & 0.01 \\
\hline Nitrate as $\mathrm{N}$ & B0XK22 & 699-21-6 & $02 / 07 / 2000$ & 9.5 & $\mathrm{mg} / \mathrm{L}$ & & 20 & 0.4 & 0.21 \\
\hline Nitrite as N & B0XK22 & 699-21-6 & $02 / 07 / 2000$ & 0.044 & $\mathrm{mg} / \mathrm{L}$ & & 1 & 0.02 & 0.0074 \\
\hline Sulfate & B0XK22 & $699-21-6$ & $02 / 07 / 2000$ & 28.9 & $\mathrm{mg} / \mathrm{L}$ & & 5 & 2.5 & 0.54 \\
\hline Total Alkalinity & B0XK22 & $699-21-6$ & $02 / 07 / 2000$ & 102 & $\mathrm{mg} / \mathrm{L}$ & & 1 & 5 & 2.2 \\
\hline Chloride & B0XK11 & $699-8-17$ & $02 / 08 / 2000$ & 10.4 & $\mathrm{mg} / \mathrm{L}$ & & 5 & 1 & 0.17 \\
\hline Fluoride & B0XK11 & $699-8-17$ & $02 / 08 / 2000$ & 0.38 & $\mathrm{mg} / \mathrm{L}$ & & 1 & 0.1 & 0.01 \\
\hline Nitrate as $\mathrm{N}$ & B0XK11 & 699-8-17 & $02 / 08 / 2000$ & 7 & $\mathrm{mg} / \mathrm{L}$ & & 10 & 0.2 & 0.11 \\
\hline Nitrite as $\mathrm{N}$ & B0XK11 & $699-8-17$ & $02 / 08 / 2000$ & ND & $\mathrm{mg} / \mathrm{L}$ & $\mathrm{U}$ & 1 & 0.02 & 0.0074 \\
\hline Sulfate & B0XK11 & $699-8-17$ & $02 / 08 / 2000$ & 54.8 & $\mathrm{mg} / \mathrm{L}$ & & 10 & 5 & 1.1 \\
\hline Total Alkalinity & B0XK11 & 699-8-17 & $02 / 08 / 2000$ & 121 & $\mathrm{mg} / \mathrm{L}$ & & 1 & 5 & 2.2 \\
\hline Chloride & B0XJY3 & 699-9-E2 & $02 / 10 / 2000$ & 11.5 & $\mathrm{mg} / \mathrm{L}$ & & 5 & 1 & 0.17 \\
\hline Fluoride & $\mathrm{B} 0 \mathrm{XJY} 3$ & 699-9-E2 & $02 / 10 / 2000$ & 0.34 & $\mathrm{mg} / \mathrm{L}$ & & 1 & 0.1 & 0.01 \\
\hline Nitrate as $\mathrm{N}$ & B0XJY3 & 699-9-E2 & $02 / 10 / 2000$ & 3.2 & $\mathrm{mg} / \mathrm{L}$ & & 5 & 0.1 & 0.22 \\
\hline Nitrite as N & B0XJY3 & 699-9-E2 & $02 / 10 / 2000$ & ND & $\mathrm{mg} / \mathrm{L}$ & $\bar{U}$ & 1 & 0.02 & 0.0074 \\
\hline Sulfate & B0XJY3 & 699-9-E2 & $02 / 10 / 2000$ & 41.6 & $\mathrm{mg} / \mathrm{L}$ & & 5 & 2.5 & 0.54 \\
\hline Total Alkalinity & B0XJY3 & 699-9-E2 & $02 / 10 / 2000$ & 138 & $\mathrm{mg} / \mathrm{L}$ & & 1 & 5 & 2.2 \\
\hline Chloride & B0XK99 & $\begin{array}{l}\text { C3071/ } \\
\text { ENW-MW1 }\end{array}$ & $02 / 09 / 2000$ & 16.5 & $\mathrm{mg} / \mathrm{L}$ & & 20 & 4 & 0.69 \\
\hline Fluoride & B0XK99 & $\begin{array}{l}\text { C3071/ } \\
\text { ENW-MW1 }\end{array}$ & $02 / 09 / 2000$ & 0.23 & $\mathrm{mg} / \mathrm{L}$ & & 1 & 0.1 & 0.01 \\
\hline Nitrate as N & B0XK99 & $\begin{array}{l}\text { C3071/ } \\
\text { ENW-MW1 }\end{array}$ & $02 / 09 / 2000$ & 12.4 & $\mathrm{mg} / \mathrm{L}$ & & 20 & 0.4 & 0.21 \\
\hline Nitrite as $\mathrm{N}$ & B0XK99 & $\begin{array}{l}\text { C3071/ } \\
\text { ENW-MW1 }\end{array}$ & $02 / 09 / 2000$ & ND & $\mathrm{mg} / \mathrm{L}$ & $\mathrm{U}$ & 1 & 0.02 & $\overline{0.0074}$ \\
\hline
\end{tabular}


Table C.5. (contd)

\begin{tabular}{|c|c|c|c|c|c|c|c|c|c|}
\hline Constituent & $\begin{array}{c}\text { Sample } \\
\text { Number }\end{array}$ & Well Name & Sample Date & $\begin{array}{c}\text { Value } \\
\text { Reported }\end{array}$ & Units & $\begin{array}{c}\text { Lab } \\
\text { Qualifier }^{(2)}\end{array}$ & $\begin{array}{c}\text { Dilution } \\
\text { Factor }\end{array}$ & $\begin{array}{c}\text { Reporting } \\
\text { limit }\end{array}$ & MDL \\
\hline Sulfate & B0XK99 & $\begin{array}{l}\text { C3071/ } \\
\text { ENW-MW1 }\end{array}$ & $02 / 09 / 2000$ & 82.8 & $\mathrm{mg} / \mathrm{L}$ & & 20 & 10 & 2.2 \\
\hline Total Alkalinity & B0XK99 & $\begin{array}{l}\text { C3071/ } \\
\text { ENW-MW1 }\end{array}$ & $02 / 09 / 2000$ & 268 & $\mathrm{mg} / \mathrm{L}$ & & 1 & 5 & 2.2 \\
\hline Chloride & B0XKB0 & $\begin{array}{l}\text { C3072/ } \\
\text { ENW-MW2 }\end{array}$ & $02 / 10 / 2000$ & 53.3 & $\mathrm{mg} / \mathrm{L}$ & & 20 & 4 & 0.69 \\
\hline Fluoride & BOXKB0 & \begin{tabular}{|l|} 
C3072/ \\
ENW-MW2
\end{tabular} & $02 / 10 / 2000$ & 0.24 & $\mathrm{mg} / \mathrm{L}$ & & 1 & 0.1 & 0.01 \\
\hline Nitrate as $\mathrm{N}$ & BOXKB0 & $\begin{array}{l}\text { C3072! } \\
\text { ENW-MW2 }\end{array}$ & $02 / 10 / 2000$ & 14.2 & $\mathrm{mg} / \mathrm{L}$ & & 20 & 0.4 & 0.21 \\
\hline Nitrite as N & $\mathrm{B} 0 \mathrm{XKB} 0$ & $\begin{array}{l}\text { C3072/ } \\
\text { ENW-MW2 }\end{array}$ & $02 / 10 / 2000$ & ND & $\mathrm{mg} / \mathrm{L}$ & $\mathrm{U}$ & 1 & 0.02 & 0.0074 \\
\hline Sulfate & $\mathrm{B} 0 \times \mathrm{XKB} 0$ & $\begin{array}{l}\text { C3072/ } \\
\text { ENW-MW2 }\end{array}$ & $02 / 10 / 2000$ & 117 & $\mathrm{mg} / \mathrm{L}$ & & 10 & 5 & 1.1 \\
\hline Total Alkalinity & BOXKB0 & $\begin{array}{l}\text { C3072/ } \\
\text { ENW-MW2 }\end{array}$ & $02 / 10 / 2000$ & 306 & $\mathrm{mg} / \mathrm{L}$ & & 1 & 5 & 2.2 \\
\hline Chloride & $\mathrm{B} 0 \mathrm{XKB1}$ & $\begin{array}{l}\text { C3073/ } \\
\text { ENW-MW3 }\end{array}$ & $02 / 10 / 2000$ & 17.5 & $\mathrm{mg} / \mathrm{L}$ & & 20 & 4 & 0.69 \\
\hline Fluoride & B0XKB1 & $\begin{array}{l}\text { C3073/ } \\
\text { ENW-MW3 }\end{array}$ & $02 / 10 / 2000$ & 0.14 & $\mathrm{mg} / \mathrm{L}$ & & 1 & 0.1 & 0.01 \\
\hline Nitrate as N & B0XKB1 & $\begin{array}{l}\text { C3073/ } \\
\text { ENW-MW3 }\end{array}$ & $02 / 10 / 2000$ & 6.6 & $\mathrm{mg} / \mathrm{L}$ & & 20 & 0.4 & 0.21 \\
\hline Nitrite as $\mathrm{N}$ & B0XKB1 & $\begin{array}{l}\text { C3073/ } \\
\text { ENW-MW3 }\end{array}$ & $02 / 10 / 2000$ & ND & $\mathrm{mg} / \mathrm{L}$ & $\mathrm{U}$ & 1 & 0.02 & 0.0074 \\
\hline Sulfate & $\mathrm{B} 0 \mathrm{XKB1}$ & $\begin{array}{l}\text { C3073/ } \\
\text { ENW-MW3 }\end{array}$ & $02 / 10 / 2000$ & 142 & $\mathrm{mg} / \mathrm{L}$ & & 20 & 10 & 2.2 \\
\hline Total Alkalinity & $\mathrm{BOXKBI}$ & $\begin{array}{l}\text { C3073/ } \\
\text { ENW-MW3 }\end{array}$ & $02 / 10 / 2000$ & 448 & $\mathrm{mg} / \mathrm{L}$ & & 1 & 5 & 2.2 \\
\hline Chloride & B0XKB2 & $\begin{array}{l}\text { C3074/ } \\
\text { ENW-MW4 }\end{array}$ & $02 / 10 / 2000$ & 12.5 & $\mathrm{mg} / \mathrm{L}$ & & 10 & $\overline{2}$ & 0.35 \\
\hline Fluoride & B0XKB2 & $\begin{array}{l}\text { C3074/ } \\
\text { ENW-MW4 }\end{array}$ & $02 / 10 / 2000$ & 0.29 & $\mathrm{mg} / \mathrm{L}$ & & 1 & 0.1 & 0.01 \\
\hline Nitrate as $\mathrm{N}$ & BOXKB2 & $\begin{array}{l}\text { C3074/ } \\
\text { ENW-MW4 }\end{array}$ & $02 / 10 / 2000$ & 6.9 & $\mathrm{mg} / \mathrm{L}$ & & 10 & 0.2 & 0.11 \\
\hline Nitrite as N & B0XKB2 & $\begin{array}{l}\text { C3074/ } \\
\text { ENW-MW4 }\end{array}$ & $02 / 10 / 2000$ & ND & $\mathrm{mg} / \mathrm{L}$ & $\overline{\mathrm{U}}$ & 1 & 0.02 & 0.0074 \\
\hline Sulfate & BOXKB2 & \begin{tabular}{|l} 
C3074/ \\
ENW-MW4
\end{tabular} & $02 / 10 / 2000$ & 65.2 & $\mathrm{mg} / \mathrm{L}$ & & 10 & 5 & 1.1 \\
\hline Total Alkalinity & $\mathrm{B} 0 \mathrm{XKB} 2$ & $\begin{array}{l}\text { C3074/ } \\
\text { ENW-MW4 }\end{array}$ & $02 / 10 / 2000$ & 222 & $\mathrm{mg} / \mathrm{L}$ & & 1 & 5 & 2.2 \\
\hline Chloride & B0KXB3 & $\begin{array}{l}\text { C3075/ } \\
\text { ENW-MW5 }\end{array}$ & $02 / 09 / 2000$ & 10.7 & $\mathrm{mg} / \mathrm{L}$ & & 1 & 0.2 & 0.035 \\
\hline Fluoride & $\mathrm{B} 0 \mathrm{KXB} 3$ & $\begin{array}{l}\text { C3075/ } \\
\text { ENW-MW5 }\end{array}$ & $02 / 09 / 2000$ & 0.34 & $\mathrm{mg} / \mathrm{L}$ & & 1 & 0.1 & 0.01 \\
\hline Nitrate as N & $\mathrm{B} 0 \mathrm{KXB} 3$ & $\begin{array}{l}\text { C3075i } \\
\text { ENW-MW5 }\end{array}$ & $02 / 09 / 2000$ & 8.4 & $\mathrm{mg} / \mathrm{L}$ & & 10 & 0.2 & 0.11 \\
\hline
\end{tabular}


Table C.5. (contd)

\begin{tabular}{|c|c|c|c|c|c|c|c|c|c|}
\hline Constituent & $\begin{array}{l}\text { Sample } \\
\text { Number }\end{array}$ & Well Name & Sample Date & $\begin{array}{c}\text { Value } \\
\text { Reported }\end{array}$ & Units & $\begin{array}{c}\text { Lab } \\
\text { Qualifier }^{(a)}\end{array}$ & $\begin{array}{l}\text { Dilution } \\
\text { Factor }\end{array}$ & $\begin{array}{c}\text { Reporting } \\
\text { Limit }\end{array}$ & MDL \\
\hline Nitrite as $\mathrm{N}$ & $\mathrm{B0KXB3}$ & $\begin{array}{l}\text { C3075/ } \\
\text { ENW-MW5 }\end{array}$ & $02 / 09 / 2000$ & $\mathrm{ND}$ & $\mathrm{mg} / \mathrm{L}$ & $\mathrm{U}$ & 1 & 0.02 & 0.0074 \\
\hline Sulfate & $\mathrm{B} 0 \mathrm{KXB} 3$ & $\begin{array}{l}\text { C3075/ } \\
\text { ENW-MW5 }\end{array}$ & $02 / 09 / 2000$ & 50.9 & $\mathrm{mg} / \mathrm{L}$ & & 10 & 5 & 1.1 \\
\hline Total Alkalinity & B0KXB3 & $\begin{array}{l}\text { C3075/ } \\
\text { ENW-MW5 }\end{array}$ & $02 / 09 / 2000$ & 144 & $\mathrm{mg} / \mathrm{L}$ & & 1 & 5 & 2.2 \\
\hline Chloride & $\mathrm{B} 0 \mathrm{KXB} 4$ & $\begin{array}{l}\text { C3076/ } \\
\text { ENW-MW6 }\end{array}$ & $02 / 09 / 2000$ & 16.6 & $\mathrm{mg} / \mathrm{L}$ & & 10 & 2 & 0.35 \\
\hline Fluoride & B0KXB4 & $\begin{array}{l}\text { C3076I } \\
\text { ENW-MW6 }\end{array}$ & $02 / 09 / 2000$ & 0.26 & $\mathrm{mg} / \mathrm{L}$ & & 1 & 0.1 & 0.01 \\
\hline Nitrate as $\mathrm{N}$ & $\mathrm{B} 0 \mathrm{KXB} 4$ & $\begin{array}{l}\text { C3076/ } \\
\text { ENW-MW6 }\end{array}$ & $02 / 09 / 2000$ & 7.8 & $\mathrm{mg} / \mathrm{L}$ & & 10 & 0.2 & 0.11 \\
\hline Nitrite as N & B0KXB4 & $\begin{array}{l}\text { C3076i } \\
\text { ENW-MW6 }\end{array}$ & $02 / 09 / 2000$ & ND & $\mathrm{mg} / \mathrm{L}$ & $\mathrm{U}$ & 1 & 0.02 & 0.0074 \\
\hline Sulfate & $\mathrm{B} 0 \mathrm{KXB4}$ & $\begin{array}{l}\text { C3076/ } \\
\text { ENW-MW6 }\end{array}$ & $02 / 09 / 2000$ & 102 & $\mathrm{mg} / \mathrm{L}$ & & 10 & 5 & 1.1 \\
\hline Total Alkalinity & $\mathrm{B} 0 \mathrm{KXB} 4$ & $\begin{array}{l}\text { C3076/ } \\
\text { ENW-MW6 }\end{array}$ & $02 / 09 / 2000$ & 222 & $\mathrm{mg} / \mathrm{L}$ & & 1 & 5 & 2.2 \\
\hline Chloride & B0XKB5 & $\begin{array}{l}\text { C3077/ } \\
\text { ENW-MW7 }\end{array}$ & $02 / 15 / 2000$ & 4.8 & $\mathrm{mg} / \mathrm{L}$ & & 1 & 0.2 & 0.035 \\
\hline Fluoride & B0XKB5 & $\begin{array}{l}\text { C3077/ } \\
\text { ENW-MW7 }\end{array}$ & $02 / 15 / 2000$ & 0.22 & $\mathrm{mg} / \mathrm{L}$ & & 1 & 0.1 & 0.01 \\
\hline Nitrate as $\mathrm{N}$ & B0XKB5 & \begin{tabular}{|l|} 
C3077/ \\
ENW-MW7 \\
\end{tabular} & $02 / 15 / 2000$ & 0.36 & $\mathrm{mg} / \mathrm{L}$ & & 1 & 0.02 & 0.011 \\
\hline Nitrite as N & B0XKB5 & $\begin{array}{l}\text { C3077/ } \\
\text { ENW-MW7 }\end{array}$ & $02 / 15 / 2000$ & ND & $\mathrm{mg} / \mathrm{L}$ & $\bar{U}$ & 1 & 0.02 & 0.0074 \\
\hline Sulfate & B0XKB5 & $\begin{array}{l}\text { C3077/ } \\
\text { ENW-MW7 }\end{array}$ & $02 / 15 / 2000$ & 21.5 & $\mathrm{mg} / \mathrm{L}$ & & 2 & 1 & 0.22 \\
\hline Total Alkalinity & B0XKB5 & \begin{tabular}{|l|} 
C3077/ \\
ENW-MW7
\end{tabular} & $02 / 15 / 2000$ & 172 & $\mathrm{mg} / \mathrm{L}$ & & 1 & 5 & 2.2 \\
\hline Chloride & B0XKB6 & $\begin{array}{l}\text { C3078/ } \\
\text { ENW-MW8 }\end{array}$ & $02 / 11 / 2000$ & 12.7 & mg/L & $\mathrm{C}$ & 10 & 2 & 0.35 \\
\hline Fluoride & $\mathrm{B} 0 \mathrm{XKB} 6$ & $\begin{array}{l}\text { C3078/ } \\
\text { ENW-MW8 }\end{array}$ & $02 / 11 / 2000$ & 0.3 & $\mathrm{mg} / \mathrm{L}$ & & I & 0.1 & 0.01 \\
\hline Nitrate as $\mathrm{N}$ & B0XKB6 & \begin{tabular}{|l|} 
C3078/ \\
ENW-MW8
\end{tabular} & $02 / 11 / 2000$ & 0.35 & $\mathrm{mg} / \mathrm{L}$ & & 1 & 0.02 & 0.011 \\
\hline Nitrite as N & B0XKB6 & $\begin{array}{l}\text { C3078/ } \\
\text { ENW-MW8 }\end{array}$ & $02 / 11 / 2000$ & ND & $\mathrm{mg} / \mathrm{L}$ & $\bar{U}$ & 1 & 0.02 & 0.0074 \\
\hline Sulfate & B0XKB6 & $\begin{array}{l}\text { C3078/ } \\
\text { ENW-MW8 }\end{array}$ & $02 / 11 / 2000$ & 47.4 & $\mathrm{mg} / \mathrm{L}$ & & 10 & 5 & 1.1 \\
\hline Total Alkalinity & B0XKB6 & $\begin{array}{l}\text { C3078! } \\
\text { ENW-MW8 }\end{array}$ & $02 / 11 / 2000$ & 216 & $\mathrm{mg} / \mathrm{L}$ & & 1 & 5 & 2.2 \\
\hline Chloride & B0XKB7 & $\begin{array}{l}\text { C3079/ } \\
\text { ENW-MW9 }\end{array}$ & $02 / 11 / 2000$ & 26.7 & $\mathrm{mg} / \mathrm{L}$ & $\mathrm{C}$ & 20 & 4 & 0.69 \\
\hline Chloride $^{(6)}$ & B0XKB8 & $\begin{array}{l}\text { C3079/ } \\
\text { ENW-MW9 }\end{array}$ & $02 / 11 / 2000$ & 26.6 & $\mathrm{mg} / \mathrm{L}$ & $\mathrm{C}$ & 20 & 4 & 0.69 \\
\hline
\end{tabular}


Table C.5. (contd)

\begin{tabular}{|c|c|c|c|c|c|c|c|c|c|}
\hline Constituent & $\begin{array}{c}\text { Sample } \\
\text { Number }\end{array}$ & Well Name & Sample Date & \begin{tabular}{|c|}
$\begin{array}{c}\text { Value } \\
\text { Reported }\end{array}$ \\
\end{tabular} & Units & $\begin{array}{c}\text { Lab } \\
\text { Qualifier }^{(a)}\end{array}$ & $\begin{array}{c}\text { Dilution } \\
\text { Factor }\end{array}$ & $\begin{array}{c}\text { Reporting } \\
\text { Limit } \\
\end{array}$ & MDL \\
\hline Fluoride & B0XKB7 & $\begin{array}{l}\text { C3079/ } \\
\text { ENW-MW9 }\end{array}$ & $02 / 11 / 2000$ & 0.23 & $\mathrm{mg} / \mathrm{L}$ & & 1 & 0.1 & 0.01 \\
\hline Fluoride $^{(b)}$ & B0XKB8 & $\begin{array}{l}\text { C3079/ } \\
\text { ENW-MW9 } \\
\end{array}$ & $02 / 11 / 2000$ & 0.23 & $\mathrm{mg} / \mathrm{L}$ & & 1 & 0.1 & 0.01 \\
\hline Nitrate as N & B0XKB7 & $\begin{array}{l}\text { C3079/ } \\
\text { ENW-MW9 }\end{array}$ & $02 / 11 / 2000$ & 32.5 & $\mathrm{mg} / \mathrm{L}$ & & 50 & 1 & 0.53 \\
\hline Nitrate as $\mathrm{N}^{(b)}$ & B0XKB8 & $\begin{array}{l}\text { C3079/ } \\
\text { ENW-MW9 }\end{array}$ & $02 / 11 / 2000$ & 33.6 & $\mathrm{mg} / \mathrm{L}$ & & 50 & 1 & 0.53 \\
\hline Nitrite as N & B0XKB7 & $\begin{array}{l}\text { C3079/ } \\
\text { ENW-MW9 }\end{array}$ & $02 / 11 / 2000$ & ND & $\mathrm{mg} / \mathrm{L}$ & $\bar{U}$ & 1 & 0.02 & 0.0074 \\
\hline Nitrite as $\mathrm{N}^{(\mathrm{b})}$ & B0XKB8 & $\begin{array}{l}\text { C3079/ } \\
\text { ENW-MW9 }\end{array}$ & $02 / 11 / 2000$ & ND & $\mathrm{mg} / \mathrm{L}$ & $\bar{U}$ & 1 & 0.02 & 0.0074 \\
\hline Sulfate & B0XKB7 & $\begin{array}{l}\text { C3079/ } \\
\text { ENW-MW9 }\end{array}$ & $02 / 11 / 2000$ & 259 & $\mathrm{mg} / \mathrm{L}$ & & 20 & 10 & 2.2 \\
\hline Sulfate $^{(b)}$ & B0XKB8 & \begin{tabular}{|l|} 
C3079/ \\
ENW-MW9 \\
\end{tabular} & $02 / 11 / 2000$ & 251 & $\mathrm{mg} / \mathrm{L}$ & & 20 & 10 & 2.2 \\
\hline Total Alkalinity & B0XKB7 & $\begin{array}{l}\text { C3079/ } \\
\text { ENW-MW9 }\end{array}$ & $02 / 11 / 2000$ & 182 & $\mathrm{mg} / \mathrm{L}$ & & 1 & 5 & 2.2 \\
\hline Total Alkalinity ${ }^{(6)}$ & B0XKB8 & $\begin{array}{l}\text { C3079/ } \\
\text { ENW-MW9 }\end{array}$ & $02 / 11 / 2000$ & 202 & $\mathrm{mg} / \mathrm{L}$ & & 1 & 5 & 2.2 \\
\hline Chloride ${ }^{(c)}$ & \begin{tabular}{|l} 
B0XKB7 \\
DUP
\end{tabular} & $\begin{array}{l}\text { C3079/ENW- } \\
\text { MW9 DUP }\end{array}$ & $02 / 11 / 2000$ & 27.7 & $\mathrm{mg} / \mathrm{L}$ & $\mathrm{C}$ & 20 & 3.8 & 0.69 \\
\hline Fluoride $^{(c)}$ & $\begin{array}{l}\text { B0XKB7 } \\
\text { DUP }\end{array}$ & $\begin{array}{l}\text { C3079/ENW- } \\
\text { MW9 DUP }\end{array}$ & $02 / 11 / 2000$ & 0.23 & $\mathrm{mg} / \mathrm{L}$ & & 1 & 0.44 & 0.01 \\
\hline Nitrate as $\mathrm{N}^{(\mathrm{c})}$ & $\begin{array}{l}\text { B0XKB7 } \\
\text { DUP }\end{array}$ & $\begin{array}{l}\text { C3079/ENW- } \\
\text { MW9 DUP }\end{array}$ & $02 / 11 / 2000$ & 32.6 & $\mathrm{mg} / \mathrm{L}$ & . & 50 & 0.19 & 0.53 \\
\hline Nitrite as $\mathrm{N}^{(\mathrm{c})}$ & $\begin{array}{l}\text { B0XKB7 } \\
\text { DUP }\end{array}$ & $\begin{array}{l}\text { C3079/ENW- } \\
\text { MW9 DUP }\end{array}$ & $02 / 11 / 2000$ & ND & $\mathrm{mg} / \mathrm{L}$ & $\bar{U}$ & 1 & 0.02 & 0.0074 \\
\hline Sulfate $^{(\mathrm{c})}$ & \begin{tabular}{|l} 
B0XKB7 \\
DUP
\end{tabular} & $\begin{array}{l}\text { C3079/ENW- } \\
\text { MW9 DUP }\end{array}$ & $02 / 11 / 2000$ & 257 & $\mathrm{mg} / \mathrm{L}$ & & 20 & 0.47 & 2.2 \\
\hline Total Alkalinity ${ }^{(c)}$ & \begin{tabular}{|l} 
B0XKB7 \\
DUP
\end{tabular} & $\begin{array}{l}\text { C3079/ENW- } \\
\text { MW9 DUP }\end{array}$ & $02 / 11 / 2000$ & 180 & $\mathrm{mg} / \mathrm{L}$ & & 1 & 1.1 & 2.2 \\
\hline Chloride & B0XKB9 & ENW-31 & $02 / 08 / 2000$ & 4.4 & $\mathrm{mg} / \mathrm{L}$ & & 1 & 0.2 & 0.035 \\
\hline Fluoride & B0XKB9 & ENW-31 & $02 / 08 / 2000$ & 1.1 & $\mathrm{mg} / \mathrm{L}$ & & 1 & 0.1 & 0.01 \\
\hline Nitrate as $\mathrm{N}$ & B0XKB9 & ENW-31 & $02 / 08 / 2000$ & 0.033 & $\mathrm{mg} / \mathrm{L}$ & & 1 & 0.02 & 0.011 \\
\hline Nitrite as N & B0XKB9 & ENW-31 & $02 / 08 / 2000$ & ND & $\mathrm{mg} / \mathrm{L}$ & $\bar{U}$ & 1 & 0.02 & 0.0074 \\
\hline Sulfate & B0XKB9 & ENW-31 & $02 / 08 / 2000$ & 16.4 & $\mathrm{mg} / \mathrm{L}$ & & 1 & 0.5 & 0.11 \\
\hline Total Alkalinity & B0XKB9 & ENW-31 & $02 / 08 / 2000$ & 170 & $\mathrm{mg} / \mathrm{L}$ & & 1 & 5 & 2.2 \\
\hline Chloride & $\mathrm{BOXKCO}$ & ENW-32 & $02 / 08 / 2000$ & 3.9 & $\mathrm{mg} / \mathrm{L}$ & & 1 & 0.2 & 0.035 \\
\hline Fluoride & BOXKCO & ENW-32 & $02 / 08 / 2000$ & 0.7 & $\mathrm{mg} / \mathrm{L}$ & & 1 & 0.1 & 0.01 \\
\hline Nitrate as $\mathrm{N}$ & BOXKC0 & ENW-32 & $02 / 08 / 2000$ & 0.02 & $\mathrm{mg} / \mathrm{L}$ & & 1 & 0.02 & 0.011 \\
\hline Nitrite as $\mathrm{N}$ & BOXKCO & ENW-32 & $02 / 08 / 2000$ & ND & $\mathrm{mg} / \mathrm{L}$ & $\mathrm{U}$ & 1 & 0.02 & 0.0074 \\
\hline Sulfate & $\mathrm{BOXKCO}$ & ENW-32 & $02 / 08 / 2000$ & 15.5 & $\mathrm{mg} / \mathrm{L}$ & & 1 & 0.5 & 0.11 \\
\hline Total Alkalinity & $\mathrm{B} 0 \times \mathrm{XKCO}$ & ENW-32 & $02 / 08 / 2000$ & 164 & $\mathrm{mg} / \mathrm{L}$ & & 1 & 5. & 2.2 \\
\hline \multicolumn{10}{|c|}{ Quality Control Samples } \\
\hline Chloride $^{(\mathrm{d})}$ & B0XK45 & \begin{tabular}{|l|} 
EBL $121 /$ \\
$699-13-3 A$
\end{tabular} & $02 / 07 / 2000$ & $\mathrm{ND}$ & $\mathrm{mg} / \mathrm{L}$ & $\mathrm{U}$ & 1 & 0.2 & 0.035 \\
\hline
\end{tabular}


Table C.5. (contd)

\begin{tabular}{|c|c|c|c|c|c|c|c|c|c|}
\hline Constituent & $\begin{array}{l}\text { Sample } \\
\text { Number }\end{array}$ & Well Name & Sample Date & $\begin{array}{c}\text { Value } \\
\text { Reported }\end{array}$ & Units & $\begin{array}{c}\text { Lab } \\
\text { Qualifier }\end{array}$ & \begin{tabular}{|c|} 
Dilution \\
Factor
\end{tabular} & $\begin{array}{c}\text { Reporting } \\
\text { Limit }\end{array}$ & MDI \\
\hline Fluoride $^{(d)}$ & B0XK45 & $\begin{array}{l}\text { EBL 121/ } \\
699-13-3 A\end{array}$ & $02 / 07 / 2000$ & ND & $\mathrm{mg} / \mathrm{L}$ & $\mathrm{U}$ & 1 & 0.1 & 0.01 \\
\hline Nitrate as $\mathrm{N}^{(\mathrm{d})}$ & B0XK45 & $\begin{array}{l}\text { EBL 121/ } \\
699-13-3 \mathrm{~A}\end{array}$ & $02 / 07 / 2000$ & $\mathrm{ND}$ & $\mathrm{mg} / \mathrm{L}$ & $\mathrm{U}$ & 1 & 0.02 & .0 .01 \\
\hline Nitrite as $\mathrm{N}^{(\mathrm{d})}$ & B0XK45 & $\begin{array}{l}\text { EBL 121/ } \\
699-13-3 A\end{array}$ & $02 / 07 / 2000$ & ND & $\mathrm{mg} / \mathrm{L}$ & $\overline{\mathrm{U}}$ & 1 & 0.02 & 0.0074 \\
\hline Sulfate $^{(\mathrm{d})}$ & $\overline{\mathrm{B} 0 \mathrm{XK} 45}$ & $\begin{array}{l}\text { EBL 121/ } \\
699-13-3 \mathrm{~A}\end{array}$ & $02 / 07 / 2000$ & ND & $\mathrm{mg} / \mathrm{L}$ & $\bar{U}$ & 1 & 0.5 & $\overline{0.11}$ \\
\hline Total Alkalinity $^{(d)}$ & B0XK45 & $\begin{array}{l}\text { EBL 121/ } \\
699-13-3 \mathrm{~A}\end{array}$ & $02 / 07 / 2000$ & ND & $\mathrm{mg} / \mathrm{L}$ & $\mathrm{U}$ & 1 & 5 & 2.2 \\
\hline Chloride $^{(e)}$ & B0XK06 & $\begin{array}{l}\text { EBL 122/ } \\
699-13-3 \mathrm{~A}\end{array}$ & $02 / 07 / 2000$ & 0.11 & $\mathrm{mg} / \mathrm{L}$ & B & 1 & 0.2 & 0.035 \\
\hline Fluoride $^{(e)}$ & B0XK06 & \begin{tabular}{|l|} 
EBL 122/ \\
$699-13-3 A$ \\
\end{tabular} & $02 / 07 / 2000$ & ND & $\mathrm{mg} / \mathrm{L}$ & $\bar{U}$ & 1 & 0.1 & 0.01 \\
\hline Nitrate as $N^{(\ell)}$ & B0XK06 & $\begin{array}{l}\text { EBL 122/ } \\
699-13-3 \mathrm{~A}\end{array}$ & $02 / 07 / 2000$ & ND & $\mathrm{mg} / \mathrm{L}$ & $\bar{U}$ & 1 & 0.02 & 0.011 \\
\hline Nitrite as $\mathrm{N}^{(e)}$ & B0XK06 & $\begin{array}{l}\text { EBL 122/ } \\
699-13-3 A\end{array}$ & $02 / 07 / 2000$ & ND & $\mathrm{mg} / \mathrm{L}$ & $\mathrm{U}$ & 1 & 0.02 & 0.0074 \\
\hline Sulfate $^{(e)}$ & B0XK06 & $\begin{array}{l}\text { EBL 122/ } \\
699-13-3 A\end{array}$ & $02 / 07 / 2000$ & ND & $\mathrm{mg} / \mathrm{L}$ & $\overline{\mathrm{U}}$ & 1 & 0.5 & 0.11 \\
\hline Total Alkalinity ${ }^{(e)}$ & B0XK06 & $\begin{array}{l}\text { EBL 122/ } \\
699-13-3 A\end{array}$ & $02 / 07 / 2000$ & ND & $\mathrm{mg} / \mathrm{L}$ & $\mathrm{U}$ & 1 & 5 & 2.2 \\
\hline Chloride & B0XK34 & \begin{tabular}{|l}
$\mathrm{EBL} 123 /$ \\
$699-13-1 \mathrm{~B}$
\end{tabular} & $02 / 08 / 2000$ & ND & $\mathrm{mg} / \mathrm{L}$ & $\bar{U}$ & 1 & 0.2 & 0.35 \\
\hline Fluoride & B0XK34 & $\begin{array}{l}\text { EBL 123/ } \\
699-13-1 \mathrm{~B}\end{array}$ & $02 / 08 / 2000$ & ND & $\mathrm{mg} / \mathrm{L}$ & $\bar{U}$ & 1 & 0.1 & 0.01 \\
\hline Nitrate as N & B0XK34 & $\begin{array}{l}\text { EBL 123/ } \\
699-13-1 \mathrm{~B}\end{array}$ & $02 / 08 / 2000$ & ND & $\mathrm{mg} / \mathrm{L}$ & $\mathrm{U}$ & 1 & 0.02 & 0.011 \\
\hline Nitrite as $\mathrm{N}$ & B0XK34 & $\begin{array}{l}\text { EBL 123/ } \\
699-13-1 \mathrm{~B}\end{array}$ & $02 / 08 / 2000$ & ND & $\mathrm{mg} / \mathrm{L}$ & $\overline{\mathrm{U}}$ & 1 & 0.02 & 0.0074 \\
\hline Sulfate & $\mathrm{B} 0 \times \mathrm{XK} 34$ & $\begin{array}{l}\text { EBL 123/ } \\
699-13-1 B\end{array}$ & $02 / 08 / 2000$ & ND & $\mathrm{mg} / \mathrm{L}$ & $\bar{U}$ & 1 & 0.5 & 0.11 \\
\hline Total Alkalinity & B0XK34 & $\begin{array}{l}\text { EBL 123/ } \\
699-13-1 \mathrm{~B}\end{array}$ & $02 / 08 / 2000$ & 5 & $\mathrm{mg} / \mathrm{L}$ & $\overline{\mathrm{U}}$ & 1 & 5 & 2.2 \\
\hline Chloride & B0XJW3 & $\begin{array}{l}\text { EBL 124/C3075/ } \\
\text { ENW-MW5 }\end{array}$ & $02 / 09 / 2000$ & 0.12 & $\mathrm{mg} / \mathrm{L}$ & $\mathrm{B}$ & 1 & 0.2 & 0.035 \\
\hline Fluoride & B0XJW3 & $\begin{array}{l}\text { EBL 124/C3075/ } \\
\text { ENW-MW5 }\end{array}$ & $02 / 09 / 2000$ & ND & $\mathrm{mg} / \mathrm{L}$ & $\overline{\mathrm{U}}$ & 1 & 0.1 & 0.01 \\
\hline Nitrate as $\mathrm{N}$ & B0XJW3 & $\begin{array}{l}\text { EBL 124/C3075/ } \\
\text { ENW-MW5 }\end{array}$ & $02 / 09 / 2000$ & 0.02 & $\mathrm{mg} / \mathrm{L}$ & & 1 & 0.02 & 0.011 \\
\hline Nitrite as N & B0XJW3 & $\begin{array}{l}\text { EBL 124/C3075/ } \\
\text { ENW-MW5 }\end{array}$ & $02 / 09 / 2000$ & ND & $\mathrm{mg} / \mathrm{L}$ & $\bar{U}$ & 1 & 0.02 & $\overline{0.0074}$ \\
\hline Sulfate & B0XJW3 & $\begin{array}{l}\text { EBL 124/C3075/ } \\
\text { ENW-MW5 }\end{array}$ & $02 / 09 / 2000$ & ND & $\mathrm{mg} / \mathrm{L}$ & $\overline{\mathrm{U}}$ & 1 & 0.5 & 0.11 \\
\hline Total Alkalinity & B0XJW3 & $\begin{array}{l}\text { EBL 124/C3075/ } \\
\text { ENW-MW5 }\end{array}$ & $02 / 09 / 2000$ & 5 & $\mathrm{mg} / \mathrm{L}$ & $\bar{U}$ & 1 & 5 & 2.2 \\
\hline
\end{tabular}


Table C.5. (contd)

\begin{tabular}{|c|c|c|c|c|c|c|c|c|c|}
\hline Constituent & $\begin{array}{c}\text { Sample } \\
\text { Number }\end{array}$ & Well Name & Sample Date & \begin{tabular}{|c|} 
Value \\
Reported
\end{tabular} & Units & \begin{tabular}{|c|} 
Lab \\
Qualifier $^{(a)}$
\end{tabular} & $\begin{array}{c}\text { Dilution } \\
\text { Factor }\end{array}$ & $\begin{array}{c}\text { Reporting } \\
\text { Limit }\end{array}$ & MDL \\
\hline Chloride & B0XIV3 & \begin{tabular}{|l|} 
FTB 322/ \\
$699-13-3 \mathrm{~A}$
\end{tabular} & $02 / 07 / 2000$ & ND & $\mathrm{mg} / \mathrm{L}$ & $\mathrm{U}$ & 1 & 0.2 & 0.035 \\
\hline Fluoride & B0XJV3 & $\begin{array}{l}\text { FTB 322/ } \\
699-13-3 \text { A }\end{array}$ & $02 / 07 / 2000$ & ND & $\mathrm{mg} / \mathrm{L}$ & $\bar{U}$ & 1 & 0.1 & 0.01 \\
\hline Nitrate as $\mathrm{N}$ & B0XJV3 & $\begin{array}{l}\text { FTB 322/ } \\
699-13-3 \text { A }\end{array}$ & $02 / 07 / 2000$ & ND & $\mathrm{mg} / \mathrm{L}$ & $\mathrm{U}$ & 1 & 0.02 & 0.011 \\
\hline Nitrite as N & B0XJV3 & $\begin{array}{l}\text { FTB 322/ } \\
699-13-3 \text { A }\end{array}$ & $02 / 07 / 2000$ & ND & $\mathrm{mg} / \mathrm{L}$ & $\mathrm{U}$ & 1 & 0.02 & 0.0074 \\
\hline Sulfate & $\mathrm{B} 0 \mathrm{XJV3}$ & $\begin{array}{l}\text { FTB 322/ } \\
699-13-3 \text { A }\end{array}$ & $02 / 07 / 2000$ & ND & $\mathrm{mg} / \mathrm{L}$ & $\mathrm{U}$ & 1 & 0.5 & 0.11 \\
\hline Total Alkalinity & B0XJV3 & $\begin{array}{l}\text { FTB 322/ } \\
699-13-3 A\end{array}$ & $02 / 07 / 2000$ & 5 & $\mathrm{mg} / \mathrm{L}$ & $\mathrm{U}$ & 1 & 5 & 2.2 \\
\hline Chloride & $\mathrm{B} 0 \times \mathrm{XK} 26$ & $\begin{array}{l}\text { FTB 323/ } \\
699-21-6\end{array}$ & $02 / 07 / 2000$ & ND & $\mathrm{mg} / \mathrm{L}$ & $\overline{\mathrm{U}}$ & 1 & 0.2 & 0.035 \\
\hline Fluoride & $\mathrm{B} 0 \times \mathrm{XK26}$ & $\begin{array}{l}\text { FTB 323/ } \\
699-21.6\end{array}$ & $02 / 07 / 2000$ & ND & $\mathrm{mg} / \mathrm{L}$ & $\mathrm{U}$ & 1 & 0.1 & 0.01 \\
\hline Nitrate as $\mathrm{N}$ & B0XK26 & $\begin{array}{l}\text { FTB 3231 } \\
699-21-6\end{array}$ & $02 / 07 / 2000$ & 0.016 & $\mathrm{mg} / \mathrm{L}$ & $B$ & 1 & 0.02 & 0.011 \\
\hline Nitrite as N & B0XK26 & $\begin{array}{l}\text { FTB 323/ } \\
699-21-6\end{array}$ & $02 / 07 / 2000$ & ND & $\mathrm{mg} / \mathrm{L}$ & $\bar{U}$ & 1 & 0.02 & 0.0074 \\
\hline Sulfate & B0XK26 & $\begin{array}{l}\text { FTB 323/ } \\
699-21-6\end{array}$ & $02 / 07 / 2000$ & ND & $\mathrm{mg} / \mathrm{L}$ & $\overline{\mathrm{U}}$ & 1 & 0.5 & 0.11 \\
\hline Total Alkalinity & B0XK26 & $\begin{array}{l}\text { FTB 323/ } \\
699-21-6\end{array}$ & $02 / 07 / 2000$ & 5 & $\mathrm{mg} / \mathrm{L}$ & $\mathrm{U}$ & 1 & 5 & 2.2 \\
\hline \multicolumn{10}{|c|}{$\begin{array}{l}\text { (a) } \mathrm{ND} / \mathrm{U}=\text { Result is non-detect. } \\
\mathrm{B}=\text { Estimated value. Result less than the reporting limit. } \\
\mathrm{C}=\text { Blank contamination. } \\
\text { (b) Field duplicate. } \\
\text { EBL = Equipment blank; FTB = Full trip blank; MDL = Minin }\end{array}$} \\
\hline
\end{tabular}


Table C.6. Filtered Metal Results for 618-11 Burial Ground Investigation, February 2000 (detects only)

\begin{tabular}{|c|c|c|c|c|c|c|c|c|}
\hline Constituent & $\begin{array}{l}\text { Sample } \\
\text { Number }\end{array}$ & Well Name & Sample Date & $\begin{array}{c}\text { Value } \\
\text { Reported }\end{array}$ & Units & $\begin{array}{c}\text { Lab } \\
\text { Qualifier }^{(a)}\end{array}$ & $\begin{array}{c}\text { Reporting } \\
\text { Limit }\end{array}$ & MDL \\
\hline Barium & $\mathrm{B} 0 \mathrm{XJY} 8$ & 699-10-E12 & $02 / 08 / 2000$ & 58.6 & $\mathrm{ug} / \mathrm{L}$ & B & 200 & 6.7 \\
\hline Calcium & B0XJY8 & 699-10-E12 & $02 / 08 / 2000$ & 71,900 & $\mathrm{ug} / \mathrm{L}$ & & 5,000 & 103 \\
\hline Chromium & B0XJY8 & 699-10-E12 & $02 / 08 / 2000$ & 3.6 & $\mathrm{ug} / \mathrm{L}$ & B & 10 & 3 \\
\hline Iron & B0XJY8 & 699-10-E12 & $02 / 08 / 2000$ & 54.5 & $\mathrm{ug} / \mathrm{L}$ & $\mathrm{B}$ & 100 & 8.6 \\
\hline Magnesium & B0XJY8 & 699-10-E12 & $02 / 08 / 2000$ & 22,300 & $\mathrm{ug} / \mathrm{L}$ & & 5,000 & 99.2 \\
\hline Potassium & B0XJY8 & 699-10-E12 & $02 / 08 / 2000$ & 5,970 & $\mathrm{ug} / \mathrm{L}$ & & 5,000 & 1,700 \\
\hline Sodium & B0XJY8 & 699-10-E12 & $02 / 08 / 2000$ & 16,700 & $\mathrm{ug} / \mathrm{L}$ & & 5,000 & 102 \\
\hline Strontium & B0XJY8 & 699-10-E12 & $02 / 08 / 2000$ & 547 & $\mathrm{ug} / \mathrm{L}$ & & 50 & 3.1 \\
\hline Vanadium & B0XJY8 & 699-10-E12 & $02 / 08 / 2000$ & 12 & $\mathrm{ug} / \mathrm{L}$ & B & 50 & 2 \\
\hline Zinc & B0XJY8 & 699-10-E12 & $02 / 08 / 2000$ & 8.8 & $\mathrm{ug} / \mathrm{L}$ & B & 20 & 3 \\
\hline Barium & B0XNV6 & 699-12-4D & $02 / 07 / 2000$ & 48.5 & $\mathrm{ug} / \mathrm{L}$ & B & 200 & 6.7 \\
\hline Calcium & B0XJV6 & 699-12-4D & $02 / 07 / 2000$ & 47,000 & $\mathrm{ug} / \mathrm{L}$ & & 5,000 & 103 \\
\hline Chromium & B0XJV6 & $699-12-4 \mathrm{D}$ & $02 / 07 / 2000$ & 3.4 & $\mathrm{ug} / \mathrm{L}$ & B & 10 & 3 \\
\hline Iron & B0XJV6 & 699-12-4D & $02 / 07 / 2000$ & 45.6 & $\mathrm{ug} / \mathrm{L}$ & B & 100 & 8.6 \\
\hline Magnesium & B0XJV6 & 699-12-4D & $02 / 07 / 2000$ & 12,500 & $\mathrm{ug} / \mathrm{L}$ & & 5,000 & 99.2 \\
\hline Manganese & B0XJV6 & $699-12-4 \mathrm{D}$ & $02 / 07 / 2000$ & 2.5 & $\mathrm{ug} / \mathrm{L}$ & B & 15 & 1.1 \\
\hline Potassium & B0XJV6 & 699-12-4D & $02 / 07 / 2000$ & 7,290 & $\mathrm{ug} / \mathrm{L}$ & & 5,000 & 1,700 \\
\hline Sodium & B0XJV6 & 699-12-4D & $02 / 07 / 2000$ & 16,700 & $\mathrm{ug} / \mathrm{L}$ & & 5,000 & 102 \\
\hline Strontium & B0XJV6 & 699-12-4D & $02 / 07 / 2000$ & 266 & $\mathrm{ug} / \mathrm{L}$ & & 50 & 3.1 \\
\hline Vanadium & B0XJV6 & 699-12-4D & $02 / 07 / 2000$ & 9.4 & $\mathrm{ug} / \mathrm{L}$ & B & 50 & 2 \\
\hline Zinc & B0XJV6 & 699-12-4D & $02 / 07 / 2000$ & 10.2 & $\mathrm{ug} / \mathrm{L}$ & B & 20 & 3 \\
\hline Aluminum & B0X 5 55 & 699-13-1A & $02 / 08 / 2000$ & 1,060 & $\mathrm{ug} / \mathrm{L}$ & & 200 & 19.7 \\
\hline Barium & B0XJW5 & 699-13-1A & $02 / 08 / 2000$ & 28.3 & $\mathrm{ug} / \mathrm{L}$ & B & 200 & 6.7 \\
\hline Calcium & B0XJW5 & 699-13-1A & $02 / 08 / 2000$ & 26,800 & $\mathrm{ug} / \mathrm{L}$ & & 5,000 & 103 \\
\hline Iron & B0XJW5 & 699-13-1A & $02 / 08 / 2000$ & 204 & $\mathrm{ug} / \mathrm{L}$ & & 100 & 8.6 \\
\hline Magnesium & B0XJW5 & 699-13-1A & $02 / 08 / 2000$ & 10,200 & $\mathrm{ug} / \mathrm{L}$ & & 5,000 & 99.2 \\
\hline Manganese & B0XJW5 & 699-13-1A & $02 / 08 / 2000$ & 49.2 & $\mathrm{ug} / \mathrm{l}$ & & 15 & 1.1 \\
\hline Potassium & B0XJW5 & $699-13-1 \mathrm{~A}$ & $02 / 08 / 2000$ & 7,780 & $\mathrm{ug} / \mathrm{L}$ & & 5,000 & 1,700 \\
\hline Sodium & B0XJW5 & 699-13-1A & $02 / 08 / 2000$ & 22,200 & $\mathrm{ug} / \mathrm{L}$ & & 5,000 & 102 \\
\hline Strontium & B0XJW5 & 699-13-1A & $02 / 08 / 2000$ & 262 & $\mathrm{ug} / \mathrm{L}$ & & 50 & 3.1 \\
\hline Varadium & B0XJW5 & 699-13-1A & $02 / 08 / 2000$ & 7.7 & $\mathrm{ug} / \mathrm{L}$ & B & 50 & 2 \\
\hline Zinc & B0XJW5 & $699-13-1 \mathrm{~A}$ & $02 / 08 / 2000$ & 7.5 & $\mathrm{ug} / \mathrm{L}$ & B & 20 & 3 \\
\hline Barium & BOWJX4 & 699-13-1B & $02 / 08 / 2000$ & 36.9 & $\mathrm{ug} / \mathrm{L}$ & B & 200 & 6.7 \\
\hline Calcium & B0WJX4 & 699-13-1B & $02 / 08 / 2000$ & 23,600 & $u g / L$ & & 5,000 & 103 \\
\hline Iron & B0WJX4 & 699-13-1B & $02 / 08 / 2000$ & 84.9 & $\mathrm{ug} / \mathrm{L}$ & B & 100 & 8.6 \\
\hline Magnesium & B0WJX4 & 699-13-1B & $02 / 08 / 2000$ & 9,420 & $\mathrm{ug} / \mathrm{L}$ & & 5,000 & 99.2 \\
\hline Manganese & B0WJX4 & 699-13-1B & $02 / 08 / 2000$ & 94.2 & $\mathrm{ug} / \mathrm{L}$ & & 15 & 1.1 \\
\hline Potassium & B0WJX4 & 699-13-1B & $02 / 08 / 2000$ & 7,350 & $\mathrm{ug} / \mathrm{L}$ & & 5,000 & 1,700 \\
\hline Sodium & B0WJX4 & $699-13-1 B$ & $02 / 08 / 2000$ & 21,900 & $\mathrm{ug} / \mathrm{L}$ & & 5,000 & 102 \\
\hline Strontium & B0WJX4 & 699-13-1B & $02 / 08 / 2000$ & 224 & $\mathrm{ug} / \mathrm{L}$ & & 50 & 3.1 \\
\hline Zinc & B0WJX4 & 699-13-1B & $02 / 08 / 2000$ & 5.9 & ug/L & B & 20 & 3 \\
\hline Aluminum & B0WJX8 & $699-13-1 \mathrm{C}$ & $02 / 08 / 2000$ & 39.3 & $\mathrm{ug} / \mathrm{L}$ & B & 200 & 19.7 \\
\hline Barium & B0WJX8 & $699-13-1 \mathrm{C}$ & $02 / 08 / 2000$ & 26.2 & $u g / L$ & B & 200 & 6.7 \\
\hline Calcium & B0WJX8 & $699-13-1 \mathrm{C}$ & $02 / 08 / 2000$ & 11,700 & $u g / L$ & & 5,000 & 103 \\
\hline Iron & B0WJX8 & 699-13-1C & $02 / 08 / 2000$ & 172 & $\mathrm{ug} / \mathrm{L}$ & & 100 & 8.6 \\
\hline Magnesium & B0WJX8 & 699-13-1C & $02 / 08 / 2000$ & 2,760 & $\mathrm{ug} / \mathrm{L}$ & B & 5,000 & 99.2 \\
\hline Manganese & B0WJX8 & $699-13-1 \mathrm{C}$ & $02 / 08 / 2000$ & 19.6 & $\mathrm{ug} / \mathrm{L}$ & & 15 & 1.1 \\
\hline
\end{tabular}


Table C.6. (contd)

\begin{tabular}{|c|c|c|c|c|c|c|c|c|}
\hline Constituent & $\begin{array}{c}\text { Sample } \\
\text { Number }\end{array}$ & Well Name & Sample Date & $\begin{array}{c}\text { Value } \\
\text { Reported }\end{array}$ & Units & $\begin{array}{c}\text { Lab } \\
\text { Qualifier }^{(2)}\end{array}$ & $\begin{array}{c}\text { Reporting } \\
\text { Limit }\end{array}$ & MDL \\
\hline Potassium & B0WXX8 & $699-13-1 \mathrm{C}$ & $02 / 08 / 2000$ & 7,700 & $\mathrm{ug} / \mathrm{L}$ & & 5,000 & 1,700 \\
\hline Sodium & B0WJX8 & $699-13-1 \mathrm{C}$ & $02 / 08 / 2000$ & 53,300 & $\mathrm{ug} / \mathrm{L}$ & & 5,000 & 102 \\
\hline Strontium & B0WJX8 & 699-13-1C & $02 / 08 / 2000$ & 73.2 & $\mathrm{ug} / \mathrm{L}$ & & 50 & 3.1 \\
\hline Zinc & B0WJX8 & $699-13-1 C$ & $02 / 08 / 2000$ & 11.6 & $\mathrm{ug} / \mathrm{L}$ & B & 20 & 3 \\
\hline Aluminum & BOXJT2 & $699-13-3 \mathrm{~A}$ & $02 / 07 / 2000$ & 20.4 & $\mathrm{ug} / \mathrm{L}$ & $\mathrm{B}$ & 200 & 19.7 \\
\hline Barium & $\overline{\text { BOXJT2 }}$ & $699-13-3 A$ & $02 / 07 / 2000$ & 85.3 & $\mathrm{ug} / \mathrm{L}$ & B & 200 & 6.7 \\
\hline Barium $^{(\mathrm{b})}$ & BOXJV0 & $699-13-3 A$ & $02 / 07 / 2000$ & 83.8 & $\mathrm{ug} / \mathrm{L}$ & $B$ & 200 & 6.7 \\
\hline Calcium & BOXJT2 & $699-13-3 A$ & $02 / 07 / 2000$ & 76,600 & $\mathrm{ug} / \mathrm{L}$ & & 5,000 & 103 \\
\hline Calcium $^{(6)}$ & BOXJV0 & $699-13-3 \mathrm{~A}$ & $02 / 07 / 2000$ & 74,300 & $\mathrm{ug} / \mathrm{L}$ & & 5,000 & 103 \\
\hline Iron & BOXJT2 & $699-13-3 \mathrm{~A}$ & $02 / 07 / 2000$ & 87 & $\mathrm{ug} / \mathrm{L}$ & B & 100 & 8.6 \\
\hline Iron $^{(b)}$ & BOXJV0 & 699-13-3A & $02 / 07 / 2000$ & 89.6 & $\mathrm{ug} / \mathrm{L}$ & B & 100 & 8.6 \\
\hline Magnesium & BOXJT2 & $699-13-3 \mathrm{~A}$ & $02 / 07 / 2000$ & 18,300 & $\mathrm{ug} / \mathrm{L}$ & & 5,000 & 99.2 \\
\hline Magnesium ${ }^{(6)}$ & BOXJV0 & 699-13-3A & $02 / 07 / 2000$ & 17,700 & $\mathrm{ug} / \mathrm{L}$ & & 5,000 & 99.2 \\
\hline Manganese & BOXJT2 & $699-13-3 \mathrm{~A}$ & $02 / 07 / 2000$ & 5.6 & $\mathrm{ug} / \mathrm{L}$ & B & 15 & 1.1 \\
\hline Manganese ${ }^{(b)}$ & BOXJV0 & 699-13-3A & $02 / 07 / 2000$ & 5.5 & $\mathrm{ug} / \mathrm{L}$ & $\mathrm{B}$ & 15 & 1.1 \\
\hline Potassium & BOXJT2 & $699-13-3 \mathrm{~A}$ & $02 / 07 / 2000$ & 7,980 & $\mathrm{ug} / \mathrm{L}$ & & 5,000 & 1,700 \\
\hline Potassium $^{(b)}$ & BOXJV0 & 699-13-3A & $02 / 07 / 2000$ & 8,460 & $\mathrm{ug} / \mathrm{L}$ & & 5,000 & 1,700 \\
\hline Sodium & BOXJT2 & $699-13-3 A$ & $02 / 07 / 2000$ & 21,600 & $\mathrm{ug} / \mathrm{L}$ & & 5,000 & 102 \\
\hline Sodium $^{(b)}$ & BOXJV0 & $699-13-3 \mathrm{~A}$ & $02 / 07 / 2000$ & 20,700 & $\mathrm{ug} / \mathrm{L}$ & & 5,000 & 102 \\
\hline Strontium & BOXJT2 & $699-13-3 A$ & $02 / 07 / 2000$ & 389 & $\mathrm{ug} / \mathrm{L}$ & & 50 & 3.1 \\
\hline Strontium & BOXJV0 & 699-13-3A & $02 / 07 / 2000$ & 381 & $\mathrm{ug} / \mathrm{L}$ & & 50 & 3.1 \\
\hline Vanadium & BOXJT2 & $699-13-3 \mathrm{~A}$ & $02 / 07 / 2000$ & 13.5 & $\mathrm{ug} / \mathrm{L}$ & $\mathrm{B}$ & 50 & 2 \\
\hline Vanadium $^{(\text {(b) }}$ & BOXJV0 & 699-13-3A & $02 / 07 / 2000$ & 14.7 & $\mathrm{ug} / \mathrm{L}$ & B & 50 & 2 \\
\hline Zinc & BOXJT2 & 699-13-3A & $02 / 07 / 2000$ & 33 & $\mathrm{ug} / \mathrm{L}$ & & 20 & 3 \\
\hline Zinc $^{(b)}$ & BOXJV0 & $699-13-3 A$ & $02 / 07 / 2000$ & 21.7 & $\mathrm{ug} / \mathrm{L}$ & & 20 & 3 \\
\hline Barium & $\mathrm{B} 0 \mathrm{XK} 18$ & $699-15-15 B$ & $02 / 08 / 2000$ & 46.7 & $\mathrm{ug} / \mathrm{L}$ & $B$ & 200 & 6.7 \\
\hline Calcium & $\mathrm{B} 0 \mathrm{XK} 18$ & 699-15-15B & $02 / 08 / 2000$ & 52,400 & $\mathrm{ug} / \mathrm{L}$ & & 5,000 & 103 \\
\hline Chromium & B0XK18 & $699-15-15 B$ & $02 / 08 / 2000$ & 4.5 & $\operatorname{ug} / \mathrm{L}$ & B & 10 & 3 \\
\hline Iron & B0XK18 & $699-15-15 B$ & $02 / 08 / 2000$ & 37.2 & $\mathrm{ug} / \mathrm{L}$ & & 100 & 8.6 \\
\hline Magnesium & B0XK18 & 699-15-15B & $02 / 08 / 2000$ & 10,800 & $\mathrm{ug} / \mathrm{L}$ & & 5,000 & 99.2 \\
\hline Manganese & B0XK18 & 699-15-15B & $02 / 08 / 2000$ & 1.8 & $\mathrm{~B}$ & & 15 & 1.1 \\
\hline Potassium & B0XK18 & 699-15-15B & $02 / 08 / 2000$ & 8,550 & $\mathrm{ug} / \mathrm{L}$ & & 5,000 & 1,700 \\
\hline Sodium & B0XK18 & $699-15-15 B$ & $02 / 08 / 2000$ & 21,100 & $\operatorname{ug} / \mathrm{L}$ & & 5,000 & 102 \\
\hline Strontium & B0XK18 & 699-15-15B & $02 / 08 / 2000$ & 276 & $\mathrm{ug} / \mathrm{L}$ & & 50 & 3.1 \\
\hline Vanadium & B0XK18 & 699-15-15B & $02 / 08 / 2000$ & 13 & $\mathrm{ug} / \mathrm{L}$ & B & 50 & 2 \\
\hline Zinc & B0XK18 & 699-15-15B & $02 / 08 / 2000$ & 136 & $\mathrm{ug} / \mathrm{L}$ & & 20 & 3 \\
\hline Aluminum & $\mathrm{B} 0 \mathrm{XK13}$ & $699-17-5$ & $02 / 07 / 2000$ & $\overline{46.4}$ & $\mathrm{ug} / \mathrm{L}$ & $\mathrm{B}$ & 200 & 19.7 \\
\hline Barium & B0XK13 & $699-17-5$ & $02 / 07 / 2000$ & 65.4 & $u g / L$ & B & 200 & 6.7 \\
\hline Calcium & $\mathrm{B} 0 \mathrm{XK13}$ & $699-17-5$ & $02 / 07 / 2000$ & 52,300 & $\mathrm{ug} / \mathrm{L}$ & & 5,000 & 103 \\
\hline Chromium & B0XK13 & $699-17-5$ & $02 / 07 / 2000$ & 3.4 & $\mathrm{ug} / \mathrm{L}$ & B & 10 & 3 \\
\hline Iron & $\mathrm{B} 0 \mathrm{XK} 13$ & $699-17-5$ & $02 / 07 / 2000$ & 138 & $\mathrm{ug} / \mathrm{L}$ & & 100 & 8.6 \\
\hline Magnesium & B0XK13 & $699-17-5$ & $02 / 07 / 2000$ & 14,300 & ug/L & & 5,000 & 99.2 \\
\hline Manganese & $\mathrm{B} 0 \mathrm{XK} 13$ & $699-17-5$ & $02 / 07 / 2000$ & 37 & $\mathrm{ug} / \mathrm{L}$ & & 15 & 1.1 \\
\hline Potassium & $\mathrm{B} 0 \mathrm{XK} 13$ & $699-17-5$ & $02 / 07 / 2000$ & 7,160 & $\mathrm{ug} / \mathrm{L}$ & & 5,000 & 1,700 \\
\hline Sodium & $\mathrm{B} 0 \mathrm{XK} 13$ & $699-17-5$ & $02 / 07 / 2000$ & 13,000 & ug/L & & 5,000 & 102 \\
\hline Strontium & $\mathrm{B} 0 \times \mathrm{XK13}$ & $699-17-5$ & $02 / 07 / 2000$ & 318 & $\mathrm{ug} / \mathrm{L}$ & & 50 & 3.1 \\
\hline Zinc & B0XK13 & $699-17-5$ & $02 / 07 / 2000$ & 17.4 & $\mathrm{ug} / \mathrm{L}$ & B & 20 & 3 \\
\hline
\end{tabular}


Table C.6. (contd)

\begin{tabular}{|c|c|c|c|c|c|c|c|c|}
\hline Constituent & $\begin{array}{l}\text { Sample } \\
\text { Number }\end{array}$ & Well Name & Sample Date & $\begin{array}{c}\text { Value } \\
\text { Reported }\end{array}$ & Units & $\begin{array}{c}\text { Lab } \\
\text { Qualifier }^{(2)}\end{array}$ & $\begin{array}{c}\text { Reporting } \\
\text { Limit }\end{array}$ & MDL \\
\hline Barium & B0XK21 & $699-21-6$ & $02 / 07 / 2000$ & 59.2 & $\mathrm{ug} / \mathrm{L}$ & B & 200 & 6.7 \\
\hline Calcium & $\mathrm{B} 0 \times \mathrm{XK} 21$ & $699-21-6$ & $02 / 07 / 2000$ & 43,500 & $u g / L$ & & 5,000 & 103 \\
\hline Chromium & B0XK21 & $699-21-6$ & $02 / 07 / 2000$ & 3 & $\mathrm{ug} / \mathrm{L}$ & $\bar{B}$ & 10 & 3 \\
\hline Iron & $\mathrm{B} 0 \times \mathrm{XK} 21$ & $699-21-6$ & $02 / 07 / 2000$ & 378 & $\mathrm{ug} / \mathrm{L}$ & & 100 & 8.6 \\
\hline Magnesium & B0XK21 & $699-21-6$ & $02 / 07 / 2000$ & 9,860 & $\mathrm{ug} / \mathrm{L}$ & & 5,000 & 99.2 \\
\hline Manganese & B0XK21 & $699-21-6$ & $02 / 07 / 2000$ & 50.1 & $\mathrm{ug} / \mathrm{L}$ & & 15 & 1.1 \\
\hline Potassium & $\mathrm{B} 0 \times \mathrm{XK} 21$ & $699-21-6$ & $02 / 07 / 2000$ & 6,320 & $\mathrm{ug} / \mathrm{L}$ & & 5,000 & 1,700 \\
\hline Sodium & $\mathrm{B} 0 \times \mathrm{XK} 21$ & 699-21-6. & $02 / 07 / 2000$ & 8,580 & $\mathrm{ug} / \mathrm{L}$ & & 5,000 & 102 \\
\hline Strontium & $\mathrm{B} 0 \times \mathrm{XK} 21$ & $699-21-6$ & $02 / 07 / 2000$ & 242 & $\mathrm{ug} / \mathrm{L}$ & & 50 & 3.1 \\
\hline Vanadium & $\mathrm{B} 0 \times \mathrm{XK} 21$ & $699-21-6$ & $02 / 07 / 2000$ & 6.6 & $\mathrm{ug} / \mathrm{L}$ & B & 50 & 2 \\
\hline Zinc & $\mathrm{B} 0 \mathrm{XK} 21$ & $699-21-6$ & $02 / 07 / 2000$ & 8.6 & $\mathrm{ug} / \mathrm{L}$ & $\bar{B}$ & 20 & 3 \\
\hline Aluminum & B0XK10 & 699-8-17 & $02 / 08 / 2000$ & 29.1 & $\mathrm{ug} / \mathrm{L}$ & $\mathrm{B}$ & 200 & 19.7 \\
\hline Barium & B0XK10 & $699-8-17$ & $02 / 08 / 2000$ & 38.2 & $u g / L$ & B & 200 & 6.7 \\
\hline Calcium & B0XK10 & $699-8-17$ & $02 / 08 / 2000$ & 45,500 & $\mathrm{ug} / \mathrm{L}$ & & 5,000 & 103 \\
\hline Chromium & B0XK10 & $699-8-17$ & $02 / 08 / 2000$ & 5.9 & $\mathrm{ug} / \mathrm{L}$ & $\mathrm{B}$ & 10 & 3 \\
\hline Iron & $\mathrm{B} 0 \times \mathrm{XK10}$ & 699-8-17 & $02 / 08 / 2000$ & 37.4 & $\mathrm{ug} / \mathrm{L}$ & & 100 & 8.6 \\
\hline Magnesium & $\mathrm{B} 0 \times \mathrm{XK10}$ & $699-8-17$ & $02 / 08 / 2000$ & 12,300 & $\mathrm{ug} / \mathrm{L}$ & & 5,000 & 99.2 \\
\hline Manganese & $\overline{\mathrm{B} 0 \times K 10}$ & 699-8-17 & $02 / 08 / 2000$ & 2.5 & $\mathrm{ug} / \mathrm{L}$ & $\bar{B}$ & 15 & 1.1 \\
\hline Potassium & $\mathrm{B} 0 \times \mathrm{XK} 10$ & 699-8-17 & $02 / 08 / 2000$ & 8,200 & ug $/ \mathrm{L}$ & & 5,000 & 1,700 \\
\hline Sodium & $\mathrm{B} 0 \times \mathrm{XK10}$ & $699-8-17$ & $02 / 08 / 2000$ & 20,800 & $\operatorname{ug} / \mathrm{L}$ & & 5,000 & 102 \\
\hline Strontium & $\mathrm{B} 0 \times \mathrm{XK10}$ & 699-8-17 & $02 / 08 / 2000$ & 254 & $\mathrm{ug} / \mathrm{L}$ & & 50 & 3.1 \\
\hline Vanadium & B0XK10 & 699-8-17 & $02 / 08 / 2000$ & 10 & $\mathrm{ug} / \mathrm{L}$ & $\mathrm{B}$ & 50 & 2 \\
\hline Zinc & $\mathrm{B} 0 \mathrm{XK10}$ & $699-8-17$ & $02 / 08 / 2000$ & 116 & $\mathrm{ug} / \mathrm{L}$ & & 20 & 3 \\
\hline Barium & B0XJY2 & 699-9-E2 & $02 / 10 / 2000$ & 51.1 & $\mathrm{ug} / \mathrm{L}$ & $\mathrm{B}$ & 200 & 6.7 \\
\hline Calcium & B0XJY2 & 699-9-E2 & $02 / 10 / 2000$ & 40,500 & $\mathrm{ug} / \mathrm{L}$ & & 5,000 & 103 \\
\hline Iron & B0XJY2 & 699-9-E2 & $02 / 10 / 2000$ & 60.4 & $\mathrm{ug} / \mathrm{L}$ & $\bar{B}$ & 100 & 8.6 \\
\hline Magnesium & B0XJY2 & 699-9-E2 & $02 / 10 / 2000$ & 13,700 & $\mathrm{ug} / \mathrm{L}$ & & 5,000 & 99.2 \\
\hline Manganese & B0XJY2 & $699-9-E 2$ & $02 / 10 / 2000$ & 6.3 & $\mathrm{ug} / \mathrm{L}$ & $\mathrm{B}$ & 15 & 1.1 \\
\hline Potassium & B0XJY2 & 699-9-E2 & $02 / 10 / 2000$ & 7,310 & $\mathrm{ug} / \mathrm{L}$ & & 5,000 & 1,700 \\
\hline Sodium & B0XJY2 & $699-9-\mathrm{E} 2$ & $02 / 10 / 2000$ & 24,700 & $\mathrm{ug} / \mathrm{L}$ & & 5,000 & 102 \\
\hline Strontium & $\mathrm{B} 0 \mathrm{XJY2}$ & 699-9-E2 & $02 / 10 / 2000$ & 289 & $\mathrm{ug} / \mathrm{L}$ & & 50 & 3.1 \\
\hline Zinc & B0XJY2 & \begin{tabular}{|l|}
$699-9-E 2$ \\
\end{tabular} & $02 / 10 / 2000$ & 12.8 & ug $/ \mathcal{L}$ & $\bar{B}$ & 20 & 3 \\
\hline Barium & B0XK87 & $\begin{array}{l}\text { C3071/ } \\
\text { ENW-MW1 }\end{array}$ & $02 / 09 / 2000$ & 79.3 & $\mathrm{ug} / \mathbb{L}$ & $\bar{B}$ & 200 & 6.7 \\
\hline Calcium & $\overline{B 0 \times K 87}$ & $\begin{array}{l}\text { C3071/ } \\
\text { ENW-MW1 }\end{array}$ & $02 / 09 / 2000$ & 106,000 & $\operatorname{ug} / \mathrm{L}$ & & 5,000 & 103 \\
\hline Iron & B0XK87 & $\begin{array}{l}\text { C3071/ } \\
\text { ENW-MW1 }\end{array}$ & $02 / 09 / 2000$ & 122 & $\mathrm{ug} / \mathrm{L}$ & & 100 & 8.6 \\
\hline Magnesium & B0XK87 & $\begin{array}{l}\text { C3071/ } \\
\text { ENW-MW1 }\end{array}$ & $.02 / 09 / 2000$ & 24,400 & $\mathrm{ug} / \mathrm{h}$ & & 5,000 & 99.2 \\
\hline Potassium & B0XK87 & $\begin{array}{l}\text { C3071/ } \\
\text { ENW-MW1 }\end{array}$ & $02 / 09 / 2000$ & 9,770 & $\mathrm{ug} / \mathrm{L}$ & & 5,000 & 1,700 \\
\hline Sodium & B0XK87 & $\begin{array}{l}\text { C3071/ } \\
\text { ENW-MW1 }\end{array}$ & $02 / 09 / 2000$ & 23,700 & ug/h & & 5,000 & 102 \\
\hline Strontium & B0XK87 & $\begin{array}{l}\text { C3071/ } \\
\text { ENW-MW1 }\end{array}$ & $02 / 09 / 2000$ & 506 & ug/L & & 50 & 3.1 \\
\hline
\end{tabular}


Table C.6. (contd)

\begin{tabular}{|c|c|c|c|c|c|c|c|c|}
\hline Constituent & $\begin{array}{l}\text { Sample } \\
\text { Number }\end{array}$ & Well Name & Sample Date & $\begin{array}{c}\text { Value } \\
\text { Reported }\end{array}$ & Units & $\begin{array}{c}\text { Lab } \\
\text { Qualifier }^{(a)}\end{array}$ & $\begin{array}{c}\text { Reporting } \\
\text { Limit }\end{array}$ & MDL \\
\hline Vanadium & B0XK87 & $\begin{array}{l}\text { C3071/ } \\
\text { ENW-MW1 }\end{array}$ & $02 / 09 / 2000$ & 6 & $\overline{u g g / L}$ & $\mathrm{~B}$ & 50 & 2 \\
\hline Zinc & B0XK87 & $\begin{array}{l}\text { C3071/ } \\
\text { ENW-MW1 }\end{array}$ & $02 / 09 / 2000$ & 19.5 & $\mathrm{ug} / \mathrm{L}$ & $\bar{B}$ & 20 & 3 \\
\hline Barium & B0XK88 & $\begin{array}{l}\mathrm{C} 3072 / \\
\text { ENW-MW2 }\end{array}$ & $02 / 10 / 2000$ & 76.7 & ug/L & B & 200 & 6.7 \\
\hline Calcium & B0XK88 & $\begin{array}{l}\text { C3072/ } \\
\text { ENW-MW2 }\end{array}$ & $02 / 10 / 2000$ & 139,000 & $\mathrm{ug} / \mathrm{L}$ & & 5,000 & 103 \\
\hline Chromium & B0XK88 & $\begin{array}{l}\text { C3072/ } \\
\text { ENW-MW2 }\end{array}$ & $02 / 10 / 2000$ & 4.6 & $\mathrm{ug} / \mathrm{L}$ & B & 10 & 3 \\
\hline Iron & B0XK88 & $\begin{array}{l}\text { C3072/ } \\
\text { ENW-MW2 }\end{array}$ & $02 / 10 / 2000$ & 148 & $\mathrm{ug} / \mathrm{L}$ & & 100 & 8.6 \\
\hline Magnesium & B0XK88 & \begin{tabular}{|l|} 
C3072/ \\
ENW-MW2
\end{tabular} & $02 / 10 / 2000$ & 32,600 & $\mathrm{ug} / \mathrm{L}$ & & 5,000 & 99.2 \\
\hline Potassium & B0XK88 & $\begin{array}{l}\text { C3072/ } \\
\text { ENW-MW2 }\end{array}$ & $02 / 10 / 2000$ & 10,600 & ug/L & & 5,000 & 1,700 \\
\hline Sodium & $\mathrm{B0XK88}$ & $\begin{array}{l}\text { C3072/ } \\
\text { ENW-MW2 }\end{array}$ & $02 / 10 / 2000$ & 34,700 & $\mathrm{ug} / \mathrm{L}$ & & 5,000 & 102 \\
\hline Strontium & B0XK88 & $\begin{array}{l}\text { C3072/ } \\
\text { ENW-MW2 }\end{array}$ & $02 / 10 / 2000$ & 670 & $\mathrm{ug} / \mathrm{L}$ & & 50 & 3.1 \\
\hline Vanadium & B0XK88 & $\begin{array}{l}\text { C3072/ } \\
\text { ENW-MW2 }\end{array}$ & $02 / 10 / 2000$ & 5.8 & $\mathrm{ug} / \mathrm{L}$ & B & 50 & 2 \\
\hline Zinc & B0XK88 & $\begin{array}{l}\text { C3072/ } \\
\text { ENW-MW2 }\end{array}$ & $02 / 10 / 2000$ & 8.2 & $\mathrm{ug} / \mathrm{L}$ & $\mathrm{B}$ & 20 & 3 \\
\hline Aluminum & B0XK89 & $\begin{array}{l}\text { C3073 } \\
\text { ENW-MW3 }\end{array}$ & $02 / 10 / 2000$ & 33.5 & $\mathrm{ug} / \mathrm{L}$ & B & 200 & 19.7 \\
\hline Barium & B0XK89 & $\begin{array}{l}\text { C3073/ } \\
\text { ENW-MW3 }\end{array}$ & $02 / 10 / 2000$ & 75.8 & $\mathrm{ug} / \mathrm{L}$ & B & 200 & 6.7 \\
\hline Calcium & B0XK89 & $\begin{array}{l}\text { C3073/ } \\
\text { ENW-MW3 }\end{array}$ & $02 / 10 / 2000$ & 166,000 & $\mathrm{ug} / \mathrm{L}$ & & 5,000 & 103 \\
\hline Chromium & B0XK89 & $\begin{array}{l}\text { C3073/ } \\
\text { ENW-MW3 }\end{array}$ & $02 / 10 / 2000$ & 3.7 & $\mathrm{ug} / \mathrm{L}$ & B & 10 & 3 \\
\hline Iron & B0XK89 & $\begin{array}{l}\text { C3073/ } \\
\text { ENW-MW3 }\end{array}$ & $02 / 10 / 2000$ & 81.2 & $\mathrm{ug} / \mathrm{L}$ & $B$ & 100 & 8.6 \\
\hline Magnesium & B0XK89 & \begin{tabular}{|l|} 
C3073/ \\
ENW-MW3
\end{tabular} & $02 / 10 / 2000$ & 36,000 & $\mathrm{ug} / \mathrm{L}$ & & 5,000 & 99.2 \\
\hline Potassium & B0XK89 & $\begin{array}{l}\text { C3073/ } \\
\text { ENW-MW3 }\end{array}$ & $02 / 10 / 2000$ & 11,800 & $\mathrm{ug} / \mathrm{L}$ & & 5,000 & 1,700 \\
\hline Sodium & B0XK89 & $\begin{array}{l}\text { C3073/ } \\
\text { ENW-MW3 }\end{array}$ & $02 / 10 / 2000$ & 44,900 & $\overline{u g} / \mathrm{L}$ & & 5,000 & 102 \\
\hline Strontium & B0XK89 & $\begin{array}{l}\text { C3073/ } \\
\text { ENW-MW3 }\end{array}$ & $02 / 10 / 2000$ & 731 & $\overline{u g} / \mathrm{L}$ & & 50 & 3.1 \\
\hline Vanadium & B0XK89 & \begin{tabular}{|l|} 
C3073/ \\
ENW-MW3
\end{tabular} & $02 / 10 / 2000$ & 6.6 & $\operatorname{ug} / \mathrm{L}$ & $B$ & 50 & 2 \\
\hline Zinc & B0XK89 & $\begin{array}{l}\text { C3073/ } \\
\text { ENW-MW3 }\end{array}$ & $02 / 10 / 2000$ & 9.6 & $\mathrm{ug} / \mathrm{L}$ & B & 20 & 3 \\
\hline
\end{tabular}


Table C.6. (contd)

\begin{tabular}{|c|c|c|c|c|c|c|c|c|}
\hline Constituent & $\begin{array}{l}\text { Sample } \\
\text { Number }\end{array}$ & Well Name & Sample Date & $\begin{array}{c}\text { Value } \\
\text { Reported }\end{array}$ & Units & $\begin{array}{c}\text { Lab } \\
\text { Qualifier }^{(2)}\end{array}$ & $\begin{array}{c}\text { Reporting } \\
\text { Limit }\end{array}$ & MDL \\
\hline Aluminum & B0XK90 & $\begin{array}{l}\text { C3074! } \\
\text { ENW-MW4 }\end{array}$ & $02 / 10 / 2000$ & 27.8 & $\mathrm{ug} / \mathrm{L}$ & $\mathrm{B}$ & 200 & 19.7 \\
\hline Barium & B0XK90 & $\begin{array}{l}\text { C3074l } \\
\text { ENW-MW4 }\end{array}$ & $02 / 10 / 2000$ & 70.4 & $u g / L$ & & 200 & 6.7 \\
\hline Calcium & B0XK90 & $\begin{array}{l}\text { C3074/ } \\
\text { ENW-MW4 }\end{array}$ & $02 / 10 / 2000$ & 79,300 & $\mathrm{ug} / \mathrm{L}$ & & 5,000 & 103 \\
\hline Chromium & B0XK90 & $\begin{array}{l}\text { C3074/ } \\
\text { ENW-MW4 }\end{array}$ & $02 / 10 / 2000$ & 4.3 & $\mathrm{ug} / \mathrm{L}$ & B & 10 & 3 \\
\hline Iron & B0XK90 & $\begin{array}{l}\text { C3074l } \\
\text { ENW-MW4 }\end{array}$ & $02 / 10 / 2000$ & 121 & $\mathrm{ug} / \mathrm{L}$ & & 100 & 8.6 \\
\hline Magnesium & B0XK90 & $\begin{array}{l}\text { C3074! } \\
\text { ENW-MW4 }\end{array}$ & $02 / 10 / 2000$ & 18,000 & $\mathrm{ug} / \mathrm{L}$ & & 5,000 & 99.2 \\
\hline Potassium & B0XK90 & $\begin{array}{l}\text { C3074/ } \\
\text { ENW-MW4 }\end{array}$ & $02 / 10 / 2000$ & 7,560 & $\mathrm{ug} / \mathrm{L}$ & & 5,000 & 1,700 \\
\hline Sodium & B0XK90 & $\begin{array}{l}\text { C3074l } \\
\text { ENW-MW4 }\end{array}$ & $02 / 10 / 2000$ & 27,200 & $\mathrm{ug} / \mathrm{L}$ & & 5,000 & 102 \\
\hline Strontium & B0XK90 & $\begin{array}{l}\text { C3074/ } \\
\text { ENW-MW4 }\end{array}$ & $02 / 10 / 2000$ & 374 & $\overline{\mathrm{ug} / \mathrm{L}}$ & & 50 & 3.1 \\
\hline Vanadium & B0XK90 & $\begin{array}{l}\text { C3074l } \\
\text { ENW-MW4 }\end{array}$ & $02 / 10 / 2000$ & 7.4 & $\mathrm{ug} / \mathrm{L}$ & $\bar{B}$ & 50 & 2 \\
\hline Zinc & B0XK90 & $\begin{array}{l}\text { C3074! } \\
\text { ENW-MW4 }\end{array}$ & $02 / 10 / 2000$ & 14.1 & $\overline{u g} / \mathrm{L}$ & $\bar{B}$ & 20 & 3 \\
\hline Barium & B0XK91 & $\begin{array}{l}\text { C3075/ } \\
\text { ENW-MW5 }\end{array}$ & $02 / 09 / 2000$ & 48 & $\mathrm{ug} / \mathrm{L}$ & B & 200 & 6.7 \\
\hline Calcium & B0XK91 & $\begin{array}{l}\text { C3075/ } \\
\text { ENW-MW5 }\end{array}$ & $02 / 09 / 2000$ & 49,200 & $\mathrm{ug} / \mathrm{L}$ & & 5,000 & 103 \\
\hline Chromium & B0XK91 & $\begin{array}{l}\text { C3075! } \\
\text { ENW-MW5 }\end{array}$ & $02 / 09 / 2000$ & 4.3 & $\mathrm{ug} / \mathrm{L}$ & $\bar{B}$ & 10 & 3 \\
\hline Magnesium & B0XK91 & $\begin{array}{l}\text { C3075/ } \\
\text { ENW-MW5 }\end{array}$ & $02 / 09 / 2000$ & 13,000 & $\mathrm{ug} / \mathrm{L}$ & & 5,000 & 99.2 \\
\hline Potassium & B0XK91 & $\begin{array}{l}\text { C3075/ } \\
\text { ENW-MW5 }\end{array}$ & $02 / 09 / 2000$ & 7,580 & $\mathrm{ug} / \mathrm{L}$ & & 5,000 & 1,700 \\
\hline Sodium & B0XK91 & $\begin{array}{l}\text { C3075/ } \\
\text { ENW-MWS }\end{array}$ & $02 / 09 / 2000$ & 19,500 & $\overline{u g} / \mathrm{L}$ & & 5,000 & 102 \\
\hline Strontium & B0XK91 & $\begin{array}{l}\text { C3075/ } \\
\text { ENW-MW5 }\end{array}$ & $02 / 09 / 2000$ & 268 & $\mathrm{ug} / \mathrm{L}$ & & 50 & 3.1 \\
\hline Vanadium & B0XK91 & $\begin{array}{l}\text { C3075/ } \\
\text { ENW-MW5 }\end{array}$ & $02 / 09 / 2000$ & 9.3 & $\mathrm{ug} / \mathrm{L}$ & B & 50 & 2 \\
\hline Zinc & B0XK91 & $\begin{array}{l}\text { C3075/ } \\
\text { ENW-MW5 }\end{array}$ & $02 / 09 / 2000$ & 8.6 & $\mathrm{ug} / \mathrm{L}$ & B & 20 & 3 \\
\hline Barium & B0XK92 & $\begin{array}{l}\text { C3076/ } \\
\text { ENW-MW6 }\end{array}$ & $02 / 09 / 2000$ & 75.8 & $\mathrm{ug} / \mathrm{L}$ & $\bar{B}$ & 200 & 6.7 \\
\hline Calcium & B0XK92 & \begin{tabular}{|l|} 
C3076/ \\
ENW-MW6
\end{tabular} & $02 / 09 / 2000$ & 82,200 & $\mathrm{ug} / \mathrm{L}$ & & 5,000 & 103 \\
\hline Chromium & B0XK92 & $\begin{array}{l}\text { C3076/ } \\
\text { ENW-MW6 }\end{array}$ & $02 / 09 / 2000$ & 3 & $\mathrm{ug} / \mathrm{L}$ & $\bar{B}$ & 10 & 3 \\
\hline
\end{tabular}


Table C.6. (contd)

\begin{tabular}{|c|c|c|c|c|c|c|c|c|}
\hline Constituent & $\begin{array}{l}\text { Sample } \\
\text { Number }\end{array}$ & Well Name & Sample Date & $\begin{array}{c}\text { Value } \\
\text { Reported }\end{array}$ & Units & $\begin{array}{c}\text { Lab } \\
\text { Qualifier }^{(a)}\end{array}$ & $\begin{array}{c}\text { Reporting } \\
\text { Limit }\end{array}$ & MDL \\
\hline Iron & B0XK92 & $\begin{array}{l}\text { C3076/ } \\
\text { ENW-MW6 }\end{array}$ & $02 / 09 / 2000$ & 38.4 & $\overline{\mathrm{ugg} / \mathrm{L}}$ & $\mathrm{B}$ & 100 & 8.6 \\
\hline Magnesium & B0XK92 & $\begin{array}{l}\text { C3076/ } \\
\text { ENW-MW6 }\end{array}$ & $02 / 09 / 2000$ & 20,400 & $\mathrm{ug} / \mathrm{L}$ & & 5,000 & 99.2 \\
\hline Potassium & B0XK92 & $\begin{array}{l}\text { C3076/ } \\
\text { ENW-MW6 }\end{array}$ & $02 / 09 / 2000$ & 9,610 & $\mathrm{ug} / \mathrm{L}$ & & 5,000 & 1,700 \\
\hline Sodium & B0XK92 & $\begin{array}{l}\text { C3076l } \\
\text { ENW-MW6 }\end{array}$ & $02 / 09 / 2000$ & 26,300 & $\mathrm{ug} / \mathrm{L}$ & & 5,000 & 102 \\
\hline Strontium & B0XK92 & $\begin{array}{l}\text { C3076/ } \\
\text { ENW-MW6 }\end{array}$ & $02 / 09 / 2000$ & 462 & $\mathrm{ug} / \mathrm{L}$ & & 50 & 3.1 \\
\hline Zinc & B0XK92 & $\begin{array}{l}\text { C3076i } \\
\text { ENW-MW6 }\end{array}$ & $02 / 09 / 2000$ & 6.8 & $\mathrm{ug} / \mathrm{L}$ & B & 20 & 3 \\
\hline Barium & B0XK93 & $\begin{array}{l}\text { C3077/ } \\
\text { ENW-MW7 }\end{array}$ & $02 / 15 / 2000$ & 35.7 & $\mathrm{ug} / \mathrm{L}$ & B & 200 & 0.9 \\
\hline Calcium & B0XK93 & $\begin{array}{l}\text { C3077/ } \\
\text { ENW-MW7 }\end{array}$ & $02 / 15 / 2000$ & 38,100 & $\mathrm{ug} / \mathrm{L}$ & & 5,000 & 65.3 \\
\hline Iron & B0XK93 & $\begin{array}{l}\text { C3077/ } \\
\text { ENW-MW7 }\end{array}$ & $02 / 15 / 2000$ & 30.6 & $\mathrm{ug} / \mathrm{L}$ & B & 100 & 30.3 \\
\hline Magnesium & $\overline{\mathrm{B} 0 \mathrm{XK} 93}$ & $\begin{array}{l}\text { C3077/ } \\
\text { ENW-MW7 }\end{array}$ & $02 / 15 / 2000$ & 7,840 & $\mathrm{ug} / \mathrm{L}$ & & 5,000 & 101 \\
\hline Manganese & B0XK93 & $\begin{array}{l}\text { C3077/ } \\
\text { ENW-MW7 }\end{array}$ & $02 / 15 / 2000$ & 7.7 & $\mathrm{ug} / \mathrm{L}$ & B & 15 & 0.9 \\
\hline Potassium & B0XK93 & $\begin{array}{l}\text { C3077/ } \\
\text { ENW-MW7 }\end{array}$ & $02 / 15 / 2000$ & 5,510 & $\mathrm{ug} / \mathrm{L}$ & & 5,000 & 1,810 \\
\hline Sodium & B0XK93 & \begin{tabular}{|l} 
C3077/ \\
ENW-MW7
\end{tabular} & $02 / 15 / 2000$ & 9,140 & $\mathrm{ug} / \mathrm{L}$ & & 5,000 & 44.2 \\
\hline Strontium & B0XK93 & \begin{tabular}{|l|} 
C3077/ \\
ENW-MW7
\end{tabular} & $02 / 15 / 2000$ & 186 & $\mathrm{ug} / \mathrm{L}$ & & 50 & 0.4 \\
\hline Vanadium & B0XK93 & $\begin{array}{l}\text { C3077/ } \\
\text { ENW-MW7 }\end{array}$ & $02 / 15 / 2000$ & 6.9 & $\mathrm{ug} / \mathrm{L}$ & $\mathrm{B}$ & 50 & 4.7 \\
\hline Zinc & B0XK93 & \begin{tabular}{|l|} 
C3077/ \\
ENW-MW7
\end{tabular} & $02 / 15 / 2000$ & 18.5 & $\mathrm{ug} / \mathrm{L}$ & B & 20 & 4.2 \\
\hline Barium & B0XK94 & $\begin{array}{l}\text { C3078I } \\
\text { ENW-MW8 }\end{array}$ & $02 / 11 / 2000$ & 55.6 & $\mathrm{ug} / \mathrm{L}$ & $\bar{B}$ & 200 & 6.7 \\
\hline Calcium & B0XK94 & $\begin{array}{l}\text { C3078I } \\
\text { ENW-MW8 }\end{array}$ & $02 / 11 / 2000$ & 68,200 & $\mathrm{ug} / \mathrm{L}$ & & 5,000 & 103 \\
\hline Iron & B0XK94 & \begin{tabular}{|l|} 
C3078' \\
ENW-MW8
\end{tabular} & $02 / 11 / 2000$ & 175 & ug/L & & 100 & 8.6 \\
\hline Magnesium & B0XK94 & $\begin{array}{l}\text { C3078/ } \\
\text { ENW-MW8 }\end{array}$ & $02 / 11 / 2000$ & 15,700 & $\mathrm{ug} / \mathrm{L}$ & & 5,000 & 99.2 \\
\hline Manganese & B0XK94 & $\begin{array}{l}\text { C3078/ } \\
\text { ENW-MW8 }\end{array}$ & $02 / 11 / 2000$ & 1.3 & $\mathrm{ug} / \mathrm{L}$ & B & 15 & 1.1 \\
\hline Potassium & B0XK94 & $\begin{array}{l}\text { C3078/ } \\
\text { ENW-MW8 }\end{array}$ & $02 / 11 / 2000$ & 6,730 & $\mathrm{ug} / \mathrm{L}$ & & 5,000 & 1,700 \\
\hline Sodium & B0XK94 & \begin{tabular}{|l|} 
C3078/ \\
ENW-MW8
\end{tabular} & $02 / 11 / 2000$ & 25,300 & $\mathrm{ug} / \mathrm{L}$ & & 5,000 & 102 \\
\hline
\end{tabular}


Table C.6. (contd)

\begin{tabular}{|c|c|c|c|c|c|c|c|c|}
\hline Constituent & $\begin{array}{c}\text { Sample } \\
\text { Number }\end{array}$ & Well Name & Sample Date & $\begin{array}{c}\text { Value } \\
\text { Reported }\end{array}$ & Units & $\begin{array}{c}\text { Lab } \\
\text { Qualifier }^{(\mathrm{a})}\end{array}$ & $\begin{array}{c}\text { Reporting } \\
\text { Limit }\end{array}$ & MDL \\
\hline Strontium & B0XK94 & $\begin{array}{l}\text { C3078/ } \\
\text { ENW-MW8 }\end{array}$ & $02 / 11 / 2000$ & 329 & $\mathrm{ug} / \mathrm{L}$ & & 50 & 3.1 \\
\hline Vanadium & B0XK94 & \begin{tabular}{|l|} 
C3078/ \\
ENW-MW8
\end{tabular} & $02 / 11 / 2000$ & 9.3 & $\mathrm{ug} / \mathrm{L}$ & B & 50 & 2 \\
\hline Zinc & B0XK94 & $\begin{array}{l}\text { C3078/ } \\
\text { ENW-MW8 }\end{array}$ & $\begin{array}{c}02 / 11 / 2000 \\
.\end{array}$ & 37.9 & $\mathrm{ug} / \mathrm{L}$ & & 20 & 3 \\
\hline Barium & B0XK95 & $\begin{array}{l}\text { C3079/ } \\
\text { ENW-MW9 }\end{array}$ & $02 / 11 / 2000$ & 46.5 & $\mathrm{ug} / \mathrm{L}$ & B & 200 & 6.7 \\
\hline Barium $^{(6)}$ & B0XK96 & $\begin{array}{l}\text { C3079/ } \\
\text { ENW-MW9 }\end{array}$ & $02 / 11 / 2000$ & 49.2 & $\mathrm{ug} / \mathrm{L}$ & B & 200 & 6.7 \\
\hline Calcium & B0XK95 & \begin{tabular}{|l|} 
C3079/ \\
ENW-MW9
\end{tabular} & $02 / 11 / 2000$ & 146,000 & $\mathrm{ug} / \mathrm{L}$ & & 5,000 & 103 \\
\hline Calcium $^{(b)}$ & B0XK96 & $\begin{array}{l}\text { C3079/ } \\
\text { ENW-MW9 }\end{array}$ & $02 / 11 / 2000$ & 156,000 & $\mathrm{ug} / \mathrm{L}$ & & 5,000 & 103 \\
\hline Chromium $^{(\text {b) }}$ & B0XK96 & $\begin{array}{l}\text { C3079/ } \\
\text { ENW-MW9 }\end{array}$ & $02 / 11 / 2000$ & 3.4 & $\mathrm{ug} / \mathrm{L}$ & B & 10 & 3 \\
\hline Cobalt & B0XK95 & $\begin{array}{l}\text { C3079/ } \\
\text { ENW-MW9 }\end{array}$ & $02 / 11 / 2000$ & 3.1 & $\mathrm{ug} / \mathrm{h}$ & $B$ & 50 & 2.8 \\
\hline Cobalt $^{(b)}$ & B0XK96 & $\begin{array}{l}\text { C3079/ } \\
\text { ENW-MW9 }\end{array}$ & $02 / 11 / 2000$ & 3 & $\mathrm{ug} / \mathrm{L}$ & $\mathrm{B}$ & 50 & 2.8 \\
\hline Iron & $\overline{\mathrm{B} 0 \mathrm{XK} 95}$ & $\begin{array}{l}\text { C3079/ } \\
\text { ENW-MW9 }\end{array}$ & $02 / 11 / 2000$ & 71.7 & $\mathrm{ug} / \mathrm{L}$ & $\bar{B}$ & 100 & 8.6 \\
\hline Iron $^{(5)}$ & B0XK96 & $\begin{array}{l}\text { C3079/ } \\
\text { ENW-MW9 }\end{array}$ & $02 / 11 / 2000$ & 262 & $\overline{u g} / \mathrm{L}$ & & 100 & 8.6 \\
\hline Magnesium & B0XK95 & $\begin{array}{l}\text { C3079/ } \\
\text { ENW-MW9 }\end{array}$ & $02 / 11 / 2000$ & 35,300 & $\mathrm{ug} / \mathrm{L}$ & & 5,000 & 99.2 \\
\hline Magnesium $^{(b)}$ & B0XK96 & $\begin{array}{l}\text { C3079/ } \\
\text { ENW-MW9 }\end{array}$ & $02 / 11 / 2000$ & 37,700 & $\overline{\mathrm{ug} / \mathrm{L}}$ & & 5,000 & 99.2 \\
\hline Potassium & B0XK95 & $\begin{array}{l}\text { C3079/ } \\
\text { ENW-MW9 }\end{array}$ & $02 / 11 / 2000$ & 9,950 & $\mathrm{ug} / \mathrm{L}$ & & 5,000 & 1,700 \\
\hline Potassium $^{(6)}$ & B0XK96 & $\begin{array}{l}\text { C3079/ } \\
\text { ENW-MW9 }\end{array}$ & $02 / 11 / 2000$ & 10,400 & $\mathrm{ug} / \mathrm{L}$ & & 5,000 & 1,700 \\
\hline Sodium & B0XK95 & $\begin{array}{l}\text { C3079/ } \\
\text { ENW-MW9 }\end{array}$ & $02 / 11 / 2000$ & 53,300 & $\overline{\mathrm{ug} / \mathrm{L}}$ & & 5,000 & 102 \\
\hline Sodium $^{(b)}$ & B0XK96 & $\begin{array}{l}\text { C3079/ } \\
\text { ENW-MW9 }\end{array}$ & $02 / 11 / 2000$ & 56,700 & $\mathrm{ug} / \mathrm{L}$ & & 5,000 & 102 \\
\hline Strontium & B0XK95 & \begin{tabular}{|l|} 
C3079/ \\
ENW-MW9
\end{tabular} & $02 / 11 / 2000$ & 700 & $\mathrm{ug} / \mathrm{L}$ & & 50 & 3.1 \\
\hline Strontium ${ }^{(b)}$ & B0XK96 & $\begin{array}{l}\text { C3079/ } \\
\text { ENW-MW9 }\end{array}$ & $02 / 11 / 2000$ & 742 & $\mathrm{ug} / \mathrm{L}$ & & 50 & 3.1 \\
\hline Vanàdium & B0XK95 & $\begin{array}{l}\text { C3079/ } \\
\text { ENW-MW9 }\end{array}$ & $02 / 11 / 2000$ & 6 & ug/L & $\bar{B}$ & 50 & 2 \\
\hline Vanadium $^{(b)}$ & B0XK96 & \begin{tabular}{|l|} 
C3079/ \\
ENW-MW9
\end{tabular} & $02 / 11 / 2000$ & 6 & $\mathrm{ug} / \mathrm{L}$ & $\bar{B}$ & 50 & 2 \\
\hline Zinc & B0XK95 & $\begin{array}{l}\text { C3079/ } \\
\text { ENW-MW9 }\end{array}$ & $02 / 11 / 2000$ & 7.8 & $\mathrm{ug} / \mathrm{L}$ & B & 20 & 3 \\
\hline
\end{tabular}


Table C.6. (contd)

\begin{tabular}{|c|c|c|c|c|c|c|c|c|}
\hline Constituent & $\begin{array}{c}\text { Sample } \\
\text { Number }\end{array}$ & Well Name & Sample Date & $\begin{array}{c}\text { Value } \\
\text { Reported }\end{array}$ & Units & $\begin{array}{c}\text { Lab } \\
\text { Qualifier }^{(2)}\end{array}$ & $\begin{array}{c}\text { Reporting } \\
\text { Limit }\end{array}$ & MDL \\
\hline Zinc $^{(6)}$ & B0XK96 & $\begin{array}{l}\text { C3079/ } \\
\text { ENW-MW9 }\end{array}$ & $02 / 11 / 2000$ & 9.2 & $\overline{u g / L}$ & $\mathrm{~B}$ & 20 & 3 \\
\hline Barium & $\mathrm{B} 0 \mathrm{XK} 97$ & ENW-31 & $02 / 08 / 2000$ & 59.8 & $\mathrm{ug} / \mathrm{L}$ & $\mathrm{B}$ & 200 & 6.7 \\
\hline Calcium & $\overline{B 0 \times K 97}$ & ENW-31 & $02 / 08 / 2000$ & 20,800 & $\mathrm{ug} / \mathrm{L}$ & & 5,000 & 103 \\
\hline Iron & B0XK97 & ENW-31 & $02 / 08 / 2000$ & 42.4 & $\mathrm{ug} / \mathrm{L}$ & $\bar{B}$ & 100 & 8.6 \\
\hline Magnesium & B0XK97 & ENW-31 & $02 / 08 / 2000$ & 6,080 & $\mathrm{ug} / \mathrm{L}$ & & 5,000 & 99.2 \\
\hline Manganese & B0XK97 & ENW-31 & $02 / 08 / 2000$ & 13.4 & $\mathrm{ug} / \mathrm{L}$ & $B$ & 15 & 1.1 \\
\hline Potassium & B0XK97 & ENW-31 & $02 / 08 / 2000$ & 7,580 & $\mathrm{ug} / \mathrm{L}$ & & 5,000 & 1,700 \\
\hline Sodium & B0XK97 & ENW-31 & $02 / 08 / 2000$ & 49,500 & $u g / L$ & & 5,000 & 102 \\
\hline Strontium & B0XK97 & ENW-31 & $02 / 08 / 2000$ & 154 & $\mathrm{ug} / \mathrm{L}$ & & 50 & 3.1 \\
\hline Zinc & B0XK97 & ENW-31 & $02 / 08 / 2000$ & 9.2 & $\mathrm{ug} / \mathrm{L}$ & $B$ & 20 & 3 \\
\hline \begin{tabular}{|l|} 
Aluminum \\
\end{tabular} & B0XK98 & ENW-32 & $02 / 08 / 2000$ & 84.1 & $\mathrm{ug} / \mathrm{L}$ & $B$ & 200 & 19.7 \\
\hline Barium & B0XK98 & ENW-32 & $02 / 08 / 2000$ & 55.6 & $\mathrm{ug} / \mathrm{L}$ & $\bar{B}$ & 200 & 6.7 \\
\hline Calcium & B0XK98 & ENW-32 & $02 / 08 / 2000$ & 22,400 & $\mathrm{ug} / \mathrm{L}$ & & 5,000 & 103 \\
\hline Iron & B0XK98 & ENW-32 & $02 / 08 / 2000$ & 194 & $\mathrm{ug} / \mathrm{L}$ & & 100 & 8.6 \\
\hline Magnesium & B0XK98 & ENW-32 & $02 / 08 / 2000$ & 6,380 & $\mathrm{ug} / \mathrm{L}$ & & 5,000 & 99.2 \\
\hline Manganese & B0XK98 & ENW-32 & $02 / 08 / 2000$ & 29.5 & $\mathrm{ug} / \mathrm{L}$ & & 15 & 1.1 \\
\hline Potassium & B0XK98 & ENW-32 & $02 / 08 / 2000$ & 8,220 & ug/L & & 5,000 & 1,700 \\
\hline Sodium & B0XK98 & $\overline{E N W-32}$ & $02 / 08 / 2000$ & 43,600 & $\mathrm{ug} / \mathrm{L}$ & & 5,000 & 102 \\
\hline Strontium & B0XK98 & ENW-32 & $02 / 08 / 2000$ & 164 & $\mathrm{ug} / \mathrm{L}$ & & 50 & 3.1 \\
\hline Zinc & B0XK98 & ENW-32 & $02 / 08 / 2000$ & 9.5 & $\mathrm{ug} / \mathrm{L}$ & B & 20 & 3 \\
\hline \multicolumn{9}{|c|}{ Quality Control Samples } \\
\hline Aluminum $^{(c)}$ & $\overline{B 0 X J Y 5}$ & $\begin{array}{l}\text { EBL } 121 / \\
699-13-3 \mathrm{~A}\end{array}$ & $02 / 07 / 2000$ & 32.2 & $\mathrm{ug} / \mathrm{L}$ & B & 200 & 19.7 \\
\hline $\mathrm{CaIcium}^{(\mathrm{c})}$ & B0XJY5 & $\begin{array}{l}\text { EBL 121/ } \\
699-13-3 \mathrm{~A}\end{array}$ & $02 / 07 / 2000$ & 180 & ug/L & $\bar{B}$ & 5,000 & 103 \\
\hline Iron $^{\text {(c) }}$ & B0XJY5 & \begin{tabular}{|l|} 
EBL 121/ \\
$699-13-3 A$
\end{tabular} & $02 / 07 / 2000$ & 68.4 & $\operatorname{ug} / \mathrm{L}$ & B & 100 & 8.6 \\
\hline Sodium ${ }^{(\text {(c) }}$ & B0XJY5 & $\begin{array}{l}\text { EBL 121/ } \\
699-13-3 A\end{array}$ & $02 / 07 / 2000$ & 226 & ug $/ \mathrm{L}$ & B & 5,000 & 102 \\
\hline $\operatorname{Zinc}^{(c)}$ & B0XJY5 & $\begin{array}{l}\text { EBL 121/ } \\
699-13-3 A\end{array}$ & $02 / 07 / 2000$ & 21 & $\operatorname{ug} / \mathrm{L}$ & & 20 & 3 \\
\hline Aluminum $^{(\mathrm{d})}$ & B0XK44 & $\begin{array}{l}\text { EBL 122/ } \\
699-13-3 \mathrm{~A}\end{array}$ & $02 / 07 / 2000$ & 23.7 & $\operatorname{ug} / \mathrm{L}$ & B & 200 & 19.7 \\
\hline Calcium $^{(\mathrm{d})}$ & B0XK44 & $\begin{array}{l}\text { EBL 122/ } \\
699-13-3 A\end{array}$ & $02 / 07 / 2000$ & 217 & $\mathrm{ug} / \mathrm{L}$ & B & 5,000 & 103 \\
\hline Iron $^{\text {(d) }}$ & B0XK44 & \begin{tabular}{|l} 
EBL 122/ \\
$699-13-3 A$
\end{tabular} & $02 / 07 / 2000$. & 86.6 & $\mathrm{ug} / \mathrm{L}$ & B & 100 & 8.6 \\
\hline Sodium $^{(\mathrm{d})}$ & B0XK44 & $\begin{array}{l}\text { EBL 122/ } \\
699-13-3 A\end{array}$ & $02 / 07 / 2000$ & 207 & ugg/L & B & 5,000 & 102 \\
\hline $\operatorname{Zinc}^{(d)}$ & B0XK44 & $\begin{array}{l}\text { EBL 122/ } \\
699-13-3 \mathrm{~A}\end{array}$ & $02 / 07 / 2000$ & 26.1 & $\operatorname{ug} / \mathrm{L}$ & & 20 & 3 \\
\hline Calcium & B0XK33 & \begin{tabular}{|l|} 
EBL 123/ \\
$699-13-1 B$
\end{tabular} & $02 / 08 / 2000$ & 347 & $u g / L$ & $\bar{B}$ & 5,000 & 103 \\
\hline Sodium. & B0XK33 & \begin{tabular}{|l|} 
EBL 123/ \\
$699-13-1 \mathrm{~B}$
\end{tabular} & $02 / 08 / 2000$ & 401 & ug/L & B & 5,000 & 102 \\
\hline
\end{tabular}


Table C.6. (contd)

\begin{tabular}{|c|c|c|c|c|c|c|c|c|}
\hline Constituent & $\begin{array}{l}\text { Sample } \\
\text { Number }\end{array}$ & Well Name & Sample Date & $\begin{array}{c}\text { Value } \\
\text { Reported }\end{array}$ & Units & $\begin{array}{c}\text { Lab } \\
\text { Qualifier }^{(a)}\end{array}$ & $\begin{array}{c}\text { Reporting } \\
\text { Limit }\end{array}$ & MDL \\
\hline Zinc & $\mathrm{B} 0 \mathrm{XK} 33$ & $\begin{array}{l}\text { EBL 123/ } \\
699-13-1 B\end{array}$ & $02 / 08 / 2000$ & 6.7 & ug $/ \mathrm{L}$ & B & 20 & 3 \\
\hline Calcium & B0XJW2 & $\begin{array}{l}\text { EBL 124/ } \\
\text { ENW-MW5 }\end{array}$ & $02 / 09 / 2000$ & 354 & ug/L & B & 5,000 & 103 \\
\hline Sodium & B0XJW2 & $\begin{array}{l}\text { EBL 124 } \\
\text { /ENW-MW5 }\end{array}$ & $02 / 09 / 2000$ & 468 & $\mathrm{ug} / \mathrm{L}$ & B & 5,000 & 102 \\
\hline Zinc & BOXJW2 & $\begin{array}{l}\text { EBL 124/ } \\
\text { ENW-MW5 }\end{array}$ & $02 / 09 / 2000$ & 7.6 & $\mathrm{ug} / \mathrm{L}$ & B & 20 & 3 \\
\hline Calcium & B0XJV2 & $\begin{array}{l}\text { FTB 322/ } \\
699-13-3 \text { A }\end{array}$ & $02 / 07 / 2000$ & 174 & ug $/ \mathrm{L}$ & B & 5,000 & 103 \\
\hline Cobalt & B0XJV2 & $\begin{array}{l}\text { FTB 322/ } \\
699-13-3 \text { A }\end{array}$ & $02 / 07 / 2000$ & 4.3 & ug/L & $\mathrm{B}$ & 50 & 2.8 \\
\hline Iron & $\mathrm{B} 0 \mathrm{XJ} 2$ & $\begin{array}{l}\text { FTB 322 } \\
699-13-3 \text { A }\end{array}$ & $02 / 07 / 2000$ & 55.3 & ug $/ \mathrm{L}$ & $B$ & 100 & 8.6 \\
\hline Sodium & B0XJV2 & $\begin{array}{l}\text { FTB 322 } \\
699-13-3 \text { A }\end{array}$ & $02 / 07 / 2000$ & 219 & ug/L & $\bar{B}$ & 5,000 & 102 \\
\hline Zinc & B0XJV2 & $\begin{array}{l}\text { FTB 322/ } \\
699-13-3 \text { A }\end{array}$ & $02 / 07 / 2000$ & 17.6 & $\mathrm{ug} / \mathrm{L}$ & $\mathrm{B}$ & 20 & 3 \\
\hline \begin{tabular}{|l|} 
Aluminum \\
\end{tabular} & B0XK25 & $\begin{array}{l}\text { FTB 323! } \\
699-21-6\end{array}$ & $02 / 07 / 2000$ & 35.3 & $u g / L$ & $\bar{B}$ & 200 & 19.7 \\
\hline Calcium & B0XK25 & $\begin{array}{l}\text { FTB 323/ } \\
699-21-6\end{array}$ & $02 / 07 / 2000$ & 411 & ug/L & B & 5,000 & 103 \\
\hline Iron & B0XK25 & $\begin{array}{l}\text { FTB 323/ } \\
699-21-6\end{array}$ & $02 / 07 / 2000$ & 371 & ug $/ \mathrm{L}$ & & 100 & 8.6 \\
\hline Sodium & B0XK25 & $\begin{array}{l}\text { FTB 323/ } \\
699-21-6\end{array}$ & $02 / 07 / 2000$ & 462 & $u g / L$ & $\mathrm{~B}$ & 5,000 & 102 \\
\hline Zinc & B0XK25 & $\begin{array}{l}\text { FTB 3231 } \\
699-21-6\end{array}$ & $02 / 07 / 2000$ & 8.7 & ug $/ \mathrm{L}$ & $B$ & 20 & 3 \\
\hline $\begin{array}{ll}\text { (a) } & \text { B=E } \\
\text { (b) } & \text { Field } \\
\text { (c) } & \text { Befor } \\
\text { (d) After } \\
\text { Note: Sample } \\
\text { EBL } & =\text { Equipr }\end{array}$ & $\begin{array}{l}\text { stimated res } \\
\text { fuplicate. } \\
\text { sample. } \\
\text { sample. } \\
\text { s reported a }\end{array}$ & Value is less & Ian reporting li & nit. & 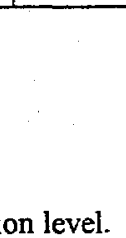 & & & \\
\hline
\end{tabular}


Table C.7. Organic Results for 618-11 Burial Ground Investigation, February 2000

\begin{tabular}{|c|c|c|c|c|c|c|c|c|}
\hline Constituent & $\begin{array}{l}\text { Sample } \\
\text { Number }\end{array}$ & Well Name & $\begin{array}{c}\text { Sample } \\
\text { Date }\end{array}$ & $\begin{array}{c}\text { Value } \\
\text { Reported }\end{array}$ & Units & $\begin{array}{c}\text { Lab } \\
\text { Qualifier }^{(a)}\end{array}$ & $\begin{array}{l}\text { Reporting } \\
\text { Limit }\end{array}$ & $\mathbf{M D L}$ \\
\hline Methylene Chloride & BOXJT3 & $699-13-3 A$ & $02 / 07 / 2000$ & 3.4 & $\mathrm{ug} / \mathrm{L}$ & $\mathrm{B}$ & 1 & 0.37 \\
\hline Carbon Tetrachloride & BOXJT3 & $699-13-3 A$ & $02 / 07 / 2000$ & 0.24 & ug/L & $\mathbf{J}$ & 1 & 0.23 \\
\hline Trichloroethene & BOXJT3 & $699-13-3 A$ & $02 / 07 / 2000$ & 0.32 & ug/L & $\mathbf{J}$ & 1 & 0.16 \\
\hline bis(2-Ethylhexyl) phthalate & BOXJT3 & $699-13-3 \mathrm{~A}$ & $02 / 07 / 2000$ & 1.4 & ug/L & $\mathrm{J}$ & 10 & 1.3 \\
\hline Methylene Chloride & BOXJVI & $699-13-3 \mathrm{~A}$ & $02 / 07 / 2000$ & 3 & $\mathrm{ug} / \mathrm{L}$ & B & 1 & 0.37 \\
\hline Carbon Tetrachloride & BOXJVI & 699-13-3A & $02 / 07 / 2000$ & 0.24 & $\mathrm{ug} / \mathrm{L}$ & $\mathbf{J}$ & 1 & 0.23 \\
\hline Chlorobenzene & B0XJV7 & 699-12-4D & $02 / 07 / 2000$ & 0.41 & $\mathrm{ug} / \mathrm{L}$ & $\mathrm{J}$ & 1 & 0.28 \\
\hline Methylene Chloride & B0XJW6 & $699-13-1 \mathrm{~A}$ & $02 / 08 / 2000$ & 0.68 & $\mathrm{ug} / \mathrm{L}$ & $\mathrm{J}$ & 1 & 0.37 \\
\hline \multicolumn{9}{|c|}{ Quality Control Samples } \\
\hline Methylene Chloride & $\mathrm{B} 0 \times \mathrm{K} 50$ & $\begin{array}{l}\text { FXR 520/ } \\
699-13-3 \mathrm{~A} \\
\end{array}$ & $02 / 07 / 2000$ & 0.51 & $\mathrm{ug} / \mathrm{L}$ & $\mathrm{J}$ & 1 & 0.37 \\
\hline Chloroform & $\mathrm{B} 0 \times \mathrm{XK50}$ & $\begin{array}{l}\text { FXR 520/ } \\
699-13-3 \mathrm{~A}\end{array}$ & $02 / 07 / 2000$ & 0.59 & $\mathrm{ug} / \mathrm{L}$ & $\bar{J}$ & 1 & 0.23 \\
\hline Chloroform & B0XJV3 & $\begin{array}{l}\text { FTB 322/ } \\
699-13-3 A \\
\end{array}$ & $02 / 07 / 2000$ & 0.54 & $u g / L$ & $\mathrm{~J}$ & 1 & 0.23 \\
\hline Chloroform ${ }^{(b)}$ & $\mathrm{B} 0 \mathrm{XK} 45$ & $\begin{array}{l}\text { EBL 121/ } \\
699-13-3 A\end{array}$ & $02 / 07 / 2000$ & 17 & $u g / L$ & & 1 & 0.23 \\
\hline Bromodichloromethane $^{(b)}$ & B0XK45 & $\begin{array}{l}\text { EBL 121/ } \\
699-13-3 \mathrm{~A}\end{array}$ & $02 / 07 / 2000$ & 0.43 & $\mathrm{ug} / \mathrm{L}$ & $\mathrm{J}$ & 1 & 0.2 \\
\hline Chloroform ${ }^{(c)}$ & B0XK06 & $\begin{array}{l}\text { EBL 122/ } \\
699-13-3 A\end{array}$ & $02 / 07 / 2000$ & 11 & $\mathrm{ug} / \mathrm{L}$ & & 1 & 0.23 \\
\hline Trichloroethene $\mathrm{e}^{(c)}$ & B0XK06 & $\begin{array}{l}\text { EBL 122/ } \\
699-13-3 \mathrm{~A}\end{array}$ & $02 / 07 / 2000$ & 0.21 & $\mathrm{ug} / \mathrm{L}$ & $\mathbf{J}$ & 1 & 0.16 \\
\hline Bromodichloromethane $^{(\mathcal{c})}$ & B0XK06 & $\begin{array}{l}\text { EBL 122/ } \\
699-13-3 A \\
\end{array}$ & $02 / 07 / 2000$ & 0.33 & $u g / L$ & $\mathbf{J}$ & 1 & 0.2 \\
\hline $\begin{array}{l}\text { bis(2-Ethylhexyl) } \\
\text { phthalate } \text { (c) }^{\text {(c) }}\end{array}$ & B0XK06 & $\begin{array}{l}\text { EBL 122/ } \\
699-13-3 \mathrm{~A} \\
\end{array}$ & $02 / 07 / 2000$ & 2.3 & $\mathrm{ug} / \mathrm{L}$ & JB & 10 & 1.3 \\
\hline Methylene Chloride & B0XK51 & \begin{tabular}{|l|} 
FXR 521/ \\
$699-13-1 A$ \\
\end{tabular} & $02 / 08 / 2000$ & 0.82 & $\mathrm{ug} / \mathrm{L}$ & $\bar{J}$ & 1 & 0.37 \\
\hline Chloroform & B0XK51 & $\begin{array}{l}\text { FXR 521/ } \\
699-13-1 A\end{array}$ & $02 / 08 / 2000$ & 0.57 & $u g / L$ & $\mathrm{~J}$ & 1 & 0.23 \\
\hline Chloroform & B0XK34 & $\begin{array}{l}\text { EBL 123/ } \\
699-13-1 B\end{array}$ & $02 / 08 / 2000$ & 10 & $u g / L$ & & 1 & 0.23 \\
\hline Methylene Chloride & B0XJW3 & \begin{tabular}{|l} 
EBL 124/C3075/ \\
ENW-MW5 \\
\end{tabular} & $02 / 09 / 2000$ & 0.72 & $\mathrm{ug} / \mathrm{L}$ & $\mathrm{J}$ & 1 & 0.37 \\
\hline Bromodichloromethane & B0XJW3 & $\begin{array}{l}\text { EBL 124/C3075/ } \\
\text { ENW-MW5 }\end{array}$ & $02 / 09 / 2000$ & 0.51 & $u g / L$ & $\mathrm{~J}$ & 1 & 0.2 \\
\hline Chloroform & B0XJW3 & $\begin{array}{l}\text { EBL 124/C3075/ } \\
\text { ENW-MW5 }\end{array}$ & $02 / 09 / 2000$ & 23 & $\mathrm{ug} / \mathrm{L}$ & & 1 & 0.23 \\
\hline bis(2-Ethylhexyl) phthalate & B0XJW3 & $\begin{array}{l}\text { EBL 124/C3075/ } \\
\text { ENW-MW5 }\end{array}$ & $02 / 09 / 2000$ & 1.7 & $u g / L$ & $\mathrm{JB}$ & 10 & 1.3 \\
\hline Methylene Chloride & $\mathrm{B} 0 \mathrm{XK52}$ & $\begin{array}{l}\text { FXR 522/C3076/ } \\
\text { ENW-MW6 }\end{array}$ & $02 / 09 / 2000$ & 0.98 & $\mathrm{ug} / \mathrm{L}$ & JB & 1 & 0.37 \\
\hline Chloroform & $\mathrm{B} 0 \times \mathrm{XK52}$ & $\begin{array}{l}\text { FXR 522/C3076/ } \\
\text { ENW-MW6 }\end{array}$ & $02 / 09 / 2000$ & 0.55 & $\mathrm{ug} / \mathrm{L}$ & $\mathbf{J}$ & 1 & 0.23 \\
\hline \multicolumn{9}{|c|}{$\begin{array}{l}\text { (a) } \mathrm{B}=\text { Method blank contamination. The associated method blank contains the t } \\
\mathrm{J}=\text { Estimated result. Result is less than reporting limit. } \\
\text { (b) Before sampling. } \\
\text { (c) After sampling. } \\
\text { Note: Samples reported as non-detect are omitted. } \\
\text { EBL = Equipment blank; FTB = Full trip blank; MDL = Minimum detection level. }\end{array}$} \\
\hline
\end{tabular}


Table C.8. Field Parameter Results for 618-11 Burial Investigation, February 2000

\begin{tabular}{|c|c|c|c|c|c|}
\hline Constituent & $\begin{array}{c}\text { Sample } \\
\text { Number }\end{array}$ & Well Name & Sample Date & $\begin{array}{c}\text { Value } \\
\text { Reported }\end{array}$ & Units \\
\hline Conductivity & B0XJY9 & 699-10-E12 & $02 / 08 / 2000$ & 609 & $\mathrm{uS} / \mathrm{cm}$ \\
\hline pH Measurement & B0XJY9 & 699-10-E12 & $02 / 08 / 2000$ & 7.4 & $\mathrm{pH}$ \\
\hline Temperature & B0XJY9 & 699-10-E12 & $02 / 08 / 2000$ & 17.6 & Deg C \\
\hline Turbidity & B0XJY9 & 699-10-E12 & $02 / 08 / 2000$ & 4.61 & NTU \\
\hline Conductivity & B0XJV7 & $699-12-4 \mathrm{D}$ & $02 / 07 / 2000$ & 413 & $\mathrm{uS} / \mathrm{cm}$ \\
\hline pH Measurement & B0XNV7 & $699-12-4 D$ & $02 / 07 / 2000$ & 7.94 & $\mathrm{pH}$ \\
\hline Temperature & B0XJV7 & $699-12-4 \mathrm{D}$ & $02 / 07 / 2000$ & 17.1 & Deg C \\
\hline Turbidity & B0XJV7 & 699-12-4D & $02 / 07 / 2000$ & 10.6 & NTU \\
\hline Conductivity & B0XJW6 & $699-13-1 \mathrm{~A}$ & $02 / 08 / 2000$ & 307 & $\mathrm{uS} / \mathrm{cm}$ \\
\hline pH Measurement & B0XJW6 & 699-13-1A & $02 / 08 / 2000$ & 8.09 & $\mathrm{pH}$ \\
\hline Temperature & B0XJW6 & 699-13-1A & $02 / 08 / 2000$ & 17.4 & Deg C \\
\hline Turbidity & B0XJW6. & 699-13-1A & $02 / 08 / 2000$ & 1.85 & NTU \\
\hline Conductivity & B0XJX5 & $699-13-1 B$ & $02 / 08 / 2000$ & 289 & $\mathrm{uS} / \mathrm{cm}$ \\
\hline pH Measurement & B0XJX5 & 699-13-1B & $02 / 08 / 2000$ & 8.23 & $\mathrm{pH}$ \\
\hline Temperature & B0XJX5 & $699-13-1 B$ & $02 / 08 / 2000$ & 17.1 & Deg C \\
\hline Turbidity & B0XJX5 & 699-13-1B & $02 / 08 / 2000$ & 12.2 & NTU \\
\hline Conductivity & B0XJX9 & 699-13-1C & $02 / 08 / 2000$ & 330 & $\mathrm{uS} / \mathrm{cm}$ \\
\hline pH Measurement & $\mathrm{B} 0 \times \mathrm{XJX} 9$ & $699-13-1 C$ & $02 / 08 / 2000$ & 8.44 & $\mathrm{pH}$ \\
\hline Temperature & $\mathrm{B} 0 \mathrm{XJX} 9$ & $699-13-1 C$ & $02 / 08 / 2000$ & 20.8 & Deg C \\
\hline Turbidity & B0XJX9 & $699-13-1 C$ & $02 / 08 / 2000$ & 30.3 & NTU \\
\hline Conductivity & B0XJT3 & $699-13-3 \mathrm{~A}$ & $02 / 07 / 2000$ & 624 & $\mathrm{uS} / \mathrm{cm}$ \\
\hline pH Measurement & B0XJT3 & 699-13-3A & $02 / 07 / 2000$ & 7.7 & pH \\
\hline Temperature & B0XJT3 & $699-13-3 A$ & $02 / 07 / 2000$ & 17.1 & Deg C \\
\hline Turbidity & $\mathrm{B} 0 \mathrm{XJT} 3$ & $699-13-3 \mathrm{~A}$ & $02 / 07 / 2000$ & 5.19 & NTU \\
\hline Conductivity & B0XK19 & $699-15-15 B$ & $02 / 08 / 2000$ & 481 & $\mathrm{uS} / \mathrm{cm}$ \\
\hline pH Measurement & B0XK19 & $699-15-15 B$ & $02 / 08 / 2000$ & 7.98 & $\mathrm{pH}$ \\
\hline Temperature & B0XK19 & $699-15-15 B$ & $02 / 08 / 2000$ & 18.9 & Deg C \\
\hline Turbidity & B0XK19 & 699-15-1SB & $02 / 08 / 2000$ & 3.44 & NTU \\
\hline Conductivity & B0XK14 & $699-17-5$ & $02 / 07 / 2000$ & 425 & $\mathrm{uS} / \mathrm{cm}$ \\
\hline $\mathrm{pH}$ Measurement & B0XK14 & $699-17-5$ & $02 / 07 / 2000$ & 8.61 & $\mathrm{pH}$ \\
\hline Temperature & B0XK14 & $699-17-5$ & $02 / 07 / 2000$ & 17.8 & Deg C \\
\hline Turbidity & B0XK14 & $699-17-5$ & $02 / 07 / 2000$ & 10.6 & NTU \\
\hline Conductivity & B0XK22 & $699-21-6$ & $02 / 07 / 2000$ & 334 & $\mathrm{uS} / \mathrm{cm}$ \\
\hline pH Measurement & $\mathrm{B} 0 \times \mathrm{KK} 22$ & $699-21-6$ & $02 / 07 / 2000$ & 8 & $\mathrm{pH}$ \\
\hline Temperature & $\mathrm{B} 0 \times \mathrm{K} 22$ & $699-21-6$ & $02 / 07 / 2000$ & 17.1 & Deg C \\
\hline Turbidity & $\mathrm{B} 0 \times \mathrm{K} 22$ & 699-21-6 & $02 / 07 / 2000$ & 3.4 & NTU \\
\hline Conductivity & B0XK11 & $699-8-17$ & $02 / 08 / 2000$ & 426 & $\mathrm{uS} / \mathrm{cm}$ \\
\hline pH Measurement & B0XK11 & $699-8-17$ & $02 / 08 / 2000$ & 8.19 & $\mathrm{pH}$ \\
\hline Temperature & B0XK11 & 699-8-17 & $02 / 08 / 2000$ & 18.1 & Deg C \\
\hline Turbidity & B0XK11 & $699-8-17$ & $02 / 08 / 2000$ & 1.47 & NTU \\
\hline Conductivity & B0XJY3 & 699-9-E2 & $02 / 10 / 2000$ & 380 & $\mathrm{uS} / \mathrm{cm}$ \\
\hline Dissolved Oxygen & B0XJY3 & 699-9-E2 & $02 / 10 / 2000$ & 0.99 & $\mathrm{mg} / \mathrm{L}$ \\
\hline pH Measurement & B0XJY3 & 699-9-E2 & $02 / 10 / 2000$ & 7.99 & $\mathrm{pH}$ \\
\hline Temperature & BOXJY3 & 699-9-E2 & $02 / 10 / 2000$ & 17.1 & $\operatorname{Deg} C$ \\
\hline Turbidity & B0XJY3 & 699-9-E2 & $02 / 10 / 2000$ & 0.8 & NTU \\
\hline Conductivity & B0XK99 & C3071/ENW-MW1 & $02 / 09 / 2000$ & 827 & $\mathrm{uS} / \mathrm{cm}$ \\
\hline Dissolved Oxygen & B0XK99 & C3071/ENW-MW1 & $02 / 09 / 2000$ & 6.39 & $\mathrm{mg} / \mathrm{L}$ \\
\hline pH Measurement & B0XK99 & C3071/ENW-MW1 & $02 / 09 / 2000$ & 7.13 & $\mathrm{pH}$ \\
\hline Temperature & B0XK99 & C3071/ENW-MW1 & $02 / 09 / 2000$ & 16.4 & Deg C \\
\hline Turbidity & B0XK99 & C3071/ENW-MWl & $02 / 09 / 2000$ & 16 & NTU \\
\hline Conductivity & B0XKBO & C3072/ENW-MW2 & $02 / 10 / 2000$ & 927 & $\mathrm{uS} / \mathrm{cm}$ \\
\hline Dissolved Oxygen & $\mathrm{B} 0 \times \mathrm{XKB} 0$ & C3072/ENW-MW2 & $02 / 10 / 2000$ & 6.26 & $\mathrm{mg} / \mathrm{L}$ \\
\hline
\end{tabular}


Table C.8. (contd)

\begin{tabular}{|c|c|c|c|c|c|}
\hline Constituent & $\begin{array}{l}\text { Sample } \\
\text { Number }\end{array}$ & Well Name & Sample Date & $\begin{array}{c}\text { Value } \\
\text { Reported }\end{array}$ & Units \\
\hline pH Measurement & $\mathrm{B} 0 \mathrm{XKBO}$ & C3072/ENW-MW2 & $02 / 10 / 2000$ & 7.19 & $\mathrm{pH}$ \\
\hline Temperature & B0XKB0 & C3072/ENW-MW2 & $02 / 10 / 2000$ & 17.1 & Deg C \\
\hline Turbidity & $\mathrm{B} 0 \times \mathrm{KKBO}$ & C3072/ENW-MW2 & $02 / 10 / 2000$ & 8.62 & NTU \\
\hline Conductivity & B0XKB1 & C3073/ENW-MW3 & $02 / 10 / 2000$ & 1,075 & $\mathrm{uS} / \mathrm{cm}$ \\
\hline Dissolved Oxygen & $\mathrm{B} 0 \mathrm{XKB1}$ & C3073/ENW-MW3 & $02 / 10 / 2000$ & 4.12 & $\mathrm{mg} / \mathrm{L}$ \\
\hline pH Measurement & $\mathrm{B} 0 \mathrm{XKBI}$ & C3073/ENW-MW3 & $02 / 10 / 2000$ & 6.95 & $\mathrm{pH}$ \\
\hline Temperature & B0XKB1 & C3073/ENW-MW3 & $02 / 10 / 2000$ & 17.5 & $\operatorname{Deg} C$ \\
\hline Turbidity & $\mathrm{B} 0 \mathrm{XKB1}$ & C3073/ENW-MW3 & $02 / 10 / 2000$ & 4.83 & NTU \\
\hline Conductivity & B0XKB2 & C3074/ENW-MW4 & $02 / 10 / 2000$ & 623 & $\mathrm{uS} / \mathrm{cm}$ \\
\hline Dissolved Oxygen & $\mathrm{B} 0 \mathrm{XKB2}$ & C3074/ENW-MW4 & $02 / 10 / 2000$ & 7.01 & $\mathrm{mg} / \mathrm{L}$ \\
\hline pH Measurement & B0XKB2 & C3074/ENW-MW4 & $02 / 10 / 2000$ & 7.3 & $\mathrm{pH}$ \\
\hline Temperature & B0XKB2 & C3074/ENW-MW4 & $02 / 10 / 2000$ & 16.6 & Deg C \\
\hline Turbidity & B0XKB2 & C3074/ENW-MW4 & $02 / 10 / 2000$ & 15 & NTU \\
\hline Conductivity & B0XKB3 & C3075/ENW-MW5 & $02 / 09 / 2000$ & 448 & $\mathrm{uS} / \mathrm{cm}$ \\
\hline Dissolved Oxygen & B0XKB3 & C3075/ENW-MW5 & $02 / 09 / 2000$ & 6.99 & $\mathrm{mg} / \mathrm{L}$ \\
\hline pH Measurement & B0XKB3 & C3075/ENW-MW5 & $02 / 09 / 2000$ & 7.74 & $\mathrm{pH}$ \\
\hline Temperature & B0XKB3 & C3075/ENW-MW5 & $02 / 09 / 2000$ & 17.8 & Deg C \\
\hline Turbidity & B0XKB3 & C3075/ENW-MW5 & $02 / 09 / 2000$ & 2.68 & NTU \\
\hline Conductivity & B0XKB4 & C3076/ENW-MW6 & $02 / 09 / 2000$ & 689 & $\mathrm{uS} / \mathrm{cm}$ \\
\hline Dissolved Oxygen & B0XKB4 & C3076/ENW-MW6 & $02 / 09 / 2000$ & 4.6 & $\mathrm{mg} / \mathrm{L}$ \\
\hline pH Measurement & B0XKB4 & C3076/ENW-MW6 & $02 / 09 / 2000$ & 7.48 & $\mathrm{pH}$ \\
\hline Temperature & B0XKB4 & C3076/ENW-MW6 & $02 / 09 / 2000$ & 17.5 & Deg C \\
\hline Turbidity & B0XKB4 & C3076/ENW-MW6 & $02 / 09 / 2000$ & 1.39 & NTU \\
\hline Conductivity & B0XKB5 & C3077/ENW-MW7 & $02 / 15 / 2000$ & 10 & $\mathrm{uS} / \mathrm{cm}$ \\
\hline pH Measurement & B0XKB5 & C3077/ENW-MW7 & $02 / 15 / 2000$ & 7.29 & $\mathrm{pH}$ \\
\hline Temperature & B0XKB5 & C3077/ENW-MW7 & $02 / 15 / 2000$ & 13.6 & Deg C \\
\hline Turbidity & B0XKB5 & C3077/ENW-MW7 & $02 / 15 / 2000$ & 1.37 & NTU \\
\hline Conductivity & B0XKB6 & C3078/ENW-MW8 & $02 / 11 / 2000$ & 520 & $\mathrm{uS} / \mathrm{cm}$ \\
\hline Dissolved Oxygen & B0XKB6 & C3078/ENW-MW8 & $02 / 11 / 2000$ & 7.72 & $\mathrm{mg} / \mathrm{L}$ \\
\hline pH Measurement & B0XKB6 & C3078/ENW-MW8 & $02 / 11 / 2000$ & 7.67 & $\mathrm{pH}$ \\
\hline Temperature & B0XKB6 & C3078/ENW-MW8 & $02 / 1 \cdot 1 / 2000$ & 15.9 & Deg C \\
\hline Turbidity & B0XKB6 & C3078/ENW-MW8 & $02 / 11 / 2000$ & 2.29 & $\mathrm{NTU}$ \\
\hline Conductivity & BOXKB 9 & ENW-31 & $02 / 08 / 2000$ & 354 & $\mathrm{uS} / \mathrm{cm}$ \\
\hline Dissolved Oxygen & B0XKB9 & ENW-31 & $02 / 08 / 2000$ & 0.91 & $\mathrm{mg} / \mathrm{L}$ \\
\hline pH Measurement & B0XKB9 & ENW-31 & $02 / 08 / 2000$ & 8.08 & $\mathrm{pH}$ \\
\hline Temperature & B0XKB9 & ENW-31 & $02 / 08 / 2000$ & 18.2 & Deg C \\
\hline Turbidity & B0XKB9 & ENW-31 & $02 / 08 / 2000$ & 1.75 & NTU \\
\hline Conductivity & BOXKC0 & ENW-32 & $02 / 08 / 2000$ & 354 & $\mathrm{uS} / \mathrm{cm}$ \\
\hline Dissolved Oxygen & $\mathrm{BOXKCO}$ & ENW-32 & $02 / 08 / 2000$ & 0.18 & $\mathrm{mg} / \mathrm{L}$ \\
\hline $\mathrm{pH}$ Measurement & $\mathrm{BOXKCO}$ & ENW-32 & $02 / 08 / 2000$ & 8.08 & $\mathrm{pH}$ \\
\hline Tempetature & $\mathrm{BOXKC0}$ & ENW-32 & $02 / 08 / 2000$ & 17 & Deg C \\
\hline Turbidity & BOXKCO & ENW-32 & $02 / 08 / 2000$ & 0.56 & NTU \\
\hline Conductivity & B0XKB7 & C3079/ENW-MW9 & $02 / 11 / 2000$ & 1,179 & $\mathrm{uS} / \mathrm{cm}$ \\
\hline Dissolved Oxygen & $\mathrm{B} 0 \mathrm{XKB}$ ? & C3079/ENW-MW9 & $02 / 11 / 2000$ & 7.21 & $\mathrm{mg} / \mathrm{L}$ \\
\hline pH Measurement & B0XKB7 & C3079/ENW-MW9 & $02 / 11 / 2000$ & 7.57 & $\mathrm{pH}$ \\
\hline Temperature & B0XKB7 & C3079/ENW-MW9 & $02 / 11 / 2000$ & 16.9 & $\operatorname{Deg} C$ \\
\hline Turbidity & B0XKB7 & C3079/ENW-MW9 & $02 / 11 / 2000$ & 2.27 & NTU \\
\hline
\end{tabular}


Table C.9. Total Activity Parameter Results for 618-11 Burial Ground Investigation, February 2000

\begin{tabular}{|c|c|c|c|c|c|c|c|c|c|}
\hline Constituent & $\begin{array}{l}\text { Sample } \\
\text { Number }\end{array}$ & Well Name & Sample Date & \begin{tabular}{|c|} 
Alpha by Liquid \\
Scintillation Result $\mathrm{pCi} / \mathrm{mL}$ \\
MDL $=.20$
\end{tabular} & $\begin{array}{c}\text { Alpha Error by LC } \\
\% \\
\end{array}$ & $\begin{array}{c}\text { Lab } \\
\text { Qualifier }\end{array}$ & \begin{tabular}{|c|} 
Beta by Liquid \\
Scintillation Result \\
pCi/mL MDL $=.30$ \\
\end{tabular} & $\begin{array}{c}\text { Beta Error by LC } \\
\% \\
\end{array}$ & Units \\
\hline ACTIVITY_SCAN & B0XJW4 & $699-12-4 \mathrm{D}$ & $02 / 07 / 2000$ & $4.40 \mathrm{E}-02$ & $1.00 \mathrm{E}+03$ & $\mathrm{U}$ & $1.90 \mathrm{E}+00$ & $5.00 \mathrm{E}+01$ & $\mathrm{pCi} / \mathrm{L}$ \\
\hline ACTIVITY_SCAN & B0XJX3 & $699-13-1 A$ & $02 / 08 / 2000$ & $3.00 \mathrm{E}+00$ & $2.50 \mathrm{E}+01$ & & $1.60 \mathrm{E}+01$ & $1.50 \mathrm{E}+01$ & $\mathrm{pCi} / \mathrm{L}$ \\
\hline ACTIVITY SCAN & B0XJX7 & $699-13-1 B$ & $02 / 08 / 2000$ & $3.30 \mathrm{E}+00$ & $2.50 \mathrm{E}+01$ & & $3.10 \mathrm{E}+00$ & $3.10 \mathrm{E}+01$ & $\mathrm{pCi} / \mathrm{L}$ \\
\hline ACTIVITY_SCAN & BOXJYI & $699-13-1 \mathrm{C}$ & $02 / 08 / 2000$ & $-2.00 \mathrm{E}-01$ & $2.25 \mathrm{E}+02$ & $\mathrm{U}$ & $1.00 \mathrm{E}+00$ & $8.50 \mathrm{E}+01$ & $\mathrm{pCi} / \mathrm{L}$ \\
\hline ACTIVITY_SCAN & B0XJV4 & $699-13-3 \mathrm{~A}$ & $02 / 07 / 2000$ & $5.00 \mathrm{E}-01$ & $1.10 \mathrm{E}+02$ & & $3.80 \mathrm{E}+03$ & $1.00 \mathrm{E}+01$ & $\mathrm{pCi} / \mathrm{L}$ \\
\hline ACTIVITY_SCAN & B0XK68 & $699-15-15 B$ & $02 / 08 / 2000$ & $6.00 \mathrm{E}-01$ & $9.00 \mathrm{E}+01$ & & $1.20 \mathrm{E}+00$ & $7.00 \mathrm{E}+01$ & $\mathrm{pCi} / \mathrm{L}$ \\
\hline ACTIVITY_SCAN & B0XK70 & $699-17-5$ & $02 / 07 / 2000$ & $-3.00 \mathrm{E}-01$ & $1.50 \mathrm{E}+02$ & $\mathrm{U}$ & $7.00 \mathrm{E}-01$ & $1.00 \mathrm{E}+01$ & $\mathrm{pCi} / \mathrm{L}$ \\
\hline ACTIVITY_SCAN & B0XK73 & $699-21-6$ & $02 / 07 / 2000$ & $-3.00 \mathrm{E}-01$ & $1.45 \mathrm{E}+02$ & $\mathrm{U}$ & $1.20 \mathrm{E}+01$ & $1.50 \mathrm{E}+01$ & $\mathrm{pCi} / \mathrm{L}$ \\
\hline ACTIVITY_SCAN & B0XK74 & 699-9-E2 & $02 / 10 / 2000$ & $1.90 \mathrm{E}+00$ & $3.50 \mathrm{E}+01$ & & $3.00 \mathrm{E}+00$ & $3.10 \mathrm{E}+01$ & $\mathrm{pCi} / \mathrm{L}$ \\
\hline ACTIVITY_SCAN & B0XKD3 & C3071/ENW-MWI & $02 / 09 / 2000$ & $1.10 \mathrm{E}+00$ & $5.20 \mathrm{E}+01$ & & $7.00 \mathrm{E}+00$ & $2.00 \mathrm{E}+01$ & $\mathrm{pCi} / \mathrm{L}$ \\
\hline ACTIVITY_SCAN & BOXKD4 & C3072/ENW-MW2 & $02 / 10 / 2000$ & $4.00 \mathrm{E}-01$ & $1.11 \mathrm{E}+02$ & & $2.10 \mathrm{E}+00$ & $4.20 \mathrm{E}+01$ & $\mathrm{pCi} / \mathrm{L}$ \\
\hline ACTIVITY_SCAN & B0XKD5 & C3073/ENW-MW3 & $02 / 10 / 2000$ & $8.00 \mathrm{E}-01$ & $6.50 \mathrm{E}+01$ & & $2.00 \mathrm{E}+00$ & $4.50 \mathrm{E}+01$ & $\mathrm{pCi} / \mathrm{L}$ \\
\hline ACTIVITY_SCAN & B0XKD6 & C3074/ENW-MW4 & $02 / 10 / 2000$ & $5.00 \mathrm{E}-01$ & $1.01 \mathrm{E}+02$ & & $7.80 \mathrm{E}+00$ & $2.00 \mathrm{E}+01$ & $\mathrm{pCi} / \mathrm{L}$ \\
\hline ACTIVITY SCAN & B0XKD7 & C3075/ENW-MW5 & $02 / 09 / 2000$ & $2.10 \mathrm{E}-02$ & $1.00 \mathrm{E}+03$ & $\mathrm{U}$ & $8.40 \mathrm{E}+00$ & $2.00 \mathrm{E}+01$ & $\mathrm{pCi} / \mathrm{L}$ \\
\hline ACTIVITY_SCAN & B0XKD8 & C3076/ENW-MW6 & $02 / 09 / 2000$ & $8.00 \mathrm{E}-01$ & $6.50 \mathrm{E}+01$ & & $3.50 \mathrm{E}+00$ & $3.00 \mathrm{E}+01$ & $\mathrm{pCi} / \mathrm{L}$ \\
\hline ACTIVITY_SCAN & B0XKD9 & C3077/ ENW-MW7 & $02 / 15 / 2000$ & $-2.00 \mathrm{E}-01$ & $1.70 \mathrm{E}+02$ & $\mathrm{U}$ & $1.00 \mathrm{E}+00$ & $8.00 \mathrm{E}+01$ & $\mathrm{pCi} / \mathrm{L}$ \\
\hline ACTIVITY_SCAN & BOXKF0 & C3078/ENW-MW8 & $02 / 11 / 2000$ & $7.00 \mathrm{E}-01$ & $7.50 \mathrm{E}+01$ & & $1.40 \mathrm{E}+00$ & $6.00 \mathrm{E}+01$ & $\mathrm{pCi} / \mathrm{L}$ \\
\hline ACTIVITY_SCAN & BOXKF1 & C3079/ENW-MW9 & $02 / 11 / 2000$ & $9.00 \mathrm{E}-01$ & $6.00 \mathrm{E}+01$ & & $2.60 \mathrm{E}+00$ & $4.00 \mathrm{E}+01$ & $\mathrm{pCi} / \mathrm{L}$ \\
\hline
\end{tabular}


Appendix D

Quality Control Sample Definitions

)

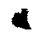




\section{Appendix D}

\section{Quality Control Sample Definitions}

\section{D.1 Field Quality Samples}

Equipment Blank (EBL) - A field blank sample that is used to check for sample contamination caused by unclean sampling equipment or the sampling equipment itself. Generally, equipment blanks are only collected at wells that are sampled using non-dedicated pumps. Equipment blanks are prepared by passing Type II reagent water through the pump or manifold after the equipment has been decontaminated (sometimes just prior to sampling a well) and collecting the rinsate in preserved bottles.

Field Duplicate - A replicate sample used to determine the repeatability of the sampling and analytical measurement process by comparing results with an identical sample collected at the same time and location.

Field Transfer Blank - A field blank sample that is used to check for in-the-field sample contamination by volatile organic compounds. Field transfer blanks are prepared near a well sampling site by filling preserved VOA sample bottles with Type II reagent water that has been transported to the field. Field transfer blanks are normally prepared at the same time VOA samples are being collected from the well. After collection, the field transfer blank bottles are sealed and placed in the same sample storage container as the rest of the samples. Field transfer blanks are not removed from the storage container until they have been delivered to the lab.

Full Trip Blank (FTB) - A field blank sample that is used to check for sample contamination resulting from sample bottles, preservatives, and sample storage and handling. Full trip blanks are initially prepared in the laboratory by filling a preserved bottle set with Type II reagent water. After the bottles have been sealed, they are transported to the field in the same storage container that will be used for groundwater samples collected that day. Full trip blanks are not removed from the storage container until they have been delivered to the laboratory.

Split Samples - Replicate samples sequentially collected from the same location and analyzed by different laboratories.

\section{D.2 Laboratory Quality Control Samples}

Laboratory Control Sample - A sample of Type II reagent water that is spiked with known amounts of target analyte(s). The sample is extracted (if appropriate) and analyzed to monitor the performance of the analytical method. 
Matrix Duplicate - A replicate analysis of a regular (i.e., groundwater) sample. Matrix duplicates and matrix spike duplicates are used to evaluate the precision of an analysis.

Matrix Spikes/Matrix Spike Duplicates - Samples that are prepared by adding known quantities of one or more target analytes to a sample prior to extraction and analysis. Comparison of the original (unspiked) sample and matrix spike results provides information about the suitability of an analysis for the sample matrix. Matrix spike duplicates are replicate matrix spike samples that are used to assess the precision of an analysis.

Method Blank - A sample of Type II reagent water that is prepared in the laboratory, extracted (if appropriate), and analyzed as if it were a regular sample. Method blanks are used to monitor the possible introduction of contaminants during sample preparation and analysis. 


\section{Distribution}

No. of

Copies

OFFSITE

2 J. Chasse

Energy Northwest

P.O. Box 968

Richland, WA 99352

R. A. Danielson

Washington State Department of Health 5508 Englewood Avenue

Yakima, WA 98908

R. E. Jaquish

Washington State Department of Health 1232 Vintage Ave.

Richland, WA 99352

State of Oregon Office of Energy

625 Marion Street N.E.

Salem, OR 97310

ATTN: D. Dunning

Washington State Department of

Ecology, MS 7600

P.O. Box 47600

Olympia, WA $98504-7600$

Washington Statement Department of Health Division of Radiation Protection

P.O. Box 47827

Olympia, WA 98504-7827

ATTN: D. McBaugh
No. of

Copies

ONSITE

29 DOE Richland Operations Office

M. J. Furman (3)

A5-13

R. D. Hildebrand

A5-13

R. G. McLeod (3)

$\mathrm{H} 0-12$

K. M. Thompson (20)

A5-13

Public Reading Room (2)

H2-53

5 Bechtel Hanford, Inc.

K. R. Fecht

HO-02

M. J. Graham

H0-09

G. W. McNair

$\mathrm{H} 0-21$

G. B. Mitchem

$\mathrm{H} 0-21$

BHI Document and Information Services

3 CH2M Hill Hanford, Inc.

J. V. Borghese

H9-03

L. C. Hulstrom

H9-03

L. C. Swanson

H9-02

Washington State Department of Ecology

D. Goswami

B5-18

2 U.S. Environmental Protection Agency

L. E. Gadbois

B5-01

D. R. Sherwood

B5-01 
No. of

Copies

32 Pacific Northwest National Laboratory

P. E. Dresel (10)

J. S. Fruchter

R. E. Gephart

M. J. Hartman

J. W. Lindberg

S. P. Luttrell

J. P. McDonald

L. F. Morasch
No. of

Copies

K. B. Olsen

K6-96

R. M. Smith

F. A. Spane, Jr.

D. L. Stewart

C. J. Thompson

P.D. Thorne

W. D. Webber

B. A. Williams

Information Release Office (7)
K6-96

K6-96

$\mathrm{K} 6-96$

$\mathrm{K} 6-96$

K9-33

K6-96

K6-81

K1-06

K6-96

K6-86 